
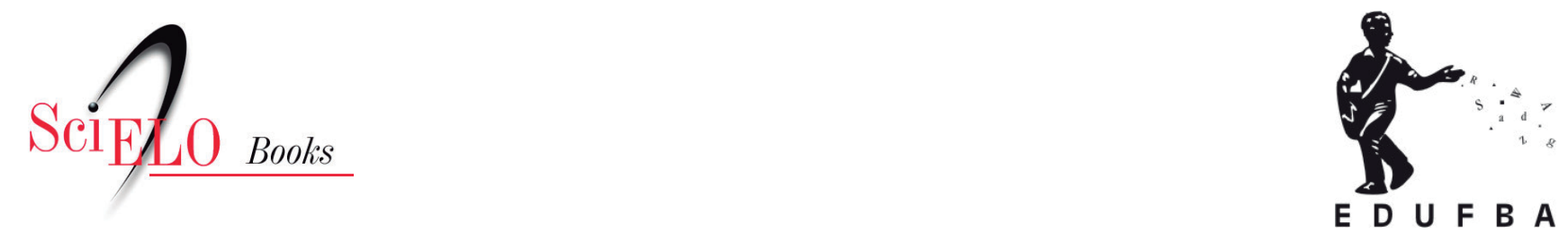

\title{
Tópicos em saúde, ambiente e trabalho um olhar ampliado
}

\author{
Rita de Cássia Pereira Fernandes \\ Mônica Angelim Gomes de Lima \\ Tânia Maria de Araújo \\ (orgs.)
}

FERNANDES, R.C.P., LIMA, M.A.G., and ARAÚJO, T.M., comps. Tópicos em saúde, ambiente e trabalho: um olhar ampliado [online]. Salvador: EDUFBA, 2014, 508 p. ISBN: 978-65-5630-012-2. https://doi.org/10.7476/9786556300122.

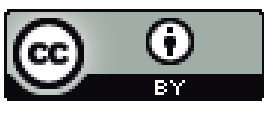

All the contents of this work, except where otherwise noted, is licensed under a Creative Commons Attribution 4.0 $\underline{\text { International license. }}$

Todo o conteúdo deste trabalho, exceto quando houver ressalva, é publicado sob a licença Creative Commons Atribição $\underline{4.0}$.

Todo el contenido de esta obra, excepto donde se indique lo contrario, está bajo licencia de la licencia Creative Commons Reconocimento 4.0. 


\section{Tópicos em saúde, ambiente e trabalho \\ um olhar ampliado}


UNIVERSIDADE FEDERAL DA BAHIA

Reitora

Dora Leal Rosa

Vice-reitor

Luiz Rogério Bastos Leal

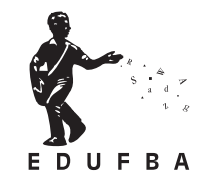

EDITORA DA UNIVERSIDADE FEDERAL DA BAHIA

Diretora

Flávia Goullart Mota Garcia Rosa

Conselho Editorial

Alberto Brum Novaes

Angelo Szaniecki Perret Serpa

Caiuby Alves da Costa

Charbel Ninõ El-Hani

Cleise Furtado Mendes

Dante Eustachio Lucchesi Ramacciotti

Evelina de Carvalho Sá Hoisel

José Teixeira Cavalcante Filho

Maria Vidal de Negreiros Camargo

EDUFBA

Rua Barão de Jeremoabo, s/n Campus de Ondina 40170-115 Salvador-BA

Tel: (71) 3283-6160/6164

edufba@ufba.br

www.edufba.ufba.br 
Rita de Cássia Pereira Fernandes, Mônica Angelim Gomes de Lima e Tânia Maria de Araújo

(Organizadoras)

\section{Tópicos em saúde, ambiente e trabalho um olhar ampliado}


2014, Autores

Direitos para esta edição cedidos à EDUFBA.

Feito o depósito legal

Grafia atualizada conforme o Acordo Ortográfico da Língua Portuguesa de 1990, em vigor no Brasil desde 2009.

$1^{\mathrm{a}}$ reimpressão: 2014

Projeto Gráfico

Angela Garcia Rosa e Josias Almeida Jr.

Capa e Editoração

Josias Almeida Jr.

Revisão e Normalização

Rosane Rubim

Sistema de Bibliotecas - UFBA

Tópicos em saúde, ambiente e trabalho : um olhar ampliado / Rita de Cássia Pereira Fernandes, Mônica Angelim Gomes de Lima, Tânia Maria de Araújo, (Organizadores) ; prefácio, Sergio Koifman. - Salvador: EDUFBA, 2014.

$508 \mathrm{p}$.

ISBN 978-85-232-1211-7

1. Saúde e trabalho - Bahia. 2. Trabalho - Aspectos ambientais - Bahia. 3. Promoção da saúde dos empregados - Bahia. I. Fernandes, Rita de Cássia Pereira. II. Lima, Mônica Angelim Gomes de. III. Araújo, Tânia Maria de. IV. Koifman, Sergio.

Editora filiada à

E

ASOCIACION DE EDITORIALES UNIVERSITARIAS DE AMERICA LATINA Y EL CARIBE

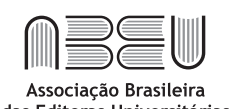

das Editoras Universitárias
$\mathrm{CBaL}$ 


\section{Sumário}

Prefácio

Sergio Koifman

Apresentação

\section{PARTE I - Estudos sobre trabalho}

O trabalho dos fisioterapeutas em UTI:

entre o real e o prescrito

Rosângela Cunha da Rocha

Mônica Angelim Gomes de Lima

Rita de Cássia Pereira Fernandes

Características do trabalho e condições de saúde dos delegados de polícia civil

Gerfson Moreira Oliveira

Tânia Maria de Araújo

Fernando Martins Carvalho

Percepção de riscos ocupacionais em catadores de materiais recicláveis

Denise Alves Miranda de Oliveira

Luiz Roberto Santos Moraes

Trabalho e distúrbios musculoesqueléticos

na limpeza urbana

Adilton Luiz Pio Pereira

Rita de Cássia Pereira Fernandes

Marisqueiras da Ilha das Fontes: descrição do trabalho e da tradição incorporadas na pesca artesanal

Thais Mara Dias Gomes

Mônica Angelim Gomes de Lima

Maria do Carmo Soares de Freitas

Processo laboral e a saúde dos trabalhadores em centros de atenção psicossocial

Maria de Fátima Prates Budde

Tânia Maria de Araújo 
Sintomas vocais e absenteísmo em teleoperadores sindicalizados

Flávia Silva Santa Mônica

Maria Lúcia Vaz Masson

Tânia Maria de Araújo

Abordagem teórico-prática sobre as condições ambientais

e laborais de uma escola da rede municipal de Salvador-Bahia 209 Patrícia Farias Uchôa

Luiz Roberto Santos Moraes

Previdência social, acidente de trabalho e nexo técnico epidemiológico

Rita Franco Rego

Edriene Barros Teixeira

Denismar Borges de Miranda

Paulo Gilvane Lopes Pena

\section{PARTE II - Estudos Ambientais}

Mudanças climáticas e aspectos relacionados com o estado da Bahia

Tania Mascarenhas Tavares

Sérgio Telles de Oliva

Rodolfo Rojas Guarín

Carolina L. Wilches Arciniegas

Medidas de óxido nitroso $\left(\mathrm{N}_{2} \mathrm{O}\right)$ emitido por culturas de mamona e girassol para produção do agro diesel e potencial contribuição para as mudanças climáticas Tania Mascarenhas Tavares Rodolfo Rojas Guarín Carolina L. Wilches Arciniegas

Sergio Telles de Oliva

Uso de neblina ativada para redução das emissões de bioaerossóis em um aterro sanitário

Tania Mascarenhas Tavares

Eagles M. Alves

Carolina L. Wilches Arciniegas

As viúvas do amianto: significados da contaminação por asbesto

Cláudia de Oliveira d'Arede

Mônica Angelim Gomes de Lima

Maria do Carmo S. Freitas 
O gerenciamento ambiental das perdas de catalisador usado nas unidades de craqueamento catalítico em refinarias de petróleo: riscos à saúde pública $\mathrm{e}$ ao meio ambiente

Wanderley Ferreira da Silva Júnior

Severino Soares Agra Filho

Fernando Martins Carvalho

\section{PARTE III - Novos desafios do campo da saúde, ambiente e trabalho: temas emergentes e abordagens metodológicas}

Conhecimento e atitudes sobre câncer da mama e do colo do útero entre trabalhadoras da área de saúde

Gilberto Andrade Tavares

Marco Antônio Vasconcelos Rêgo

Comportamento de industriários quanto à prevenção do câncer da próstata

André Luis Santos Virgulino

Marco Antônio Vasconcelos Rêgo

O trabalhador-doente e sua família no contexto do adoecimento, absenteísmo e o processo de retorno ao trabalho

Paulo Roberto Ferreira da Rocha

Mônica Angelim Gomes de Lima

$O$ percurso etnometodológico de uma pesquisa em Santo Amaro-BA

Maiza Ferreira de Andrade

Luiz Roberto Santos Moraes

Sobre os autores 



\section{Prefácio}

A economia brasileira ingressa no século XXI participando do reduzido conjunto de nações com crescimento econômico considerado pujante, e constituindo com a Rússia, Índia, China e África do Sul o grupo econômico emergente dos BRICS. Converte-se assim na segunda economia considerada como mais importante nas Américas, posicionando-se atrás apenas dos Estados Unidos. No plano mundial, passa a ocupar a sétima posição de maior crescimento em 2011, sendo prevista a posição de $4^{\mathrm{a}}$ maior economia no plano mundial em 2050.

Frente a esta perspectiva determinada sob uma ótica economicista da realidade brasileira, qual é o retrato das condições de vida e saúde dos trabalhadores que permearam esta realidade atuando diretamente em tais transformações? O presente livro buscou explorar e descrever as condições vivenciadas na atualidade por diversos segmentos destes trabalhadores na região mais antiga de colonização da sociedade brasileira, o estado da Bahia.

Ao longo de dezoito capítulos, os autores perpassam diversas condições de trabalho distintas, afetando a gênese e permanência dos problemas de saúde gerados entre os trabalhadores e seus familiares. Entre as primeiras, incluem-se desde as formas mais avançadas do desenvolvimento capitalista da economia como a exploração de derivados do petróleo àquelas consideradas mais atrasadas e virtualmente inexistentes em países capitalistas desenvolvidos, como a exploração manual de mariscos e resíduos sólidos em precárias condições de trabalho. As realidades do desenvolvimento e do subdesenvolvimento são assim apresentadas com olhar detalhado e minucioso na ótica das condições de saúde dos trabalhadores que exercem múltiplas atividades, e não por aquela dos lucros gerados pela comercialização de suas respectivas mercadorias. O cenário descrito pelos trabalhos apresentados é assim bem distante daquele esperado para aquele conjunto certificado como vitrine de uma das mais importantes economias mundiais. 
A multiplicidade de objetos de análise abordados nesta publicação, a qual inclui as atividades econômicas do desenvolvimento e outras que retratam a histórica exploração das camadas empobrecidas da população, revela as disparidades retratadas nas condições de saúde dos trabalhadores na Bahia. Estas podem ser assim analisadas enquanto uma amostra do que, em maior ou menor intensidade e magnitude, igualmente se apresenta no conjunto da população brasileira de trabalhadores.

Diversos outros problemas de saúde da população urbana contemporânea, associados ao ambiente de trabalho no estado da Bahia foram também incorporados e analisados, incluindo-se, por exemplo, os distúrbios musculoesqueléticos em trabalhadores da limpeza urbana, condições de saúde de delegados da polícia civil, e os sintomas vocais e absenteísmo em teleoperadores. Adicionalmente, a análise de condições geradoras do processo saúde/doença de relevância na atualidade, como as mudanças climáticas, por exemplo, e as condições de trabalho na indústria de petróleo e na exploração das fibras de asbesto, foi também incorporada. A saúde em grupos particulares de trabalhadores, como profissionais de saúde, e a prevenção de câncer em trabalhadores foram igualmente objeto de atenção na organização dos conteúdos da publicação. Igualmente relevante e merecendo destaque pode ser citada a proposta de inclusão de diferentes abordagens metodológicas na realização dos estudos apresentados, incluindo investigações com abordagens quantitativas e outras qualitativas, compondo um conjunto abrangente sobre as condições de saúde dos trabalhadores no estado da Bahia.

Em seu conjunto, os trabalhos agrupados são reveladores do descompasso ainda vivido no Brasil, caracterizado por um lado pela potencial pujança do desenvolvimento econômico em curso no país e, por outro lado, pelas precárias condições de saúde e bem estar de seus trabalhadores. Neste sentido, a presente publicação representa uma rica documentação pioneira no Brasil, instrumento importante para todos os pesquisadores neste campo, com interesse sobre seus reflexos nas 
condições de saúde dos principais atores e pessoas direta ou potencialmente afetadas neste processo, os trabalhadores nela envolvidos e seus familiares.

Sergio Koifman ${ }^{1}$

1 Graduado em Medicina pela Universidade do Estado do Rio de Janeiro (1974), Mestre em Medicina Social , área de Epidemiologia, pela Universidad Nacional Autonoma de Mexico Xochimilco (1978), Doutor em Medicina Preventiva pela Universidade de São Paulo (1988) e Pós-doutor na School of Ocupational Health, McGill University, Montreal, Canada (1991-93). Pesquisador titular da Fundação Oswaldo Cruz, e coordenador do Programa de Pós-Graduação em Saúde Pública e Meio Ambiente da Escola Nacional de Saúde Pública/ Fiocruz, docente permanente no mesmo programa e no Mestrado em Saúde Coletiva da Universidade Federal do Acre (Associação Temporária UFAC- Fiocruz pela CAPES). Pesquisador 1A do CNPq desde 1997 e consultor ad-hoc do CNPq, FAPESP, FAPERJ, CAPES e Ministério da Saúde. 



\section{Apresentação}

Rigotto (2003), ${ }^{1}$ em um artigo publicado na Revista Brasileira de Epidemiologia, intitulado "Saúde ambiental e saúde dos trabalhadores: uma aproximação promissora entre o verde e o vermelho", discute as relações entre esses três campos de saberes com o propósito de explorar as suas aproximações teóricas e práticas. Este é um desafio que se coloca na atualidade. É com base nesse desafio que desenvolvemos esse livro, também no intuído de explicitar essas aproximações. Assim, o material aqui oferecido apresenta-se como uma possibilidade de articulação da saúde, do ambiente e do trabalho, concatenando as várias disciplinas que estruturam esses campos.

A definição fundante desta iniciativa repousa na concepção de que os padrões de saúde e qualidade de vida das populações são estabelecidos por redes complexas de relações entre produção e ambiente. No dizer de Laurell (1982), ${ }^{2}$ "o processo de saúde-doença é determinado pelo modo como o homem se apropria da natureza em um dado momento; apropriação esta que se realiza por meio do processo de trabalho, baseado em um determinado grau de desenvolvimento das forças produtivas e das relações sociais de produção".

A integração das abordagens inscritas nos campos do ambiente e da produção (trabalho) constitui-se, assim, uma necessidade para a adequada compreensão do processo de saúde e de doença das populações. Entende-se que é na intersecção das relações entre a sociedade e a natureza que se deve buscar os determinantes dos processos de adoecimento, reconhecendo a centralidade do processo de produção na determinação do modelo de desenvolvimento de cada sociedade e, consequentemente, dos perfis de adoecimento.

Os desafios para articulação desses campos constituem desafios para superar os grandes problemas contemporâneos, advindos dos

1 RIGOTTO, Raquel Maria. Saúde Ambiental \& Saúde dos Trabalhadores: uma aproximação promissora entre o Verde e o Vermelho. Revista Brasileira de Epidemiologia, v. 6, n. 4, p. 388-404, 2003.

2 LAURELL, A.C. La salud-enfermidad como proceso social. Revista Lationoamericana de Salud, n. 2, p. 7-25, 1982. 
processos de industrialização e urbanização das sociedades humanas, com significativos impactos ambientais e na saúde humana e dos demais seres vivos.

No estado da Bahia, existem grandes problemas ambientais e ocupacionais, como os impactos negativos resultantes do crescimento do parque industrial petroquímico de Camaçari (contaminação do lençol freático e casos de benzenismo e de esteatohepatite não alcoólica); a contaminação do solo e de manguezais por resíduos sólidos perigosos de origem industrial (chumbo em Santo Amaro da Purificação e asbestos em Bom Jesus da Serra); radiações ionizantes (urânio em Caetité); os efeitos de grandes obras de saneamento ambiental (programa Bahia Azul no Recôncavo) e rodoviárias (construção da Linha Verde); e a polêmica gestão dos recursos hídricos (transposição das águas do rio São Francisco). Situações que envolvem preocupações, a um só tempo, ambientais e ocupacionais.

$\mathrm{Na}$ perspectiva de contribuir para a avaliação dos problemas complexos advindos desses processos sociais e de promover a articulação entre os campos de saúde, trabalho e ambiente, ancorado nos pressupostos teóricos mencionados acima, foi criado na UFBA, em 2007, o Programa de Pós-Graduação em Saúde, Ambiente e Trabalho (PGSAT), fruto da integração de pesquisadores e docentes de várias áreas do conhecimento (medicina preventiva e social, química, engenharia sanitária, nutrição, estatística). O Programa foi desenhado para capacitar profissionais de diversas áreas do conhecimento, interessados e comprometidos com as questões ambientais ou em saúde do trabalhador, para a análise crítica, planejamento, implementação, desenvolvimento e avaliação de políticas públicas e tecnologias na área da Saúde, Ambiente e Trabalho, considerando o quadro epidemiológico, econômico, jurídico-institucional e sócio-antropológico. Esse Programa constitui-se em esforço coletivo para superar os limites de um mesmo campo disciplinar, insuficiente para dar conta dos complexos problemas das sociedades contemporâneas, caracterizadas pela sobreposição de perfis de adoecimento e por amplas desigualdades sociais, raciais e de gênero.

Este livro expressa parte dos esforços desenvolvidos no PGSAT na tentativa de integrar diversas contribuições que se articulam na confluência de diferentes disciplinas para avaliar, dar visibilidade, debater, 
discutir os problemas vivenciados por diversos grupos e problemas que envolvem as áreas temáticas de interesse.

O livro encontra-se estruturado em três partes que se concatenam para oferecer uma visão ampla dos problemas enfrentados. A primeira parte aborda os estudos ocupacionais. Diferentes contribuições oriundas de investigações de condições de trabalho e saúde são apresentadas, envolvendo diversos grupos ocupacionais (trabalhadores da saúde, delegados, marisqueiras, atendentes de telemarketing, educadores). No estudo das condições de trabalho e saúde são empregados conhecimentos de diferentes disciplinas, reunindo métodos qualitativos e quantitativos, mensuração de ambientes de trabalho e abordagem de aspectos legais envolvidos.

A segunda parte reúne os estudos ambientais, incorporando contribuições acerca dos problemas atuais para a humanidade como as mudanças climáticas e problemas ambientais diversos. A diversidade de métodos e de abordagens é também evocada, evidenciando o quanto complexas são as relações envolvidas na triangulação entre saúde, trabalho e ambiente.

$\mathrm{Na}$ terceira parte são trazidos alguns elementos para a reflexão acerca de novos aspectos a serem incorporados aos estudos como a articulação de outras esferas das vidas dos trabalhadores e novas propostas metodológicas para superação de algumas dificuldades atuais, como a importante tarefa de comunicação, de transmissão das informações que são geradas na produção do conhecimento, a fim de transformá-las em intervenção, a partir do empoderamento das populações envolvidas.

O livro é a apresentação de um mosaico de olhares, de recortes de realidades diversas que permitem observar a diversidade do mundo que nos cerca (envolvendo a produção e o ambiente) e seus impactos na saúde. A partir dos elementos contextuais, de experiências aparentemente particulares, espera-se constituir as bases para se tecer um conhecimento integrado, evidenciando a necessidade de múltiplas lentes para um olhar ampliado. Este é o eixo estruturador desse livro. 

PARTE I

Estudos sobre trabalho 
O trabalho ocupa a maior parte do tempo da vida. Por isso fala-se da sua centralidade na vida dos sujeitos. Apesar deste lugar na existência humana, o conhecimento a respeito do trabalho, sobre o que cada um faz, a disponibilidade de meios para este fazer, o que enfrenta no labor diário, as maiores ou menores exigências e, especialmente, as repercussões do trabalho na vida dos sujeitos trabalhadores, ainda constitui espaço restrito ao se comparar esta área a tantas outras da produção do conhecimento.

Sendo o trabalho uma prática social, mutifacetada e complexa, sua apreensão requer múltiplas abordagens teóricas e metodológicas.

No Brasil, a produção científica no campo da Saúde do Trabalhador (ST) remonta, particularmente, às ultimas décadas. Artigo de Rego et al., de 2005, ${ }^{3}$ descreve a produção em ST no nosso meio a partir dos Congressos Brasileiros de Epidemiologia. Para os autores, a Constituição Federal de 1988 - que insere a ST como campo de atuação do Setor Saúde - é um divisor de águas nesta trajetória. A produção da ST encontra espaço crescente nas reflexões de pesquisadores, além da Epidemiologia, com apropriação de métodos de estudo do trabalho humano, como é o caso da produção de autores que têm como referência a Análise Ergonômica do Trabalho. Muitas perspectivas metodológicas já estão dando frutos na nossa produção local, fomentando, na comunidade científica, o debate de importantes questões a respeito do Trabalho.

Porém, esta recente e crescente produção ainda não é capaz de alterar a invisibilidade do sofrimento de muitos trabalhadores, seja no Setor de Serviços, seja na Indústria, ou no Trabalho Artesanal. Além disso, a utilização do conhecimento produzido na geração de intervenções que visem melhorar a condição dos trabalhadores ainda é muito incipiente, ou seja, registra-se ainda uma pequena apropriação deste conhecimento pelo movimento social, e um baixo volume de projetos de extensão da Universidade nos locais de trabalho.

Nesta seção, reúnem-se nove capítulos. O primeiro deles é dedicado ao estudo do trabalho em um importante segmento de atuação de trabalhadores da saúde, a Unidade de Terapia Intensiva. Analisa as exigências das tarefas postas aos fisioterapeutas em um contexto no qual os meios disponíveis são insuficientes. O segundo capítulo aborda

3 RÊGO, M.A.V. et al.. Saúde do Trabalhador nos Congressos Brasileiros de Epidemiologia. Revista Baiana de Saúde Pública, v. 29 n. 1, p. 69-79, jan./jun. 2005. 
outra categoria de trabalhadores do Setor de Serviços, os delegados de polícia, descrevendo as características do seu trabalho e as repercussões sobre sua saúde, num cenário de crescente violência urbana. Os dois capítulos seguintes dedicam-se ao estudo do trabalho e saúde dos trabalhadores no Segmento de Limpeza Urbana, área crucial de atuação de trabalhadores para a vida nas cidades. O terceiro capítulo desta seção traz a experiência dos catadores de materiais recicláveis, esta "nova" categoria, e o quarto se dedica ao estudo das exigências do trabalho (e sua relação com os distúrbios musculoesqueléticos) entre trabalhadores de coleta de lixo doméstico. O trabalho de mulheres na pesca artesanal é objeto de um estudo etnográfico que compõe o quinto capítulo, e no sexto capítulo encontra-se uma contribuição ao estudo do trabalho e sua repercussão sobre a saúde de trabalhadores dos Centros de Apoio Psicossocial. Este estudo revela o paradoxo que é ter por missão cuidar de quem padece do transtorno psíquico, e ter a própria saúde ameaçada por condições de trabalho inadequadas. Os distúrbios da voz, tão relevantes, particularmente nos novos processos de trabalho como o telemarketing, são objeto do sétimo capítulo. Depois deste, uma investigação, dedicada ao estudo de condições do meio ambiente do trabalho, compõe o capítulo que fornece elementos para se conhecer aspectos de um local de trabalho muito especial, a escola. No último capítulo desta seção encontra-se uma análise da evolução da Previdência Social no Brasil, sua relação com a notificação de acidentes de trabalho, a adoção do Nexo Técnico Epidemiológico e sua implantação sob a perspectiva da Gestão da Informação. Este conjunto de capítulos traz contribuições úteis para pesquisadores, profissionais de saúde e movimento social, na perspectiva da construção do direito ao trabalho sem sofrimento, do trabalho com dignidade e prazer. 



\section{O trabalho dos fisioterapeutas em UTI: entre o real e o prescrito}

Rosângela Cunha da Rocha Mônica Angelim Gomes de Lima Rita de Cássia Pereira Fernandes

\section{Introdução}

O setor de saúde orientado pela lógica da reestruturação produtiva tem instituído reformas organizacionais para atender a meta de ampliar a assistência através da redução de gastos e adequação dos recursos humanos. (GUEDES; LIMA; ASSUNÇÃO, 2005) Os processos de trabalho no âmbito da assistência à saúde sofreram transformações da forma de cuidados simplificados para uma abordagem e utilização de equipamentos mais complexos. Dessa maneira, gerou-se a necessidade de diversificação e especialização da força de trabalho. (SIQUEIRA; WATANABELL; VENTOLA, 1995)

De acordo com Gaspar (1997), os hospitais são instituições que oferecem consideravelmente maior possibilidade de agravos à saúde dos trabalhadores, entre todas as instituições de saúde, por apresentarem condições complexas de trabalho. No tocante a este ambiente, os riscos mais citados na literatura e que se revestem de especial significado são os biológicos. (CAIXETA; BARBOSA-BRANCO, 2005) Entre as infecções de maior risco para os trabalhadores nestes ambientes encontram-se as transmitidas por sangue e outros fluidos corpóreos, como: a Hepatite B, a Hepatite C, a Síndrome da Imunodeficiência Adquirida (SIDA), a Tuberculose, a Varicela, a Herpes-zoster, o Sarampo, entre outras. (RESENDE; FORTALEZA, 2001; PANHOTRA; SAXENA, AL-MULHIM, 2005) 
Dentre os fatores que aumentam a vulnerabilidade dos trabalhadores de saúde aos riscos biológicos, destacam-se: a complexidade de assistência prestada aos pacientes, a exigência de ritmos acelerados de produção, procedimentos com possibilidade de contato com sangue e outros fluidos corpóreos, o pouco investimento das instituições de saúde na manutenção dos meios de trabalho (materiais e equipamentos) e em medidas de proteção coletiva, entre outros. (BARBOSA, 1989; BULHÕES, 1998; SARQUIS, 2007)

Em particular, as Unidades de Terapia Intensiva (UTIs) se revestem de especial significado por se tratarem de ambientes, no espaço hospitalar, destinados a prestar assistência a pacientes criticamente enfermos, comumente com alto grau de dependência de assistência direta da equipe de saúde. Puro e colaboradores (2001) destacam a UTI como uma das áreas de maior risco de exposição dos trabalhadores aos agentes biológicos nas instituições hospitalares. Associado a isto, é uma unidade onde a incorporação de novas tecnologias e os processos de trabalho ampliam a vulnerabilidade destes profissionais.

O fisioterapeuta, como componente das equipes de saúde das UTIs, ao realizar as suas atividades cotidianas, depara-se com diversas situações que podem comprometer a sua saúde, não apenas relacionadas com o meio físico propriamente dito, com os instrumentos de trabalho, mas situações relativas às relações sociais e à organização do trabalho.

Silva e colaboradores (2008), desenvolvendo estudo em hospital universitário, constataram que os fisioterapeutas apresentam 4,6 vezes maior probabilidade de serem colonizados por microrganismos multirresistentes na execução de suas atividades, quando comparados com outros profissionais do mesmo setor. Entre as atividades realizadas pelos fisioterapeutas na UTI e que podem aumentar a exposição destes trabalhadores aos riscos biológicos estão às mobilizações e posicionamentos de pacientes potencialmente infectados ou colonizados, manobras de hiperinsuflação manual dos pulmões, exercícios de tosse, aspirações de secreções pulmonares, entre outras. Guttenberg e Spickett (2009) constataram que no ambiente hospitalar as causas de maior exposição dos fisioterapeutas aos riscos biológicos são as situações de contingências $(33,3 \%)$, as fontes contaminadas com sangue e outros fluidos corpóreos $(28,4 \%)$, e fatores organizacionais $(22,2 \%)$. 
A proposta do presente estudo é descrever as ações práticas dos fisioterapeutas diante das limitações de condições materiais e dos riscos biológicos em uma UTI. Pretende-se compreender a dinâmica das interações sociais nas práticas cotidianas dos fisioterapeutas diante dos riscos biológicos, através dos seus depoimentos.

\section{Métodos}

O estudo abrangerá os pressupostos da Etnometodologia, que define o risco como um fenômeno socialmente construído e negociado como parte de interações no cotidiano de trabalho destes profissionais. A Etnometodologia, a partir da análise das interações sociais, e a Análise Ergonômica do Trabalho (AET) contribuirão para o entendimento dos modos operatórios e estratégias que os fisioterapeutas utilizam para produzir ordem de forma detalhada e sequencial, considerando as contingências nos seus locais de trabalho.

A Etnometodologia e a AET são correntes teórico-metodológicas com vertentes na sociologia, antropologia e psicologia da cognição, as quais privilegiam a ação situada em contextos organizacionais. (THERRIEN; CARVALHO, 2009) De tal modo, a aproximação com estas duas correntes mostra-se oportuna para desvelar o fenômeno abordado neste estudo, que se refere à ação prática dos sujeitos de fisioterapia em uma UTI.

A designação 'ação situada' foi introduzida por Suchman (1987), que enfatiza a ideia de que cada curso da ação depende essencialmente das circunstâncias materiais e sociais em que estas ocorrem. Para este autor, mais do que atentar para a ação abstrata longe de sua situação e representá-la como racional, deve-se estudar como as pessoas usam as suas circunstâncias para alcançar a ação inteligente. (SUCHMAN, 1987, p. 50)

Para Coulon (1995), nos estudos do trabalho, é importante abordar as instruções que regem as ações dos atores sociais, ou seja, as ações e raciocínios práticos e especificar em que se constituem as normas e regras para assim definir os seus significados. Deve-se considerar que a ação é uma instrução que é colocada em prática. Contudo, faz-se necessário considerar que as regras nunca observam as contingências práticas, violá-las pode significar, para os membros, permitir norma- 
lizar o curso da ação. Seguir procedimentos de maneira competente não diz respeito, portanto, à conformidade ou desvio em relação aos procedimentos preestabelecidos, mas ao julgamento que se faz acerca da pertinência do procedimento em determinada situação.

Em direção semelhante, a análise ergonômica do trabalho (AET) refere-se à análise da atividade do trabalhador em situações reais de trabalho, ou seja, à compreensão de como o homem realiza o trabalho prescrito pela organização em situações reais. (ABRAHÃO, 2000) De acordo com Wisner (1994), a AET nasce como abordagem sobre o trabalho que passa a incluir o ponto de vista do trabalhador em situação de trabalho real. "Não se trata mais de fazer com que a tarefa seja descrita pela direção e sim analisar as atividades do trabalho". (WISNER, 1994, p. 93) O inventário das diferenças entre o trabalho prescrito e o real se faz importante para dar ênfase ao que é difícil e, muitas vezes, impraticável de se realizar. A tarefa refere-se ao que está prescrito pela organização, incluindo os objetivos, as normas, os meios fornecidos e as condições de trabalho. A atividade consiste em como o trabalhador realiza a tarefa ou trabalho prescrito, observando-se o objetivo proposto e os meios disponíveis nas condições reais. (LIMA, 1995)

Existem variações nas situações de trabalho e estas são permeadas pelas características individuais dos trabalhadores, pela sua competência, pelas metas de produção e pelos meios social e tecnológico. (ABRAHÃO, 2000) Assim sendo, a noção de variabilidade na AET é central, pois o trabalho nunca é o resultado imediato das normas prescritas, mas pressupõe um percurso de elaboração e reorganização por parte do trabalhador, simultaneamente cognitivo e situado na prática. (LIMA, 1995)

Como estratégia para realizar estudos nos locais de trabalho, a Etnometodologia e a AET compartilham dos princípios da metodologia etnográfica. Segundo Wisner (1994), a AET pode ser conhecida como uma pesquisa etnográfica, se voltada para detecção das dificuldades impostas pelo ambiente de trabalho e pelas exigências pragmáticas que atrapalham as atividades do trabalhador.

Nos estudos em Etnometodologia Have (2004) destaca que não existem métodos específicos e sugere as seguintes estratégias para acessar o detalhe das atividades nos estudos nos locais de trabalho: observar o que as pessoas fazem, tanto as experiências novas como as 
atividades de rotina; observar os trabalhadores, tanto os experientes como os novatos; observar como os trabalhadores seguem as instruções e o seu aprendizado; observar e gravar de forma interativa, inclusive as "mímicas incompreensíveis" e as atividades dos atores; observar e gravar as tarefas de aprendizado; combinar a etnografia e gravação no local de trabalho.

Assim, ao se destacar o papel ativo dos atores sociais, os pesquisadores devem ser capazes de contextualizar suas descrições a partir da lógica, dos raciocínios específicos e das situações de vida prática desses sujeitos.

\section{Inserção e desenvolvimento em campo}

Após concordância dos gestores do hospital com a realização do estudo, o projeto de pesquisa foi encaminhado ao Comitê de Ética em Pesquisa da Maternidade Climério de Oliveira e foi aprovado conforme Parecer n. ${ }^{\circ}$ 045/2009.

No primeiro contato com os sujeitos da pesquisa se expôs o projeto, os objetivos e os métodos a serem utilizados, ressaltaram-se os procedimentos éticos envolvidos e se convidou os fisioterapeutas a participarem de forma voluntária do estudo. Todos os participantes desta pesquisa receberam um código no intuito de não permitir a sua identificação e assinaram o Termo de Consentimento Livre e Esclarecido.

Nas primeiras visitas ao campo, procurou-se entender o funcionamento da UTI. As primeiras entrevistas foram feitas com a chefia do Serviço de fisioterapia e com o coordenador de fisioterapia da UTI. Estas entrevistas foram semiestruturadas, a partir das quais se objetivou conhecer os aspectos organizacionais do Serviço de fisioterapia na UTI. Utilizou-se um roteiro como guia, contudo, vale observar que este não foi utilizado de forma rígida, foram acrescentadas novas questões que surgiram na construção interacional com os entrevistados.

Foram realizadas também entrevistas com os componentes do Serviço de Controle de Infecção Hospitalar (SCIH), da Comissão Interna de Prevenção de Acidentes (CIPA) e do Serviço de Medicina Ocupacional do Hospital (SESAO) que tiveram como conteúdo a forma de Gestão do Risco na Instituição com ênfase nas ações voltadas para a UTI. 
Foram entrevistados vários interlocutores (fisioterapeutas, gestores, cursistas) e fez-se consulta aos documentos acerca do trabalho dos fisioterapeutas na UTI.

Realizou-se, nesta primeira etapa, um estudo global do funcionamento da UTI, da organização do trabalho, da produção e dos determinantes das tarefas.

Após essa etapa, iniciaram-se as observações, considerando as variáveis: deslocamento dos fisioterapeutas, direção do olhar (ao buscar informação), comunicação (com os colegas, com a chefia e com a pesquisadora), posturas, ações e tempo, que foram registradas em diário de campo. Observaram-se a sequência de ações, as modificações do modo operatório ditadas pelas variabilidades do processo de trabalho, dos pacientes, variabilidades entre os próprios fisioterapeutas, os padrões de comportamento (estratégias) adotados na execução das tarefas.

Foram acompanhadas as passagens de plantão da equipe de fisioterapia, as visitas, as rotinas diárias, os atendimentos fisioterapêuticos na UTI e fora desta, a evolução em prontuários, as discussões clínicas e os encontros ocorridos na copa e na sala de fisioterapia.

A partir das observações gerais, realizou-se o acompanhamento de um profissional por período de observação, com o objetivo de apreender a dinâmica da atividade de forma detalhada. Assim, foi possível realizar a crônica da atividade do fisioterapeuta na UTI. Os sujeitos da pesquisa nesta etapa foram 11 fisioterapeutas assistenciais da UTI, sete mulheres e quatro homens, com idade entre 23 e 37 anos e tempo de serviço na UTI bastante variado, mas com uma média de cinco anos.

O trabalho em campo ocorreu durante os horários da manhã, tarde e noite - incluindo feriados e finais de semana - considerando-se as variações no volume de trabalho e a diversidade das tarefas. A média de permanência diária na UTI foi de cinco horas e ocorreu entre os meses de julho e dezembro de 2009. O tempo total de observação correspondeu há 85 horas e 41 minutos. O tempo total de entrevistas não situadas correspondeu há 3 horas e 5 minutos.

$\mathrm{Na}$ observação participante, procurou-se apreender, em profundidade, a sequência das verbalizações, a atividade ordinária dos fisioterapeutas, suas estratégias e discurso tácito diante dos riscos biológicos e da insuficiência dos meios de trabalho. Interessou-se não apenas pelo discurso dos atores sociais, mas também pela sua metalinguagem de- 
sordenada, os acidentes, as contingências que se misturavam à sua prática cotidiana.

As entrevistas situadas foram iniciadas após um período de familiarização com o campo e contato com o seu cotidiano. A intenção da entrevista foi complementar os dados das observações. Desse modo, realizaram-se entrevistas situadas e/ou consecutivas às atividades dos trabalhadores. Estas foram abertas, com conteúdo organizado de acordo com as questões que surgiram em campo, pautadas no interesse da investigação e no curso das atividades.

Guérin e colaboradores (2001, p.156) fazem a seguinte descrição sobre as verbalizações simultâneas e consecutivas:

As verbalizações simultâneas apresentam o interesse de produzir explicações no próprio contexto da atividade. As condições concretas de seu exercício são apresentadas [...]. O operador está em "situação" para expressar-se, o ergonomista em "situação" para compreender [...]. As verbalizações consecutivas, por seu lado, apresentam o interesse em preservar o desenvolvimento normal da atividade. São geralmente coletadas apresentando ao operador o resultado de observações [...]. (GUÉRIN et al., 2001)

Para a validação das informações obtidas, retornou-se ao campo para autoconfrontação das situações observadas, em que os sujeitos da pesquisa foram convidados a falar sobre o seu próprio comportamento, a partir da descrição feita. Os comentários e impressões destes sobre as situações foram anotados no diário de campo.

Como resultado de todas estas etapas, foi estabelecido o diagnóstico de que os fisioterapeutas utilizam estratégias para lidar com os riscos biológicos e as limitadas condições materiais na execução de suas atividades na UTI.

\section{Resultados e discussão}

A Unidade de Terapia Intensiva Geral de um Hospital Universitário (HU) em Salvador, Bahia, destina-se a uma clientela composta de pacientes internados oriundos das enfermarias do hospital ou procedentes de outros hospitais que vêm encaminhados pela Central de Regulação do SUS. 
O HU é uma unidade hospitalar de alta complexidade, pública, geral, de grande porte, com capacidade de internação plena de 276 leitos. A capacidade da UTI é para 16 leitos, porém, na época do estudo, funcionavam dez. Seu espaço físico está dividido em área administrativa, área de internamento de pacientes, vestiários e copa.

A unidade disponibiliza, como recursos tecnológicos para o cuidado dos pacientes criticamente enfermos, respiradores, bombas infusoras, monitores de dados vitais, desfibriladores, carro de urgência equipado para ressuscitação cardiorrespiratória, entre outros. Por vezes, o quantitativo de materiais de consumo (luvas, roupas de cama, roupas privativas e para os pacientes, sabão para lavagem das mãos, entre outros) é insuficiente. Não são infrequentes reclamações acerca da qualidade e do quantitativo dos materiais e equipamentos presentes na UTI, a exemplo dos Equipamentos de Proteção Individual (EPI), respiradores, oxímetros, o que gera esforço extra, exigindo criatividade e adaptação dos membros da UTI para realizar o seu trabalho.

A equipe de profissionais que atua na UTI é composta por médicos, enfermeiros, técnicos de enfermagem, fisioterapeutas, nutricionistas, auxiliar administrativo, coordenador médico de enfermagem e de fisioterapia, além de docentes de ambas as áreas e outros profissionais que interagem diariamente esta Unidade.

Nos plantões diurnos, a equipe, geralmente, compõe-se de: um médico plantonista, quatro enfermeiras, quatro enfermeiras residentes, oito técnicos de enfermagem, dois fisioterapeutas, quatro cursistas de fisioterapia. Nos plantões noturnos, há um médico plantonista, duas enfermeiras, oito técnicos e um fisioterapeuta.

A assistência aos pacientes ocorre durante 24 horas ininterruptas. Os profissionais se revezam em três turnos de trabalho: o plantão da manhã (7 às 13h), o plantão da tarde (13 às 19h) e o plantão noturno (19 às 7h), com carga horária semanal variando entre 24, 30 e 40 horas semanais, a depender da categoria profissional.

Pela manhã o ritmo de trabalho das equipes é intenso; acontecem banhos, avaliações, prescrições, procedimentos de todas as equipes, inclusive da de fisioterapia. Os diálogos geralmente são a respeito do quadro dos pacientes e das tarefas assistenciais. O ritmo é menor no final da manhã, geralmente entre $12 \mathrm{~h} 30$ e $13 \mathrm{~h}$, quando ocorrem trocas de plantões entre as equipes e parada para almoço. 
O número de pessoas por equipe, principalmente de estudantes que circulam no ambiente da UTI, é grande e muitas vezes torna-se crítico, especialmente no período da manhã, o que interfere na circulação dos profissionais e na execução de suas tarefas.

No trabalho diurno, há poucos momentos para o descanso e estes geralmente ocorrem no horário de visita de familiares, associados à escrita em prontuários e discussões com os cursistas, ou nos horários de almoço.

No período da tarde, geralmente, ocorrem menos procedimentos, contudo, pode tornar-se crucial, com grande restrição de tempo para o fisioterapeuta realizar suas tarefas, quando há somente um fisioterapeuta de plantão na UTI, por remanejamento do seu colega para outras unidades do HU, em caso de desfalques na escala por doença ou por outros motivos.

O plantão noturno inicia-se às $19 \mathrm{~h}$, quando um dos fisioterapeutas do dia passa o plantão para o seu colega que complementará 24 horas ou para o colega que está chegando para o turno. À noite, disponibiliza-se um plantonista de fisioterapia para dez pacientes e prestação de assistência complementar nas unidades de internamento; nesse período, há um momento para descanso, o que pode acontecer ou não a depender da ocorrência de contingências durante o plantão.

Um fato peculiar desse serviço é a forma de contratação dos fisioterapeutas, havendo concursados pela Universidade e pela Secretaria de Saúde do Estado, contratados pela Fundação de Apoio à Pesquisa e Extensão (FAPEX) e bolsistas desta mesma Fundação. Os múltiplos tipos de vínculos dentro de uma mesma instituição podem gerar diferentes formas de gestão do trabalho e repercussões sobre a saúde do trabalhador.

Observa-se, assim, um processo de flexibilização das relações de trabalho no Hospital em estudo. De acordo com Baraldi e colaboradores (2008), este tipo de relação de trabalho no Brasil, costuma ocorrer no setor de saúde, nas situações em que o principal empregador é o Estado (Municípios, Estado e União) em decorrência de um duplo movimento: por ausência de concursos públicos e pela utilização intensiva de contratação de pessoas através de Organismos Internacionais, Organizações Não-Governamentais (ONGs), Organização da Sociedade Civil de Interesse Público (OSCIP), Cooperativas, entre outras Organizações. 
Para Druck (1999), a contratação através de terceiros tem implicado em um processo de precarização dentro e fora das empresas. No interior das empresas, este processo interfere nas relações de trabalho, quando há transferência dos custos e obrigações trabalhistas para terceiros, gerando duas categorias de servidores: os efetivos (de primeira classe) e os subcontratados (de segunda classe), no que se refere às condições de trabalho e aos salários.

No tocante aos riscos ocupacionais, Borges e Franco (1997) chamam atenção para o fato de que o processo de terceirização aumenta os riscos para acidentes no trabalho e desenvolvimento de doenças pelos trabalhadores, além da falta de proteção destes, porquanto a responsabilidade de garantir a saúde e a segurança é, geralmente, transferida para terceiros.

Outro fato que chama a atenção na UTI são os múltiplos vínculos dos fisioterapeutas com outras instituições. Isto gera uma quantidade elevada de horas trabalhadas no mês. A maioria dos fisioterapeutas desta UTI acumula carga horária mensal de 240 horas e alguns atingem até 360 horas de serviço. Isto é reflexo de um mercado de trabalho complexo e desigual que impõe baixos salários, demandando, o acúmulo de vários empregos.

\section{O fisioterapeuta na dinâmica da UTI}

O fisioterapeuta na assistência aos pacientes internados, presta cuidados respiratórios e motores, uma vez que, com frequência, os pacientes neste ambiente estão internados por longo período e sob ventilação artificial.

A reexpansão pulmonar, a remoção de secreções e a mobilização dos pacientes são as principais técnicas utilizadas, assim como a participação nos ajustes e instituição da ventilação mecânica, do desmame ventilatório e das extubações.

Diversos estudos mostram a importância das atividades dos fisioterapeutas na UTI, destacando-se a redução do tempo de permanência na ventilação mecânica; redução dos custos da UTI e da estadia no Hospital; redução da ansiedade do paciente durante o desmame do respirador; rápida mobilização com redução dos efeitos da imobilidade no leito e melhoria da independência funcional dos pacientes in- 
ternados. (ELY; BAKER; DUNGAN, 1996; HORST et al.,1998; HALL; WOOD,1987 DEAN; ROSS 1992; DEAN, 1994) Segundo Richardson (1999), o conhecimento profissional do fisioterapeuta na sua prática cotidiana é consolidado em uma dinâmica contextual, a partir de sua experiência pessoal, da capacidade de sintetizar e interpretar os fatos e assim definir a sua atuação.

Os membros do grupo adquirem uma perspectiva compartilhada através de meios que tácita ou explicitamente negociam e interagem. Não é incomum para o fisioterapeuta, ao olhar para os movimentos respiratórios de um paciente que se encontra na ventilação artificial, perceber que este necessita ser abordado. Ao pegar o seu estetoscópio para auscultá-lo rapidamente, o seu colega, por sua vez, já se aproxima do leito ajudando-o nas condutas e nos ajustes ventilatórios. Assim, ambos normalizam e restabelecem um movimento torácico próximo ao aceitável.

É no seu cotidiano que estes se deparam com situações em que cuidar do paciente é prioridade, muitas vezes em detrimento dos cuidados com o seu próprio corpo e com a sua saúde. O primeiro compromisso estabelecido é com seu paciente, como na cena descrita: o (a) fisioterapeuta é chamado durante um procedimento de traqueostomia na UTI para ajustar os parâmetros ventilatórios do paciente. Durante o procedimento, nota que o seu braço fora sujo por respingos de sangue do paciente; não fazia uso de óculos ou capa de proteção. Após garantir que o procedimento fora realizado e que o paciente estava bem ajustado no respirador, sai e dirige-se à pesquisadora e mostra-lhe o braço sujo. (CENA 1/ FISIOTERAPEUTA “D”)

\section{O trabalho prescrito}

A estrutura organizacional do HU foi reformulada no ano de 2007, com substituição das estruturas hierárquicas verticais, por um modelo circular/transversal. No modelo de gestão organizacional circular, não se eliminam as hierarquias, mas adota-se como meta mudar o centro das atenções da instituição para os usuários e assim facilitar a comunicação dentro da instituição. (HUPES, 2009)

A carga horária de trabalho dos fisioterapeutas assistenciais da UTI é de 120 horas mensais (30 horas semanais). Os dias de trabalho 
são prefixados com plantões ininterruptos de 24 horas na UTI e complementação da carga horária de 6 horas nas Unidades de Internação (UIs). Os fisioterapeutas mais antigos do serviço e concursados pela universidade têm prioridade para escolha dos plantões.

O quantitativo de pacientes é dividido entre os dois fisioterapeutas assistentes e o estagiário de fisioterapia. O coordenador de fisioterapia da UTI, eventualmente, no período da manhã, participa da assistência aos pacientes e da supervisão aos cursistas durante os atendimentos, quando ocorre remanejamento de um dos fisioterapeutas assistenciais da UTI, por carência em outras unidades do hospital.

Funcionam duas atividades docentes de fisioterapia na UTI, quais sejam: um estágio supervisionado vinculado a duas faculdades de Salvador e um curso de extensão vinculado à universidade. $\mathrm{O}$ curso não ocorre durante o período noturno, conforme negociação entre os fisioterapeutas e os gestores, uma vez que, segundo os fisioterapeutas, acompanhar o cursista durante as 24 horas gera uma demanda extra de trabalho.

O quantitativo e tempo de atendimento na UTI são bastante variáveis e são baseados no quadro clínico dos pacientes. Desta forma, enquanto alguns pacientes podem ser atendidos apenas uma vez por turno de seis horas, o que totalizaria dez atendimentos no período, outros podem necessitar de vários atendimentos.

Outras tarefas que competem ao fisioterapeuta na UTI são: a montagem, instituição, troca de filtros de respiradores, monitorização e assistência ventilatória aos pacientes sob ventilação mecânica; troca de frascos de aspiração e seus circuitos, após o uso; instalação de nebulizações em pacientes sob ventilação mecânica; registro de materiais sujos de fisioterapia para encaminhamento ao Centro de Esterilização de Materiais (CME); instituição e assistência ventilatória aos pacientes durante realização de exames externos à UTI, dentro da instituição.

Cabe, além disso, ao fisioterapeuta a realização das seguintes tarefas nas UIs: assistência fisioterapêutica a pacientes procedentes da UTI, que ainda necessitem de assistência noturna ou intensiva; transporte, montagem de respirador e ajuste de parâmetros ventilatórios a pacientes que necessitem de ventilação mecânica, enquanto não houver vagas nas UTIs, no período noturno ou em emergências. 
O controle de desempenho individual é realizado de acordo com o vínculo institucional. Para os servidores da universidade, é realizado a cada 18 meses, através da avaliação formal dos seguintes critérios: adaptabilidade; alcance de resultados; atendimento ao público; capacidade de solução de problemas; compromisso ético; compromisso com as funções, responsabilidades e metas; domínio das ferramentas de trabalho; interesse em capacitar-se profissionalmente; qualidade no trabalho; relacionamento interpessoal; trabalho em equipe e utilização racional dos recursos. Esta avaliação constitui-se um dos critérios utilizados para progressão do servidor na carreira pública.

Para os servidores de Secretaria de Estado que estão em fase de estágio probatório, é aplicada uma avaliação formal a cada seis meses. Os seguintes itens são ponderados: assiduidade; disciplina; iniciativa; produtividade e responsabilidade. A avaliação é realizada pela chefia imediata, justapondo-se a uma autoavaliação, sendo que o resultado pode variar de insatisfatório a excelente. Para os funcionários da Fundação de Apoio à Pesquisa não existe uma avaliação formal e esta é feita de forma subjetiva, de acordo com a necessidade que é determinada pela chefia imediata e pelo coordenador da UTI.

\section{A forma de gestão de riscos}

A realização de tarefas dentro da UTI está subordinada a normas de biossegurança que padronizam critérios a serem seguidos pelos trabalhadores que atuam naquele ambiente. Pressupõe-se, assim, que o modelo de segurança adotado na UTI baseia-se na forma tradicional que corresponde à prescrição de procedimentos e comportamentos seguros.

É importante citar que a legislação que dispõe sobre a Política Nacional de Biossegurança no Brasil está vinculada à Lei $\mathrm{n}^{\circ} 11.105$, de 25 de março de 2005. A Portaria $\mathrm{n}^{\mathrm{o}} 37$, de 6 de dezembro de 2002, instituiu a Norma Regulamentadora (NR) 32, que trata especificamente da segurança e saúde do trabalho nos estabelecimentos de assistência à saúde.

Na UTI, encontra-se disponível o "Manual de Infecção Hospitalar", que foi elaborado pelo SCIH e discorre sobre as precauções básicas que dizem respeito a medidas que devem ser adotadas pelos trabalhadores de saúde, quando em contato com sangue e fluidos corpóreos, de 
qualquer paciente considerado como potencialmente infeccioso para o vírus HIV, Hepatites $\mathrm{B}$ e $\mathrm{C}$ e de outros patógenos sanguíneos. Essas medidas incluem a utilização de EPI e/ou Equipamentos de Proteção Coletiva (EPC). (BRASIL, 1983)

No tocante ao fornecimento dos EPIs, conforme se observa na fala dos fisioterapeutas, esses materiais nem sempre são de boa qualidade, $o$ que gera insegurança para eles, como verbaliza um dos fisioterapeutas: "Aqui todas são muito finas" [refere-se à capa descartável]. "Essas luvas são de péssima qualidade, são extremamente porosas [...]. Essa daqui não cabe nem 1L de água, se colocar 2L, ela nem vai, ela estoura" [refere-se ao teste de vazamento da luva sugerido pelo SCIH que consiste em colocar 2L de água dentro da luva e observar vazamentos; se ocorrerem é porque é de qualidade duvidosa] (FISIOTERAPEUTA "F").

Observa-se a culpabilidade do trabalhador implícita no fluxograma (disponível na UTI) a ser seguido pelos trabalhadores em caso de acidentes com sangue e fluído biológico, quando em contato com mucosas, ou acidentes perfurocortantes. Neste fluxograma estão contidas importantes informações das etapas a serem seguidas após o acidente, contudo evidencia-se em uma das etapas o encaminhamento do profissional acidentado para treinamento. Este encaminhamento pode estar baseado na concepção sobre acidente de trabalho (AT) e sua causalidade que admite ser o AT acarretado apenas por imperícia do trabalhador. Neste caso, o contexto no qual o acidente foi gerado e as condições reais encontradas durante o cumprimento das tarefas são negligenciadas.

\section{O trabalho real}

As circunstâncias em que o trabalhador se encontra para executar suas tarefas diferem das condições determinadas a priori, observando -se que, muitas vezes, entram em choque com as tentativas de padronização, haja vista os processos organizacionais e a estrutura existente.

\section{Relações entre as equipes}

A UTI, por ser um local de circulação mais restrita de pessoas, permite um convívio mais próximo entre as equipes de trabalhadores que ali atuam. Em geral, o relacionamento observado é afetivo e cordial. 
As equipes conversam durante os plantões de forma amigável, interagem entre si nos horários que conseguem tirar alguma folga.

No desenvolvimento das tarefas, observa-se complementaridade e interdependência das diferentes categorias profissionais. Podem-se mencionar como exemplos situações em que a equipe de enfermagem realiza transferências de pacientes do leito para macas com o auxílio de fisioterapeutas e médicos. Outra situação seria quando a equipe de fisioterapia coloca o paciente para deambular ou faz transferência deste do leito para cadeira, com o auxílio da equipe de enfermagem no manuseio de soluções e medicamentos em uso.

Todavia, nesta complexa trama de saberes, cuidados e interações sociais, ocorrem situações de conflitos e até de disputa entre esses trabalhadores. Podem-se citar situações conflitantes entre as equipes de fisioterapia e enfermagem, no que se refere à aspiração dos pacientes. Observam-se atitudes de relutância das equipes em relação ao que lhes cabe como tarefa. Podem-se trazer à baila situações em que o fisioterapeuta é interrompido durante a realização de atendimento a um paciente para que realize exclusivamente aspiração de secreção respiratória em outro paciente, como se evidencia na fala seguinte:

A equipe de enfermagem não aspira o paciente. Eventualmente acontece,
elas fazem depois do banho, mas a maioria não faz, tanto é que elas dão ba-
nho na paciente, depois elas mandam chamar a gente dizendo que o paciente
está desconfortável. A gente sabe que é secreção. Teoricamente, se elas estão
dando banho no paciente, fazer uma aspiração no paciente que está descon-
fortável, não deixa de ser uma higiene, então elas podem aspirar, porque não
é coisa só da gente. [...] A gente não tem como ficar aspirando. Imagine que
aqui tem 10 pacientes, se toda hora a gente ficar indo no leito do paciente
pra realizar uma aspiração que a equipe de enfermagem poderia ter feito, a
gente deixa de dar atendimento a outro paciente. Se a gente tiver que aspirar
mais 3,4 vezes cada paciente, são 10 [refere-se ao quantitativo de pacientes].
(FISIOTERAPEUTA "D")

A cena demonstra que a indefinição do que cabe como tarefa aos profissionais pode ser objeto de conflito entre os membros das equipes de fisioterapia e de enfermagem. Em um estudo qualitativo realizado por Nascimento e colaboradores (2006), referente à profissionalização da fisioterapia, nas décadas de 50 a 80 em Minas Gerais, os autores ressaltam que a definição e o desenvolvimento das competências do fisioterapeuta nas equipes de saúde foram motivo de disputa e conflitos 
entre os profissionais de enfermagem e de fisioterapia, sendo que as atividades passaram a ser desenvolvidas e estruturadas de acordo com sua complexidade, ficando estabelecido que as atividades consideradas de menor complexidade começaram a ser delegadas aos auxiliares de enfermagem e as de maior complexidade foram incorporadas pelos fisioterapeutas.

De acordo com Farrell, Schimiti e Heinemann (2001), na convivência multiprofissional, as equipes muitas vezes podem se tornar polarizadas na luta pelo poder entre subgrupos, com diferentes visões sobre como estes devem funcionar. À medida que os membros convivem, descobrem as divergências sobre sua missão, como o trabalho deve ser organizado e as formas de controle de determinados grupos sobre os outros.

Considerando que a profissão de fisioterapeuta teve sua autonomia profissional reconhecida, a partir do Decreto Lei no. 938 de 13 de outubro de 1969, portanto há apenas 41 anos, e que não há no Código de Ética desta categoria o que lhe cabe como tarefa, é esperado que sua autonomia e suas competências sejam desenvolvidas dentro de visões, muitas vezes, inconciliáveis, de distintos atores, a partir dos diferentes espaços que ocupam numa mesma instituição. (CECÍLIO, 2005)

Outra situação que expressa esta tensão ocorre quando os fisioterapeutas, durante a realização de atividades assistenciais aos pacientes, são surpreendidos pela equipe de enfermagem que inicia os banhos e até curativos antes que os fisioterapeutas finalizem as suas tarefas. Isso força o fisioterapeuta a acelerar a execução de um procedimento que já está em curso e interromper outras condutas que realizaria naquele momento, fragmentando assim suas atividades. A cena descrita a seguir pode evidenciar esta experiência.

O fisioterapeuta está no isolamento respiratório, em uso de capa, máscara de barreira, luvas, aspirando um paciente e, durante suas condutas, um técnico de enfermagem entra no quarto e o avisa que terá de iniciar o banho, pois o plantão está pesado e ele está atrasado. O fisioterapeuta argumenta que está no meio de um procedimento, mas cede. Quando sai do quarto, comenta com a pesquisadora: “[...] preferi não contestar muito, pois não conheço bem este técnico e não quero causar atritos entre as equipes de fisioterapia e enfermagem, que têm um bom relacionamento $[. .$.$] ". O fisioterapeuta interrompe a sua atividade, reti-$ 
ra todos os EPIs e sai do quarto, dirigindo-se para outro leito. (CENA 2/ FISIOTERAPEUTA “O”)

$\mathrm{Na}$ análise dessa cena, evidencia-se que, embora o fisioterapeuta, no seu discurso expresse que tem um bom relacionamento com a equipe de enfermagem, em vários momentos percebe-se o desrespeito e o não reconhecimento da importância do trabalho do fisioterapeuta, com prejuízo na sua autonomia nesta unidade.

Naronem e Wikstrom-Grotell (1999) salientam que a autonomia do profissional pode estar comprometida se não houver uma clara definição da especificidade da fisioterapia e apropriação por parte do fisioterapeuta do seu espaço nas equipes de saúde. Nascimento e colaboradores (2006), de forma semelhante, consideram que para afirmação efetiva do fisioterapeuta se faz necessário o estabelecimento da competência (seu saber e fazer) como instrumento de sua apropriação e atuação, o que denota ser capaz de delimitar seu papel na equipe interdisciplinar.

\section{O rápido aumento da demanda de trabalho ou demandas conflitantes}

No ambiente da UTI, são constantes as intercorrências com os pacientes, o que consiste em situações clínicas de emergência, fazendo com que toda a equipe se mobilize rapidamente. Isto gera célere intensificação da demanda de trabalho e aumento das restrições de tempo. De acordo com Guérin e colaboradores (2001), a intensificação do trabalho refere-se ao uso das capacidades cognitivas e fisiológicas dos trabalhadores, que a depender das escolhas de soluções e dos compromissos firmados, podem ultrapassar seus limites e contribuir para sua exposição aos riscos e consequente degradação da sua saúde.

Pode-se observar que o tempo é um dos elementos mais importantes na determinação dos modos operatórios dos fisioterapeutas. A complexidade do atendimento e a demanda de pacientes impõem ao fisioterapeuta o desenvolvimento de habilidades para que essas restrições sejam superadas, ainda que essas ocasionem agravos à saúde. Além disso, esses profissionais estão submetidos a protocolos de operacionalização de suas tarefas e necessitam de margem de tempo e de 
liberdade durante o seu trabalho para operacionalizar as suas atividades dentro das situações reais que se apresentam no seu cotidiano.

A fala de um Fisioterapeuta evidencia o que se diz:

O ritmo da UTI é muito intenso. Paciente de UTI já é um paciente que precisa de um cuidado maior, mas os pacientes daqui precisam de um cuidado maior ainda, porque são pacientes que já chegam bem debilitados ou vêm acumulando ao longo do tempo algum problema, doença por cima de doença. Ele termina chegando aqui bem gravizinho, já bem difícil de cuidar, então a gente já sai cansado por conta disso. São pacientes que a gente tem que trabalhar bastante. A gente tem um protocolo a ser seguido, então a gente tem que fazer, trabalhar a parte ventilatória toda do paciente [...]. (FISIOTERAPEUTA “D”)

Nas ocasiões de maior demanda, o risco de acidentes aumenta consideravelmente. A dificuldade é saber como conciliar rapidez e atenção, com cuidado na execução da tarefa em situações de emergência, em que a prioridade é restabelecer as condições clínicas do paciente. Isso é caracterizado pela cena descrita abaixo: A fisioterapeuta está orientando um cursista para higienizar um oxímetro que transferirá de um paciente para outro; ao olhar para o monitor observa e comenta: "paciente parou"; corre e ajuda nas manobras de cardiorressuscitação da paciente "A". Após reversão da situação, vai participar da ventilação da paciente "B", que será submetida a uma cardioversão elétrica; para isso, adapta uma luva de procedimentos como, reservatório de oxigênio na bolsa valva e começa a ventilar a paciente. Neste momento, há 11 pessoas ao lado da paciente. A fisioterapeuta então é chamada para uma nova urgência, pois o paciente " $\mathrm{C}$ " está com grande esforço respiratório. Transfere a ventilação do "B" para um dos médicos residentes e se dirige rapidamente ao paciente " $\mathrm{C}$ ". Após exame, começa a aspirar e ajusta o respirador. Constatado que o paciente "D" está "dessaturando" e ventilando mal, a fisioterapeuta mais uma vez é solicitada, então avalia, aspira, ajusta o respirador. Retorna para a paciente "B" para ajudar e então comenta: "fisioterapeuta não consegue nem tomar remédio". Mais uma vez é chamada, pois o paciente " $\mathrm{B}$ ' que fez vários períodos de bradicardia agora está com muita secreção pulmonar e "dessaturando". Sai correndo, começa a aspirar sem máscara. No decorrer da aspiração pega a máscara que se encontrava próximo ao seu rosto e a ajusta de qual- 
quer maneira, então cogita: "é muita aspiração em tão pouco tempo". (CENA 3/ FISIOTERAPEUTA “D”)

Como se pode observar, são quatro pacientes que, simultaneamente, apresentaram intercorrências clínicas com súbito aumento da demanda de trabalho para o fisioterapeuta. Assim, a pressão de tempo determina a maior vulnerabilidade do trabalhador ao contato com fluidos corpóreos dos pacientes com a sua pele e as suas mucosas.

Os fisioterapeutas experimentam constantes interrupções em suas rotinas de trabalho, decorrentes das emergências e das diversas contingências ocorridas com grande frequência na UTI ou em outras unidades. A cena abaixo evidencia uma dessas situações:

O fisioterapeuta é interrompido durante as suas condutas e é solicitado a atender a um telefonema procedente da UI. Observa-se que durante o telefonema se mostra irritado com o conteúdo da conversa e comenta: "coleta é só aspirar e colocar no copo". Após desligar o telefone, diz: "ela [refere-se à enfermeira de uma Unidade de Internamento] quer que eu vá lá fazer uma cultura do paciente. Qualquer profissional pode fazer isso. Ligar para aqui e eu ter que ir lá embaixo, fazer uma aspiração do paciente! Aí é demais". (CENA 4/ FISIOTERAPEUTA “D”)

Pode-se perceber, desta forma, que o fisioterapeuta não tem alto grau de controle sobre o trabalho no qual está inserido, embora sua capacidade de regulação seja fundamental para que ele possa gerir as variabilidades. Segundo Abrahão (2000, p. 51),

[...] quanto maior a variabilidade das situações, menor a probabilidade de antecipação, exigindo assim, maior competência dos trabalhadores para a passagem de uma operação prescrita a uma ação situada (contextualizada). Esta competência possibilita, também, redefinir a atividade, favorecendo a reconstituição de situações anteriores por meio de reformulações, utilizando para isto recursos do próprio contexto como, por exemplo, o apelo à competência de outros trabalhadores, a elaboração de novos parâmetros para esta atividade ou, até mesmo, a utilização eventual de uma estratégia operatória antiga.

\section{As estratégias utilizadas diante das limitações de materiais}

$\mathrm{Na}$ UTI, os fisioterapeutas, muitas vezes, encontram limitadas condições materiais e inadequação de equipamentos. Tais limitações levam esses sujeitos a desenvolverem estratégias operatórias - depen- 
dentes das experiências adquiridas durante a sua vida profissional, no relacionamento com o outro - para gerirem as variações internas e externas, minimizando assim os riscos biológicos ao desenvolverem o seu trabalho.

Para Barros e colaboradores (2006), por meio de um estudo realizado em um Pronto-Socorro de um Hospital, ficaram evidentes a criação de vínculos e as negociações cotidianas entre os trabalhadores para que a efetuação do trabalho fosse possível e tivesse melhor qualidade. Tal posicionamento demonstrou o desenvolvimento de estratégias para lidar com a alta imprevisibilidade do trabalho.

Segundo Guérin e colaboradores (2001), as atividades de um operador em um determinado momento são organizadas em função de diferentes objetivos e, a depender da situação, a margem de manobra que este tem para atender a tais objetivos pode ser maior ou menor.

Outra situação observada diz respeito à falta de materiais privativos nos leitos dos pacientes sob isolamento de contato. No Manual de Infecções Hospitalar da SCIH do Hospital, consta que nos leitos em isolamento de contato deve haver preferencialmente um estetoscópio disponível para uso exclusivo. Contudo, vê-se a cena descrita adiante: ao entrar no quarto e pegar o estetoscópio de uso privativo do paciente, o fisioterapeuta percebe que o mesmo encontra-se com defeito, sem uma das olivas, e o diafragma solta com facilidade. Então, avisa à cursista que esta deve pegar três luvas, sendo que uma das luvas deverá ser utilizada sobre o diafragma do seu estetoscópio para protegê-lo. O fisioterapeuta justifica que optou por colocar a luva por se tratar de uma proteção a mais, para que, ao transportar o seu estetoscópio junto com seus pertences pessoais em sua mochila e posteriormente usá-lo em outros pacientes, a cursista não corresse o risco de contaminação. Em seguida, faz a seguinte verbalização para a pesquisadora:

No caso desse leito, que não tem disponível estetoscópio pra gente fazer a avaliação [...], temos que usar o nosso estetoscópio, que é uma coisa que não gosto de fazer, particularmente, mas com a limitação que a gente tem no hospital, a gente não tem outra opção. (CENA 5/FISIOTERAPEUTA “H”)

Percebe-se que, ao usar uma luva amarrada sobre o diafragma do estetoscópio durante a ausculta dos pulmões do paciente, o fisioterapeuta faz uso de uma regulação para assim supostamente prevenir a 
contaminação de seu estetoscópio, minimizando os riscos de transmitir infecção para outros pacientes e para ele mesmo. Assim, à medida que o conhecimento tácito do fisioterapeuta vai se consolidando, o mesmo vai lançando mão de estratégias para vencer as adversidades no contexto da UTI.

De acordo com Abrahão (2000), no trabalho real existem situações em que não é suficiente para o trabalhador apenas cumprir regras, é necessário interpretar, corrigir e, muitas vezes criar, para atender às exigências da situação de trabalho.

Outra situação observada ocorreu durante a realização de aspirações de secreções pulmonares nos pacientes internados na UTI. Note-se na cena descrita abaixo:

Durante a aspiração de um paciente, a cursista chama o fisioterapeuta e comenta: "o vácuo não está pegando nada, o vácuo não está funcionando". O fisioterapeuta, então, faz ajustes na conexão do frasco de aspiração com o vácuo e com a válvula de controle de força do vácuo e então pergunta: "Está funcionando, não está? Pela zoada acho que está [...]. Quem aguenta?” Posteriormente, comenta que demorou muito nos atendimentos na noite anterior por conta de o vácuo de aspiração estar com problemas e completa: "a sorte é que os outros estavam tranquilos, não requereram muita atenção" [refere-se aos demais pacientes da UTI]. (CENA 6/ FISIOTERAPEUTA “B”)

$\mathrm{Na}$ cena descrita, observa-se que o trabalhador usou sua competência, mobilizando sua subjetividade e desenvolvendo uma atitude que permitisse uma antecipação dos eventos, para assim realizar o seu trabalho. Esta ação foi compartilhada pelo (a) cursista.

Em uma das cenas, os fisioterapeutas usam como estratégia o racionamento de capa descartável para evitar falta desse dispositivo de proteção: Um fisioterapeuta está pronto para colocar uma paciente na posição sentada e chama seu colega para auxiliar: "vamos aqui, que esta paciente é muito pesada". O colega então responde: "não, vamos economizar a capa, né?". Neste dia, a UTI está com sete pacientes sob isolamento de contato e para atender a esses se faz necessário o uso de capas descartáveis de proteção (CENA 7/FISIOTERAPEUTAS “S” e “D”).

Segundo Guérin e colaboradores (2001), os responsáveis pela organização do trabalho frequentemente minimizam a variabilidade do trabalho, dos sistemas técnicos, da diversidade dos serviços a realizar, 
ou dão a impressão de que essa variabilidade é totalmente previsível e controlável; contudo, é no exercício vivo de suas funções que os trabalhadores vão passar por momentos em que só o seu trabalho permite a regulação desses incidentes, e isto não é simples.

A despeito dos riscos de contato com material biológico nos olhos durante suas tarefas, principalmente aspirações de secreções pulmonares, os fisioterapeutas as realizam sem uso de óculos de proteção. Constatemos nas cenas e falas abaixo demonstradas:

O fisioterapeuta realiza, juntamente com a cursista, manobras de tosse assistida, pressurizações com o respirador e aspirações de secreções em um paciente tetraplégico que tem dificuldade de eliminar secreções. Durante as condutas, o paciente não só apresenta grande volume de secreção purulenta como também apresenta intercorrências, sangramento de vias aéreas superiores importantes. Para realização das condutas, observa-se que o fisioterapeuta não faz uso de máscara ou óculos de proteção. Após conseguir estabilizar a situação clínica do paciente, através de ações conjuntas com a equipe, e quando se dirige para a higienização das mãos, relata sobre o não uso dos EPIs: "estresse, estresse puro". (CENA 8/ FISIOTERAPEUTA “Q”)

Mas é porque aqueles óculos realmente atrapalham muito. Eu não enxergo nada com aquilo, porque fica embaçando, então eu não consigo enxergar. Aquilo então fica me agoniando porque não estou enxergando e acabo fazendo sem [...]. Não acopla direito [...]. (FISIOTERAPEUTA “B”)

Eu geralmente não uso óculos, porque incomoda muito, embaça e eu não consigo enxergar nada mesmo. Só uso quando é uma bactéria que ainda não se sabe muito os mecanismos de contaminação, quando ainda não está esclarecido [...]. (FISIOTERAPEUTA “P”)

De acordo com Porto (2007), o trabalhador, pela maior exposição devido ao uso incorreto de EPIs pode, de vítima, ser perversamente transformado em culpado pelos gestores, através da atribuição de conceitos, como a classificação de ato inseguro, por exemplo. Contudo, esta avaliação mostra-se preconceituosa e descontextualizada da realidade cotidiana vivida por estes trabalhadores. As falas e cenas descritas demonstram que o uso dos EPIs, na maioria das vezes, não só gerou grande desconforto aos trabalhadores, impossibilitando a realização da sua tarefa, como também ficou impraticável devido às contingências 
apresentadas. Muitas vezes, o desconforto no uso do EPI decorre de sua inadequação ao uso e baixa qualidade que inviabiliza ao trabalhador executar sua tarefa. Neste caso, ele faz a opção de realizar a tarefa sem se proteger. Conforme afirma Guérin e colaboradores (2001), o primeiro compromisso do trabalhador é com a conclusão da tarefa. Ou seja, os trabalhadores agem diante das condições encontradas, muitas vezes tendo que se afastar da regra, do comportamento que na norma seria seguro, para assim cumprir as suas tarefas. (HORLIK- JONES, 2008)

\section{O saber de prudência: as estratégias invisíveis de proteção}

São várias as racionalidades práticas desenvolvidas pelos fisioterapeutas diante dos riscos biológicos observadas no cotidiano desta UTI. Isto pode ser desvelado na cena e fala abaixo:

Ao aspirar os pacientes, o fisioterapeuta sempre se posicionava por trás da cabeceira destes, fora da direção das secreções respiratórias que poderiam ser expelidas quando o paciente tossisse. Posteriormente, na autoconfrontação, o mesmo explica: "Eu, quando estou sem óculos, me protejo, procuro ficar por trás da cabeceira do paciente para evitar que a secreção pegue em mim”. (CENA 9/ FISIOTERAPEUTA “B”)

Segundo Amalberti (1996) apud Diniz, Assunção e Lima (2005), o trabalhador age mobilizando os seus recursos cognitivos para avaliar a situação; avalia, por isso, a possibilidade de risco no procedimento em curso, verificando o nível de exigência e os resultados esperados e assim elabora uma ação apropriada.

A cena abaixo demonstra uma dessas situações:

Em um plantão, o fisioterapeuta começou a trocar os filtros que são colocados entre a via aérea artificial dos pacientes e os tubos corrugados dos respiradores. Estes filtros encontram-se, quase sempre, com secreções respiratórias em seu interior. Em todas as trocas o (a) Fisioterapeuta sempre procedia da seguinte forma: primeiro desconectava o tubo do filtro, virava este tubo contrário à sua direção e aí então trocava o filtro. Ao ser convidado a verbalizar, afirmou: "sempre que tem secreção eu só abro aqui para evitar que venha no meu rosto". (CENA 10/ FISIOTERAPEUTA “B”) 
Observou-se também que todas as vezes que os fisioterapeutas aspiravam secreções respiratórias dos pacientes, esses só fechavam o vácuo de aspiração após acabarem todo o procedimento e colocarem a borracha de silicone pendurada sobre o frasco de aspiração. Esta é uma forma de proteção utilizada por esses sujeitos, visto que, assim, evitam que as secreções que tenham ficado no silicone após o procedimento retornem, ao elevarem o silicone para enrolar sobre o frasco e venham a ter contato com sua pele ou mucosa.

Outro procedimento que revela o saber de prudência dos fisioterapeutas é a utilização de duas luvas ao aspirar as secreções respiratórias dos pacientes; verificou-se, em dada ocorrência, que esses profissionais usavam uma luva estéril por cima da luva de procedimento. Em outras ocasiões, percebe-se que esta é uma estratégia de proteção por não confiar na qualidade das luvas.

A cena seguinte demonstra outra estratégia: Ao entrar nos isolamentos de contato e vestir a capa de proteção, observa-se que o fisioterapeuta faz um furo em cada manga, próximo ao punho, e através deste introduz o seu polegar. Posteriormente calça as luvas de procedimentos, as quais envolvem o punho por cima da capa. Assim, impede que a manga se desloque para cima e o seu punho fique descoberto durante as aspirações de secreções. (CENA 11/ FISIOTERAPEUTA “C”)

Garfinkel (2006) convenciona que o mundo do ator social no seu trabalho não é objeto do seu pensamento, mas é um campo particular onde ele vai agir como um intérprete crítico, sob condições específicas. Assim sendo, podemos inferir que o ator social no seu trabalho vai desempenhar o seu papel baseado em um universo de elementos peculiares que para ele é reconhecido como: real, relevante e significante; desse modo, ele vai interpretar esse universo abalizado no seu contexto específico.

\section{O acúmulo de funções do fisioterapeuta}

Além de realizar as atividades de fisioterapia motora e respiratória na UTI, o fisioterapeuta participa do transporte de pacientes sob ventilação mecânica ao Setor de Bioimagem do Hospital. Além disso, responsabiliza-se por retirar o respirador do paciente na UTI, transportar o aparelho até o Setor de Bioimagem, reinstituir a ventilação no paciente 
e promover assistência ventilatória durante a realização do exame, o que inclui ajustes necessários no respirador.

Assim, uma das estratégias utilizadas por esse sujeito é permanecer no local durante o exame, o que evita repetidos retornos ao setor quando surge qualquer problema no respirador. Evidencia o fato a fala de um dos fisioterapeutas da cena descrita abaixo: "Prefiro ficar no local durante toda a realização do exame, pois assim evito que ao retornar para a UTI seja chamado para fazer novos ajustes na ventilação mecânica, por alguma alteração clínica no paciente". (CENA 12/ FISIOTERAPEUTA “G”)

O fisioterapeuta enfrenta também outras restrições durante a participação no transporte de pacientes, pois os elevadores disponíveis no Hospital possuem muitos problemas. Podem-se mencionar: pequeno espaço interno, o que faz com que a equipe se divida em dois elevadores; demora a chegar ao piso solicitado, devido ao número reduzido de elevadores e quebras constantes.

Tais contingências consomem grande parte do tempo disponível do fisioterapeuta para realizar as suas tarefas assistenciais na UTI, o que o faz compensar esse tempo com a aceleração de suas atividades para cumprir as metas estabelecidas.

Outra tarefa que compete aos fisioterapeutas da UTI é o atendimento de intercorrências clínicas nas unidades de internamento, no período das 19 às 7h, e não raramente em outros horários em que não se consegue contatar o fisioterapeuta da unidade. Muitas vezes, o fisioterapeuta, depois de instituir a ventilação, prefere aguardar o primeiro resultado da gasometria, que se faz necessário para adequação ventilatória, sabendo que ao chegar à UTI será imediatamente chamado para ajustar parâmetros, o que demandará maior tempo e deslocamento. Todos estes desvios de função provocam interferências no trabalho do fisioterapeuta ao retornar para UTI, impondo-lhe restrição de tempo.

Igualmente, outra função prescrita aos fisioterapeutas da UTI é a realização de atendimentos nas unidades de internamento em pacientes que necessitam de assistência fisioterapêutica noturna, o que faz com que esses se desloquem para as unidades com frequência. As múltiplas funções às quais o fisioterapeuta é submetido durante o seu plantão geram aumento de carga de trabalho. 


\section{Considerações finais}

A caracterização das tarefas no contexto de trabalho de uma UTI, através do uso de elementos da Etnometodologia e da AET, possibilitou, por meio da análise das ações dos fisioterapeutas, a identificação das variabilidades do trabalho, evidenciando como são geradas as demandas extraordinárias e como os trabalhadores agem diante das inadequações dos meios de trabalho associadas aos riscos biológicos presentes no seu cotidiano. Constatou-se, portanto, como reagem esses profissionais em um ambiente tão complexo como a UTI, onde ocorrem transformações da situação de trabalho em ínfimos interstícios, nas chamadas urgências e emergências, em que se faz necessário o contato direto ao assistir o paciente grave.

A análise do trabalho permitiu desvelar que o fisioterapeuta na UTI, ao realizar o trabalho real, lança mão de suas competências para regular e assim gerir estratégias a fim de minimizar os riscos de contaminação com material biológico e mitigar a inadequação dos recursos materiais na realização das suas atividades.

Evidenciaram-se os múltiplos tipos de vínculos de trabalho dos fisioterapeutas na UTI, que podem gerar diferentes formas de gestão do trabalho, gestão de pessoal e repercussões sobre a saúde do trabalhador. Há entre eles, os fisioterapeutas concursados, servidores da Universidade, mas há os terceirizados. Sabe-se que o processo de terceirização tem sido identificado com o aumento de insegurança dos trabalhadores, porquanto a responsabilidade de garantir a saúde e a segurança é, geralmente, transferida para terceiros. Além disso, foi possível constatar o acúmulo de vínculos de trabalho dos fisioterapeutas com outras instituições, o que pode refletir os baixos salários, demandando, o acúmulo de vários empregos. Com isso, alguns atingem carga horária mensal de até 360 horas de serviço.

Embora o fisioterapeuta, no seu discurso, expresse que as relações interpessoais na UTI sejam satisfatórias, evidenciou-se que no cotidiano do trabalho, em que se exercem múltiplos saberes, cuidados e interações sociais, ocorrem situações de conflitos e até de disputa entre os trabalhadores, em particular entre fisioterapeutas e equipe de enfermagem. Parece que a indefinição do que cabe como tarefa aos profissionais pode ser objeto de conflito, mas não se pode omitir que sendo 
a fisioterapia uma profissão de mais recente regulamentação, a afirmação efetiva do fisioterapeuta requer a consolidação da sua competência (seu saber e fazer), como instrumento de sua apropriação e atuação, a fim de delimitar seu papel na equipe interdisciplinar.

O controle de riscos na UTI está baseado na elaboração de regras e em manuais operacionais para diversas situações, que têm como objetivo, supostamente, proteger os profissionais na execução do seu trabalho. Contudo, esta concepção de segurança, que corresponde à prescrição de procedimentos e comportamentos seguros, admite que o dano à saúde dos trabalhadores ou o acidente de trabalho, em particular, decorre da imperícia do trabalhador, negligenciando, nesta perspectiva de análise, o contexto no qual o acidente foi gerado e as condições reais encontradas durante o cumprimento das tarefas. No trabalho real, existem situações em que não é suficiente para o trabalhador apenas cumprir regras, é necessário interpretar, corrigir e, muitas vezes criar, para atender às exigências da situação de trabalho.

O estudo revelou a centralidade da variável tempo na definição da carga de trabalho para os fisioterapeutas. Trata-se de um dos elementos mais importantes na determinação dos modos operatórios dos fisioterapeutas, quando a dificuldade é saber como conciliar rapidez e atenção, com cuidado na execução da tarefa em situações de emergência, em que a prioridade é restabelecer as condições clínicas do paciente. A pressão de tempo determina a maior vulnerabilidade do trabalhador no contato com fluidos corpóreos dos pacientes com a sua pele e as suas mucosas.

Os fisioterapeutas experimentam constantes interrupções em suas rotinas de trabalho, decorrentes das emergências e das diversas contingências ocorridas com grande frequência na UTI, evidenciando-se a existência de demandas conflitantes em um contexto de limitadas condições materiais e inadequação de equipamentos. Tais limitações levam esses sujeitos a desenvolverem estratégias operatórias, dependentes das experiências adquiridas durante a sua vida profissional, para gerirem as variações internas e externas, mobilizando sua subjetividade e desenvolvendo uma atitude que permita a antecipação de eventos, com o fim de assegurar o cumprimento das tarefas e minimizar os riscos biológicos, com o seu saber de prudência.

Ao gerar regulações para contornar as perturbações no seu trabalho, o fisioterapeuta age como um decodificador das regras diante da 
situação concreta do seu cotidiano, do seu espaço de atuação, delimitando o que é real e, assim, estabelece metas e compromissos de qualidade e produção. Por isso, não pode ser julgado com um descumpridor de normas e rotinas ou como um ser que está naturalizando o risco no seu cotidiano, mas como um ser inteligente capaz de regular perturbações com compromisso e qualidade, ainda que, muitas vezes, em detrimento da sua própria saúde.

Este estudo traz elementos para se compreender, em outros contextos, como os fisioterapeutas realizam suas ações práticas diante da insuficiência dos meios, e dos riscos biológicos, visando a atender as exigências do trabalho.

\section{Referências}

ABRAHÃO, Júlia Issy. Reestruturação Produtiva e Variabilidade do Trabalho: Uma Abordagem da Ergonomia. Psicologia: Teoria e Pesquisa, n. 16, p. 49-54, jan.- abr. 2000.

BARALDI, Solange et al. Globalização e seus Impactos na Vulnerabilidade e Flexibilização das Relações de Trabalho em Saúde.

Trabalho Educação e Saúde, n. 6, p. 539-548, nov. 2008/2009.

BARBOSA, Anadergh. Riscos ocupacionais em hospitais: um desafio aos profissionais da área de saúde ocupacional. 1989. 126 f. Dissertação (Mestrado em Medicina). Universidade Federal de Santa Catarina, Florianópolis, 1989.

BARROS, M. E. de B. et al. As Articulações Saúde e Trabalho: Relato de Experiência em um Hospital Público. Cadernos de Saúde Coletiva, Rio de Janeiro, n.14, p.451-468, set. 2006.

BORGES, A.; FRANCO, A. Mudanças de Gestão: Para Além dos Muros da Fábrica. In: FRANCO, Tânia (Org.). Trabalho Riscos Industriais e Meio Ambiente: Rumo ao Desenvolvimento Sustentável. EDUFBA: Salvador, 1997. 242 p.

BRASIL. Ministério da Saúde. Norma Regulamentadora - NR

6. Diário Oficial da União, Brasília - DF., 14 mar. 1983.

BULHÕES, I. Riscos do trabalho de enfermagem. 2. ed. Correio Carioca: Rio de Janeiro, 1998, 221 p.

CAIXETA, R. de B.; BARBOSA-BRANCO, A. Acidente de trabalho, com material biológico, em profissionais de saúde de hospitais 
públicos do Distrito Federal, Brasil, 2002/2003. Caderno de Saúde Pública, n. 21, p. 737-746, mai.- jun. 2005.

CECílIO, L. C. de O. É possível trabalhar o conflito como matériaprima da gestão em saúde? Cadernos de Saúde Pública, Rio de Janeiro, n. 21, p. 508-516, mar.- abr., 2005.

COULON, A. Etnometodologia. Vozes: Rio de Janeiro, 1995. 134 p.

DEAN, E. Oxygen transport: a physiologically-basead conceptual framework for the pratice of cardiopulmonary physiotherapy. Physiotherapy, n. 6, p. 347-355, jun. 1994.

DEAN, E.; ROSS, J. Discordance between cardiopulmonary physiology and physical therapy: toward a rotinal basis for practice. Chest, n. 6, p. 1694-1698, jun. 1992.

DINIZ, E. P. H.; ASSUNÇÃO, A.A.; LIMA, F. de P.A. Prevenção de acidentes: o reconhecimento das estratégias operatórias dos motociclistas profissionais com base para a negociação de acordo coletivo. Congresso brasileiro de Ergonomia, XII. Recife, 2005. Disponível em: <www. scielosp.org/scieloOrg/php/art.... >. Acesso em: 13 jul. 2009.

DRUCK, M. da G. Terceirização: (Des) fordizando a fábrica. EDUFBA: Salvador, 1999. 280 p.

ELY, E.W.; BAKER A.M.; DUNGAN D.P. Effect on the duration of mechanical ventilation of identifying patients capable breathing spontaneously. New Englad Journal Medicine, n. 335, p.1864-1865, Dec. 1996.

FARRELL, M. P.; SCHMITT, M.H; HEINEMANN, G.D. Informal Roles and the Stages of Interdisciplinary Team Development. Journal of Interprofessional Care, n. 3, p. 281-295, Aug., 2001.

GARFINKEL, H. Seeing Socilogically: the routine grounds of social action. Paradigm: Colorado, 2006. 239 p.

GASPAR, P.J.S. Enfermagem profissão de risco e de desgaste: perspective do enfermeiro de urgência. Nursing, n. 10, p. 23-24, 1997.

GUEDES, R. M. de A.; LIMA, F. de P. A.; ASSUNÇÃO, A. A. O programa de qualidade no setor hospitalar e as atividades reais de enfermagem: o caso da medicação. Ciências e Saúde Coletiva, n. 10, p. 63-76, out./dez. 2005.

GUÉRIN, F. et al. Compreender o Trabalho para Transformá-lo A Prática da Ergonomia. São Paulo: Edgard Blucher, 2001. 198 p.

GUTTENBERG, Y.V.; SPICKETT, J. A Survey of Occupational Exposure to blood and Body Fluids in Physiotherapists in Western Australia.

Asia- Pacific Journal of Public Health, n. 4, p. 508-519, Oct. 2009. 
HALL, J. B.; WOOD, L.D. Liberation of the patient from mecanical ventilation. Journal of the American Medical Association, n. 27, p. 621-1628, Marc., 1987.

HAVE, P.T. Understanding Qualitative Research and Ethnomethodology. London: SAGE, 2004. 196 p.

HORLIK-JONES, T. Risk, Praxis and Everyday Life. ISA World Forum of Sociology, Barcelona, set. 2008. Disponível em: <http://www.riskanduncertainty.net/Tom_HorlickJones.pdf > . Acesso em: 10 de outubro de 2008.

HORST, H. M. et al. Decrease in ventilation time with a standardized weaning process. Archives of Surgery, n. 133, p. 483-488, 1998.

HUPES - Hospital Universitário Professor Edgar Santos.

Material Institucional. Disponível em: < http:intranethupes. ufba.br. >. Acesso em: 01 dez. 2009.

LIMA, F. de P.A. de. Introdução à análise ergonômica do trabalho. Belo Horizonte, 1995. (notas de Aula).

NARONEM, L.; WIKSTROM-GROTELL, C. Professional Theoretical Paper: Towards a paradigm-oriented approach I Physical Therapy. Physical Therapy Theory and Pratice International Journal, n. 3, p. 175-184, 1999.

NASCIMENTO, M.C. et al. A Profissionalização da Fisioterapia em Minas Gerais. Revista Brasileira de Fisioterapia, São Carlos, n. 2, p. 241-247, 2006.

PANHOTRA, B. R.; SAXENA, A. K.; AL-MULHIM, A. S. Hepatitis $B$ vírus vaccination compliance among health care workers in intensive care unit: necessity to improve protection of attending physicians. Intensive Care medicine, n. 11, p. 1596, Nov. 2005.

PORTO, M.F. de S. Uma Ecologia Política dos Riscos: princípios para integrarmos o local e o local na promoção da saúde e da justiça ambiental. Rio de Janeiro: Fiocruz, 2007. 248 p.

PURO, V. et al. Risk of Exposure to Bloodborne Infection for Italian Healthcare Workers, by Job Category and Work Area. Infection Control and Hospital. Epidemiology, n. 4, p. 206-210, Apr. 2001.

RESENDE, M.R.; FORTALEZA, C.M.C.B. Risco ocupacional entre profissionais da área de saúde e medidas de proteção. In: COLIBRINI, M. R. C.; FIGUEIREDO, R. M. de; PAIVA M. C. (orgs.). Leito-dia em AIDS: uma experiência multiprofissional. São Paulo: Atheneu, 2001. p. 139-157. 
RICHARDSON, B. Professional Development. Physiotherapy, n. 9, p. 467-474, Sep., 1999.

SARQUIS, L. M. M. O Monitoramento do Trabalhador de Saúde, após Exposição a Fluidos Biológicos. São Paulo, 2007. 195 f. Tese (Doutorado em Enfermagem). Escola de Enfermagem, Universidade São Camilo, 2007.

SILVA, E. C. B. F. et al. Prevalence and Risk Factors for Staphylococcus Aureus in Health Care Workers at a University Hospital of Recife-PE. Brazilian Journal of Infectious Diseases, Salvador, n. 6, p. 504-508, Dec. 2008.

SIQUEIRA, M. M.; WATANABELL, F. S.; VENTOLA, A. Desgaste Físico e Mental dos trabalhadores de enfermagem: uma análise sob enfoque gerencial. Revista Latino-Americano de Enfermagem, n. 1, p. 45-47, Jan. 1995.

SUCHMAN, L. A. Plans and Situated Actions: The

Problem of Human Machine Communication (Learning in Doing: Social, Cognitive and Computational Perspectives). Cambridge: Cambridge University Press, 1987. 203 p.

THERRIEN, J.; CARVALHO, A.D.F. O professor no Trabalho: Epistemologia da Prática e Ação/ Cognição Situada- Elementos para Análise da Práxis Pedagógica. Revista Brasileira de Formação de Professores, Cristalina, n. 1, p. 129-147, maio 2009. WISNER, A.A Inteligência no Trabalho: Textos Selecionados de Ergonomia. São Paulo: Fundacentro, 1994. 191 p. 



\section{Características do trabalho e condições de saúde dos delegados de polícia civil}

Gerfson Moreira Oliveira

Tânia Maria de Araújo

Fernando Martins Carvalho

\section{Introdução}

No Brasil, produções científicas recentes sobre profissionais da segurança pública contribuem para aprofundar a compreensão de seu contexto profissional, suas condições de saúde/doença, relação com os determinantes sociais e seu impacto na saúde pública. (MINAYO; SOUZA, 2003; MINAYO; SOUZA; CONSTANTINO, 2008)

A organização do trabalho da polícia civil repercute na saúde destes trabalhadores que apresentam alta prevalência de doenças físicas e mentais. O trabalho da polícia civil baseia-se em prescrições burocráticas e disciplinares bastante restritivas, o que diminui a possibilidade de intervenções do indivíduo sobre o próprio trabalho. Além disso, existe a precarização do trabalho, falta de recursos materiais, humanos e políticas de segurança públicas ineficientes. (MINAYO; SOUZA, 2003)

Sinais de adoecimento físico, níveis elevados de estresse e sintomas psicológicos são frequentemente encontrados em policiais. Estes profissionais apresentam maior risco de desenvolver estresse pós-traumático (resultante da frequente exposição a traumas), síndrome de burnout (resultante da forma como está organizado o trabalho), problemas psicossociais (como representações conflitivas da profissão e baixa autoestima) e suicídio. (KELLEY, 2005; STURAR, 2008; ANDRADE; SOUZA; MINAYO, 2009)

Os estudos sobre trabalho policial e saúde abordam, em sua maioria, os agentes de polícia civil e militar e, menos frequentemente, os 
delegados de polícia. Os delegados têm atribuições específicas no setor de segurança pública e vivenciam dificuldades no ambiente de trabalho que afetam a saúde, a qualidade de vida e provocam adoecimento.

Delegados de polícia civil constituem um grupo ocupacional de grande vulnerabilidade entre as carreiras jurídicas brasileiras. Vários fatores se articulam para produzir este quadro como as características profissionais, psicossociais, políticas e institucionais do trabalho desenvolvido. (BONELLI, 2003)

Em um amplo estudo sobre o perfil dos delegados de polícia civil no Brasil, foram selecionadas amostras em nove estados brasileiros, entre eles, a Bahia. A pesquisa destacou importantes elementos sobre as características do trabalho destes profissionais, como dificuldades na gestão da instituição, baixo empenho dos governantes na implantação de políticas de segurança pública efetivas, falta de recursos para subsidiar o funcionamento da polícia civil, além de marginalização da instituição, com impactos na saúde e qualidade de vida dos delegados e no desenvolvimento das suas atividades. (SADEK; ARANTES, 2003)

Conhecer as características do trabalho e as condições de saúde/ doença deste grupo ocupacional poderá ser útil para fundamentar medidas de proteção à saúde desses profissionais e de reordenamento do trabalho, visando melhorar a qualidade da atenção prestada à população.

O objetivo deste estudo foi descrever as características do trabalho e as condições de saúde dos delegados de polícia civil da cidade de Salvador, Bahia, Brasil.

\section{Método}

Foi realizado um estudo epidemiológico de corte transversal com delegados e delegadas da polícia civil, em efetivo exercício profissional nos diversos cargos dos setores técnico-administrativos, delegacias especializadas e circunscricionais, localizados na cidade de Salvador, Bahia.

O critério de inclusão dos sujeitos foi estar em pleno exercício profissional e concordar em participar da pesquisa. Dos 165 delegados da capital, passíveis de serem incluídos no estudo, 152 (92,2\%) participaram da entrevista e responderam ao questionário. Oito $(4,8 \%)$ delegados não aceitaram participar e cinco (3,0\%) não foram localiza- 
dos durante a coleta de dados. As entrevistas foram realizadas por três psicólogos treinados, entre os meses de maio e setembro de 2010.

A participação dos delegados de polícia foi voluntária e as informações foram coletadas por meio de entrevistas e aplicação de questionário no ambiente de trabalho, em local reservado.

O questionário padronizado contemplou cinco blocos de questões com informações sobre: a) características sociodemográficas e estilo de vida; b) informações gerais sobre a atividade profissional incluindo questões relacionadas aos aspectos psicossociais do trabalho (medidos pelo Job Content Questionnaire - JCQ); c) informações sobre a saúde geral (contendo questões sobre a percepção do estado de saúde, uso de medicações, diagnóstico médico prévio, queixas de saúde e utilização do serviço médico da instituição); d) informações sobre a saúde mental, utilizando-se o Self-Reporting Questionnaire - SRQ-20; e) segurança laboral com questões sobre segurança pessoal no trabalho e violência. (KARASEK, 1993; ARAÚJO; KARASEK, 2008; MARI; WILLIAMS, 1986) Para detectar uso abusivo de álcool, o questionário C.A.G.E. foi incluído no bloco sobre estilo de vida. Para alcançar maior especificidade (menor número de falsos positivos) foi adotado o ponto de corte de duas ou mais respostas positivas, conforme critérios adotados em outras pesquisas com trabalhadores que identificaram sensibilidade de 88\% e especificidade de 83\%. (MANSUR; MONTEIRO, 1983; AMARAL; MALBERGIER, 2004)

O JCQ traduzido como Questionário sobre o Conteúdo do Trabalho, utilizado para avaliar aspectos psicossociais do trabalho, direciona-se especificamente à estrutura social e psicológica de atividades profissionais diversas, sendo também utilizado para relacionar situações de trabalho a doenças ocupacionais. (ARAÚJO; GRAÇA; ARAÚJO, 2003)

O JCQ fundamenta-se teoricamente no Modelo Demanda-Controle (MDC), que postula uma relação entre nível de controle do trabalhador sobre o processo de trabalho e as exigências psíquicas relativas à execução das tarefas. A combinação desses dois fatores estabelece quatro situações distintas no trabalho: alta exigência (alta demanda psicológica e baixo controle); trabalho ativo (alta demanda e alto controle); trabalho passivo (baixa demanda e baixo controle) e baixa exigência (baixa demanda e alto controle). Cada uma destas situações resultaria em implicações 
diferenciadas no desempenho das tarefas e na saúde dos trabalhadores, sendo as situações de trabalho ativo e baixa exigência condições mais favoráveis e as situações de alta exigência e de trabalho passivo as que oferecem maior risco à saúde física e mental e ao comprometimento no desenvolvimento profissional. (ARAÚJO et al., 2006) Nesta pesquisa, foi utilizada versão validada para trabalhadores no Brasil. (ARAÚJO; KARASEK, 2008)

Para obtenção dos indicadores psicossociais do trabalho propostos neste modelo, as escalas foram construídas conforme orientação do manual do JCQ. (KARASEK, 1993) Para composição dos grupos do modelo demanda-controle, as escalas foram dicotomizadas adotando-se a mediana como ponto de corte. Os resultados encontrados serviram de referência para classificação dos sujeitos nos quadrantes do modelo: baixa exigência, trabalho ativo, trabalho passivo e alta exigência. (ARAÚJO; GRAÇA; ARAÚJO, 2003)

O instrumento utilizado para avaliar a saúde mental foi o SRQ-20. O SRQ-20 é indicado para estudos populacionais; é um instrumento de triagem de transtornos mentais comuns (TMC). TMC é uma expressão criada por Goldberg e Huxley (1992) para designar sintomas não psicóticos como diminuição de energia, irritabilidade, dificuldade de concentração, humor deprimido/ansioso, sintomas somáticos e pensamentos depressivos, que evidenciam vulnerabilidade das condições de saúde mental do indivíduo, mas não se configuram, necessariamente, como um diagnóstico clínico. Os TMC são considerados como problema de saúde pública devido ao impacto na qualidade de vida e no trabalho das pessoas, além das demandas geradas nos serviços de saúde. (GOLEDBERG; HUXLEY, 1993; COUTINHO; ALMEIDA FILHO; MARI, 1999) Na população brasileira, o SRQ-20 foi utilizado para avaliar TMC em diferentes ocupações como gestores professores e policiais civis. (BRANT; DIAS, 2004; REIS et al., 2008; SOUZA et al., 2007)

Diferentes pontos de corte têm sido adotados em pesquisas com o SRQ-20 com valores que variam de 5 a 8 pontos para suspeição de TMC conforme o sexo, com pontos de corte menores na população masculina $(5 / 6)$ e maiores na população feminina (7/8). (FERNANDES et al., 2002) Conforme outras pesquisas, neste estudo foram adotados pontos de corte diferenciados para homens e mulheres: para os delegados adotou-se ponto de cinco ou mais questões positivas; para as delega- 
das adotou-se ponto de sete ou mais questões positivas. (FERNANDES et al., 2002; PALMA et al., 2009)

A análise dos dados incluiu informações sociodemográficos (idade, sexo, nível de instrução, renda), estilo de vida (uso de cigarro, prática de esporte e atividades regulares de lazer), condições de saúde geral, características profissionais e segurança no trabalho, assim como aspectos psicossociais do trabalho. A prevalência de transtornos mentais comuns e a de uso abusivo de álcool foram estimadas. Os questionários foram numerados e tabulados utilizando-se o programa Statistical Package for the Social Sciences (SPSS), versão 9.0 para Windows. Após digitação, cada formulário passou por dupla revisão.

Com o objetivo de preservar a identidade dos sujeitos da pesquisa, manteve-se o anonimato do(a) delegado(a) no preenchimento do questionário. O estudo foi aprovado pelo Comitê de Ética do Hospital São Rafael (processo no CE CEP/HSR 41/09) em 07/12/2009.

\section{Resultados}

Os delegados de polícia civil de Salvador, Bahia tinham média de idade de 45,7 anos ( $\mathrm{DP}=9)$, estando $59,8 \%$ na faixa etária entre 40 e 59 anos. Nesta população, mais da metade $(59,9 \%)$ era do sexo feminino; $62,5 \%$ declararam ser casado ou ter união estável e 75,6\% tinham filhos. Quanto à formação profissional, $75 \%$ possuíam algum tipo de pós-graduação (especialização: $67,8 \%$ e mestrado/doutorado: 7,2\%). A renda média variou de $\mathrm{R} \$ 5.000,00$ a $\mathrm{R} \$ 8.000,00$ para $59,8 \%$ do grupo. A prática de atividade física regular (igual ou superior a três vezes na semana) foi referida por $42,1 \%$ dos respondentes; $75,5 \%$ mantinham algum tipo de atividade de lazer semanalmente. O hábito de fumar foi referido por $11,8 \%$ dos delegados; $48,6 \%$ relataram consumo de bebida alcoólica (eventual ou regular) e 7,2\% do total de delegados foram classificados pelo CAGE como suspeitos de uso abusivo do álcool. A utilização de drogas ilícitas nos últimos 10 anos foi referida por $3,3 \%$ dos entrevistados.

Dos 152 delegados de polícia civil, a média de tempo de trabalho na carreira foi de 17,35 anos ( $\mathrm{DP}=9,04$ anos) e a carga horária total de trabalho foi de 42,5 horas semanais ( $\mathrm{DP}=6,8$ horas); $12 \%$ dos entrevistados exerciam atividades remuneradas fora da polícia. A maioria dos 
delegados tinha como atividade principal a execução de tarefas administrativas $(63,2 \%)$ e a jornada de trabalho predominante no grupo era de oito horas por dia $(65,1 \%)$.

Tabela 1 - Características do trabalho de 152 delegados de polícia civil de Salvador, Bahia, 2010.

\begin{tabular}{l|c|c}
\multicolumn{1}{c|}{ Características do Trabalho } & $\mathbf{n}$ & $\%$ \\
\hline Tipo de função & & \\
\hline Funções técnicas de caráter administrativo & 96 & 63,2 \\
\hline Funções técnicas com ênfase operacional & 56 & 36,8 \\
\hline Carga horária de trabalho & & \\
\hline Somente horário administrativo - 8horas por dia & 99 & 65,1 \\
\hline Somente regime de plantão de 12 e/ou 24 horas de trabalho & 32 & 21,0 \\
\hline Horário administrativo e plantão & 21 & 13,8 \\
\hline Jornada de trabalho & & \\
\hline Ser requerido a fazer horas extras com frequência & 42 & 27,6 \\
\hline Regime de sobre aviso & 39 & 25,7 \\
\hline
\end{tabular}

Fonte: (OLIVEIRA; ARAÚJO; CARVALHO, 2010).

Sobre as condições de trabalho, 52,6\% dos delegados afirmaram não dispor, ou dispor com pouca frequência, de equipamentos suficientes e adequados para realização das atividades. Em relação ao reconhecimento e satisfação no trabalho, $52,0 \%$ não se sentiam reconhecidos e $35,5 \%$ não estavam satisfeitos com o trabalho realizado, sendo que $21,1 \%$ dos delegados não se candidatariam ao seu emprego novamente.

Quanto aos aspectos psicossociais do trabalho, 55,3\% dos delegados tinham baixo controle sobre o trabalho; alta demanda psicológica foi relatada por $50,0 \%$ dos profissionais e $46,0 \%$ referiram baixo suporte social. Referindo-se ao controle sobre o seu trabalho, $61,2 \%$ dos delegados consideraram a sua atividade repetitiva; a impossibilidade de tomar suas próprias decisões foi o item mais referido na dimensão de controle relativo à autoridade decisória $(41,5 \%)$. O trabalho excessivo e a exigência de rapidez perceptiva foram os itens de demanda psicológica mais citados pelos delegados $(75,6 \%$ e $69,1 \%$, respectivamente). 
Dentre os fatores que compõem o suporte social, destacou-se a falta de auxílio do superior na realização das tarefas $(47,4 \%)$ e a falta de preocupação do superior com o bem estar da equipe $(36,2 \%)$.

Considerando os quadrantes do Modelo Demanda Controle, observou-se maior frequência da dimensão "trabalho passivo" $(29,6 \%)$, seguida de "trabalho de alta exigência" $(25,7 \%)$. As frequências correspondentes aos aspectos psicossociais do trabalho são apresentadas na Tabela 2.

Tabela 2 - Frequência de respostas afirmativas sobre aspectos psicossociais do trabalho, segundo dimensões do Modelo Demanda-Controle, por 152 delegados de polícia civil de Salvador, Bahia, 2010.

\begin{tabular}{|c|c|c|}
\hline Questões do JCQ (referência) & $\mathbf{n}$ & $\%$ \\
\hline \multicolumn{3}{|l|}{ CONTROLE SOBRE O TRABALHO } \\
\hline Baixo controle & 84 & 55,3 \\
\hline Alto controle & 68 & 44,7 \\
\hline \multicolumn{3}{|l|}{ Uso de habilidades } \\
\hline Trabalho repetitivo & 93 & 61,2 \\
\hline Impossibilidade de fazer diferentes tarefas & 59 & 38,8 \\
\hline Não desenvolve habilidades próprias & 55 & 36,2 \\
\hline Trabalho não requer que aprenda coisas novas & 13 & 8,6 \\
\hline Trabalho não requer alto nível de habilidade & 10 & 6,6 \\
\hline \multicolumn{3}{|l|}{ Autoridade Decisória } \\
\hline Não permite tomar as próprias decisões & 63 & 41,5 \\
\hline O que diz sobre o trabalho não é considerado & 40 & 26,3 \\
\hline Pouca liberdade de decisão sobre o próprio trabalho & 31 & 20,4 \\
\hline Não ser criativo no trabalho & 17 & 11,2 \\
\hline \multicolumn{3}{|l|}{ DEMANDA PSICOLÓGICA NO TRABALHO } \\
\hline Alta demanda & 76 & 50,0 \\
\hline Baixa demanda & 76 & 50,0 \\
\hline Demandas psicológicas & & \\
\hline
\end{tabular}




\begin{tabular}{|c|c|c|}
\hline Trabalho excessivo & 115 & 75,6 \\
\hline Trabalho requer muita rapidez & 105 & 69,1 \\
\hline Tempo insuficiente para executar as tarefas & 99 & 65,1 \\
\hline Demandas conflitantes no trabalho & 89 & 58,5 \\
\hline \multicolumn{3}{|l|}{ SUPORTE SOCIAL NO TRABALHO } \\
\hline Alto suporte & 82 & 54,0 \\
\hline Baixo suporte & 70 & 46,0 \\
\hline \multicolumn{3}{|l|}{ Suporte da chefia } \\
\hline Superior imediato não auxilia na realização de tarefas & 72 & 47,4 \\
\hline Superior imediato não se preocupa com o bem estar da equipe & 55 & 36,2 \\
\hline Tratamento com falta de respeito do superior imediato & 12 & 7,9 \\
\hline \multicolumn{3}{|l|}{ Suporte de colegas } \\
\hline Não recebe ajuda de colegas de trabalho & 25 & 16,4 \\
\hline Colegas de trabalho não são amigáveis & 14 & 9,2 \\
\hline Falta de respeito dos colegas de trabalho & 5 & 3,3 \\
\hline \multicolumn{3}{|l|}{ QUADRANTES DO MODELO DEMANDA-CONTROLE } \\
\hline Trabalho de baixa exigência (baixa demanda + alto controle) & 31 & 20,4 \\
\hline Trabalho passivo (baixa demanda + baixo controle) & 45 & 29,6 \\
\hline Trabalho ativo (alta demanda + alto controle) & 37 & 24,3 \\
\hline Trabalho com alta exigência (alta demanda + baixo controle) & 39 & 25,7 \\
\hline
\end{tabular}

Fonte: (OLIVEIRA; ARAÚJO; CARVALHO, 2010).

Quando questionados em relação ao estado de saúde, 95,4\% consideravam que a sua saúde era boa e 4,6\% referiram ter saúde ruim. O uso atual de medicação ansiolítica foi referido por 10,5\% dos participantes, sendo que $27,7 \%$ afirmaram já ter feito uso de medicação no passado. Dos 152 delegados, 86,2\% registraram diagnóstico médico de uma ou mais doenças nos últimos 30 dias. As principais doenças diagnosticadas foram: gastrite $(34,9 \%)$, varizes $(27,7 \%)$, hipertensão arterial sistêmica 
$(25,7 \%)$, depressão $(21,1 \%)$ e artrite $(20,3 \%)$, conforme apresentado na Tabela 3.

Tabela 3 - Frequência de diagnósticos médicos referidos por 152 delegados de polícia civil de Salvador, Bahia, Brasil, 2010.

\begin{tabular}{l|l|l}
\multicolumn{1}{c|}{ Diagnósticos médicos } & n & \multicolumn{1}{c}{$\%$} \\
\hline Gastrite & 53 & 34,9 \\
\hline Varizes & 41 & 27,7 \\
\hline Hipertensão Arterial Sistêmica & 39 & 25,7 \\
\hline Depressão & 32 & 21,1 \\
\hline Artrite & 31 & 20,3 \\
\hline Hérnia de Disco & 26 & 17,1 \\
\hline LER-DORT & 15 & 9,9 \\
\hline Doença dos rins & 14 & 9,2 \\
\hline Hipotireoidismo & 12 & 7,9 \\
\hline Outros & 55 & 36,2 \\
\hline Não tem diagnóstico médico de doença & 21 & 13,8 \\
\hline
\end{tabular}

Fonte: (OLIVEIRA; ARAÚJO; CARVALHO, 2010).

A prevalência global de TMC foi de $37,5 \%$, variando segundo o sexo: $41 \%$ entre os delegados e $35 \%$ entre as delegadas. As questões do SRQ-20 com maiores proporções de respostas positivas estavam no grupo referente a "humor deprimido/ansioso" e "sintomas somáticos".

Tabela 4 - Frequência de respostas afirmativas às perguntas do Self-Reporting Questionnaire-20 (SRQ-20), por 152 delegados de polícia civil de Salvador, Bahia, Brasil, 2010.

\begin{tabular}{l|c|c}
\multicolumn{1}{c|}{ Informações do SRQ-20 } & $\mathbf{n}$ & $\%$ \\
\hline Sintomas somáticos & & \\
\hline Dormir mal & 72 & 47,4 \\
\hline Ter sensações desagradáveis no estômago & 57 & 37,5 \\
\hline Ter dores de cabeça freqüentes & 53 & 34,9 \\
\hline
\end{tabular}




\begin{tabular}{|c|c|c|}
\hline Ter má digestão & 49 & 32,2 \\
\hline Ter falta de apetite 2 & 24 & 15,8 \\
\hline Ter tremores nas mãos & 11 & 7,2 \\
\hline \multicolumn{3}{|l|}{ Diminuição da energia } \\
\hline Sente-se cansado o tempo todo & 54 & 35,5 \\
\hline Dificuldade para realizar, com satisfação, as tarefas diárias & 49 & 32,2 \\
\hline Se cansar com facilidade & 46 & 30,3 \\
\hline Trabalho diário causa sofrimento & 31 & 20,4 \\
\hline Ter dificuldade para tomar decisões & 22 & 14,5 \\
\hline Ter dificuldade para pensar com clareza & 22 & 14,5 \\
\hline \multicolumn{3}{|l|}{ Humor deprimindo/ansioso } \\
\hline Sente-se nervoso, tenso ou preocupado & 88 & 57,9 \\
\hline Ter se sentido triste ultimamente & 57 & 37,5 \\
\hline Assusta-se com facilidade & 38 & 25,0 \\
\hline Ter chorado mais do que de costume & 16 & 10,5 \\
\hline \multicolumn{3}{|l|}{ Pensamentos depressivos } \\
\hline Ter perdido o interesse pelas coisas & 26 & 17,1 \\
\hline Ser incapaz de desempenhar um papel útil na vida & 6 & 3,9 \\
\hline Sente-se uma pessoa inútil na vida & 6 & 3,9 \\
\hline Ter idéia de acabar com a própria vida & 3 & 2,0 \\
\hline
\end{tabular}

Fonte: (OLIVEIRA; ARAÚJO; CARVALHO, 2010).

No momento da realização do estudo, $39,5 \%$ dos delegados estavam em tratamento médico por algum motivo e $7,2 \%$ referiram acompanhamento psicológico. A não utilização do serviço de saúde ocupacional da polícia civil foi referida por $84,9 \%$ dos delegados; $98,7 \%$ referiram não utilizar o serviço de psicologia da polícia. 


\section{Discussão}

Os delegados de polícia civil de Salvador compõem uma população de meia-idade com predomínio do sexo feminino, com união estável, filhos e formação profissional com nível de especialização. Esses dados de faixa etária, situação conjugal e número de filhos convergem com o perfil dos delegados de polícia do Brasil. Entretanto, delegados de Salvador apresentaram maior nível de escolaridade e mais mulheres na profissão, em relação ao estudo nacional, que identificou titulação máxima de graduação e apenas $17,1 \%$ de mulheres. (SADEK; ARANTES, 2003)

A inserção de mulheres na área de segurança pública teve início a partir do século XX e seu aumento tem sido justificado pela maior participação feminina no mercado de trabalho, pelas políticas de ações afirmativas e leis antidiscriminatórias e de proteção às mulheres. (SILVEIRA, 2009; ROSA; BRITO; OLIVEIRA, 2007) No Brasil, algumas pesquisas ressaltam que as "habilidades femininas" de comunicação, adaptação e flexibilidade também foram responsáveis pela maior abertura das instituições policiais às mulheres, uma vez que elas poderiam contribuir para a melhoria da imagem da polícia na sociedade, tradicionalmente percebida como: machista, violenta e totalitária. (HAGEN, 2005; SILVEIRA, 2009)

Esta inserção, entretanto, não se deu de forma tranquila, uma vez que as mulheres tiveram que alinhar os seus comportamentos a uma cultura organizacional fortemente marcada por valores masculinos e mecanismos rígidos de mediação das relações de trabalho. (ROSA; BRITO; OLIVEIRA, 2007) Estudo realizado com policiais do Rio Grande do Sul relatou que a participação feminina na polícia civil ocasionou uma divisão sexual do trabalho, onde as mulheres tenderiam a ser afastadas de atividades de enfrentamento (ênfase operacional) e destinadas a funções de caráter mais burocrático (ênfase administrativa), desenvolvidas no âmbito das delegacias e não em atividades de rua. (HAGEN, 2005) Embora o perfil dos delegados pesquisados em Salvador apresente maior número de profissionais exercendo atividades administrativas, quando se observa os dados por grupo de gênero, $41 \%$ dos delegados entrevistados estavam exercendo atividades mais operacionais, sendo que esta proporção entre as delegadas da pesquisa foi de $34 \%$. Contudo, o fato 
de terem sido selecionadas apenas unidades lotadas na capital pode ter influenciado nestes resultados.

Quanto às delegadas da cidade de Salvador e São Paulo, pesquisas realizadas nestas capitais, ressaltaram desequilíbrio proporcional entre homens e mulheres na profissão no que se refere à ocupação de postos mais elevados na hierarquia profissional. Apesar de ter havido aumento expressivo de delegadas, existe maior numero de delegados no topo da categorial profissional. (BAHIA, 2002; SILVEIRA, 2009)

Para o exercício do cargo de delegado de polícia civil é necessária graduação em Direito. O elevado nível de escolaridade entre os delegados indica busca de qualificação e aprimoramento, já que a maioria relatou ter curso de pós-graduação. Dentre outros fatores de motivações pessoais para busca do conhecimento, o auxílio em gratificações de até $20 \%$ sobre o salário pode ser um importante incentivo para este nível elevado na qualificação dos delegados.

A renda referida por estes profissionais foi heterogênea. Disparidades de remuneração entre delegados nos diversos estados brasileiros, além de defasagem em relação às demais carreiras jurídicas, foram apontadas em outros estudos, como motivo de insatisfação e justificativa para o exercício de outras atividades profissionais remuneradas, em paralelo, além da polícia. (SADECK; ARANTES, 2003) Atividades remuneradas fora da polícia civil também foram referidas pelos delegados entrevistados, sendo a docência a ocupação mais exercida.

De modo geral, mais da metade dos delegados praticava atividade física com regularidade, mantinha atividades de lazer semanalmente e referiu não ter o hábito de fumar. A prática de atividade física regular foi superior aos dados encontrados em pesquisas com policiais civis e militares do Rio de Janeiro $(13,1 \%)$ e para a população de Salvador (13,8\%). (MINAYO; SOUZA; CONSTANTINO, 2008; BRASIL, 2009) A frequência de tabagismo entre os delegados foi similar à população soteropolitana $(11,3 \%)$ e menor que a da população brasileira $(15,5 \%)$. (BRASIL, 2009) A frequência do consumo de álcool e a suspeição de alcoolismo entre os delegados foram inferiores ao resultado encontrado em agentes penitenciários $(68,5 \%)$, porém, superior ao observado para a população soteropolitana (5,6\%). (SILVA; VIEIRA, 2008; FERNANDES, et al., 2002; BRASIL, 2009) 
A utilização de drogas ilícitas por delegados de Salvador foi menos frequente do que por policiais que atuavam em unidades penitenciárias no Canadá (14,7\%). (LAVIGNE; BOURBONNAIS, 2010) O relato de consumo de substâncias psicotrópicas em pesquisas com profissionais da segurança pública, entretanto, deve ser avaliado com cuidado já que, apesar da garantia de anonimato, os dados podem estar subestimados. O frequente contato de profissionais da segurança pública com traficantes e usuários de drogas, e a sua potencial vulnerabilidade nas estruturas informais de poder poderiam influenciar no uso de drogas. (FERNANDES et al., 2002) As condições de vulnerabilidade no trabalho, como baixo suporte de colegas e supervisores e relações de desequilíbrio entre esforço e recompensa, associam-se ao uso de drogas entre policiais. (LAVIGNE; BOURBONNAIS, 2010)

O tempo de trabalho como delegado de polícia foi longo, representando a situação de estabilidade como servidores públicos. No entanto, é importante ressaltar que o fato de possuírem estabilidade na instituição não garante a estabilidade na função. Os delegados podem ser transferidos ou remanejados para os mais diversos setores e localidades na corporação de acordo com os interesses da administração pública, que por sua vez, estão vinculadas às estratégias políticas do governo vigente. A interferência política partidária na cúpula da polícia civil tem sido considerada como obstáculo ao bom funcionamento da instituição, assim como na eficácia da segurança pública no país. (SADEK; ARANTES, 2003; HAGEN, 2005) A lei orgânica da polícia civil (BAHIA, 2009) prevê mecanismos para promoção e desenvolvimento profissional, minimizando a influência de interesses políticos na carreira do delegado; entretanto, na Bahia, a lei foi aprovada em fevereiro de 2009 e ainda não foi plenamente efetivada.

A carga horária semanal de trabalho referida foi compatível com o estabelecido em outras profissões. Entretanto, a maioria dos delegados sente fadigada ao fim de uma jornada de trabalho, o que sugere uma atividade profissional de elevada exigência. Três situações importantes podem estar relacionadas a esta queixa: a) o regime de plantão de até 24 horas ininterruptas praticadas por $35 \%$ dos delegados. Isto requer prontidão perceptiva e disposição para vivenciar longa jornada de trabalho, uma vez que precisam estar em alerta para responder, prontamente, aos mais diversos tipos de ocorrências; b) a prática de outras 
atividades remuneradas exercidas em horários de folga dos delegados, que pode comprometer o descanso efetivo dos profissionais; $c$ ) a prática frequente de horas extras, que revela limitação no efetivo do número de delegados na capital, sobrecarga de trabalho, acúmulo de funções e potencialização dos riscos aos quais estão submetidos. Escalas de plantão de 24 horas foram consideradas pelos policiais civis e militares, do Rio de Janeiro, como principal causa de cansaço, irritabilidade, insônia e desgaste mental. (MINAYO; SOUZA; CONSTANTINO, 2008)

Elevada proporção dos delegados afirmou não dispor de equipamentos suficientes e adequados para realização de suas atividades. A falta de equipamentos e recursos (materiais, financeiros e humanos) para desenvolver as atividades profissionais tem sido um dos principais problemas enfrentados pelos profissionais da segurança pública no Brasil. (MIANAYO; SOUZA; CONSTANTINO, 2008) Equipamentos danificados, viaturas sem manutenção adequada, rádios quebrados, ausência de salas de repouso, falta de treinamentos e de pessoal qualificado são algumas das dificuldades apontadas nas pesquisas realizadas no setor. (MINAYO; SOUZA, 2003; SADEK; ARANTES, 2003) Estas condições podem explicar porque elevada proporção dos delegados não se sentiam reconhecidos no trabalho e não estavam satisfeitos com as atividades profissionais.

O baixo controle sobre o próprio trabalho, referido por percentual elevado de delegados, revelou características de um trabalho repetitivo e de pouca autonomia profissional. De modo geral, quando as atividades são desenvolvidas em delegacias, o delegado tem função de chefia, de gestão, o que implicaria em maior autonomia no trabalho. Porém, nesta pesquisa, mais de $60 \%$ dos delegados entrevistados atuavam em unidades técnicas administrativas realizando tarefas mais burocráticas e rotineiras, comandados e supervisionados, o que explicaria, em parte, os resultados apresentados. A estrutura organizacional das polícias civil e militar ainda é tradicional, com forte referência da administração pública burocrática, pautada na hierarquia e na disciplina. A organização do trabalho da polícia, baseada neste modelo de gestão, dá maior importância aos aspectos formais da instituição, gerando uma visão fragmentada do trabalho, com pouco destaque para os trabalhadores. Somado a estas questões, existe o componente de precarização do trabalho que coloca o policial no centro de forças conflitivas constantes, 
o que desencadeia consequências danosas para a sua saúde física e mental. (SILVA; VIEIRA, 2008)

Os dados sobre suporte social caracterizaram uma população que recebe apoio dos colegas de trabalho indicando um clima colaborativo estabelecido entre os delegados e a sua equipe de trabalho. Para alguns estudiosos da atividade policial, o perigo da profissão torna o policial isolado socialmente devido à sua desconfiança em relação às pessoas, o que favoreceria uma maior solidariedade com os colegas de trabalho. (REINER, 2000; MINAYO; SOUZA, 2003) Porém, cabe destacar que um percentual significativo dos entrevistados referiu não receber apoio do superior imediato na realização das tarefas, nem perceberam preocupação dos chefes com o bem estar da equipe. Estes resultados convergem com os resultados obtidos em estudo realizado com policiais do Recife que identificaram falta de apoio dos superiores no contexto de trabalho. (FERREIRA; AUGUSTO; SILVA, 2008) A falta de apoio da chefia e o precário empenho governamental no fortalecimento das instituições policiais (civil e militar) têm sido evidenciados por diversas pesquisas com estes profissionais no Brasil, sendo considerado como um dos principais obstáculos ao bom funcionamento da segurança pública no país. (SADEK; ARANTES, 2003; MINAYO; SOUZA; CONSTANTINO, 2008)

Alta demanda psicológica foi identificada no grupo estudado. Apesar de nem todas as tarefas envolverem perigo, muitos delegados percebiam o trabalho como de elevada exigência psicológica por terem que trabalhar com demandas conflitantes, de forma excessiva e com ritmo acelerado. Exigências psicológicas excessivas desencadeiam doenças físicas e psíquicas que comprometem a saúde e a qualidade de vida dos trabalhadores. Neste contexto, as corporações policiais se destacam da população em geral e de outras categorias profissionais pela pesada carga de trabalho e sofrimento, justificando, portanto, um maior desgaste físico e mental. (MINAYO; SOUZA; CONSTANTINI, 2008)

A dimensão do modelo demanda/controle mostrou maior frequência de delegados em situações de trabalho passivo (baixo controle e baixa demanda), seguidos de trabalho de alta exigência (baixo controle e alta demanda). Estes dados encontrados sugerem que a maioria dos delegados do estudo, vivencia experiências de trabalho consideradas desfavoráveis ao desempenho ocupacional saudável e à satisfação 
profissional. De acordo com as referências (MDC), a experiência profissional na condição de trabalho passivo pode conduzir ao declínio na atividade global do indivíduo e à redução da capacidade de produzir soluções para as atividades e problemas enfrentados. Já a condição do trabalho de alta exigência apresenta maior risco para o aparecimento de problemas de ordem psicológica e doenças como fadiga, ansiedade, depressão e doenças físicas. (ARAÚJO; GRAÇA; ARAUJO, 2003).

Os principais diagnósticos de saúde referidos estavam relacionados com aspectos psicossomáticos e de saúde mental, disfunções do aparelho circulatório e vascular e doenças do sistema osteoarticular. Queixas relacionadas à saúde mental, disfunções do aparelho circulatório e do sistema osteoarticular, são convergentes com outras pesquisas com policiais. (MINAYO; SOUZA; CONSTANTINO, 2008)

A prevalência de TMC foi elevada quando comparada a estudos com policiais civis $(20,2 \%)$ e agentes penitenciários de Salvador (30,7\%). (MINAYO; SOUZA, 2003; FERNANDES et al., 2002) Dentre os sintomas mais referidos, destacaram-se os relacionados ao humor deprimido/ansioso, questões psicossomáticas e diminuição de energia. Problemas psicossomáticos e de saúde mental são, frequentemente, encontrados em policiais, sendo os sintomas psicológicos apontados como os de maior prevalência. (STURAR, 2008)

Estudos realizados com policiais militares e agentes penitenciários identificaram maior propensão ao sofrimento psíquico entre as mulheres policiais. (MORAES et al., 2001; SANTOS et al., 2010) Neste estudo, no entanto, destacou-se prevalência de TMC um pouco mais elevada em delegados quando comparados às delegadas. Souza e colaboradores (2007) não identificaram diferenças significativas na prevalência de TMC em policiais civis conforme o gênero, porém, ressaltaram que o sofrimento psíquico é maior entre aqueles que exerciam atividades operacionais e que os homens policiais percebiam mais situações de risco no trabalho do que as colegas de profissão. Em nossos achados, a proporção de delegados exercendo atividades operacionais (de maior exposição à criminalidade) foi maior do que a de delegadas. Este fato pode justificar, em parte, os resultados encontrados. No entanto, ressaltamos que diferentes características e contextos do trabalho destas profissionais podem interferir na comparação entre os estudos. Destaca-se, ainda, que o aprofundamento acerca dos aspectos relacionados 
ao gênero e repercussões na saúde mental constitui foco relevante para estudos futuros.

Apesar do perfil de saúde apresentado, com expressiva proporção de indivíduos com TMC e diagnóstico médico referido de doenças, quando perguntados sobre a percepção das condições de saúde, quase a totalidade se considerava em bom estado de saúde. Observou-se, entretanto, que a vulnerabilidade das condições de saúde é frequente na rotina de trabalho desses profissionais e o reconhecimento de situações de tensão e fragilidade é ofuscado pela pressão de muitos delegados em sustentar uma imagem de "fortaleza" que não sucumbe frente às dificuldades. Para Dejours (1992), os trabalhadores tendem a controlar a doença diante de atividades profissionais adversas, desenvolvendo, coletivamente, mecanismos de defesas psicológicas que permitem que o trabalhador as domine, e em situações especificas, tenha menor consciência do seu adoecimento.

Quanto aos recursos e ações de saúde promovidas pela polícia civil a estes trabalhadores, percentual expressivo dos delegados não costumava utilizar o serviço médico ou de psicologia da polícia, tendo como principal justificativa o desconhecimento da existência dos mesmos. Estes dados sugerem que, dentre outros fatores, as ações de saúde ocupacional da polícia civil não são expressivas no grupo pesquisado, necessitando de maior investimento voltado à prevenção de agravos e promoção da saúde dos delegados.

De acordo com a Secretaria Nacional de Segurança Pública (SNSP), apesar da dedicação de alguns profissionais e a existência de programas pontuais de atenção à saúde do policial no Brasil, em quase todos os estados $(96,2 \%)$, a qualidade dos serviços de saúde ocupacional é precária, devido à carência de pessoal especializado, recursos materiais e falta de apoio superior. Os serviços de saúde avaliados oferecem maior atenção à saúde física, além das atividades não enfatizarem a prevenção de doenças e a promoção da saúde. (BRASIL, 2009)

O método de aplicação de questionário através da entrevista na realização desta pesquisa constituiu-se em uma oportunidade de escuta para estes trabalhadores. Observou-se, durante o trabalho de campo, a necessidade de expressão de queixas e conflitos relacionados tanto ao mundo do trabalho como à vida pessoal. O espaço de escuta como estratégia de fortalecimento emocional e suporte psicossocial, visando o 
manejo das situações de conflito e o aprimoramento da saúde dos profissionais da segurança pública, tem sido negligenciado pela maioria dos gestores da polícia, ao longo dos últimos anos no Brasil. (ANDRADE; SOUZA; MINAYO, 2009) Na Bahia, de acordo com a Academia de Polícia Civil (ACADEPOL), existem apenas três psicólogos para todo o efetivo de delegados de polícia, agentes de polícia e escrivães da polícia civil do estado.

Nossos achados devem ser considerados com cautela em função de possíveis vieses. Os estudos de corte transversal apresentam limitações, pois incluem apenas as pessoas que resistiram aos problemas de saúde apresentados e, por coletarem simultaneamente dados de exposição e de doença, não possibilitam apreensão de relação temporal entre ambas. Ainda existe a possibilidade de perdas de informações decorrentes de delegados que abandonaram a profissão por problemas de saúde relacionados ou não ao trabalho, e que, por alguma razão, estavam ausentes, afastados, ou tinham falecido no período de realização do estudo. Situações vivenciadas fora do contexto de trabalho também poderiam influenciar a saúde física e/ou mental dos indivíduos pesquisados.

Apesar do reduzido número de delegados participantes da pesquisa, obtivemos alta taxa de respostas. Para Minayo, Souza e Constantino (2008), limitações metodológicas são frequentes nas investigações realizadas com a polícia em todo o mundo, especialmente no Brasil, devido às restrições ao acesso de informações por parte das instituições e/ou pelo receio que os policiais têm de serem prejudicados quando informam sobre si próprios.

\section{Considerações finais}

Esta pesquisa revelou, dentre outros agravos, a magnitude dos problemas de saúde física e mental presentes no cotidiano dos profissionais estudados e as principais dificuldades enfrentadas no contexto de trabalho. Muitos destes problemas já foram ressaltados na literatura científica internacional e evidenciados nos estudos brasileiros com policiais civis. (MINAYO; SOUZA, 2003) Os resultados encontrados destacaram que, em sua maioria, os delegados de polícia civil pesquisados exerciam atividades administrativas, eram do gênero feminino e não se sentiam reconhecidos no trabalho. Com relação aos aspectos 
psicossociais do trabalho, observou-se predominância de situações envolvendo baixo controle sobre o próprio trabalho, maior demanda psicológica e baixo suporte social da chefia, configurando condições desfavoráveis na vivência profissional (trabalho passivo e trabalho de alta exigência). Verificou-se elevada ocorrência de problemas de saúde e alta prevalência de Transtornos Mentais Comuns (TMC) entre os delegados do estudo; registrou-se baixa utilização dos serviços de atenção integral à saúde disponibilizada pela instituição aos delegados de polícia, tanto em aspectos terapêuticos quanto em ações de prevenção de agravos e promoção da saúde; relataram, ainda, condições precárias de trabalho principalmente em relação aos equipamentos de segurança e proteção e apresentaram altas demandas físicas e emocionais na realização da atividade profissional.

O delegado de polícia civil exerce uma função de extrema importância no auxilio a justiça brasileira. Além das competências e habilidades investigativas, fundamentais na aplicação da justiça criminal e na repressão ao crime, este profissional lida com as mais diversas situações de conflitos e tensões tanto no seu contexto de trabalho como nas adversidades presentes nos centros urbanos do país. Daí a necessidade de cuidar dos aspectos institucionais que promovam o desenvolvimento de carreira e maior qualidade de vida no trabalho. Para Dejours (1992), quando a organização do trabalho não é opressora, estes sujeitos podem conjugar seus desejos e realizações pessoais e ou profissionais com as necessidades econômicas, com mais saúde e autonomia.

\section{Referências}

AMARAL, R.B.; MALBERGIER, A. Avaliação do C.A.G.E. Revista Brasileira de Psiquiatria, v. 26, n. 3, p. 156-163, 2004.

ANDRADE, E.R; SOUZA, E.R; MINAYO, M.C.S. Intervenção visando auto-estima e qualidade de vida dos policiais civis no Rio de Janeiro. Ciência e Saúde Coletiva, v. 14, n. 1, p. 275-285, 2009.

ARAÚJO, T.M; KARASEK, R. Validity and reliability of the job content questionnaire in formal and informal jobs in Brazil. Scandinavian

Journal of Work, Environment \& Health Suppl, n. 6, p. 52-59, 2008. 
ARAÚJO, T.M; GRAÇA, C.C; ARAÚJO, E. Estresse ocupacional e saúde: contribuições do modelo demanda-controle. Ciência \& Saúde Coletiva, v. 8, n. 3, p. 285-297, 2003.

ARAÚJO, T.M. et al. Aspectos psicossociais do trabalho e distúrbios psíquicos entre trabalhadores de enfermagem. Revista Saúde Pública, v. 29, n. 1, p. 424-433, 2006.

BAHIA, M.C. Mulheres no comando das organizações: um caso de polícia. 2002. Tese. (Doutorado em Administração) - Núcleo de Pós Graduação em Administração, Universidade Federal da Bahia, Salvador, 2002.

BAHIA. Lei no 11.370, de 04 de fevereiro de 2009. Estabelece a Lei Orgânica da Policia Civil do Estado da Bahia, Diário Oficial do Estado, 05 fev. 2009.

BRASIL. MINISTÉRIO DA JUSTIÇA. Secretaria Nacional de Segurança Pública. Relatório Técnico - Mapeamento dos Programas de Atenção à Saúde das Instituições Estaduais de Segurança Pública, 2009. Disponível em: <http://www.segurancacidada.org.br> Acesso em: 20 abr. 2009.

. MINISTÉRIO DA SAÚDE. Dados de Saúde Vigitel 2009.

Disponível em: <http://portal.saude.gov.br/portal/saude/profissional/ visualizar_texto.cfm?idtxt $=30864$ \&janela $=1>$ Acesso em: 27 nov. 2010.

BONELLI, M.G. Perfil social e de carreira dos delegados de polícia. In: Maria Tereza Sadek, organizadora. Delegados de Polícia. 1. ed. São Paulo: Sumaré: Fundação Ford, 2003. p. 31-67.

BRANT, L. C. ; DIAS, E. C. Trabalho e sofrimento em gestores de uma empresa pública em reestruturação. Cadernos de Saúde Pública, Rio de Janeiro, v. 20, n. 4, p. 942-949, 2004.

CALAZANS, M. E. A constituição de mulheres em policiais: um estudo sobre policiais femininas na Brigada Militar do Rio Grande do Sul. 2003. Dissertação (Mestrado em Psicologia) Programa de Pós- Graduação em Psicologia Social e Institucional, Universidade Federal Rio Grande do Sul, Porto Alegre, 2003.

COUTINHO, E. S. F; ALMEIDA-FILHO, N; MARI, J. J. Fatores de risco para morbidade psiquiátrica menor: resultados de um estudo transversal em três áreas urbanas do Brasil. Revista de Psiquiatria Clínica, n. 26, p. 246-256, 1999.

DEJOURS, C. A loucura do trabalho: estudo de psicopatologia do trabalho. São Paulo: Cortez: Oboré, 1992.

FERREIRA, D. K. S; AUGUSTO, L. G. S; SILVA, J. M. Trabalho e Saúde dos Policiais Militares do Recife-PE. In: Congresso 
Mundial de Epidemiologia, XVIII e Congresso Brasileiro de Epidemiologia, VII. Anais... Porto Alegre - Brasil, 2008.

FERNANDES, R.C.P. et al. Trabalho e cárcere: um estudo com agentes penitenciários da região metropolitana de Salvador, Brasil.

Cadernos de Saúde Pública, n. 18, p. 807-816, 2002.

FERNANDEZ, M. M. Mujeres policía. Madrid, Centro de Investigaciones Sociologicas, Siglo XXI de Espana, 134 p. 1994.

GOLDEBERG, D.; HUXLEY, P. Common mental disorders a bio-social model. 2. ed. London: Tavistock:Routledge, 1993.

HAGEN, A. M. M. O trabalho policial: estudo da policia civil do estado do Rio Grande do Sul. 2005. Tese (Doutorado em Sociologia) Universidade Federal do Rio Grande do Sul, Porto Alegre 2005.

KARASEK, R.A. Job Content Questionnaire and User's Guide. Columbia University 1993. Disponível em: <www.jcqcenter.org.> Acesso em: 20 set. 2009.

KELLEY, T.M. Mental health and prospective police professionals. International Journal of Police Strategies \& Management. n.28, p.6-29, 2005.

LAVIGNE, E; BOURBONNAIS, R. Psychosocial work environment, interpersonal violence at work and psychotropic drug use among correctional officers. International Journal of Law and Psychiatry. v. 33, n. 2, p. 122-129, 2010.

MANSUR, J.; MONTEIRO, M. G. Validation of the "CAGE" alcoholism screening test in a Brazilian psychiatric inpatient hospital setting. Brazil Journal Medical and Biological Research, Ribeirão Preto, v. 16, n. 3, p. 215-218, 1983.

MARI, J. J.; WILLIAMS, P. A validity study of a psychiatric screening questionnaire (SRQ-20) in primary care in the city of São Paulo.

British Journal of Psychiatry, n. 148, p. 23-26, 1986.

MINAYO, M. C. S.; SOUZA, E. R. Missão investigar: entre o ideal e a realidade de ser policial. Rio de Janeiro: Garamond, 2003.

MINAYO, M. C. S.; SOUZA, E. R.; CONSTANTINO, P. (Coordenadoras). Missão prevenir e proteger: condições de vida, trabalho e saúde dos policiais militares do rio de janeiro. Rio de Janeiro: Editora Fiocruz. 2008. 328 p. 
MINAYO, M. C. S.; ASSIS, S. C.; OLIVEIRA, R. V. Impacto das atividades profissionais na saúde física e mental dos Policiais Civis e Militares do Rio de Janeiro. Ciência \& Saúde Coletiva. v. 16, n. 4, p. 2199-2209, 2011.

MORAES, L. F. R. et al. Implicações do gênero na qualidade de vida e estresse no trabalho da Polícia Militar do Estado de Minas Gerais. In: Congresso de Ciências Humanas, Letras e Artes, V. Anais... Ouro Preto/Mariana, Universidade Federal de Ouro Preto, p. 56, 2001.

PALMA, A. et al. Nível de ruído em ambiente de trabalho do professor de educação física em aulas de ciclismo indoor. Revista de Saúde Pública. v. 43, n. 2, p. 345-351, 2009.

PORTO, L. A. et al. Associação entre distúrbios psíquicos e aspectos psicossociais do trabalho de professores. Revista de Saúde Pública, v. 40, n. 5 p. 818-26, 2006.

REIS, E. J. F. B. et al. Trabalho e distúrbios psíquicos em professores da rede municipal de Vitória da Conquista, Bahia, Brasil. Cadernos de Saúde Pública, Rio de Janeiro, v. 21, n. 5, p. 1480-1490, 2005.

ROSA, A. R.; BRITO, M. J.; OLIVEIRA, F. M. Os Sentidos da Violência nas Organizações: uma Análise Construcionista da História de Vida de uma Policial Militar. Revista Eletrônica Gestão e Sociedade. v. 1, n. 1 jan./jun. 2007.

SANTOS, D. C. et al. Prevalência de transtornos mentais comuns em agentes penitenciários. Revista Brasileira de Medicina do Trabalho, v. 8, n. 1 p. 33-38, 2010.

SANTOS, K. O. B.; ARAÚJO, T. M.; OLIVEIRA, N. F. Estrutura Fatorial e Consistência Interna do Self Report Questionary (SRQ-20) em população urbana. Cadernos de Saúde Pública. Rio de Janeiro, v. 25, n. 1 p. 214-222, 2009.

SANTOS, I. S. et al. Comparing validity of Edinburg scale and SRQ20 in screening for post-partum depression. Clinical Practice and Epidemiology in Mental Health. n. 3, p. 18, 2007.

SADEK, M. T.; ARANTES, R. B. Delegados de Polícia: quem são e o que pensam. In Segurança Cidadã e Polícia na Democracia. Cadernos Adenauer, Rio de Janeiro, v. 4, n. 3, p. 57-70, 2003. SILVA, M. B.; VIEIRA, S. B. O processo de Trabalho do Militar Estadual e a Saúde Mental. Revista Saúde e Sociedade de São Paulo, v. 17, n. 4 p. 161-170, 2008. 
SILVEIRA, M. N. B. As Delegadas de Polícia de São Paulo: profissionalismo e gênero. 2009. Dissertação (Mestrado em Sociologia). Universidade Federal de São Carlos, São Paulo, 2009.

SOUZA, E. R. et al. Sofrimento psíquico entre policiais civis: uma análise sob a ótica de gênero. Cadernos de. Saúde Pública, v. 23 n. 1, p. 105-114, 2007.

SOUZA, E. R.; MINAYO, M. C. S. Policial, risco como profissão: morbimortalidade vinculada ao trabalho. Revista Ciência e Saúde Coletiva, v. 10, n. 4, p. 917-928, 2005.

SOUZA, E. R.; MINAYO, M. C. S.; ASSIS, S. G. Construção histórica de uma categoria social. In: MINAYO, M. C. S.; SOUZA, E. R. Missão investigar: entre o ideal e a realidade de ser policial. Rio de Janeiro: Garamond, p. 51-78, 2003.

STURAR, H. Suicidality among police. Current Opinion in Psychiatry, v. 21, n. 5 p. 505-509, 2008. 



\section{Percepção de riscos ocupacionais em catadores de materiais recicláveis}

Denise Alves Miranda de Oliveira

Luiz Roberto Santos Moraes

\section{Introdução}

O advento da industrialização, dos aglomerados urbanos, a era dos descartáveis e a cultura do consumismo contribuem para gerar um grave problema ambiental e de saúde pública, causado pela grande quantidade de resíduos sólidos depositados na natureza, em quantidade e em composição, difíceis de serem decompostos pelo ambiente. Estes resíduos dispostos inadequadamente nos meios urbanos e rurais repercutem negativamente sobre a qualidade do meio, da vida e da saúde da população.

Há muito tempo, as civilizações já reconhecem os malefícios causados pelo descarte inadequado dos resíduos sólidos, a exemplo da poluição do solo, do subsolo, das águas superficiais e subterrâneas, do ar, do desmatamento, da obstrução de bueiros, das enchentes e dos desmoronamentos, e admitem também que são complexos os mecanismos viáveis para a resolução destes problemas. (OLIVEIRA, 2011)

Uma das alternativas no gerenciamento integrado dos resíduos sólidos urbanos é a coleta seletiva, a qual pode ser definida como um conjunto de procedimentos de recolhimento diferenciado dos resíduos sólidos que podem ser reutilizados ou reciclados. É uma atividade reconhecida como capaz de reduzir o descarte no meio ambiente dos materiais úteis que podem ser reintroduzidos no processo produtivo, contribuindo para a salubridade ambiental, o saneamento básico, a sustentabilidade urbana e a inclusão social com geração de trabalho, emprego e renda. (JACOBI, 2006) 
A coleta seletiva ganhou reconhecimento e está presente em muitos países, por contribuir para a promoção da educação ambiental voltada à diminuição do consumo, do desperdício, matéria orgânica, energia, na sustentabilidade urbana. Além destas questões ambientais, promove a valorização econômica dos materiais reutilizáveis e recicláveis, a geração de negócios, trabalho e renda, principalmente, para aqueles excluídos do mercado de trabalho formal. (SINGER, 2003)

A coleta seletiva insere-se com relevância estratégica no novo momento da economia mundial, caracterizado pelo respeito ao meio ambiente, pela participação da população e pela proposição de políticas de desenvolvimento sustentável. (JOIA; SILVA, 2004, p. 2)

Esta coleta consiste na separação e recolhimento dos resíduos sólidos descartados, segundo sua constituição ou características físicas, devendo ser iniciada na fonte geradora. Para que a coleta seletiva seja eficaz e eficiente, é necessário que a segregação dos materiais reutilizáveis ou recicláveis seja realizada por responsável pela geração dos resíduos sólidos.

A coleta seletiva possibilita à reutilização, a reciclagem, a substituição de matérias primas por outras que sejam mais adequadas à preservação do meio ambiente, reduzindo os impactos ambientais causados pela disposição inadequada de resíduos sólidos, uma vez que redireciona o que fazer com eles.

No Brasil, ainda são poucos os programas de coleta seletiva na fonte geradora, sendo esta atividade desenvolvida, principalmente, por catadores de materiais recicláveis. O trabalho realizado por estes trabalhadores consiste em catar, separar, transportar, acondicionar e, às vezes, beneficiar o material contido nos resíduos sólidos que tem valor de mercado e poderá ser vendido para reutilização ou reciclagem.

Atualmente, consideram-se catadores de materiais reutilizáveis e/ ou recicláveis as pessoas físicas de baixa renda que se dedicam às atividades de coleta, triagem, beneficiamento, processamento, transformação e comercialização de materiais reutilizáveis e recicláveis. (BRASIL, 2010)

Com o fim de contribuir com o conhecimento acerca desta nova modalidade de trabalho e acerca dos trabalhadores que o protagonizam, 
definiu-se pela realização de uma pesquisa qualitativa com catadores de materiais recicláveis em Salvador, Bahia.

A motivação pelo estudo do profissional catador de materiais recicláveis surgiu em uma reunião, com participação da comunidade da área de abrangência da Unidade de Saúde da Família, onde a primeira autora trabalhava. Quando no levantamento de problemas da área, o grupo apontou os catadores de materiais recicláveis como um "problema”, pois estes, durante sua atividade, rasgavam os sacos plásticos à procura de materiais recicláveis e deixavam os rejeitos dispostos nas calçadas das residências. Estes trabalhadores foram identificados, como integrantes de uma ONG de catadores, localizada próxima a Unidade de Saúde da Família, o que levou a primeira autora a refletir sobre o processo de trabalho dos catadores, os riscos à saúde aos quais estão diariamente expostos e sobre qual percepção de risco ocupacional apresentam estes catadores.

Esta pesquisa é justificada pela importância deste numeroso grupo social, constituído por idosos, homens, mulheres e crianças, os quais ainda são uma presença "invisível" constante nas ruas brasileiras, investidos da luta pela sobrevivência, em busca de inclusão e inserção no campo do labor. Além disso, os catadores de materiais recicláveis trazem à sociedade uma valorosa contribuição ambiental e para a saúde pública, resultante do fruto deste trabalho em estruturação e processo de desenvolvimento.

A pesquisa teve como objetivo analisar a percepção de riscos ocupacionais de catadores de materiais recicláveis de uma cooperativa no município de Salvador, Bahia.

\section{Percurso metodológico}

A pesquisa adotou como base científica uma metodologia qualitativa com o objetivo de descrever a percepção de riscos ocupacionais do grupo de catadores de materiais recicláveis de uma cooperativa em Salvador, Bahia, considerando a potencialidade desta ferramenta para a compreensão das dinâmicas sociais e formas de reflexão estabelecidas pelo grupo.

A definição do campo de pesquisa contemplou a escolha do espaço, do grupo de participantes, o estabelecimento de critérios para a seleção 
da cooperativa e de estratégia para a entrada em campo. Priorizou-se a cooperativa que, além de disponibilidade e interesse, os cooperativados exercessem atividade de coleta no território da rua.

O estudo foi realizado em 2010 com a participação de um grupo de catadores de materiais recicláveis, trabalhadores de uma cooperativa situada no Subúrbio Ferroviário de Salvador, Bahia.

Os participantes do estudo, representados pela totalidade dos cooperativados, formam um grupo de cinco homens e cinco mulheres, com idade entre 18 e 59 anos, com uma média de 38,5 anos, e escolaridade variando de $1^{\circ}$ grau a $2^{\circ}$ grau completo, com uma média de oito anos de escolarização.

Os sujeitos convidados concordaram em participar voluntariamente da pesquisa, sendo respeitados os seguintes critérios de inclusão: serem integrantes da Cooperativa em questão, serem maiores de 18 anos, incluindo homens e mulheres.

Iniciou-se o trabalho de campo com a técnica da observação participante. A escolha das situações de observação visava à abrangência do cotidiano e rotina das atividades. As visitas da primeira autora ao campo ocorreram em média três vezes por semana, durante o turno matutino, estendendo-se até o final das atividades dos cooperativados.

A observação foi realizada em três ambientes: 1. O galpão, sede da Cooperativa, imóvel de um único cômodo para a realização de todas as atividades, desde as administrativas até a seleção, separação e armazenamento do material. Neste espaço os catadores permanecem realizando triagem e armazenamento do material; 2. O Condomínio Parque Empresarial da Lagoa (Complexo de Fábricas - denominação utilizada pelos catadores de materiais recicláveis - assim denominado na pesquisa). É uma área de $130.000 \mathrm{~m}^{2}$ onde funcionam 20 galpões de indústrias de diversos segmentos de atividade econômica, entre essas, indústrias de: móveis de madeira e metal, tapetes, vestuário, embalagens, papel higiênico e alimentos. Localiza-se próximo ao galpão da Cooperativa e é considerado o grande doador de materiais recicláveis; 3. O percurso entre o Condomínio Parque Empresarial da Lagoa e a sede da Cooperativa, trecho com pavimentação precária, declives, solo irregular e trânsito movimentado.

As anotações consideradas importantes para a análise das entrevistas como informações sobre conversas, atitudes, expressões, 
relacionamentos, tomada de decisões, comportamentos, gestos, contexto histórico, situações reais, interferências, pausas, comentários, ou seja, as demonstrações que se referiram ao tema estudado foram registradas em Diário de Campo.

Após conhecido o processo de trabalho por meio da observação e estreitamento do respeito e confiança, iniciou-se a técnica da entrevista individual, sendo aplicado um roteiro de entrevista semiestruturado. O roteiro para efeito de análise foi dividido em quatro seções, contemplando perguntas sobre: a. identificação; b. história profissional; c. levantamento de noções sobre risco, segurança e saúde; d. percepção de risco. A partir desse instrumento, objetivou-se construir um perfil socioeconômico, de saúde e ocupacional do grupo, identificar o processo de trabalho e conhecer a percepção dos riscos ocupacionais.

A técnica da entrevista, de natureza individual, permitiu a obtenção de dados subjetivos relacionados às atividades de trabalho, experiências, sentidos, significados, valores, crenças, apreciações e costumes dos sujeitos entrevistados, e a técnica de observação participante permitiu observar fenômenos que não são obtidos por meio da entrevista. (CRUZ et al., 2002)

As entrevistas foram gravadas, com auxílio de gravador de voz, para posteriores transcrições das falas na íntegra e análise dos discursos. Aconteceram no galpão da Cooperativa, durante o turno de trabalho.

A análise dos dados foi feita com base nos preceitos da Análise do Discurso, visando realizar uma apreensão das condições de produção e significação de textos, inferindo a partir da linguagem e sua organização os processos de sua construção. (MINAYO, 2007)

Assim, o estudo discursivo, em suas análises, considera não apenas o que é dito, mas o que já foi dito e até mesmo o não dito, atentando, também, para a posição social e histórica dos sujeitos e para as formações discursivas às quais se filiam os discursos. (FRASSON, 2007) Os princípios e os procedimentos analíticos da análise de discurso podem situar melhor o indivíduo com a linguagem, o mundo, os outros sujeitos, os sentidos e com a história. (ORLANDI, 2009)

O texto oriundo das entrevistas foi submetido a várias operações classificatórias: decompor cada frase em proposições, restabelecer a ordem corrente na frase, reagrupar os termos de ligação, refazendo o discurso, buscando as dependências funcionais da linguagem evidenciada 
na frase. E há vários procedimentos como: proceder ao estudo das palavras do texto; separar os termos constituintes, analisar os adjetivos, os substantivos, os verbos e os advérbios; realizar a análise da construção das frases, construir uma rede semântica entre o social e o gramatical e elaborar a análise, considerando a produção social do texto como constitutiva do seu próprio sentido. (MINAYO, 2007)

A análise das entrevistas foi enriquecida pelo poder da observação participante na subjetividade dos personagens, na fala, nos detalhes dos gestos e expressões dos trabalhadores no local da pesquisa.

Os aspectos éticos foram contemplados em conformidade com a Resolução no 196/1996 do Conselho Nacional de Saúde (CNS), referente aos aspectos para pesquisa com seres humanos. (BRASIL, 1996)

\section{O ingresso de catadores de materiais recicláveis na cooperativa}

A Cooperativa de catadores de materiais recicláveis estudada nesta pesquisa foi implantada como uma estratégia que trouxesse emprego e renda para os moradores do bairro. Durante este processo, o grupo enfrentou diversos entraves como falta de treinamento em segurança no trabalho, dificuldade de acesso a equipamentos como carrinho para coleta e transporte de materiais e ao galpão para triagem e armazenagem do montante coletado.

Posteriormente, com o intuito de aumentar a renda, os integrantes da referida cooperativa começaram a executar um trabalho paralelo junto a um atravessador, período em que o grupo de cooperativados era responsável por realizar apenas a triagem do material. Nas horas livres, continuavam a coletar porta-a-porta o material para a Cooperativa.

Neste grupo, as ocupações anteriores à atividade com coleta de materiais recicláveis referiam-se a atividades do setor terciário, principalmente vinculadas ao comércio, trabalho doméstico, prestação de serviços, sempre ligadas ao mercado informal. O grupo de trabalhadores de 18 a 20 anos teve experiência com trabalhos de gesseiro, ajudante de pedreiro, vendedor de água envasada, garçom, manicure, estágio para Menor Aprendiz no Centro Administrativo da Bahia (CAB) e os sujeitos acima de 47 anos já trabalharam como costureira, cozinheira, 
doceira, lavadeira de roupas, construção civil, soldador, babá, empregos domésticos, serviços gerais e venda de temperos.

A situação de desemprego vivenciada pelas catadoras deste grupo, antes da inserção na Cooperativa, apareceu como precursora de depressão. A inserção no mercado de trabalho promovida pela atividade de coleta de material reciclável é trazida como fundamental para o redirecionamento de suas vidas. Para elas, esta ocupação ocasiona prazer, alegria, bem estar, formação de vínculos de amizade, poder aquisitivo e satisfação pessoal.

Para os catadores com idade maior do que 47 anos, permanecer na Cooperativa é uma opção. Demonstram paixão pela atividade. Eles fazem parte da história de luta da Cooperativa. Existe o sentimento de pertença e de valor. Portanto, cada dia de trabalho traz satisfação, alegria, diversão, sensação de dever cumprido. A satisfação pessoal pelo trabalho de catador entre aqueles com idade mais avançada também foi encontrada no estudo de Almeida, Elias, Magalhães (2009).

Pressupõe que esta elevada satisfação referida, diminua a percepção de risco. Por se tratar de uma atividade prazerosa, o risco fica oculto.

Entre os catadores mais jovens, aqueles com idade entre 18 e 20 anos, o trabalho na Cooperativa representa uma experiência passageira, pois a sua pretensão é a de que sua permanência na Cooperativa seja provisória. Esta ocupação é sinônimo de ajuda, forma de ocupar o tempo de uma maneira produtiva e de gerar renda. O tempo médio de experiência com a coleta seletiva é de 2,4 anos, ao passo que entre os que têm acima de 47 anos este tempo é de 7,8 anos.

Estes catadores de materiais recicláveis têm a coleta seletiva como principal fonte de renda, além do benefício social do programa Bolsa Família, recebido por cinco membros do grupo. O rendimento mensal varia de $\mathrm{R} \$ 100,00$ (cem reais) a $\mathrm{R} \$ 150,00$ (cento e cinquenta reais) e é variável de acordo com a quantidade de materiais coletados a cada mês.

O Brasil tem vivenciado, principalmente na década de 90, transições nos setores econômico, social, demográfico e tecnológico que atingem diretamente o mercado de trabalho, a dinâmica e as estruturas setoriais e ocupacionais. Como exemplo disso, tem-se o desemprego, o surgimento de novas formas de contratação, o trabalho informal, a flexibilidade nas relações de emprego, a abertura comercial e a reforma do papel do Estado. (NAVARRO, 2007) Mesmo com o incremento 
ocorrido no emprego nos últimos dez anos, as formas alternativas e muitas vezes precárias de trabalho não foram superadas.

Nos contextos capitalistas, o emprego configura uma atividade humana, visa à manutenção e à sobrevivência da espécie, aquisição de bens, prazer, satisfação e realização pessoal, aceitabilidade social, promoção das relações interpessoais, inspiração, desenvolvimento da autonomia e criatividade. Estabelece sentimento de inclusão, integração e convívio social, de respeitabilidade, de pertença, de contentamento, estruturador de identidade pessoal e profissional. (OLIVEIRA, 2011)

A inserção dos trabalhadores estudados na atividade de coleta de material reciclável pode refletir a insuficiente oferta de empregos formalizados no Brasil, mesmo considerando o incremento do emprego já referido. Neste cenário, os trabalhadores têm procurado novos mecanismos capazes de garantir a geração de renda e o suprimento de suas necessidades básicas. Dessa forma, a coleta seletiva de materiais reutilizáveis e/ou recicláveis pode ser considerada uma oportunidade que viabiliza a inclusão no mundo do trabalho. Ainda que não garanta direitos sociais e trabalhistas, tais como os sistemas de proteção a trabalhadores que adoecem ou se acidentam no trabalho, a coleta seletiva ganha importância e vem crescendo continuamente. Representa uma possibilidade de inserção no mundo social e do trabalho, gera renda e trabalho para homens e mulheres que, por meio desta atividade, garantem a sua subsistência. (OLIVEIRA, 2011)

O ingresso no trabalho com os resíduos sólidos se dá, em grande parte, pela baixa escolaridade (que dificulta a conquista de outras profissões melhor remuneradas), crise econômica, desemprego e necessidade de ajudar nas despesas do lar, como meio de sobrevivência e independência, forma de fazer amigos, integração no mercado de trabalho, de sentir-se útil e produtivo. Porém, esta modalidade de trabalho não deixa de ter a conotação negativa construída socialmente em torno dos resíduos sólidos, ou seja, daquilo que é jogado fora, que gera asco, discriminação e preconceito. (MEDEIROS; MACEDO, 2006)

Normalmente, os trabalhadores de materiais reutilizáveis e/ou recicláveis aderem a esta atividade devido à exclusão do mercado formal de trabalho. Para os trabalhadores do presente estudo, antes de iniciarem a atividade como catadores, muitos, já tinham tido outras experiências em diferentes ramos produtivos. Estudo de Medeiros e Macedo 
(2006) cita experiências profissionais anteriores de trabalhadores que coletam materiais recicláveis como mecânicos, lanterneiros, pedreiros, pintores, pescadores, cozinheiras, costureiras, vigilantes, auxiliares de protéticos, balconistas e artistas plásticos.

Nesta conjuntura de ainda desemprego, informalidade, precarização das relações de trabalho, desigualdades sociais, pobreza, forma de consumo instituída e geração de grandes quantidades de resíduos sólidos, a atividade de coleta seletiva desenvolvida pelos catadores de materiais recicláveis surge como possibilidade de sustento. Acrescido das discussões ecológicas, ganha relevância ambiental e econômica, mas continua a se relacionar com um fenômeno de exclusão social instalado na sociedade. (SIQUEIRA; MORAES, 2009)

\section{Catador de materiais recicláveis, cotidiano e risco}

O cotidiano de trabalho dos sujeitos cooperativados deste estudo consiste em coleta manual de resíduos sólidos, carregamento e descarregamento do caminhão nos momentos de venda e recebimento de material doado, reparos e condução dos carrinhos de coleta, compactação da carga no interior do carrinho de coleta, triagem por composição, limpeza, armazenamento, distribuição e venda.

Costumam trabalhar oito horas por dia, mas a jornada de trabalho está mais relacionada à quantidade de trabalho do que ao cumprimento de uma carga horária fixa. Em dias de menor carga de trabalho, são liberados após a finalização das tarefas. Não costumam apresentar absenteísmo no trabalho, e, quando o fazem, isso se dá apenas por causas relacionadas à saúde.

Os riscos mais citados são a presença de materiais perfurantes e cortantes nos resíduos coletados, os riscos relacionados ao manuseio de carga, ou seja, ao trabalho físico pesado, com uso de força e posturas anômalas do corpo, de acidentes como quedas e acidentes de trânsito, manuseio de substâncias irritantes como pós e produtos químicos e a informalidade.

Principal personagem da coleta seletiva, o catador de material reciclável, enfrenta ambiente e condições precárias de trabalho. Embora 
desenvolva uma atividade de importância ambiental, depara-se com adversidades no seu ambiente de trabalho, informalidade, violência, invisibilidade, exclusão social, discriminação e exposição a riscos.

Além dos catadores de materiais recicláveis autônomos caminhando diariamente pelas ruas com pesados fardos sob a cabeça e ombros, ou empurrando seus carrinhos, associações e cooperativas de catadores de materiais recicláveis também agem nesta atividade de forma mais organizada e em parcerias. As cooperativas atuando organizadas no processo de coleta seletiva visam gerar trabalho, renda, inclusão social, ações de educação ambiental, segurança no trabalho, capacitação, formação, cooperação técnica e financeira, divulgação e valorização da atividade de catação e aumento da quantidade e qualidade dos materiais coletados para maior poder de negociação, preços e competitividade.

Segundo Oliveira (2011), a ocupação do catador é marcada por precárias condições de trabalho, exposição a riscos, insalubridade, má remuneração, menosprezo, preconceitos e ausência de garantias trabalhistas que os defendam, principalmente, em condições de acidentes de trabalho, doenças, aposentadoria, décimo terceiro salário e seguro desemprego. As situações são tão adversas que contribuem para que a identidade profissional dos catadores seja assinalada pela exclusão social.

Os catadores de materiais recicláveis tiveram sua profissão regulamentada em 2002, com o registro na Classificação Brasileira de Ocupações (CBO) sob o número 5192-05. No rol das suas atribuições, consta a função de catar, selecionar e vender materiais recicláveis como papel, papelão e vidro, bem como materiais ferrosos e não ferrosos e outros materiais reaproveitáveis ou recicláveis.

A CBO de 2002 define que o trabalhador é exposto às variações climáticas, aos riscos de acidentes de trânsito, contaminações e cortes na manipulação do material e à violência urbana. (BRASIL, 2002)

O trabalho com materiais recicláveis é reconhecido como atividade que interfere diretamente no processo saúde/doença dos trabalhadores. Tem o potencial de trazer danos a sua saúde, pois estes podem adoecer ou morrer por consequência da profissão ou condições adversas em que seu trabalho é ou foi realizado. (FERREIRA; ANJOS, 2001)

Os principais riscos citados pelos trabalhadores estudados são os mesmos descritos na literatura e bem definidos por diversos estudos da 
área. (PORTO et al., 2004; VELLOSO; SANTOS; ANJOS, 1997; GONÇALVES, 2005) Os agentes frequentemente presentes nos resíduos sólidos são os de ordem física como: poeiras, ruídos excessivos, frio, calor, fumaça; químicos como líquidos que vazam de pilhas e baterias, óleos e graxas, pesticidas, herbicidas, solventes, tintas, produtos de limpeza, cosméticos, remédios, aerossóis, metais pesados como chumbo, cádmio e mercúrio; agentes biológicos, tais como microrganismos patogênicos: vírus, bactérias e fungos; riscos de acidentes com materiais perfurocortantes, com vidros, lascas de madeira, objetos pontiagudos; uso de força, posturas inadequadas, vibração e levantamento manual de peso. Os acidentes e doenças neste tipo de atividade geralmente acontecem em decorrência da precarização e falta de condições adequadas de trabalho. (FERREIRA; ANJOS, 2001)

Os ambientes e condições insalubres de trabalho são os principais responsáveis pela incidência, cada vez maior, de doenças ocupacionais entre os trabalhadores da coleta de materiais recicláveis. Mas, vale ressaltar que a exposição do indivíduo a situações que podem ocasionar acidentes e lesões sofre interferência do contexto, do comportamento e das medidas de prevenção tomadas. A percepção do risco, a sensação e condições de segurança, a autogestão e o conhecimento também podem influenciar nas ações de controle adotadas pelos trabalhadores.

\section{Risco ocupacional dos catadores da cooperativa}

No presente estudo, os catadores relatam não se preocuparem com o risco decorrente da manipulação dos resíduos descartados nos contenedores do Complexo de Fábricas por não conhecerem exatamente o que manipulam durante a coleta dos materiais. $\mathrm{O}$ reconhecimento da exposição à determinada substância presente nos resíduos sólidos como um fator de risco, só é feito, na maioria das vezes, depois de contato físico com repercussões negativas sobre o corpo.

Portanto, são o cotidiano do trabalho, as experiências pessoais ou alheias, as histórias de acidentes e incidentes passados pelos mais experientes que norteiam o comportamento de exposição. À medida que o trabalhador manuseia o resíduo sólido, começa a conhecer as características que determinam seu risco. São características físicas como 
aspecto, textura, cheiro e cor que passam a condicionar a exposição ou não do cooperativado a determinadas situações.

O desconhecimento dos catadores sobre o potencial de dano dos produtos encontrados e coletados favorece uma abordagem pouco segura. Possivelmente, o contato com os resíduos desconhecidos, não desperta nos catadores o temor e a preocupação com as repercussões sobre a saúde que justifiquem a sua não exposição. A aquisição do material reciclável, objeto de interesse dos trabalhadores que gera ganhos financeiros, parece exigir atenção superior à preocupação com a existência de riscos que podem ocorrer com o manuseio dos materiais desconhecidos.

Normalmente, o grupo não costuma apresentar cautela diante de conjunturas nunca antes vivenciadas, sejam estas circunstâncias ou exposições a resíduos sólidos, por não imaginá-las como uma situação potencial de risco.

O desconhecimento dos catadores de materiais recicláveis sobre os resíduos manipulados aumenta a vulnerabilidade, os acidentes e as doenças ocupacionais.

No entanto, nas ocasiões, durante a coleta de materiais recicláveis, onde o advento adverso, ou seja, o risco eminente já é conhecido, os catadores assumem uma postura preventiva, cautelosa, precavida antes do enfrentamento das situações. Assim sendo, mesmo diante da percepção e constatação do risco, a ocasião é enfrentada.

Portanto, a presença do risco pode ser desconsiderada neste contexto que relaciona lucro à quantidade de materiais coletados. Por mais perigosa que represente a circunstância, se gerar possibilidade de venda do material, é tida como parte do processo, e tolerada. Apenas quando a situação de perigo é interpretada como superior ao benefício trazido pela coleta, o comportamento é o do não enfrentamento, ou seja, de evitar a exposição.

Nessas situações percebidas como de risco, utilizam alternativas que buscam proteção e minimização, a exemplo da realização de movimentos menos bruscos no intuito de proteger-se, diminuindo a dispersão de pós. Reconhece-se também a naturalização na manipulação das substâncias contidas nos contenedores.

Neste contexto de incertezas, de desigualdades e de exposição a riscos enfrentados diariamente pelos catadores de materiais recicláveis, 
a percepção de risco ocupacional implica em desvelar os significados inerentes à percepção do indivíduo frente às situações corriqueiras de trabalho.

A exposição e vulnerabilidade individual do trabalhador a situações de risco estão vinculadas a condições cognitivas, econômicas, políticas, de poder, comportamentais, situacionais e sociais. (AYRES et al., 1999)

Outro fator que está relacionado à aceitabilidade do risco é o benefício advindo desta exposição. A abordagem do risco é complexa, envolve percepção, confiança no sistema regulador e quando os benefícios para determinado grupo são considerados superiores aos prejuízos, a tendência é a minimização e aceitação dos riscos. (NAVARRO, 2007; SANTOS, 1990; FERREIRA; ANJOS, 2001)

Assim, os experimentos vivenciados no passado interferem sobre a percepção do risco, principalmente em tarefas cotidianas, determinando o conceito pessoal de risco. (SANDERS; McCORMICK, 1993; JASANOFF, 1998; NOYES, 2001; MORAES et al., 2002)

Normalmente, o trabalhador quando nega o risco, o faz, como estratégia defensiva, devido ao enfrentamento constante de situações de perigo e termina por elaborar estratégias cognitivas de minimização do risco. (LIMA, 1998)

A aceitação e a minimização dos riscos pelos catadores de materiais recicláveis podem favorecer o aumento do número de acidentes e doenças ocupacionais. Para uma atitude preventiva é interessante que o trabalhador detecte, decifre e torne o risco significativo. Se o risco não é identificado, o trabalhador pode não assumir uma postura defensiva como a situação exige.

A perspectiva da inter-relação entre pessoa e ambiente naturaliza a abordagem do risco como se o enfrentamento fosse algo inerente à atividade, parecendo tornar invisível e insignificante o potencial de risco para o catador de materiais recicláveis. O valor, importante na caracterização do risco, é atribuído ao material reciclável e não à fonte potencial de dano. 


\section{Processo de trabalho, ambientes e percepção de risco}

Observou-se que a percepção de risco dos cooperativados sofre influência do espaço físico (sede da Cooperativa, Complexo de Fábricas ou percurso entre estes), condições e processo de trabalho realizado. E no enfrentamento dos riscos verificaram-se as variáveis gênero e tempo de serviço como determinantes na divisão de tarefas consideradas de risco pelos cooperativados do estudo.

As reproduções sociais definem as relações de gênero construídas dentro da organização da cooperativa pesquisada. Percebeu-se a existência de diferenciação entre homens e mulheres quanto à distribuição de tarefas. Trazem o mote de trabalho masculino e feminino. A atividade de coleta no Complexo de Fábricas, o manuseio do carrinho de transporte, a compactação da carga em cima do carro de transporte e as atividades consideradas mais penosas ficam a cargo dos homens.

$\mathrm{Na}$ avaliação do processo de trabalho, algumas atividades consideradas penosas, que precisam necessariamente ser realizadas fora do espaço da sede da Cooperativa, são delegadas aos homens, enquanto as mulheres permanecem no espaço da Cooperativa. É como se o homem exercesse o papel do "provedor" e a mulher da "cuidadora".

No concernente a gênero, Poeschl (2003), em seu estudo sobre as representações das diferenças entre os sexos, conclui que existe uma reprodução social das relações assimétricas entre os sexos na sociedade. Esta reprodução define atividades específicas, destinadas aos homens e às mulheres, que são perpetuadas na vida cultural cotidiana e interferem na tomada de decisões e posicionamento frente às situações diárias.

Esta representação da força masculina é mais frequente nos discursos femininos das cooperativadas com maior tempo de serviço e é bem aceita pelos sujeitos masculinos, que sendo mais jovens, assumem a responsabilidade por tais tarefas. Pressupõe-se que os fatores idade e respeito à determinação da execução das tarefas sejam determinantes na aceitação da exposição a tais situações, caracterizadas pelo grupo, como as mais perigosas.

A divisão de tarefas também é definida a partir do tempo de experiência com coleta seletiva, que é fator predisponente à exposição a 
situações consideradas como risco pelo grupo. Enquanto o cooperativado vai adquirindo experiência, ele permanece no espaço do galpão da sede da Cooperativa, considerado seguro. As tarefas intituladas como perigosas, a exemplo da coleta no Complexo de Fábricas, são executadas pelos mais experientes. Os novatos são poupados da exposição das tarefas vistas como perigosas, como um movimento de proteção e prevenção de acidentes.

Relativo aos ambientes de trabalho caracterizados pelos sujeitos da pesquisa como Complexo de Fábricas, percurso entre o Complexo de Fábricas e a sede da Cooperativa, estes possuem características e percepção de riscos ora distintas, ora comuns.

Vale ressaltar que, para os catadores de materiais recicláveis, o seu trabalho não tem uma única representação ou sentido, ele é ambíguo, refletindo a dialética saúde/doença, limpeza/sujeira, controle/vulnerabilidade, aceitação/negação, medo/segurança.

No ambiente do Complexo de Fábricas os catadores se referem a possibilidade de exposição a substâncias como: pós de alumínio, de serra e de vidro (das indústrias de móveis), tinta, solvente (principalmente das indústrias de vestuário), alimentos deteriorados (do restaurante), a cortes, a acidentes perfurocortantes, a quedas e a levantamento manual de peso.

Em relação às substâncias em pó reconhecidas como um risco, os catadores costumam fazer uma escala de perigo da exposição a partir da natureza do pó. Avaliam o risco à saúde, quantificando o volume e a natureza do pó existente dentro dos contenedores de onde retiram os materiais reutilizáveis e/ou recicláveis como papelões. O conhecimento sobre o assunto construído a partir das interpretações das informações disponíveis auxilia o grupo na tomada de decisões e na avaliação do risco-benefício.

Em relação à tarefa de compactação da carga durante a coleta de materiais, esta é considerada uma atividade eminentemente masculina. Os trabalhadores temem risco de queda e possibilidade do carrinho virar durante sua execução. Reconhecem nesta tarefa a necessidade de habilidades como agilidade, coragem e força, características, para o grupo, típicas dos homens, reforçando que as atividades reconhecidas como risco são delegadas à população jovem e masculina. Subentende-se que este subgrupo é capaz de superar as atividades que requerem 
mais força e de sair ileso das circunstâncias quando exposto a diferentes situações de risco.

Sobre a prática da compactação da carga e a presença de materiais ferrosos coletados e depositados no interior do carrinho de coleta, o catador não reconhece como um risco, pois o costume de colocá-los num canto do mesmo parece ser suficiente para evitar acidentes durante esta prática.

O risco associado à presença de materiais perfurocortantes durante o manuseio com o resíduo está presente no discurso de todos os cooperativados. Os trabalhadores reconhecem que os principais riscos ocupacionais são os acidentes com materiais perfurocortantes. A presença do objeto perfurocortante no resíduo sólido manipulado é tida como sinônimo de risco.

Portanto, os materiais cortantes e perfurantes são, naturalmente, representados e percebidos como risco, porém não foi observado temor a tais exposições. Para o grupo, a presença desses materiais é inerente aos resíduos sólidos e, portanto, a sua profissão, restando aos catadores utilizarem estratégias para a prevenção de acidentes como uso de luvas e sendo a manipulação realizada com cautela e atenção.

A percepção de risco ocupacional relacionado à presença de materiais perfurocortantes é comum nos estudos com catadores de materiais recicláveis. (VELLOSO; SANTOS; ANJOS, 1997) Assim também, é comum o relato de acidentes por tais materiais.

No percurso entre o Complexo de Fábricas e a sede da Cooperativa os catadores caracterizam a caminhada com os resíduos sólidos, no carrinho de transporte, como atividade difícil, perigosa, cansativa, com risco de atropelamento, de quedas, do carro de transporte virar, de manuseio de peso, de exposição ao sol e necessidade de percorrer longa caminhada.

A altura da carga que causa dificuldade de visibilidade, a instabilidade e o peso do carrinho adicionado ao da carga coletada, o trânsito movimentado, o peso da carga, as condições de má conservação dos carrinhos e as características do trajeto durante a condução dos materiais são relatadas como causas dos incidentes e acidentes no trajeto com os materiais coletados. O grupo considera não ter governabilidade sobre estes problemas, o que aumenta sua vulnerabilidade. 
O grupo demonstra um sentimento ambíguo em relação ao carrinho de coleta. O reconhecem como um instrumento de trabalho facilitador, importante e vital, mas, também como sinônimo de peso, risco, instabilidade, dificuldade, sobrecarga e cansaço.

Compreende-se que a percepção de risco do grupo sobre a condução do carrinho de coleta como um evento de risco, sendo necessárias desenvolturas para a sua realização. Mesmo diante da percepção de risco, o grupo não relaciona insatisfação ou medo, costuma naturalizar tais exposições como inerentes ao processo e como próprio da sua atividade enquanto catador de materiais recicláveis.

No concernente à sede da Cooperativa, esta é caracterizada pelo grupo como extensão da casa, ambiente de trabalho harmonioso, seguro e limpo. A sede foi resultado de conquista, luta, portanto há um sentimento de posse, de lar, de aconchego. Na sede, trabalham pessoas com vínculos familiares e afetivos sólidos, que se preocupam umas com as outras, não há chefes, apenas amigos e relações de autonomia, o que permite considerar que a sede da Cooperativa é percebida como um fator de proteção.

Após uma primeira triagem realizada ainda no Complexo de Fábricas, os resíduos sólidos parecem perder o potencial de risco ao chegarem à sede da Cooperativa. É como se já fossem conhecidos e inofensivos. Como se o ambiente da sede da Cooperativa e o grupo de cooperativados promovessem uma segurança. As práticas que justificam esta conclusão são a rejeição do uso da luva na sede, usando-a exclusivamente no território da rua, e os discursos de que a sede é limpa, rejeitando a conotação de sujeira e risco e da comparação do galpão a uma atmosfera de lar, culturalmente associado à segurança. É como se o território da rua oferecesse riscos de contaminação e o da sede da Cooperativa não.

A partir dos discursos dos catadores observou-se que o ambiente físico da sede da Cooperativa é considerado como um espaço seguro e livre da exposição ao risco comparado as suas casas. Esta ideia é difundida pelos catadores com maior tempo de permanência na Cooperativa.

Em relação aos riscos associados ao manuseio de carga, posturas anômalas e uso de força, eles são representados apenas quando relacionados à coleta de materiais recicláveis, à condução do carinho de transporte e ao levantamento dos big bags. O efeito dor é relatado como proveniente destas ações. Apenas o grupo responsável pela coleta na rua 
e por conduzir o carrinho com o material coletado é que traz referência a esses riscos, traduzidos pelo resultado das dores no corpo, principalmente, no segmento dos braços, coluna e pernas.

A representação das queixas ergonômicas oriundas do trabalho está associada à satisfação pessoal que também está associada à idade. O grupo com maior idade não refere dor após a jornada de trabalho. A ocorrência da dor parece estar relacionada ao efeito do tipo de tarefa desenvolvida e ao grau de satisfação pessoal na atividade. Apresenta uma relação diretamente proporcional à tarefa e inversamente proporcional à satisfação. No grupo de 18 a 20 anos, responsável pela coleta e condução do carrinho carregado de resíduos sólidos, a dor e o cansaço físico após a jornada de trabalho estão presentes. Já entre os maiores de 47 anos de idade, grupo onde foi observada maior referência à satisfação e realização profissional, o resultado dor relacionada à ocupação está ausente.

Os catadores, maiores de 47 anos, mesmo diante de sobrecarga física sobre o corpo como, levantamento manual de peso, trabalho físico pesado, postura inadequada, repetitividade, trabalho em pé ou de cócoras, torção do tronco e flexão da coluna, ritmo excessivo de trabalho, não referem presença de risco no ambiente da sede da Cooperativa, confirmando a conotação de segurança que envolve este ambiente. Além disso, conclui-se que, em se tratando de uma atividade com alta demanda física, o discurso da negação da dor proveniente do trabalho entre aqueles maiores de 47 anos de idade, remete também a uma negação e não percepção do risco. Sobressai uma postura de superação, difundida entre eles, como requisito necessário ao enfrentamento da atividade laboral e como sinônimo de força. Logo, a percepção deste tipo de risco relacionado à atividade de coleta de materiais recicláveis é tênue e restrita à atividade de coleta.

A ausência de direitos trabalhistas aparece nos discursos como um fator de risco ocupacional. O trabalhador sem garantias, quanto à aposentadoria e desamparado em casos de acidentes ou doenças, se expõe a fortes cargas físicas, por vezes, desconsiderando limites físicos e protelando tratamentos de saúde, em função da busca pelo aumento da lucratividade, diretamente relacionada à quantidade da coleta de materiais reciclados. Estudo de Medeiros e Macedo (2006) também retrata a preocupação dos catadores quanto à ausência de garantias trabalhistas. 
Os catadores percebem a situação de informalidade como um agravante dos riscos vivenciados no dia-a-dia, pois em todas as situações de doenças ocorridas no grupo que resultaram em muitos dias de afastamento, os cooperativados tiveram prejuízos financeiros, decorrentes dos descontos ocorridos devido às faltas e, consequente, redução na coleta. Os relatos exprimem que sem previdência, por vezes, negligenciam a saúde, colocando em primeiro plano a necessidade básica da subsistência, percebendo tal atitude como um fator de risco.

Trabalhar em equipe tem um grande significado nas falas dos catadores, pois o trabalho é eminentemente coletivo e para alcançar os objetivos dependem do esforço e união de todos. A importância dada ao grupo na organização do trabalho também pode ser detectada no estudo de Santos (1990).

As relações de trabalho são caracterizadas por todo o grupo como harmoniosas, colaborativas, confiáveis e respeitosas. Os cooperativados se consideram membros de uma mesma família. Os integrantes se amparam e têm a responsabilidade de se protegerem. Estar em grupo representa segurança. O trabalho em grupo é visto como um fator de proteção, segurança, de prevenção de acidentes, o que tornaria o trabalho mais seguro.

As expressões "uma família", usada para representar os colegas de trabalho, e "casa", indicando o local de trabalho, explicam e ratificam a conotação do aconchego e segurança culturalmente atribuídos ao lar e à família. Percebeu-se que o "trabalho em família" é tido como promissor de segurança, de conforto e tranquilidade. O grupo se ampara e mostra-se solidário. $\mathrm{O}$ trabalho em grupo tem uma representatividade grande e chega a apresentar uma conotação de superpoder, sendo que cada integrante demonstra ser corresponsável pela segurança de todos.

Neste contexto, o trabalhador assume a responsabilidade pela prevenção, por sua saúde e a do grupo, surgindo a autoculpabilização nos casos de acidentes, pois o risco é entendido como controlável, sendo o comportamento cauteloso supostamente suficiente para a prevenção de acidentes.

O enfrentamento do risco com naturalização é difundido entre os mais experientes e está presente durante todo o processo de trabalho. São as informações preventivas centradas na experiência e no bom 
senso do grupo que fortalecem os cooperativados na superação de limites, perigos e dificuldades diárias.

O grupo acredita exercer uma gestão sobre os riscos, principalmente, os relacionados a acidentes perfurocortantes, os mais identificados pelo grupo.

Além disto, o trabalho em equipe, reconhecido como fator de segurança para o grupo, também é admitido como uma forma de enfrentar o risco.

O uso dos equipamentos de proteção individual também é tido como uma forma de enfrentamento da situação percebida como risco. Para o grupo estudado, o uso de equipamentos de proteção individual (EPI) como luvas, botas, máscara, calça e roupas de manga comprida e o cuidado e atenção na realização das atividades estão relacionados à segurança e à prevenção de acidentes. $\mathrm{O}$ equipamento de proteção individual mais utilizado pelo grupo é a luva.

O uso de fardas, o manuseio dos materiais afastados do corpo e a mesa de triagem surgem como medidas de diminuição do risco de contaminação. O contato físico do resíduo sólido com o corpo está no discurso dos catadores como elemento propenso a acidentes e doenças.

Embora os catadores percebam e citem a existência de fatores de risco, não reconhecem suas queixas ou problemas de saúde atuais como ocupacionais. Justificam-nos com outras questões, como idade e doenças prévias. E o risco, em muitos momentos, só transita no imaginário.

Mesmo diante de uma atividade insalubre, o grupo pouco menciona a presença de doenças associadas à catação. Apenas os acidentes perfurocortantes, as quedas e as infecções de pele são associados à ocupação, como também encontrado nos estudos de Ferreira e Anjos (2001), Porto et al. (2004), Miura (2004), Medeiros e Macedo (2006), Cavalcante e Franco (2007).

Com referência às experiências pessoais de doenças ocupacionais, os relatos se direcionam para terceirização, naturalização, negação, minimização e eufemização. Existe uma dificuldade de reconhecer a doença e a dor do momento presente como ocupacionais. Os acidentes, sim, adquirem um caráter real de infortúnio, mas as doenças assumem uma possibilidade abstrata.

Quando questionados sobre acidentes de trabalho, a maioria já sofreu um ou mais acidentes ou doenças consideradas ocupacionais. 
Sexo, escolaridade, idade e tempo de experiência com a coleta não estão associados à ocorrência de acidentes típicos de trabalho. No entanto, as doenças de pele estão associadas ao tempo de exposição com a coleta, ou seja, ao tempo de experiência com este trabalho.

Para os catadores cooperativados, o espaço da sede da Cooperativa tem uma representatividade bastante significativa, principalmente, para os cooperativados com maior tempo de atividade. É notável os sentimentos de amor, orgulho, autoafirmação, esperança e valorização dispensados à Organização. Assinalam este ambiente e os materiais que ali se encontram como seguros, limpos e inofensivos. O potencial de risco dos materiais recicláveis coletados na rua desaparece ao cruzar o portão de acesso da sede da Cooperativa, ao ponto dos cooperativados não distinguirem no lugar a presença de riscos.

\section{Considerações finais}

A percepção de risco dos catadores de materiais recicláveis é diminuída pela necessidade de sobrevivência. $O$ valor recai sobre o material reciclável, que gera rendimento e subsistência, e o risco assume um papel sutil no imaginário.

A primeira menção dada ao risco é relativa aos cortes e perfurações causados pelos materiais perfurocortantes encontrados nos resíduos sólidos, seguidos pelos riscos relacionados ao manuseio de carga, ao trabalho físico pesado, ao uso de força e posturas anômalas do corpo, e a questão da informalidade.

A respeito da exposição ocupacional, diante das circunstâncias e resíduos desconhecidos, não foi observado nos catadores estudados da Cooperativa um sentimento de preocupação, medo, ou antecipação. As possíveis consequências adversas são ignoradas, as percepções do risco costumam acontecer no cotidiano e após exposições com consequências deletérias sobre o corpo. Diante de situações nunca antes vividas, que promoveram repercussões desagradáveis, comunicam os eventos adversos aos demais para que esta exposição possa ser evitada.

Apenas os riscos palpáveis e visíveis são percebidos e referidos. Aquilo que pode ser visto e sentido como os cortes, as infecções de pele, as substâncias em pó são, facilmente, percebidos e identificados como riscos ocupacionais. 
Quando o risco é percebido como uma realidade, o modo de enfrentamento é a ação com cuidado, cautela, atenção e coragem. A prevenção de riscos está intimamente relacionada ao trabalho com alto nível de atenção que é difundido como sinônimo de proteção. A atenção de todo o grupo tem o poder de protegê-los, surgindo uma ideologia defensiva.

O risco percebido só é encarado quando acreditam nos benefícios compensatórios de tais exposições e quando o controle dos processos permite que a gestão seja facilitada, transformando no subconsciente uma atividade considerada inicialmente perigosa em inofensiva.

A percepção de risco está associada à proximidade do evento para os mais vulneráveis. Aqueles que trabalham diretamente com a coleta seletiva no território da rua são os que referem perceber os riscos de acidentes de trabalho, cortes, infecções por substâncias como pós de alumínio, de serra e de vidro, queda, sobrecarga de trabalho, levantamento de peso e risco de acidentes de trânsito e com o carrinho de transporte do material coletado.

O significado de trabalho para o grupo é equivalente à saúde e a negação da doença é prova de força. Associar trabalho à doença não é frequente entre o grupo. É como se o trabalho só gerasse benefícios. E quando mencionam, é comum o relato ser na terceira pessoa e no tempo passado como se o problema já superado não lhes pertencesse. As marcas e cicatrizes são demonstradas como "troféus" que registram superação e são provas de que tantos caminhos já foram percorridos, garantindo o sentimento de posse pela Cooperativa e pelas conquistas alcançadas.

O corpo dos cooperativados é um instrumento de trabalho e perceber este corpo como "sadio" torna-se essencial para garantia, inclusive, de sua permanência na Cooperativa. Sem amparos sociais, como o da Previdência Social, os catadores temem que, sem sua própria força de trabalho, representada pela autoafirmação da saúde e negação das queixas atuais como ocupacionais, sejam considerados rejeitos e, assim, como os resíduos sólidos, sejam desprezados.

No estudo da percepção do risco no ambiente e no processo de trabalho, existiu uma polarização risco/benefício, aceitação/negação, medo/enfrentamento. Aqueles riscos altamente perceptíveis, aceitos e difundidos pelos mais experientes, como os acidentes perfurocortantes 
e as doenças de pele, surgem nos discursos e nas histórias de vida. São considerados inevitáveis, enfrentados diariamente.

Os catadores que permanecem no ambiente supostamente seguro da sede da Cooperativa não costumam referir riscos. Provavelmente, este "silêncio" não represente impessoalidade, mas sim, uma condição de distanciamento e de proteção, já que o enfrentamento do risco é tido como inevitável, tornando-se, portanto, desnecessário ratificá-lo.

A gestão participativa, a autonomia e o trabalho em grupo representam uma valorização do trabalho de coleta de materiais recicláveis, ofuscam a informalidade e trazem o sentimento de profissionalização e emancipação para esta classe profissional.

A negação do risco é observável e a superação das dificuldades faz-se necessária em uma situação de instabilidade financeira, na qual o único meio de gerir recursos financeiros é uma maior quantidade de materiais recicláveis coletados. A relação de negação e minimização do risco, consolidada coletivamente, ocorre a partir da necessidade de sobrevivência do catador e de sua família.

Mesmo diante de todas as dificuldades enfrentadas - como baixo rendimento, falta de insumos, exposição a riscos, sobrecarga de trabalho - sentem-se motivados a continuar equacionando e superando tais questões na esperança de dias melhores, traduzidos como aumento do rendimento, acesso a insumos e garantias sociais, a exemplo da Previdência Social. Entre eles, é marcante a projeção otimista em relação ao futuro, pois acreditam que a articulação com os poderes públicos lhes garantirá, um dia, condições dignas de trabalho.

A percepção de risco ocupacional entre catadores de materiais recicláveis revela que o essencial para a melhoria de vida e trabalho destes trabalhadores, não se resume à implantação de medidas de educação em saúde que sensibilize sobre a percepção de riscos ocupacionais, mas, sobretudo, o que importa é a adoção de políticas públicas e medidas individuais que viabilizem a garantia de acesso a direitos sociais, trabalhistas, melhores condições de subsistência, além de uma ampla discussão sobre riscos sob a ótica do trabalhador, fundamental para o sucesso destas ações. A recomendação de outros estudos sobre riscos ocupacionais sob o "ponto de vista" do trabalhador faz-se importante para instrumentalizar as políticas públicas, com o fim de promover dignidade e segurança no trabalho. 


\section{Referências}

ADAMETES, C. M. O olhar da inclusão: possibilidades de pesquisa com uma catadora de lixo. 1998. 149f. Dissertação (Mestrado em Sociologia) Universidade Estadual Paulista Júlio de Mesquita Filho, Araraquara, São Paulo, 1998.

ALMEIDA, J. R; ELIAS, E. T; MAGALHÃES, M. A. Efeito da idade sobre a qualidade de vida e saúde dos catadores de materiais recicláveis de uma associação em Governador Valadares, Minas Gerais, Brasil. Ciência \& Saúde Coletiva, v. 14, n. 6, p. 2169-2180, 2009.

AYRES, J. R. C. M. et al. Vulnerabilidade e prevenção em tempos de AIDS. In: BARBOSA, R. M. ; PARKER, R. (Orgs. ). Sexualidade pelo avesso: direitos, identidades e poder. São Paulo: Editora 34, 1999. p. 49-72.

BRASIL. Ministério do Meio Ambiente. Lei no 12. 305, de 02 de agosto 2010, institui a Política Nacional de Resíduos Sólidos e dá outras providências. Diário Oficial da União, Brasília, 03 ago. 2010.

. Ministério do Trabalho e Emprego. Portaria n ${ }^{\circ} 397$, de 09 de outubro de 2002. Aprova a Classificação Brasileira de Ocupações - CBO. Diário Oficial da União, Brasília, 10 out. 2002.

. Ministério do Trabalho e Emprego. Classificação Brasileira

de Ocupações. 2002. Disponível em: < http://www.mtecbo.gov.br/ busca/descricao.asp?codigo=5192-05> . Acesso em: 01 abr. 2009.

. Ministério da Saúde. Conselho Nacional de Saúde, Resolução no 196 de 10 de outubro de 1996. Aprova as diretrizes e normas regulamentadoras de pesquisas envolvendo seres humanos. Diário Oficial da União. Brasília, out. 1996.

CARMO, S. A semântica do lixo e o desenvolvimento socioeconômico dos catadores de recicláveis: considerações sobre um estudo de caso múltiplo em cooperativas na cidade do Rio de Janeiro.

Caderno EBAPE. BR, v. 7, n. 4, p. 591-606, 2009.

CAVALCANTE, S. ; FRANCO, M. F. A. Profissão perigo: percepção de risco à saúde entre os catadores do lixão do Jangurussu. Revista Malestar e Subjetividade, Fortaleza, v. 7, n. 1, p. 211-231, 2007.

CRUZ NETO, O. ; MOREIRA, M. R. ; SUCENA, L. F. M. Grupos focais e pesquisa social qualitativa: o debate orientado como técnica de investigação. In: ENCONTRO da Associação Brasileira de Estudos Populacionais. Ouro Preto - MG. 13 abr. 2002. Disponível em: <www.dppg.cefetmg. br/mtp/TecnicadeGruposFocaisdoc >. Acesso em: 15 abr. 2011. 
DEJOURS, C. A loucura do trabalho. São Paulo: Cortez Editora, 1992.

FERREIRA, J. A. ; ANJOS, L. A. Aspectos de saúde coletiva e ocupacional associados à gestão dos resíduos sólidos municipais.

Caderno Saúde Pública. v. 17, n. 3, p. 689-696, 2001.

FRASSON, C. B. Análise do discurso: considerações básicas, 2007. In: Cadernos da Funcamp, v. 6, n. 6, 2007.

GONÇALVES, R. Catadores de materiais recicláveis: trabalhadores fundamentais na cadeia de reciclagem do país. Serviço Social e Sociedade, v. 82, n. 65, p. 87-109, 2005.

GONÇALVES, H. H; ABEGÃO, L. H. Da ausência do trabalho à viração: a importância da catação na manutenção da vida. In: Encontro da ANNPAS, II, 2004, Anais... Indaiatuba, São Paulo. Disponível em: <http:\\www.anppas.org.br/encontro/segundo/ Papers/GT/GT09/HeloisaeLuis.pdf>. Acesso em: 23 abr. 2009.

JACOBI, P. Sustentabilidade ambiental, consumo e cidadania. Ambient. Soc. [online], v. 9, n. 1, p. 183-186, 2006.

JASANOFF, S. The political science of risk perception. Reliability Engineering \& System Safety, n. 59, p. 91-99, 1998.

JOIA, P. R; SILVA, M. S. F. Sistema de coleta seletiva dos resíduos sólidos domiciliares produzidos na cidade de Aquidauana. In: SIMPÓSIO sobre Recursos Naturais e Sócio-econômicos do Pantanal, 2004, CORUMBÁ-MS. Anais. . . Corumbá: EMBRAPA, 2004.

JUNCÁ, D. C. de M. Mais que sobras e sobrantes: trajetórias de sujeitos no lixo, 2004. 250f. Tese (Doutorado em Saúde Pública) Escola Nacional de Saúde Pública, Fundação Oswaldo Cruz, Rio de Janeiro, 2004.

LIMA, M. L. Factores sociais na percepção de riscos. Revista da Associação Portuguesa de Psicologia, v. 12, p. 11-28, 1998.

MEDEIROS, L. F. R. ; MACEDO, K. B. Catador de material reciclável: uma profissão para além da sobrevivência?

Psicologia \& Sociedade, v. 18, p. 62-71, 2006.

MINAYO, M. C. de S. O desafio do conhecimento: pesquisa qualitativa em saúde. 8. ed. São Paulo: Hucitec, 2007.

MIURA, P. C. O. Tornar-se catador: uma análise psicossocial. 2004. 134f. Dissertação (Mestrado em Psicologia Social) - Pontifícia Universidade Católica de São Paulo, São Paulo, 2004.

MORAES, L. R. S. Acondicionamento e coleta de resíduos sólidos domiciliares e impactos na saúde de crianças residentes em 
assentamentos periurbanos de Salvador, Bahia, Brasil. Cadernos de Saúde Pública, Rio de Janeiro, n. 23, p. 643-649, 2007.

MORAES, T. et al. Da norma ao risco: transformações na produção de subjetividades contemporâneas. Psicologia em estudo, n. 1, p. 91-102, 2002.

NAVARRO, M. V. T. Conceito e controle de riscos a saúde em radiodiagnóstico: uma abordagem de vigilância sanitária. 2007. 182f. Tese (Doutorado em Saúde Coletiva) - Instituto de Saúde Coletiva, Universidade Federal da Bahia, Salvador, 2007.

NOYES, J. Designing for humans. Hove (East Sussex), Psychology Press, 2001.

OLIVEIRA, D. A. M. Percepção de Riscos Ocupacionais em Catadores de Materiais Recicláveis: Estudo em uma Cooperativa em Salvador-Bahia. 2011. 176f. Dissertação (Mestrado em Saúde, Ambiente e Trabalho) - Faculdade de Medicina da Bahia, Universidade Federal da Bahia, Salvador, 2011.

ORLANDI, E. P. Análise de discurso: princípios e fundamentos. 8. ed. Campinas, SP: Pontes, 2009.

POESCHL, G. Representações das diferenças entre os sexos, práticas familiares e relações entre homens e mulheres. Revista Estudos. Goiânia: UCG, v. 30, n. 1, p. 31-49, 2003.

PORTO, M. et al. Lixo, trabalho e saúde: um estudo de caso com catadores em um aterro metropolitano no Rio de Janeiro. Cadernos de Saúde Coletiva, v. 20, p. 1503-1514, 2004.

SANDERS, M. S. ; McCORMICK, E. J. Human error, accidents, and safety. In: . Human Factors in Engineering and

Design. 7. ed. New York: McGraw-Hill, 1993. p. 655 - 695.

SANTOS, J. B. F. As condições de trabalho e as suas repercussões na vida e na saúde dos catadores de lixo do aterro sanitário do Jangurussu: relatório de pesquisa. Fortaleza, CE: SINE/CE, 1990.

SINGER, P. As grandes questões do trabalho no Brasil e a economia solidária. Proposta, Rio de Janeiro, Fase, n. 97, jun. /ago. 2003.

SIQUEIRA, M. M; MORAES, M. S. Saúde coletiva, resíduos sólidos urbanos e os catadores de lixo. Ciência saúde coletiva, v. 14, n. 6, p. 2115-2122, 2009.

VELLOSO, M. P; SANTOS. E. M; ANJOS, L. A. Processo de trabalho e acidentes de trabalho em coletores de lixo domiciliar na cidade de Rio de Janeiro. Caderno de Saúde Pública, Rio de Janeiro, v. 13, p. 603-700, 1997. 


\section{Trabalho e distúrbios musculoesqueléticos na limpeza urbana}

Adilton Luiz Pio Pereira

Rita de Cássia Pereira Fernandes

\section{Introdução}

Os Distúrbios Musculoesqueléticos (DME) são um dos problemas mais frequentes e mais dispendiosos em todo o mundo, configurando-se como importante doença relacionada ao trabalho em todos os países, independente do seu grau de industrialização. Nos Estados Unidos, aproximadamente um milhão de pessoas, a cada ano, relata afastar-se do trabalho para tratar ou recuperar-se de dor musculoesquelética. (NATIONAL RESEARCH COUNCIL; INSTITUTE OF MEDICINE, 2001; BRANDÃO; HORTA; TOMASI, 2005; MARRAS et al., 2009) Dados da Previdência Social no Brasil (2010) mostram que os DME mais prevalentes, no ano de 2009 , foram as lesões no ombro, no dorso e em membros superiores, com 19,7\%, 13,1\% e 9,5\%, respectivamente.

Os DME são caracterizados por

diversos sinais e sintomas de desordens inflamatórias e/ou degenerativas que acometem tendões, nervos, músculos, articulações, circulação e bursas, e resultam principalmente em dor e incapacidade funcional. (MAGNAGO et al. 2010)

Os DME são multicausais, de diagnóstico e estabelecimento de nexo causal com o trabalho mais complexo e nem sempre claro, necessitam de múltiplas abordagens, que não só tratem os sintomas, mas que interfiram nos aspectos ambientais, organizacionais e nas relações de trabalho, implicados na sua causalidade. 
Estudos têm demonstrado que há uma relação entre DME e demanda física no trabalho, além disso, alguns estudos fornecem também suporte à associação entre DME e demanda psicossocial no trabalho. $\mathrm{O}$ efeito dos fatores psicossociais para DME pode ser, em parte ou inteiramente, independente de fatores físicos. (NATIONAL RESEARCH COUNCIL; INSTITUTE OF MEDICINE, 2001; PUNNETT; WEGMAN, 2004; COSTA; VIEIRA, 2009)

De acordo com revisão sistemática conduzida pelo National Research Council - NRC e Institute of Medicine - IM (2001), os estudos para DME em extremidades superiores evidenciaram forte associação desses com a alta demanda psicológica e o baixo suporte social. Revisão de literatura feita por Woods (2005) também constatou evidências de associação entre DME e baixo suporte social. Os mecanismos pelos quais o suporte social influencia o sistema musculoesquelético ainda não estão claros, porém acredita-se que um ambiente de trabalho colaborativo pode dar aos trabalhadores melhor oportunidade de lidar com o sofrimento e, dessa forma, prevenir o surgimento de dores mais severas. $\mathrm{Na}$ atividade de coleta de resíduo sólido, os colegas podem fornecer ajuda ao trabalhador no manuseio de carga e com isso diminuir os sintomas musculoesqueléticos.

Algumas características individuais e exposições não ocupacionais podem ser incluídas como variáveis associadas aos DME, como: a idade, o consumo de bebida alcoólica, características antropométricas, hábito de fumar e atividade física. (KUORINKA; FORCIER, 1995)

Diversos estudos no Brasil têm destacado a elevada morbidade por DME em profissionais das áreas de serviço e indústria. (CARDOSO et al., 2009, GRAÇA; ARAÚJO; SILVA, 2006; PICOLOTO; SILVEIRA, 2008, FERNANDES; CARVALHO; ASSUNÇÃO, 2011) Isso destaca a importância do tema para a saúde coletiva e para a vigilância epidemiológica dos DME.

Considerando a importância dos DME como problema de saúde pública, definiu-se pela realização de um estudo sobre esse problema em trabalhadores de limpeza urbana. A escolha desses trabalhadores foi motivada pela presença marcante de fatores de risco para DME já descritos na literatura, nos processos de trabalho e na limpeza urbana, pelo relato de busca de serviço de saúde por trabalhadores de limpeza urbana com quadros de DME. Em revisão da literatura nacional, não 
foram encontrados estudos epidemiológicos sobre DME em trabalhadores da limpeza urbana.

Assim, foi conduzido este estudo com o objetivo de estimar a prevalência de DME, descrever as características ocupacionais na limpeza urbana na cidade de Salvador e identificar os fatores associados ao agravo.

\section{O trabalho na limpeza urbana em Salvador}

A cidade de Salvador está situada na Região Nordeste do Brasil, ocupa uma área de $313 \mathrm{~km} 2$ (sendo $283 \mathrm{~km} 2$ no continente e $30 \mathrm{~km} 2$ nas Ilhas). O sistema de limpeza urbana e manejo de resíduos sólidos nesta cidade são geridos pela Secretaria Municipal de Serviços Públicos e Prevenção à Violência - SESP. O sistema operacional é composto pela Empresa de Limpeza Urbana de Salvador - LIMPURB, empresa pública responsável pela definição de políticas, fiscalização e controle dos serviços, cadastro das empresas privadas transportadoras de resíduos de responsabilidade do gerador, limpeza das praças e jardins, e por uma empresa concessionária, responsável pela implantação, operação e manutenção do Aterro Sanitário Metropolitano Centro e Estação de Transbordo. O sistema conta ainda com os serviços de uma empresa responsável pela instalação de sanitários portáteis químicos; com um Consórcio, formado por quatro empresas responsável pela execução dos serviços de limpeza urbana. Criada, embora ainda não regulamentada, há a Agência Reguladora e Fiscalizadora dos Serviços de Limpeza Urbana e Manejo de Resíduos Sólidos de Salvador - ARSAL. O custeio dos serviços de limpeza urbana é de responsabilidade do Fundo Municipal de Limpeza Urbana - FMLU. (BAHIA, 2012)

A operação dos serviços de limpeza urbana e manejo de resíduos sólidos no município de Salvador, realizada pelas empresas terceirizadas, são de vasta abrangência e incorporam os serviços especiais de limpeza urbana, a varrição de vias e logradouros públicos, a limpeza urbana e manejo de resíduos sólidos em áreas de difícil acesso, a limpeza de praias, a limpeza urbana e manejo de resíduos sólidos em lagoas e espelhos d'água, a coleta e transporte de resíduos sólidos domiciliares, a coleta e transporte de resíduos de construção e demolição, a limpeza urbana e manejo de resíduos sólidos nas Ilhas de Maré, Bom Jesus e 
dos Frades, o transporte de materiais recicláveis, a lavagem de vias e logradouros públicos, a educação ambiental, a operação carnaval, a operação chuva e a operação dengue. (BAHIA, 2012)

Apesar da legislação existente e da formalização de sistemas de gestão da limpeza urbana, além do fato da produção, disposição e coleta de lixo, e suas implicações sobre o meio ambiente e a saúde da população já serem amplamente discutidos na literatura, os aspectos relacionados à saúde e bem-estar dos trabalhadores de limpeza urbana ainda são pouco estudados.

Segundo Velloso (2008), desde a idade média, o lixo esteve associado com as palavras "praga", "peste" ou "pestilência", significando algo que produzia um alto índice de mortalidade. Somente a partir de 1970, o lixo passou a ser considerado como um problema ambiental. A visão de que o lixo está associado a enfermidades continua até o momento presente, ao tempo em que se mantém a discriminação dos trabalhadores que são responsáveis pelo seu manuseio e destinação final.

No Brasil, esses trabalhadores estão acostumados a ser chamados de "garis". A origem deste nome teve início no século XX, na época em que os serviços de limpeza urbana eram feitos pelos Irmãos Garys, da Companhia Industrial do Rio de Janeiro, que desempenhava os serviços de coleta, transporte e destino final do lixo. (VELLOSO, 2008)

Esses trabalhadores, em geral, são invisíveis para a sociedade, apesar da importância social do seu labor. Velloso (2008) relata a experiência do psicólogo social Fernando Braga da Costa que revelou esta invisibilidade do coletor do lixo quando, no curso de um projeto acadêmico, travestido de gari, realizou a varrição de ruas no campus da Universidade de São Paulo, com o objetivo de abordar a percepção humana condicionada à divisão social do trabalho. O estudo permitiu afirmar, no contexto abordado, que as pessoas enxergam mais o resultado do trabalho e menos os sujeitos humanos que o executam. (VELLOSO, 2008)

A atividade de limpeza urbana faz parte dos serviços não exclusivos do Estado, ou seja, aqueles que ele provê, mas que podem ser oferecidos pelo setor privado e pelo setor público não estatal. Porém, ao terceirizar essa atividade, o Estado também terceiriza a gestão da força de trabalho e privatiza as relações de trabalho e com isso há uma perda da autonomia e do controle que o trabalhador exerce sobre sua própria 
atividade, fazendo com que apareçam situações que podem levar ao seu adoecimento. (SANTOS et al., 2009)

Os estudos sobre terceirização trazem o consenso quanto à precarização do trabalho e à fragilização social do trabalhador. Há evidência de redução salarial, perda de direitos trabalhistas e intensificação do trabalho, assim como má condição de saúde do trabalhador, refletida pelo grande número de acidentes e adoecimento físico e mental. (ARAÚJO, 2001; DRUCK, 2011)

O trabalho de limpeza urbana é muito complexo e apresenta características próprias como: a variabilidade da produção e do ambiente, a variabilidade do tempo, as questões de segurança e uso propriamente do corpo. Para a realização da sua atividade, o trabalhador passa a desenvolver competências específicas e passa a adotar estratégias de regulação, pois sua atividade se desenvolve em condições não controladas, como: trânsito urbano, intempéries, relação com a população, panes dos equipamentos. (VASCONCELOS et al., 2008; CAMADA; PATARO; FERNANDES, 2012)

Os trabalhadores que fazem a coleta do lixo podem se encontrar expostos a situações adversas de trabalho, não só nos aspectos físicos exigidos pela atividade, como também nos aspectos psicossociais. Ao fazerem a manipulação do resíduo sólido, eles ficam expostos aos resíduos contaminados e à sobrecarga de trabalho, e o aspecto psicossocial, há falta de reconhecimento da população e dos empregadores. Esses aspectos refletem-se na autoestima que costuma ser baixa nessa categoria, contribuindo para as morbidades que afetam esses trabalhadores. (ILÁRIO, 1989; ROBAZZI et al., 1994; VELLOSO; SANTOS; ANJOS, 1997)

Estudos que focalizam as demandas do trabalho da coleta de lixo apontam o papel importante da exposição aos aerodispersóides, o que é compatível com o achado de queixas respiratórias entre os trabalhadores. Verifica-se excesso de risco para bronquites e outros problemas pulmonares, embora pouco se saiba sobre a causalidade desses problemas na relação com o trabalho na coleta de lixo. A literatura também aponta entre os trabalhadores da limpeza urbana, os acidentes de trabalho, muitas vezes, decorrentes do difícil acesso ao lixo, do seu mau acondicionamento ou do inadequado desenho ou condição de uso 
dos meios e equipamentos, em um contexto de excesso de trabalho. (KUIJER; SLUITER; FRIGS-DRESEN, 2010; PAULSEN et al., 1995)

Os trabalhadores de limpeza urbana desenvolvem suas atividades num território diversificado e complexo, a rua. Isto pressupõe que essa atividade coloca estes trabalhadores expostos a vários outros riscos que podem estar ou não diretamente relacionados às suas atividades ocupacionais, como por exemplo, atropelamentos, mordeduras de cães, violência urbana (assaltos, envolvimento em brigas, balas perdidas), condições precárias das vias públicas e inadequação de condição ou uso dos equipamentos de proteção individual, o que demonstra a complexidade dessa função. (OLIVEIRA, 2008)

A exposição dos trabalhadores a uma diversidade de agentes nocivos à saúde torna o trabalho na limpeza urbana um dos mais arriscados e insalubres.

A literatura ainda destaca os problemas cardiovasculares, perdas auditivas, tabagismo e alcoolismo como problemas de saúde de destaque nesse grupo ocupacional. (ROBAZZI et al., 1994; MIGLIORANSA et al., 2003)

As altas demandas biomecânicas também presentes na limpeza urbana são associadas aos problemas musculoesqueléticos, frequentes entre os coletores. Alguns autores chamam atenção para as tarefas que implicam puxar, empurrar, inclinar cargas, ou seja, excessiva manipulação de peso, na determinação dos problemas musculoesqueléticos nesse grupo ocupacional. (PATARO; FERNANDES, no prelo; KUIJER; SLUITER; FRIGS-DRESEN, 2010; PAULSEN et al., 1995)

Constatada a elevada prevalência de possíveis fatores de risco para DME na limpeza urbana, estudos que investiguem esses efeitos à saúde podem contribuir para a melhoria nas condições de trabalho neste setor de serviços, ao fornecerem subsídios para possíveis tomadas de decisões relativas às intervenções necessárias.

\section{Métodos}

Foi realizado um estudo de corte transversal com 657 trabalhadores de limpeza urbana de Salvador, Bahia. Optou-se pela realização de um censo com coletores, motoristas, agentes especiais e trabalhadores da manutenção. Foram incluídos no estudo todos os trabalhadores 
ativos. Aqueles que se encontravam afastados temporariamente do trabalho por licença médica foram contatados para participar da pesquisa, a fim de minimizar o efeito sobrevivência do trabalhador sadio.

Para a coleta de dados, foi aplicado um questionário aos trabalhadores, durante o expediente de trabalho, em local reservado, assegurando privacidade. Esse instrumento para a coleta de dados foi uma adaptação do questionário elaborado e utilizado por Fernandes (2004) para o estudo de DME em trabalhadores da indústria de plástico.

A equipe de entrevistadores, formada pelo autor principal, outro pesquisador e estudantes de graduação em fisioterapia e enfermagem, foi treinada previamente para o uso do instrumento, esclarecida acerca de cada item do questionário e das alternativas de resposta.

O questionário continha perguntas sobre aspectos sociodemográficos, história ocupacional no emprego atual e vida laboral pregressa, demandas físicas e psicossociais no trabalho, sobre presença de filhos, hábito de fumar, consumo de bebidas alcoólicas, uso de medicamentos e de tranquilizante, atividades domésticas, atividades físicas e esportivas e questões sobre DME. Foram realizadas medidas de peso e altura com o objetivo de calcular o índice de massa corporal.

Os dados sobre demanda física no trabalho foram obtidos por meio de questões respondidas pelos trabalhadores em escala de 0 a 5 pontos, com âncoras nas extremidades. As questões foram relativas as posturas de trabalho (gerais e de segmentos corporais), movimentos repetitivos, força muscular exercida, levantamento e manuseio de cargas.

Os aspectos psicossociais do trabalho (demanda psicológica, controle sobre o trabalho e suporte social) foram verificados com o uso do Job Content Questionnaire (JCQ). (KARASEK, 1985; ARAÚJO; KARASEK, 2008) Muito se tem usado o modelo demanda-controle de Karasek (1985), levando-se em consideração também o suporte social, nas pesquisas sobre DME. Neste estudo com trabalhadores de limpeza urbana foi evidenciada a necessidade de considerar simultaneamente as variáveis de demanda, controle e suporte. Para que isso fosse possível foi utilizado o critério proposto por Devereux, Buckle e Vlachonikolis (1999) que consideram alta exposição a esses estressores, a satisfação de pelo menos duas das seguintes condições: de alta demanda, baixo controle e baixo suporte. 
Dados sobre sintomas de DME foram coletados por meio da versão ampliada do Nordic Musculoskeletal Questionnaire (NMQ), instrumento amplamente utilizado em investigações epidemiológicas sobre DME, em todo o mundo. (KUORINKA; FORCIER, 1995) Avaliou-se a presença de dor ou desconforto nos últimos 12 meses nas áreas anatômicas estudadas e sua severidade, duração e frequência.

Foi definido como "caso de DME", dor em uma ou mais das seguintes áreas corporais: mão, punho, antebraço, cotovelo, pescoço, ombro ou parte alta do dorso, nos últimos doze meses, com duração de mais de uma semana ou frequência mínima mensal, não decorrente de trauma agudo, acompanhada de pelo menos um dos seguintes sinais de gravidade: grau de severidade maior ou igual a 3, em uma escala numérica de 0 a 5 , com âncoras nas extremidades (nenhum desconforto a desconforto insuportável); busca de atenção médica pelo problema; ausência ao trabalho (oficial ou não); mudança de trabalho por restrição de saúde.

A prevalência de dor nos últimos doze meses, sem critério de duração, frequência e gravidade, foi descrita para permitir comparação com a literatura, já que boa parte dos estudos apenas registra dor nos últimos doze meses, sem especificá-la.

A população foi, em uma primeira etapa, descrita de acordo com as variáveis sociodemográficas, de hábitos de vida e ocupacionais, todas de interesse para o estudo dos DME: idade, estado civil, escolaridade, presença de filhos menores de dois anos de idade, tempo de trabalho (incluindo vínculos formais e informais), regime de trabalho, horas-extras, demandas físicas no trabalho, demandas psicossociais no trabalho, atividade física ou esportiva, trabalho doméstico, sobrepeso, obesidade, tabagismo, uso de bebida alcoólica. Essas variáveis foram utilizadas na etapa seguinte de análise, na qual foram investigados os possíveis fatores associados aos DME em pescoço ou ombro ou parte alta do dorso (DMEP).

Todas as variáveis foram dicotomizadas. A presença de sobrepeso ou obesidade foi considerada com índice de massa corporal (IMC) $>25$ $\mathrm{Kg} / \mathrm{m}^{2}$; estado civil foi estratificado em casados ou que "viviam juntos" e não casados, que incluíam solteiros, viúvos e divorciados; para o uso de bebida alcoólica, o consumo com frequência de uma vez ou mais na semana foi adotado como ponto de corte. As demais variáveis foram 
utilizadas tendo a mediana como ponto de corte. Tabagismo não foi incluído na análise multivariada, devido à sua baixa prevalência na população estudada.

$\mathrm{Na}$ abordagem estatística dos dados, foram obtidos a prevalência de DME nos diversos segmentos dos membros superiores, pescoço e parte alta do dorso, as médias e seus respectivos desvios-padrão ou a mediana, para algumas variáveis independentes, e o percentual de exposição para as demais variáveis. Descreveram-se também as demandas físicas no trabalho, utilizando-se sua distribuição de acordo com os quartis. Utilizou-se na etapa descritiva e na análise tabular o programa Epi-Info 6.04.

Considerando-se a magnitude de trabalhadores cuja ocupação era a de coletor, e conhecidas às características peculiares desta ocupação já descritas em literatura por Camada, Pataro e Fernandes (2012), optou-se por apresentar os resultados da etapa descritiva para coletores e não coletores (estes agrupando motoristas, agentes especiais e pessoal de manutenção).

Para a identificação dos fatores associados aos DME em pescoço ou ombro ou parte alta do dorso, realizou-se a análise de regressão logística não condicional, utilizando-se o programa estatístico R. A pré-seleção das variáveis independentes foi baseada na plausibilidade biológica das associações.

Considerando tratar-se de um censo, e sabendo que os métodos da inferência estatística se aplicam apenas para análise de resultados obtidos a partir de uma amostra aleatória, os resultados descritivos não apresentam testes estatísticos e os resultados finais da modelagem na regressão logística foram apresentados apenas através da medida de associação, sem incluir intervalos de confiança. (STRASAK et al., 2007; SILVANY NETO, 2008; CONCEIÇÃO, 2008)

Como o resultado final da regressão logística fornece a odds ratio como medida de associação, esta foi convertida para razão de prevalência, com o cálculo de seus respectivos intervalos de confiança pelo método Delta. (OLIVEIRA; SANTANA; LOPES, 1997)

Este projeto de pesquisa foi aprovado pelo Comitê de Ética em Pesquisa do Hospital São Rafael com o número do processo no 48/09.

Todos os trabalhadores pesquisados foram informados sobre os objetivos da pesquisa, sobre a instituição responsável por esta, e de 
que a empresa apenas liberou o acesso dos pesquisadores à empresa, não tendo qualquer participação na realização da pesquisa. Os trabalhadores que aceitaram participar do estudo assinaram um Termo de Consentimento Livre e Esclarecido e foram assegurados do sigilo das informações, da participação voluntária e do anonimato.

\section{Resultados}

Dos 657 trabalhadores inseridos na limpeza urbana, foram estudados 624 , todos do sexo masculino. O percentual de perdas e recusas foi de $5 \%$.

A média da idade dos entrevistados foi de 33 anos, variando de 19 a 74 anos, no entanto apenas 26 indivíduos tinham mais de 50 anos. Apenas $37 \%$ possuíam o ensino médio completo. Setenta e dois por cento dos trabalhadores eram casados, ou viviam junto com um parceiro estável, e $18 \%$ possuíam filhos menores de dois anos. Foi constatado o hábito de fumar em $15 \%$ dos trabalhadores e o consumo de bebidas alcoólicas com frequência de uma vez por semana ou mais foi referido por $57 \%$ da população estudada (dados não mostrados em tabela neste trabalho).

Dos trabalhadores, $59 \%$ eram coletores e $41 \%$, não coletores. Eram 367 coletores, 118 motoristas, 84 agentes especiais de limpeza e 55 trabalhadores de manutenção (civil, elétrica e mecânica). Os coletores apresentaram em menor proporção o IMC elevado (sobrepeso ou obesidade), 30\%, do que os não coletores (61\%). Quanto às demandas físicas no trabalho, a postura anômala de tronco se fez presente para $78 \%$ dos coletores e $29 \%$ dos não coletores (Figura 1). Os coletores estavam muito mais envolvidos em trabalhos dinâmicos (83\%) que os não coletores $(26 \%)$ e exerciam maior esforço físico, tal como levantamento de carga. Durante sua jornada de trabalho, a maioria dos coletores trabalhava com os braços elevados (79\%), enquanto uma menor proporção dos não coletores mantinha essa posição (39\%). Os coletores estavam mais expostos às elevadas demandas psicossociais do trabalho $(55 \%)$ que os não coletores (44\%) e seu trabalho envolvia maior proporção de horas extras que os não coletores (94\% e $73 \%$, respectivamente), apesar da alta proporção desta jornada extra para todos (Tabela 1). 
Tabela 1 - Características sociodemográficas, ocupacionais e hábitos de vida de Coletores e não Coletores da Limpeza Urbana. Salvador, 2010 (N=624).

\begin{tabular}{l|c|c}
\multicolumn{1}{c|}{ Características } & Coletores & $\begin{array}{c}\text { Não } \\
\text { Coletores }\end{array}$ \\
\hline População & $\%$ & $\%$ \\
\hline Estado civil (casado ou vive junto) & 59 & 41 \\
\hline Uso de bebida pelo menos uma vez na semana & 70 & 75 \\
\hline Faz alguma atividade física de lazer & 58 & 57 \\
\hline Tem filhos menores que dois anos & 45 & 53 \\
\hline IMC (sobrepeso ou obesidade) & 20 & 15 \\
\hline Faz horas extras & 30 & 61 \\
\hline Vibração de corpo inteiro & 94 & 73 \\
\hline Postura anômala de tronco & 66 & 55 \\
\hline Trabalho dinâmico & 78 & 29 \\
\hline Esforço físico (manuseio de carga) & 83 & 12 \\
\hline Trabalho agachado & 81 & 26 \\
\hline Braços elevados & 79 & 39 \\
\hline Alta demanda psicossocial & 55 & 44 \\
\hline
\end{tabular}

Fonte: (PEREIRA; FERNANDES, 2010) 
Figura 1 - A exigência de posturas anômalas de tronco na realização do trabalho de Coletores

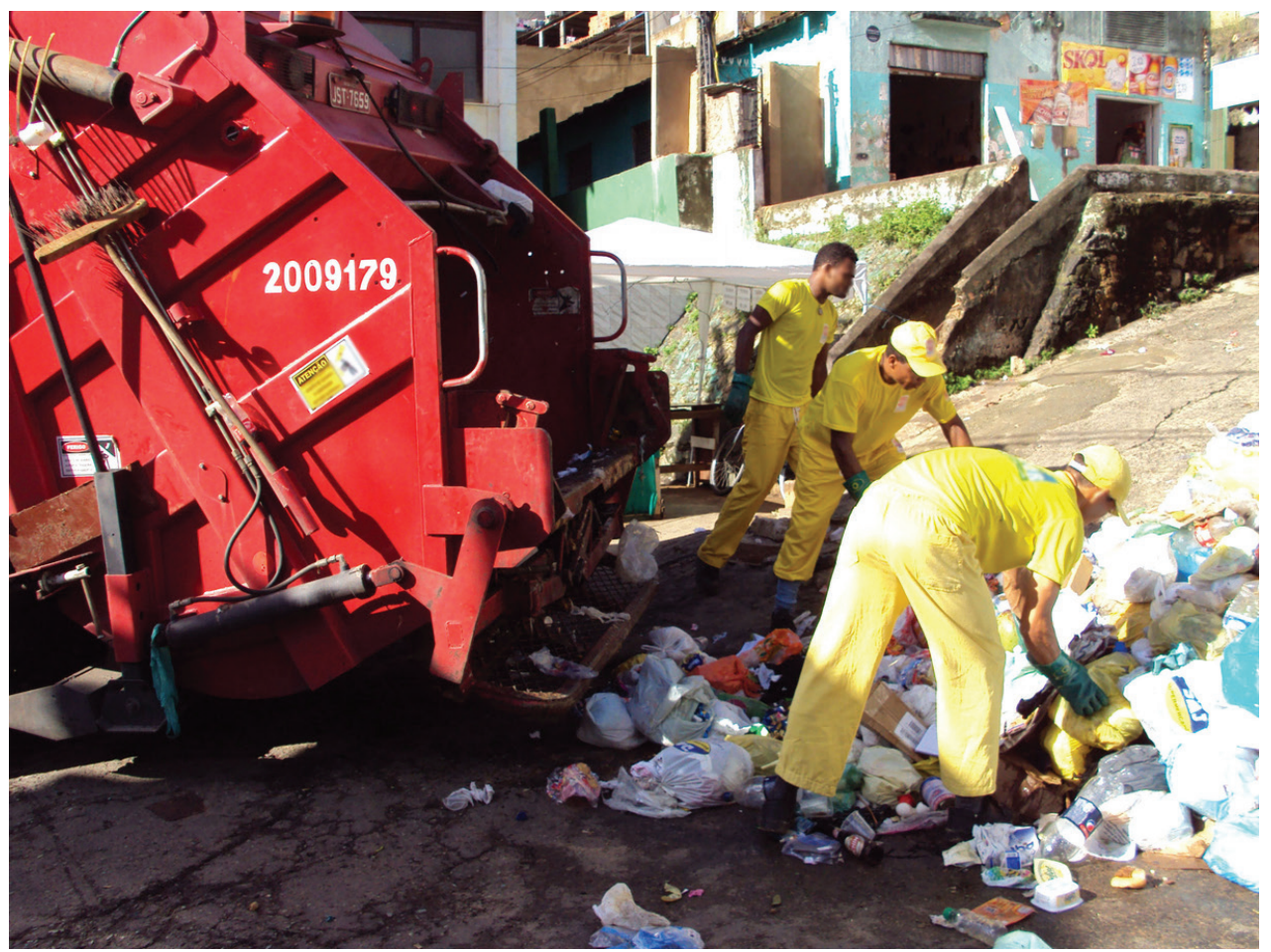

Fonte: (PEREIRA; FERNANDES, 2010)

Na tabela 2 é mostrada a distribuição da exposição para 12 variáveis de demandas físicas, avaliadas por meio de escalas de 6 pontos (0 a 5), com âncoras nas extremidades. Descreveu-se na tabela o ponto da escala de resposta (0 a 5) nos $1^{\circ}(\mathrm{Q} 1), 2^{\circ}(\mathrm{Q} 2)$ e $3^{\circ}(\mathrm{Q} 3)$ quartis. A distribuição é apresentada para toda a população, para coletores e não coletores nos três diferentes quartis. Observa-se, quanto às posturas gerais de trabalho, que quase todo o trabalho é realizado na postura em pé ou andando para coletores (Figura 2). Para o trabalho sentado, o ponto 0 na escala, jamais sentado, se mantém até pelo menos o terceiro quartil para esses trabalhadores. Apenas entre os não coletores registra-se o trabalho sentado (pontos $>0$ ), para os quais o ponto $2 \mathrm{da}$ escala é atingido no segundo quartil. O trabalho dos coletores é muito dinâmico, implicando a postura de trabalho andando, correndo e saltando de diferentes níveis. Para eles, o tempo todo (ponto 5 da escala) o trabalho é feito andando (ponto 5 já no $1^{\circ}$ quartil), ao passo que para os não coletores o ponto 2 da escala é atingido no segundo quartil. As atividades com levantamento de carga são referidas como mais frequentes pelos coletores e chegam a ocupar quase toda a jornada. $\mathrm{Na}$ Tabela 2, é possível observar os dados que caracterizam a exposição 
para toda a população, mas a distribuição por grupo de ocupação indica a existência de tarefas e demandas bastante diferentes para coletores e não coletores. As posturas inadequadas como: agachado, tronco inclinado para frente ou rodado e braços elevados acima da altura dos ombros, eram comuns no dia a dia, particularmente entre os coletores.

Tabela 2 - Demandas físicas no trabalho, distribuídas por quartis (Q), para trabalhadores da Limpeza Urbana. Salvador, 2010.

\begin{tabular}{|c|c|c|c|c|c|c|c|c|c|}
\hline \multirow{2}{*}{$\begin{array}{l}\text { Demanda Física } \\
\begin{array}{c}0=\text { jamais } 5=0 \\
\text { tempo todo }\end{array}\end{array}$} & \multicolumn{3}{|c|}{ População Total } & \multicolumn{3}{|c|}{ Coletor } & \multicolumn{3}{|c|}{ Não Coletor } \\
\hline & $1^{\circ} \mathrm{Q}$ & $2^{\circ} \mathrm{Q}$ & $3^{\circ} \mathrm{Q}$ & $1^{\circ} \mathrm{Q}$ & $2^{\circ} \mathrm{Q}$ & $3^{\circ} \mathrm{Q}$ & $1^{\circ} \mathrm{Q}$ & $2^{\circ} \mathrm{Q}$ & $3^{\circ} \mathrm{Q}$ \\
\hline Trabalho sentado & 0 & 0 & 2 & 0 & 0 & 0 & 0 & 2 & 5 \\
\hline Trabalho em pé & 3 & 5 & 5 & 5 & 5 & 5 & 0 & 3 & 5 \\
\hline Trabalho andando & 1 & 3 & 5 & 5 & 5 & 5 & 0 & 2 & 5 \\
\hline Correndo & 0 & 4 & 5 & 5 & 5 & 5 & 0 & 0 & 0 \\
\hline $\begin{array}{l}\text { Saltando de níveis dife- } \\
\text { rentes }\end{array}$ & 2 & 4 & 5 & 4 & 5 & 5 & 0 & 2 & 3 \\
\hline Trabalho agachado & 1 & 3 & 5 & 3 & 4 & 5 & 0 & 1 & 3 \\
\hline $\begin{array}{l}\text { Tronco inclinado para } \\
\text { frente }\end{array}$ & 2 & 4 & 5 & 3 & 5 & 5 & 1 & 3 & 4 \\
\hline Tronco rodado & 2 & 4 & 5 & 3 & 5 & 5 & 1 & 3 & 4 \\
\hline $\begin{array}{l}\text { Braços acima da altura } \\
\text { dos ombros }\end{array}$ & 1 & 3 & 5 & 3 & 5 & 5 & 0 & 2 & 3 \\
\hline Levantando carga & 2 & 4 & 5 & 4 & 5 & 5 & 0 & 1 & 4 \\
\hline Empurrando carga & 1 & 4 & 5 & 3 & 4 & 5 & 0 & 1 & 3 \\
\hline Puxando carga & 1 & 3 & 5 & 3 & 4 & 5 & 0 & 0 & 4 \\
\hline
\end{tabular}

Fonte: (PEREIRA; FERNANDES, 2010) 
Figura 2 - O trabalho de Coletores, em pé ou andando durante quase toda a jornada.

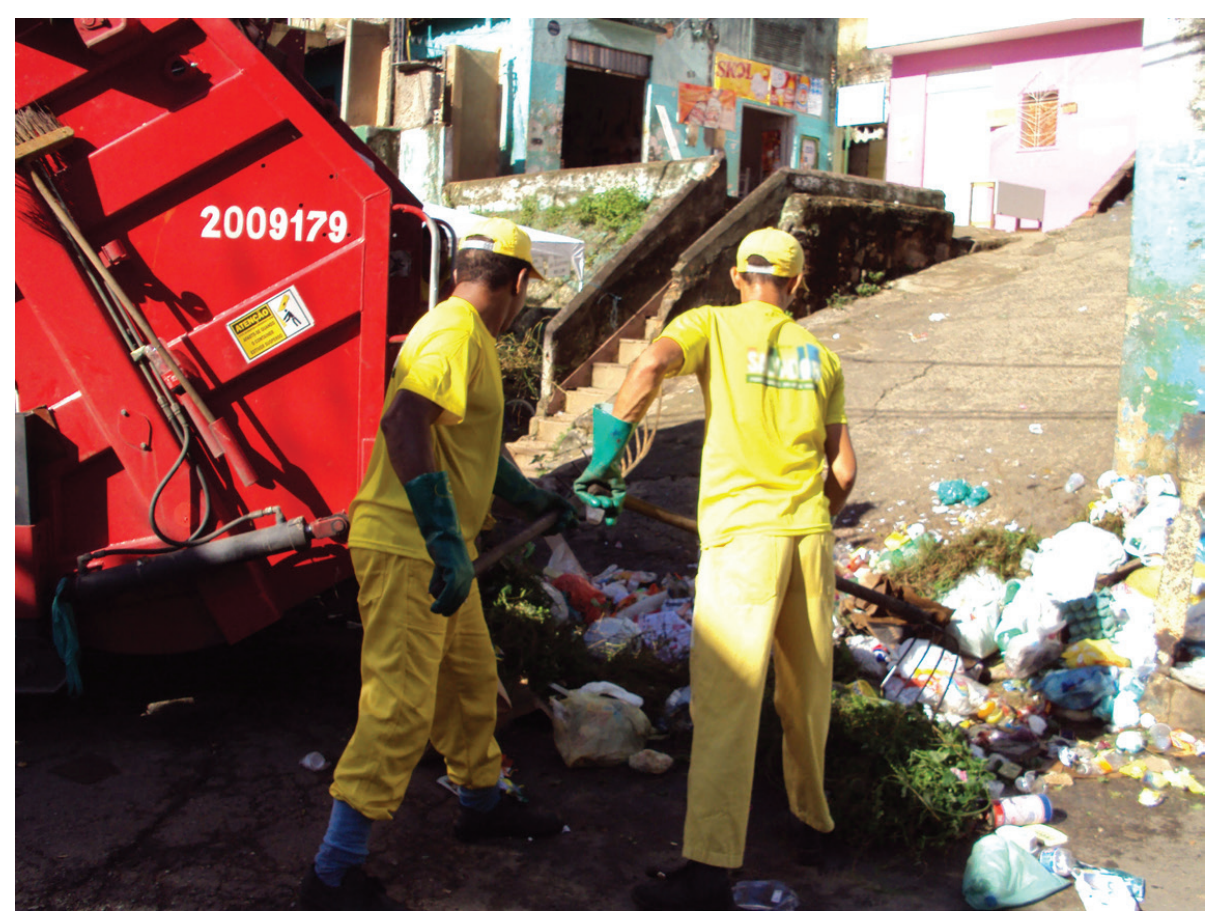

Fonte: (PEREIRA; FERNANDES, 2010)

Quanto à queixa de dor musculoesquelética, que se referia há pelo menos um episódio de dor em qualquer segmento dos membros superiores, pescoço e parte alta do dorso nos últimos doze meses, verificou-se uma prevalência nesta população de trabalhadores de limpeza urbana de $52 \%$. Os coletores referiram maior prevalência de dor em pescoço ou ombro ou parte alta do dorso (41\%) que os não coletores $(33 \%)$, no entanto, para a região distal dos membros superiores (MMSS) não houve diferença marcante (Tabela 3). 
TABELA 3 - Prevalência de dor nos últimos doze meses, segundo segmento de membros superiores, pescoço e parte alta do dorso em trabalhadores da Limpeza Urbana. Salvador, 2010. $(\mathrm{N}=624)$

\begin{tabular}{l|c|c|c}
\multicolumn{1}{c|}{ Segmento corporal referido } & $\begin{array}{c}\text { População } \\
\text { Total }\end{array}$ & $\begin{array}{c}\text { Coletor } \\
\%\end{array}$ & $\begin{array}{c}\text { Não } \\
\text { coletor } \\
\%\end{array}$ \\
\hline $\begin{array}{l}\text { Em alguma região dos membros superiores ou pescoço } \\
\text { ou parte alta do dorso }\end{array}$ & 52 & 54 & 49 \\
\hline Pescoço ou ombro ou parte alta do dorso & 38 & 41 & 33 \\
\hline Cotovelo ou antebraço ou punho ou mão & 27 & 28 & 26 \\
\hline Pescoço & 16 & 14 & 18 \\
\hline Ombro & 24 & 29 & 18 \\
\hline Cotovelo ou antebraço & 10 & 10 & 10 \\
\hline Punho ou mão & 21 & 23 & 18 \\
\hline Parte alta do dorso & 14 & 15 & 13 \\
\hline
\end{tabular}

Fonte: (PEREIRA; FERNANDES, 2010)

Quanto à prevalência de dor, com duração de mais de uma semana ou frequência mínima mensal, com algum outro sinal de gravidade, conforme já descrito, em pelo menos um dos segmentos dos membros superiores, pescoço ou parte alta do dorso, esta foi de $39 \%$ para a população inteira. Constatou-se a mais elevada prevalência para dor em ombros, com $18 \%$, quando se descreveu cada segmento separadamente. A prevalência de dor em pelo menos um dos segmentos da região referida foi mais elevada nos coletores $(42,0 \%)$, do que nos não coletores (35\%) (Tabela 4). 
Tabela 4 - Prevalência de Distúrbios Musculoesqueléticos ${ }^{1}$, segundo segmento de membros superiores, pescoço e parte alta do dorso, em trabalhadores da Limpeza Urbana. Salvador, 2010. $(\mathrm{N}=624)$

\begin{tabular}{l|c|c|c}
\multicolumn{1}{c|}{ Segmento corporal referido } & $\begin{array}{c}\text { População } \\
\text { Total }\end{array}$ & $\begin{array}{c}\text { Coletor } \\
\%\end{array}$ & $\begin{array}{c}\text { Não } \\
\text { coletor }\end{array}$ \\
\hline $\begin{array}{l}\text { Em alguma região dos membros superiores ou pescoço } \\
\text { ou parte alta do dorso }\end{array}$ & 39 & 42 & 35 \\
\hline Pescoço ou ombro ou parte alta do dorso & 28 & 31 & 24 \\
\hline $\begin{array}{l}\text { Extremidades superiores distais (cotovelo ou antebraço } \\
\text { ou punho ou mão) }\end{array}$ & 20 & 23 & 17 \\
\hline Pescoço & 11 & 10 & 12 \\
\hline Ombro & 18 & 21 & 13 \\
\hline Cotovelo ou antebraço & 7 & 8 & 6 \\
\hline Punho ou mão & 15 & 18 & 12 \\
\hline Parte alta do dorso & 11 & 12 & 10 \\
\hline
\end{tabular}

${ }^{1}$ Dor nos últimos doze meses, com duração de mais de uma semana ou frequência mínima mensal, não decorrente de trauma agudo, acompanhada de pelo menos um dos seguintes sinais de gravidade: grau de severidade maior ou igual a 3, busca de atenção médica pelo problema, ausência ao trabalho, mudança de trabalho.

Fonte: (PEREIRA; FERNANDES, 2010)

Por meio da análise multivariada verificou-se que DME em pescoço ou ombro ou parte alta do dorso (DMEP) foi 1,25 vezes mais frequente entre expostos à postura de braços acima dos ombros. A exposição às elevadas demandas psicossociais $(\mathrm{RP}=1,32)$ e o tempo de trabalho na empresa maior que 56 meses $(\mathrm{RP}=1,28)$ associaram-se com DMEP. Beber uma vez ou mais na semana $(\mathrm{RP}=0,68)$ e ter filhos menores de dois anos $(\mathrm{RP}=0,63)$ estavam associados à DMEP, de forma inversa (Tabela 5). 
Tabela 5 - Distúrbios Musculoesqueléticos em pescoço, ombro ou parte alta do dorso e fatores associados, em trabalhadores da Limpeza Urbana. Salvador, 2010.

\begin{tabular}{l|c|c}
\multicolumn{1}{c|}{ Variáveis associadas } & RP bruta & RP ajustada \\
\hline Beber uma ou mais vezes por semana & 0,79 & 0,68 \\
\hline Ter filhos < que dois anos & 0,64 & 0,63 \\
\hline Postura de trabalho com braços acima dos ombros & 1,30 & 1,25 \\
\hline Demandas psicossociais & 1,34 & 1,32 \\
\hline Tempo de trabalho $>56$ meses & 1,33 & 1,28 \\
\hline
\end{tabular}

Fonte: (PEREIRA; FERNANDES, 2010)

\section{Discussão}

A prevalência de dor em geral e de dor com duração ou frequência e gravidade especificadas em alguma região dos membros superiores, pescoço ou parte alta do dorso de trabalhadores de limpeza urbana em Salvador, foi elevada. Essa prevalência foi superior às relatadas por outros estudos com trabalhadores do setor de serviço e indústria. (GRAÇA; ARAÚJO; SILVA, 2006; PICOLOTO; SILVEIRA, 2008; CARDOSO et al., 2009; FERNANDES; CARVALHO; ASSUNÇÃO, 2011) Deve-se ressaltar que os estudos citados, embora tenham utilizado o NMQ como instrumento para coleta de dados de dor musculoesquelética, não utilizaram os critérios de gravidade que foram utilizados neste estudo, para definição de "caso de DME", com exceção de Fernandes, Carvalho e Assunção (2011).

O critério utilizado neste estudo para definição de caso considera: se há ou não dor nos últimos doze meses, incorpora a duração de mais de uma semana ou a frequência de pelo menos uma vez por mês, levando à busca de atenção médica ou mudança de trabalho; ou se apresenta grau de severidade maior ou igual a 3 (em 0 a 5). Esta dor em trabalhadores que se encontravam em plena atividade de trabalho representa importante morbidade nesta população, tendo em vista, a possibilidade de evolução para quadros incapacitantes, uma vez que os trabalhadores continuam na mesma atividade de trabalho que pode estar relacionada com a dor. $\mathrm{O}$ uso deste critério para definição de caso visou aumentar a especificidade da queixa, permitindo apontar com uma 
maior propriedade, a dimensão e relevância dos DME nessa população de trabalhadores de limpeza urbana.

Realizou-se descrição conjunta de ombro, pescoço e parte alta do dorso porque esses segmentos corporais atuam como uma unidade funcional, ou seja, é difícil identificar especificamente o local de origem do sintoma referido. (NATIONAL RESEARCH COUNCIL; INSTITUTE OF MEDICINE, 2001) Portanto, dor referida em ombro pode ter origem em pescoço e vice-versa, além do envolvimento da parte superior do dorso que pode ser referido em um desses outros locais. No entanto, para fins de comparação com outros estudos, descreveram-se também as prevalências para pescoço e ombro, separadamente.

Picoloto e Silveira (2008) relataram prevalência de $18 \%$ para os sintomas nos punhos, em metalúrgicos, enquanto Mehrad e colaboradores (2008), em estudo no Irã, constataram que 7,5\% dos coletores referiam dor nos punhos ou mãos. Neste estudo, entre coletores, foi encontrada a prevalência de $23 \%$ para sintomas de dor nos punhos ou mãos. No mesmo estudo de Mehrad et al. (2008), foi encontrada prevalência de dor nos ombros de $18 \%$, enquanto no presente estudo, entre os coletores, foi encontrada prevalência de $29 \%$ de dor neste segmento. Portanto, a magnitude de queixa entre os coletores é relevante e superior ao encontrado, inclusive, em trabalhadores da mesma categoria em outro país.

Considerando os casos mais específicos, ou seja, aqueles com duração, frequência e gravidade de dor estabelecidas, a prevalência de DME para alguma região de MMSS ou pescoço ou parte alta do dorso (DMEP) em coletores foi de $42,0 \%$ e para as regiões do ombro e pescoço, separadamente, $21 \%$ e $10 \%$, respectivamente. Fernandes e colaboradores (2010), em estudo com os trabalhadores da indústria de plásticos da Região Metropolitana de Salvador, encontraram prevalência de DME em alguma região de MMSS ou pescoço ou parte alta do dorso de $31 \%$, enquanto para a região do ombro, $11 \%$ e pescoço, $7 \%$.

O ombro apresentou-se como sendo a principal região dos MMSS acometida nos coletores. Além disso, verificou-se que a prevalência de sintomas em pescoço, ombro ou parte alta do dorso, tomadas conjuntamente, foi mais alta $(31 \%)$ do que a prevalência em extremidades distais de MMSS (antebraço ou punho ou mão), de 23\%, com a principal contribuição dada por dor em punho ou mão, que corresponde 
a 18\%. Fernandes, Carvalho e Assunção (2011) também encontraram maior prevalência em pescoço, ombro ou parte alta do dorso $(20,6 \%)$ do que em extremidades distais $(18,7 \%)$, mas esta diferença foi pouco relevante. Portanto, neste estudo, verificou-se maior magnitude de DME em membros superiores comparada à encontrada por Fernandes, Carvalho e Assunção (2011) em trabalhadores, das áreas de operação e manutenção da indústria de plásticos. Considerando que os trabalhadores industriários estudados por Fernandes, Carvalho e Assunção (2011) realizavam atividades com marcada demanda física para o corpo, pela exigência de esforço e manuseio de carga, os resultados da morbidade entre os trabalhadores de limpeza urbana e, em especial, entre os coletores podem ser reveladores das demandas intensas postas a esses trabalhadores na jornada diária.

Neste sentido, os achados sobre as demandas físicas no trabalho da Limpeza Urbana são relevantes e evidenciam uma alta carga de trabalho físico. Os coletores exercem tarefas com alta exigência sobre o corpo, como andar, correr e saltar de diferentes níveis durante a coleta do lixo. Por outro lado, o manuseio de carga está presente durante toda a jornada. Entre os motoristas, o trabalho sentado é mais presente. Em estudo ergonômico realizado com uma amostra da mesma população do presente estudo, Camada, Pataro e Fernandes (2012) verificaram que durante o manuseio de contêineres ou tonéis, os coletores realizam constantes movimentos de empurrar, puxar e levantar cargas pesadas. Afirmam as autoras que a intensa demanda física sob ritmo de trabalho acelerado contribui para o comprometimento da saúde e, em particular, para a ocorrência de sintomas musculoesqueléticos.

A partir da análise multivariada, este estudo apresentou também resultados que mostram a contribuição das demandas físicas e psicossociais no trabalho para o desenvolvimento de DME em pescoço, ombro e parte alta do dorso (DMEP), que se associaram positivamente com essas demandas.

Fonseca e Fernandes (2010), em estudo com técnicos e auxiliares de enfermagem, encontraram associação positiva entre DMEP e demandas físicas no trabalho, particularmente manuseio de carga. No presente estudo, foi encontrada associação entre DMEP e postura de trabalho com braços acima dos ombros. 
Alguns estudos têm apresentado associação entre DME em regiões centrais como pescoço, ombros, ou parte alta do dorso e demanda psicossocial; já em regiões periféricas as demandas físicas do trabalho têm sido observadas como o principal preditor. (TOOMINGAS et al.; 1997, PINHEIRO; TRÓCCOLI; PAZ, 2006) Neste estudo, os mais expostos a demandas psicossociais (incorporando as dimensões de demanda psicológica, controle no trabalho e suporte social) também apresentam maior prevalência de DMEP. Esta associação também foi verificada por Fonseca e Fernandes (2010) entre os técnicos e auxiliares de enfermagem, por Fernandes e colaboradores (2010) entre os trabalhadores da indústria de plástico e por Andersen, Haahr e Frost (2007) em uma coorte de trabalhadores do setor de serviços.

O ritmo acelerado é, entre as demandas psicossociais, o fator de risco mais citado na literatura, especialmente associado aos DME em extremidades superiores. Camada, Pataro e Fernandes (2012) constataram que, a fim de atender às exigências da gestão e atingir as metas de produção do serviço, os coletores realizam suas atividades em ritmo acelerado. Assim, os resultados esperados pela gestão somente são atingidos à custa de hipersolicitação física e psíquica dos trabalhadores. As autoras discutem, além disso, que um período de descanso insuficiente é fator de desgaste físico e pode precipitar distúrbios musculoesqueléticos.

Mas, além da alta demanda psicológica (que incorpora o ritmo acelerado) e do baixo controle, alguns estudos referem o baixo suporte social como fator associado aos DME em pescoço e ombros. (AHLBERG-HULTEN; THEORELL; SIGALA, 1995; SMITH et al., 2004)

O maior tempo de trabalho na empresa apresentou associação com a maior prevalência de DMEP. Assim como nesta pesquisa, o estudo realizado por Fonseca e Fernandes (2010) encontrou associação entre tempo de trabalho e DMEP. A força da associação encontrada neste estudo foi inferior ao encontrado por Fonseca e Fernandes (2010), mas o tempo de trabalho associado ao maior adoecimento foi maior que 19 anos (>228 meses) para trabalhadoras de enfermagem. Portanto, os trabalhadores da limpeza urbana já apresentam DMEP em um tempo mais curto de trabalho, o que pode indicar a natureza mais penosa daquela atividade. 
Há estudos que apontam que as atividades ligadas ao cuidado de casa ou de filhos podem contribuir para o surgimento de DME, principalmente em mulheres. (STRAZDINS; BAMMER, 2004) Neste estudo, a associação entre DMEP e ter filhos menores de dois anos foi negativa, ou seja, esta variável representou possível fator de proteção. A literatura atribui os cuidados com os filhos pequenos uma sobrecarga para os membros superiores que poderia então representar fator de risco para dor nesta região. (FERNANDES, 2004; PINHEIRO; TRÓCCOLI; PAZ, 2006) Entretanto, o achado do presente estudo remete para a possibilidade de ter filhos constituir um estado emocional que protegeria para a percepção ou registro da dor entre esses pais. Além disso, não se pode afastar uma questão de gênero, já que a população estudada é composta por homens e esses podem não estar se responsabilizando habitualmente pelo cuidado com os filhos. Com mulheres, mães trabalhadoras, os resultados poderiam ser diferentes. Esta discussão, ainda preliminar, carece de novos estudos.

O uso de bebida apresentou associação negativa com DMEP. Segundo Mabuchi e colaboradores (2007), este uso poderia se constituir em uma forma de fuga para diminuir os efeitos da sobrecarga de trabalho e o sofrimento psíquico, porque ao proporcionar distensionamento de situações desconfortáveis geradas pelo estresse poderia reduzir a percepção ou o registro da dor. Além disso, a redução do estresse poderia ter efeito direto sobre a própria musculatura, distensionando-a. (PINHEIRO; TRÓCCOLI: PAZ, 2006)

\section{Considerações finais}

A elevada prevalência de DME em membros superiores encontrada entre os trabalhadores estudados, bem como as demandas físicas e psicossociais às quais estão expostos, apontam para a necessidade de atenção para essa categoria profissional e suas condições de trabalho.

Os achados sobre as demandas físicas no trabalho da Limpeza Urbana são relevantes e evidenciam uma alta carga de trabalho físico. Entre as ocupações, as tarefas exercidas principalmente pelos coletores são de alta exigência sobre o corpo, implicando manuseio de carga durante toda a jornada de trabalho. 
A intensa demanda física sob ritmo de trabalho acelerado contribui para a ocorrência de sintomas musculoesqueléticos, como se constatou neste estudo em que os mais expostos a demandas psicossociais (incorporando as dimensões de demanda psicológica, controle no trabalho e suporte social) apresentaram maior prevalência de DMEP.

Além disso, o achado de curto tempo de inserção na Limpeza Urbana com alta prevalência de DME, haja vista a média de tempo de trabalho de apenas 56 meses, pode indicar a natureza mais penosa desta atividade.

Faz-se necessária a aplicação do conhecimento já produzido para a melhoria das condições de trabalho desses trabalhadores. Porém, são bem vindos novos estudos, principalmente os de caráter analítico, para indicar novos caminhos a serem seguidos para a adoção de medidas preventivas.

\section{Referências}

AHLBERG-HULTEN, G. K.; THEORELL T.; SIGALA F. Social support, job strain and musculoskeletal pain among female health care personnel. Scandinavian Journal of Work, Environment \& Health, v. 21, n 6, p. 435-39, 1995.

ANDERSEN, J. H.; HAAHR, J. P.; FROST, P. Risk factors for more severe regional musculoskeletal symptoms: A two-year prospective study of a general working population. Arthritis \& Rheumatism, v. 56, n. 4, p. 1355-1364, 2007.

ARAÚJO, A. J. S. Paradoxos da Modernização: terceirização e segurança dos trabalhadores em uma refinaria de petróleo. Tese (Doutorado em Saúde Pública), 2001. Escola Nacional de Saúde Pública, Fundação Oswaldo Cruz, Rio de Janeiro, 2001.

ARAÚJO, T. M.; KARASEK, R. Validity and reliability of the job content questionnaire in formal and informal jobs in Brazil. Scandinavian Journal of Work Environment Health Suppl, v. 2, n. 6, p. 52-59, 2008.

BAHIA. Prefeitura Municipal de Salvador, Secretaria de Serviços Públicos e Prevenção à Violência. Plano Básico de Limpeza Urbana e Manejo de Resíduos Sólidos de Salvador, Salvador-Ba. , 2012. Disponível em: <www.limpurb.salvador.pub.gov.ba.br/>. Acesso em: 02 jul. 2012. 
BRANDÃO, A. G.; HORTA B. L.; TOMASI E. Sintomas

de Distúrbios osteomusculares em bancários de Pelotas e região: prevalência e fatores associados. Revista Brasileira de Epidemiologia, v. 8, n. 3, p. 295-305, 2005.

BRASIL. MINISTÉRIO DE PREVIDÊNCIA E ASSISTÊNCIA SOCIAL (MPAS). Anuário Estatístico da Previdência Social 2010. Disponível em: <http://www.mpas.gov.br> Acesso em: 12 dez. 2010.

CAMADA, I. M. O.; PATARO, S. M. S.; FERNANDES, R. C. P. Heavy physical work under time pressure: the garbage collection service- a case study. Work, v. 41, p. 462-469, 2012.

CARDOSO, J. P. et al. Prevalência de dor musculoesquelética em professores. Revista Brasileira de Epidemiologia, v. 12, n. 4, p. 604-14, 2009.

CESAT - Centro Estadual de Referência em Saúde do Trabalhador. Perfil Epidemiológico da Saúde do Trabalhador Síntese-Bahia. Bahia, 2009. CONCEIÇÃO, M. J. Leitura Crítica dos Dados Estatísticos em Trabalhos Científicos. Rev. Bras. Anestesiol, n. 58, p. 260-266, 2008.

COSTA, B. R.; VIEIRA, E. R. Risk factors for work-related musculoskeletal disorders: a systematic review of recent longitudinal studies. American Journal of Industrial Medicine, v. 53, n. 3, p. 285-323, 2009.

DEVEREUX, J. J. , BUCKLE, P. W. , VLACHONIKOLIS, I. Interactions between physicaland psychosocial risk factors at work increase the risk of back disorders: an epidemiological approach.

Occupational Environmental Medicine, v. 56, p. 343-353, 1999.

DRUCK, G. Trabalho precarização e resistências: novos e velhos desafios? In: DRUCK, G.; FRANCO, T (Org. ). Trabalho, precarização e resistências. Caderno CRH, Salvador, Universidade Federal da Bahia, v. 24, n. 1, p. 35-55, 2011.

FERNANDES, R. C. P. Distúrbios Musculoesqueléticos e trabalho industrial. 2004, 287f. Tese (Doutorado em saúde pública) - Instituto de Saúde Coletiva, Universidade Federal da Bahia, Salvador, 2004.

FERNANDES, R. C. P. et al. Muskuloskeletal disorders among workers in plastic manufacturing plants. Revista Brasileira de Epidemiologia, n. 13, p. 11-10, 2010.

FERNANDES, R. C. P.; CARVALHO, F. M.; ASSUNÇÃO, A. A. Prevalence of musculoskeletal disorders among plastics industry workers. Cadernos de Saúde Pública, v. 27, n. 1, p. 78-86, 2011. 
FONSECA, N. R.; FERNANDES, R. C. P. Fatores associados aos distúrbios musculoesqueléticos em trabalhadores de enfermagem. Revista LatinoAmericana de Enfermagem, v. 18, n. 6, p. 1076-1083, nov. /dez. 2010.

GRAÇA, C. C.; ARAÚJO, T. M.; SILVA, C. E. P. Prevalência de dor muscoloesquelética em cirurgiões-dentistas. Revista Brasileira de Saúde Pública, v. 30, n. 1, p. 59-76, jan. /jun. 2006.

ILÁRIO, E. Estudo de morbidade em coletores de lixo de um grande centro urbano. Revista Brasileira de Saúde Ocupacional, v. 17, n. 66, p. 7-12, 1989.

KALIMO, R. Psychosocial factors and worker's health: an overview. Word Health Organization, 1987.

KARASEK, R. Job Content Instrument: Questionnaire and User's guide. Massachusetts: University of Massachusetts. Amherst, 1985.

KUIJER, P. P. F. M.; SLUITER, J. K.; FRINGS-DRESEN, M. H. W. Health and Safety in Waste Collection: Towards EvidenceBased Worker Health Surveillance. American Journal of Industrial Medicine, v. 53, p. 1040-1064, 2010.

KUORINKA, I.; FORCIER, L. Work related musculoskeletal disorders (WMSDs): a reference book for prevention. London: Taylor \& Francis, 1995.

MABUCHI, A. S. et al. Uso de bebidas alcoólicas. Revista LatinoAmericana de Enfermagem, v. 15, n. 3, maio-jun., 2007.

MAGNAGO, T. S. B. S. et al. Distúrbios músculoesqueléticos em trabalhadores de enfermagem: associação com condições de trabalho. Revista Brasileira de Enfermagem, v. 60, n. 6, p. 701-705, 2010.

MARRAS, W. S. et al. National occupational researchagenda (NORA) future directions in occupational musculoskeletal disorder health research. Applied Ergonomics, v. 40, p. 15-22, 2009.

MEHRDAD, R. et al. Musculoskeletal disorders among municipal solid wast workers. Acta Medica Iranica, v. 46, n. 3, 2008.

MIGLIORANSA, M. H. et al. Estudo epidemiológico dos coletores de lixo seletivo. Revista Brasileira de Saúde Ocupacional, v. 28, n. 107/108, p. 19-28, 2003.

NATIONAL RESEARCH COUNCIL - NRC; INSTITUTE OF MEDICINE - IM Musculoskeletal disorders and the workplace: low back and upper extremities. Panel on musculoskeletal disorders and the workplace. Commission on behavioral and social sciences and education. Washington, DC: National Academy Press, 2001. 
OLIVEIRA, M. G. Características organizacionais e acidentes ocupacionais em empresas de limpeza urbana de Salvador-

Ba. 2008. Tese (Doutorado em saúde pública). Instituto de Saúde

Coletiva - Universidade Federal da Bahia, Salvador, 2008.

OLIVEIRA, N. F.; SANTANA, V. S.; LOPES, A. A. Razões de prevalência e uso do método delta para intervalos de confiança em regressão logística. Revista Saúde Pública, v. 31, p. 90-99, 1997.

PATARO, S. M. S.; FERNANDES, R. C. P. Trabalho físico pesado e dor lombar: a realidade na limpeza urbana. Revista Brasileira de Epidemiologia (aceito para publicação em 21 de janeiro de 2013). No prelo.

PAULSEN, O. M. et al. Collection of domestic waste. Review of occupational health problems and their possible causes. The Science of the Total Environment, v. 170, p. 1-19, 1995.

PICOLOTO, D.; SILVEIRA, E. Prevalência de sintomas osteomusculares e fatores associados em trabalhadores de uma indústria metalúrgica de Canoas - RS. Ciência e Saúde coletiva, v. 13, n. 2, p. 507-516, 2008.

PINHEIRO, F. A.; TRÓCCOLI, B. T.; PAZ, M. G. T. Preditores Psicossociais de Sintomas Osteomusculares: A Importância das Relações de Mediação e Moderação. Psicologia: Reflexão \& Crítica, v. 19, n. 1, p. 142-150, 2006.

PUNNETT, L.; WEGMAN, D. H. Work-related musculoskeletal disorders: the epidemiologic evidence and the debate. Journal of Electromyography and Kinesiology, v. 14, n. 1, p. 13-23, 2004.

ROBAZZI, M. L. C. C. et al. Algumas considerações sobre o trabalho dos coletores de lixo. Revista Brasileira de Saúde Ocupacional, v. 20, n. 76, p. 34-41, 1994.

SANTOS, C. C. Reestruturação produtiva do setor de limpeza urbana de Salvador: repercussões sobre o trabalhador. 2011. Dissertação (Mestrado) Universidade Católica do Salvador, 2011.

SANTOS, C. O. M. et al. Desregulamentação do trabalho e desregulação da atividade: o caso da terceirização da limpeza urbana e o trabalho dos garis. Produção, v. 19, n. 1, p. 202-213, 2009.

SILVANY NETO, A. M. Bioestatística sem segredos. Salvador, 2008. 321p.

SMITH, D. R. et al. Musculoskeletal Disorders among Professional Nurses in Mainland China. Journal of Professional Nursing, v. 20, n. 6, p. 390-395, 2004. 
SPURGEON, A.; GOMPERTS, D.; HARRINGTON, J. M. Modifiers of non-especific symptoms in occupational and environmental syndromes. Occup Helth Med, v. 53, p. 361-366, 1996.

STRASAK, A. M. et al. Statistical errors in medical research - a review of common pitfalls. Swiss Med Wkl, v. 137, p. 44-49, 2007.

STRAZDINS, L.; BAMMER, G. Women, work and musculoskeletal health. Social Science and Medicine, v. 58, p. 997-1005, 2004.

TOOMINGAS, A. et al. Associations between self-rated and psychosocial work conditions and musculoskeletal symptoms and signs. Scandinavian Journal of Work, Environment and Health, v. 23, p. 130-139, 1997.

VASCONCELOS, R. C. et al. Aspectos de complexidade do trabalho de coletores de lixo domiciliar: a gestão da variabilidade do trabalho na rua. Gestão \& Produção, v. 15, n. 2, p. 407-419, 2008.

VELLOSO, M. P. Os restos na história: percepções sobre resíduos. Ciência \& Saúde Coletiva, v. 13, n. 6, p. 1953-1964, 2008.

VELLOSO, M. P.; SANTOS, E. M.; ANJOS, L. A. Processo de trabalho e acidentes de trabalho em coletores de lixo domiciliar na cidade do Rio de Janeiro, Brasil. Caderno de Saúde Pública, v. 13, n. 4, p. 693-700, 1997.

WOODS, V. Work-related musculoskeletal health and social support. Occupational Medicine, v. 55, p. 177-189, 2005. 


\section{Marisqueiras da Ilha das Fontes: descrição do trabalho e da tradição incorporadas na pesca artesanal}

Thais Mara Dias Gomes

Mônica Angelim Gomes de Lima Maria do Carmo Soares de Freitas

\section{Introdução}

A temática da saúde do trabalhador artesanal em geral é pouco explorada. Verificam-se relatos históricos como o do médico Bernadino Ramazzini (1985), pioneiro em descrever sistematicamente doenças do trabalho para 54 profissões artesanais, dentre elas, o ofício de pescador e suas respectivas doenças profissionais. Há de se ressaltar que o estudo em questão transita na pesca tradicional marítima e fluvial e não na atividade de extração de mariscos.

A construção da Saúde do Trabalhador envolve o reconhecimento da multiplicidade de mundos do trabalho e, por isso, suas práticas devem adotar abordagens inclusivas de categorias tradicionais. A pesca artesanal representa um desses desafios. Trata-se de homens, crianças e principalmente mulheres expostas aos mais variados riscos e a processos de adoecimento sem acesso à proteção da saúde dos trabalhadores. São categorias de trabalhadores vulneráveis no mundo contemporâneo, em condições de pobreza e que resistem à gigantesca hegemonia da sociedade industrial e terciária, preservando o saber-fazer do pescador artesanal/marisqueira. 
O Brasil apresenta uma extensão litorânea de cerca de 8.500 quilômetros e uma Zona Economicamente Exclusiva - ZEE ${ }^{1}$ de 3,5 milhões de $\mathrm{km}^{2}$, representados principalmente pela região Nordeste. (IBAMA, 2006) O estado da Bahia possui 427 milhas e cerca de $800 \mathrm{~km}$ em linha reta. Ao considerar as reentrâncias, essa distância aproxima-se de 1.200 $\mathrm{km}$, representando $14 \%$ da costa brasileira. (IBAMA, 2006) As áreas denominadas Litoral Norte, Baía de Todos os Santos/Recôncavo, Baixo Sul, Litoral Sul e Extremo Sul são formadas por 44 municípios, estando inseridas 347 comunidades pesqueiras, sendo 9 delas localizadas no município de São Francisco do Conde ${ }^{2}$. (BAHIA, 2005)

Esse vasto litoral (Figura 1) possui um grande número de estuários, formando um complexo de manguezais e coroas. Segundo Marta Vannuci (1999), a pesca artesanal/mariscagem brasileira ocorre principalmente nos ambientes de mangue, possuindo o Brasil a segunda maior área do mundo, com cerca de $25.000 \mathrm{Km}^{2}$. (IUCN ${ }^{3}, 1983$ )

Neste enorme complexo de manguezais, ecossistema cuja riqueza biótica é fartamente comprovada, habitam espécies que possuem parte ou todo o seu ciclo de vida nesses ambientes.

Nos ambientes existentes entre os manguezais e os estuários dos rios, locais onde ocorre a mistura entre as águas marinhas salgadas e as águas doces, encontra-se uma variedade de mariscos. Sob o domínio de marés, a movimentar-se quatro vezes por dia o ambiente marítimo oferta mariscos como Crassostrea rhizophorae "ostra do mangue" (Figura 1).

1 Um novo conceito de espaço marítimo foi introduzido a partir da criação de ZEE que dá uma série de direitos ao estado dela detentor. Direitos exclusivos de soberania para fins de exploração e aproveitamento, conservação e gestão dos recursos naturais, vivos ou não vivos, das águas sobrejacentes ao leito do mar, do leito e seu subsolo, bem como para a produção de energia a partir da água, marés, correntes e ventos. (IBAMA, 2006)

2 Comunidades pesqueiras de São Francisco do Conde: Sede, Caipe, Engenho de Baixo, Ilha das Fontes, Madruga, Monte Recôncavo, Ilha do Pati, Santo Estevão e Paramirim.

3 IUCN - International Union for Conservation of Nature and Natural Resources. A União Internacional para Conservação da Natureza e Recursos Naturais contribui nas soluções para os principais desafios ambientais e os problemas enfrentados no planeta, com atuação continental em temas como biodiversidade, mudanças climáticas e energia. 
Figura 1 - Crassostrea rhizophorae "ostra do mangue"

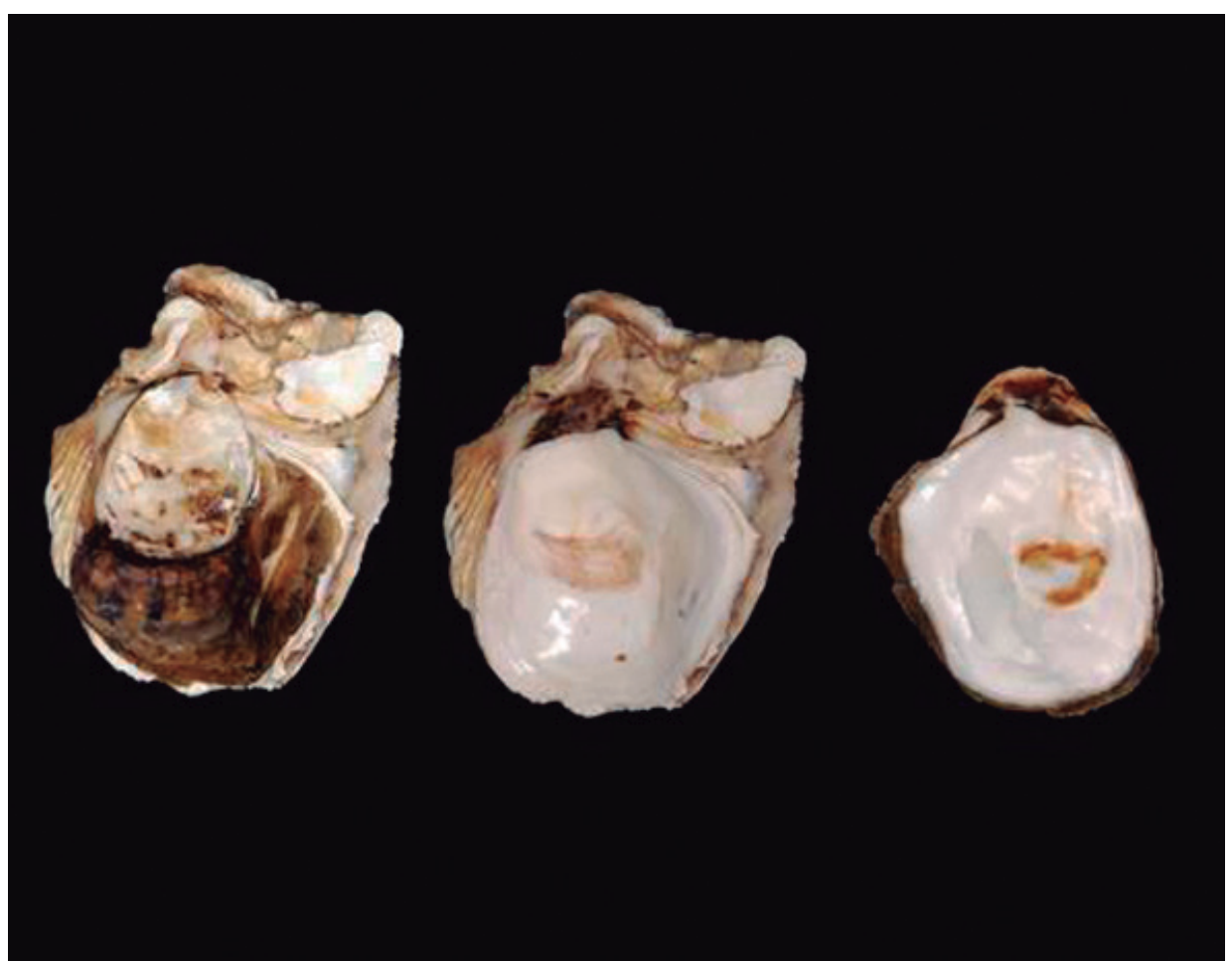

Fonte: (GOMES, 2011)

A Organização Internacional do Trabalho (OIT) estima um contingente de 25 a 34 milhões de homens e mulheres, envolvidos na pesca no âmbito global, sendo aproximadamente $75 \%$ artesãos. (ARNASON, 1998) Segundo dados do Registro Geral da Pesca (RGP) do Ministério da Pesca e Aquicultura, até 31/12/2009 estavam registrados 833.205 pescadores profissionais, distribuídos nas 26 Unidades da Federação e no Distrito Federal.

A região Nordeste concentra o maior número de pescadores, com 386.081 , que representa $46,3 \%$ do total do país, seguida pela Região Norte, com 266.476 (31,9\%). Juntas, essas regiões respondem por $78,3 \%$ do universo de pescadores profissionais do Brasil. (BRASIL, 2011) Organizações não governamentais adiantam que esses números podem chegar ao dobro do oficial, considerando o alto grau de informalidade típica das atividades desses povos das águas que sobrevivem cultuando tradições milenares.

O estado da Bahia possui um total de 105.455 mil pescadores cadastrados, sendo $54,9 \%$ do sexo masculino e $45,1 \%$ do sexo feminino, ocupando o primeiro lugar na Região Nordeste em quantidade de pescadores cadastrados. (BRASIL, 2011) 
A falta de informação ocorre em decorrência da pesca, quase sempre, está associada à atividade em alto mar, provavelmente porque o principal produto da sua captura, o peixe, é simbolizado pelo pescador, no barco, em mar aberto. (LEITÃO, 2009) Corrobora com esse cenário a forma de pesagem do marisco acontecer com o produto final já beneficiado. Essa ideia contribui para que as atividades desenvolvidas pelas mulheres no setor pesqueiro não sejam abordadas claramente nos estudos, ou apareçam como uma prática de complemento à renda familiar. Há uma carência significativa de informações sobre as particularidades do gênero no setor pesqueiro 4 . Segundo o Centro de Estudos e Pesquisas Josué de Castro (2000), a pesca e a coleta realizada por mulheres constituem um trabalho invisível.

As culturas tradicionais coexistem na relação do homem com o meio natural, com práticas, valores e conhecimentos empíricos adquiridos e acumulados através das várias gerações. (DIEGUES, 2004) Nesse contexto o homem modifica o meio assim como o meio impõe ao homem suas características, tornando-se parte de sua cultura. Em meio ao processo adaptativo de sobrevivência, as comunidades tradicionais desenvolvem técnicas produtivas inseridas num processo de produção particular, o da pequena produção mercantil. (DIEGUES, 1983)

O corpo de saberes que orienta o comportamento e as estratégias de pesca e mariscagem é essencial para prever situações em que a pesca pode ser produtiva. Sem esse conhecimento preciso seria impossível à sobrevivência e reprodução dessas comunidades num ambiente marinho sujeito a frequentes e perigosas mudanças de tempo.

A realização das tarefas não é uma situação estática ou padronizada, pode variar de uma comunidade para outra, assim como o perfil socioeconômico da região também se altera como descreve o Centro de estudos e pesquisas Josué de Castro (2000). Mais do que uma atividade econômica, a pesca artesanal/mariscagem no Brasil revela-se como um modo de vida, como um elemento organizador das demais dimensões da vida social. (DIEGUES, 2004)

Por ser o artesão o proprietário dos meios de produção, a concepção do trabalho e a execução encontravam-se unidas. Ao invés

4 Dados da Rede Latino Americana das Mulheres no Setor Pesqueiro - organização suportada pela FAO (Food and Agriculture Organization) a qual o Brasil está inserido. Fonte: http:// mujeres.infopesca.org 
de controlado pelo processo da produção, é o homem que o domina, submetendo-o à sua vontade. Portanto, é necessária uma inflexão nos elementos característicos do processo de produção artesanal, dentre os elementos característicos, inexiste um mercado de compra e venda da força de trabalho, com formalidades contratuais trabalhistas, situação de emprego e desemprego. (PENA; FREITAS; CADIM, 2011) Ressalta-se que pescador artesanal possui uma lógica diferenciada na relação com a natureza o que lhe permite transitar em seu meio através do domínio de sua técnica.

$\mathrm{Na}$ tentativa de se aproximar desta realidade, as autoras se propõem a descrever uma comunidade pesqueira em São Francisco do Conde, a Ilha das Fontes. É a partir da compreensão desse espaço que se apresenta o cenário da pesquisa. 'Em cena', as mulheres pescadoras/ marisqueiras e as próprias autoras numa perspectiva compreensiva, tomada por uma problemática que emerge do campo empírico e transita pelo simbólico. Neste sentido, buscou-se descrever o trabalho de pescadoras/marisqueiras na extração da ostra, apresentando as tarefas e o contexto temporal em que são executadas, compreender o cotidiano de vida e os significados da dor no trabalho de mariscagem.

\section{Métodos}

Trata-se de uma abordagem etnográfica na comunidade pesqueira de Ilha das Fontes/São Francisco do Conde. Foram utilizadas entrevistas em profundidade, conversas informais, registro de observação participante do cotidiano da Ilha: trabalho na maré, ambiente doméstico, áreas de lazer como praças e bares, espaços religiosos, análise do trabalho e análise documental. Para condução das entrevistas partiu-se de uma pergunta disparadora sobre como ser ou tornar-se marisqueira na Ilha das Fontes.

Optou-se pela perspectiva fenomenológico-compreensiva como referencial metodológico, pois ao longo desse campo foi privilegiada a interação e auto-observação para construção do entendimento. Esse estudo requereu uma aproximação com a ergonomia da Escola Francesa como referencial teórico na análise e compreensão do trabalho na maré.

Assume-se a Antropologia Interpretativa orientada pela perspectiva hermenêutica, dominante na fenomenologia compreensiva na 
construção desse trabalho. Como refere François Laplantine (2003, p. 121, 122),

[...] o etnógrafo é aquele que deve ser capaz de viver nele mesmo a tendência principal da cultura que estuda. [...] uma verdadeira aculturação invertida, na qual, longe de compreender uma sociedade apenas em suas manifestações “exteriores” (Durkheim), devo interiorizá-la nas significações que os próprios indivíduos atribuem a seus comportamentos.

Esse "encontro etnográfico" requer "um olhar devidamente sensibilizado pela teoria disponível”. (OLIVEIRA, 1998, p. 19) Dessa forma, a observação participante sobre o trabalho etnográfico formulada em termos hermenêuticos é uma dialética entre a experiência e a interpretação. (GEERTZ, 1989) Como afirma Paul Ricoeur (1978), essa hermenêutica, explicita ou implicitamente, permite conhecer a si mesmo mediante a compreensão do outro.

O primeiro momento da pesquisa consistiu na identificação de uma comunidade pesqueira do município de São Francisco do Conde/BA5. Existem no município de São Francisco do Conde nove comunidades que sobrevivem da pesca artesanal. Ao analisar a realidade de acesso aos serviços de saúde, distância da sede e localização geográfica, a região de Ilha das Fontes destacou-se como local de estudo.

O trabalho de campo ocorreu entre os meses de janeiro de 2011 a janeiro de 2012, com variações no período de estadia na comunidade pesqueira, entre 1 a 6 dias. As visitas ocorriam em dias programados pela primeira autora em comum acordo com as informantes identificadas, observando o calendário lunar, o horário de chegada e possíveis alterações marítimas (maré tardeira ou cedeira).

A escolha dos interlocutores ocorreu por indicação da própria comunidade, em conjunto com a observação da primeira autora da pesquisa, sendo escolhidas as que realmente poderiam contribuir para ajudar a responder à questão de pesquisa. Preserva-se a identidade dos entrevistados não revelando seus nomes verdadeiros.

Esse projeto de pesquisa obteve aprovação pelo Comitê de Ética em Pesquisa da Maternidade Climério de Oliveira. Nesse sentido, os aspectos éticos foram contemplados em conformidade com a Resolução

5 Terceiro município brasileiro com maior PIB per capita. Sua população estimada pelo IBGE em 2009 era de 31.699 habitantes. 
CNS 196/96, para pesquisa em seres humanos. Foram promovidas reuniões e apresentação/discussão do projeto com os representantes dos pescadores do município de São Francisco do Conde.

\section{Resultados e discussão}

Famosa pelas inúmeras fontes espalhadas por toda a sua extensão daí o seu nome -, a Ilha das Fontes fica a cerca de $5 \mathrm{~km}$ de São Francisco do Conde. É considerada a melhor água das redondezas, e suas fontes são tidas como as maiores. A Ilha abriga, ainda, as ruínas de um antigo engenho com um legado histórico-cultural amplo. Essa particularidade torna-se representativa quando, nas estatísticas, 95\% da população de São Francisco é negra. É importante salientar que as comunidades pesqueiras da Baía de Todos os Santos são localidades antigas da nação brasileira e se constituem em áreas povoadas por remanescentes de Quilombos desde o século XVI. Nesse sentido é uma região importante pela herança cultural no Brasil; locais onde geralmente persistem sistemas produtivos tradicionais como a produção do pescado.

Conhecer as complexas variações do tempo e suas relações com a movimentação das marés é de fundamental importância em uma comunidade pesqueira. Lua e sol se posicionam de forma variada e cíclica em relação à Terra e determinam a dinâmica das marés, rios e canais litorâneos. Nas fases da Lua nova e cheia, o fenômeno resultante da atração gravitacional exercida pela Lua sobre a Terra, e em menor escala, do Sol sobre a Terra, proporciona uma maior variação das marés, conhecidas como "maré-grande". Contrariamente, nas "marés-mortas", durante os quartos crescentes e minguantes, a atração gravitacional é menor e resultam em marés de fraca elevação.

A divisão territorial na Ilha é feita pelos próprios moradores, a "parte da frente" relativamente descrita anteriormente, a "parte alta", a "ponta" e a "costa". Verifica-se uma infraestrutura habitacional bastante deficitária, com existência de casas de lona, taipa e alvenaria. A infraestrutura social é bastante precária, não existe tratamento de esgotos. Há aproximadamente três anos uma parte da comunidade teve acesso à água encanada. Já o candeeiro deixou de ser utilizado na comunidade há sete anos. 
$\mathrm{Na}$ comunidade de Ilha das Fontes não existe assistência médica permanente, a visita médica é realizada uma vez na semana. A demanda relatada por dois funcionários do Programa de Saúde da Família (PSF), enfermeiro e agente comunitária de saúde, segue as proposta das políticas de intervenção básica como programa de hipertensão arterial, diabetes e pré-natal. Com pouco relato de idas ao posto em decorrência de dor ou acidente proveniente do trabalho.

A principal fonte de renda dos moradores é a pesca artesanal (mariscagem, principalmente para as mulheres), observa-se, no entanto, alguns moradores vinculados à prefeitura e com benefícios sociais como: Programa de Assistência Social (PAS) e Bolsa Família. A existência do PAS é uma particularidade do município de São Francisco do Conde.

A imersão no universo pesqueiro da Ilha das Fontes permitiu o tecer histórico de tradição inerente ao ofício de mariscagem, seguindo a compreensão desse espaço feminino e inclusivo, com presença de crianças, idosos e excepcionais; o tecer do aprendizado na maré e a liberdade no território das águas. Apresentam-se as sete etapas do trabalho da mariscagem da ostra: "a preparação para o trabalho", "a ida à maré", "a coleta", "o retorno da maré", "o cozimento do marisco", "a cata do marisco" e "a venda". Nessa longa jornada de trabalho desvendam-se estratégias, mitos, interpretações do corpo, identidade e pertencimento. Assim como surgem relatos de dor, adoecimento e acidentes na maré.

\section{A tradição em ser/tornar-se marisqueira}

O caráter tradicional da pesca é inerente ao ato de pescar, "algo é entregue" de geração a geração para reproduzir-se ao longo do tempo. Não podemos perder de vista que a linguagem é a expressão da experiência vivida e é um dos elementos da realidade. (RICOEUR, 1978) Imbricados nessa lógica transcendental, a vida é relembrada em sua história passada para construção e reconstrução da vida presente. Ao problematizar as noções de tradição e herança cultural busca-se um diálogo com as evidências e com as narrativas orais dos sujeitos. (HALL, 2006) Através da história pregressa de ancestrais pescadores, vivenciam-se situações de extrema dificuldade e adaptações que garantiram a permanência do trabalho nos dias atuais. 
Antes mesmo de nascer, ainda na barriga da mãe o processo de aprendizagem é iniciado e possibilitado por essa construção do simbolismo familiar. (MAUSS, 2003) "Mamãe mariscava, papai vivia na maré". (VERA, 60 ANOS, novembro de 2011) O nascer e crescer na maré é o que permite a prática e o desenvolvimento de habilidades no ofício de mariscagem: a confecção dos instrumentos que maneja com perícia, saber a melhor localização da mariscagem, o tipo de maré, o treino do olhar na identificação do marisco.

A reprodução social da família de pescadores em Ilha das Fontes é intencionalmente estruturada a partir da transmissão dos saberes e elementos socioculturais. (BOURDIEU, 1989) É na infância que esse aprendizado se materializa, sendo circunscrita entre a casa, a rua, a maré e a escola. Nessa fase de reconhecimento do ambiente marítimo, que tradicionalmente são definidos os papéis ocupados pelo homem e pela mulher na comunidade pesqueira. (DIEGUES, 1983) Essa distinção entre os saberes femininos e masculinos ocorre conforme o espaço de construção de identidade e construção social deste mesmo espaço. (BECK, 1989) Na comunidade de Ilha das Fontes são as mulheres que exercem a atividade de mariscagem. Por não possuírem embarcação transitam nas proximidades da costa, seja no mangue ou na "coroa", onde extraem, com auxílio de facas, o "sarnambi" (Phacoides pectinatus), "sururu" (Mytella guyanensis), "tarioba" (Macoma constricta, "chumbinho" (Anomalocardia brasiliana) e "ostra" (Crassostrea rhizophorae).

Esse corpo de saberes orienta o comportamento das marisqueiras, as estratégias de trabalho e também é essencial para prever situações de perigo e dificuldade. Nesse sentido, o conhecimento tradicional ajuda as marisqueiras na construção de seus próprios mapas mentais que as orientam onde e como mariscar, no entrar e sair do mangue. "Dentro do mangue logo minha mãe olhou pro sol e disse - olha Tatiana se a gente vê o sol na nossa direção é o lugar da saída". (TATIANA, 27 ANOS, outubro de 2011)

A percepção visual, para identificação do marisco, ou espacial, para localizar-se no mangue através da analise da posição do sol, se relacionam e se constroem no aprendizado prático, o sentir, o estar ali, o viver o cotidiano da mariscagem interagindo com o ambiente. A percepção constitui-se na interpretação do mundo pelo indivíduo a partir do que 
se vê, sente, cheira, escuta, enfim, apreende com os sentidos. É na existência, o "está ali", que não escapa do passar dos dias, que se cria, se imagina, se sente, se entende a vida, a vida na maré.

Sobre tal fato, Diegues (1983), ao caracterizar o pescador artesanal, diz que o ponto definidor deste não se resume ao ato de viver da pescaria, mas dominar plenamente, os meios de produção da pesca. O que possibilita a mariscagem é a autonomia de trabalho, pois o saber-fazer compreende o controle dos processos de confecção e conserto dos instrumentos, e conhecimento da mariscagem, que permitem gerar esse sentimento de ser liberto, por apresentar a qualidade de certa "independência" no que concerne ao "mundo externo" à pesca. "A melhor coisa é trabalhar com as coisas que é seu, trabalhar com as coisas dos outros é ruim, é muita humilhação". (JACQUELINE, 34 ANOS, outubro de 2011)

O principal aspecto positivo é o fato de trabalharem para si mesmas, além de não terem horário fixo. Neste sentido, identificam a liberdade como uma das características da atividade de mariscagem. Essas relações emergem em um contexto de liberdade, compreendida como o poder fundamental que se tem de ser o sujeito de todas as experiências, não se distingue de sua inserção no mundo. (MERLEAU-PONTY, 1999)

A liberdade do trabalho na maré não é determinada exteriormente, imposta por gerências, mas interiormente, de natureza subjetiva, determinada pelas condições sociais de sobrevivência. Dessa forma, quando há falta de alimento para a família ou dinheiro para gastos relativos à sobrevivência, tais necessidades econômicas impõem os ritmos de trabalho e vida nas comunidades pesqueiras.

Ao se projetar para o futuro pode-se inferir que a transmissão dos saberes específicos sobre a pesca artesanal/mariscagem poderá perderse ou ser ignorada entre as novas gerações. Observa-se que, os mais jovens são atraídos pelas possíveis ofertas de emprego no setor de serviços, na expectativa de uma melhor qualidade de vida e trabalho.

Em meio a essa circunstância observa-se outra relacionada ao pertencimento à comunidade pesqueira. (HALL, 2006) Mesmo que os mais jovens partam em busca de novas perspectivas de trabalho, as relações com o mar permanecem constituindo a base da sustentabilidade nos momentos de retorno à comunidade em decorrência do desemprego. A sobrevivência da pesca artesanal/mariscagem parece apontar para 
uma resistência enquanto o "fazer", enquanto "forma de trabalho", que envolve a história familiar, cultural, geográfica de aprendizado e, sobretudo, a garantia de quando tudo lhe faltar, o mar estará sempre a servi-lhe os recursos da sobrevivência.

Uma vez que os moradores de alguma forma são relacionados uns aos outros pelo parentesco, a reciprocidade entendida aqui como a experiência da retribuição e necessidade de cooperação, configura-se como um elemento estrutural e estruturante para a constituição da rede de sociabilidade, e por conseguinte da sobrevivência do povoado. (LÉVI-STRAUSS, 1982; SCHUTZ, 1979)

\section{O trabalho no mangue: a coleta da "ostra"}

Através das narrativas das marisqueiras e das "lentes" 6 , que buscam conhecer, vivenciar, compreender e interpretar o fenômeno, com o suporte da análise ergonômica, observa-se que o trabalho da marisqueira de Ilha das Fontes contempla em geral sete etapas. Um dia o trabalho pode iniciar-se às 7 horas da manhã e findar-se 12 horas depois, noutro a saída é feita com o dia ainda escuro só retornando ao fim da tarde. (GUERIN et al., 2001)

Tanto as saídas como os retornos dependem da maré, a descobrir e encobrir a fonte de sobrevivência dessa gente que dela vive. Em meio a essa jornada de trabalho permeiam outras, pois a elas cabem o cuidar dos filhos e companheiros, os afazeres domésticos e o preparo da alimentação.

As interações entre o ciclo do dia, o ciclo da maré e o ciclo produtivo com a casa, a natureza e o cotidiano, reflete a existência de relações sobrepostas entre o trabalho na maré e a vida de uma marisqueira. Representam a teia de relações, muitas vezes, implícitas, inerentes ao mundo da pesca artesanal, mais especificamente, na atividade de mariscagem.

A compreensão das etapas que constituem o trabalho na maré, neste caso o marisco "ostra", é apreendida no lócus da atividade, na

6 Lentes de quem acredita existirem inúmeras formas de ver e interpretar o que é visto, considerando-se que valores e comportamentos formadores de diferentes identidades permeiam essas formas diversas de olhar o outro e de, a posteriori, como refletindo a imagem de um espelho, tecer novo olhar sobre si mesmo (GERBER, R. M. Temporalidade pesqueira e espaços feminino e masculino em Ganchos. In: RIAL C; GODIO, M. (Org.) Pesca e turismo: etnografias da globalização no litoral do Atlântico Sul, Florianópolis: NUPPE/CFH/UFSC, 2006. p.113-128). 
interpretação das narrativas e na experimentação do corpo em atividade através da experiência na Ilha das Fontes.

\section{As Etapas do trabalho}

$1^{a}$ Etapa: a preparação para o trabalho - o que vestir, o que levar, o que comer?

O corpo frágil construído socioculturalmente para a mulher perde significado nas comunidades pesqueiras. Corpos que ganham forma e força não pela construção metódica e racionalizada por meio de exercícios programados, alimentação balanceada, ingestão de substâncias sintéticas ou cirurgias, mas pelo trabalho manual/braçal realizado na maré. Esse corpo forte no trabalho é comparado, por elas, ao corpo do homem, capaz de realizar "atividades de homem".

Vestem-se para o trabalho utilizando os recursos que lhes são disponíveis para amenizar os riscos a que são expostos. Definem o abastecimento nem sempre o necessário para a manutenção da longa jornada na maré/mangue, mas o possível economicamente ao dia de trabalho. Em dez minutos estão prontas para iniciar a jornada. Também confecciona e improvisa os instrumentos de trabalho da mariscagem, uma faca ou facão para retirada da "ostra" e um balde para o transporte, como é observado na Figura 2. Nessa relação de "pertencimento" transparece a expressão de independência e autonomia do trabalhador da maré/mariscagem. (HALL, 2006) 
Figura 2 - Instrumentos de trabalho

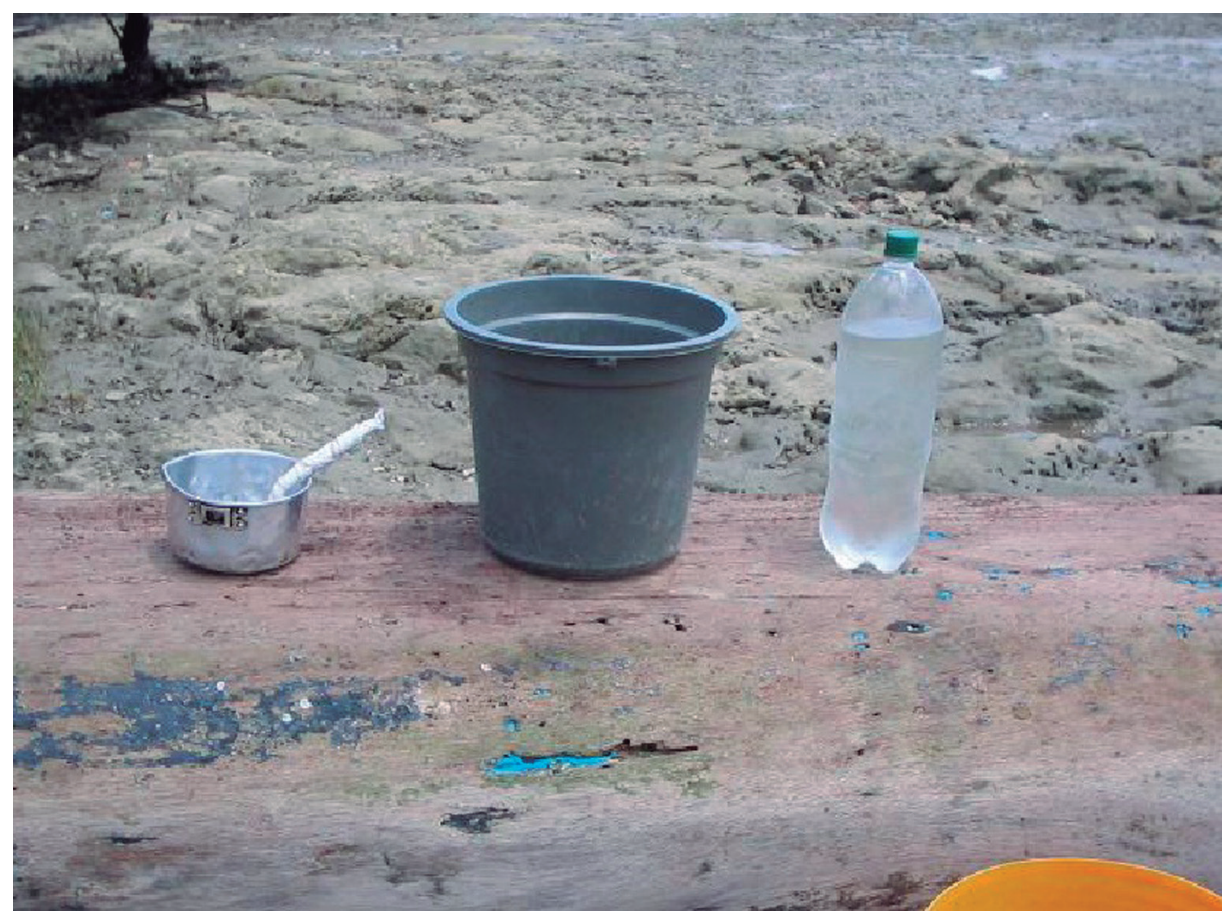

Fonte: Fotos da pesquisa (GOMES, 2011)

\section{$2^{a}$ Etapa: ida à maré/mangue}

$\mathrm{Na}$ Ilha das Fontes, diferente do que ocorre em outras regiões pesqueiras, o trajeto ao mangue tem duração de vinte minutos, facilitado pela proximidade das casas às áreas de extração da ostra. Porém, não a isenta do olhar atento aos perigos do trajeto. A depender do local de coleta e do tipo de marisco coletado encontram-se novas dificuldades, necessitando de preparo para enfrentá-las. As vestimentas, os esforços, a habilidade do corpo ao transitar em regiões de mangue são diferenciadas. Nesse ambiente, a possibilidade de afundamento é grande, para isso estratégias de como caminhar de forma ágil e firme são passadas para evitar acidentes. O calçado preso ao pé é necessário para evitar cortes, assim como calça e camisa comprida para proteger do sol e de mosquitos.

No entanto, o uso de óleo diesel ${ }^{7}$ na pele é frequente para inibir a picada dos mosquitos. Na maré grande há mais mosquitos, o que difi-

7 Segundo dados do National Institute for Occupational Safety and Health (NIOSH, 1988), a exposição ao óleo diesel pode provocar câncer. 
culta o trabalho. Segundo Guérin e colaboradores ${ }^{8}$ (2005), o contexto geográfico influencia as condições de deslocamento ao local de trabalho e, portanto, as interações entre sua atividade de trabalho.

\section{$3^{a}$ Etapa: coleta da "ostra"}

A imagem vista nos manguezais configura-se como um mosaico de corpos, ora com a coluna fletida, apoiando-se em uma das pernas, ora agachadas e sentadas sobre os calcanhares "cócoras". No momento da coleta, o tronco é inclinado "envergado" para frente, apoiando-se com um braço sobre uma das pernas o que lhe permite um leve descanso. $\mathrm{O}$ outro fica livre para segurar o instrumento que dá continuidade a sua mão. Essa inclinação perdura por horas, cotidianamente, entre as raízes de manguezais, de tal forma que com elas se assemelham (Figura 3). Muitas vezes, para possibilitar a extração de mais "ostras", a marisqueira aguardava sentada nas galhas do manguezal o segundo ciclo da maré para continuar a coleta. Observam-se rápidos e precisos movimentos com as mãos.

$\mathrm{O}$ ambiente de mangue ainda exige outras posturas, pois muitas vezes a lama encobre as pernas, chegando à região da cintura. Exige equilíbrio e agilidade para não cair ou atolar. "Uma vez atolada, só com a ajuda de alguém para nos tirar do buraco que nosso corpo desenhou na lama". (DIÁRIO DE CAMPO, set./2011). O risco de afogamento na lama revela os perigos do mangue e a preferência pelo trabalho na costa "coroa".

O tempo tomado pelo trabalho é quase absoluto, cinco a seis horas. Dispensava-se qualquer treinamento extra. A marisqueira aprende silenciosamente os gestos, a utilização de forças, as estratégias de trabalho, o melhor local para retirada do marisco/ostra. Aprende a lidar com os ciclos do seu corpo (menstruação, gravidez, amamentação) e o trabalho na maré. Surgem mitos impressos no corpo da mulher, o útero que interioriza a lama do mangue como me explica Tatiana (27 ANOS, out./2011):

[...] no mangue a mulher não pode mariscar porque a mulher tem útero, e para mariscar no mangue é mais arriscado que o homem, minha mãe contava de uma moça que morreu e no exame transvaginal o médico viu o útero dela

8 Guérin e colaboradores (2005) são utilizados como referências na análise ergonômica do trabalho para auxiliar na compreensão e interpretação do trabalho na maré. 
cheio de lama de mangue, ela mariscava abaixada, o vapor do salitre às vezes caía no buraco, a lama introduzia e entrava, passava às vezes com lama na cintura, ela terminou se prejudicando.

Uma característica da prática médica é não se basear em um conhecimento propriamente dito quando se trata de explicações das classes populares. (BOLTANSKI, 2004) A comunicação médico/paciente esbarra nas barreiras linguísticas e analogias feitas para facilitar a compreensão, porém as explicações são geralmente vagas e o confundimento propicia os mitos.

Por ser um trabalho realizado em ambiente aberto, as marisqueiras estão sujeitas às mudanças de temperatura. A umidade, as temperaturas instáveis, a maresia, deveria haver ali uma aprendizagem, uma educação, sobretudo uma autoeducação dos sentidos, para suportar as dificuldades do ofício. (ZOLA,1979) Autoaprendizagem para sobreviver. E assim como os mineradores de Émile Zola, o corpo da marisqueira com o tempo também parece gastar menos energia, internaliza os códigos da economia de força sem nenhuma explicação científica, mas tão somente essa enorme capacidade que tem o ser humano de adaptarse para não morrer, antes de buscar as formas de transformar, para daí viver. (ZOLA, 1979)

Figura 3 - Coleta 'coluna fletida'

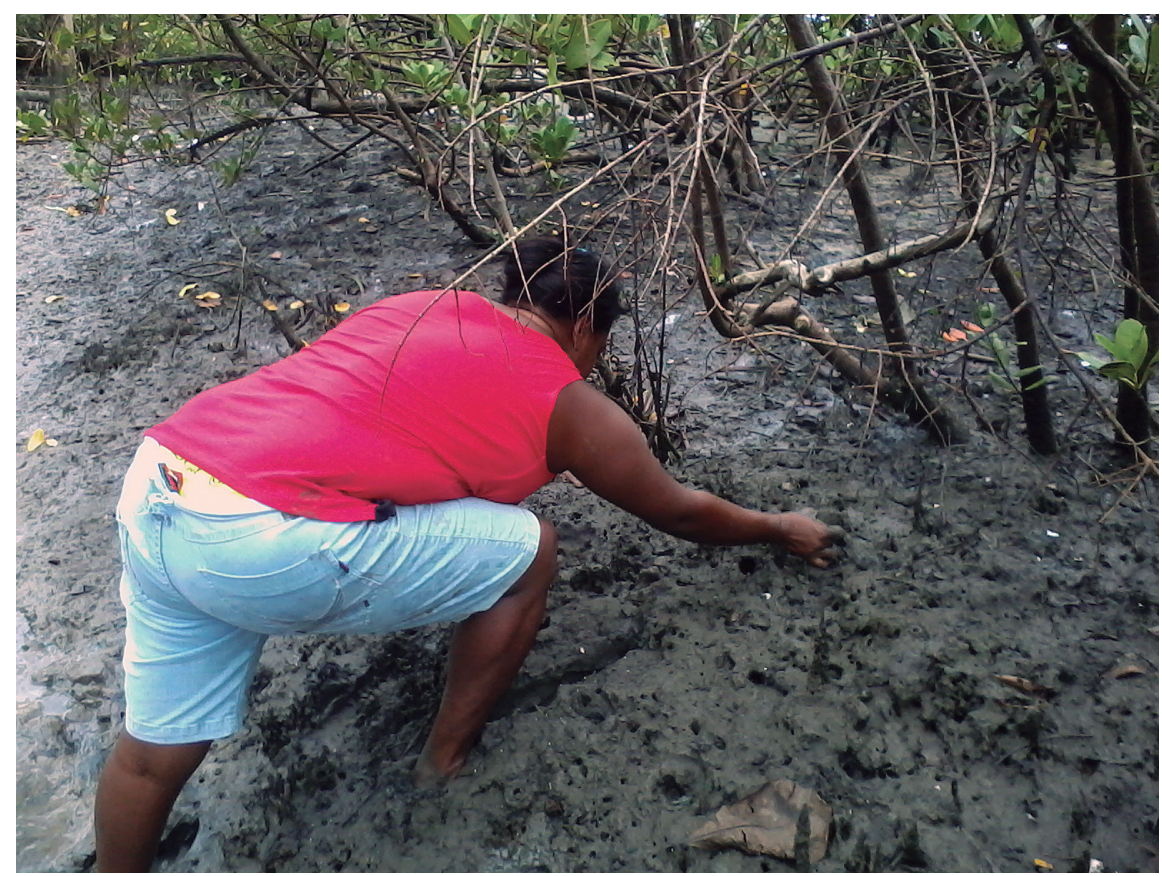

Fonte: Fotos da pesquisa (GOMES, 2011) 


\section{$4^{a}$ Etapa: retorno da maré}

O mesmo trajeto de ida é percorrido, porém com o sobrepeso da "ostra" que pode variar entre 20 ou 40 quilos, a depender da maré/ mangue, realizado em aproximadamente trinta minutos. No retorno do mangue a marisqueira se percebe e é percebida pelos que lá não estavam como suja. Há uma rejeição, um conflito com isso, que não está na dimensão corporal. Há um conflito na própria identidade de marisqueira, que se faz não apenas pelas habilidades que adquiriu na maré, mas porque ela é aquela que vai ao mangue e que fica "suja, com mau cheiro" e vira mangue também, essa relação segundo o Centro de estudos e pesquisas Josué de Castro (2001) qualifica-se como verdadeira simbiose.

Os odores da vida cotidiana representam a intimidade mais secreta do indivíduo: fragrâncias do corpo, das roupas, das casas, dos ambientes. Para percebê-los é necessário, o efeito, o contraste, a indiferença. (LE BRETON, 2011) Aliás, é através do odor que imediatamente se recorre quando se trata de difamar ou discriminar o outro.

O discurso social estigmatiza antes os odores como "maus" e associa a feminilidade à presença de cheiros doces, diferente do cheiro do corpo que trabalha no mangue. O odor corporal exalado pelo corpo constitui a "assinatura de sua presença no mundo". (LE BRETON, 2011, p.180) Dessa forma Vera nos explica esse pertencimento ao mangue é próprio do ofício da mariscagem. "Não é todo mundo que vem aqui não, para ser marisqueira tem que mariscar, entrar no mangue, se atolar - [risos]. (DIÁRIO DE CAMPO, 2011)

\section{$5^{a}$ Etapa: o cozimento da "ostra"}

Arruma-se a ostra em uma panela para fervê-la no fogo à lenha (Figura 4). Lenha que é extraída previamente nos arredores da Ilha. Corta-se a lenha ou fazem uso de galhas que já encontram ao chão. A fumaça invade os poucos cômodos existentes. Uma fumaça que invade não só a casa, mas o corpo, após a inalação a tosse não demora a aparecer. Com toda aquela fumaça os olhos ardem, o nariz irrita, mas com o passar do tempo o corpo parece se acostumar. O momento do cozimento e da cata sobrepõe-se no ir e vir de cozer a "ostra", inalar fumaça, carregar panela e despejar na bacia perdura, até que a última "ostra" seja cozida. 
Figura 4 - Cozimento do marisco

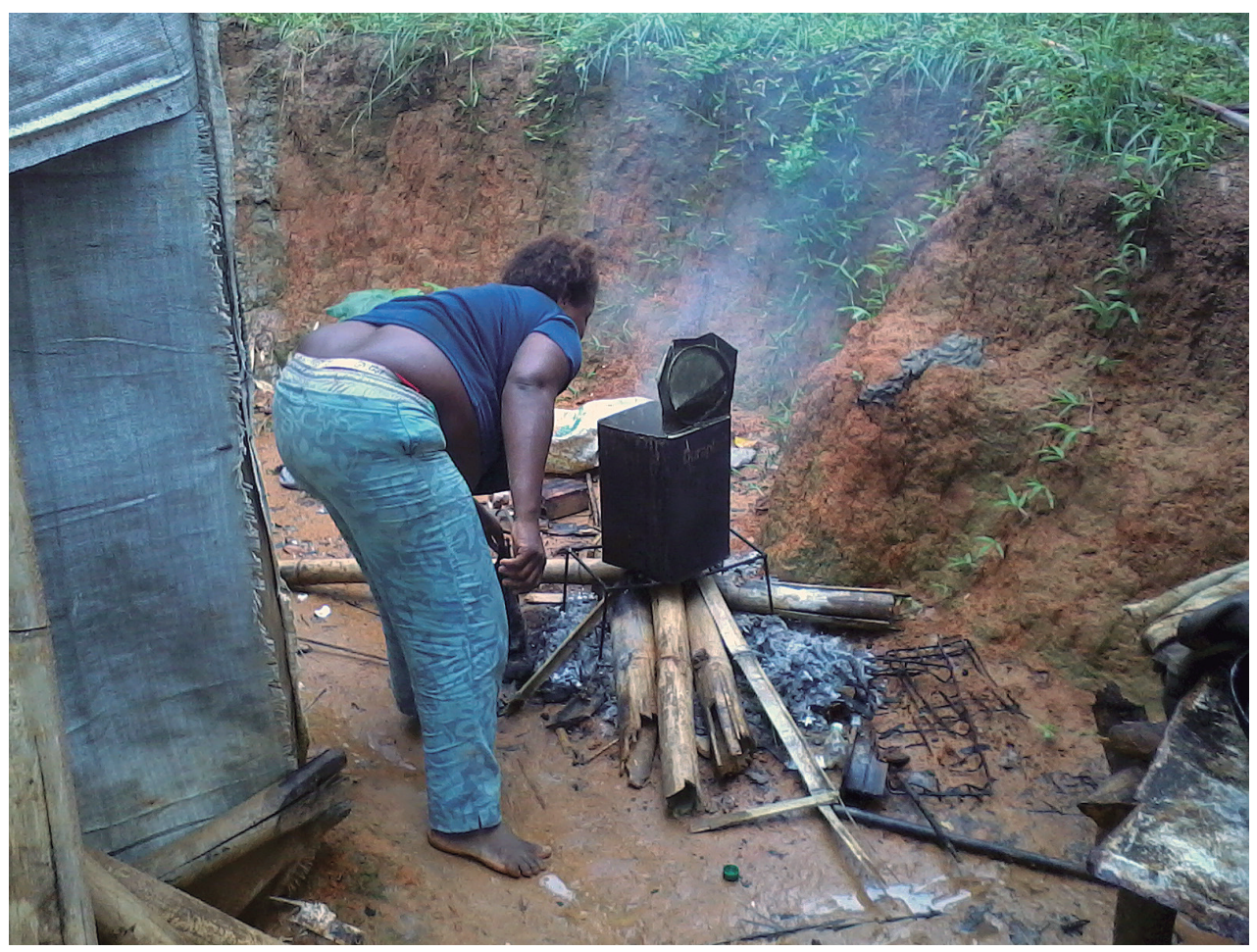

Fonte: Fotos da pesquisa (GOMES, 2011)

\section{$6^{a}$ Etapa: a cata do marisco}

"Ela cata sentada ao chão, onde também estão os mariscos depositados em pequenas vasilhas, além de animais (gatos ou cachorros) a transitar". (DIARIO DE CAMPO, Out./2011)

Rodeada pelas ostras (Figura 5), a vida parece não ser guiada por nenhuma lógica de tempo. O trabalho termina quando a última ostra é aberta, muitas vezes após seis horas de cata. Todos os processos da ostra pareciam ser mais difíceis, sua coleta, seu transporte, seu cozimento e sua cata. O conhecimento prático observado na execução do ofício de marisqueira é um dos domínios das técnicas corporais. Segundo Le Breton (2007), esse conhecimento é resultado da competência profissional sedimentada em um conjunto de gestos de base, assim como um grande número de movimentos coordenados nos quais o homem cristaliza, com o passar dos anos, sua experiência secular. "Trata-se de modalidades de ação de sequencias de gestos, de sincronias musculares que se sucedem na busca de uma finalidade precisa". (LE BRETON, 2007, p. 39) Segundo Merleau- Ponty (1999, p. 198) “a aquisição do 
hábito é sim a apreensão de uma significação, mas é a apreensão motora de uma significação motora".

É no momento da cata que o corpo encontra no ambiente doméstico, não só a catar, mas intercalar com o cuidar dos filhos que já retornaram da escola, o cuidar da comida e dos afazeres da casa. Apesar do esforço repetitivo inerente à etapa, este é o momento mais agradável.

Figura 5 - Cata do marisco

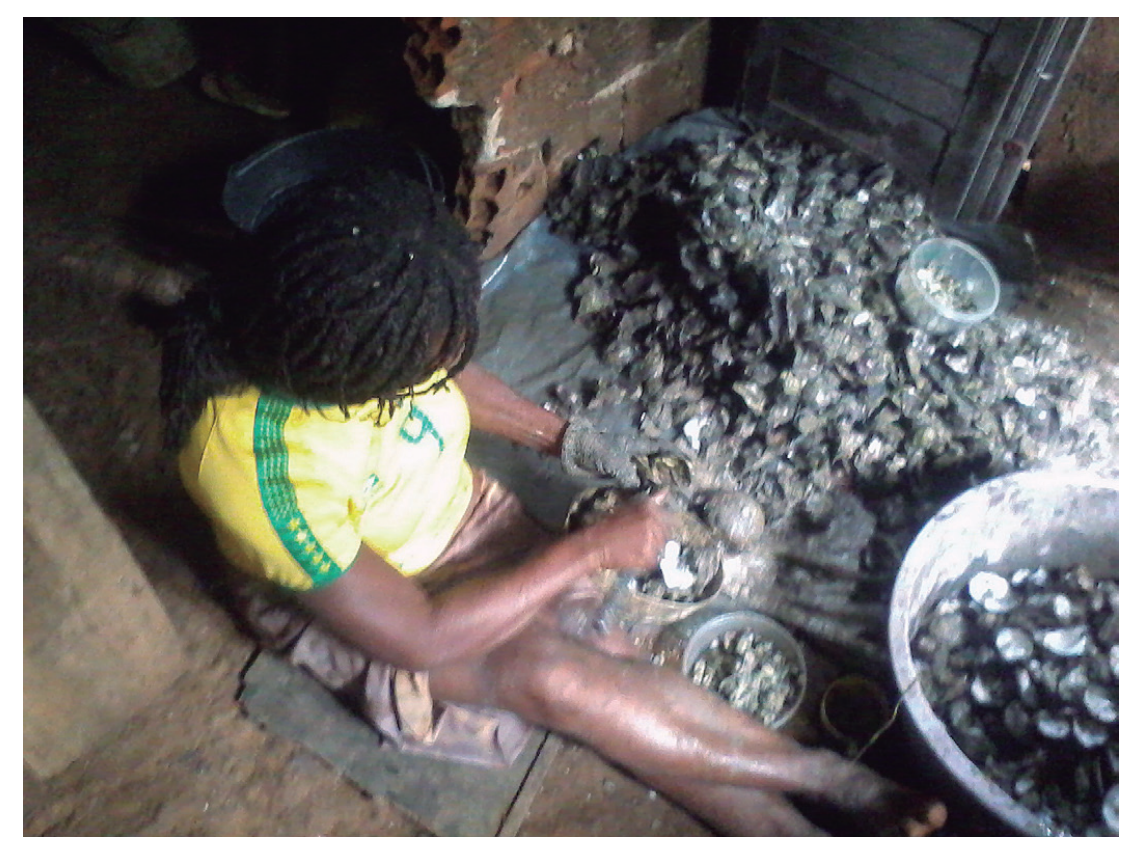

Fonte: Fotos da pesquisa (GOMES, 2011)

\section{$7^{a}$ Etapa: a venda}

Nesse cotidiano de trabalho a semana passa, para aos sábados ocorrer o deslocamento para Candeias, local onde acontece a venda dos mariscos. Lá, também são realizadas as feiras da semana, com o próprio dinheiro adquirido com a venda. Vende-se um alimento para comprar outros alimentos.

O corpo cansado da jornada de trabalho semanal não pode deixar de atravessar a Ilha em direção a Candeias, lá a feira é movimentada e passam até cinco horas a vender seus mariscos. Em barracas eles se misturam às verduras, às frutas, ervas medicinais e tantos outros pequenos produtos para consumo. A venda também acontece na própria Ilha. 
No entanto, há de se ressaltar que para as marisqueiras, não há férias, descanso semanal e feriados remunerados. A decisão do não trabalho implica na perda da produção correspondente. Um dia que não seja dispensado ao trabalho, muitas vezes, representa ter que desinteirar o quilo já armazenado.

Esse trabalho expresso nas adversidades do campo, realizado sobre condições extremas de esforço e jornada de trabalho exaustiva; sujeito a intempéries e acidentes na maré/mangue é percebido com dores e odores. Ao tempo vivencia a vulnerabilidade social em que se inserem as comunidades pesqueiras, mantêm-se na sua tradição oral, perpassando gerações e possibilitando a sobrevivência da população que dela vive.

\section{Dor: um modo-de-ser-no-mundo}

O trabalho e a força física utilizada na execução da atividade determinam, em certo ponto, a compreensão e a experiência das enfermidades. Para construir uma explicação mínima para o fenômeno da doença, os indivíduos não necessitam do conhecimento biomédico. Ao contrário, as imagens fornecidas pela sua cultura compõem a rede de significados que lhe permite entender os diferentes eventos, como por exemplo, a doença. (GEERTZ, 1989) Assim, não lhes basta somente conhecer os agentes causadores, através de técnicas de diagnóstico. A experiência da doença não se resume ao sucesso ou insucesso desta ou daquela forma de diagnosticá-la e tratá-la, mas, sobretudo retrata uma visão e posição no mundo daqueles que a vivenciam. (ALVES; SOUZA, 1999)

Cada atividade laboral impõe diferentes demandas ao corpo do trabalhador, com diferentes respostas desde o cansaço (fadiga) à dor muscular aguda ou crônica. No estudo apresentado, a percepção da doença é possibilitada por sinais e sensações corporais como cansaço e fraque$\mathrm{za}$, indicando que algo impede o funcionamento "normal" do corpo. No ofício de mariscagem, a fadiga corporal geral (disease) entendida pelo modelo biomédico, é diagnosticada através de presença de movimentos repetitivos, posturas adotadas no trabalho no mangue. (PENA; FREITAS; CADIJM, 2011) Pretende-se neste estudo ampliar signos e significados expressos nesse cansaço.

O trabalho impõe ao corpo uma continuidade de etapas, longa jornada, carregamento de peso, posturas, gestos, movimentos repetitivos. Ao narrarem o "cansaço da maré", elas revelam seu aparecimento prin- 
cipalmente após as etapas desenvolvidas fora do ambiente doméstico. Esse cansaço cessa quando é possível um repouso, no entanto, mesmo à noite, enquanto "[...] os demais operários cansados do labor diurno metem-se na cama para passarem comodamente à noite, num sono reparador, as noites dos pescadores estão cheias de trabalho e insônias". (RAMAZZINI, 1985)

Esse perceber da doença expressa à importância social do corpo como meio de existência para aqueles que dele dependem para sobreviver. Não somente uma parte do corpo dói, este corpo dói por inteiro, é o "cansaço da maré", percebido como físico, mas também mental. Nesse contexto, o trabalho acontece, o cansaço desaparece para novamente reaparecer após um novo dia de trabalho. Com o passar dos anos de trabalho, essa fadiga torna-se sinal de fraqueza impedindo a continuidade do trabalho como relata Tatiana (27 ANOS, out./2011): "Eu estava fraca, chegava em casa tinha vez que eu nem catava no mesmo dia, não aguentava mais". E assim, Vera questiona-se sobre a necessidade de parar, pois o corpo já não mais consegue dar conta de tantas fadigas acumuladas no trabalho. "A maré cansa a pessoa, tendo a idade assim é mais para continuar na maré?”. (VERA, 60 ANOS, nov./2011)

A sobrecarga de trabalho, associada às mínimas condições materiais, limita a vida dessas trabalhadoras das águas a movimentos de revolta às situações insuportáveis dentro das fronteiras que aprenderam a tolerar, onde a violência que os atinge é sutil, é escamoteada na hipersolicitação do corpo, no cansaço, na dor e nos acidentes que os atinge.

\section{Considerações finais}

Diante de uma atividade de caráter artesanal, sem as gerências próprias do contexto industrial, onde a tarefa é prescrita pela tradição cultural, o mergulho nas histórias e narrativas dos saberes tradicionais e a observação do trabalho na maré foram necessários mediante as abordagens etnográfica e ergonômica. As atividades na terra são exercidas por mulheres, além de possibilitar a inclusão do trabalho de crianças, idosos e pessoas com necessidades especiais. São reconhecidas como marisqueiras e exercem uma atividade que envolve tradições tecidas geração após geração, desvendando os caminhos da arte de ser marisqueira. Detentoras de um vasto arsenal de saberes marítimos, elas criam e 
recriam um modo de ser no mundo, através do habitus de vida singular. (BOURDIEU, 1989)

O mangue, local de riquezas, mitos, ritos e perigos, é sinalizado como o ambiente mais difícil à realização do ofício de marisqueira. A caracterização da tarefa nesse contexto permitiu identificar as variabilidades do trabalho no mangue, com presença de movimentos repetitivos; posturas adotadas como flexão de coluna por tempo prolongado; evidenciando como são geradas as demandas extras e como as exigências cognitivas e físicas podem ser exacerbadas pela demanda temporal da maré. As precárias condições de trabalho, com uso mínimo de equipamentos de proteção individual expõem essas trabalhadoras a riscos de acidentes e adoecimento no trabalho.

Porém, é possível afirmar que a mariscagem extrapola e recria os significados do trabalho, que vai além da necessidade de sobrevivência, possibilitando liberdade e prazer para as mulheres que dela vivem. As reflexões contidas nesse estudo permeiam horizontes extremos de mesmo cenário. De um lado o desamparo social que impõe às marisqueiras um estado constante de vulnerabilidades. Do outro, o amparo circunscrito na riqueza das tradições orais, na liberdade do ofício, no domínio dos meios de produção, em programas assistenciais como o PAS e a bolsa família, o que lhes permitem sair da linha tênue da extrema miséria às condições mínimas de sobrevivência.

As implicações desse estudo ao trabalho na maré ratificam a necessidade da compreensão sociocultural e valorização da tradição e do prazer na arte de mariscagem para proposição de medidas preventivas ao trabalho. Compreender o trabalho para transformá-lo faz-se necessário à medida que as intervenções de caráter preventivo na comunidade sejam condizentes com o habitus de vida e trabalho. (GUERIN et al., 2005) A imposição de práticas como pausas, alongamentos, exercícios não garantem a adoção destas pela comunidade, pois a maré não segue a lógica da ginástica laboral em uma empresa. As negociações de ações preventivas são articuladas em campo, em conjunto com elas, estabelecendo limites e possibilidades à sua realização.

Não buscamos discussões especulativas com relação ao fim da atividade pesqueira artesanal, pois inúmeras seriam as repercussões não apenas nas comunidades que dela vivem, mas também para as regiões que consomem o produto final de seu trabalho, o marisco. Assumir a 
discussão da pesca artesanal, em especial do trabalho exercido pelas mulheres na mariscagem, permitiu uma aproximação do trabalho na maré, não apenas com o olhar da avaliação biomecânica realizada pela Fisioterapia, mas extrapolando esse olhar sistemático para compreendê-lo em sua dimensão subjetiva e cultural. Um corpo forte, moldado pelo trabalho braçal, impregnado de lama do mangue, e por isso sujo e com odores, mas que tolera a dor no trabalho para continuar sobrevivendo dele.

As devolutivas do estudo seguem como prioridades na continuidade dos estudos desenvolvidos em comunidades pesqueiras, visando melhorias nas condições de vida e trabalho. Um importante passo foi dado no que concerne à compreensão do cenário da mariscagem na Ilha das Fontes. As proposições aqui levantadas emergiram nesse contexto e dessa forma, possibilitarão a ampliação de novos debates.

\section{Referências}

ALVES, P. C; SOUZA, I. M. Escolha e avaliação de tratamento para problemas de saúde: considerações sobre itinerários terapêuticos. In: RABELO, M. C; ALVES, P. C.; SOUZA, I. M. Experiência de doença e narrativa. Rio de Janeiro: Editora Fiocruz, 1999. p. 125-38.

ARNASON, R. General Profile. In: ILO - International Labors Organization. Encyclopedia of Occupational Health and Safety, 1998. Disponível em: <http://www.ilo.org/safework_bookshelf> Acesso em: 18 jan 2011

BAHIA Pesca. Boletim estatístico da pesca marítima e estuarina. Bahia: [s. n. ], 2005.

BECK, A. Pertence à mulher: mulher e trabalho em comunidades pesqueiras do litoral de Santa Catarina. Rio Grande do Norte, Natal: 1989. (Programa de pesquisa e conservação de áreas úmidas do Brasil, IOUSP - F. Ford - IUCN) Fórum de discussão sobre o universo social da mulher, a pesca e sua relação com a ecologia. [s. n].

BOLTANSKI, L. As classes sociais e o corpo. São Paulo: Paz e Terra, 2004. BOURDIEU, P. O poder simbólico. Lisboa: Difel, 1989.

BRASIL. Ministério da Pesca e Aquicultura Boletim Estatístico da Pesca e Aquicultura - Brasil 2008 - 2009, Brasília, 2011. 100 p.

CASTRO, J. de. Homens e caranguejos. Rio de Janeiro: Civilização Brasileira, 2001. 
CENTRO de Estudos e Pesquisas Josué de Castro. Trabalho da mulher pescadora em comunidades pesqueiras do litoral de Pernambuco: sistematização preliminar para correções/reformulações. In:

TALLER latino-americano sobre gênero e o trabalho da mulher em comunidades pesqueiras costeiras. Recife, maio 2000.

DIEGUES, A. C. S. Pescadores, Camponeses e Trabalhadores do Mar. São Paulo: Ática, 1983.

DIEGUES, A. C. S. A pesca construindo sociedades: leituras em antropologia marítima e pesqueira. São Paulo: Núcleo de Apoio à Pesquisa sobre Populações Humanas e Áreas Úmidas Brasileiras/USP, 2004.

FAO, Food and Agriculture Organization of the United Nations. The State of World Fisheries and Aquaculture. 2006.

GEERTZ, Clifford. A Interpretação das Culturas.

Rio de Janeiro: Guanabara Koogan, 1989.

GERBER, R. M. Temporalidade pesqueira e espaços feminino e masculino em Ganchos. In: RIAL C; GODIO, M. (Org. ) Pesca e turismo: etnografias da globalização no litoral do Atlântico Sul, Florianópolis: NUPPE/CFH/UFSC, 2006.

GUÉRIN, F. et al. Compreender o trabalho para transformá-lo: a prática da ergonomia. São Paulo: Edgard Blucher, 2001.

HALL, S. Notas sobre a desconstrução do popular. In: HALL, S. Da diáspora: identidades e mediações culturais. Belo Horizonte: Ed. UFMG, 2006.

IBAMA. Monitoramento da atividade pesqueira no litoral do Brasil - Projeto ESTATPESCA: relatório final. Convênio SEAP/IBAMA/ FROZZE nº109/2004, Brasília, 2006.

IUCN. Global Status of Mangrove Ecosystems. Commission on Ecology Papers. International Union for Conservation of Nature and Natural Resources, Gland, Switzerland. n. 3, 1983.

LAPLANTINE, F. Aprender Antropologia. São Paulo, Editora Brasiliense, 2003.

LE BRETON, D. A Sociologia do corpo. Petrópolis-RJ: Editora Vozes, 2007. Antropologia do corpo e modernidade.

Petrópolis-RJ: Editora Vozes, 2011.

LEITÃO, M. R. A. O Papel da mulher no desenvolvimento local. Recife: Editora FASA, 2009. 
LÉVI-STRAUSS, C. As estruturas elementares do parentesco. Petrópolis-RJ., Vozes: 1982.

MAUSS, M. Sociologia e antropologia. São Paulo: Cosac/Naify, 2003

MERLEAU-PONTY, M. Fenomenologia da percepção.

São Paulo: Martins Fontes, 1999.

OLIVEIRA, R. C. de. O Trabalho do antropólogo. Brasília/

São Paulo: Paralelo Quinze/Editora da Unesp, 1998.

PENA, P. G. L; FREITAS, C.; CADIM, A. Trabalho artesanal, cadências infernais e lesões por esforços repetitivos: estudo de caso em uma comunidade de mariscadeiras na Ilha de Maré, Bahia.

Ciência \& Saúde Coletiva, v. 16, n. 8, 2011, p. 3383-3392.

RAMAZZINI B. As doenças dos trabalhadores. São

Paulo: Fundacentro/Ministério do Trabalho, 1985.

RIAL, C. Revisitando a etnografia Mar-de-dentro: pesca, turismo e a transformação do espaço social. In: RIAL, C; GODIO, M.

(Org. ). Pesca e turismo: etnografias da globalização no litoral do Atlântico Sul. Florianópolis: NUPPE/CFH/UFSC, 2006.

RICOUER, P. O conflito das interpretações: ensaios de hermenêutica. Rio de Janeiro: Imago, 1978.

. Tempo e Narrativa. Campinas: Papirus. 1994.

SCHUTZ, A. O mundo das relações sociais. In: WAGNER, H. R. (Org. ). Fenomenologia e relações sociais: textos escolhidos de Alfred Schutz. Rio de Janeiro: Jorge Zahar, 1979.

VANNUCCI, M. Os manguezais e nós: uma síntese de percepção. São Paulo: Editora da Universidade de São Paulo, 1999.

ZOLA, É. Germinal. São Paulo: Abril Cultural, 1979. 


\section{Processo laboral e a saúde dos trabalhadores em centros de atenção psicossocial}

Maria de Fátima Prates Budde

Tânia Maria de Araújo

\section{Introdução}

Diversas mudanças, em diferentes âmbitos, vêm tornando cada vez mais complexo o cenário de práticas do campo da saúde mental no Brasil. Dentre os temas abordados pela IV Conferência Nacional de Saúde Mental Interdisciplinar, realizada em dezembro de 2010, destacam-se a: ampliação e difusão territorial dos novos serviços, com incremento do número de trabalhadores de saúde mental, em um contexto de terceirização e precarização do emprego, e com amplo contingente de trabalhadores com inserção recente nas atividades profissionais e no ativismo político do campo; a diversificação do movimento antimanicomial [...]; a presença e participação mais ativa e autônoma de usuários e familiares; a presença de diversas agências e atores políticos intersetoriais; as novas características do trabalho e de tecnologia em saúde mental no SUS, [...]; uma expansão de serviços públicos de saúde mental que não foi acompanhada por uma oferta e capacitação compatível de profissionais psiquiatras para o trabalho em saúde pública, gerando uma carência de profissionais em saúde mental.

Como ilustrado nos temas citados acima, as mudanças do modelo de atenção redefiniram os processos de trabalho, inauguraram novas exigências do trabalho e introduziram muitos, novos e complexos desafios.

A reestruturação do modelo de atenção em saúde mental no Brasil implicou novos modos de constituição dos serviços e, consequentemente, 
alterou a composição das equipes nos novos dispositivos de tratamento, em particular, dos Centros de Atenção Psicossocial (CAP). As mudanças no modo de constituição dos serviços produziram alterações no processo de trabalho existente (no objeto, nos instrumentos e nas próprias atividades), e, consequentemente, na composição das equipes. As alterações decorrentes do reordenamento dos serviços de saúde mental, por sua vez, geraram significativa modificação dos atributos técnicos requeridos dos diferentes profissionais que, a partir deste momento, tiveram que lidar com novas demandas e atribuições.

Os trabalhadores em saúde mental se deparam, ainda hoje, com o desafio de implantar e implementar um novo modelo de atenção. Considerando todas as interfaces que o trabalho da atenção psicossocial apresenta, espera-se que estes trabalhadores tenham os conhecimentos necessários para intervir em diferentes campos de atuação; na realidade os técnicos devem desdobrar-se em identidades e atribuições múltiplas, com o objetivo de atuar no centro de um território virtual e de uma rede de subjetividades de uma comunidade. Espera-se deste novo trabalhador que ele possa intermediar as mudanças sociais necessárias ao resgate dos direitos de cidadania enquanto promove a inclusão social de pessoas portadoras de transtornos mentais. Este técnico deverá dominar vários e complexos campos do conhecimento: técnico, social, ético, jurídico e político. (DELGADO, 1989; BRASIL, 2004; BICHAFF, 2006; LANCMAN, 2008)

Os novos serviços em saúde mental se propõem a lidar, na realidade, com novos recursos que, iniciando pela estrutura física dos serviços, passam pelos conhecimentos especializados das diferentes áreas profissionais e aplicação de novas técnicas (por exemplo, oficinas com diferentes finalidades, incluindo geração de renda). Nos Centros de Atenção Psicossocial, todos os agentes e todos os meios que vierem a ser utilizados, necessitam ser apreendidos para poderem ser coordenados com a finalidade de transformar o objeto de trabalho, o usuário, realizando, desta maneira, a proposta da reabilitação psicossocial. (MILHOMEN et al., 2007)

Observa-se, entretanto, que as novas equipes, ao assumirem a responsabilidade de implantarem o novo modelo preconizado de atenção em saúde mental, o fazem sem dispor, muitas vezes, de recursos técnicos e de formação e capacitação para fazê-lo adequadamente. (OLIVEIRA et 
al., 2003; BICHAFF, 2006; MILHOMEN et al., 2007; RABELO; COUTINHO, 2009)

Em virtude da importância que os CAPS adquiriram no processo de reestruturação da atenção em saúde mental, por sua expansão e difusão, pelo seu potencial em abarcar parcela significativa da população brasileira portadora de transtorno mental crônico e pelo contingente de trabalhadores envolvidos, procura-se neste estudo refletir sobre o trabalho desenvolvido nesses centros, utilizando como referência a teorização de Laurell e Noriega (1989) sobre processo de trabalho em saúde a partir do modelo de desgaste e nos conceitos teóricos sobre a relação prazer e sofrimento no trabalho. (DEJOURS, 2009)

Assim, este estudo tem como objetivos: descrever as características do processo de trabalho de profissionais em saúde mental e a percepção dos trabalhadores sobre as cargas laborais às quais estão submetidos; e identificar características dos diferentes tipos de cargas de trabalho e os riscos à saúde mental a que os trabalhadores estão expostos nos seus cotidianos de trabalho.

A pretensão deste estudo é ser mais uma peça na construção do arsenal desse novo modelo de assistência à saúde mental, particularmente, no que diz respeito às novas práticas desenvolvidas pelos trabalhadores nesses serviços e no fato de possibilitar uma melhor compreensão dos aspectos relacionados ao fator humano, fundamental na consolidação dos princípios da Reforma Psiquiátrica.

\section{Metodologia}

\section{Bases conceituais e teóricas adotadas}

Este estudo foi construído a partir das bases conceituais e metodológicas do modelo de desgaste de Laurell e Noriega (1989), ancorado no modelo operário italiano. Adotou-se também os conceitos teóricos sobre a relação prazer, sofrimento e trabalho propostos pela psicodinâmica do trabalho, na perspectiva da escola dejouriana. (DEJOURS, 2009)

O método de investigação utilizado para a pesquisa foi baseado nos princípios do Modelo Operário Italiano. (LAURELL; NORIEGA, 1989) 
Nesta abordagem, é proposto o uso de entrevistas coletivas com o objetivo de fazer um levantamento dos dados empíricos que permitam compreender as relações entre os processos de trabalho, a saúde física e psíquica, e o papel dos trabalhadores na construção do conhecimento e na transformação da realidade. O modelo possibilita ainda, aos trabalhadores, a reconstrução dos processos de trabalho, com identificação de danos e riscos, aos quais podem estar expostos. (FACCHINI et al., 1991)

Nesse modelo, nas investigações das relações entre trabalho e saúde, o foco é direcionado a duas categorias centrais de análise: "as cargas de trabalho" e os "processos de desgaste". $\mathrm{Na}$ análise do processo de trabalho, o conceito de "cargas de trabalho" busca ressaltar os elementos que interatuam dinamicamente entre si e o corpo do trabalhador, gerando processos de adaptação que se traduzem em desgaste. O conceito de carga tem como finalidade possibilitar uma análise do processo de trabalho que extrai e sintetiza os elementos que determinam de modo importante, o nexo biopsíquico da coletividade operária e confere a esta um modo histórico e específico de "andar a vida". (ARAÚJO, 2004)

O entendimento do "desgaste" como uma categoria integrada ao de "cargas de trabalho" permite introduzir no pensamento uma representação coerente do que são as transformações negativas originadas pela interação dinâmica das cargas nos processos biológicos e psíquicos humanos. O desgaste é definido como a perda de capacidade efetiva e/ ou potencial, biológica e psíquica, ou seja, não se refere a um processo particular isolado, mas sim ao conjunto dos processos biopsíquicos. (LAURELL; NORIEGA, 1989)

A relação entre processo de trabalho, cargas de trabalho e de desgaste, possibilita entender e predizer quais são os processos que consomem a força de trabalho ou desgastam as capacidades consideradas vitais para o trabalhador. Desta forma, à medida que se sabe que tipo de processo está presente num posto de trabalho, pode-se identificar quais são as principais cargas e os traços gerais do padrão de desgaste.

$\mathrm{Na}$ produção do conhecimento sobre os processos de trabalho em saúde mental e percepção de riscos a que estão submetidos os trabalhadores, foram utilizados os conceitos de cargas laborais propostos por Facchini (1993), Laurel e Noriega (1989) que incluem: a) cargas físicas; 
b) cargas químicas; c) cargas biológicas; c) cargas mecânicas; d) cargas fisiológicas; e) cargas psíquicas.

Em qualquer processo de trabalho podem ser encontrados estes tipos de cargas, com menor ou maior intensidade, que podem interagir entre si, potencializando ou somando-se no contexto individual e coletivo da vida dos trabalhadores.

Além do conceito de cargas de trabalho, proposto no modelo de desgaste, foram também utilizadas neste estudo as contribuições do modelo da psicodinâmica do trabalho.

O interesse maior da psicodinâmica é analisar o trabalho, seu conteúdo, sua significação e suas formas múltiplas de produção de sofrimento ou de prazer. (DEJOURS, 2009) Nesta abordagem, as relações que se estabelecem entre o trabalhador e o seu trabalho podem ser apreendidas por meio da compreensão dos procedimentos defensivos que ajudam os trabalhadores a resistir psiquicamente à agressão que compõe determinadas formas de organização do trabalho. Esse referencial subsidia a discussão de como os trabalhadores fazem para resistir às agressões ao seu funcionamento psíquico.

Na proposição da psicodinâmica do trabalho, o sofrimento implica um estado de luta do indivíduo contra as pressões ligadas à organização do trabalho. Por organização do trabalho entende-se a divisão do trabalho, isto é, a divisão de tarefas, os ritmos impostos e os prescritos, as hierarquias, repartições de responsabilidades e os sistemas de controle. (DEJOURS, 2009)

Dentre os conceitos utilizados nesta teoria destacam-se o do prazer no trabalho, de sofrimento criativo e de sofrimento patogênico. Através destes, pode-se entender as relações que se estabelecem entre a organização do trabalho e o sofrimento psíquico. A fala do trabalhador tem papel destacado nesse modelo - a análise da fala e dos silêncios dos trabalhadores permite compreender as formas subjetivas de estruturação da vida mental no trabalho: sua fonte de prazer e de sofrimento e os modos coletivos de vivência da vida no trabalho. (DEJOURS, 2009)

Nesta teoria, a linguagem pode ser mobilizada como expressão da dinâmica do reconhecimento dos problemas, como atividade semiótica que estrutura a realidade do trabalho e como intermediadora da ação. $\mathrm{Na}$ teoria dejouriana e no modelo de desgaste, o trabalhador é compreendido como o portador de uma história singular pré-existente e capaz 
de construir uma análise muito precisa da organização e das situações de trabalho. (COUTINHO NETO, 1998; DEJOURS, 2004)

\section{Local da pesquisa e sujeitos entrevistados}

Este estudo foi realizado no município de Salvador, capital do Estado da Bahia. Administrativamente, o município encontra-se dividido em 12 Distritos Sanitários. Em Salvador, estavam implantados, em 2010, 19 CAPS, sendo 18 municipais e um criado por uma Organização Não Governamental (ONG), distribuídos pelos distritos sanitários. Em seis Distritos Sanitários foram implantados mais de um CAPS, e esta decisão foi tomada após a observação de critérios técnicos tais como: alta concentração populacional, alto índice de população de baixa renda, de violência e "grotões" de miséria, região com concentração de turistas e de fácil aquisição de drogas, de dificuldade de acesso para outros serviços especializados, seja pela inexistência na proximidade ou pela considerável extensão territorial dos distritos. (MONTEIRO, 2007)

Inicialmente foram selecionados seis CAPS para a realização do estudo. Nas unidades escolhidas foram realizadas entrevistas coletivas com os trabalhadores em seus locais de trabalho.

Os critérios utilizados para a escolha das seis unidades foram: o tempo de credenciamento, composição multiprofissional das equipes, localização geográfica e a experiência reconhecida na área de saúde mental (trajetória de envolvimento com os novos modelos de atenção), pois, desta maneira, as equipes poderiam ter vivenciado a construção dos novos saberes e das novas práticas em saúde mental.

Os convites para a participação no estudo foram feitos, aos trabalhadores, nos próprios locais de trabalho, após uma campanha de sensibilização onde foi destacada a importância da participação e incorporação dos trabalhadores à pesquisa.

Ao todo, participaram das entrevistas 86 profissionais de saúde dos seis CAPS municipais incluídos na pesquisa.

Os CAPS selecionados estavam localizados nos Distritos Sanitários Barra/Rio Vermelho, Itapajipe, Cabula/Beiru, Boca do Rio e Centro Histórico; portanto, abrangiam áreas geográficas distintas, possibilitando avaliação de uma maior diversidade de situações. 


\section{Procedimentos do trabalho de campo}

Para a coleta de dados sobre o processo de trabalho em saúde mental e percepção de riscos, foram realizadas entrevistas semi-estruturadas conduzidas a partir de um roteiro previamente definido. O roteiro da entrevista abarcou quatro blocos de questões que incluíam:

1. Bloco I - Características da organização do trabalho;

2. Bloco II - Características do processo do trabalho;

3. Bloco III - Trabalho e saúde: exposição a riscos;

4. Bloco IV - Prazer e dor no trabalho cotidiano.

Como estratégia para delinear o percurso e permitir uma melhor aproximação com o objeto de estudo, as unidades foram visitadas para a apresentação da pesquisa e de seus objetivos, nas reuniões de equipe, por sugestão da própria equipe, considerando que este seria o único dia em que todos os profissionais se encontravam no local de trabalho.

As entrevistas tiveram uma duração média de uma hora e vinte minutos e foram gravadas com autorização prévia dos trabalhadores e transcritas posteriormente para a análise dos dados.

Os dados foram coletados nos meses de julho, agosto e setembro do ano de 2010.

\section{Análise dos dados}

A técnica da Análise de Conteúdo foi utilizada para a interpretação dos dados. Esta pode ser definida como um conjunto de instrumentos metodológicos, que visam obter, através de procedimentos sistemáticos e objetivos de descrição do conteúdo das mensagens, indicadores (quantitativos ou não) que permitam a inferência de conhecimentos relativos às condições de produção destas mensagens. (BARDIN, 2009) A análise de conteúdo é um processo de investigação utilizado para quantificar material qualitativo através de categorização e tabulação de dados obtidos em entrevistas, anúncios, recortes, propagandas, textos, documentos oficiais, discursos, dentre outros.

Minayo (2008) sintetiza o percurso do trabalho dos dados a partir da perspectiva da análise de conteúdo em três etapas. Na primeira etapa tem-se a pré-análise, que consiste na escolha dos documentos a serem analisados e na retomada dos pressupostos e dos objetivos iniciais 
da pesquisa. Deve-se indagar sobre as relações entre as etapas realizadas, elaborando indicadores que orientem a compreensão do material e a interpretação final. Esta pré-análise pode ser decomposta nas seguintes tarefas: leitura flutuante (o pesquisador toma contato direto e intenso com o material produzido); constituição dos Corpos (diz respeito ao universo estudado em sua totalidade e deve responder as seguintes normas de validade qualitativa: exaustividade, representatividade e homogeneidade); Formulação e reformulação dos pressupostos e objetivos (consiste na retomada da etapa exploratória, tendo como parâmetro a leitura exaustiva do material com base nas indagações iniciais). Nessa fase pré-analítica determinam-se a unidade de registro (palavra chave ou frase), a unidade de contexto (delimitação do contexto de compreensão da unidade de registro), os recortes, a forma de categorização, a modalidade de codificação e os conceitos teóricos mais gerais. Na segunda deve ser feita a exploração do material, que consiste numa operação classificatória que visa alcançar o núcleo de compreensão do texto e a busca de categorias pelo investigador. Na terceira etapa tem-se o tratamento dos resultados obtidos e interpretação.

A análise dos dados, feita neste estudo, seguiu os passos operacionais descritos por Minayo (2008), e permitiu o estabelecimento de relações entre as diferentes fontes, buscando articular o material empírico e o referencial teórico-metodológico adotado, na tentativa de obter respostas para os questionamentos e objetivos que nortearam este estudo.

Desse modo, a análise contemplou três etapas sintetizadas por Minayo (2008). Na primeira etapa foi feita a organização dos dados - primeiro contato com o material coletado. Na segunda etapa ocorreu a exploração do material - constituiu na exploração classificatória, visando à busca da compreensão do texto. Nesta fase realizou-se leitura flutuante, depois leitura exaustiva do material, sendo estabelecida a categorização. O critério eleito para obter o núcleo de compreensão do texto foi o de categoria temática, que foram obtidos dos temas utilizados nas entrevistas. Após a definição desses núcleos, os dados foram recortados, classificados e inseridos em seus respectivos núcleos. Os princípios da objetividade e da fidelidade foram observados para evitar as distorções que porventura surgissem. Na terceira etapa fezse o tratamento dos resultados obtidos e a interpretação - nesta etapa 
trabalhou-se na construção da síntese, na realização das interpretações, interrelacionando-as com o quadro teórico apresentado.

Para ordenamento e estruturação da análise buscou-se explorar os elementos/chave constantes no roteiro utilizado, organizando-se a análise com base na caracterização da organização e do processo de trabalho, percepção de riscos à saúde e elementos produtores de prazer e sofrimento no cotidiano laboral. Adicionalmente uma nova categoria analítica, pela importância registrada pelos trabalhadores, foi destacada e explorada na análise: a violência envolvida na cena de trabalho desses profissionais.

\section{Resultados e discussão}

\section{Característica do processo e da organização do trabalho}

O início de um dia de trabalho no CAPS começava quando as portas da unidade eram abertas e por elas passavam os usuários e os profissionais. Já na chegada os profissionais encontravam os usuários que chegavam muito cedo e uma demanda definida para atendimento.

Geralmente quando a gente chega aqui já é aguardado pelo usuário lá fora, né? Porque ele já vem demandando uma série de coisas do dia-a-dia, pergunta coisas referentes à medicação, das atividades que irá fazer. (COORDENADORA, CAPS 4 )

"[...] quando a gente chega, já começa a atender na porta, no portão já encontramos usuários demandando alguma coisa”. (PSICÓLOGO, CAPS 2)

O serviço encontrava-se organizado de modo que, normalmente, houvesse sempre um profissional de plantão - uma pessoa responsável pelo acolhimento, encaminhamento, e pelo apoio para as intercorrências e a recepção de familiares. Os serviços, a depender do local e da segurança, ficavam abertos das $8 \mathrm{~h}$ às $17 \mathrm{~h}$.

As tarefas diárias desenvolvidas pelos trabalhadores de CAPS eram compostas por oficinas terapêuticas e profissionalizantes, grupos terapêuticos, atendimentos individuais (psicoterapias, prescrição de medicamentos e orientações), visitas domiciliares, atendimento às famílias, 
trabalho comunitário de integração da rede, cuidados com a saúde física do usuário (marcação de consultas médicas e odontológicas), ações educativas de promoção do desenvolvimento da cidadania dos usuários e seus familiares, atividades externas de lazer, cumprimento de uma agenda com órgãos e instituições públicas, trabalho administrativo, atualização do prontuário, busca ativa, elaboração e acompanhamento do plano terapêutico individual, oficinas de geração de renda e assistência às Residências Terapêuticas ${ }^{1}$.

Havia a distribuição dos pacientes de referência pela coordenação e a determinação das prioridades era feita no acolhimento, onde se identificavam as necessidades dos usuários e, de acordo com as demandas, eram agendados os procedimentos e condutas a serem adotadas.

As assembleias com os usuários e reuniões de equipe aconteciam, em geral, semanalmente. Mensalmente os técnicos trabalhavam na confecção de Autorização para Procedimentos de Alta Complexidade (APACS) - que são formulários, que devem ser preenchidos pelos profissionais, para o registro do conjunto de procedimentos a que se refere à Portaria $n^{\circ}$ 189/02 e incluem: atendimento individual, atendimento em grupo, atendimento em oficinas terapêuticas, atendimento às famílias e atividades comunitárias.

A integração da equipe, em todas as entrevistas realizadas, foi descrita como boa pelos entrevistados; as divergências e os conflitos foram mencionados como desafios, uma forma de funcionamento baseada na discussão coletiva que elevava o crescimento profissional, conforme atestam os depoimentos dos trabalhadores: "O que eu acho enriquecedor é quando estamos discutindo casos aqui no CAPS, cada um dá sua opinião, cada um fala do seu olhar, isso enriquece muito e traz um grande aprendizado para a gente". (EDUCADOR FÍSICO, CAPS 3)

A interlocução para a divisão das tarefas era feita pela coordenação, geralmente nas reuniões de equipe. As tarefas eram direcionadas de acordo com a demanda e com o perfil e a especificidade profissional dos trabalhadores. As definições de papéis e de atribuições de cada

1 Os CAPS foram incorporados inicialmente como serviços estratégicos no Fundo de Ações Estratégicas e Compensações (FAEC) do Ministério da Saúde através das Portarias no 336/02 e $n^{\circ} 189 / 02$. Sendo assim, esses instrumentos normativos alteraram a fonte de financiamento dos CAPS e incluíram na Tabela SIA/SUS códigos para os grupos de procedimentos na área de saúde mental. Note-se que o valor de cada procedimento descrito na Portaria incluía todos os atos, atividades e materiais necessários à sua realização. (BRASIL, 2004) 
profissional neste novo modelo de atenção, no entanto, não estavam muito claras, o que gerava conflitos, mas podiam também estruturar possibilidades para o diálogo e para a construção de alternativas novas para o trabalho.

"Até há pouco tempo discutíamos o papel da enfermeira, seu lugar e as intervenções". (PSICÓLOGO, CAPS 5)

"Quando existem visões diferentes pode existir conflito, então, numa equipe multidisciplinar o desafio é grande, porque o modelo é novo e os conflitos aparecem, mas estes fazem com que a equipe cresça". (ENFERMEIRA, CAPS 1)

Desse modo, em todas as unidades estudadas, a organização do trabalho em saúde mental era, na percepção dos trabalhadores, a priori, concebido como um trabalho em equipe, estruturado a partir de definições coletivas estabelecidas em processos de discussão do grupo.

"[...] a ideia de uma equipe multiprofissional é boa, ela deve ter um vínculo de afetividade, companheirismo, de compreender a disponibilidade e especificidade de cada um, porque cada um é distinto". (MÉDICO, CAPS 1)

As definições que são estabelecidas nas reuniões das equipes de trabalho compõem a chamada grade de atividades ${ }^{2}$ cotidianas dos serviços. No entanto, concretamente, a realização das atividades diárias era estabelecida por situações diversas que demandavam atenção (nem sempre como previsto) e dependiam, também, do perfil da gestão e da coordenação dos serviços.

\section{O Ambiente de Trabalho}

A percepção dos trabalhadores sobre as cargas de trabalho evidenciou que os fatores mais relevantes para o desgaste sofrido estavam relacionados ao ambiente de trabalho, especialmente a infraestrutura física dos locais de trabalho (com destaque para as cargas físicas e biológicas).

2 Grade de atividades corresponde a um planejamento de atribuições e de responsabilidades pelas tarefas e ações em um dado período de tempo; incluem responsabilidade por casos de pacientes específicos e por atividades correlatas a cada trabalhador. É, portanto, um mapa de organização do trabalho de atenção à saúde mental em um período de tempo (atividades, responsável, tempo). 
As queixas registradas evidenciaram claramente a inadequação dos espaços utilizados para o serviço prestado. Dentre os problemas elencados, destacaram-se o calor intenso no verão, a falta de ventilação nas salas de trabalho de grupo, o barulho intenso oriundo da rua ou dos próprios usuários na unidade, umidade das paredes - o que facilitava a formação de fungos; falta de manutenção e higienização precária dos prédios e dos sanitários utilizados por todos. Portanto, constatou-se que os espaços físicos existentes não atendiam às necessidades dos serviços, sendo, em geral, construções alugadas que, para funcionar como um CAPS exigiam improvisações as mais variadas para que, minimamente, pudessem atender às demandas das atividades planejadas.

Outra dificuldade enfrentada pelos trabalhadores estava associada à falta de espaços reservados, nos quais, com uma determinada privacidade, fosse possível redigir as anotações nos prontuários, almoçar ou discutir algum caso sem serem interrompidos por algum usuário do serviço, como atestam os relatos dos profissionais: "A coordenação fez uma programação de ficar sempre um técnico de plantão, e ao meio dia, então, a gente queria ter um tempo também para poder descansar em paz [...]". (ASSISTENTE SOCIAL, CAPS 5) "Você está aqui escrevendo, aí o usuário abre a porta, em outro contexto você podia dizer, agora não, não interrompa, estou ocupado[...]”. (PSICÓLOGO, CAPS 5)

Afora as dificuldades de espaço e tempo para a necessária reflexão de cada caso atendido, cabe registrar a ausência de salas adequadas, reservadas, no qual seja possível estabelecer-se a possibilidade de acolhimento, de expressão de situações íntimas, muitas vezes dolorosas, sendo obstáculo muito significativo para o trabalho em saúde mental, pois impossibilita o mínimo da preservação da intimidade dos pacientes.

\section{As Cargas Laborais: as demandas excessivas em foco}

As atividades exercidas pelos trabalhadores de saúde mental tinham escopo amplo, com grande diversidade de atribuições e papéis, sendo um trabalho que exigia muito do trabalhador. As reclamações sobre as cargas laborais demonstraram que estes técnicos exerciam suas atividades sob alta pressão psicológica. As queixas mais frequentes foram de falta de tempo para realizar as atividades programadas, dificuldade no 
cumprimento da carga horária contratada, o fato da maioria dos trabalhadores cumprirem dupla ou tripla jornada de trabalho e exigência, por parte da gestão, para aumentarem o número de atendimentos.

"Você fica com a cabeça pesada porque tem de cumprir a carga horária em outro lugar". (TERAPEUTA OCUPACIONAL CAPS 2)

Essa responsabilidade, muitas vezes, era vivenciada com sofrimento pelos trabalhadores:

"Angústia, uma palavra angústia [...] exatamente porque a gente tem as atividades de grupo, as oficinas que a gente planeja e temos de dar conta de uma quantidade de usuários referências". (ASSISTENTE SOCIAL, CAPS 2)

"A gente vem para o CAPS pensando em poder realizar todas as atividades que supostamente estariam programadas. No dia a dia não conseguimos realizar por conta das outras demandas que vão surgindo". (ASSISTENTE SOCIAL, CAPS 3)

Os profissionais consideravam que as várias demandas ocasionavam uma sobrecarga na rotina, pois além do trabalho manual, burocrático, havia o trabalho mental de reflexão e de busca de solução para os problemas que surgiam. Além disto, foi observado, no discurso dos profissionais, que estes assumiam, muitas vezes, o trabalho que deveria ser feito pelas secretarias de ação social e outros órgãos no município.

Além das demandas excessivas, os profissionais chamaram a atenção para a contínua necessidade de vigília que precisavam manter. O fato da clientela de um CAPS ser formada, na sua maioria, por pacientes com transtornos mentais severos e persistentes, e que, às vezes, apresentavam um comportamento de difícil previsibilidade, que podia mudar repentinamente, exigia que a equipe ficasse o tempo inteiro em estado de alerta.

[...] convivemos com pacientes com alto poder de agressividade, então o risco é grande, já se pegou paciente aqui que agrediu, de agressão física, paciente chegar aqui, eh, armado de faca, paciente chegar aqui com pedaço de espelho guardado na bolsa, guardado na sacola porque agrediu alguém, um vizinho [...], então a área em que nós trabalhamos é uma área de alta periculosidade. (ASSISTENTE SOCIAL, CAPS 6)

Outro aspecto destacado nas entrevistas referiu-se às situações de intervenção que não estavam previstas e que demandavam atenção 
imediata da equipe, impossibilitando que as atividades planejadas fossem executadas. Essas situações conformavam as chamadas intercorrências. Tais situações, não raro, dificultavam a manutenção da rotina diária criada e discutida nas reuniões de equipe, e sinalizavam a constante necessidade de replanejamento das ações a serem executadas no cotidiano do serviço. A análise do processo de trabalho descrito, mesmo superficialmente, parece apontar para um ponto de tensão nesta direção.

[...] e outra coisa é a sua intervenção também. E você tem de se policiar e perguntar por que a clínica te envolve o tempo inteiro? Estar modulando essa autocrítica é que é o fator estressor [...] eu poderia dizer: agora não, estou ocupado [...], enfim se ele está com uma demanda, você tem de intervir, e esse tempo inteiro de clinica é um grande estressor. (PSICÓLOGO, CAPS 5)

Estas situações que exigiam uma atenção imediata sem prévio planejamento, estabeleciam, no dizer dos trabalhadores, um paradoxo, dificultando a continuidade das atividades de rotina, necessárias para o alcance dos bons resultados nas condutas terapêuticas estabelecidas (requisito importante no tratamento de pacientes com adoecimento psíquico). Desta forma, evidenciou-se que o trabalho em saúde mental guardava sempre uma necessidade latente, que podia ou não se revelar no dia de trabalho, devendo o profissional estar atento ao seu entorno e pronto para atuar segundo a exigência que for explicitada.

"A rotina é fundamental para os grupos e oficinas, mas tem outra rotina clínica que não tem rotina: são as intercorrências". (PSICÓLOGO, CAPS 5 )

"São dois paradoxos: devemos planejar todas as atividades como necessidade de organizar o serviço e, por outro lado, o trabalho em saúde mental é algo muito dinâmico, muito vivo". (PSICÓLOGA, CAPS 2)

No enfrentamento da tensão entre o planejado e o inusitado, mobilizador de toda a atenção e intervenção no trabalho diário, destacouse o processo de cooperação e ajuda mútua entre os trabalhadores nas unidades. No geral, havia uma relação pautada por elevada cooperação, todos os profissionais presentes, ajudavam a cuidar dos mais variados acontecimentos diários, que faziam parte da rotina destes serviços.

"Voltando à rotina, voltamos à discussão da urgência/emergência, o usuário pode chegar aqui em crise, aí temos que encaminhar para algum lugar, então alguém vai”. (PSICÓLOGO, CAPS 5) 
Entre as cargas psíquicas ou riscos capazes de provocar estresse ou tensão emocional destacou-se o fato de vários trabalhadores atribuírem à instabilidade dos vínculos trabalhistas como um dos fatores que mais repercutiam na saúde mental deles, conforme ilustra a fala de um profissional:

A instabilidade de vínculos é um fantasma constante... isso mexe com a autoestima [...] é uma coisa que magoa. Este é um fantasma constante na vida da gente, é você estar acreditando, gostar tanto e saber que a qualquer momento você não existe mais. (PSICOPEDAGOGA, CAPS 3)

A informalidade e incertezas sobre a situação no trabalho, assim como ausência de benefícios sociais e de proteção da legislação trabalhista são, segundo alguns autores, responsáveis pelo desenvolvimento de ansiedade e depressão nos trabalhadores. (SELIGMANN-SILVA, 1994; LUDEMIR, 2005)

Além das cargas psíquicas decorrentes da insegurança no trabalho, dos vínculos empregatícios instáveis, temporários, ganharam destaque também aquelas relativas ao tipo de trabalho realizado: o contato contínuo com o sofrimento psíquico de outras pessoas. Esse fator foi também mencionado como desencadeador de intenso sofrimento, elevando as exigências emocionais da ocupação.

"A gente lida muito com esse sofrimento do paciente, é um sofrimento que tem continuidade, que acompanha seu dia-a-dia". (PSICÓLOGO, CAPS 4)

O que pra mim é muito complicado, eu acho que é a coisa do desgaste emocional, eu tenho um atendimento que me mobiliza muito às vezes; enfim, porque, eu acho que é isso mesmo, me mobiliza muito. É um pai de um rapaz que era do CAPS ad, que tem um transtorno associado ao uso das drogas, e que bate no pai, O pai é um senhor que não sabe mais o que fazer, e no último atendimento eu disse: eu não sei mais o que fazer para ajudar o senhor! Ele me disse: eu sei, mas eu vim aqui conversar porque eu preciso dividir isso com alguém! É um peso muito grande, eu fico meio emocionada, é um peso. Pra mim é muito pesado, tem dias que chego em casa destruída emocionalmente! [...] de ver a mãe de A., que é uma mulher frágil, né? Cheia de ruguinhas [...]. (TERAPEUTA OCUPACIONAL, CAPS 1)

O convívio com o sofrimento é algo constante no CAPS. O cuidado cotidiano de pessoas portadoras de transtorno mental requer, da equipe de trabalhadores, intenso trabalho de acompanhamento da clientela, 
incluindo aspectos que vão da defesa dos direitos sociais à satisfação de necessidades básicas como a moradia e alimentação. Ou seja, em realidades como a brasileira, onde as desigualdades sociais fazem parte do labutar diário das pessoas, estar exposto diariamente a este sofrimento, às limitações concretas na execução do trabalho, tendo a suposta onipotência do profissional da saúde constantemente posta em cheque por contextos de precariedade em que não é possível resolver os problemas dos pacientes (nem mesmo aqueles cuja solução já é bem conhecida) pode causar sofrimento e frustração. O profissional de saúde, ao conviver com o sofrimento alheio, pode desencadear uma revivência de momentos de sofrimentos pessoais, pois conviver com o sofrimento pode gerar sofrimento. $\mathrm{O}$ trabalhador lida com gente, doente e sofrendo psiquicamente no cotidiano da clínica e, muitas vezes, frente a conflitos intensos dos pacientes e familiares. Desse modo, o temor de ser invadido por ansiedade intensa e incontrolada pode estar presente na própria natureza do trabalho. (PITTA, 2003; LAGO; CODO, 2010)

Outro aspecto que deve ser levado em consideração no trabalho desenvolvido no CAPS refere-se, dentre os ensinamentos sobre a clínica desenvolvida nestes novos dispositivos, ao "modo CAPS de operar o cuidado". Este modo e a noção de "clínica ampliada" ou "clínica da reforma" 3implica íntima relação do serviço, ou seja, do trabalhador com a comunidade e com o sofrimento psíquico apresentado pelo paciente. Essa estreita ligação é compreendida como elemento central na promoção das mudanças e evolução no quadro do paciente, com ênfase na noção de cuidado. (PITTA, 1996; LEAL et al., 2007; BOFF, 2008)

Essa relação de cuidado pode colocar em risco a saúde do trabalhador, no momento em que envolve proximidade (que pode gerar confusão e fusão com o outro), revelando que todos são humanos, podendo padecer dos mesmos males - o profissional de saúde mental se vê compelido a ouvir e suportar um conjunto de angústias, de conflitos, de obstáculos diante de cada ato, de cada pessoa com quem se defronta na prática.

3 Expressão encontrada em texto de Leal e colaboradores (2007) e Delgado (1989). Segundo esses autores, "clinica da reforma" se deve à palavra reforma, referindo-se a uma clinica da Reforma Psiquiátrica brasileira, observam também que a expressão "clinica da reforma" aparece como sinônimo das seguintes expressões: "clinica da atenção psicossocial", "clinica ampliada", "clinica do cotidiano". 


\section{Cargas sociais - exposição à violência}

A partir da reconstrução do processo de trabalho nos CAPS emergiu um novo tipo de exposição ocupacional que foi denominada de "carga social". Estas cargas estavam presentes no ambiente externo de trabalho, quando os trabalhadores dedicavam-se às intervenções fora do local de trabalho, na comunidade: o trabalho de matriciamento, de busca ativa e de visita à residência dos usuários.

As cargas advindas dessa nova exigência do trabalho se caracterizavam pela insegurança com relação à proteção, integridade física e psíquica dos trabalhadores, deflagrada por situações de vulnerabilidade e de violência, às quais estes trabalhadores encontravam-se expostos quando entravam em comunidades lideradas por pessoas envolvidas com o tráfico de drogas ou trabalhavam em unidades situadas em comunidades consideradas perigosas. Esta carga foi insistentemente trazida à discussão, sendo de extrema importância no relato dos trabalhadores, que a apontaram como situação de grande vulnerabilidade social às quais estavam expostos.

As tarefas que mais apresentam riscos são as intervenções externas, porque quando a galera sai pra fazer uma intervenção domiciliar, sai ela e ela munida dela, no nível dela e do colega do lado e do motorista, então a gente não tem nenhum mecanismo de defesa que não seja a gente sair correndo e gritar por socorro. (COORDENADORA, CAPS 1)

Segundo os profissionais, o nível de tensão causado pela insegurança nas imediações do local de trabalho é outro fator muito estressante. Os relatos evidenciaram que muitos profissionais foram ameaçados por moradores de rua que viviam nas imediações das unidades dos CAPS, além de se preocuparem em serem agredidos dentro da unidade:

É essa galera que fica aqui na sinaleira, pedindo dinheiro, que entra aqui e ameaça a gente, e depois a gente vai pegar o ônibus aí na frente onde eles estão. Outro dia uma colega saiu, o rapaz veio aqui ameaçar todo mundo e ela não teve coragem de sair pra trabalhar, ficou esperando o motorista chegar pra ir embora, então isso é estressante, isso é complicado pra qualidade do serviço. Eles, já jogaram "xixi” aqui, porque já tiveram dias em que a gente não tinha segurança e [...] porque a gente já tava tantos dias sem segurança, numa tensão tão grande que ficamos, eu e uma colega, aqui na porta, entrincheiradas pra vigiar, e qualquer pessoa que entrasse a gente gritasse. Já teve a situação de estarmos sem segurança e as meninas estarem aqui na sala e 
entrar uma pessoa que não é do CAPS e se trancar aqui. Então, assim, isso é estressante, não é o usuário, não é o nosso usuário. (TERAPEUTA OCUPACIONAL, CAPS 1)

[...] risco, existe. Aqui a gente já teve problema no momento em que eu fui tentar conter um usuário e eu tava sozinha, eu tava errada porque fui tentar fazer sozinha e me machuquei, ele me machucou, não foi intencionalmente "vou te machucar", mas, e aí? No momento em que eu tentei segurar ele pra que ele não saísse daquele jeito, ele saiu me arrastando e me machucou, mas não foi nada grave, mas é, acontece. (TERAPEUTA OCUPACIONAL, CAPS 1)

A vida do profissional que vive na comunidade onde trabalhava, elevava ainda mais a percepção de risco e de insegurança:

Eu falo enquanto profissional e moradora da região, desta comunidade. Hoje eu me deparo com situações de uso de drogas e questionar com o usuário, lidar com a situação [...] questionar sobre o tráfico e me lembrar que estou na comunidade [...] Hoje em dia eu me questiono: meu filho de três anos estuda aqui próximo ao CAPS, eu deixo ele na escola e venho para o CAPS andando. E aí os usuários podem saber onde moro, onde meu filho estuda e como é isso em outras situações sociais? (ASSISTENTE SOCIAL, CAPS 2)

As questões de violência, portanto, apareceram como uma carga de significativa magnitude entre os trabalhadores e ocorrem de diferentes fontes:

1. Da população excluída socialmente que circula em torno dos locais de trabalho;

2. Dos usuários dos serviços que podem ficar violentos em algumas situações;

3. Das comunidades em que os serviços estão inseridos, muitas vezes dominadas pelo tráfico de drogas.

Esta violência vivenciada pelos trabalhadores dos CAPS, na maioria das vezes ocultada pela falta de sinais e sintomas característicos de uma situação típica de violência, não é reconhecida. Estudos apontam que a exposição prolongada a essas condições pode gerar situações duradouras de perda de iniciativa e de passividade, por vezes, patogênicas e prejudiciais tanto para o trabalhador, quanto para as instituições, sobretudo, quando a eficácia do trabalho requer um engajamento ativo deste. Portanto, quando os trabalhadores de saúde mental, "munidos deles mesmos" (como eles próprios referem) saíam para o trabalho externo, 
conviviam frequentemente com comunidades consideradas de risco, sem contar com os aparatos de proteção necessários. Eles se utilizavam das experiências passadas para constituir maneiras próprias de lidar com a situação e, assim, enfrentar os conflitos cotidianos, ou se sentiam socialmente vulneráveis, o que, por sua vez, desencadeava sofrimento psiquico. (FRANCO, 2004; LANCMAN et al., 2007; DEJOURS, 2009)

\section{Os problemas de saúde}

Uma queixa recorrente foi a de infecção constante por escabiose. Os profissionais relataram que não usavam luvas descartáveis durante os momentos de contato físico com os pacientes e que isto acabava sendo fonte de contínuas infecções e problemas de pele para os trabalhadores. Apontaram ainda que, embora esse fosse um assunto delicado, era uma realidade que a gestão precisava considerar e buscar soluções para equacionar o problema, especialmente porque parecia espelhar um paradigma de que o doente mental não sofre de outras enfermidades clínicas. Apenas considerar que era preconceituoso o uso de luvas para o contato com os pacientes, ou o seu inverso, negar que havia um problema concreto envolvido, eram posicionamentos que negavam a ideia de que o paciente fosse visto em suas várias dimensões (corpo e mente).

Dentre as queixas referentes à própria saúde ganharam destaque os relatos de nervosismo, insônia, sintomas depressivos e hipertensão arterial. Dados da literatura apontam que grande parte das reações adversas à saúde ocorre quando a demanda do trabalho é alta e o grau de controle do trabalhador sobre o trabalho é baixo. (ARAÚJO; CERQUEIRA; ARAÚJO, 2003) Estudos brasileiros com profissionais de saúde mental como os de Nogueira-Martins (2002), De Marco e colaboradores (2008) e de outras categorias profissionais do setor de serviços como Fernandes e colaboradores (2002), Araújo e colaboradores (2003), Reis e colaboradores (2005), Montanhol, Tavares e Oliveira (2006), Tomasi e colaboradores (2008) e Schmidt e colaboradores (2009), encontraram resultados coerentes com essa hipótese de que situações envolvendo elevadas demandas e baixo controle são nocivas à saúde física e mental. 
Outra queixa relevante foram as infecções urinárias, comumente relacionadas às restrições de tempo, de cadência da organização do trabalho (ritmos acelerados) ou de condições inadequadas do ambiente laboral (instalações com precária higienização).

"Eu mesma quando estou aqui trabalhando, não vou ao banheiro, então eu saio daqui meio dia para chegar em outro lugar, apertada". (ENFERMEIRA, CAPS 2)

Foi relatado que as condições higiênicas nos banheiros não eram adequadas, o que fazia com que muitos dos técnicos evitassem o uso dos mesmos ou não bebessem água durante a estadia no serviço.

Os trabalhadores referiram ocorrência de dores de cabeça constantes e as relacionavam com a tensão permanente no serviço. Segundo relatos, nos últimos meses que antecederam a coleta de dados, haviam sido nomeados novos gerentes dos serviços e estes, por sua vez, tinham pouca ou nenhuma experiência em gestão de serviços de saúde mental. Esses novos gestores conduziam o trabalho em moldes verticalizados, marcado por posições autoritárias, nas quais as sugestões dos profissionais não eram aceitas, inibindo, assim, qualquer ação nova do trabalhador, o que gerava tensões relevantes.

Como consequência, observou-se, que em alguns CAPS, houve uma desestruturação das equipes em decorrência das mudanças na forma de conduzir a política de saúde mental, trazendo incoerência e contradições entre os saberes, práticas dos trabalhadores e o modelo de gestão adotado, como se pode observar nas falas dos trabalhadores:

[...] eu tive problemas com a direção porque atendi individualmente um paciente. Eu coloquei isso no relatório e fui chamada pelo gerente que me disse que meu relatório estava errado! Ele disse que em CAPS só podemos fazer atendimento grupal. (ASSISTENTE SOCIAL, CAPS 2)

[...] acontece que os chefes não têm visão e ficam querendo cobrar apenas o horário. (FISIOTERAPEUTA, CAPS 2)

A gestão do trabalho aparece como um elemento ordenador do fazer em saúde mental, ficando evidente o grau de dependência da aderência ou não do gestor às práticas inovadoras defendidas pelo novo modelo. Portanto, uma nova fragilidade se revelou na cena do trabalho: o modelo avançará mais ou menos a depender da correlação de forças que estava estabelecida em cada local de trabalho. Nesse ponto, a ca- 
pacidade de cooperação e de coesão das equipes de trabalho exerce papel central. Quanto mais integrada for a equipe, menos vulnerável será o processo de implantação do novo modelo. No entanto, a existência de vínculos laborais frágeis, temporários, despontou como obstáculo maior nas possibilidades de coesão das equipes. Assim, este dilema aparece como um desafio marcante a ser enfrentado.

As informações obtidas a respeito da percepção dos trabalhadores com referência a relação entre saúde e trabalho nas unidades, permitiram identificar que esta era percebida como precária, e até mesmo de vulnerabilidade. Segundo estes trabalhadores, havia falta de interesse dos gestores em tomar conhecimento sobre suas reais condições de trabalho.

[...] na verdade, esta administração nunca veio aqui pra procurar ver a situação do CAPS, do atendimento, das nossas necessidades, como a gente está se sentindo nesse lugar que a gente foi colocado". (ASSISTENTE SOCIAL, CAPS 4)

No discurso dos trabalhadores emergiu a queixa sobre a invisibilidade do profissional/técnico. Observou-se, contudo, que não era propriamente o técnico de saúde mental que era invisível, mas sim o seu trabalho, que se tornava invisível para os gestores, na medida em que não era materializado em produtos concretos, palpáveis. Ou seja, boa parte do trabalho realizado não era passível de ser mensurado em procedimentos; portanto, não era contabilizada nas planilhas de serviços executados - conforme exigência dos órgãos competentes. Essa porção imaterial do trabalho, embora essencial para a atenção em saúde mental, mantinha-se invisível, não contabilizada. (LANCMAN, 2008) Assim, o trabalho real, executado cotidianamente, era invisível aos gestores, porque não resultava em indicadores de produtividade ou de qualidade compatíveis com o processo de produção, nem com o valor do serviço realizado. Essa lógica de avaliação do trabalho conformava situações de sofrimento e inadequação nos trabalhadores: o necessário para o bom desempenho no trabalho chocava-se com os indicadores de valorização adotados pela gestão, colocando em risco o reconhecimento das etapas e dos recursos necessários à operacionalização do trabalho em saúde mental.

A dinâmica do reconhecimento pode acontecer de duas maneiras: a primeira é denominada de reconhecimento de utilidade, sendo realizada 
pelos níveis hierárquicos superiores e pelo usuário do serviço ofertado; a segunda é denominada de julgamento estético, realizada pelos colegas de trabalho, por aqueles que conhecem a especificidade do trabalho e podem avaliar o esforço despendido pelo trabalhador em realizá-lo. A ausência ou dificuldades desses processos de reconhecimento podem acarretar falhas no desenvolvimento da identidade do indivíduo e nas possibilidades de transformação do sofrimento gerado pelo trabalho em prazer. (FRANCO, 2004; LANCMAN, 2008; DEJOURS et al., 2009)

A falta de suporte psicológico estabeleceu-se como fator capaz de desagregar a saúde mental dos trabalhadores:

"Nós precisamos de suporte. Eu tenho meu suporte psicanalítico, que eu acho que se não fosse isso, eu não ia conseguir". (TERAPEUTA OCUPACIONAL, CAPS 2)

Nós já tivemos supervisão clínico-institucional, foi um período que ajudou bastante o grupo. Na época, trazíamos as angústias do cotidiano e aí de alguma forma a supervisão nos dava um suporte! A supervisão é o instrumento! (PSICÓLOGA, CAPS 2)

Diante dos discursos dos trabalhadores pode-se concluir que o momento é de muita dificuldade institucional, aparentemente resultado da ausência de medidas de apoio para as equipes de trabalhadores. Desde 2004, em São Paulo, no I Congresso Brasileiro de CAPS, já havia incentivos para projetos de Supervisão Clínico-Institucional de CAPS. No entanto, como mostram nossos dados, as situações em que se contava com esse apoio ainda era exceção.

\section{Potencialidade e limites dos processos de trabalho em saúde mental}

$\mathrm{Na}$ avaliação sobre as potencialidades e os limites do trabalho nos CAPS, os profissionais relataram que a reconstrução psíquica dos pacientes e o reconhecimento recebido da família e do usuário constituíam as maiores fontes de prazer na realização do trabalho. No discurso dos trabalhadores, o fato de poder oferecer bom atendimento e de poder ajudar o paciente ou a sua família a melhorar suas condições de saúde e de vida eram fatores que proporcionavam muito prazer no trabalho. 
Teve ocasião em que eu chorei mesmo! Porque a gente está fragilizada e às vezes embola tudo, não é que você vai se envolver com as questões do paciente, mas você sai mexida mesmo e não consegue manter a neutralidade o tempo todo! (PSICÓLOGO, CAPS 4)

A necessidade de formação e qualificação dos trabalhadores foi pautada em todas as entrevistas. Os trabalhadores fizeram referência à necessidade de capacitação de recursos humanos, como uma forma de se adequarem para o enfrentamento das novas estratégias em saúde mental.

“[...] assim, aprendi que somos técnicos em saúde mental, aí temos um nome, que bom! Senão seria uma coisa assim, todo mundo faz tudo. (ENFERMEIRA, CAPS 3)

A princípio, para quem nunca trabalhou neste sistema, é meio que desorganizador, porque a gente fica meio perdida, meio confusa. Mesmo porque não há uma preparação anterior. Não tem capacitação. A gente vai se capacitando e contando com a boa vontade de quem já está ali, né? Eu acho que é um perigo e ao mesmo tempo exige destes profissionais um dinamismo, um interesse, é uma faca de dois gumes [...] eu acho que, quem trabalha em CAPS está preparado para trabalhar em qualquer lugar. (ENFERMEIRA CAPS 3)

Estes resultados estão em concordância com estudos realizados no Brasil sobre a formação específica de trabalhadores em saúde mental. Segundo as pesquisas, a ausência ou insuficiência na formação para a atuação em saúde mental, sobre novo paradigma, tem sido destacada como obstáculo às mudanças preconizadas. (OLIVEIRA et al., 2003; BISCHAF, 2006)

Uma estratégia encontrada para o enfrentamento da falta de formação e capacitação continuada foi, segundo os trabalhadores, a troca de informações e textos.

"Eu acho que tem um longo caminho ainda. Falta muita coisa a nível de rede, a nível de informação, entendeu? A própria capacitação dos profissionais que trabalham, pois capacitados eles levam junto o CAPS". (ASSISTENTE SOCIAL, CAPS 6)

"[...]nós procuramos nos especializar, ler e nos informar". (EDUCADOR FÍSICO, CAPS 4)

Os trabalhadores se organizavam para que, nas reuniões de equipe, algum tempo pudesse ser disponibilizado para a discussão de textos técnicos. Deve-se pontuar que desde a II Conferência Nacional de 
Saúde Mental, realizada em dezembro de 1992, se enfatiza a necessidade de garantir práticas de ensino, pesquisa e extensão que poderiam favorecer "novas atitudes dos futuros profissionais em relação à doença mental e que estimulem o desenvolvimento do potencial dos indivíduos com sofrimento psíquico"; No entanto, em Salvador, as capacitações foram feitas de forma pontual e não atingiram a todos os trabalhadores dos CAPS, como mencionado pelos trabalhadores.

\section{Considerações finais}

A descrição dos processos de trabalho de um setor laborativo ou a avaliação do trabalho de uma categoria profissional implica sempre no temor de não conseguir englobar os aspectos envolvidos no trabalho em sua totalidade.

A análise das cargas de trabalho evidenciou que os fatores mais relevantes para o desgaste dos trabalhadores estavam relacionados à inadequação dos espaços utilizados, especialmente a infraestrutura física dos locais de trabalho, às cargas psíquicas, entre essas a insegurança no trabalho. Este último elemento incluiu dois tipos de insegurança: um relacionado ao tipo de vínculo empregatício, ocasionada por contratos de trabalho temporários; e a insegurança com relação à proteção e integridade física e psíquica dos trabalhadores, deflagrada por situações de vulnerabilidade e de violência.

Nesta investigação, partiu-se do pressuposto de que, mesmo com quase uma década de discussão e trabalho, os desafios continuam sendo muitos, envolvendo diferentes dimensões.

Segundo Dejours e colaboradores (2009), o trabalho deve ser entendido como um continuum que se estende para além de seu espaço restrito e influencia outras esferas da vida. As relações que ocorrem no trabalho constituem uma grande fonte de desenvolvimento da identidade do indivíduo e da transformação do sofrimento em prazer, por meio dos vários processos de reconhecimento. Quando o reconhecimento do seu fazer não ocorre, a desvalorização pode atingir outros espaços da vida cotidiana, portanto, o compromisso com os trabalhadores é fundamental para a manutenção desses serviços e, por conseguinte, é necessário por parte dos gestores, manter a motivação desses, 
reconhecendo-os como os principais agentes das práticas e políticas de saúde mental.

Observou-se que, como o trabalho em saúde mental pode ser desestabilizador, é necessário que se criem espaços de trocas, que funcionem como ponto de apoio para as equipes e que fortaleçam as estratégias de cooperação; sendo neste caso a supervisão de equipes de suma importância para a saúde mental dos trabalhadores.

Não obstante, devem ser mencionadas as dificuldades administrativas e financeiras para a operacionalização destas modificações, considerando o atual cenário político nacional, onde se preconiza atualmente o corte de verbas para a saúde mental, pressionando estados e municípios a trabalharem com verbas mínimas neste setor. (BICHAFF, 2006)

Finalmente, destacou-se que se faz necessário, assim como preconiza a política de saúde mental, que os trabalhadores possam contar com uma política de recursos humanos e gestão do trabalho que contemple a democratização das relações de trabalho e das discussões em todos os níveis de gestão, que haja condições de melhoria dos processos de trabalho, que se incorpore a questão da segurança do trabalhador, a saúde e saúde mental, que seja institucionalizada a supervisão clínica e institucional, que a jornada de trabalho seja adequada para todos os profissionais, assim como a isonomia salarial entre eles, e que, desta forma, se combata a precarização das relações de trabalho existentes atualmente.

\section{Referências}

ARAÚJO, T. M. CERQUEIRA, C. G.; ARAÚJO, E. M. Estresse ocupacional e saúde: contribuições do modelo demanda-controle.

Ciências e Saúde Coletiva, v. 8, n. 4, p. 991-1003, 2003.

ARAÚJO, T. M. O olhar do sujeito sobre o trabalho que executa: sua percepção sobre os riscos e as tarefas. In: SAMPAIO, J. R. (Org.). Qualidade de vida, saúde mental e psicologia social - Estudos Contemporâneos II. São Paulo: CASA DO PSICÓLOGO, 2004.

BARDIN, L. Análise de conteúdo. Lisboa: Edições 70, LDA, 2009.

BICHAFF, R. O trabalho nos centros de atenção psicossocial: uma reflexão crítica das práticas e suas contribuições para a consolidação da reforma psiquiátrica. 2006, 217f. Dissertação 
(Mestrado em Enfermagem Psiquiátrica). Escola de Enfermagem, Universidade de São Paulo, São Paulo, 2006.

BRASIL. MINISTÉRIO DA SAÚDE. Secretaria de Atenção à Saúde. Departamento de Ações Programáticas. Saúde Mental no SUS:

Os Centros de Atenção Psicossocial. Brasília: Ministério da Saúde, 2004.

BOFF, L. Saber cuidar - ética do humano - compaixão

pela terra. 15. ed. Rio de Janeiro: Vozes, 2008.

COUTINHO NETO, O. B. Estudo sobre cargas de trabalho e processo de desgaste das auxiliares de enfermagem em um hospital universitário de Pernambuco. 1998. 60f. Dissertação (Mestrado em Saúde Coletiva). CPQAM, FIOCRUZ - Departamento de Saúde Coletiva/NESC, Recife, 1998.

DE MARCO, P. F. et al. O impacto do trabalho em saúde mental: transtornos psiquiátricos menores, qualidade de vida e satisfação profissional. Jornal Brasileiro de Psiquiatria, São Paulo, v. 57, n. 3, p. 178-183, 2008.

DEJOURS, C. et al. Psicodinâmica do trabalho. São Paulo: Atlas, 2009.

DELGADO, P. Projeto de Lei nº 367/89. Brasília, 1989.

FACCHINI, L. A. et al. Modelo operário e percepção de riscos ocupacionais e ambientais: o uso exemplar de estudo descritivo. Revista de Saúde Pública, v. 25, n. 5, p. 394-400, 1991. . Uma contribuição da Epidemiologia: o modelo da determinação social aplicado à saúde do trabalhador. In: ROCHA, Lys Esther et al. (org. ) Isto é trabalho de gente? Vida, Doença e Trabalho no Brasil. São Paulo: Vozes, 1993.

FERNANDES, R. C. P. et al. Trabalho e cárcere: um estudo com agentes penitenciários da Região Metropolitana de Salvador, Brasil. Caderno de Saúde Pública, v. 18, n. 3, p. 807-816, 2002.

FRANCO, T. A centralidade do trabalho na visão da psicodinâmica de Dejours. Caderno CRH, v. 17, n. 41, p. 309-321, 2004.

LAGO, K.; CODO, W. Fadiga por compaixão: o sofrimento dos profissionais de saúde. Petrópolis-RJ. : Vozes, 2010.

LANCMAN, S. et al. O trabalho na rua e a exposição à violência no trabalho: um estudo com agentes de trânsito. Interface Comunicação, Saude, Educação, v. 11, n. 21, p. 79-92, 2007. . (Org. ). Políticas públicas e processos de trabalho em saúde mental. Brasília: Paralelo 15, 2008. 
LAURELL, A. C.; NORIEGA, M. Para o estudo da saúde na sua relação com o processo de trabalho. In: Processo de produção e saúde. Trabalho e desgaste operário. São Paulo: Hucitec, 1989.

LEAL, E. M. et al. Clínica e cotidiano: o CAPS como dispositivo de desinstitucionalização. In: PINHEIRO, R. et al. Desinstitucionalização da saúde mental: contribuições para estudos avaliativos. CEPESCIMS/UERJ-ABRASCO. Rio de Janeiro, p. 137-158, 284, 2007.

LUDEMIR, A. B. Associação dos TMC com a informalidade das relações de trabalho. Jornal Brasileiro de Psiquiatria, v. 54, n. 3, p. 198-204, 2005.

MILHOMEN, M. A. G. C. et al. , O trabalho em equipe nos Centros de Atenção Psicossocial - CAPS. Cogitare Enfermagem, v. 12, n. 1, p. 101-108, 2007.

MINAYO, M. C. O desafio do conhecimento: pesquisa qualitativa em saúde. São Paulo: Hucitec, 2008.

MONTANHOLI, L. L.; TAVARES, D. M. S.; OLIVEIRA, G. R. Estresse: fatores de risco no trabalho do enfermeiro hospitalar. Revista Brasileira de Enfermagem, v. 59, n. 5, p. 661-665, 2006.

MONTEIRO, D. A. A função dos ambulatórios de psiquiatria no processo de construção da reforma psiquiátrica, nos SUS, em Salvador. Projeto de qualificação. Instituto de Saúde Coletiva, Universidade Federal da Bahia, 2007.

NOGUEIRA-MARTINS, M. C. F. A experiência de supervisão de hospitais em um Programa de Humanização. In: CONGRESSO Brasileiro de Psicologia Ciência e profissão, I. Anais... São Paulo, 2002.

OLIVEIRA, A. G. B. et al. A reforma psiquiátrica e o processo de trabalho das equipes de saúde mental. Revista Paulista de Enfermagem, v. 22, p. 31-42, 2003.

PEDUZZI, M. Trabalho em equipe de saúde da perspectiva de gerentes de serviços de saúde: possibilidades da prática comunicativa orientada pelas necessidades de saúde dos usuários e da população. 2007, 247f. Tese (Doutorado em enfermagem) Escola de Enfermagem, Universidade de São Paulo, USP, 2007.

PITTA, A. M. F. Reabilitação psicossocial no

Brasil. São Paulo: Hucitec, 1996. . Hospital: dor e morte como ofício. 5. ed. São Paulo: Hucitec, 2003. RABELO, A; COUTINHO, D. M. Análise da Saúde Mental no Estado da Bahia. Gazeta Médica da Bahia, v. 78, n. 2, p. 104-119, 2009. 
RAMMINGER, T. Trabalhadores de saúde mental: reforma psiquiátrica, saúde do trabalhador e modos de subjetivação nos serviços de saúde mental, 2005. 118f. Dissertação (Mestrado em psicologia) Instituto de Psicologia, Universidade Federal do Rio Grande do Sul, Porto Alegre, 2005.

REIS, E. J. F. B. et al. Trabalho e distúrbios psíquicos em professores da rede municipal de Vitória da Conquista, Bahia, Brasil. Cadernos de Saúde Pública, v. 21, n. 5, p. 1480-1490, 2005.

SELIGMANN-SILVA, E. Desgaste Mental do Trabalho. São Paulo: Cortez Editora. 1994.

SCHMIDT, D. R. C. et al. Estresse ocupacional entre profissionais de enfermagem do bloco cirúrgico. Texto \& Contexto Enfermagem, Florianópolis, v. 18, n. 2, p. 330-337, jun. 2009.

TOMASI, E. et al. Perfil sociodemográfico e epidemiológico dos trabalhadores da atenção básica à saúde nas regiões Sul e Nordeste do Brasil. Caderno de Saúde Pública, v. 24, p. 193-201, 2008.

YASUI, S. CAPS: estratégia de produção de cuidado e de bons encontros. In: PINHEIRO, R. et al. Desinstitucionalização da saúde mental: contribuições para estudos avaliativos. 1 ed., CEPESC-IMS/UERJ-ABRASCO. Rio de Janeiro, 2007. 


\section{Sintomas vocais e absenteísmo em teleoperadores sindicalizados}

Flávia Silva Santa Mônica

Maria Lúcia Vaz Masson

Tânia Maria de Araújo

\section{Introdução}

A voz vem sendo empregada, cada vez mais, como um importante instrumento de trabalho. Além dos profissionais mais tradicionais no uso da voz profissional (professores, atores e cantores), mudanças no mundo do trabalho nas últimas décadas têm feito surgir novas ocupações que utilizam a voz como principal ferramenta de trabalho. As várias modalidades de atendimento ao cliente no mercado competitivo das empresas configuram-se em uma dessas novas ocupações do mundo contemporâneo.

$\mathrm{O}$ avanço das tecnologias de telecomunicações ampliou as ferramentas de marketing criando, assim, uma nova categoria de trabalhadores: os teleoperadores ou teleatendentes. Estes profissionais atuam em centrais de teleatendimento, chamadas de call centers. Nesse contexto, a voz do teleoperador representa o elo entre consumidor e fornecedor.

Apesar do crescimento exponencial do teleatendimento com base em amplas possibilidades de seu uso no moderno mercado de trabalho, não se observou, na mesma velocidade, a incorporação de medidas de proteção aos trabalhadores. Assim, os processos de adoecimento têm sido frequentes nesse grupo, especialmente com relação aos agravos à saúde vocal. (JONES et al., 2002; LETHO et al., 2005; RECHENBERG, 2005; CEREST-SP, 2006; FERREIRA et al., 2008b; FERREIRA; SANTOS; LIMA, 2009; OLIVEIRA; BEHLAU; COUVEIA, 2009; CHRISTMANN et al., 2010; PIWOWARCZYK et al., 2010; RECHENBERG; 
GOULART; ROITHMANN, 2011; DASSIE-LEITE; LOURENÇO; BEHLAU, 2011). A ausência ao trabalho (absenteísmo) pode ser um indicativo importante dos processos de adoecimento em curso nesse grupo ocupacional.

Este capítulo busca descrever os agravos à saúde vocal, incluindo dados sobre absenteísmo, observados em teleoperadores que procuraram atendimento no Sindicato dos Trabalhadores em Telecomunicações da Bahia (SINTTEL-BA). Objetiva descrever a frequência de sintomas vocais, absenteísmo por problemas vocais e possíveis causas relacionadas à ausência ao trabalho, referidas por esses trabalhadores. Ademais, o estudo se propõe a refletir sobre os aspectos nocivos à saúde vocal, relacionados aos fatores ambientais e organizacionais do trabalho, que interferem na qualidade da saúde e da vida dos trabalhadores.

Além do estudo empírico, que permitirá avaliar uma situação concreta de trabalho em teleatendimento e os agravos vocais, serão também discutidos aspectos conceituais essenciais para a compreensão do campo de estudo apresentado. Desta forma, serão abordados aspectos relacionados ao setor de teleatendimento, à voz profissional, ao distúrbio de voz relacionado ao trabalho e ao absenteísmo por problemas de saúde.

\section{Serviços de teleatendimento/telemarketing}

Entende-se como trabalho de teleatendimento/telemarketing aquele cuja comunicação com interlocutores clientes e usuários é realizada à distância por intermédio da voz e/ou mensagens eletrônicas, com a utilização simultânea de equipamentos de audição/escuta e fala telefônica e sistemas informatizados ou manuais de processamento de dados. O call center é o principal ambiente de trabalho, no qual essa atividade é conduzida via telefone com utilização simultânea de terminais de computador. (BRASIL, 2007)

Segundo o Código Brasileiro de Ocupações, o profissional que lida diretamente com o cliente via teleatendimento é denominado "atendente", "operador de telemarketing" ou "teleoperador". Tais profissionais exercem as funções de atendimento ao cliente, oferecem serviços e produtos, prestam serviços técnicos especializados, realizam pesquisas e fazem serviços de cobrança e cadastramento. (BRASIL, 2012) 
De acordo com a Associação Brasileira de Telesserviços, no Brasil, o principal contratante de call center é o setor de serviços financeiros, seguido pelo de comércio varejista, telecomunicações, seguros, saúde e editoras/gráficas. Mais da metade dos centros de atendimento $(76 \%)$ foram implantados após o processo de privatização do setor de telecomunicações ocorrido em 1998, mostrando essa estratégia como elemento privilegiado na redução dos custos de implantação e manutenção das empresas em função, principalmente, da competitividade nesse setor. (OLIVEIRA JUNIOR, 2005)

O telemarketing - como canal de vendas, de atendimento ao consumidor ou de prestação de serviços - concretizou-se como a principal estratégia de muitas empresas, em várias situações e contextos de competição por mercados de consumidores. A consequência desse processo foi o crescimento geométrico dos profissionais dessa categoria de trabalhadores. (BEHLAU et al., 2005)

O trabalho em teleatendimento/telemarketing é dividido em duas modalidades principais: ativo e receptivo. Na modalidade ativa, a empresa toma a iniciativa de contato com o público, sendo utilizada majoritariamente para vendas. Já na modalidade receptiva, é o cliente quem entra em contato com a empresa, sendo o Serviço de Atendimento ao Consumidor (SAC) a aplicação mais conhecida.

As exigências no trabalho dos teleoperadores diferem com relação à modalidade de atendimento realizado. No telemarketing ativo há demanda de um profissional com segurança ao falar, com habilidade e capacidade de argumentação. Já na modalidade receptiva, o teleoperador deve ser gentil, paciente e ter capacidade de ouvir e interpretar as necessidades do cliente. (RATTO; ALBERMAZ; PELTIER, 2004) Segundo Algodoal e Alozza (2004), no ramo do telesserviço é indispensável ter como foco a voz, a fala, a linguagem e a audição numa relação de troca estabelecida pela comunicação. Portanto, a integração entre essas habilidades humanas, aliadas ao raciocínio rápido e à capacidade de previsão de comportamentos de outras pessoas, são exigências da profissão. Assim, essa não é uma atividade simples, de fácil execução como aparentemente parece ser. Exige rapidez de raciocínio, atenção, criatividade, habilidade comunicativa e paciência. Os processos de seleção, nesse caso, levam em conta o perfil vocal e comportamental que possam auxiliar na eficiência das ações de telemarketing. (BEHLAU; PONTES, 2005) 
As características dos processos de trabalho de teleatendimento assemelham-se às características do trabalho das telefonistas, acrescidas de elementos que intensificaram substantivamente o trabalho, especialmente o seu ritmo e cadência. (ARAÚJO, 2004) Com o uso de novas tecnologias e a informatização ampla do processo produtivo, por exemplo, os clientes são automaticamente direcionados ao atendimento, portanto o ritmo do trabalho é ditado pelos equipamentos, restringindo o controle do teleoperador sobre o seu próprio trabalho. Além disto, as demandas emocionais também cresceram significativamente nessa nova ocupação em função, sobretudo, do tipo de atendimento que deve ser oferecido: atender o cliente, seguir rigorosamente a rotina de procedimentos estabelecimentos pela empresa (muitas vezes ineficiente) e manter, em qualquer circunstância, a cordialidade e o mesmo tom de voz, mesmo frente às manifestações de insatisfação do cliente quando este não tem as suas demandas atendidas.

O trabalho em teleatendimento baseia-se em formas tradicionais de organização do trabalho centradas em relações de controle intenso do ritmo de trabalho (controle exercido pelos equipamentos e pela gerência), uso também intensivo das habilidades exigidas na atividade (no caso, o uso da voz), remuneração baseada na produtividade (alcance de metas) e supressão contínua de emoções geradas por situações de conflito e tensão na realização das tarefas diárias. (VILELA; ASSUNÇÃO, 2004; MOCELIN; SILVA, 2008)

\section{A voz profissional e distúrbio de voz relacionado ao trabalho}

A voz profissional é definida como uma forma de comunicação oral utilizada por indivíduos que dela dependem para exercer sua atividade ocupacional. (SBORL et al., 2004) Segundo Behlau e colaboradores (2005), o uso da voz em caráter profissional, sem o necessário preparo específico, pode sobrecarregar o aparelho fonador e gerar adaptações deficientes que se refletem numa disfonia/distúrbio.

As características da organização do trabalho (ritmo e jornada de trabalho, sistema hierárquico, nível de demandas laborais, controle sobre a atividade) e as condições do ambiente laboral (físicas, biológicas, 
químicas e ergonômicas) são elementos que também podem contribuir para os processos de agravos à saúde vocal. (ARAÚJO et al., 2008)

O Distúrbio de Voz Relacionado ao Trabalho (DVRT) é definido como qualquer alteração vocal que diminua, comprometa ou impeça a atuação e/ou a comunicação do trabalhador, diretamente relacionada ao uso da voz durante a atividade ocupacional; poderá ou não haver uma lesão orgânica da laringe. Geralmente o inicio dos sintomas é insidioso: predomina no final do dia, em função do uso excessivo da voz durante o trabalho e piora no decorrer dos dias. Com o descanso, a voz tende a melhorar. Contudo, no decorrer do tempo, os sintomas começam a se apresentar continuamente e sem expectativa de melhora. (BRASIL, 2012)

A disfonia relacionada ao trabalho manifesta-se por diversos sinais e sintomas que podem estar presentes concomitantemente ou não. Segundo pesquisas, os sinais e sintomas mais comuns relatados pelos teleoperadores são: garganta seca, cansaço para falar, pigarro, perda e falhas na voz, rouquidão, ardência e dor de garganta, tensão na região de pescoço, ombros e coluna. (FERREIRA et al., 2008b; CHRISTMANN et al., 2010; MORREIRA et al., 2010; PIWOWARCZYK et al., 2010; AMORIM et al., 2011; DASSIE-LEITE; LOURENÇO; BEHLAU, 2011) Dependendo da intensidade dos sintomas e do impacto destes na execução da atividade profissional, poderá haver a necessidade de afastamento e/ou ausência do trabalho.

O Distúrbio de Voz Relacionado ao Trabalho (DVRT) apresenta natureza multicausal e está associado a fatores ambientais e organizacionais do trabalho. Em geral, o teleoperador não dispõe de um ambiente ocupacional adequado ao desempenho de suas atividades profissionais, estando exposto a fatores de riscos ambientais (mudança brusca de temperatura, ambiente frio ou quente demais, presença de carpete, ar condicionado, poeira, fumaça e ruído) e fatores organizacionais desfavoráveis (uso intenso da voz, estresse relacionado ao trabalho, pausas insuficientes, relacionamento insatisfatório com chefia, colegas e clientes). (FERREIRA et al., 2008b)

Há também fatores relacionados às características individuais tais como idade, sexo feminino, uso vocal inapropriado ou excessivo, atividades extraprofissionais com alta demanda vocal, alergias respiratórias, doenças de vias aéreas superiores, influências hormonais, medicações, 
etilismo, tabagismo, falta de hidratação, estresse, refluxo gastroesofágico e outros que também estão relacionados aos agravos vocais. Os fatores de risco e predisponentes podem atuar de forma isolada e/ou combinada para o desenvolvimento do distúrbio vocal. (BRASIL, 2012)

No Brasil, a portaria GM/no 104/2011define as terminologias adotadas na legislação nacional sobre doenças, agravos e eventos em saúde pública de notificação compulsória em todo o território brasileiro. Esta portaria ainda não incluiu a disfonia relacionada ao trabalho entre os agravos de notificação compulsória no Sistema de Informação de Agravos de Notificação (SINAN). Uma tentativa de modificar essa realidade foi dada com a elaboração do Protocolo "Distúrbio de Voz Relacionado ao Trabalho" (DVRT), que foi posto em consulta pública, finalizada em abril de 2012, com vistas à inclusão da Disfonia na lista das doenças relacionadas ao trabalho a ser adotada nacionalmente.

Dados da literatura têm mostrado elevadas frequências de alterações vocais entre os profissionais da voz. (RECHENBERG, 2005; CEREST-SP., 2006; ARAÚJO et al., 2008; CEBALLOS et al., 2011) Desse modo, a notificação obrigatória desses agravos é de suma importância, pois permitirá o dimensionamento mais verdadeiro da situação atual e abrirá a possibilidade de detectar os fatores que interferem na produção vocal e no adoecimento, tornando viável o planejamento de ações de prevenção de distúrbios vocais e de promoção da saúde junto aos profissionais que utilizam a voz como instrumento de trabalho.

\section{Absenteísmo}

Absenteísmo é um conceito complexo. Neste estudo empregou-se a definição da Fundação Européia (1997) que define como incapacidade temporária, prolongada ou permanente para trabalhar, devido a problemas de saúde. Tornou-se um dos assuntos mais polêmicos e preocupantes na área de call center que, estatisticamente, é um setor com índice elevado de absenteísmo no Brasil. (ZAMBON, 2009)

O absenteísmo configura-se como alvo constante de atenções e preocupações por parte dos empresários, executivos e médicos do trabalho. Para os empresários, porque influi negativamente no balanço econômico, podendo representar perdas significativas na produtividade esperada. Para os profissionais da saúde, é objeto de avaliação e 
análise, considerando que é tarefa dos serviços de saúde ocupacional e de medicina do trabalho conhecer a situação de saúde dos trabalhadores, acompanhar sua evolução e identificar os fatores que podem estar contribuindo para as ocorrências de falta ao trabalho, de modo a permitir a elaboração de medidas de prevenção e promoção da saúde nos ambientes de trabalho. (MARQUES NETO, 2006)

Quick e Lapertosa (1982) dividem o absenteísmo em cinco tipos: a) absenteísmo voluntário (devido a razões particulares não justificadas por doença); b) absenteísmo por doença (ausências por doenças ou procedimentos médicos, excetuando-se os infortúnios profissionais); c) absenteísmo por patologia profissional (devido a acidentes de trabalho ou doença profissional); d) absenteísmo legal (faltas ao serviço amparadas por leis, como: gestação, motivos particulares, doação de sangue e serviço militar); e) e absenteísmo compulsório (impedimento ao trabalho devido à suspensão imposta pelo patrão, por prisão ou outro impedimento que não permita o trabalhador chegar ao local de trabalho).

As principais causas do absenteísmo nos call centers são doenças, direitos legais (doação de sangue, participação em júris ou eleições, licença maternidade, entre outros), fatores sociais (doença de familiares, dificuldades com transportes) e desmotivação.

No call center, o absenteísmo é um indicador de qualidade dos serviços prestados. As ausências dos funcionários provocam alterações importantes no fluxo de atendimento. Como existe um dimensionamento do número de funcionários necessários para atender certa demanda de chamadas, a ausência do teleoperador modifica o planejamento do trabalho, bem como o número de chamadas a serem atendidas em um dado período de tempo. Quando o funcionário se ausenta do trabalho, gera atraso no tempo de espera para o cliente ser atendido, pois a empresa teve redução na sua força de trabalho, o que gera insatisfação do cliente, consequentemente, redução dos indicadores de qualidade do atendimento. (ZAMBON, 2009)

Portanto, as constantes faltas dos trabalhadores podem ajudar na identificação de possíveis problemas estruturais na empresa, servindo como alerta de que algo na organização e no ambiente ocupacional não vai bem. Em relação ao absenteísmo e à disfonia em teleoperadores, provavelmente a presença de um quadro disfônico parece culminar em 
absenteísmo e/ou afastamento do trabalho, pelo fato da voz ser a principal ferramenta utilizada.

A existência de inúmeros sintomas vocais em teleoperadores e o elevado absenteísmo nessa categoria profissional motivaram a realização deste estudo. Optou-se por realizá-lo no Sindicato dos Trabalhadores em Telecomunicações da Bahia (SINTTEL-BA), devido à resistência por parte das empresas da cidade do Salvador quanto à disponibilidade de acesso para aplicação de questionário relacionado à saúde no ambiente ocupacional.

\section{Materiais e metodos}

Realizou-se um estudo epidemiológico de corte transversal, com caráter descritivo. Utilizou-se uma amostra de conveniência composta por 80 teleoperadores que buscaram atendimento no Sindicato dos Trabalhadores em Telecomunicações da Bahia (SINTTEL-BA), no período de julho a outubro de 2010. Foram incluídos operadores de telemarketing ativo e receptivo, sem restrição de faixa etária e de ambos os sexos. Os trabalhadores procuram o sindicato para os serviços de homologação da rescisão de contrato de trabalho, atendimento médico ou jurídico e busca de informações. Cada teleoperador, que compareceu ao sindicato e aceitou participar do estudo, foi entrevistado. A coleta de dados foi realizada durante o horário de funcionamento do sindicato nos turnos da manhã e/ou tarde, de segunda a sexta-feira, em dias alternados. Portanto, o critério de inclusão foi ter procurado o sindicato e aceitar participar do estudo.

\section{Instrumento de pesquisa}

Foi utilizado um questionário adaptado de Ferreira e colaboradores (2008b), sendo acrescidas perguntas referentes ao absenteísmo. O instrumento contém 21 questões, sendo parte delas avaliada aqui, a saber: dados sociodemográficos e funcionais, sintomas vocais presentes nas últimas duas semanas, causas desses sintomas na percepção do teleoperador e absenteísmo. As características sociodemográficas e do trabalho estudadas foram: sexo, idade, tempo de profissão, carga horária semanal, modalidade de atendimento (ativo, receptivo e híbrido), setor 
de atendimento (televendas, atendimento ao cliente, help desk, cobrança, suporte técnico, retenção e pesquisa).

A aplicação do questionário foi realizada pela primeira autora do estudo. Os sujeitos foram abordados na sala de espera do SINTTEL-BA e convidados a participar da pesquisa. Os que se dispuseram voluntariamente a participar assinaram o termo de consentimento livre e esclarecido e responderam ao instrumento.

\section{Variáveis de estudo}

Nesta pesquisa, conforme estabelecido nos objetivos, foram investigados os sintomas vocais, absenteísmo e possíveis causas relacionadas à ausência ao trabalho.

Para analisar a frequência de sintomas vocais foi solicitado ao teleoperador que respondesse à questão "sintomas vocais presentes nas duas últimas semanas". A partir de uma lista de sintomas previamente elaborada que incluíram: cansaço ao falar, ardor na garganta, falhas na voz, rouquidão, perda da voz, pigarro, esforço ao falar, garganta e/ou boca seca, voz mais grossa, voz mais fina, voz fraca, voz forte, voz pior pela manha e voz pior pela noite. O teleoperador respondia os sintomas ocorridos nas últimas duas semanas.

Possíveis causas ocupacionais dos sintomas referidos foram avaliadas com base na questão "em sua opinião, esse sintoma acontece por quê?" As respostas foram estruturadas da seguinte forma: uso intenso da voz, presença de carpete no ambiente de trabalho, mobiliário inadequado, presença de ar condicionado, presença de ruído no ambiente, presença de ruído ao headset, ambiente frio ou quente demais, mudança brusca de temperatura, presença de poeira, presença de produto de limpeza com cheiro forte, presença de fumaça, estresse relacionado ao trabalho, falta de intervalos para descanso e relacionamento insatisfatório com a chefia, colegas ou clientes.

O absenteísmo foi analisado com base na questão "nos últimos seis meses você faltou trabalho por problemas de voz?", sendo aceita apenas uma resposta com escala dicotômica ( $\operatorname{sim} /$ não). 


\section{Análise dos dados}

Os resultados foram digitados em planilha específica e analisados descritivamente com auxílio do programa SPSS (Statistical Package for Social Sciences), versão 17.0 para Windows.

A análise descritiva dos dados incluiu a descrição da população estudada e das variáveis de interesse já mencionadas. Os dados sociodemográficos foram calculados em médias de: idade, tempo de serviço e carga horária semanal. Para definição do serviço procurado no Sindicato as respostas, inicialmente abertas, foram categorizadas nos seguintes serviços: atendimento médico, atendimento jurídico, homologação e informações. As frequências dos sintomas vocais e das possíveis causas dos sintomas referidas foram descritas em número e percentual. A frequência de absenteísmo por problemas vocais foi estimada da mesma maneira (número e percentual). Para a definição do problema vocal que provocou o absenteísmo, consideraram-se as respostas abertas dos trabalhadores que faltaram ao trabalho, as quais foram posteriormente categorizadas em rouquidão, perda da voz, dor de garganta, inflamação de garganta e problemas múltiplos, quando referiam mais de um motivo (rouquidão + perda de voz, rouquidão + inflamação da garganta, rouquidão + perda de voz + dor). Para o atendimento de saúde procurado devido ao absenteísmo, foi estimada a frequência de categorias profissionais previamente estabelecidas (médico otorrinolaringologista, médico do trabalho, fonoaudiólogo e outros).

O tempo de afastamento do trabalho foi calculado segundo número de faltas em dias consecutivos, considerando as opções: um dia, dois dias, sete dias, 15 dias e uma alternativa aberta para responder ao número de dias faltosos que não se enquadrava nas faixas descritas.

Analisou-se também se houve necessidade de afastamento em função desse problema em resposta dicotômica ( $\operatorname{sim} /$ não) e se o trabalhador procurou atendimento especializado (fonoaudiologia e otorrinolaringologia) por causa do problema de voz.

\section{Aspectos éticos}

O projeto de pesquisa foi aprovado pelo Comitê de Ética em Pesquisa da Escola Bahiana de Medicina e Saúde Pública (protocolo 
$\mathrm{n}^{\circ}$ 065/2010). A direção do SINTTEL-BA autorizou a coleta dos dados. Os trabalhadores entrevistados assinaram o termo de consentimento livre e esclarecido, conforme descrito anteriormente, em acordo com a Resolução no. 196/96.

\section{Resultados e discussão}

A amostra contou com a participação de 80 teleoperadores, sendo $20 \%$ do sexo masculino e $80 \%$ do feminino, com média de idade de 28 anos; idade mínima de 19 anos e máxima de 52 anos. O serviço do Sindicato mais procurado pelos teleoperadores foi o de homologação $(68,8 \%)$, seguido do serviço médico $(26,3 \%)$ e de outros serviços que somaram $5 \%$.

A presença majoritária de mulheres no ramo do telesserviço é corroborada por outros estudos. (MOCELIN; SILVA, 2008; CHRISTMANN et al., 2010; MORREIRA et al., 2010; PIWOWARCZYK et al., 2010; AMORIM et al., 2011; DASSIE-LEITE; LOURENÇO; BEHLAU, 2011; RECHENBERG; GOULART; ROITHMANN, 2011) O call center no Brasil apresenta $76,2 \%$ de participação do sexo feminino em sua força de trabalho e $23,8 \%$ de homens. (OLIVEIRA JUNIOR, 2005) A amostra aqui estudada é compatível, portanto, com o perfil encontrado no setor de telemarketing como um todo.

Esse predomínio de participação feminina nesse setor decorre da busca de espaço no mercado de trabalho pelas mulheres, por um lado, e, por outro, pelas características dos postos de trabalho nesse setor (em geral, marcado por formas autoritárias de gestão do trabalho, com restrição de tempo, modos rígidos de execução das tarefas e vínculos empregatícios precários), reunindo características dos postos de trabalho comumente designados às mulheres na divisão sexual do trabalho no capitalismo. (ARAÚJO et al., 2006) Em estudo sobre o panorama da situação das mulheres no mercado de trabalho no Brasil, Bruschini (2007) pontua crescimento intenso e constante da participação feminina no mercado de trabalho, mas destaca que ainda há uma tendência de inserção das mulheres em empregos de má qualidade com predomínio em atividades precárias e informais. Destaca ainda, nesse perfil, uma tendência mais recente de acesso a carreiras e profissões de prestígio e a cargos de gerência e diretoria, por parte de mulheres escolarizadas - 
movimento ainda restrito em função das dificuldades de acesso escolar, de modo geral, no país.

Ressalta-se, também, o turno de trabalho (carga horária de seis horas diárias), permitindo que as mulheres possam conciliar a atividade laboral com as atividades exercidas na família, como o cuidado da casa e dos filhos. A literatura aponta que, para as mulheres, a conciliação do trabalho remunerado e doméstico tem significado a opção por postos de trabalho de tempo parcial. (BRUSCHINI, 2007)

Em relação à situação funcional, os trabalhadores referiram atuar no setor, em média, há 38 meses (pouco mais de três anos na atividade), com carga horária média de 36 horas semanais. O turno dos teleoperadores é de seis horas diárias, com 15 minutos de intervalo.

Sobre a faixa etária, a maioria dos teleoperadores estava entre 20 a 24 anos $(42,6 \%)$ e entre 25 a $29(30,7 \%)$, representando $73,3 \%$ do total. A possibilidade de um emprego de meio período atrai jovens profissionais que, muitas vezes, possuem duas profissões ou jornada dupla de trabalho. (BEHLAU et al., 2005) A predominância de adultos jovens também foi encontrada em outras pesquisas. (FERREIRA et al., 2008b; MOCELIN; SILVA, 2008; MORREIRA et al., 2010; AMORIM et al., 2011; DASSIE-LEITE ; LOURENÇO; BEHLAU, 2011) As empresas de call center empregam, na sua grande maioria, jovens vivenciando o primeiro emprego que não têm a pretensão de seguir carreira no ramo. O teleatendimento é encarado como uma atividade temporária, com alta rotatividade de trabalhadores, o que implica no fato de não haver envelhecimento dos empregados, pois há uma forte tendência a deixar o emprego quando se atinge uma determinada faixa etária, que parece coincidir com a conclusão da formação educacional. (VILELA; ASSUNÇÃO, 2004; MOCELIN; SILVA, 2008) Provavelmente, devido a esses fatores, o serviço mais procurado pelos sujeitos desta pesquisa tenha sido o de homologação, visando à formalização do término do vínculo trabalhista.

A maioria dos entrevistados atuava no setor de atendimento ao cliente $(56,3 \%)$, seguido pelos setores de televendas $(28,8 \%)$, suporte técnico $(2,5 \%)$ e retenção $(1,3 \%)$. Parte dos teleoperadores atuava em mais de um setor (10\%). Segundo a distribuição por modalidade de teleatendimento, $70 \%$ dos teleoperadores entrevistados estavam na função exclusivamente receptiva, $15 \%$ atuavam na função híbrida e o mesmo 
percentual em função exclusivamente ativa. Esses achados são consistentes com os de outros estudos. (FERREIRA et al., 2008b; MOCELIN; SILVA, 2008; RECHENBERG, 2005) O atendimento receptivo mostra-se mais prejudicial, particularmente à voz, pois esta modalidade, quando comparada ao atendimento ativo, é marcada pelo grande fluxo de ligações e inexistência de pausas entre os atendimentos, havendo maior exigência vocal. As demandas emocionais do trabalho também são intensificadas neste tipo de atendimento - o que pode elevar ainda mais o estresse ocupacional, já gerado pela demanda excessiva e o baixo controle sobre o trabalho. $\mathrm{O}$ atendimento ativo também promoveria desgaste da voz, mas em grau menor. (GUENA, 2009)

Todos os teleoperadores entrevistados referiram, pelo menos, um tipo de sintoma vocal. Os sintomas vocais mais referidos nas duas últimas semanas foram: garganta e/ou boca seca (41,3\%), ardor na garganta e falhas na voz (ambos com 33,8\%), rouquidão e pigarro (31,3\% para ambos) (Tabela 1). Estes achados corroboram estudos de outros autores. (FERREIRA et al., 2008b; PIWOWARCZYK et al., 2010; DASSIE-LEITE; LOURENÇO; BEHLAU, 2011; AMORIM et al., 2011; RECHENBERG; GOULART; ROITHMANN, 2011) 
Tabela 1 - Distribuição de sintomas vocais presentes nas duas últimas semanas referidas por teleoperadores $(\mathrm{N}=80)$. Salvador, 2010.

\begin{tabular}{|c|c|c|}
\hline Sintomas & $\mathbf{n}$ & $(\%)$ \\
\hline Garganta/boca seca & 33 & 41,3 \\
\hline Ardor na garganta & 27 & 33,8 \\
\hline Falhas na voz & 27 & 33,8 \\
\hline Rouquidão & 25 & 31,3 \\
\hline Pigarro & 25 & 31,3 \\
\hline Cansaço ao falar & 21 & 26,3 \\
\hline Voz mais grossa & 10 & 12,5 \\
\hline Voz fraca & 09 & 11,3 \\
\hline Voz pior pela manhã & 09 & 11,3 \\
\hline Voz pior pela noite & 07 & 8,8 \\
\hline Perda da voz & 07 & 8,8 \\
\hline Esforço ao falar & 07 & 8,8 \\
\hline Voz mais fina & 05 & 6,3 \\
\hline Voz forte & 01 & 1,3 \\
\hline
\end{tabular}

Fonte: (MÔNICA; MASSON; ARAÚJO, 2010)

As prováveis causas dos sintomas vocais referidos mais citadas foram: uso intenso da voz $(70,0 \%)$, estresse relacionado ao trabalho $(46,4 \%)$ e circunstâncias decorrentes de condições do ambiente de trabalho como presença de ar condicionado $(57,5 \%)$ e ambiente frio ou quente demais $(35,5 \%)$ (Tabela 2$)$.

Dentre os hábitos relacionados à voz que eram realizados imediatamente antes ou durante o trabalho destacaram-se: ingerir gelado ou tomar café (ambos com 45,0\%) falar muito (41,3\%) e ingerir chocolate $(36,3 \%)$. Tais hábitos são prejudiciais à voz e deveriam ser evitados durante o período de atuação profissional. Os gelados provocam descarga de muco nas pregas vocais, como um sistema de defesa contra o choque térmico da mudança de temperatura. O consumo de café pode favorecer o refluxo gastresofágico, que é extremamente irritante para a sensível mucosa da laringe. (BEHLAU; PONTES, 1995, BEHLAU et al., 2001) A situação piora ainda mais, considerando-se as condições de trabalho em que os teleoperadores geralmente estão submetidos, com 
intenso uso da voz, pausas restritas e dificuldade de acesso a alimentos saudáveis.

Tabela 2 - Distribuição das possíveis causas para os sintomas vocais referidas pelos teleoperadores $(\mathrm{N}=80)$. Salvador, 2010

\begin{tabular}{l|c|c}
\multicolumn{1}{c|}{ Causas referidas } & n & (\%) \\
\hline Uso intenso da voz & 56 & 70,0 \\
\hline Presença de ar condicionado & 46 & 57,5 \\
\hline Estresse no trabalho & 37 & 46,3 \\
\hline Ambiente frio ou quente demais & 30 & 37,5 \\
\hline Presença de poeira & 27 & 33,8 \\
\hline Mudança brusca de temperatura & 19 & 23,8 \\
\hline Presença de ruído ao telefone (headset) & 16 & 20,0 \\
\hline Mobiliário inadequado & 11 & 13,8 \\
\hline Maior número de intervalos para descanso & 10 & 12,5 \\
\hline Presença de ruído no ambiente & 10 & 12,5 \\
\hline Relacionamento insatisfatório com chefia, colegas e clientes & 09 & 11,3 \\
\hline Presença de carpete no ambiente de trabalho & 08 & 10,0 \\
\hline Presença de produto de limpeza com cheiro forte & 04 & 5,0 \\
\hline
\end{tabular}

Fonte: (MÔNICA; MASSON; ARAÚJO, 2010)

A análise da situação de saúde dos teleoperadores incluiu avaliação de problemas de saúde relativos às vias aéreas, ao aparelho auditivo e morbidade em geral (Tabela 3 ). Com relação às vias aéreas destacaram-se as rinites $(36,3 \%)$ e as sinusites $(23,8 \%)$. Coceira no ouvido $(30,0 \%)$, dificuldade de ouvir e zumbido (ambos com 22,5\%) foram os problemas do aparelho auditivo mais frequentemente relatados. Quando se avaliou a saúde em geral, os teleoperadores relataram, em maior frequência, problemas de coluna $(37,5 \%)$, problemas emocionais $(32,5 \%)$, distúrbios do sono $(31,3 \%)$ e problemas digestivos $(21,3 \%)$. 
Tabela 3 - Distribuição de problemas em vias aéreas, no aparelho auditivo e de saúde geral, referidos pelos teleoperadores $(\mathrm{N}=80)$. Salvador, 2010

\begin{tabular}{|c|c|c|}
\hline Problemas de Saúde & $\mathbf{n}$ & $(\%)$ \\
\hline \multicolumn{3}{|c|}{ Vias aéreas } \\
\hline Rinite & 29 & 36,3 \\
\hline Sinusite & 19 & 23,8 \\
\hline Amigdalite & 08 & 10,0 \\
\hline Faringite & 04 & 5,0 \\
\hline Laringite & 03 & 3,8 \\
\hline Asma & 02 & 2,5 \\
\hline Bronquite & 01 & 1,3 \\
\hline \multicolumn{3}{|c|}{ Aparelho auditivo } \\
\hline Coceira no ouvido & 24 & 30,0 \\
\hline Intolerância a sons & 19 & 23,8 \\
\hline Zumbido & 18 & 22,5 \\
\hline Dificuldade de ouvir & 18 & 22,5 \\
\hline Intolerância a sons & 19 & 23,8 \\
\hline Dor no ouvido & 16 & 20,0 \\
\hline \multicolumn{3}{|c|}{ Saúde Geral } \\
\hline Problemas de Coluna & 30 & 37,5 \\
\hline Problemas emocionais & 26 & 32,5 \\
\hline Distúrbios do sono & 25 & 31,3 \\
\hline Problemas digestivos & 17 & 21,3 \\
\hline Problemas circulatórios & 16 & 20,0 \\
\hline Problemas psiquiátricos & 12 & 15,0 \\
\hline Problemas neurológicos & 12 & 15,0 \\
\hline LER/DORT & 09 & 11,3 \\
\hline Problemas hormonais & 06 & 7,5 \\
\hline
\end{tabular}

Fonte: (MÔNICA; MASSON; ARAÚJO, 2010)

A morbidade referida pelos teleoperadores foi compatível com as exigências do trabalho e coerentes com estudos junto a essa população. (FERREIRA et al., 2008b; CHRISTMANN et al., 2010; PIWOWARCZYK et al., 2010; MOREIRA et al., 2010; DASSIE-LEITE; LOURENÇO; BEHLAU, 2011; AMORIM et al., 2011; RECHENBERG; GOULART; ROITHMANN, 2011) Queixas de coceira no ouvido, dificuldade de 
ouvir e zumbido estão relacionadas às demandas excessivas sobre o aparelho auditivo. O uso contínuo de aparelhos como headsets por jornada de trabalho de seis horas (com apenas 15 minutos de descanso) pode representar exposição importante para as queixas referidas. A queixa de problema de coluna foi a mais relevante, estando, provavelmente, associada à postura sentada mantida durante a atividade laboral. Por fim, os sintomas psicossomáticos também tiveram destaque: os problemas emocionais, distúrbios do sono e problemas digestivos podem ser indicativos de vivência constante de situações envolvendo elevado nível de estresse ocupacional.

No ambiente do call center são necessários equipamentos de ar condicionado, pela presença dos computadores em funcionamento. Alguns indivíduos são muitos sensíveis ao ar condicionado, isto porque o resfriamento do ar realizado através da retirada de umidade do meio ambiente, resseca a mucosa do trato vocal. A movimentação da mucosa fica comprometida devido à diminuição da lubrificação laríngea em decorrência da presença do ar condicionado. (BEHLAU; PONTES, 1995) A queixa de garganta seca, relatada por significativo percentual dos teleoperadores, pode ser em função da combinação entre exposição ao ar condicionado e abertura frequente da cavidade oral pelo uso contínuo da voz. (RECHENBERG, 2005)

Os teleoperadores, por trabalharem em ambiente com baixa temperatura, enfrentam mudanças bruscas de temperaturas e, por não terem o hábito de hidratação oral, apresentam problemas de falta de lubrificação e/ou hidratação laríngea. (BEHLAU et al., 2005) Vale ressaltar que tal hábito é imposto pela organização do trabalho, que dificulta a ingestão de líquidos. No estudo de Rocha e colaboradores (2006) foi evidenciado que o aumento da ingestão de água representava a necessidade dos trabalhadores de ir ao banheiro com maior frequência, o que era um problema diante da dificuldade dos teleoperadores afastarem-se do posto de trabalho durante os horários de pico das ligações.

Estudos evidenciam relação estatisticamente significante entre as afecções respiratórias altas e o sintoma de ardor na garganta. (FERREIRA; SANTOS; LIMA, 2009) As afecções respiratórias afetam a hidratação do trato vocal, causam ressecamento na faringe e, consequentemente, irritação na garganta. No geral, há um ressecamento do 
trato vocal por conta da respiração oral, fato que acarreta uma sensação de ardor na garganta. (BEHLAU et al., 2001)

Segundo Behlau e Pontes (1995), a voz rouca é a manifestação mais comum de alteração vocal. Esse tipo de voz geralmente está relacionado a lesões orgânicas na laringe, representando uma alteração na vibração das pregas vocais. Queixas como rouquidão, falhas na voz e cansaço vocal, podem ser decorrentes do uso prolongado da voz durante a jornada de trabalho, sendo indicativo de sobrecarga vocal. (JONES et al., 2002; LETHO et al., 2005) Para Amorim e colaboradores (2011), tais sintomas podem sugerir um quadro inicial de disfonia, gerando riscos elevados para a função vocal em virtude da permanência nas atividades profissionais, mesmo diante de desconforto fonatório. Os achados deste estudo reforçam a hipótese de que há uma estreita relação entre a presença da rouquidão e o uso abusivo da voz, como tem sido observado em vários estudos na literatura. (ARAÚJO et al., 2008)

Um sintoma presente nos quadros gripais é o pigarro, cuja finalidade é expelir a secreção que se acumula nas pregas vocais. Contudo, o hábito de realizá-lo com frequência, independentemente desses quadros, confere atrito constante, causando aumento na produção de muco como estratégia de defesa deste impacto. Esse ciclo vicioso compromete a emissão vocal, forçando um novo ato de pigarrear. (PINHO, 1997)

Segundo Behlau e colaboradores (2005), o pigarro também pode ser consequência do ressecamento provocado pela refrigeração do ambiente, como ocorre nas centrais de teleatendimento. A falta de manutenção no ar condicionado geralmente aumenta a incidência de doenças respiratórias.

A literatura alerta para uma série de alterações que podem influenciar o estabelecimento do quadro disfônico, as quais podem contribuir para sua manutenção e recorrências. As principais dizem respeito aos distúrbios alérgicos, faríngeos, bucais, nasais, otológicos, pulmonares, digestivos, hormonais e neurovegetativos. Os distúrbios nasais e alérgicos - rinite e sinusite - foram os mais referidos. Estes alteram a ressonância e podem modificar o padrão vibratório da laringe, induzindo a uma contração na produção dos sons. Alguns indivíduos referem o início de sua disfonia em decorrência de abuso vocal em situações de quadro alérgico ou gripal. (BEHLAU; PONTES, 1995) 
Estudo concluiu que os teleoperadores tinham duas vezes mais chances de apresentar um ou mais sintomas vocais, principalmente se fossem mulher, sedentárias, fumantes, e se tivessem problemas nasais, ou exposição a ambiente frio. (JONES et al. 2002)

$\mathrm{O}$ ambiente físico das centrais de telemarketing e a própria função de teleoperador podem agir como estressores ou potencializadores de estresse, pois o cotidiano do teleoperador está marcado por situações que geram reações de irritação, ansiedade e até medo e confusão. Também, a própria situação de uma possível dificuldade de comunicação, passa a ser um agente estressor. (MONTORO, 1998) Como exemplos estão: o fato de ter que lidar com o controle de tempo das ligações, a manutenção do script, o monitoramento de atrasos, pausas e ausências por meio de pontuações, a produtividade e a cobrança por resultados. (VILELA; ASSUNÇÃO, 2004) Os teleoperadores referem que a postura permanente durante seis horas diárias, o toque constante do sinal telefônico, o uso do fone de ouvido e instabilidade no emprego são aspectos geradores do estresse. (FERREIRA et al., 2008a) O estresse ocupacional tem sido associado a diversos processos de adoecimento físico e mental em diferentes grupos ocupacionais. (ARAÚJO; CERQUEIRA; ARAÚJO, 2003)

Para avaliar a relação entre sintomas vocais e aspectos laborais, analisaram-se os três sintomas mais relevantes (garganta e/ou boca seca, falha na voz e rouquidão) (Tabela 4). Para esses sintomas investigados, a frequência foi mais elevada entre aqueles que referiram condições de trabalho desfavoráveis. As diferenças mais marcantes foram observadas quando o teleoperador referiu uso intenso da voz: a ocorrência do sintoma, quando essa condição estava presente, foi 10 vezes maior para rouquidão $(44,6 \%$ contra $5,2 \%) ; 5,2$ vezes maior para falhas na voz (43,5\% contra $8,3 \%)$; e 4,1 vezes maior para garganta/boca seca $(51,7 \%$ contra $12,5 \%)$ (Tabela 4$)$. Merece destaque também a presença de estresse ocupacional que aumentou 2,4 vezes mais a frequência de garganta/boca seca; 1,5 vezes a frequência de falhas na voz; e 1,4 vezes a rouquidão. 
Tabela 4 - Frequência (\%) de sintomas vocais segundo presença (sim) e ausência (não) das condições de trabalho referidas nos teleoperadores $(N=80)$. Salvador, 2010

\begin{tabular}{|c|c|c|c|c|c|c|}
\hline \multirow{2}{*}{$\begin{array}{l}\text { Características e condições do } \\
\text { trabalho referidas }\end{array}$} & \multicolumn{2}{|c|}{$\begin{array}{l}\text { Garganta/ } \\
\text { Boca seca }\end{array}$} & \multicolumn{2}{|c|}{ Falhas na voz } & \multicolumn{2}{|c|}{ Rouquidãc } \\
\hline & Sim & Não & Sim & Não & Sim & Não \\
\hline Uso intenso da voz & 51,7 & 12,5 & 42,9 & 8,3 & 44,6 & 4,2 \\
\hline Presença de ar condicionado & 50,0 & 20,6 & 43,5 & 17,6 & 32,6 & 23,5 \\
\hline Estresse no trabalho & 45,9 & 16,3 & 51,4 & 20,9 & 37,8 & 25,6 \\
\hline Ambiente frio ou quente demais & 56,7 & 30,0 & 46,7 & 26,0 & 33,0 & 30,0 \\
\hline Presença de poeira & 59,2 & 32,0 & 51,9 & 20,8 & 33,3 & 30,2 \\
\hline Mudança brusca de temperatura & 68,4 & 32,8 & 36,8 & 32,8 & 42,1 & 27,9 \\
\hline Presença de ruído ao telefone (headset) & 68,8 & 34,4 & 56,3 & 28,1 & 50,0 & 26,6 \\
\hline Mobiliário inadequado & 63,6 & 37,7 & 54,5 & 29,0 & 54,5 & 27,5 \\
\hline Maior número de intervalos para descanso & 38,6 & 30,0 & 30,0 & 60,0 & 50,0 & 28,6 \\
\hline Presença de ruído no ambiente & 40,0 & 40,0 & 50,0 & 31,4 & 50,0 & 28,6 \\
\hline $\begin{array}{l}\text { Relacionamento insatisfatório com chefia, } \\
\text { colegas e clientes }\end{array}$ & 44,4 & 40,8 & 44,4 & 31,0 & 44,4 & 32,4 \\
\hline
\end{tabular}

Fonte: (MÔNICA; MASSON; ARAÚJO, 2010)

Com relação ao absenteísmo, 35\% dos teleoperadores $(n=28)$ faltaram ao trabalho nos últimos seis meses por problemas na voz. As faixas de dias faltosos mais frequentes foram dois dias, $(35,7 \%)$; três dias $(28,6 \%)$; e um dia $(10,7 \%)$.

Quando perguntados sobre qual foi o problema vocal que os impossibilitou comparecer ao exercício de sua função, a maioria relatou sintoma único de rouquidão $(46,4 \%)$, seguido por problemas múltiplos (rouquidão e perda da voz ou rouquidão e inflamação da garganta, $21,4 \%$ ) (Tabela 5). 
Tabela 5 - Distribuição dos teleoperadores que faltaram ao serviço ${ }^{1}(\mathrm{n}=28)$ segundo tipo de problema de voz referido, atendimentos procurados e exigência/ condições de trabalho referidos como causa do afastamento. Salvador, 2010

\begin{tabular}{l|c|c}
\multicolumn{1}{c|}{ VARIÁVEIS } & $\mathrm{n}$ & $(\%)$ \\
\hline Problemas vocais referidos (N=28) & & \\
\hline Rouquidão & 13 & 46,4 \\
\hline Inflamação na garganta & 05 & 17,9 \\
\hline Perda da voz & 03 & 10,7 \\
\hline Dor de garganta & 01 & 3,6 \\
\hline Múltiplos ${ }^{17}$ & 06 & 21,4 \\
\hline Atendimentos procurados (N=28) & & \\
\hline Médico ORL & 16 & 57,1 \\
\hline Fonoaudiólogo & 02 & 7,2 \\
\hline Médico do trabalho & 01 & 3,6 \\
\hline Outros ${ }^{18}$ & 06 & 21,4 \\
\hline Não informaram & 03 & 10,7 \\
\hline Fatores associados ao afastamento referidos como causa (n=28) & $\mathrm{n}$ & $\%$ \\
\hline Uso intenso da voz & 18 & 64,7 \\
\hline Ambiente frio ou quente demais & 13 & 46,4 \\
\hline Presença de ar condicionado & 12 & 42,9 \\
\hline Estresse no trabalho & 10 & 35,7 \\
\hline Presença de poeira & 08 & 28,6 \\
\hline Mudança brusca de temperatura & 06 & 21,4 \\
\hline Presença de ruído ao telefone (headset) & 05 & 18,9 \\
\hline Mobiliário inadequado & 04 & 14,3 \\
\hline Presença de ruído no ambiente & 02 & 7,1 \\
\hline Relacionamento insatisfatório com chefia, colegas e clientes & 04,3 \\
\hline & & 7,1 \\
\hline
\end{tabular}

Fonte: (MÔNICA; MASSON; ARAÚJO, 2010)

As taxas de absenteísmo mostraram-se similares (29\%) às encontradas por Reichenberg, Goulart e Roithmann (2011) e maiores nos teleoperadores quando comparadas às dos professores Smith e

1 A análise do número de dias ausentes evidenciou que as faixas de dias faltosos mais frequentes foram dois dias $(35,7 \%)$; três dias $(28,6 \%)$ e um dia $(10,7 \%)$.

2 Mais de um problema referido, a saber: rouquidão + perda de voz, rouquidão + inflamação da garganta, rouquidão + perda de voz + dor.

3 Emergência, atendimento clínico e ortopédico. 
colaboradores (1998), Simberg, Sala e Ronnemaa (2004), 20\% e 18\%, respectivamente. Tal situação parece reforçar a percepção de que, na vigência de uma disfonia, o trabalho torna-se inviável entre teleoperadores, uma vez que a voz é condição sine qua non de trabalho. Para os professores, a presença da disfonia, em estágio inicial, não parece tão crítica a ponto de gerar taxas de absenteísmo muito elevadas, dada a possibilidade de utilizar outros recursos pedagógicos que viabilizavam a continuidade do trabalho. (RECHENBERG; GOULART; ROITHMANN, 2011)

Um maior nível de controle sobre as atividades laborais cotidianas possibilita uso de outros recursos para poupar a voz nesses momentos. No entanto, cabe mencionar que esse recurso, aparentemente benéfico entre professores, não raro, disfarça a relevância do sintoma, contribuindo para o seu agravamento e cronificação. (ARAÚJO et al., 2008)

Com relação à procura de atendimento na área da saúde frente ao problema vocal apresentado, a maioria dos teleoperadores afirmou procurar um otorrinolaringologista $(57,1 \%)$; um pequeno percentual que buscou o fonoaudiólogo $(7,2 \%)$ e o médico do trabalho do sindicato $(3,6 \%)$ (Tabela 3$)$. Outras especialidades como emergência e clínica médica foram também procuradas pelos entrevistados (21,4\%) (Tabela 5).

Entre os teleoperadores que se afastaram do trabalho, o período de tempo de afastamento mais frequente foi de dois $(35,7 \%)$ e de três dias $(28,6 \%)$. A alta frequência de procura por serviços de saúde evidenciou que o trabalhador vislumbrava uma solução, ainda que imediata, para os seus problemas de voz. O fato da maior procura ser pelo otorrinolaringologista pode estar relacionado a uma busca de alívio de sintomas. Como a disfonia relacionada ao trabalho ainda não é reconhecida como doença ocupacional, há um limite jurídico para o estabelecimento do nexo causal da doença, sendo que as possibilidades de afastamento do trabalho ficam restritas a renovações sistemáticas de atestados por doenças comuns.

Estudos têm demonstrado claramente os resultados benéficos das intervenções fonoaudiológica em teleoperadores, como realização de oficinas para melhorias nos padrões do perfil vocal, principalmente nas mulheres. Após a realização de um curto treinamento de dois dias houve relatos de diminuição da fadiga vocal, da sensação de muco, do 
pigarro ao longo do dia e melhora dos hábitos vocais devido ao treinamento. (LETHO et al., 2003, MOREIRA et al., 2010)

Pela multifatorialidade envolvida na disfonia, a avaliação de um profissional com alteração vocal requer uma atuação multidisciplinar, envolvendo, na fase do diagnóstico, o otorrinolaringologista, a avaliação fonoaudiológica e do médico do trabalho que, mesmo diante de uma disfonia funcional (sem a evidência de uma lesão), podem entendê-la como um distúrbio de voz relacionado ao trabalho. (CEREST-SP, 2006; BRASIL, 2012) Entretanto, apesar desse problema de voz gerar severas limitações e incapacidade para o trabalho, o fato de não constar na lista de agravos relacionados ao trabalho limita também as garantias para fins previdenciários e securitários. A discussão do protocolo, colocado em consulta pública recentemente, está em fase de compilação e deverá dar as diretrizes para o estabelecimento de condutas voltadas para a vigilância, promoção da saúde, prevenção da doença, diagnóstico, notificação, tratamento e reabilitação do distúrbio da voz relacionado ao trabalho, independentemente do vínculo empregatício e do tipo de inserção do trabalhador no mercado. (BRASIL, 2012)

O uso intensivo da voz foi a exigência/condição de trabalho responsável pelo maior percentual de afastamentos do trabalho: $64,3 \%$ dos teleoperadores que faltaram ao trabalho relataram uso intenso da voz (Tabela 5). A presença de ar condicionado, ambiente frio ou quente demais e estresse no trabalho foram os fatores responsáveis pelos afastamentos observados (respectivamente: $46,4 \%$, 42,9\% e 35,7\%). Como já descrito, esses fatores constituem importantes exposições ocupacionais nessa categoria de trabalhadores, devendo ser propostas medidas para redução, controle ou eliminação dessas exposições.

\section{Considerações finais}

$\mathrm{Na}$ população de teleoperadores estudada, os sintomas vocais mostraram-se frequentes, sendo que aspectos relacionados ao ambiente (presença de ar condicionado, ambiente frio ou quente demais) e à organização do trabalho (uso frequente da voz e estresse no trabalho) foram as causas autorreferidas de maior frequência. A ocorrência de absenteísmo por problema de voz foi elevada, atingindo mais de um terço da população estudada. 
O presente estudo adotou delineamento transversal, sendo realizado por meio de entrevista, com o uso de instrumento estruturado. Todos os aspectos analisados foram autorreferidos pelos trabalhadores. Sabe-se que este tipo de estudo apresenta limitações metodológicas importantes, como o viés recordatório e a inviabilidade de checar a veracidade dos dados, uma vez que nenhuma medida objetiva foi realizada. Adicionalmente, estudos em um único ponto do tempo (transversais) impedem análise de sequência temporal entre os eventos, portanto, não é possível determinar se foram os fatores ambientais e organizacionais que produziram os sintomas vocais ou se esses antecederam a exposição ocupacional.

Cabe também ressaltar que a amostra pesquisada incluiu trabalhadores que procuraram o sindicato com intuitos específicos, como visitas ao serviço médico, o que, consequentemente, pode ter contribuído para a superestimação das frequências dos sintomas investigados. Assim, é importante destacar que os sintomas vocais aqui encontrados não refletem, necessariamente, uma aproximação da realidade dos teleoperadores, mas sim de teleoperadores sindicalizados da cidade do Salvador. Contudo, cabe ressaltar que os resultados aqui encontrados são corroborados por outros estudos que realizaram pesquisa com essa categoria de trabalhadores em outros ambientes laborais. Assim, possíveis vieses de seleção, ainda que não possam ser afastados, parecem não ter influenciado significativamente os achados obtidos.

Outro cuidado na interpretação dos resultados obtidos refere-se à análise descritiva privilegiada neste estudo que focalizou apenas os fatores ocupacionais relacionados aos agravos vocais. Embora tenha sido este o objetivo do estudo, deve-se registrar que outros fatores, além daqueles relacionados ao trabalho podem estar associados aos agravos vocais. Desse modo, estimula-se a realização de estudos futuros com a inclusão, na análise, de outros fatores associados aos agravos vocais, possibilitando uma avaliação mais ampla e rigorosa desses eventos.

Essas limitações do estudo realizado alertam para que os resultados obtidos sejam avaliados com cautela.

É importante salientar a alta ocorrência dos sintomas, que deixa evidente a necessidade de aplicação de medidas que visem controlar fatores ocupacionais nestes ambientes, os quais, certamente, contribuem com o adoecimento do trabalhador. 


\section{Referências}

ALGODOAL, J.; ALOZZA, R. G. Voz na empresa. In: FERREIRA, L. P.; BÉFI-LOPES, D. M.; LIMONGI, S. C. O. Tratado de Fonoaudiologia. São Paulo: Roca, 2004. p. 170-176.

AMORIM, G. O et al. Comportamento vocal de teleoperadores pré e pós-jornada de trabalho. Jornal da Sociedade Brasileira de Fonoaudiologia, v. 23, n. 2, p. 170-176, 2011.

ARAÚJO, T. M.; CERQUEIRA, C. G.; ARAÚJO, E. M. Estresse ocupacional e saúde: contribuições do Modelo Demanda-Controle.

Ciência \& Saúde Coletiva, v. 8, n. 4, p. 991-1003, 2003.

ARAÚJO, T. M. O olhar do sujeito sobre o trabalho que executa: sua percepção sobre os riscos e as tarefas - Um estudo com trabalhadores em telecomunicações. In: SAMPAIO, J. R. (Org.). Qualidade de vida no trabalho e Psicologia Social. 2. ed. São Paulo: Casa do Psicólogo, 2004. p. 367-398.

. et al. Diferenciais de gênero no trabalho docente e repercussões sobre a saúde. Ciência \& Saúde Coletiva, v. 11, n. 1, p. 1117-1129, 2006.

. et al. Fatores associados a alterações vocais em professoras.

Cadernos de Saúde Pública, v. 24, p. 1229, 2008.

BEHLAU, M.; PONTES, P. (org. ). Avaliação e tratamento das disfonias. São Paulo: Lovise, 1995.

BEHLAU, M. et al. Avaliação de voz. In: BEHLAU, M. (org. ). Voz: o livro do especialista. Rio de Janeiro: Revinter, v. 1, 2001. p. 85-245.

. et al. Voz profissional: aspectos gerais e atuação

fonoaudiologia. In: . (org. ) Voz: o livro do especialista.

Rio de Janeiro: Revinter, v. 2, 2005, p. 287-407.

BRASIL. Ministério da Saúde. Protocolo Distúrbio de Voz

Relacionado ao Trabalho. 2012. Disponível em: <http://189. 28.

128. 179:8080/pisast/saude-do-trabalhador/apresentacao/ protocolode-complexidade-diferenciada >. Acesso em: 09 jul. 2012.

. Ministério do Trabalho e Emprego. Código Brasileiro

de Ocupações. Disponível em: <http://www.mtecbo.gov. br/cbosite/pages/home.jsf>. Acesso em: 09 jul. 2012.

. ANEXO II DA NR-17. Portaria SIT n. ${ }^{\circ}$ 09, 30 de março de 2007. Diário Oficial [da] República Federativa do Brasil, 02 abr. 2007. Disponível em: <http:www.mte.gov.br>. Acesso em: 04 jul. 2012. 
BRUSCHINI, M. C. A. Trabalho e gênero no Brasil nos últimos dez anos. Cadernos de Pesquisa, v. 37, n. 132, p. 537-572, 2007.

CEBALLOS, A. G. C. et al. Avaliação perceptivo- auditiva e fatores associados à alteração vocal em professores. Revista Brasileira de Epidemiologia, v. 14, p. 285-295, 2011.

CEREST-SP. Distúrbios de voz relacionados ao trabalho. Boletim Epidemiológico Paulista, Ano 3, n. 26, 2006. Disponível em: http://www. cve.saude.sp.gov.br/agencia/bepa26_dist.htm. Acesso em: 04 jul. 2012.

CHRISTMANN, M. K et al. Características de trabalho e de hábitos e queixas vocais de operadores de telemarketing. Revista Salusvita, Bauru, v. 29, n. 3, p. 215-228, 2010.

DASSIE-LEITE, A. P.; LOURENÇO, L.; BEHLAU, M. Relação entre dados ocupacionais, sintomas e avaliação vocal de operadores de telesserviços. Revista da Sociedade Brasileira de Fonoaudiologia, v. 16, n. 1, p. 59-63, 2011.

FERREIRA, L. P. et al. Assessoria fonoaudiologia: análise de um processo de construção entre o fonoaudiólogo e o teleoperador. Revista Distúrbios da Comunicação, v. 20, n. 2, p. 219-228, 2008 a.

. et al. Condições de produção vocal de teleoperadores: correlação entre questões de saúde, hábitos e sintomas vocais. Revista da Sociedade Brasileira de Fonoaudiologia, v. 13, n. 4, p. 307-15, 2008 b.

; SANTOS, J. G.; LIMA, M. F. B. Sintoma vocal e sua provável causa: levantamento de dados em uma população. Revista CEFAC. v. 11, n. 1, p. 110-118, 2009.

FUNDAÇÃO EUROPÉIA para a Melhoria das Condições de vida e trabalho. A Preservação do Absentismo no trabalho: sinopse da investigação. Luxemburgo: Serviço das Publicações oficiais das comunidades Europeias, 1997. Disponível em: <www.ourofound.europa. eu/pubdocs/1997/15/pt/1/ef9715pt.pdf>Acesso em: 15 jul, 2012.

GUENA, R. M. Dando voz ao trabalhador: os significados da disfonia para os operadores de telemarketing. Dissertação (Mestrado em Saúde Coletiva) - Universidade Federal da Bahia - instituto de Saúde Coletiva, Salvador, 2009. Disponível em: $<$ http://www. isc.ufba.br/teses.php? externa=2>. Acesso em: 10 jul. 2012.

JONES, K. et al. Prevalence and risk factors for voice problems among telemarketers. Archives of Otolaryngology - Head \& Neck Surgery, v. 128, n. 5, p. 571-577, 2002. 
LETHO, L et al. Experiences of a Short Vocal Training Course for Call-Centre Customer Service Advisors. Folia Phoniatrica Logopaedica, v. 55, p. 163-176, 2003.

. et al. E Voice symptoms of call-centre customer service advisers experienced during a work-day and effects of a short vocal training course. Logopedics Phoniatrics Vocology. Finland, v. 30, n. 1, p. 14-27, 2005.

MARQUES NETO, A. D. Absenteísmo nas empresas. 2006. TCC (Graduação em Administração) Centro Universitário de Brasília - Faculdade de Ciências Sociais Aplicadas. Brasília, 2006. Disponível em: $<$ http://repositorio. uniceub. br/bitstream/ 123456789/2013/1/20401048. pdf. >. Acesso em: 01 jun. 2012.

MONTORO, O. C. P. O estresse na comunicação do telemarketing. 1998. (Monografia de Conclusão do Curso de Especialização em Voz) - Centro de Especialização em Fonoaudiologia Clínica. São Paulo, 1998. Disponível em: <http://www.cefac.br/library/teses/4b2730 58cd37e68efd1a76aba9dd1de8.pdf> Acesso em: 06 jul. 2012.

MOCELIN, D. G.; SILVA, L. F. S. C. O telemarketing e o perfil sócio-ocupacional dos empregados em Call Centers. Caderno CRH, v. 21, n. 53, p. 365-387, 2008.

MOREIRA, T. C. et al. Intervenção fonoaudiologia para consultores em um serviço de teleatendimento: bem-estar vocal. Revista CEFAC, v. 12, n. 6, p. 936-944, 2010.

OLIVEIRA, A. G. A.; BEHLAU, M.; GOUVEIA, N. Vocal symptoms in telemarketers: a random and controlled field trial, Folia Phoniatrica Logopaedica, v. 6, p. 76-82, 2009.

OLIVEIRA JUNIOR, A. M. M. (Coord. ) Relatório da Indústria de Call Centers no Brasil - Programa de Pós Graduação em Administração da PUC-SP, 2005. Disponível em:<http://files. blogdocallcenter. com/200000755666bc6765c/Relatorio_Brasil_GCCP_ V13-versao\%20\%20oficial. pdf >. Acesso em: 09 jun. 2013.

PIWOWARCZYK, T. et al. Sintomas vocais, perfil de participação e atividades vocais (PPAV) e desempenho profissional dos operadores de teleatendimento. In: CONGRESSO Brasileiro de Fonoaudiologia, $18^{\circ}$. Curitiba, 2010. Anais Eletrônicos. Disponível em: <http://www.sbfa. org.br/portal/anais2010/resumos/3651.pdf>. Acesso em: 17 jun. 2012.

PINHO, S. M. R. Manual de higiene vocal para os profissionais da voz. Carapicuíba: Pró-Fono, 1997.

QUICK, T. C.; LAPERTOSA, J. B. Análise do absenteísmo em Usina Siderúrgica. Rev. Bras. Saúde Ocup. , v. 18, n. 69, p. 65-70, 1982. 
SILVA, D. M. P. P.; MARZIALE, M. H. P. Absenteísmo de trabalhadores de enfermagem em um hospital universitário. Rev Latino-Am. Enfermagem, Ribeirão Preto, v. 8, n. 5, p. 44-51, out. 2000.

RATTO, L.; ALBERMAZ, B.; PELTIER, M. Aplicações do telemarketing. In: Telemarketing: comunicação, funcionamento, mercado de trabalho. Rio de Janeiro: SENAC, 2004. Disponível em: http://books. google. com. br/books/ about/TELEMAR KETING_COMUNICA\%C3\%87AO_FUNCIONAMENTO. html?id=BYNkmZ_4ukwC\&redir_esc=y. Acesso em: 10 jul. 2012.

RECHENBERG, L. Prevalência de sintomas vocais em operadores de telemarketing. 2005. Dissertação (Mestrado em Ciências Médicas) Programa de Pós-Graduação em Medicina, Faculdade de Medicina, Universidade Federal do Rio Grande Do Sul. Porto Alegre, 2005. Disponível em:<http:// www.lume.ufrgs.br/handle/10183/15175. . . Acesso em: 09 jul. 2012.

RECHENBERG, L; GOULART, B. N. G; ROITHMANN, R. Impacto da atividade laboral de teleatendimento em sintomas e queixas vocais: estudo analítico. Jornal da Sociedade Brasileira de Fonoaudiologia, v. 23, n. 4, p. 301-307, 2011.

ROCHA, L. E et al. Distúrbios osteomusculares relacionados ao trabalho do ombro entre operadores de central de atendimento telefônico de empresa de transporte aéreo no Brasil. Boletim Saúde. São Paulo, 11 maio 2006. Disponível em: <http://www.sumarios.org/sites/default/ files/pdfs/v19_n1_07disturbiososteom.pdf>. Acesso em: 08 jul. 2012.

SBORL et al. Consenso Nacional sobre Voz Profissional - Voz e Trabalho: uma questão de saúde e direito do trabalhador. Rio de Janeiro, 2004. Disponível em: <http://www.iocmf.com.br/codigos/ consenso2004\%20voz\%20profissional.pdf>. Acesso em: 05 jun. 2012.

SIMBERG, S.; SALA, S.; RONNEMAA, A. M. A comparison of the prevalence of vocal symptoms among teacher students and other university students. J Voice, v. 18, n. 3, p. 363-368, 2004.

SMITH, E. et al. Frequency of voice problems among teachers and other occupations. J Voice, v. 12, n. 4, p. 480-488, 1998.

VILELA, L. V. O.; ASSUNÇÃO, A. A. Os mecanismos de controle da atividade no setor de teleatendimento e as queixas de cansaço e esgotamento dos trabalhadores. Cadernos de Saúde Pública, v. 20, n. 4, p. 1069-1078, 2004.

ZAMBON, K. F. O absenteísmo no Call Center. Monografia. 2009. TCC (Graduação em Administração). Faculdades Metropolitanas Unidas, São Paulo, 2009. Disponível em:< http://arquivo. fmu. br/prodisc/admfmu/kz. pdf>. Acesso em: 01 jun. 2013. 


\section{Abordagem teórico-prática sobre as condições ambientais e laborais de uma escola da rede municipal de Salvador-Bahia}

Patrícia Farias Uchôa

Luiz Roberto Santos Moraes

\section{Introdução}

O quadro de agravo da saúde docente sinaliza uma preocupação com o futuro da educação e uma ameaça ao desenvolvimento da sociedade de forma sustentável. Percebe-se que não existe, nas instituições de ensino, o cumprimento da legislação vigente relacionada à Saúde e Segurança do Trabalho, denominada Lei $\mathrm{n}^{\circ} 6.514$, de 22 de dezembro de 1977, que contempla as Normas Regulamentadoras (NR) de Segurança do Ministério do Trabalho e Emprego. (BRASIL, 2009) Vale ressaltar, entretanto, que a maioria das NR é desenvolvida com base nos limites necessários para a salubridade do ambiente de trabalho. A condição ideal de bem-estar do trabalhador, porém, deve estar condizente com as normas utilizadas no campo de estudo do Conforto Ambiental.

$\mathrm{Na}$ atividade laboral do professor, limites de tolerância estabelecidos pela NR15-Norma para Atividades e Operações Insalubres são limites inadequados para avaliar as condições de bem-estar do docente. (BRASIL, 2009) O trabalho docente requer atividade intelectual de ensino/aprendizagem. Vale ressaltar que os professores da rede municipal são regidos pelo estatuto do Regime Jurídico Único (RJU). A proteção da saúde no ambiente de trabalho é um dever Constitucional do empregador e do Estado e está definida como um direito social determinado pela necessidade de redução dos riscos inerentes ao trabalho, por meio 
de normas de saúde, higiene e segurança, de acordo com o Artigo 6, inciso XXII, do Capítulo II da Constituição Federal de 1988. (BRASIL, 2009) Segundo a Portaria $n^{\circ} 3.214 / 2009$, do Ministério do Trabalho, as empresas públicas, os órgãos da Administração Pública direta e indireta, que possuam empregados regidos pela Consolidação das Leis do Trabalho-CLT manterão, obrigatoriamente, serviços de engenharia e medicina do trabalho, a fim de promover a saúde e proteger a integridade do trabalhador no ambiente de trabalho. (BRASIL, 2009) Estes serviços também devem ser adotados para a modalidade da relação de trabalho da Administração Pública direta sob Regime Jurídico Único com o objetivo de assegurar o cumprimento do referido dispositivo Constitucional ao estatutário.

Este capítulo visa tratar de questões relacionadas à avaliação das condições do ambiente laboral de uma escola municipal na cidade de Salvador-Bahia. Por meio de diversas estratégias metodológicas, a pesquisa realizada teve como objetivo apresentar um diagnóstico abrangente das condições do ambiente do trabalho docente nesta escola, considerando parâmetros normativos e citações de referências na área, tendo sido realizadas as seguintes atividades: análise das características da edificação e seu entorno, monitorização dos níveis de pressão sonora, temperatura e iluminação para fins de avaliação ambiental e ocupacional, formulários de anotações das atividades cotidianas e entrevistas complementares relacionadas à percepção dos fatores físicoambientais.

\section{Metodologia e resultados}

A metodologia e os resultados desta pesquisa estão apresentados em itens específicos sistematizados da seguinte forma:

- Seleção da escola objeto de estudo;

- Monitorização para fins de avaliação ocupacional;

- Monitorização para fins de avaliação ambiental;

- Percepção dos professores da Escola Brigadeiro Eduardo Gomes sobre as características do seu ambiente de trabalho.

Este estudo envolveu avaliações bem diversificadas e com metodologias específicas, normatizadas e extensas. As monitorizações envolveram fatores presentes nos ambientes de trabalho como ruído, 
temperatura e iluminação. Cada aspecto foi avaliado considerando-se especificidades e abordagens diferentes com base em parâmetros ocupacionais e ambientais.

Desta forma, o conteúdo coletado se apresentou complexo por abranger muitos dados. Assim, optou-se em apresentar os aspectos metodológicos de cada parâmetro avaliado, seguido dos resultados inerentes a cada item. Desse modo, a apresentação dos aspectos metodológicos adotados para análise de cada item, dos resultados obtidos no estudo e da comparação desses resultados com o que está estabelecido nas normas que regulamentam os ambientes de trabalho e a legislação ambiental estão apresentados em conjunto. Esse procedimento foi adotado a fim de proporcionar um entendimento mais direto, objetivo e adequado dos dados coletados e analisados.

\section{Seleção da escola objeto de estudo}

A seleção do objeto de estudo foi realizada a partir de análise de resultados produzidos por um estudo anterior, em 2006, orientado por professores do Departamento de Medicina Preventiva e Social da Universidade Federal da Bahia e do Núcleo de Epidemiologia da Universidade Estadual de Feira de Santana. Na análise realizada, foi utilizado questionário estruturado contendo informações sobre: características sociodemográficas, características gerais do trabalho docente, aspectos psicossociais do trabalho, condições do ambiente escolar e avaliação de possíveis efeitos sobre a saúde vocal, dentre outros. Para fins de selecionar o local deste estudo, foram analisadas as variáveis contidas no terceiro bloco do questionário que incluíam dados sobre ventilação, umidade, calor, acústica, ruído excessivo, ruído externo excessivo e luminosidade. Esses dados foram analisados com vistas a selecionar uma escola para a realização de avaliação ambiental e ocupacional. A análise foi feita após a seleção de uma Coordenadoria Regional de Educação (CRE) do município, dentre todas existentes.

A CRE selecionada foi a de número seis por ser esta a coordenadoria com o maior número de questionários aplicados aos professores da rede municipal, totalizando 533. Além disso, de acordo com dados fornecidos pela Secretaria Municipal da Educação, Cultura, Esporte e Lazer, a CRE 6 (Itapuã) possui o maior número de escolas (49 unidades), 
portanto, sendo a regional de Salvador com o maior número de escolas também. (SALVADOR, 2012) Para a escolha da escola a ser estudada foi utilizado como critério de seleção específico os resultados obtidos com a análise das variáveis descritas acima (relativas a ruído, temperatura e iluminação). Assim, depois de selecionada a CRE 6 (Itapuã), foi feita a seleção da escola com o maior percentual de queixas dos professores com relação ao seu ambiente e trabalho.

Com base nesses procedimentos minuciosos de seleção, em que foram avaliadas diversas características do ambiente escolar, a Escola Municipal Brigadeiro Eduardo Gomes da CRE 6 (Itapuã) se apresentou como a instituição de maior percentual de queixa referidas pelos professores da rede municipal.

\section{Características da edificação da escola Brigadeiro Eduardo Gomes e seu entorno}

A Escola Brigadeiro Eduardo Gomes (BEG) está localizada no bairro de São Cristóvão, entre duas vias de circulação intensa. Uma via é caracterizada como coletora I (Avenida Aliomar Baleeiro) e a outra é caracterizada como via local (Rua Lauro de Freitas). A zona de concentração de situação do lote é residencial, entretanto, seu entorno é caracterizado por uma zona de concentração de uso comercial e de serviços. As edificações que margeiam o lado Sul da edificação escolar possuem, em média, dois pavimentos e estão voltadas, em sua maioria, para o comércio e serviço local. A instituição de ensino selecionada é da modalidade fundamental II (6a a 9a série) disposta em somente um pavimento; funciona nos turnos da manhã, tarde e noite e possui seis salas de aula. O muro que delimita o lote do terreno é todo em alvenaria e não possibilita visibilidade do interior da edificação.

Por estar situada em área inadequada, a Escola BEG sofre interferências do entorno urbano no ambiente da sala de aula. A proximidade do Aeroporto (ruído proveniente das aeronaves que passam com frequência durante o dia e em altura reduzida) e a localização entre duas vias de circulação intensa de veículos (ruído proveniente do trânsito e do comércio com edificações de baixo gabarito) são fatores agravantes para a configuração de um ambiente de ensino saudável. Existe, também, um 
terminal de ônibus no lado norte do entorno da edificação e a frequência de ônibus estacionados ou em movimento é constante.

Além da interferência do ruído urbano, as salas de aula possuem grande interferência do ruído proveniente da própria escola, pois ficam localizadas ao redor do pátio coberto e as paredes que dão para o pátio possuem aberturas horizontais, acima da lousa, para favorecer a ventilação cruzada. Isso dificulta o controle do ruído em sala de aula, principalmente, quando alguma turma fica sem professor no horário de aula. A Escola BEG contém seis salas de aula, diretoria, secretaria, uma cantina, dois banheiros, uma sala dos professores, uma sala de informática, uma sala de vídeo, uma biblioteca, um pátio coberto e uma quadra esportiva, em um pavimento (Figura 1).

A disposição das salas de aula é ao redor do pátio coberto e a quadra esportiva fica localizada próxima às salas, provocando interferências de ruído nas salas quando utilizada para aulas práticas de educação física. A quadra foi disposta na área poente do terreno. Ambientes como a sala de professores, biblioteca, sala de informática e sala de vídeo, entretanto, estão localizadas no fundo do lote (Figura 1), sofrendo interferências do poente e próximo da quadra. A sala 03 recebe, no período da tarde, incidência solar direta, na parede lateral voltada para a quadra. Esta sala, também, tem a sua acústica prejudicada devido ao ruído advindo da quadra em momentos de aula de educação física de outra turma. As salas 01, 02 e 03 recebem incidência da luz solar durante todo o dia, no inverno e em parte do equinócio (pela manhã). As salas 04 e 05 recebem incidência solar durante todo o ano, pela manhã. 
Figura 1 - Planta baixa da escola indicando acesso e localização das salas de aula.

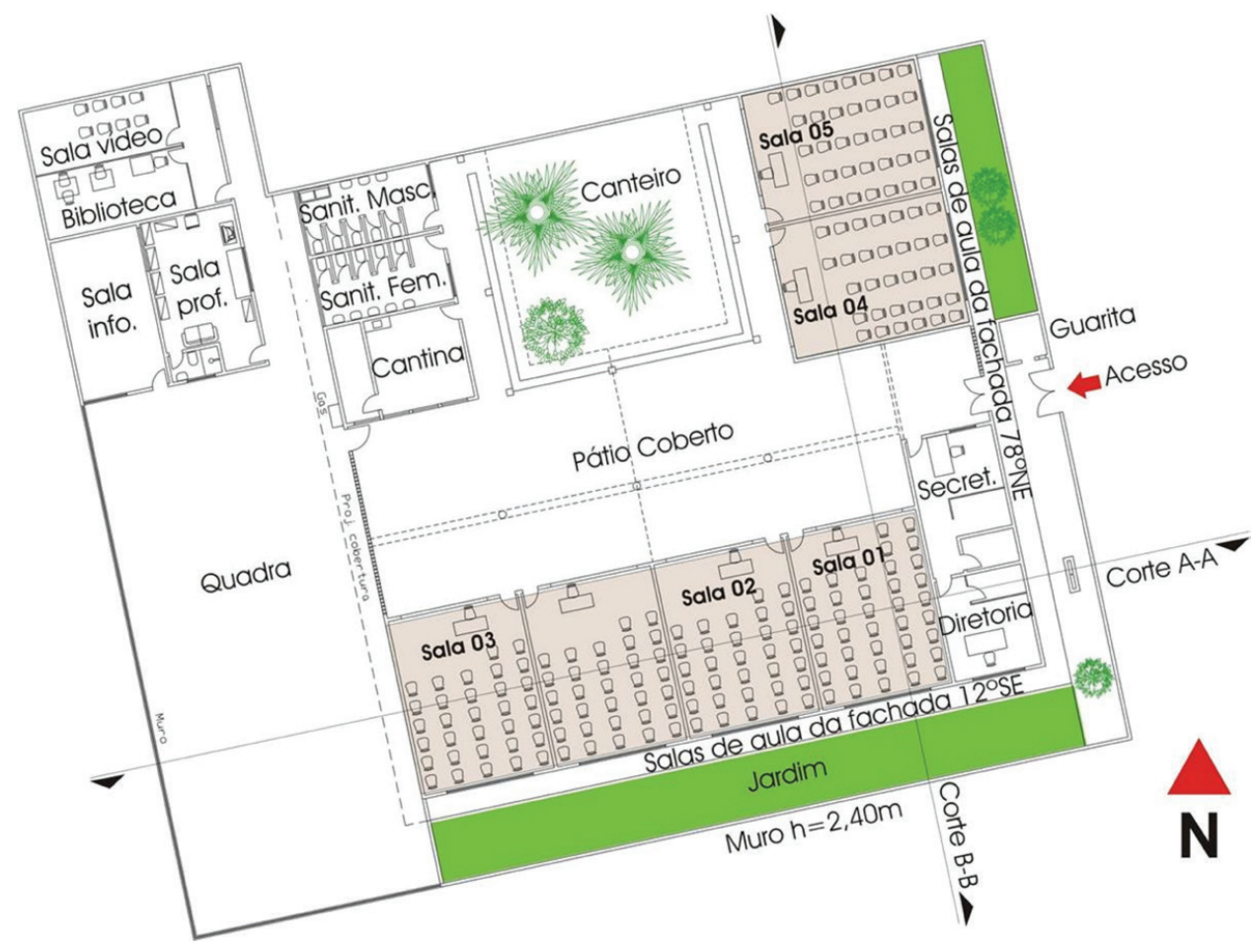

Fonte: (UCHÔA, 2009)

O edifício escolar possui laje coberta com telha em fibrocimento. As salas de aula estão dispostas, na maior parte, voltadas para a fachada $12^{\circ} \mathrm{SE}$. Não existe iluminação zenital na cobertura, o que contribuiria para a melhoria da iluminação em sala de aula. Entretanto, o nível de ruído aumentaria no momento da passagem das aeronaves, devido à proximidade de altura dos voos.

As salas de aula são padronizadas e possuem dimensões de $6,00 \mathrm{~m}$ x $8,00 \mathrm{~m}$, totalizando $48,00 \mathrm{~m}^{2}$. O edifício tem pé direito de $3,13 \mathrm{~m}$ com salas de aula com ventilação cruzada, por meio de janelas de correr com telas em aço nas fachadas e aberturas localizadas acima da lousa no lado oposto à janela. Cada sala possui dois ventiladores de parede giratórios localizados nas paredes laterais na altura de $2,30 \mathrm{~m}$ do piso. A abertura de entrada possui área maior que a abertura de saída do vento. O correto seria o inverso para aumentar a eficiência da ventilação.

As salas estão posicionadas a barlavento (região de onde sopra o vento em relação ao edifício) da edificação. Os ventos predominantes sopram em direção às fachadas $12^{\circ} \mathrm{SE}$ e $78^{\circ} \mathrm{NE}$, onde estão localizadas as janelas. 
A forma da edificação tem grande influência no conforto ambiental, visto que interfere diretamente nos fluxos de ar do interior e do exterior e, também, na quantidade de luz e calor recebidos pelo prédio. Esse aspecto tem sido desconsiderado, e são frequentes, por medidas de economia, coberturas de escolas com telhas de fibrocimento amianto que absorvem o calor e transformam as salas de aulas em verdadeiras estufas, motivo de frequentes queixas de alunos e professores. (RIBEIRO, 2004, p.110)

As salas de aula da Escola BEG são favorecidas pelos ventos Nordeste, Leste e Sudeste. Os ventos predominantes, entretanto, possuem dificuldade em adentrar a edificação da Escola devido à existência de um muro maciço limítrofe que circunda todo o lote da edificação e devido à existência de uma tela quadriculada, em aço, nas janelas das salas de aula. A posição e o tamanho das esquadrias na sala de aula, portanto, devem ser planejadas de forma a minimizar a propagação do ruído entre os ambientes internos da edificação. No caso da Escola BEG, as aberturas de saída de vento localizadas acima da lousa, contribui bastante para a interferência do ruído externo à sala de aula.

A dificuldade na criação de condições acústicas adequadas está, principalmente, ligada à localização das escolas, em geral próximas a vias movimentadas, à falta de recuo, à localização e tamanho de janelas das salas de aula e à localização das quadras de esporte. (BERTOLI, 2001) Além disso, as carteiras não apresentam proteção de borracha nos pés de ferro e por isso o atrito gerado com o piso da sala resulta em elevado nível de ruído. A durabilidade dessas peças de borracha é reduzida e logo as carteiras ficam danificadas.

\section{Monitorização para fins de avaliação ocupacional}

Após a análise das características da edificação e entorno da Escola BEG, métodos quantitativos foram utilizados para a monitorização do ruído, temperatura e iluminação. Nesta fase foram selecionadas cinco das seis salas de aula, considerando que as medições seriam feitas durante todo o dia em cada sala de aula, durante uma semana. A monitorização foi iniciada na segunda-feira (02/06/2008) pela Sala 01 e nos dias seguintes seguiu-se a ordem numérica: Sala 02 (03/06/2008), 
Sala 03 (04/06/2008), Sala $04(05 / 06 / 2008)$ e Sala $05(06 / 06 / 2008)$ (Figura 1).

O período de monitorização foi de cinco dias úteis consecutivos por ser este considerado o ciclo de trabalho semanal do professor que se repete durante o mês de trabalho. Nesta etapa foi realizada a medição de ruído, temperatura e iluminação com a escola funcionando em cotidiano normal para avaliar as condições do ambiente laboral do professor em atividade. A cada aula concluída, era aplicado um questionário sobre situações relacionadas ao conforto térmico, acústico e lumínico. Como a Escola tem seis salas de aula e a semana só tem cinco dias úteis, uma sala de aula foi excluída da monitorização (a sala que não está com numeração na Figura 1) por possuir características muito semelhantes à Sala 2 já incluída nas medições (Figura 1).

Os equipamentos foram colocados na posição onde o professor passa a maior parte do tempo na aula, próximo à lousa e à mesa do professor.

As medições foram feitas com equipamentos específicos para avaliar cada fator ambiental do conforto térmico, acústico e lumínico e a calibração destes equipamentos foi realizada conforme os padrões de referência específicos. Foi utilizado um questionário adaptado, a partir dos instrumentos de outras pesquisas realizadas, elaborado com base nas Normas ISO 7.730 (1994) e ISO 10.551(1995).

As medições foram realizadas, simultaneamente (ruído, temperatura e iluminação), no período de uma semana (uma sala de aula em cada dia). A coleta de dados foi informada aos usuários da Escola, mas o tipo de equipamento e a variável de mensuração não foram informados detalhadamente a fim de não influenciar no comportamento dos alunos e na coleta dos dados.

Para avaliação do ruído foi utilizado o medidor de nível de pressão sonora digital modelo MSL-1.352C de marca Minipa. O medidor de nível de pressão sonora registra, de forma direta, o nível da pressão sonora de um fenômeno acústico.

A legislação brasileira, por meio de sua Norma Regulamentadora NR15 do MTE - Anexo A, estabelece que os níveis de ruído contínuo ou intermitente devem ser medidos em decibéis $(\mathrm{dB})$ com instrumento de nível de pressão sonora operando no circuito de compensação "A" e circuito de resposta lenta (SLOW). (BRASIL, 2009) Foi utilizado, 
também, um calibrador de nível sonoro MSL-1.336 da marca Minipa, que estava em conformidade com as Normas ANSI-1984 e IEC60.9422003 Classe 2.

Em relação ao ruído ocupacional, a monitorização foi planejada com base nas normas técnicas específicas para a atividade e o tipo de ambiente. As leituras devem ser feitas próximas ao ouvido do trabalhador. Assim sendo, a medição do nível de pressão sonora na escola foi realizada a partir do medidor de nível de pressão sonora digital, operando com estes parâmetros e intervalos programados de 10 em 10s. O importante era avaliar as salas de aula com seu cotidiano e funcionamento normal, portanto, não foram controladas as condições do ambiente. O medidor de nível de pressão sonora foi colocado no local onde o professor passa a maior parte do tempo, próximo à lousa e à mesa docente, na altura de 1,30m do piso, considerando a altura média do campo de audição de uma pessoa. As distâncias determinadas foram de $1,00 \mathrm{~m}$ da parede do quadro e $2,90 \mathrm{~m}$ da parede lateral oposta à porta. Foi utilizada como referência a NBR 10.152 da Associação Brasileira de Normas Técnicas, 1987 que estabelece níveis de conforto em escolas entre 40 e 50dB (sendo 40dB o limite confortável e 50dB o limite aceitável).

O horário de medição foi de $07 \mathrm{~h} 30$ as $11 \mathrm{~h} 50$, considerando 1.465 valores analisados e de $13 \mathrm{~h} 30$ as $17 \mathrm{~h} 40$, considerando 1.405 valores analisados, totalizando 2.870 dados por dia.

A sala 04 , monitorizada no dia $05 / 06 / 2008$, não pode ser diagnosticada com maior precisão como as outras, considerando que só foi monitorizada em uma parte no turno da manhã e outra no turno da tarde, devido a realização de atividade pedagógica sobre o Dia do Meio Ambiente, a rotina da escola foi um pouco modificada em decorrência dessa atividade.

Foram calculados os níveis de ruído mínimo (Lmin), de fundo (L90), equivalente (Leq), esporádico (L10) e máximo (Lmax) em cada turno por dia de coleta. Foi possível identificar que os níveis de ruído variaram conforme o perfil da turma. Como cada turma foi submetida à medição durante um dia, foi possível comparar os níveis de ruído equivalente de cada uma. Os resultados mostraram que a sala 01 apresentou um nível de ruído mais elevado em relação às outras. As salas 02 e 03 são utilizadas por turmas de $7^{\mathrm{a}}$ e $8^{\mathrm{a}}$ séries (02) e $9^{\mathrm{a}}$ série (03), respectivamente. A faixa etária, portanto, influencia no comportamento e na 
geração do ruído. Já as salas 01, 04 e 05 são utilizadas por turmas de $7^{\mathrm{a}}(01)$ e $6^{\mathrm{a}}$ séries (04 e 05), respectivamente. As turmas da sala 01 são de $7^{\mathrm{a}}$ série nos dois turnos, entretanto, os professores, nas entrevistas nesta sala, ressaltaram o comportamento extremamente indisciplinado dessas turmas.

Foram calculados os mesmos níveis de ruído (Lmin, L90, Leq, L10, Lmax) por dia de coleta. O dia que apresentou situação mais crítica foi o dia 02/06/2008, porque o nível de ruído equivalente (Leq) foi de $86,4 \mathrm{~dB}(\mathrm{~A})$ e ultrapassou o valor de $85 \mathrm{~dB}(\mathrm{~A})$ estabelecido como limite de tolerância pela NR 15. (BRASIL, 2009) Além disso, este mesmo dia apresentou valor de $\operatorname{Lmax}$ de $116,7 \mathrm{~dB}(\mathrm{~A})$, considerado o mais alto dos valores referentes a esta medida estatística. O item 7 do Anexo 1 da NR 15 determina que as atividades que resultem em exposição de trabalhadores a níveis de ruído, contínuo ou intermitente, superiores a $115 \mathrm{~dB}(\mathrm{~A})$, sem proteção adequada, oferecerão risco grave e iminente. O nível de $116,7 \mathrm{~dB}(\mathrm{~A})$ encontrado nas mensurações está acima do limite de $115 \mathrm{~dB}(\mathrm{~A})$ da NR 15, o que caracteriza uma situação muito atípica. (BRASIL, 2009) Este diagnóstico de monitorização é mais frequente em situações ocupacionais de grave e iminente risco, existentes geralmente, em atividades industriais ou outras caracteristicamente ruidosas. Os alunos, por sua vez, estão expostos aos mesmos eventos de risco ambiental ocupacional. As vivências em salas de aula com ambientes ruidosos e com calor excessivo se comparam às condições existentes em galpões de linhas de produção industrial. O risco de perda auditiva começa a ser significativo a partir de um nível equivalente diário de 80dBA. (INSHT, s.d.) Não significa, entretanto, que uma pessoa não possa sofrer de perda auditiva exposta a níveis de ruído mais reduzidos. A exposição ao ruído está relacionada à susceptibilidade do indivíduo que está em atividade laboral.

O professor da Escola BEG, portanto, está submetido a níveis de ruído considerados inadequados para a realização da atividade laboral. O nível de exposição diário ao ruído deve ser mantido abaixo de $80 \mathrm{~dB}(\mathrm{~A})$. (INSHT, s.d.)

No caso da Escola BEG, os níveis de ruído equivalente ultrapassaram, durante todos os dias, o nível de $80 \mathrm{~dB}(\mathrm{~A})$. Isto significa que os professores estão expostos a níveis de ruído considerados danosos à saúde. 
Os níveis de ruído esporádico (L10) apresentaram valores um pouco acima dos níveis de ruído equivalente (Leq). Os níveis de ruído de fundo (L90) variaram de 67,6 dB(A) a 71,5dB(A). Estes valores são considerados bastante elevados para a sala de aula. Portanto, para que seja mantida a diferença (sinal/ruído) de $10 \mathrm{~dB}(\mathrm{~A})$ entre o nível de fala e o ruído de fundo, a fim de que haja a inteligibilidade das palavras na sala de aula, é necessário que o professor aumente bastante o volume da voz para ser compreendido.

No estudo realizado por Bertoli (2001), levantando resultados das medições de Nível de Pressão Sonora (NPS) equivalente em 15 escolas estaduais, em três horários diferentes do dia, notou-se também que as fontes de ruído interno (próprios alunos, aparelho de ventilação) e as fontes de ruído externo (ruas ruidosas, pátio, corredores), são semelhantes em todas as escolas e a influência que elas exercem no aumento do NPS equivalente tem valores, aproximadamente, iguais.

Leucz (2001), com base em estudo realizado, traz a mensuração de ruído em quinze escolas selecionadas (cinco municipais, cinco estaduais e cinco particulares) e mostra que todas as escolas avaliadas revelaram resultados de nível de pressão sonora acima de $50 \mathrm{~dB}$, sendo este o nível limite estabelecido pela NBR 10.152 para o interior da sala de aula. (ASSOCIAÇÃO BRASILEIRA DE NORMAS TÉCNICAS, 1987) Os resultados de Nível de Pressão Sonora Equivalente - Leq variaram entre $62,5 \mathrm{~dB}(\mathrm{~A})$ a $77,5 \mathrm{~dB}(\mathrm{~A})$. O estudo, entretanto, não apresentou uma metodologia de mensuração detalhada e rigorosa. Cada sala de cada escola foi submetida a quatro pontos de medição para cálculo do Leq, e não foi apresentado o método de escolha destes pontos ou da sala selecionada para medição.

A pesquisa realizada por Eniz (2004) descreve as condições acústicas das salas de aula de escolas da rede pública e privada do Distrito Federal. Dentre as instituições avaliadas pela pesquisa, existe uma escola do ensino fundamental com as mesmas características que a Escola BEG, "prensada" entre duas avenidas movimentadas, com tráfego aéreo e terrestre intenso em sua vizinhança. O nível de pressão sonora equivalente, na escola semelhante à $\mathrm{BEG}$, foi de $82,7 \mathrm{~dB}(\mathrm{~A})$. Outros níveis observados foram: $\mathrm{Lmin}=46,6 \mathrm{~dB}(\mathrm{~A}), \mathrm{L} 90=64,4 \mathrm{~dB}(\mathrm{~A}), \mathrm{L} 10=86,5 \mathrm{~dB}(\mathrm{~A})$ e $\operatorname{Lmax}=106,8 \mathrm{~dB}(\mathrm{~A})$. A Escola $\mathrm{BEG}$, quando comparada à escola do estudo realizado por Eniz (2004), apresentou resultados semelhantes, 
o que confirma a situação crítica de edificações com este perfil avaliadas em outras pesquisas.

Em relação às medições de temperatura, a NR15 estabelece que estas devam ser realizadas no local onde permanece o trabalhador, à altura da região do corpo mais atingida. (BRASIL, 2009) Para a avaliação do conforto térmico foram utilizados: um tripé, o termômetro de globo modelo TGD-200 da marca Instrutherm e um anemômetro de palhetas designado termo anemômetro digital modelo MDA-11 da marca Minipa (para mensurar a velocidade do ar). Neste último, foi configurada a opção modo média $2 / 16 \mathrm{sec}$ para obter o valor médio de vento a cada 2 segundos. As situações estáveis das salas de aula foram: janelas abertas e iluminação artificial acionada durante todo o período de medição.

O tripé possibilitou determinar a altura ideal do equipamento para o objetivo do estudo. O termômetro de IBUTG foi colocado na posição onde o professor passa a maior parte do tempo na aula, próximo à lousa e à mesa, na altura do tronco, a 1,20m do piso. Por meio deste equipamento, foi medido, também, o IBUTG (Índice de Bulbo Úmido e Termômetro de Globo). Esta medição foi realizada a fim de investigar a exposição ao calor, considerando os limites de tolerância conforme o tipo de atividade e o regime de trabalho do professor. Os procedimentos desta avaliação foram estruturados a partir de orientações da Norma Regulamentadora Atividades e Operações Insalubres-NR15. (BRASIL, 2009) Por meio do índice IBUTG é possível estabelecer limites de tolerância para exposição ao calor, de acordo com taxa de metabolismo - Quadro 2 do Anexo 3 da NR15 - e o tipo de atividade de cada indivíduo - Quadro 1 do Anexo 3 da NR15. (BRASIL, 2009) Segundo a NR15 (BRASIL, 2009), o IBUTG é um índice de avaliação de exposição ao calor, não considerado parâmetro para conforto térmico, e sim, para tolerância a temperaturas extremas.

De acordo com o Quadro 3 do Anexo 3 da NR15 foi considerado o tipo de atividade moderada, especificamente, de pé, trabalho leve, em máquina ou bancada, com alguma movimentação (taxa de metabolismo de $220 \mathrm{kcal} / \mathrm{h}$ ). (BRASIL, 2009) De acordo com o Quadro 2 do Anexo 3 da NR15 para esta taxa de metabolismo requerida, o IBUTG máximo deve ser de 26,7. (BRASIL, 2009) Este método, geralmente, é utilizado para atividades de sobrecarga térmica (ambientes muito quentes com taxas metabólicas altas), portanto, esperou-se que os valores levantados 
fossem abaixo dos limites determinados pela NR15, considerando que estes dados são elevados para serem utilizados como parâmetros de referência no ambiente escolar. (BRASIL, 2009) Os dados foram registrados de 30 em 30 minutos por ser a temperatura uma condicionante ambiental com variações mais homogêneas. Além desse equipamento, foi utilizado o anemômetro térmico ou anemômetro de palhetas para medir a velocidade do ar. $\mathrm{O}$ anemômetro também ficou na mesma altura, próximo à mesa de trabalho do professor e foi locado a sotavento da sala de aula, o lugar menos ventilado, considerando ser o local onde o professor passa a maior parte do tempo. Por ser uma variável em que as questões subjetivas influenciam, durante as medições, foram aplicados questionários sobre as características físicas e percepção térmica dos usuários, a exemplo de idade, altura, sexo, tipo de vestimenta e sensação térmica. No questionário, também, foram incluídas questões relacionadas à percepção do conforto acústico e lumínico. Os questionários foram aplicados somente com o professor que tivesse em atividade laboral, no ambiente da sala de aula, no momento das medições.

As salas de aula mensuradas na avaliação para fins ocupacionais apresentaram resultados expressivos em relação ao conforto térmico. Como estas medições foram realizadas com a escola em funcionamento normal, o ambiente apresentou condições físicas variáveis. Foram coletados 76 dados por dia, totalizando 380 dados na semana de coleta. As variáveis coletadas foram: Tg (Temperatura de Globo), Tbs (Temperatura de Bulbo Seco), Tbu (Temperatura de Bulbo Úmido), IBUTG (Índice de Bulbo Úmido e Termômetro de Globo). A velocidade do vento foi coletada, entretanto apresentou resultados zerados em quase todo o período de coleta, por isso, esta variável foi considerada nula para os cálculos dos índices de conforto térmico. Em relação ao limite de conforto estabelecido pela ISO 7.730 (1994), o índice PMV (Predicted Mean Vote ou Voto Médio Estimado) apresentou a maior parte dos valores, durante todos os dias de medição, acima de 0,5. Quando analisado o limite adaptado para o clima quente e úmido por Lyra (2007), os valores continuam acima do limite de 0,9 , entretanto, reduziu o período de desconforto térmico.

Os dias 02, 03 e 04 apresentaram índices acima do limite de conforto durante todo o período de medição. $\mathrm{O}$ valor mais alto identificado foi de 
2,0 no horário de 10 h00 do dia 02/06/2008. O menor valor foi de 0,22 às 8 h00 do dia 06/06/2008.

Em relação ao índice PPD (Predicted Percentage of Dissatisfied ou Percentagem de Pessoas Insatisfeitas) quase todos os valores se apresentaram acima do ideal de $10 \%$ de usuários insatisfeitos, segundo a ISO (International Organization for Standardization) 7.730 (1994). O percentual mais alto calculado com base nas variáveis coletadas nos cinco dias foi de $76,7 \%$ com PMV correspondente de 2,0 e o valor mais baixo foi de 6,0\% com PMV correspondente de 0,22.

$\mathrm{O}$ índice PET (Physiological Equivalent Temperature ou Temperatura Fisiológica Equivalente) apresentou todos os valores acima da faixa de conforto recomendada por Hoppe (1999) de 22 a $24^{\circ} \mathrm{C}$ e acima da faixa de conforto adaptada por Lyra (2007) para clima quente e úmido de 22 a $26^{\circ} \mathrm{C}$. O menor valor foi de $26,6^{\circ} \mathrm{C}$ às 8 h00 de $02 / 06 / 2008$ e o maior foi de $30,7^{\circ} \mathrm{C}$ às 10 h00 de 06/06/2008.

O índice IBUTG coletado apresentou todos os valores dentro da faixa limite de 26,7 - estabelecida pela NR15 para este tipo de atividade. (BRASIL, 2009) O maior valor foi de 26,4 , às 8 h00 de $02 / 06 / 2008$ e o menor valor foi de 23,6 às 7 h30 e 8 h00 de 06/06/2008. O índice IBUTG, na presente pesquisa, apresentou todos os resultados abaixo do limite estabelecido pela NR15, entretanto apresentou um resultado de 26,4 , às 11 h00 do dia 02/06/2008, considerado bem próximo do valor limite de 26,7 . (BRASIL, 2009) Isto significa que o ambiente está próximo de ser caracterizado como insalubre, segundo a Norma citada.

O índice de temperatura efetiva, ao longo da semana de medição, apresentou-se acima da faixa de conforto recomendada pela NR17. (BRASIL, 2009) $\mathrm{O}$ valor calculado mais alto foi de $26,67^{\circ} \mathrm{C}$ e o menor valor foi de $23,33^{\circ} \mathrm{C}$. Não houve nenhum momento em que os dados calculados se localizassem dentro da faixa de conforto da norma (de 20 a $23^{\circ} \mathrm{C}$ ). Segundo os parâmetros da NR17, o ambiente avaliado dispõe de condições inadequadas de conforto. (BRASIL, 2009)

Os índices relacionados ao conforto térmico apresentaram, nesta pesquisa, resultados acima das faixas ou limites determinados pelas cinco referências citadas: ISO 7.730 (1994), NR 15, NR 17, Hoppe (1999), Lyra (2007).

O dia 02/06/2008 foi o que apresentou os valores mais altos, tanto em relação aos índices de conforto térmico, como em relação aos 
parâmetros acústicos. Os resultados elevados da monitorização do calor deste dia podem justificar o comportamento agitado dos alunos, além de se tratar da turma avaliada como a mais indisciplinada, considerando que estes se encontravam em situação de bastante desconforto em sala de aula. Esta alteração de comportamento gerou um nível de ruído mais elevado também.

Para a mensuração da iluminação foi utilizado o luxímetro digital modelo LD-590 da marca Icel que ficou localizado na mesa de trabalho do professor. De acordo com a Norma Regulamentadora de Ergonomia NR17 da Portaria n 3.214/2009, a fotocélula deste equipamento é corrigida para a sensibilidade do olho humano. (BRASIL, 2009) O equipamento foi configurado na escala 2.000lux. O fator iluminação também não tem variações grandes num mesmo ponto, entretanto, foi possível verificar, ao longo do dia, qual a variação de iluminação na mesa de trabalho do professor, posto ser considerado um local que requer apuração visual para atividades de leitura, correção de exercícios e esclarecimento de dúvidas em sala de aula.

Os níveis de iluminação natural foram comparados aos de iluminação média recomendados pela NBR 5.413 - Iluminância de Interiores, para salas de aula com usuários com idade inferior a 40 anos, onde a velocidade e precisão são importantes e onde a refletância da tarefa está entre $30 \%$ e 70\%. (ASSOCIAÇÃO BRASILEIRA DE NORMAS TÉCNICAS, 1992) Quanto aos índices de iluminação adotados neste estudo, dadas às características do observador e da tarefa, correspondem a 500lux para a lousa e 300lux para a sala de aula a serem medidos na mesa do professor. As medições de iluminação foram configuradas para intervalos de 5 em 5 segundos e o horário de medição foi de 7 h30 às 11 h50 e 13 h30 às $17 \mathrm{~h} 40$. Na medição da iluminação para fins de avaliação ocupacional, as luzes da sala ficaram acesas durante todo o período das medições, pois as aulas foram dadas com uso de iluminação artificial durante todo o tempo.

Os valores coletados no turno da manhã foram de 3.121 e no turno da tarde de 3.002. As iluminâncias médias, nas salas de aula, permaneceram com resultados acima da média de 300lux estabelecida pela NBR 5.413. (ASSOCIAÇÃO BRASILEIRA DE NORMAS TÉCNICAS, 1992) Entretanto, houve alguns momentos em que, mesmo com a luz artificial, os níveis de iluminância foram inferiores a 300lux. No dia 
05/06/2008, no período de 2 horas e 40 minutos a partir de 07h30, os valores variaram de 118 a 299lux. Isto significa que, mesmo que os resultados de iluminância média estejam acima do limite de 300lux recomendado pela NBR 5.413, existiram momentos da medição em que os níveis de iluminância apresentados foram abaixo do valor da Norma. (ASSOCIAÇÃO BRASILEIRA DE NORMAS TÉCNICAS, 1992) As salas 04 e 05, monitorizadas em 05/06/2008 e 06/06/2008, respectivamente, apresentaram condições de iluminação mais precárias nos dois turnos.

Quando apresentados os resultados das médias diárias de iluminâncias das salas em cada dia, observou-se que os dias 05/06/2008 (sala 04) e 06/06/2008 (sala 05) apresentaram as médias mais baixas. A sala 03, monitorizada em 04/06/2008 apresentou média de 571,22lux, sendo o maior valor e a sala $05(06 / 06 / 2008)$ apresentou média de 324,50lux, sendo o menor valor.

As salas pesquisadas, com orientação $78^{\circ} \mathrm{NE}$ (sala 04 e sala 05) como dito anteriormente, só recebem incidência do sol durante a manhã. Entretanto, mesmo no período da manhã, a vegetação e o muro presentes na frente das janelas interferem bastante na iluminação. A sala 01, como as salas 04 e 05, também apresentou níveis de iluminância mais baixos, entretanto, esta sala apresentava luminárias incompletas. A medição, com a sala de aula em funcionamento, foi realizada durante o dia e com as luzes acesas, observando-se os níveis de iluminância acima do valor recomendado pela NBR 5.413. (ASSOCIAÇÃO BRASILEIRA DE NORMAS TÉCNICAS, 1992)

Quando iluminadas artificialmente durante todo o dia, as salas de aula apresentaram resultados conformes aos requisitos estabelecidos na norma. Uma medida econômica a ser adotada é a opção do professor de ligar somente as lâmpadas da frente (parte mais prejudicada pela iluminação natural) e os assentos próximos às janelas seriam servidos somente pela luz natural. O edifício, portanto, foi projetado para funcionar com iluminação artificial durante o seu funcionamento. Os gastos com energia elétrica são altos e se transformam em custos inativos para o mantenedor da Escola. 


\section{Monitorização para fins de avaliação ambiental}

As medições deste período foram feitas nos dias 30/06/2008, 01/07/2008 e 02/07/2008 (segunda, terça e quarta-feira, respectivamente) por serem dias da semana normais - com exceção do dia 02/07/2008 que foi feriado local. Esta preocupação se deu para que fosse mensurado o ambiente da Escola com as características de funcionamento normal do entorno, sendo possível comparar também (o nível de ruído) com um dia atípico de feriado.

Como a escola se encontrava vazia, foi possível a mobilidade e precisão no deslocamento dos equipamentos sem maiores transtornos, devido à marcação prévia dos pontos com fita adesiva nas duas salas monitorizadas. As medições eram realizadas simultaneamente. Os equipamentos foram colocados de forma a mensurar os fatores ambientais na sala de aula. Foram selecionadas duas salas de aula padrão, com orientações distintas, para fazer uma medição alternada da temperatura, ruído e, quase simultânea da iluminação. As medições foram realizadas em duas salas selecionadas com orientações de fachada diferentes. As salas selecionadas foram: salas 02 e 04 (Figura 1), sendo as medições iniciadas pela sala 02 .

A medição do nível de pressão sonora foi realizada, a partir do medidor digital modelo MSL-1.352C de marca Minipa, utilizando-se as condições sugeridas pela NBR 10.152 da Associação Brasileira de Normas Técnicas (1987), operando no circuito de compensação "A" e circuito de resposta rápida (FAST) e os intervalos programados foram de $5 \mathrm{~s}$ em $5 \mathrm{~s}$. Além disso, este modo operativo fornece o valor de pico do nível de pressão sonora e apresenta medições mais representativas em situações de características dinâmicas como voo baixo de aeronave em alta velocidade. Como a escola estudada está sujeita a este tipo de interferência ruidosa (ruído aeronáutico) por estar localizada no raio de proximidade do Aeroporto, na medição para fins de avaliação ambiental com a edificação vazia foi determinada a adoção do modo FAST, utilizado para diagnosticar as interferências do ruído urbano no edifício.

A metodologia foi elaborada, portanto, com base na NBR 10.151 da Associação Brasileira de Normas Técnicas (2000) e no documento de Procedimentos Específicos de Medição de Ruído Ambiente do Instituto do Ambiente de Portugal. (PORTUGAL, 2003) As posições 
de medições devem situar-se pelo menos a $1 \mathrm{~m}$ das paredes ou outras superfícies refletoras, a $1,5 \mathrm{~m}$ das janelas e portas e entre $1,2 \mathrm{~m}$ a $1,5 \mathrm{~m}$ acima do solo. A NBR 10.151, determina uma distância de no mínimo $1 \mathrm{~m}$ de quaisquer superfícies, como paredes, teto, pisos e móveis. (ASSOCIAÇÃO BRASILEIRA DE NORMAS TÉCNICAS, 2000) As medições foram efetuadas em condições normais de uso do ambiente com janelas abertas, segundo a NBR 10.151. (ASSOCIAÇÃO BRASILEIRA DE NORMAS TÉCNICAS, 2000)

De acordo com os dois documentos, as medições em interior devem ser selecionadas considerando, no mínimo, três pontos distintos, afastados entre si, no mínimo $50 \mathrm{~cm}$. Segundo o Instituto do Ambiente (PORTUGAL, 2003), o resultado deve ser a média logarítmica dos valores obtidos nos três pontos. O equipamento foi locado a $1,50 \mathrm{~m}$ do perímetro da sala de aula, com distância entre os três pontos de $3,39 \mathrm{~m}$ e altura de 1,2m do piso. As medições foram programadas a intervalos de $5 \mathrm{~s}$ e em modo de resposta FAST, segundo a NBR 10.152. (ASSOCIAÇÃO BRASILEIRA DE NORMAS TÉCNICAS, 2000)

A escolha do intervalo de tempo de medição deve permitir obter um valor representativo da situação a caracterizar. No limite, a sua duração pode coincidir com a duração de todo o intervalo de tempo de referência, correspondendo assim a uma medição em contínuo. No caso de não serem efectuadas medições em contínuo, recomenda-se que o intervalo de tempo de medição acumulado do conjunto de amostras obtidas seja, no mínimo, de 30 minutos e que cada amostra não seja inferior a 10 minutos, excepto quando a duração do ruído particular for inferior. Recomenda-se que a recolha de amostras para a obtenção do valor representativo tanto do ruído ambiente como do ruído residual seja repetida em, pelo menos, dois dias distintos. (PORTUGAL, 2003, p. 3, grifo nosso)

Foram postos três pontos em duas salas com localizações diferentes. No presente estudo foram coletadas amostras de 30 minutos em cada ponto de medição de cada sala de aula, de forma alternada (de uma sala para outra). Foi utilizada como referência a NBR 10.152 da Associação Brasileira de Normas Técnicas (1987) que estabelece níveis de conforto em escolas entre 40 e $50 \mathrm{~dB}$ (sendo $40 \mathrm{~dB}$ o limite confortável e $50 \mathrm{~dB}$ o limite aceitável). As medições foram feitas na ausência de chuva, ventos fortes e outras fontes sonoras atípicas. Segundo o CREA-BA (2005), o limite estabelecido pela Lei Municipal n 5.354/1998 é 
de $70 \mathrm{~dB}$ entre $7 \mathrm{~h} 00$ e $22 \mathrm{~h} 00$ e $60 \mathrm{~dB}$ no período intermediário. A OMS aponta que o volume ideal vai até $50 \mathrm{~dB}$. Em cada ponto foram coletados 349 dados totalizando 1.047 dados a cada hora e meia em cada sala, de forma alternada. Para apresentar os resultados, os dados foram tabulados e, posteriormente, calculados os níveis equivalentes de ruído (Leq) em cada período.

Durante cada dia, foram coletados 7.329 registros, totalizando níveis de ruído equivalentes a 57,29 dB (A) no dia 30/06/2008, $57,30 \mathrm{~dB}$ (A) no dia 01/07/2008 e 56,59 dB (A) no dia 02/07/2008. Calculado o Leq diário, envolvendo os dados coletados nas salas 02 e 04 , os resultados apresentados sofreram uma variação quase imperceptível do dia 30/06/2008 para o dia 02/07/2008. O nível de ruído equivalente diário calculado teve quase o mesmo resultado nos dias 30/06/2008 e 01/07/2008. No dia 02/07/2008 o resultado do Leq diário teve uma leve queda em relação aos dias anteriores. Considerando que o dia 02/07/2008 é feriado referente à comemoração da Independência da Bahia, provavelmente o nível de ruído equivalente tenha sido reduzido porque os ruídos urbanos sofrem alterações. A frota de ônibus é reduzida, o comércio fecha as portas e o trânsito de pessoas na rua também diminui.

Os valores de Leq calculados ultrapassaram o nível de 40dB(A) (na condição de janela aberta) estabelecido pela NBR 10.151. (ASSOCIAÇÃO BRASILEIRA DE NORMAS TÉCNICAS, 2000) O elevado nível de ruído externo pode ser em decorrência dos eventos que ocorrem com frequência no entorno urbano como: passagem de aeronaves, carro de som, ônibus, helicóptero, caminhão, veículos de passagem, dentre outros.

A temperatura foi outra variável avaliada no edifício escolar sem ocupação. Para a avaliação da temperatura foi determinado um ponto central em cada sala de aula. Posteriormente, foram sendo anotados, em um formulário de observação intensiva, os valores das temperaturas de trinta em trinta minutos. Foram coletados dados de temperatura do ar ou de bulbo seco, temperatura de bulbo úmido, temperatura de globo e velocidade do ar. $\mathrm{O}$ anemômetro foi locado a $50 \mathrm{~cm}$ da abertura de entrada, localizada a barlavento, região de onde sopra o vento em relação à edificação, para que fosse possível considerar a melhor situação do ambiente. Para mensurar a temperatura, foram coletados, por dia, 
84 dados de variáveis relacionadas ao conforto térmico e estresse térmico, totalizando 252 dados coletados nos três dias. Dados de pressão de vapor e umidade relativa foram necessários para o cálculo dos índices de conforto térmico. Para calcular a pressão de vapor, foi preciso a pressão de saturação correspondente à temperatura de bulbo seco e a pressão de saturação correspondente à temperatura de bulbo úmido. Os índices IBUTG, PMV, PPD e PET foram avaliados com a escola vazia para avaliar quais as condições de conforto ambiental que o edifício dispõe como ambiente de trabalho. O IBUTG nesta fase foi calculado com o uso de fórmula específica apresentada na NR15. (BRASIL, 2009)

$\mathrm{O}$ índice PMV apresentou parte dos resultados acima da faixa de conforto estabelecida pela ISO 7.730 (1994) entre -0,5 e 0,5. Entretanto, segundo o limite adaptado por Lyra (2007) para o clima quente e úmido em estudo de dissertação de mestrado voltado para o ambiente escolar, os valores do PMV permaneceram, em grande parte, na faixa de conforto, apresentando desconforto térmico em um período menor. O valor máximo apresentado nos três dias foi de 1,12 e o valor mínimo foi de - 0,71 - ambos fora da faixa de conforto térmico. É importante ressaltar que os valores de PMV situados dentro da faixa de conforto se apresentaram como aceitáveis, considerando que a edificação estava desocupada neste período de avaliação do ambiente e as temperaturas médias compensadas são mais amenas na época de junho e julho.

$O$ índice PPD referente ao percentual de pessoas insatisfeitas, também, apresentou a maior parte dos valores dentro da faixa de conforto, quando apenas $10 \%$ das pessoas se diziam insatisfeitas. O maior percentual de pessoas insatisfeitas foi de 25,80\% às $10 \mathrm{~h} 30$ do dia 02/07/2008. O valor do índice PMV correspondente a este valor de PPD foi de 0,99.

$\mathrm{O}$ índice PET apresentou grande parte dos valores fora da faixa de conforto térmico, conforme o parâmetro entre 22 e $24^{\circ} \mathrm{C}$, estabelecido por Hoppe (1999). Lyra (2007) adaptou a faixa para o clima quente e úmido e segundo este novo parâmetro, estabelecido entre 22 a $26^{\circ} \mathrm{C}$, grande parte dos valores foi incorporada pela faixa de conforto térmico. $\mathrm{O}$ maior valor apresentado foi de $27,2^{\circ} \mathrm{C}$, às 14 h00 do dia $01 / 07 / 2008$ e o menor valor foi de $23,2^{\circ} \mathrm{C}$, às 8 h30 do dia $30 / 06 / 2008$. Considerando-se o limite de Hoppe (1999) para o índice PET, grande parte dos valores se apresentou na região considerada inadequada para o con- 
forto térmico. Quando considerado o limite adaptado por Lyra (2007), alguns valores ainda se localizaram fora do valor limite.

Nos três dias de medição, as salas de aula atingiram IBUTG máximo de 24,9 às 14 horas do dia 30/06/2008 e o mínimo de 22,8 às 8 horas do dia 02/07/2008. Neste período de medição, portanto, não foi ultrapassado o valor limite para considerar a atividade insalubre. Os valores do IBUTG ficaram abaixo do limite determinado pela NR15. (BRASIL, 2009)

O índice de temperatura efetiva apresentou a maior parte dos valores acima da faixa de conforto recomendada pela NR17 nos três dias, nas duas salas de aula. (BRASIL, 2009) O valor mais alto calculado foi de $24,17^{\circ} \mathrm{C}$ e o menor valor foi de $22,78^{\circ} \mathrm{C}$. Para efeito de avaliação da NR17, portanto, a condição da sala de aula, considerando a melhor ventilação da sala, foi precária e atribuída como desconfortável. (BRASIL, 2009) O índice TE apresentou a maior parte dos resultados acima do limite recomendado pela NR17. (BRASIL, 2009) Este índice foi adotado neste estudo, exclusivamente, a fim de verificar se atenderia ou não à NR 17, considerando ser esta a única norma regulamentadora que determina recomendações de conforto, embora, segundo a literatura, este índice não seja o mais adequado e moderno para avaliação do conforto térmico de um ambiente, por não considerar outras variáveis que envolvem esta quantificação. (BRASIL, 2009)

As medições de iluminação foram realizadas em duas salas de aula de cada escola com mesmas dimensões entre si, entretanto localizadas com diferentes orientações. A Escola permaneceu com as luzes apagadas durante os horários de medição. Somente no horário de 18 horas, as luzes da sala de aula foram acionadas. A NBR 15.215-4 - Iluminação Natural / Parte 4: Verificação Experimental das Condições de iluminação Interna das Edificações / Método de Medição da Associação Brasileira de Normas Técnicas (2004), foi utilizada como parâmetro para a metodologia de mensuração da iluminação nas salas de aula. Segundo a Norma, para dimensionar a quantidade mínima de pontos a serem medidos no ambiente, deve ser calculado o índice do local (k) por meio de equação específica.

No caso da sala de aula da Escola Brigadeiro Eduardo Gomes, o comprimento da sala é de $8 \mathrm{~m}$, a largura é de $6 \mathrm{~m}$ e a distância vertical entre a superfície de trabalho e o topo da janela é de $1,5 \mathrm{~m}$, totalizan- 
do um $\mathrm{k}=2,29$. Segundo a Tabela 2 da NBR 15215-4, para $2 \leq \mathrm{k}<3$, a quantidade mínima de pontos requeridas deve ser de 25 pontos. (ASSOCIAÇÃO BRASILEIRA DE NORMAS TÉCNICAS, 2004) As medições foram obtidas em três dias, em cinco horários diferentes. As medidas foram obtidas em quatro pontos ao longo do mesmo afastamento (um metro) da janela e para sete afastamentos diferentes $(1,20 \mathrm{~m}$; $2,40 \mathrm{~m} ; 3,60 \mathrm{~m} ; 4,80 \mathrm{~m}$ ) totalizando vinte e oito pontos por sala. Foram medidas as duas salas em seis horários diferentes: 8, 10, 12, 14, 16 e 18 horas. Por não dispor de dois luxímetros para medições simultâneas em cada sala, as medições foram iniciadas em uma das duas salas medidas em cada escola aproximadamente dez minutos antes do horário estipulado, conforme método de Ghisi e Lamberts (1997). Após este intervalo de tempo, ou seja, no início do horário estipulado iniciavam-se as medições na outra sala. Para a medição, foi utilizado um luxímetro digital. As medições foram realizadas respeitando-se a ordem e distribuição dos pontos. Segundo a NBR 15.215-4, deve-se planejar a malha evitando pontos muito próximos às paredes, portanto, recomenda-se um afastamento mínimo de 0,50m. (ASSOCIAÇÃO BRASILEIRA DE NORMAS TÉCNICAS, 2004)

Nesta fase foi utilizado um formulário em formato de planta baixa onde foram anotados os valores (lux) dos 28 pontos de iluminação de cada sala. Foi selecionado um ponto no quadro da sala que foi medido antes da sequência de medições de cada sala. $O$ ponto de medição foi colocado no centro do quadro. As medições do quadro foram feitas antes da medição dos pontos de cada sala. A fotocélula era colocada na vertical, direcionada para a parede oposta com janela, a fim de avaliar a qualidade de iluminação da área do quadro ao longo do dia com iluminação natural e artificial, no horário de $18 \mathrm{~h} 00$. O quadro tem dimensões de $2,20 \mathrm{~m} \times 1,05 \mathrm{~m}$ e se encontra na altura de $1,04 \mathrm{~m}$ da base inferior para o piso.

As salas apresentaram níveis de iluminância precários ao longo dos dias medidos quando avaliado nas condições de uso exclusivo da iluminação natural. As carteiras situadas nas filas intermediárias representaram o local de melhor qualidade de iluminação no decorrer do dia, com exceção dos horários de 16 e 18 horas.

A sala 02 apresentou, ao longo do dia, resultados mais conformes com o valor médio recomendado pela norma NBR 5.413. (ASSOCIAÇÃO 
BRASILEIRA DE NORMAS TÉCNICAS, 1992) A sala 04 apresentou grande parte dos valores abaixo do valor médio de 300lux e maior número de assentos com iluminação insuficiente para a atividade. $O$ turno noturno funcionava por meio, exclusivo, da iluminação artificial, portanto, pode-se concluir que a condição de iluminação é precária considerando que os níveis, provavelmente, devem ser inferiores ao limite de 300lux estabelecido pela NBR 5.413. (ASSOCIAÇÃO BRASILEIRA DE NORMAS TÉCNICAS, 1992)

A iluminação da lousa ao longo de todo o dia de medição não atingiu o valor médio estipulado pela NBR 5.413 de 500lux nas duas salas de aula avaliadas. (ASSOCIAÇÃO BRASILEIRA DE NORMAS TÉCNICAS, 1992) Vale considerar que a referida Norma estabelece o limite para quadro negro, portanto, este valor deve ter sido determinado por esta, considerando a refletância de luz do quadro negro. A sala 04 possui iluminação bastante deficiente em relação à sala 02 , chegando ao valor máximo de 1731 ux no período dos três dias medidos, bem inferior à média de 300lux recomendada pela NBR 5.413 para salas de aula. (ASSOCIAÇÃO BRASILEIRA DE NORMAS TÉCNICAS, 1992) Essa diferença de iluminação ocorre, também, devido à presença de duas plantas altas e frondosas localizadas na frente da janela da sala 4 . Existem, entretanto, outras condições que envolvem a avaliação do conforto luminoso.

Ghisi e Lamberts (1997) mensuraram salas de aula do Centro Tecnológico da Universidade Federal de Santa Catarina no dia 07 de junho de 1997 com o mesmo método utilizado neste trabalho. No estudo citado, as salas de aula orientadas para o Leste e o Sul tiveram seus valores variando entre faixas de 50 a 150lux no horário de 8 horas, 70 a 290lux no horário de 10 horas, 90 a 390lux no horário de 12 horas e 110 a 520lux no horário de 14 horas. Os pontos com iluminância mais baixos foram os pontos mais distantes da janela.

$\mathrm{Na}$ Escola BEG, os pontos mais distantes da janela apresentaram resultados abaixo de 300lux em todos os horários da medição e os pontos mais próximos tiveram níveis de iluminância altos na sala 02 e mais baixos na sala 04 .

A iluminação também é um fator ambiental que, quando apresentada de forma inadequada para a atividade a ser realizada no ambiente, gera problemas de saúde e prejudica a eficiência do ensino. Segundo 
Bormann (2003), valores de iluminância inferiores à 300lux tendem a gerar desconforto visual com prejuízo para a saúde dos olhos. A fadiga visual e cefaleias adquiridas em condições luminosas desapropriadas para a atividade laboral é resultado da dificuldade de acomodação da visão em decorrência dos ofuscamentos.

\section{Percepção dos professores da escola Brigadeiro Eduardo Gomes sobre as características do ambiente de trabalho}

A percepção dos professores sobre as características do seu ambiente de trabalho foram avaliadas a partir de questionários aplicados no período das medições, após cada aula ministrada em sala de aula. Os questionários foram aplicados no final da atividade laboral do professor para poder captar a percepção docente no momento de medição. A entrevista foi realizada ainda em sala de aula, antes que o professor se retirasse do ambiente avaliado. Foram cinco dias na semana (monitorização para fins ocupacionais) de entrevistas, cada dia monitorizando uma sala de aula e coletando as percepções dos professores que realizaram trabalhos no ambiente avaliado naquele dia. Os questionários foram aplicados após cada aula dada. Quando o professor dava duas aulas seguidas, os questionários foram aplicados após a última aula. Para avaliação de informações da população entrevistada, foram retirados do banco de dados os questionários aplicados para a mesma pessoa mais de uma vez, restando portanto, o total de 17 instrumentos aplicados para professores diferentes. Para as variáveis relacionadas à percepção do professor no momento da monitorização, foram considerados todos os instrumentos aplicados, mesmo que mais de uma vez para a mesma pessoa, configurando o total de 29 questionários aplicados. As entrevistas eram realizadas nas salas de aula, no momento da medição. Portanto, um mesmo professor, com as mesmas características biológicas estava sendo avaliado em momentos diferentes do dia, exposto a temperaturas e umidades diversas.

Em 02/06/2008, na sala 01 foi aplicado o maior número de questionários (9; $31 \%$ ); seguido em $03 / 06 / 2008$ na sala 02 (7; $24,1 \%)$; em $04 / 06 / 2008$ na sala $03(6 ; 20,7 \%)$; e $06 / 06 / 2008$ na sala $05(5 ; 17,2 \%)$. 
Em 05/06/2008 obteve-se o menor número de questionários aplicados $(2 ; 6,9 \%)$ porque foi o dia em que teve o evento do Dia do Meio Ambiente, quando o número de aulas foi reduzido para a realização da atividade complementar. Os professores que participaram do estudo eram, em sua maioria, do sexo feminino, correspondendo a $15(88,2 \%)$ professores entrevistados. Em relação à idade, a faixa etária predominante foi de 30 a 40 anos com 8 (47,7\%) seguida dos acima de 40 anos. A média de altura, peso e idade foram de $1,62 \mathrm{~m}( \pm 0,087) ; 60,82 \mathrm{~kg}$ $( \pm 11,33) ; 38,71$ anos $( \pm 7,40)$, respectivamente.

Em relação ao conforto em sala de aula, 22 (75,9\%) professores referiram ter dificuldade de realizar o trabalho durante a aula. Quando questionados sobre o fator ruído na sala de aula, 22 (75,9\%) professores disseram que o ruído na aula incomodou. Ao serem perguntados sobre o tipo de ruído, $17(58,6 \%)$ afirmaram que foi o ruído da sala de aula que incomodou e $5(17,2 \%)$ disseram que foi o ruído de fora da sala de aula. Em relação às notas dadas para o conforto térmico, a menor nota foi 2 dada por $2(6,9 \%)$ professores e a maior nota foi $10 \mathrm{com} 1$ $(3,4 \%)$ resposta. A nota que teve maior número de indicação foi a nota 5 referida por $7(24,1 \%)$ professores. Em relação às notas dadas ao conforto lumínico, 8 (27,6\%) professores deram notas 7 e 8 . A menor nota dada foi a nota 3 por $1(3,4 \%)$ professor e a maior nota dada foi a nota 9 , também por $1(3,4 \%)$ professor. Estes dados contribuíram para uma avaliação mais integrada do ambiente laboral docente.

\section{Considerações finais}

A Escola Brigadeiro Eduardo Gomes não favorece ao conforto ambiental, em relação à sua localização e às características do edifício. A edificação escolar não está localizada em um lugar apropriado para o ensino, devido às interferências marcantes do ruído urbano. Do ponto de vista do conforto térmico, o terreno e o edifício apresentaram algumas considerações favoráveis, entretanto, o muro limítrofe (que serve de barreira acústica) impede o aproveitamento eficiente dos ventos predominantes. Foram encontradas situações críticas em relação ao conforto em sala de aula durante todo o tempo de avaliação do ambiente. As salas de aula são voltadas para um pátio coberto e possuem aberturas voltadas para este pátio, o que agrava a sua condição acústica. 
De acordo com a literatura, o nível encontrado de $116,7 \mathrm{~dB}(\mathrm{~A})$ torna-se extremo e requer uma atitude imediata de interdição da edificação escolar. A inviabilidade do uso de equipamentos de proteção individual descarta a possibilidade de continuação das atividades escolares. As condições acústicas encontradas na Escola Brigadeiro Eduardo Gomes representam situações graves, inadmissíveis e alarmantes diante dos parâmetros legais relativos aos limites de tolerância admitidos para a saúde do trabalhador. Crianças e jovens estão submetidos a ambientes danosos e ameaçadores à saúde humana. A não interdição indicaria o exercício das atividades de ensino nas salas de aula com níveis de Leq entre $80,6 \mathrm{~dB}(\mathrm{~A})$ e $86,4 \mathrm{~dB}(\mathrm{~A})$ e esta condição, em outras ocupações em situação ambiental semelhante pressupõe o uso de protetor auricular na realização do trabalho - o que seria inaceitável para a realização do trabalho docente. A realização de exames audiométricos para identificar possíveis perdas auditivas, é outra medida prevista na legislação trabalhista e que deveria estar sendo feita. Considerando, também, a necessidade de comunicação neste ambiente de trabalho ruidoso, existe a sobrecarga do aparelho fonador e isso agrava consideravelmente as condições de desenvolvimento de disfonias ocupacionais e outras patologias de natureza psicossomáticas associadas. (BEHLAU; MADAZIO; PONTES, 2001) Vale ressaltar que as mesmas indicações preventivas de uso de protetor auricular e realização de exames médicos são aplicáveis, também, para os alunos. Além disso, a necessidade de ação preventiva para níveis superiores à $80 \mathrm{~dB}(\mathrm{~A})$, segundo a NR 9, implica na indicação de medidas de ação para controle dos resultados aferidos neste estudo. (BRASIL, 2009)

A localização entre vias de movimento intenso, a proximidade do Aeroporto Internacional de Salvador, a utilização de equipamentos ruidosos em sala de aula e a estrutura espacial inadequada do edifício, favorecem bastante ao agravamento das condições acústicas precárias da escola BEG. Considerando que o ruído urbano interfere, consideravelmente, para o aumento do nível de ruído em sala de aula, devem ser tomadas medidas para minimização tanto do ruído interno, como do ruído externo.

A Escola não possui ambiente arborizado e o muro limítrofe da edificação impede a penetração de ventos. O local é ventilado, entretanto, a forma como foi concebida a edificação não favorece ao conforto 
ambiental. As condições de trabalho do professor são inadequadas à atividade laboral, visto que os resultados apresentaram valores acima dos limites de referência. O professor necessita de muito esforço da voz e da audição que entram em conflito com a utilização de recursos que amenizem o calor. Para utilizar o ventilador em sala de aula, o professor precisa aumentar ainda mais o seu tom de voz.

A partir dos dados coletados nesta pesquisa e suas análises, espera-se ter contribuído com os estudos em avaliação de ambientes laborais e estimular a construção de parâmetros para a melhoria do mesmo nas edificações escolares. Mensurar o conforto térmico é muito peculiar devido à vasta quantidade de variáveis envolvidas nesse processo. Foi possível identificar na pesquisa realizada que os índices nacionais e internacionais passam por constantes processos de aprimoramento. Apesar da atuação de grupos de pesquisa na área de conforto ambiental, é preciso fomentar o desenvolvimento de mais pesquisas que envolvam elaboração de índices mais modernos e precisos no Brasil. À pesquisa de Lyra (2007) é uma importante referência, mostrando que os índices internacionais podem estabelecer faixas de conforto térmico não adaptadas para a realidade do clima brasileiro. É preciso que sejam realizadas mais investigações sobre estes índices para que a utilização dos mesmos estabeleçam resultados mais concisos e confiáveis.

Em relação às medições das condicionantes ambientais, os valores apresentados, em grande parte, superaram os valores estabelecidos pelas normas de referências, com exceção do IBUTG, que por se tratar de um índice para avaliação de condições de estresse térmico possui limites considerados de tolerância ao calor e não de conforto térmico. Entretanto, mesmo nestas condições, o IBUTG atingiu o valor máximo de 26,4 em todo o período de medição.

Os valores limites ou faixa de conforto das condicionantes ambientais são regulamentados e normatizados de acordo com as políticas públicas de cada país. A edificação, quando avaliada isoladamente, apresentou níveis de ruído e iluminância bem insuficientes em relação aos valores preconizados pelas referências (nacionais e internacionais). O professor, submetido a este ambiente de trabalho, terá sua saúde prejudicada ao longo da vida laborativa.

Diversas limitações foram identificadas nesta pesquisa. Mensurar condicionantes ambientais é uma atividade muito complexa que re- 
quer muito planejamento, posto que estes fatores (ruído, iluminação e temperatura) sofrem variações significativas ao longo do dia e, portanto, precisam de um método sistemático para ser mensurados.

Em relação aos índices disponíveis para avaliação do conforto térmico, foi possível identificar que estes são consolidados por meio de normas que não dispomos no Brasil. Entretanto, é possível notar que, muitas vezes, esses índices não estão adequados ao clima brasileiro e, portanto, precisam ter seus valores adaptados para cada clima do País. Isso dificulta, relativamente, a elaboração e discussão dos resultados gerados nos trabalhos nacionais. Por isso, pesquisas estão sendo desenvolvidas para adaptar os índices internacionais aos climas de cada região do Brasil. Entretanto, ainda assim, foi possível observar que a percepção subjetiva dos professores confirmou os resultados quantitativos das monitorizações.

Como observado neste estudo, o ambiente da sala de aula e o processo de trabalho do professor não contribuem para a construção de relações participativas na escola, envolvendo os professores no gerenciamento e adequação dos ambientes e condições de trabalho. O espaço escolar carece de ambiente que possibilite atividades de ensino-aprendizagem não por meio de condutas legais (estabelecendo limites de tolerância), mas de condutas de promoção à saúde e favoráveis ao conforto ambiental. O estudante da geração atual necessita de um novo ambiente educacional, onde o professor é um colaborador no processo ensino/aprendizagem. É preciso que o professor esteja mais atuante nas questões relacionadas ao seu ambiente de trabalho, para que sejam realizadas propostas inclusivas no processo de melhoria das condições de trabalho docente.

\section{Referências}

ASSOCIAÇÃO BRASILEIRA DE NORMAS TÉCNICAS. NBR 10.151 (2000): Acústica - Avaliação do Ruído em Áreas Habitadas, Visando o Conforto da Comunidade. Rio de Janeiro, 2000.

. NBR 15.215-4 (2004): Iluminação Natural - Parte 4:

Verificação Experimental das Condições de Iluminação Interna de Edificações - Método de Medição. Rio de Janeiro, 2004. 
ASSOCIAÇÃO BRASILEIRA DE NORMAS TÉCNICAS. NBR 10.152 (1987): Níveis de Ruído para o Conforto Acústico. Rio de Janeiro, 1987.

. NBR 5. 413 (1992): Normas para Iluminância

de Interiores. Rio de Janeiro, 1992.

BEHLAU, M.; MADAZIO, G. F. D; PONTES, P. Avaliação de voz. In: BEHLAU, M. (org. ). Voz: o livro do especialista.

Rio de Janeiro: Revinter, 2001. p. 85-245.

BERTOLI, S. R. Avaliação do Conforto Acústico de Prédio Escolar da Rede Pública: O Caso de Campinas. In: ENCONTRO NACIONAL, IV. , ENCONTRO LATINO-AMERICANO SOBRE CONFORTO NO AMBIENTE CONSTRUÍDO, III. , 2001, São Paulo. Anais... São Paulo: ANTAC, 2001. p. 1-8.

BORMANN, O. R. Iluminação natural em sala de aula e escritórios com uso de prateleiras de luz. Curitiba, 2003. 140f. Dissertação (Mestrado em Tecnologia) - Centro Federal de Educação Tecnológica do Paraná, Curitiba, 2003.

BRASIL. Ministério do Trabalho. Consolidação das Leis Trabalhistas, Decreto Lei 6. 214/1977 e Portaria 3. 214/1978 - Normas Regulamentadoras sobre Segurança e Medicina do Trabalho. Rio de Janeiro: Atlas, 2009.

CREA-BA. Barulho e monóxido de Carbono no Ar de Salvador. CREA-BA Revista, Salvador, 13. ed., out. /nov. /dez. 2005.

ENIZ, A. O. Poluição Sonora em Escolas do Distrito Federal. 2004. 111f. Dissertação (Mestrado em Planejamento e Gestão Ambiental) - Universidade Católica de Brasília, Brasília, 2004.

GHISI, E.; LAMBERTS, R. Avaliação das condições de iluminação natural nas salas de aula da Universidade Federal de Santa Catarina. In: ENCONTRO NACIONAL SOBRE EDIFICAÇÕES E COMUNIDADES SUSTENTÁVEIS, I. , 1997, Canela. Anais... Canela: ANTAC, 1997, p. 183-188.

HOPPE, P. The physiological equivalent temperature - a universal index for the biometeorological assessment of the thermal environment. International Journal Biometeorology, n. 43, p. 71-75, 1999.

INSHT. INSTITUTO NACIONAL DE SEGURIDAD E HIGIENE EN EL TRABAJO. Ruido. Espanha, s. d. Disponível em: <http://www.insht.es/ InshtWeb/Contenidos/Documentacion/TextosOnline/Guias_Ev_Riesgos/ Condiciones_trabajo_PYMES/cuestion13.pdf. > Acesso em: 27 jun. 2012. INTERNATIONAL ORGANIZATION FOR STANDARDIZATION. Ergonomics of the thermal environment - Assessment of 
the influence of the thermal environment using subjective judgement scales, ISO 10. 551. Genebra, 1995.

. Moderate thermal environments - Determination of the PMV and PPD indices and specification of the conditions for thermal comfort, ISO 7. 730. Genebra, 1994.

LEUCZ J. Ambiente de trabalho das salas de aula no ensino básico nas escolas de Curitiba. 2001. 60f. Dissertação (Mestrado em Engenharia de Produção) - Programa de Pós-Graduação em Engenharia de Produção, UFSC, Florianópolis, 2001.

LYRA, D. S. F. M. Aplicabilidade dos Índices de Conforto Térmico: Um Estudo de Caso em Salvador - Bahia. 2007. 131f. Dissertação (Mestrado em Engenharia Ambiental Urbana) - Escola Politécnica, Universidade Federal da Bahia, Salvador, 2007.

PORTUGAL. Ministério das Cidades. Ordenamento do Território e Ambiente. Instituto do Ambiente. Procedimentos específicos de medição de ruído ambiente. Lisboa, 2003.

OMS - ORGANIZAÇÃO MUNDIAL DE SAÚDE. Constituição da Organização Mundial de Saúde. Genebra, 1946.

RIBEIRO, S. L. Espaço Escolar: um Elemento (In) Visível no Currículo. Sitientibus, n. 31, p. 103-18, 2004.

SALVADOR. Secretaria Municipal de Educação, Cultura, Lazer e Esporte. Assunto: Educação em Números. Disponível em: <http://www.smec.salvador.ba.gov.br/site/educanumeros-escolas.php.> Acesso em: 10 jul. 2012. 


\section{Previdência social, acidente de trabalho e nexo técnico epidemiológico}

Rita Franco Rego

Edriene Barros Teixeira

Denismar Borges de Miranda

Paulo Gilvane Lopes Pena

\section{Introdução}

A Previdência Social instituiu, em 2006, o Nexo Técnico Epidemiológico Previdenciário - NTEP. Com a adoção do NTEP foi implantada uma nova metodologia para concessão dos benefícios previdenciários por acidentes de trabalho e doenças ocupacionais, baseada no cruzamento das informações relativas a dados ocupacionais e de saúde dos trabalhadores, apontando a possibilidade de nexo entre doença e trabalho.

O objetivo deste capítulo é: analisar aspectos relativos à evolução da Previdência Social no Brasil, com ênfase no processo de notificação de acidentes de trabalho e a adoção do NTEP; estabelecimento do nexo entre doença e trabalho no âmbito da Previdência Social, Seguro de Acidentes de Trabalho e sua relação com NTEP; a implantação do NTEP sob a perspectiva da Gestão da Informação; e destacar a importância da adoção do NTEP no contexto da implementação da Política Nacional de Saúde do Trabalhador.

\section{O nexo técnico epidemiológico e a previdência social no Brasil}

Conforme a legislação previdenciária, acidente do trabalho é aquele que ocorre pelo exercício do trabalho a serviço da empresa 
provocando lesão corporal ou perturbação funcional que cause morte, perda ou redução da capacidade para o trabalho permanente ou temporária. (BRASIL, 1992) Os acidentes de trabalho se manifestam de forma abrupta, muitas vezes causando sequelas e mesmo a morte de trabalhadores, contribuindo de forma considerável para as estatísticas de mortalidade por causas externas (causas violentas de morte), acometendo principalmente indivíduos do sexo masculino e em idade produtiva. As causas mais comuns de óbito por acidente são politraumatismos, queimaduras, intoxicações, etc. Já doença ocupacional, profissional ou do trabalho tem conotações com diferentes sentidos, mas para efeito da presente análise, serão tomadas como sinônimas. As doenças do trabalho são entidades nosológicas que acometem pessoas que vivenciam formas de inserção no processo produtivo de bens e serviços. No Brasil atualmente são reconhecidas oficialmente em torno de 200 patologias relacionadas ao trabalho. (BRASIL, 2001) Para efeito securitário, a previdência equipara acidente do trabalho com doença do trabalho. Nesse sentido, a presente análise abordará esses conceitos segundo essa lógica previdenciária para construir a conexão do desenvolvimento institucional.

No Brasil, uma parte substancial dos custos diretos com acidentes e doenças do trabalho recai sobre o Ministério da Previdência Social (MPS) que, por meio do Instituto Nacional do Seguro Social (INSS), tem a missão de garantir o direito previdenciário. (SANTANA et al., 2006) Os benefícios previdenciários destinam-se a pagamentos dos segurados e seus dependentes quando da perda da capacidade laboral do trabalhador. Desta forma, os acidentes e as doenças do trabalho constituem eventos de grande relevância social e econômica. De acordo com dados econômicos previdenciários, o valor total gasto com benefícios em 2006 atingiu R \$2,45 bilhões, e em 2007 alcançou cerca de R \$ 2,57 bilhões. (BRASIL, 2007a) No total dos gastos estão incluídos todos os benefícios previdenciários como: auxílio-doença acidentário, auxílio acidente, aposentadoria por invalidez acidentária, entre outros. Em 2006, a espécie de benefício com maior valor médio foi aposentadoria por invalidez acidentária, correspondendo a R \$1.020,04. Em 2007, foi aposentadoria por tempo de contribuição, equivalente a $\mathrm{R} \$ 1.073,90$, em seguida a aposentadoria por invalidez acidentária, com valor médio de $\mathrm{R} \$ 993,99$. (BRASIL, 2007a) Destaca-se, que as aposentadorias 
acidentárias estão relacionadas a acidentes e/ou doenças relacionadas ao trabalho que constituem eventos passíveis de ações de prevenção. A alta frequência de AT grave também tem forte impacto sobre a assistência à saúde, pois contribuem para a demanda dos serviços especializados, ocupação hospitalar incluindo leitos de UTI, tratamento clínico ambulatorial, serviços de reabilitação fisioterápica ou de atendimento psicoterápico por tempo prolongado. (SANTANA et al., 2009) Em geral, estas ações são custeadas pelo Ministério da Saúde (MS).

Os agravos à saúde do trabalhador conectam-se intrinsecamente com problemas vividos hoje pela sociedade brasileira nos grandes centros urbanos. As associações entre acidentes de trabalho e mortes violentas se tornam cada vez mais estreitas. No conjunto das causas externas, os acidentes de transporte relacionados ao trabalho, acidentes típicos ou de trajeto, destacam-se pela magnitude das mortes e incapacidade parcial ou total, permanente ou temporária, envolvendo trabalhadores urbanos e rurais. (BRASIL, 2001)

Deste modo, cabe à Previdência Social a identificação do nexo entre trabalho e agravo, além da compensação salarial através de benefícios previdenciários para os casos que necessitem de afastamento do trabalho. Assim, as informações provenientes dos registros previdenciários constituem um importante banco de dados sobre acidentes e doenças do trabalho. Entretanto, no Brasil, a subnotificação desses eventos constitui um fator limitante, tanto do ponto de vista jurídico quanto social, pois retira a garantia de direitos trabalhistas dos indivíduos acidentados e dificulta a implementação de políticas públicas.

Os registros sistemáticos de acidentes e doenças relacionadas com o trabalho, entre trabalhadores do mercado formal no Brasil, se iniciaram na década de 70 e, desde então, sofrem a influência de vários fatores econômicos, políticos e sociais, dentre os quais se destacam: sonegação da notificação por parte dos empregadores, mudanças na legislação, alterações no processo produtivo que inclui as transformações nos padrões de emprego. Estes fatos sempre constituíram um obstáculo para o planejamento e implantação de políticas de prevenção. Antes da adoção do NTEP a notificação de acidentes e doenças do trabalho, no âmbito previdenciário, dependia quase que exclusivamente da emissão da Comunicação de Acidente do Trabalho (CAT). As estatísticas oficiais brasileiras sobre acidentes e doenças do trabalho também eram 
elaboradas a partir das informações obtidas pela CAT, a ocorrência do acidente era registrada e reconhecida oficialmente após a CAT, estabelecendo-se o direito do trabalhador ao beneficio previdenciário acidentário junto ao INSS. Porém, o fluxo da CAT, até seu registro no INSS encontrava muitos entraves, pois a emissão da CAT dependia, em grande parte, de ato voluntário do empregador. (CORDEIRO; SAKATE; CLEMENTE, 2005) Com a adoção do NTEP, a notificação do acidente, no âmbito da Previdência Social (PS), passou a não depender exclusivamente da CAT.

No Brasil, a escassez de estudos relacionados aos acidentes e doenças ocupacionais, com objetivo de promover ações de pesquisa, vigilância, assistência, promoção, proteção e reabilitação da saúde do trabalhador, sempre dificultaram a elaboração de políticas públicas previdenciárias e intersetoriais. A ausência de dados previdenciários consistentes constitui um empecilho frequente porque dificulta a identificação e o dimensionamento de fontes de custeio que envolve políticas públicas relacionadas ao menos a três ministérios: da Previdência Social, que financia ações da Seguridade Social através do INSS; Ministério da Saúde, que financia ações de saúde por meio do Sistema Único de Saúde (SUS); e Ministério do Trabalho e Emprego (MTE), com ações de fiscalização do trabalho por parte das Superintendências Regionais do Trabalho (SRT).

O NTEP pode contribuir para a identificação de novos fatores de risco para acidentes cujo nexo causal ainda não foi estabelecido. Como, por exemplo, nos casos de acidentes relacionados às mudanças no processo produtivo. Um exemplo destas alterações na produção é a constante incorporação da informática e da robótica aos processos de trabalho, que vem ocasionando o deslocamento da força de trabalho do setor secundário para o terciário, criando deste modo, um novo padrão de fatores de risco ocupacionais. O desdobramento desses riscos em agravos resultaria na elevação da frequência dessas patologias e isso se transformaria em indicador de frequência da nova patologia emergente. 


\section{Evolução da previdência social brasileira, sua relação com a adoção do nexo técnico epidemiológico e com a notificação de acidente de trabalho}

O trabalho e suas consequências para a saúde, em especial o acidente e a doença, são descritos desde os primórdios da humanidade. O trabalho pode ser considerado um instrumento de integração social, sendo um meio de sobrevivência e de interação social. Não há dúvida que o trabalho ocupa lugar fundamental na inserção social dos indivíduos, no seu adoecer e morrer. (BRAGA, 2000) Por este motivo, examinar o curso da evolução histórica da notificação do acidente de trabalho torna-se fundamental para compreender a estrutura das normas jurídicas atuais, que amparam o sistema de proteção e reparação aos trabalhadores, em especial a seguridade social.

As relações entre saúde humana e trabalho são alvo de avaliação e estudo das mais diversas áreas do conhecimento científico. No âmbito da medicina, as primeiras associações entre trabalho e saúde surgiram na antiguidade, mas apenas em 1700, Bernardino Ramazzini relacionou um amplo leque de profissões com os problemas de saúde dos trabalhadores, valorizando a importância da ocupação para o diagnóstico e tratamento das patologias. (RAMAZZINI, 1999) Os trabalhos de Ramazzini (1999) foram considerados marco inicial da medicina do trabalho. Todavia a medicina do trabalho, enquanto especialidade médica, só surgiu na Inglaterra na primeira metade do século XIX, com a Revolução Industrial e a criação do primeiro serviço de medicina do trabalho, em 1830. (MENDES, 2005) No século XIX pós-revolução industrial, o trabalho sofreu transformações importantes, passando a ser separado de outras atividades e esferas sociais. Foi possível a separação entre a esfera doméstica e a esfera da produção, a divisão entre propriedade privada e o trabalho assalariado. Assim, surgiram novas formas de produzir e com elas novas formas de adoecer e morrer relacionadas ao trabalho. (OFFE, 1989) Foi neste contexto que as doenças do trabalho e os acidentes do trabalho se ampliaram e passaram a assumir relevância em saúde pública e a fazer parte da vida dos trabalhadores.

A primeira legislação que tratou do tema acidente do trabalho e reparação previdenciária na esfera da organização estatal foi o plano 
de Previdência aos acidentes de trabalho, que surgiu na Alemanha, em 1883, com Otto Von Bismarck. (CARNEIRO, 2008) Em 1886, na Itália, surgiram as organizações de amparo mútuo, que eram associações voluntárias de operários, baseadas na solidariedade dos contribuintes. Nestas associações os operários contribuíam para ter direito a benefícios devidos à doença, invalidez ou idade avançada. Também eram concedidos por estas associações benefícios aos familiares dos associados falecidos. Por conta das dificuldades econômicas e problemas inerentes a este sistema, estas associações terminaram em decadência. Por este motivo, em 17 de março de 1898, na Itália, surgiu à lei que tornou obrigatório, por parte dos empregadores das indústrias, o seguro para acidente relacionado ao trabalho, e esta lei constituiu o nascimento do sistema previdenciário italiano.

No Brasil, no século XIX, com a industrialização das grandes cidades, especialmente São Paulo e Rio de Janeiro, começaram a aumentar a frequência de doenças e acidentes relacionados ao trabalho. Deste modo, a evolução do sistema previdenciário não seguiu um caminho diferente, tendo, primeiramente, passado pela simples caridade, pelo mutualismo de caráter privado e facultativo, e, depois, pelo seguro social. Em 1919, foi promulgado o Decreto Legislativo n³.724, que regulamentou o seguro para acidente do trabalho, o qual tratava da proteção aos trabalhadores, iniciando-se, no Brasil, a responsabilização do empregador pela indenização ao trabalhador acidentado, ficando a cargo da polícia a função de registrar tais acontecimentos. (CORDEIRO; SARATE; CLEMENTE, 2005) A regulamentação do Seguro Acidente de Trabalho (SAT) representava, na época, uma influência do direito europeu nas relações de trabalho, em que se difundiu a teoria do risco profissional e caracterizava, no Brasil, o início de um novo regime de responsabilidade civil do empregador para com seus funcionários acidentados. O SAT representou o surgimento, no direito brasileiro, de um dos primeiros sistemas de direito social, pois refletia a necessidade de proteção à saúde dos trabalhadores à época. (SANTOS, 2007)

O Decreto ${ }^{\circ} 3.724$ foi acompanhado da edição da Lei $n^{\circ} 4.682$, de 24 de janeiro de 1923, chamada "Lei Eloy Chaves", que criou as Caixas de Aposentadorias e Pensões dos Ferroviários - CAPs. (BRASIL, 1923) Estas funcionaram, em todo o território nacional, instituindo seguro social a funcionários públicos, e eram baseadas em premissas de 
solidariedade ampla entre os trabalhadores. A partir desta lei, os empregados ferroviários passavam a contar com uma instituição previdenciária que oferecia os seguintes benefícios: aposentadoria por tempo de serviço, aposentadoria por conta de doenças e acidentes (invalidez), pensão, assistência médica e assistência farmacêutica. (CORDEIRO; SARATE; CLEMENTE, 2005)

A implantação da "Lei Eloy Chaves" representou um capítulo relevante na evolução da previdência social no Brasil, pois aceleradamente se acentuou o caráter público da tutela previdenciária, a qual, originalmente voluntária, tornou-se obrigatória, condicionada ao cumprimento das obrigações arcadas pelo empregador. A evolução previdenciária avançava favorecida pela transformação das estruturas econômicas e, posteriormente, na década de 30, durante o governo Getúlio Vargas, passou a vigorar o regime dos institutos com início da montagem de um sistema público de Previdência Social no Brasil, de modo a responder ao dinamismo político e econômico do processo de industrialização. Proliferam, assim, os Institutos de Aposentadoria e Pensões (IAPs), que eram restritos aos trabalhadores urbanos, porém agora se organizavam por categoria profissional e não mais por empresa.

Deste modo, todos os profissionais de uma mesma categoria estavam qualificados para receber os mesmos benefícios, independe da empresa à qual estivessem ligados. Além disso, a administração dos IAPs não ficava mais a cargo de empregados e patrões, como nas CAPs, o governo passou a ser parte integrante do sistema e o presidente da República nomeava o presidente de cada IAP. O sistema de contribuição passou a ter o seu comando político estabelecido por meio do sistema tripartite, formado por: estado, empregador e empregado. O custeio vinculava-se obrigatoriamente às três fontes, ocorrendo, assim, a efetivação da tutela previdenciária a entidades públicas adequadamente instituídas. (CORDEIRO; SARATE; CLEMENTE, 2005) Entretanto, a despeito dos avanços, um amplo contingente de trabalhadores ainda permanecia excluído desta tutela previdenciária, dentre os quais se destacam os autônomos, os trabalhadores domésticos e todos os trabalhadores rurais que na época, ainda eram maioria.

Um marco importante relacionado à reparação previdenciária por conta dos acidentes e doenças do trabalho ocorreu com a promulgação da Lei n7.036, em 1944, que trouxe importantes modificações, intro- 
duzindo o conceito de concausalidade. (BRASIL, 1944) No âmbito da legislação previdenciária, a causa é toda condição sem a qual o resultado não teria ocorrido, ou ainda, a totalidade das condições positivas e negativas que contribuíram para a produção do acidente. A concausa é outra causa que, associada à principal, concorre para determinado desfecho. As concausas, por si só, não iniciam e nem interrompem o processo causal, apenas o reforçam, ou seja, a concausa determina a possibilidade da lesão dever-se não somente ao acidente, mas também, a fatores preexistentes, concomitantes ou sucedidos. Se existem concausas, o acidente poderá produzir lesões diversas ou mais graves. As concausas podem ser classificadas como: preexistentes, se a causa existe antes da ocorrência do acidente; concomitantes, se ocorre no momento do acidente; supervenientes, se ocorre depois do acidente.

Associada à definição de concausalidade, a Lei n ${ }^{\circ}$ 7.036/44 ampliou o conceito de acidente do trabalho para fins de reparação, equiparando-o a doença resultante das condições de trabalho ao acidente. (BRASIL, 1944) Estabeleceu, com isso, a distinção entre doenças profissionais, que são inerentes a determinados ramos de atividade, e doenças do trabalho, que são resultantes das condições especiais ou excepcionais em que o trabalho é realizado. Esta Lei, do mesmo modo, consagrou o conceito do acidente de trajeto.

Assim, com a Lei $n^{0} 7.036 / 44$, a tutela dos acidentes foi definitivamente estendida aos acidentes ocorridos durante o percurso de ida e retorno da residência ao local de trabalho, às doenças profissionais e às doenças do trabalho. (CORDEIRO; SARATE; CLEMENTE, 2005) Posteriormente, o Decreto-Lei $n^{\circ} 7.036 / 44$ foi também relevante, por universalizar o seguro obrigatório contra acidente de trabalho.

Com a promulgação da Lei Orgânica da Previdência Social (LOPS), em 1960, ocorreu uma importante evolução no âmbito da reparação previdenciária, pois foram uniformizadas as contribuições e os planos de previdência com extensão da cobertura previdenciária aos empregadores e autônomos em geral. (BRASIL, 1960) O que veio a se consolidar em 1966, com a criação do Instituto Nacional de Previdência Social (INPS), que unificou a estrutura dos IAP. O INPS passou a se responsabilizar pelas aposentadorias, pensões e pela assistência médica de todos os trabalhadores do mercado formal e seus dependentes, com exceção do funcionalismo da União, que continuava com seu próprio instituto. 
Associado à criação do INPS, o Governo Federal passou a cogitar que o SAT deveria sair da iniciativa privada e ser estatizado. Em 1967, a Lei ${ }^{\circ} 5.316$ definiu que o SAT deveria ser responsabilidade do INPS. (CORDEIRO; SARATE; CLEMENTE, 2005) Além de instituir o monopólio estatal do SAT, incorporando-o à PS, a Lei $n^{\circ}$ 5.316, também trouxe outras mudanças relevantes: o conceito de acidente de trajeto, a ampliação do risco profissional e a implantação do programa de prevenção de acidentes e reabilitação, refletindo, assim, uma preocupação com a prevenção das causas dos acidentes. Com a promulgação desta lei, teve início no país a notificação de acidentes e doenças profissionais, através da implementação pela PS, de um formulário específico para notificação de acidente de trabalho:

O médico que primeiro atender a um acidentado do trabalho deverá comunicar à previdência social dentro de 72 (setenta e duas) horas a natureza e a provável causa da lesão ou doença e o estado do acidentado, bem como a existência ou não de incapacidade para o trabalho e, na primeira hipótese, a provável duração da incapacidade, fornecendo ao acidentado um atestado com esses elementos. (BRASIL, 1967, Art $^{\circ} 19$ )

Na década de 70 a reparação previdenciária se ampliou, passando a abranger novas categorias de trabalhadores. Os benefícios foram estendidos, em 1971, aos trabalhadores rurais, em 1972, aos empregados domésticos, e em 1973, aos trabalhadores autônomos. (BRUMER, 2002) Em 1974, no contexto da ampliação do universo de pessoas que passavam a receber benefícios previdenciários, decorrente do aumento de trabalhadores segurados, associado à incorporação de segmentos sociais desassistidos e ao envelhecimento gradativo da população, foi criado o Ministério da Previdência e Assistência Social (MPAS). A idealização desse Ministério representou um marco na evolução histórica para a previdência, apesar do período autoritário marcado pelo regime militar em vigor no país. Essa mudança foi caracterizada pela intervenção cada vez mais determinante do Estado e a adoção do conceito de seguridade social, que passou a englobar saúde, assistência e previdência. Seguindo este novo ordenamento, constitui-se através da Lei $n^{\circ}$ 6.439, de 1977, o Sistema Nacional de Previdência e Assistência Social (SINPAS). (BRASIL, 1977) Este órgão era destinado a integrar as atividades do seguro pecuniário, assistência médica e de gestão 
administrativa, financeira e patrimonial das entidades vinculadas ao MPAS. O SINPAS tinha a seguinte composição: o INPS, que cuidava da concessão e manutenção das prestações pecuniárias; o Instituto Nacional de Assistência Médica de Previdência Social (INAMPS), o qual tratava da assistência médica; a Fundação Legião Brasileira de Assistência (LBA), que prestava assistência social à população carente; a Fundação do Bem-Estar do Menor (FUNABEM), que promovia a execução da política do bem-estar social do menor; a Empresa de Processamento de Dados da Previdência Social (DATAPREV), que era responsável pelo processamento de dados da PS; o Instituto da Administração Financeira da Previdência Social (IAPAS), que era responsável pela arrecadação, fiscalização, cobrança das contribuições e outros recursos e administração financeira; a Central de Medicamentos (CEME), que era responsável pela distribuição dos medicamentos. Fica assim evidente, a complexidade que se tornou o trinômio de previdência social, saúde e seguridade social na estrutura do governo.

Posteriormente, com a democratização e a elaboração da Constituição de 1988, ocorreu uma ampliação do conceito de seguridade social, que foi saudada como uma das maiores conquistas do direito social brasileiro. (CORDERO, 2005) A nova Constituição do Brasil incorporou o conceito de seguridade social nos moldes recomendados pela Convenção ${ }^{\circ} 102 / 1952$ da Organização Internacional do Trabalho (OIT).

O capítulo da seguridade social da Constituição de 1988 introduziu uma concepção mais abrangente de seguridade social, definida como um conjunto integrado de ações destinadas a assegurar os direitos relativos à saúde, à previdência e assistência social, que deveria ser organizada pelo Poder Público. (BRASIL, 1988) O sistema passou a acolher o conceito de que a sociedade (incluindo os empregadores) se solidariza com o indivíduo trabalhador, cuja situação, quando em dificuldades, deixa de ser problema individual para constituir-se em responsabilidade social, pública.

A Constituição Federal de 1988 trouxe ainda, grandes avanços na área do direito social ao trabalho, assegurando aos trabalhadores o direito à saúde, à higiene, à segurança, à cidadania, à dignidade da pessoa humana, e aos valores sociais do trabalho e da livre iniciativa. (BRASIL, 1988) Destacam-se os Arts. $6^{\circ}$ e $7^{\circ}$, que incluem a proteção da saúde e do trabalhador, mais especificamente Art. $7^{\circ}$, em seu item XXVIII: 
"[...] seguro contra acidentes do trabalho a cargo do empregador, sem excluir a indenização a que este está obrigado, quando incorrer em dolo ou culpa". (BRASIL, 1988)

A Lei $\mathrm{n}^{\circ} 8.213 / 91$ regulamentou a finalidade e os princípios previdenciários básicos e definiu, que independente da comprovação de dolo ou culpa, o auxilio acidente, que é financiado com recursos da alíquota recolhida do SAT, será concedido e pago pela previdência. (BRASIL, 1991a) Porém, apesar da ampliação da cobertura do SAT, nem todos os que contribuíam para a previdência tinham direito à sua cobertura, pois a Lei Federal n 8.213/91 e o Decreto n 3.048/99 excluíam dos benefícios do SAT as seguintes categorias: empregados domésticos, empresários, trabalhadores autônomos e trabalhadores avulsos.

No âmbito da mudança conceitual da previdência, a partir da Constituição de 1988, qualquer pessoa, mesmo que não esteja exercendo atividade remunerada, pode contribuir para a previdência. E neste sentido, a Previdência Social passou a ser considerada um seguro social que objetiva reconhecer e conceder direitos aos seus segurados. Para ter direito a esse seguro é preciso que o cidadão contribua (princípio contributivo), havendo o reconhecimento e concessão de direitos, ocorrerá pagamento de benefício previdenciário, que substituirá a renda do trabalhador contribuinte.

Em 1990, o INPS passou a se denominar Instituto Nacional de Seguridade Social (INSS) e foi fundido com o IAPAS, passando a ter como atribuições básicas a arrecadação, administração e pagamento de benefícios. Neste mesmo ano, com a Lei $\mathrm{n}^{\circ} 8.080 / 90$, o INAMPS foi absorvido pelo MS, sendo criado o SUS. Com estas mudanças a assistência à saúde foi definitivamente separada da OS. (BRASIL, 1990)

A notificação de acidente e doença do trabalho também sofreu reformulações e, baseado no princípio contributivo, foi aprovado o Regulamento Geral da Previdência Social (RGPS). (BRASIL, 1991a) Este definiu que benefícios previdenciários consistem em prestações pecuniárias pagas aos segurados ou aos seus dependentes, de forma a atender à cobertura dos eventos de doença, invalidez, idade avançada, maternidade, salário-família e auxílio-reclusão para os dependentes dos segurados de baixa renda, e pensão por morte do segurado, homem ou mulher, ao cônjuge ou companheiro e dependentes. Atualmente, existem 95 tipos de benefícios previdenciários concedidos através do INSS, 
que são codificados da seguinte forma: B21, B31, B32, B36, B91, B92, B93, B94 (sendo estes últimos de natureza acidentária).

O RGPS ratificou que, ao se afastarem do trabalho, os filiados ao RGPS deveriam buscar amparo através do INSS. Este concede benefício de forma a atender à cobertura dos eventos de doenças, que causem incapacidade para o trabalho com finalidade de compensação salarial. Os benefícios são concedidos após avaliação realizada pela perícia médica do INSS. O benefício previdenciário se inicia no $16^{\circ}$ dia consecutivo de afastamento, para aqueles segurados vinculados ao mercado de trabalho formal (cabendo ao empregador o pagamento dos 15 dias iniciais). (BRASIL, 1991a) Para os demais segurados, o benefício previdenciário terá início na data definida como o princípio da incapacidade, conforme sua última atualização em 2010. (BRASIL, 2010) Associado aos princípios do RGPS, em 1997 foi promulgado o Decreto no 2.172/97, que regulamentou os benefícios e estabeleceu limites (máximo e mínimo) para multas pela não emissão da Comunicação de Acidente do Trabalho - CAT. Este decreto foi revogado em 1999, pelo Decreto no 3.048/99, sem perda da regulamentação anterior. (BRASIL, 1999)

Compete à perícia médica do INSS avaliar a incapacidade laborativa e estabelecer o nexo causal entre acidente e/ou doença relacionada com o trabalho, ou seja, estabelecer a relação entre acidente e/ou doença profissional ou do trabalho e a existência de agente causador do agravo na atividade exercida. O estabelecimento do nexo no âmbito da PS se relaciona com conceito de incapacidade laborativa:

É a impossibilidade temporária ou definitiva do desempenho das funções específicas de uma atividade ou ocupação, em consequência de alterações morfopsicofisiológicas provocadas por doença ou acidente, para o qual o examinado estava previamente habilitado e em exercício; O risco de vida para si ou para terceiros, ou de agravamento, que a permanência em atividade possa acarretar, está implicitamente incluído no conceito de incapacidade, desde que palpável e indiscutível. (BRASIL, 1999)

A responsabilidade está bem definida, uma vez que independente da comprovação do dolo ou culpa do empregador pelo acidente, a compensação será paga pela PS. Neste fato reside a importância dos recursos oriundos do SAT, pois este se constitui em seguro obrigatório, custeado pelos empregadores, que se destina exatamente a custear os benefícios previdenciários e o auxilio acidente, e desta forma, fazer face 
aos riscos dos processos produtivos no que se refere à ocorrência de doenças profissionais e acidentes de trabalho.

O SAT, no ano de 1991, sofreu uma importante mudança com a Lei $\mathrm{n}^{\circ} 8.212 / 91$. (BRASIL, 1991b) Com isso, as alíquotas passaram a ser definidas de acordo com uma pré-determinada graduação de riscos, assim o recolhimento passou a ser baseado em alíquotas fixadas em razão do grau de risco da atividade preponderante do contribuinte. Alíquota de $1 \%$ para risco leve, de $2 \%$ para risco médio, e de $3 \%$ para risco grave. Posteriormente, a Lei $n^{\circ} 10.666$ de 2003, modificou estas alíquotas com a introdução do Fator Acidentário Previdenciário (FAP). Em 2007, o FAP foi regulamentado pelo Decreto $n^{\circ}$ 6.042/07, com mecanismo definido pelo Decreto n ${ }^{\circ}$ 6.042/07, em seu Art.14:

Poder Executivo regulamentará a questão da redução ou incremento do SAT, em razão do desempenho da empresa em relação à respectiva atividade econômica, fixando que a variação da alíquota do SAT básica será feita a partir do Fator Acidentário Previdenciário. (BRASIL, 2007b)

Neste contexto, instituiu-se, a partir da Lei $\mathrm{n}^{\circ} 11.430$ (BRASIL, 2006), uma nova metodologia para estabelecer nexo entre trabalho e doença, para fins de concessão de benefícios previdenciários. Desse modo, o benefício concedido poderá ser caracterizado como B31 (auxílio-doença previdenciário) ou como B91 (auxílio-doença acidentário). O benefício da espécie $\mathrm{B} 91$ relaciona-se à ocorrência de acidentes de trabalho e doenças causadas ou relacionadas ao exercício profissional. O beneficio da espécie B31 é concedido pelo INSS aos segurados afastados do trabalho por conta de agravos à saúde de natureza geral, ou seja, excluindo-se acidentes ou doenças relacionadas com o trabalho. (BOFF; LEITE; AZAMBUJA, 2002) Até março de 2007 para obtenção do benefício B91, os segurados acometidos por acidentes e doenças do trabalho necessitavam apresentar uma CAT, para provar que o acidente ou doença foi decorrente do trabalho ou agravada por este. A validade das informações da CAT dependia, principalmente, do completo e exato preenchimento do formulário, tendo em vista que as informações nele contidas eram de cunho previdenciário, estatístico, epidemiológico, trabalhista e social. (OLIVEIRA, 2008)

Com a implantação do Nexo Técnico Epidemiológico Previdenciário (NTEP) em 2007, inaugura-se outra modalidade para o 
estabelecimento do nexo entre trabalho e doença. Em funcionamento nos sistemas informatizados da PS para o reconhecimento do direito do trabalhador ao benefício previdenciário acidentário (B91), esta nova modalidade (NTEP) permite com que o trabalhador não dependa apenas da apresentação da CAT para a percepção deste benefício (B91).

O Nexo Técnico Epidemiológico está baseado em um sistema de informação no qual ocorre o cruzamento das informações do código da Classificação Internacional de Doenças (CID), $10^{\text {a }}$ edição, e código da Classificação Nacional de Atividade Econômica (CNAE), apontando uma forte probabilidade de existência de nexo entre doença e trabalho, que está baseada no excesso de casos de algumas patologias no ramo de atividade econômica a que pertence o trabalhador. (OLIVEIRA, 2008)

O NTEP começou a vigorar em 01/04/2007 e, a partir deste momento, a perícia médica do INSS passou a adotar uma nova metodologia para caracterização da natureza dos benefícios concedidos por acidentes e/ou doença relacionadas ao trabalho. Até a regulamentação do NTEP, a CAT foi instrumento fundamental para notificação de acidentes do trabalho e doenças profissionais.

\section{Os nexos entre doença e trabalho no âmbito da previdência social}

Atualmente, o nexo entre doença e trabalho, de acordo com a Instrução Normativa IN/PRES n 31 , de 11/09/2008, pode ser caracterizado por meio de três alternativas: Nexo Profissional, Nexo Individual e NTEP. (BRASIL, 2008)

O Nexo Profissional pode ser considerado um Nexo Presuntivo, e está baseado nas listas A e B que foram incorporadas ao anexo II do Decreto ${ }^{\circ}$ 3.048/99. (BRASIL, 1999) O Nexo Profissional está fundamentado nas listas A e B do Decreto $n^{\circ}$ 3.048. As listas A e B foram elaboradas devido a uma necessidade de atualização e padronização em relação às condições de risco que afetam a saúde dos trabalhadores e as doenças relacionadas com o trabalho, pois a falta de atualização e padronização vinha contribuindo para o surgimento de conflitos na esfera judicial entre os segurados, PS e empregadores. (MENDES, 2005)

A lista A, relaciona os agentes etiológicos ou fatores de risco de natureza ocupacional com doenças causalmente relacionadas com os 
respectivos agentes ou fatores de risco (denominadas e codificadas segundo a CID-10). Está organizada na forma de uma tabela de entrada por agente, por exemplo: Asbestos (agente patogênico) e Mesotelioma de pleura CID C45.0 (doença) sendo considerada uma lista de doenças profissionais. (MENDES, 2005)

A lista B relaciona a doença com os agentes etiológicos ou fatores de risco de natureza ocupacional. Essa lista tem dupla entrada de doenças do trabalho ou mesopatias, pois relaciona as condições específicas em que o trabalho é executado ou prestado e a ocorrência da doença. Por exemplo: síndrome cervicobraquial (doença) e exposição a posições forçadas, gestos repetitivos e vibrações localizadas (fator de risco de natureza ocupacional). (MENDES, 2005) A partir da adoção do NTEP, as listas A e B também passaram a fazer parte dos sistemas informatizados da PS, tornando a caracterização do benefício como acidentário mais ágil.

O Nexo Individual é fundamentado em laudos que comprovem condições especiais de trabalho capazes de causar o adoecimento, mas que não constam nas listas A e B. O Nexo Individual está baseado em uma avaliação pormenorizada do perito médico do INSS e em laudos que comprovem condições especiais de trabalho capazes de causar o adoecimento, mas que não constam nas listas A e B. Sempre que houver comprovação da efetiva exposição do trabalhador aos agentes nocivos, e sendo possível constatar a associação entre a profissiografia e a doença, o Nexo Individual poderá ser aplicado.

O NTEP é baseado em critérios epidemiológicos, em que doenças com maior prevalência em determinados CNAE (ramos econômicos) em relação a outros, passaram a ser consideradas presumivelmente ocupacionais. A lista de associações CID-CNAE referente ao NTEP passou a constar da lista C do anexo II do Decreto no 3.048/99. (BRASIL, 1999)

Procedimentos e rotinas referentes ao NTEP, Nexo Individual e Nexo Profissional foram inicialmente definidos na Instrução Normativa $\mathrm{n}^{\circ} 16$, em 2007, que foi substituída no ano seguinte, para finalmente constarem da Instrução Normativa IN/PRES n ${ }^{\circ} 31$, atualmente em vigor. (BRASIL, 2008)

A adoção do NTEP e o Nexo Profissional são considerados como uma presunção legal de que a doença sofrida pelo trabalhador pode ser 
de natureza ocupacional, invertendo assim o ônus da prova. Se antes o trabalhador tinha que comprovar que a sua doença fora ocasionada pelo trabalho, agora cabe ao empregador demonstrar que a doença não possui qualquer relação com o trabalho. A finalidade da presunção acolhida pela lei é facilitar o procedimento de nexo do acidente e da doença ocupacional pela vítima. Considera-se então, uma medida normativa decisiva para superar a precariedade de condições de prova dos trabalhadores acometidos por acidentes e doenças ocupacionais, pois representam a parte mais fraca e com menores condições de produção de nexo por conta da debilidade técnica, econômica e jurídica. Por outro lado, a capacidade de prova do empregador é muito maior, pois este detém todas as informações ambientais do local de trabalho e seus efeitos na saúde do trabalhador, tendo melhores condições de prova. Assim, quando o empregador discorda do nexo presuntivo, a nova legislação considera que ele detém aptidão para produzir a prova de inexistência do nexo causal. O NTEP reduz o estigma de injusta, a burocracia excessiva e ineficiente da Previdência Social que prejudicava significativamente a concessão de benefícios às vítimas de acidentes e doenças do trabalho. (OLIVEIRA, 2008)

Após adoção do NTEP, o total de benefícios classificados como acidentários pelo INSS passou a ser formado por benefícios com e sem CAT registrada. O quantitativo total dos acidentes registrados manteve esta lógica constituída pelos acidentes informados através da CAT e benefícios acidentários para os quais não há CAT informada.

\section{Seguro de acidentes de trabalho e sua relação com o nexo técnico epidemiológico previdenciário}

A adoção do NTEP e concessão de benefícios acidentários se relacionam com o SAT, importante fonte de custeio da Seguridade Social, que financia principalmente os benefícios concedidos através do INSS para eventos advindos dos riscos ambientais do trabalho como acidentes e doenças do trabalho e aposentadorias especiais. O SAT se baseia na tarifação coletiva das empresas, calculada sobre o total das remunerações pagas aos segurados empregados e trabalhadores avulsos. 
As alíquotas do SAT são definidas pela classificação de riscos das empresas e o cálculo funciona de acordo com o Decreto $\mathrm{n}^{\circ} 3.048 / 99$, que gradua o risco em conformidade com as atividades que realizem de forma preponderante. (BRASIL, 1999) A atividade preponderante é aquela que conta com o maior número de empregados e trabalhadores avulsos, levando-se em consideração todos os estabelecimentos da empresa. Assim, as empresas são agrupadas conforme a subclasse da CNAE em uma gradação de riscos: risco leve, que corresponde ao grupo de empresas cuja alíquota de SAT é de $1 \%$; risco médio, que corresponde ao grupo cuja alíquota do SAT é de $2 \%$; risco grave, que corresponde ao grupo com a alíquota de $3 \%$. A gradação de risco das empresas é revisada a cada três anos, com objetivo de verificar o grau de acidentalidade de cada empresa dentro de um determinado grupo de CNAE. A gradação de risco sugere a probabilidade de o processo produtivo de determinado grupo de empresas pertencentes àquela subclasse da CNAE adoecer mais ou menos. (OLIVEIRA, 2008)

Em fevereiro de 2007 a PS publicou o Decreto n ${ }^{\circ}$ 6.042, que regulamentou o Fator Acidentário de Prevenção (FAP), e com este, uma nova metodologia para fixação das alíquotas do SAT. (BRASIL, 2007b) O FAP foi implementado pela PS em janeiro de 2010.

O FAP é um fator de flexibilização, um multiplicador, que varia de 0,5 a 2 pontos, que é aplicado às alíquotas de $1 \%, 2 \%$ ou $3 \%$ da tarifação coletiva por subclasse econômica das empresas, incidentes sobre a folha de salários das empresas para custear aposentadorias especiais e benefícios decorrentes de acidentes de trabalho. A aplicação deste fator estabelece uma tarifação individual, através da flexibilização do valor das alíquotas de cada empresa, podendo ser reduzidas pela metade ou elevadas ao dobro. (BRASIL, 2007b)

O cálculo do valor de FAP a ser aplicado na alíquota do SAT de cada empresa será definido de acordo com os índices de frequência, gravidade e custos dos benefícios. Os índices são comparados com os perfis das empresas da mesma atividade econômica, CNAE, definindo então, o valor do fator multiplicador (FAP). O FAP será maior na medida em que forem mais frequentes, graves e custosos, os benefícios gerados por determinada empresa, quando comparados com empresas de um mesmo grupo da CNAE. (CORRÊA FILHO, 2005) Os indicadores de frequência, gravidade e custo são elaborados a partir do conceito que a 
morbidade mais frequente e que agrava determinado ramo econômico, ou grupo de empresas, é atributo daquela modalidade de trabalho e de produção. (CORRÊA FILHO, 2005)

As bases técnicas do FAP consideram as seguintes fontes de dados para os cálculos dos índices de frequência, de gravidade e de custo: registros da CAT relativos a cada acidente ocorrido; registros de concessão de benefícios acidentários que constam nos sistemas informatizados do INSS concedidos a partir de abril de 2007; dados dos vínculos empregatícios da CNAE, número de empregados, a massa salarial, os afastamentos, as alíquotas de $1 \%, 2 \%$ ou $3 \%$, bem como valores devidos ao Seguro Social; expectativa de sobrevida do segurado obtida a partir da tábua completa de mortalidade construída pelo Instituto Brasileiro de Geografia e Estatística - IBGE. (BRASIL, 2007b)

$O$ índice de frequência indica a incidência da acidentalidade em cada empresa em determinado período de tempo e inclui todos os acidentes registrados mediante CAT e benefícios acidentários estabelecidos a partir de nexos técnicos. (BRASIL, 2007b) Para realizar o cálculo deste índice são consideradas todas as ocorrências acidentárias: auxílio doença acidentário (B91), aposentadoria por invalidez acidentária (B92), pensão por morte acidentária (B93), auxílio acidente acidentário (B94) e CAT. O índice de frequência é calculado através da seguinte fórmula: índice de frequência é igual ao número de acidentes registrados em cada empresa, somados com os benefícios acidentários sem CAT vinculada, concedidos via nexo técnico, dividido por número médio de vínculos e multiplicado por mil.

O índice de gravidade indica a gravidade das ocorrências acidentárias em cada empresa. Para cálculo deste índice são computados todos os casos relacionados às quatro modalidades de ocorrências acidentárias, sendo atribuídos pesos diferentes para cada tipo de afastamento em função da gravidade da ocorrência. O benefício de pensão por morte acidentária tem peso maior de 0,50. Para os outros benefícios, os pesos são: aposentadoria por invalidez com 0,30; auxílio doença acidentário com 0,10; e auxílio acidente acidentário com o peso também atribuído de 0,10 . O índice de gravidade é obtido através da seguinte fórmula: índice de gravidade é igual ao quantitativo de auxílio doença por acidente (B91) multiplicado por 0,1, somado ao quantitativo de aposentadorias por invalidez acidentária (B92), multiplicado por 0,3 , somado ao quan- 
titativo de pensões por morte acidentárias (B93), multiplicado por 0,5 e somado ao quantitativo de auxílio-acidente (B94), multiplicado por 0,1, dividido pelo número médio de vínculos e multiplicado por mil. (BRASIL, 2007b)

O índice de custo representa o custo dos benefícios acidentários pagos pelo INSS. Para o cálculo deste índice são computados os valores pagos pelos benefícios acidentários. No caso do auxílio doença acidentário (B91), o custo de beneficio é calculado baseado no tempo de afastamento, meses e fração de mês, do trabalhador dentro do período de cálculo do FAP. Nos casos dos benefícios de aposentadorias por invalidez acidentária (B92), pensões por morte acidentárias (B93) e auxílio acidente acidentárias (B94), os custos são calculados através de uma projeção da expectativa de sobrevida a partir da tábua completa de mortalidade do IBGE, para toda a população brasileira, considerando-se a média nacional única para ambos os sexos. O cálculo do índice de custo é obtido pela seguinte fórmula: índice de custo igual ao valor total de benefícios dividido pelo valor total de remuneração paga pelo estabelecimento aos segurados multiplicado por mil. (BRASIL, 2007b)

Após o cálculo dos índices de frequência, de gravidade e de custo, são atribuídos os percentis de ordem para as empresas, por subclasse da CNAE, para cada um desses índices. As empresas que obtiverem menores índices de frequência, gravidade e custo de acidentes e doenças do trabalho, dentro daquela subclasse da CNAE, recebem o menor percentual; por outro lado, empresas com maiores índices recebem o percentual máximo. Quando a empresa não apresentar qualquer registro de acidente ou doença do trabalho, seus índices de frequência, gravidade e custo serão nulos; deste modo seu FAP será de 0,5 , e consequentemente, sua alíquota do SAT será reduzida à metade.

O banco de dados gerado pela adoção do NTEP coleta os benefícios por incapacidade, indicando quais CNAE geraram mais benefícios acidentários. Desta forma, a adoção do NTEP possibilita a criação de um banco de dados consistente para o cálculo do FAP, estabelecendo uma relação de causalidade entre CNAE e doença que gerou beneficio. (OLIVEIRA, 2008)

Este mecanismo de flexibilidade do FAP poderá trazer modificações positivas no âmbito da proteção à saúde do trabalhador, pois permite que empresas com menos acidentes e doenças relacionadas com 
o trabalho sejam privilegiadas com uma redução na alíquota do SAT. (OLIVEIRA, 2008) Desta forma, o FAP poderá reduzir em até 50\% o imposto devido por empresas que reduzam a ocorrência de acidentes e doenças em seus trabalhadores. Poderá, também, aumentar em até duas vezes as alíquotas nos casos das empresas que apresentem indicadores de morbidade previdenciária piores que aqueles de seu próprio ramo de atividade econômica ou mais frequentes, graves e custosos que os demais setores produtivos de outros códigos de atividade econômica. (CORRÊA FILHO, 2005) O FAP passa a funcionar como um indicador de acidentes e doenças relacionadas com o trabalho das empresas. (OLIVEIRA, 2008)

Espera-se que a aplicação do FAP amplie a cultura da prevenção dos acidentes e doenças do trabalho entre as empresas e forneça subsídios para a estruturação do Plano Nacional de Segurança e Saúde do Trabalhador (PNSST), que vem sendo elaborado mediante a articulação dos Ministérios do Trabalho, Previdência e Saúde.

\section{Implantação do nexo técnico epidemiológico previdenciário: tecnologia da informação versus gestão da informação}

O principal objetivo da gestão da informação é identificar e potencializar informações estratégicas para a organização. A gestão da informação requer um processo de aprendizagem e adaptação ao ambiente, tanto externo quanto interno, por este motivo é fundamental o fluxo ininterrupto de informações, coleta e análise das mesmas para se chegar ao conhecimento e subsidiar a tomada de decisão. (ANDRADE, 2006) No caso da adoção do NTEP, a maior ênfase do processo é dada às informações provenientes do ambiente externo, que são coletadas, analisadas e monitoradas no ambiente interno. Com isso, a saúde dos trabalhadores e os agravos relacionados ao trabalho poderão ser monitorados pela Previdência por meio da gestão de informações estratégicas geradas pela adoção do NTEP.

Nesta perspectiva, a metodologia derivada da adoção do NTEP, enquanto Tecnologia da Informação vem provocando grandes mudanças no contexto organizacional da instituição, representada pela necessida- 
de de implantação de novos modelos e políticas de gestão no serviço público. Verifica-se, com isso, mudanças político-administrativas de inovação e modernização, que têm sido amplamente discutidas em virtude da emergente necessidade de otimização de resultados, associados à incessante busca por transparência na gestão pública, especialmente nos setores de saúde e previdência social. A adoção do NTEP, enquanto tecnologia da informação, enfoca a relação e reparação previdenciária (auxílios, indenizações, seguros) e associa às políticas de saúde pública de prevenção dos agravos à saúde da população trabalhadora.

Dentre os benefícios que poderão ser gerados pela adoção do NTEP, destacam-se a abordagem preventiva baseada no perfil epidemiológico da população trabalhadora, facilitando o diagnóstico dos fatores de risco condicionantes e determinantes para um grupo populacional específico e o reconhecimento, a partir das análises sistemáticas de dados gerados pela adoção do NTEP, de novos agravos ocupacionais. Isso contribuirá para divulgação de informações mais fidedignas sobre a saúde da população trabalhadora, informações estas, que contribuirão para a formação profissional daqueles que lidam com saúde do trabalhador. No futuro, os sistemas e bases de dados gerados pela adoção do NTEP, poderão ser integrados e partilhados com os sistemas e bases de dados dos Ministérios do Trabalho, Meio Ambiente e Saúde, contribuindo para a estruturação da Rede Integrada de Informações em Saúde do Trabalhador.

O processo de adoção e difusão da metodologia derivada do NTEP enquanto tecnologia da informação e comunicação provocou fortes alterações no modo como a informação é transmitida. Isto levou às mudanças na organização dos ambientes de trabalho e no contexto organizacional da Previdência, a constituição de um importante instrumento de subsídio de decisão dos peritos médicos previdenciários em relação à notificação de acidentes e doenças do trabalho.

\section{A adoção do nexo técnico epidemiológico previdenciário e a política nacional de segurança e saúde do trabalhador}

A Política Nacional de Segurança e Saúde do Trabalhador (PNSST) está inserida na política para o setor saúde envolvendo a relação entre 
Estado e Sociedade Civil. A saúde do trabalhador tem como objeto as relações entre trabalho e saúde, com o objetivo de desenvolver ações de vigilância, controle e prevenção de riscos, voltadas para promoção, proteção e recuperação da saúde do trabalhador (BRASIL, 2011).

A saúde dos trabalhadores é condicionada por fatores sociais, econômicos, tecnológicos e organizacionais relacionados ao perfil de produção e consumo, além de fatores de risco de natureza física, química, biológica, mecânica e ergonômica presentes nos diversos processos de trabalho. (SANTANA et al., 2006)

O campo do conhecimento voltado para saúde do trabalhador constantemente se altera, pois surgem novos objetos de estudo que incluem mudanças tecnológicas e organizativas dos processos de trabalho, reconhecimento de nexos causais entre trabalho e doença, diagnóstico de causa dos agravos à saúde, reconhecimento de novas doenças profissionais, controle ou eliminação de novos riscos dos ambientes laborais. (MINAYO-GOMEZ, THEDIM-COSTA, 1997) Assim, os estudos da saúde do trabalhador estão cada vez mais voltados para intervenções coletivas em uma perspectiva multicausal, com ênfase na prevenção, modificando assim, as interpretações da relação trabalho-saúde e as formas de intervenção nos ambientes de trabalho. Neste contexto merecem destaque as ações de trabalhadores, sindicatos, técnicos da área de vigilância e saúde do trabalho, legisladores e instituições acadêmicas. (MINAYO-GOMEZ, THEDIM-COSTA, 1997)

No Brasil existem várias instituições públicas com atribuições de intervenção na área de saúde do trabalhador. Historicamente, a política de Saúde do Trabalhador sempre sofreu com a falta de articulação entre estas diversas instituições, devido a uma multiplicidade e superposição de ações na área. Deste modo, na $8^{a}$ Conferência Nacional de Saúde, realizada em março de 1986, após um amplo debate, surgiram os primeiros eixos norteadores da PNSST com o objetivo de promover atenção integral à saúde do trabalhador. Posteriormente, na $2^{\mathrm{a}}$ Conferência Nacional de Saúde do Trabalhador, o fórum definido na IX Conferência Nacional de Saúde, em 1992, teve como tema central a construção da PNSST.

No âmbito da saúde, a Portaria n 1.125/05 explicitava os propósitos da política de saúde do trabalhador para o SUS, que seriam: a promoção da saúde e a redução da morbimortalidade dos trabalhadores, 
implementação de ações integradas, intra e intersetorialmente, de forma contínua, sobre os determinantes dos agravos decorrentes dos modelos de desenvolvimento e processos produtivos, com a participação de todos os sujeitos sociais envolvidos. (BRASIL, 2005) Com o objetivo de realizar estas ações e fortalecer a PNSST no SUS, foi criada, em 19 de setembro de 2002, através da Portaria $n^{\circ} 1.679$, do Governo Federal, a Rede Nacional de Atenção Integral à Saúde do Trabalhador (RENAST). Esta tem por objetivo articular, no âmbito do SUS, ações de prevenção, promoção e recuperação da saúde dos trabalhadores urbanos e rurais, independentemente do vínculo empregatício e tipo de inserção no mercado de trabalho. (BRASIL, 2002) Com a RENAST, vislumbrava-se uma boa perspectiva de apoio institucional, aporte de recursos para viabilizar ações de saúde do trabalhador na rede de saúde do SUS e o fortalecimento do controle social em saúde do trabalhador.

Atualmente, a PNSST, além de estar diretamente relacionada com as políticas dos setores Trabalho, Previdência Social, Meio Ambiente e Saúde, apresenta interfaces com as políticas econômicas, de Indústria e Comércio, Agricultura, Ciência e Tecnologia, Educação e Justiça, em uma perspectiva intersetorial e transversal. No contexto atual, o objetivo desta política é abranger o maior número de trabalhadores possível, e por isto, considera trabalhadores todos os homens e mulheres que exercem atividades para sustento próprio e/ou de seus dependentes, qualquer que seja sua forma de inserção no mercado de trabalho, no setor formal ou informal da economia.

Estão incluídos nesse grupo todos os indivíduos que trabalharam ou trabalham, tais como: empregados assalariados, trabalhadores domésticos, avulsos, rurais, autônomos, temporários, servidores públicos, trabalhadores em cooperativas e empregadores, particularmente os proprietários de micro e pequenas unidades de produção e serviços, entre outros. Também são considerados trabalhadores aqueles que exercem atividades não remuneradas, participando de atividades econômicas na unidade domiciliar; o aprendiz ou estagiário e aqueles temporária ou definitivamente afastados do mercado de trabalho por doença, aposentadoria ou desemprego. (SANTANA et al., 2006)

O perfil de morbimortalidade dos trabalhadores se caracteriza pela coexistência de acidentes de trabalho típicos, doenças profissionais e doenças relacionadas ao trabalho. (SANTANA; NOBRE; WALDVO- 
GEL, 2005) A escassez e inconsistência das informações sobre a real situação de saúde dos trabalhadores sempre dificultou a definição de prioridades, o planejamento e alocação de recursos para ações da política Nacional de Saúde do Trabalhador, além de privar a sociedade de instrumentos importantes para melhoria das condições de vida e traba1ho. (SANTANA et al, 2006) Nesse sentido, a importância da adoção do NTEP para política Nacional de Saúde dos Trabalhadores se relaciona ao reconhecimento do nexo entre acidentes, doenças e trabalho pela Previdência Social, que constitui um importante instrumento estatístico/epidemiológico de subsídio para o perfil de morte e adoecimento relacionado ao trabalho.

Apesar de todos estes avanços na legislação na área de Saúde do Trabalhador ainda existem ações não integradas e executadas por órgãos distintos e distanciados institucionalmente. A despeito de se atribuir ao SUS a responsabilidade pela assistência médica ao doente e ao acidentado do trabalho, pressupondo o atendimento deste na rede de saúde, as ações de reabilitação não foram totalmente incorporadas e são precariamente articuladas entre o SUS e a estrutura do INSS. As ações de fiscalização dos ambientes de trabalho continuam sendo primordialmente executadas pelo Ministério do Trabalho por meio da Superintendência Regional do Trabalho e Emprego - SRTE e pelo Ministério da Previdência Social, através do Instituto Nacional de Seguridade Social INSS, mas ainda falta uma articulação destas instituições com as ações da Vigilância Sanitária. O intercâmbio de informações entre o espaço social e a esfera administrativa sobre acidentes e doenças do trabalho ocasionado pela adoção do NTEP poderá proporcionar uma maior articulação das inovações institucionais com a sociedade, interações mais estreitas entre todas as esferas do Estado para a melhoria da saúde dos trabalhadores.

\section{Considerações finais}

A história da Previdência Social no Brasil mostra um longo processo de institucionalização do seguro acidentário, passando de empresas às categorias profissionais, para finalmente alcançar todo o mercado formal de trabalho pelo regime da Consolidação das Leis do Trabalho (CLT). De estrutura bipartidária, passou ao sistema tripartite com a in- 
trodução do Estado junto ao empregador e trabalhador. Nesse processo, o poder público assumiu o controle político da previdência e incorporou a evolução da noção de seguro para seguridade, ao tomar a saúde e a assistência social como objeto da proteção. Com a Constituição de 1988, a noção de seguridade emergiu como direito do cidadão e dever do Estado, estendendo-se a toda sociedade.

Nesse contexto, o seguro acidentário introduziu as modalidades de comunicação do evento doença e acidente, para desencadear os procedimentos periciais de caracterização da relação ou nexo com o trabalho. Momento marcante desse processo foi a introdução da CAT como documento de notificação obrigatória dos acidentes e doenças do trabalho para todo aquele pertencente ao mercado formal em regime CLT. A CAT sintetizava os nexos clínico, epidemiológico e administrativo necessários ao reconhecimento da doença ou acidente do trabalho. No entanto, o ônus desses procedimentos recaía sobre o trabalhador e impunha condições de subnotificação desses agravos. Todavia, estas notificações produziram informações epidemiológicas sobre um universo grande de trabalhadores, o que se constituiu em uma modalidade de inteligência, cujo uso gerencial possibilitou a estruturação de decisões capazes de conferir ao trabalhador nexos presuntivos de doenças do trabalho. Originou-se assim o NTEP, que proporcionou a inversão da lógica da prova, transferindo o ônus do contraditório para o empregador.

O NTEP resultou no aumento significativo do reconhecimento de doenças relacionadas ao trabalho, reduzindo significativamente a invisibilidade epidemiológica e o sofrimento do trabalhador na garantia dos seus direitos securitários. Mantém-se a CAT, mas o próprio aumento das notificações pelo NTEP retroalimenta as informações epidemiológicas, fortalece ainda mais a capacidade gerencial dos procedimentos de nexo presuntivo e subsídios às ações intersetoriais com o SUS e demais órgãos envolvidos na proteção do trabalhador. Há avanços ainda a serem feitos, principalmente em relação às patologias do trabalho e acidentes de categorias com difícil acesso ao sistema de saúde. No entanto, o NTEP indica que é possível aperfeiçoar a gestão pública com o uso adequado da informação, dos fundamentos de epidemiologia e dos princípios gerenciais que priorizam a garantia de direitos. Esse exemplo pode servir para outras instituições, na perspectiva de se construir uma Política de Saúde do Trabalhador efetiva, com ações de prevenção, 
promoção e recuperação da saúde dos trabalhadores urbanos e rurais, independentemente do vínculo empregatício e do tipo de inserção no mercado de trabalho.

\section{Referências}

ANDRADE, S. C. R. Processo de inclusão digital em rede empresarial do segmento de suprimentos industriais: utilização de tecnologias de informação e comunicação. Ciência da Informação, v. 35, n. 1, jan. - abr. , 2006

BOFF, M. B.; LEITE, D.; AZAMBUJA, M. I. Morbidade subjacente à concessão de benefício por incapacidade temporária para o trabalho. Revista Saúde Pública, São Paulo, v. 36, n. 3, jun. , 2002.

BRAGA, D. Acidente de trabalho com material biológico em trabalhadores da equipe de enfermagem do Centro de Pesquisas Hospital Evandro Chagas: um olhar da saúde do trabalhador. 2000. 75f. Dissertação (Mestrado em Ciências). Fundação Oswaldo Cruz, Escola Nacional de Saúde Pública, Rio de Janeiro, 2000.

BRASIL. Congresso Nacional. Lei no 6. 439 de 01 de setembro de 1977, Institui o Sistema Nacional de Previdência e Assistência social, e dá outras providências. Brasília: Diário Oficial da União, 02 set. 1977.

. Instituto Nacional do Seguro Social. Instrução Normativa INSS/PRES no 31 de 10 de setembro de 2008, Dispõe sobre procedimentos e rotinas referentes ao Nexo Técnico Previdenciário, e dá outras providências. Diário Oficial da União, 11 set. 2008.

BRASIL. Ministério da Saúde. Organização Pan-Americana de Saúde. Doenças Relacionadas ao Trabalho. Manual de Procedimentos para Serviços de Saúde. Série A. Normas e Manuais Técnicos, Brasília, n. 114. 2001.

. Ministério da Saúde. Portaria ${ }^{\circ}$ 1. 679/GM de 19 de setembro de 2002, Dispõe sobre a estruturação da rede nacional de atenção integral à saúde do trabalhador no SUS e dá outras providências. Disponível em: < http://dtr2001. saude. gov. br/sas/PORTARIAS/ Port2002/ Gm/GM-1679. htm. > Acesso em: 20 de novembro de 2011.

. Ministério da Saúde. Portaria no 1. 125/GM de 6 de julho de 2005, Dispõe sobre os propósitos da política de saúde do trabalhador para o SUS. Disponível em: <http://dtr2001. saude. gov. br/sas/PORTARIAS/ Port2005/GM/GM-1125. htm. > Acesso em: 20 de novembro de 2011. . Ministério da Previdência Social. Anuário Estatístico da Previdência Social. Brasília: MPS/DATAPREV, 2007a. 
BRASIL. Ministério da Previdência Social. Instrução Normativa INSS/ PRES n ${ }^{\circ} 45$ de 6 de agosto de 2010, Dispõe sobre a administração de informações dos segurados, o reconhecimento, a manutenção e a revisão de direitos dos beneficiários da Previdência Social e disciplina o processo administrativo previdenciário no âmbito do Instituto Nacional do Seguro Social - INSS. Diário Oficial da União, 11 ago. 2010.

. Presidência da República. Decreto-Lei no 4.682 de 24 de janeiro de 1923, Cria, em cada uma das empresas de estradas de ferro existentes no país, uma Caixa de Aposentadoria e Pensões para os respectivos empregados. Diário Oficial da União, 28 jan. 1923.

. Presidência da República. Decreto-Lei no 7.036 de 10 de novembro de 1944. Reforma da Lei Acidente de Trabalho. Diário Oficial da União, 13 nov. 1944. Disponível em: < http://www2.camara.leg. br/legin/fed/declei/1940-1949/decreto-lei-7036-10-novembro-1944389493-publicacaooriginal-1-pe.html>. Acesso em: 01 jan. 2012.

. Presidência da República. Lei no 3. 807 de 26 de agosto de 1960, Dispões sobre a Lei Orgânica da Previdência Social. Brasília: Diário Oficial da União, 05 set. 1960.

. Presidência da República. Lei nº 5. 316 de 14 de setembro de 1967, Integra o seguro de acidentes do trabalho na previdência social, e dá outras providências. Brasília: Diário Oficial da União, 18 set. 1967.

. Presidência da República. Lei no 8. 080 de 19 de setembro de 1990, Dispõe sobre as condições para a promoção, proteção e recuperação da saúde, a organização e o funcionamento dos serviços correspondentes e dá outras providências. Diário Oficial da União, 20 set. 1990.

. Presidência da República. Lei no 8. 213 de 24 de julho de 1991, Dispõe sobre os Planos de Benefícios da Previdência Social e dá outras providências. Diário Oficial da União, 14 ago. 1991a.

BRASIL. Presidência da República. Lei no 8. 212 de 24 de julho de 1991, Dispõe sobre a organização da Seguridade Social, institui Plano de Custeio, e dá outras providências. Diário Oficial da União, 25 jul. 1991b.

. Presidência da República. Decreto n ${ }^{\circ} .611$, de 21 de julho de 1992, dá nova redação ao Regulamento dos Benefícios da Previdência Social. Diário Oficial da União, 22 jul. 1992.

. Presidência da República. Decreto n ${ }^{\circ}$. 3. 048 de 06 de maio de 1999, Aprova o Regulamento dos Benefícios da Previdência Social, e da outras providência. Diário Oficial da União, 07 maio 99. 
BRASIL. Presidência da República. Lei no 11.430 de 26 de dezembro de 2006, Altera as Leis nos 8 . 213, de 24 de julho de 1991, e 9. 796, de 5 de maio de 1999, aumenta o valor dos benefícios da previdência social; e revoga a Medida Provisória ${ }^{\circ} 316$, de 11 de agosto de 2006; dispositivos das Leis $\mathrm{n}^{\text {os }} 8$. 213, de 24 de julho de 1991, 8. 444, de 20 de julho de 1992, e da Medida Provisória n ${ }^{\circ}$. 187-13, de 24 de agosto de 2001; e a Lei n ${ }^{\circ}$ 10. 699, de 9 de julho de 2003. Diário Oficial da União, 27 dez. 2006.

. Presidência da República. Decreto ${ }^{\circ} 6.042$ de 12 de fevereiro de 2007, Altera o Regulamento da Previdência Social, aprovado pelo Decreto $\mathrm{n}^{\circ} 3$. 048, de 6 de maio de 1999, disciplina a aplicação, acompanhamento e avaliação do Fator Acidentário de Prevenção - FAP e do Nexo Técnico Epidemiológico, e dá outras providências. Diário Oficial da União, 12 fev. $2007 \mathrm{~b}$.

. Presidência da República. Decreto n ${ }^{0} 7.602$ de 7 de novembro de 2011, Dispõe sobre a Política Nacional de Segurança e Saúde do Trabalhador - PNSST. Diário Oficial da União, 08 nov. 2011.

. Senado Federal. Constituição da República Federativa do Brasil de 1988. Brasília: Diário Oficial da União, 05 out. 1988.

BRUMER, A. Previdência social rural e gênero. Sociologias, Rio Grande do Sul, n. 7, p. 50-81, 2002.

CARNEIRO, L. S. Uma visão sistemática da previdência social. Revista de Direito, v. 11, n. 13, 2008.

CORDEIRO, R.; SAKATE, M.; CLEMENTE, A. P. Subnotificação de acidentes do trabalho não fatais em Botucatu. Revista Saúde Pública, São Paulo, v. 39, n. 2, abr. 2005.

CORRÊA FILHO, H. R. O Fator Acidentário Previdenciário como instrumento epidemiológico de controle de riscos do trabalho.

Revista Brasileira de Epidemiologia, v. 8, n. 4, dez. 2005.

MENDES, R. Conceito de patologia do trabalho. In: Mendes, R. (Org.).

Patologia do Trabalho. 2. ed. São Paulo: Atheneu, 2005. p. 48-92.

MINAYO-GOMEZ, C.; THEDIM-COSTA, S. A construção do campo da saúde do trabalhador: percurso e dilemas. Caderno Saúde Pública, Rio de Janeiro, v. 13, 2 jan. 1997.

OFFE, C. Trabalho: a categoria chave da sociologia? Revista Brasileira de Ciências Sociais. São Paulo, v. 4, n. 10, jun. 1989.

OLIVEIRA, P. R. Nexo Técnico Epidemiológico Previdenciário - NTEP e o Fator Acidentário de Prevenção - FAP: um novo olhar sobre a saúde do trabalhador. 2008. 240f. Tese (Doutorado em Ciências da Saúde).

Faculdade de Ciências da Saúde, Universidade de Brasília, Brasília, 2008. 
RAMAZZINI B. As doenças dos trabalhadores.

2. ed. São Paulo: Fundacentro, 1999.

SANTANA, V. S.; NOBRE, L.; WALDVOGEL, B. Acidentes de trabalho no Brasil entre 1994 e 2004: uma revisão. Ciência Saúde Coletiva, Rio de Janeiro, v. 10, n. 4, p. 841-855, out. -dez. 2005.

SANTANA, V. S. et al. Acidentes de trabalho: custos previdenciários e dias de trabalho perdidos. Revista de Saúde Pública, São Paulo, v. 6, n. 6, p. 1004-1012, 2006. . Gravidade dos acidentes de trabalho atendidos em serviços de emergência. Revista Saúde Pública, São Paulo, v. 43, n. 5, p. 750-760, out. 2009.

SANTOS, M. Direito previdenciário. Rio de Janeiro: Saraiva, 2007. 



\section{PARTE II}

\section{Estudos Ambientais}


Estudos ambientais focalizam o meio ambiente e aspectos de saúde dos seres vivos visando a suas sustentabilidades. O tema é extremamente abrangente e multidisciplinar, englobando aspectos científicos, econômicos e sociais, que interagem de forma complexa. Com o aumento da população humana e do seu consumo de bens e serviços, a sustentabilidade ambiental torna-se mais complexa e desafiante.

As demandas de estudos ambientais englobam diferentes aspectos: tipo de fonte de emissões, que podem ser naturais ou antrópicas; natureza das emissões, que podem ser químicas, físicas ou biológicas; translocamento através dos diferentes compartimentos ambientais e respectivas transformações resultantes de reações químicas, de modificações da forma física ou interações biológicas; aspectos temporais, de efeitos de emissões passadas que persistem como passivo ambiental até as previsões futuras como as mudanças climáticas; desenvolvimento de tecnologias, que reduzam ou eliminem as emissões.

Dada a complexidade das interações na natureza, os estudos ambientais são necessariamente interdisciplinares. Há uma necessidade do conhecimento generalista aliado ao conhecimento profundo do aspecto a ser abordado. As maiores contribuições para o conhecimento decorrem da geração de novas informações envolvendo aspectos específicos de duas ou mais disciplinas.

Neste livro, alguns estudos focalizando diversos aspectos ambientais são apresentados com algumas características descritas acima. Dois capítulos abordam as mudanças climáticas: o primeiro focaliza as emissões de gases estufa na produção agrícola do biodiesel e outro apresenta as mudanças previstas para o Estado da Bahia. Um capítulo apresenta o desenvolvimento de uma nova tecnologia para o abatimento da emissão de bactérias e fungos da lagoa de chorume do aterro sanitário de Salvador. Os aspectos etnográficos relacionados às mortes por exposição ao amianto são apresentados em outro capítulo. Um capítulo aborda o gerenciamento das perdas de um catalisador utilizado no refino do petróleo e o risco à saúde pública, envolvendo conhecimento de engenharia, química e saúde. 


\title{
Mudanças climáticas e aspectos relacionados com o estado da Bahia
}

\author{
Tania Mascarenhas Tavares \\ Sérgio Telles de Oliva \\ Rodolfo Rojas Guarín \\ Carolina L. Wilches Arciniegas
}

\section{Introdução}

O estado da Bahia, assim como os demais estados brasileiros, está relacionado às mudanças climáticas sob dois aspectos: a sua contribuição em termos de gases estufa para a atmosfera do planeta e os efeitos que sofrerá com as mudanças climáticas. Vamos analisar as duas situações separadamente.

\section{Impactos previstos para o estado da Bahia decorrentes das previsões de mudanças climáticas}

Ao longo da sua vida, a terra já vivenciou várias mudanças climáticas causadas por fenômenos naturais. Essas mudanças eram geralmente gradativas, em escala de tempo geológica de séculos, milênios e milhões de anos. (GRAEDEL; CRUTZEN, 1995, BAILEY et al., 2002)

No momento existe uma previsão - endossada pela ONU e por cientistas de um grande número de países do mundo -, que a temperatura média da terra irá aumentar num curto prazo de tempo geológico, menos de um século, em decorrência das emissões de gases estufa lançadas pelas atividades antrópicas. Prevê-se, também, um aumento das faixas de variações das temperaturas, ou seja, verões serão mais quentes e os invernos mais frios. (IPCC, 2007) O quarto relatório do Painel Internacional de Mudanças Climáticas, publicado em 2007 - 
o IPCC AR4 (2007) - é o maior e mais detalhado sumário da situação de mudanças climáticas já elaborado, tendo sido produzido por milhares de autores, editores e revisores de dezenas de países citando mais de 6 mil estudos científicos revisados.

Processos naturais podem se somar, compensar ou anular o aquecimento global decorrente do aumento dos gases estufas na atmosfera. A intensificação da atividade solar pode ser responsável por parte do aumento da temperatura do planeta observada nas últimas décadas. (SCAFETTA, 2010) As erupções vulcânicas, a depender de sua natureza, podem baixar a temperatura da terra durante o período no qual as partículas emitidas se mantiverem em suspensão na atmosfera. (GRAEDEL; CRUTZEN, 1995) Recentemente alguns astrônomos têm apresentado cálculos correlacionando os períodos orbitais de Júpiter e Saturno e o ciclo solilunar, com as variações de temperatura do planeta numa escala temporal de 20-60 anos e atribuindo pelo menos $60 \%$ do aquecimento observado, desde 1970, como tendo sido induzido por essas oscilações, inclusive com a previsão de uma possível estabilização ou resfriamento até 2030-2040. (SCAFETTA, 2010) Outras oscilações astronômicas estão sendo correlacionadas com variações na formação de nuvens altas, e consequentemente da reflexão da radiação incidente sobre a terra, resultando na variação de temperatura da sua superfície. Essas oscilações resultariam da variação das órbitas dos cometas em relação ao sol, com emissão maior ou menor de poeira cósmica (STOZHKOV et al., 2007) e das modulações da ionosfera (SCAFETTA, 2012). Essas últimas entraram na fase do ciclo de 60 anos favorável ao aumento da reflexão de radiação, portanto na fase de resfriamento da terra, prevendo-se uma possível estabilidade ou decréscimo da temperatura da terra nas próximas décadas (SCAFETTA, 2012).

A própria poluição atmosférica, emitida na forma de partículas, pode ter efeitos opostos em relação à temperatura, a depender do tamanho e da composição das partículas. Os efeitos podem ser diretos ou indiretos. Nos efeitos diretos, as partículas suspensas no ar absorvem radiação aquecendo o local onde estão presentes, como é o caso da fuligem. Uma parcela do aquecimento da temperatura em centros urbanos decorre das emissões de partículas veiculares e não apenas do aumento da concentração dos gases estufa. (GRAEDEL; CRUTZEN, 1995) Estudos recentes atribuem cerca de $70 \%$ do aquecimento nas 
montanhas do Himalaia, resultantes da presença de partículas de fuligem em suspensão e as principais responsáveis pelo derretimento das geleiras, ao invés do aquecimento global dos gases estufa. (SRIVASTAVA et al., 2012) Como efeitos indiretos temos as partículas de poluição do ar se concentrando em determinadas alturas da atmosfera, formando verdadeiras nuvens de material particulado que impedem a radiação solar de alcançar a superfície da terra e, portanto, causando um resfriamento. Outro efeito indireto é a indução de formação de nuvens devido ao aumento de núcleos de condensação de gotículas e partículas geladas que as compõem, aumentando a reflexão da radiação solar incidente. (IPCC, 2007)

Certamente esses aspectos publicados nos últimos cinco anos serão incorporados no próximo relatório a ser publicado em 2014, o IPCC AR5. É possível que as previsões atuais sejam revistas. Adotamos nessa avaliação dos impactos previstos para o estado da Bahia as previsões do último relatório publicado pelo IPCC, com o qual o Governo Brasileiro se alinha através do Ministério do Meio Ambiente (MMA) e do Instituto Nacional de Pesquisas Espaciais (INPE). Sugere-se que a presente avaliação seja revista em 2014, após o lançamento do próximo relatório.

De acordo com o IPCC AR4 (2007), o Brasil é vulnerável às mudanças climáticas. As mudanças climáticas principais serão o aumento de temperatura média do ar - consequentemente, do solo e das águas - e o aumento da faixa de variação das temperaturas - consequentemente, dos desastres naturais. Já existem evidências de mudanças climáticas no Brasil, mas as mudanças serão maiores e mais evidentes a partir de 2030, não só no nosso país, mas também em todo o planeta.

Os estudos mostram que, no Brasil, a temperatura média aumentou aproximadamente $0,75^{\circ} \mathrm{C}$ até o final do século 20 (considerando a média anual entre $1961-90$ de $24,9^{\circ} \mathrm{C}$ ). Em nível regional, é possível observar que, no período de 1951-2002, as temperaturas mínimas cresceram em todo o país, apresentando um aumento expressivo de até $1,4^{\circ} \mathrm{C}$ por década. As tendências de aquecimento são detectadas em nível anual e sazonal, com maiores aquecimentos no inverno e na primavera. (MARENGO, 2007)

Existem projeções do aumento futuro das temperaturas para diferentes níveis de emissões de gases estufa no planeta. (IPCC, 2077) Mantendo-se a taxa de crescimento atual das emissões (Cenário A2), 
o nordeste brasileiro se tornará, em média, 2 a $4^{\circ} \mathrm{C}$ mais quente até o fim do presente século com redução no volume de chuva que pode exceder a $60 \%$. Se as emissões de gases estufa mundiais conseguirem ser reduzidas, num cenário de baixa emissão (B2), a temperatura do nordeste brasileiro aumentará 1 a $3^{\circ} \mathrm{C}$ com redução de até $60 \%$ do volume de chuva. As variações ao longo do Século XXI foram analisadas por Marengo (2007), examinando as previsões dos diversos modelos utilizados pelo IPCC e por outras instituições, resumindo as anomalias de temperatura, umidade e chuva do nordeste, para três faixas de tempo, 2010 a 2040, 2041 a 2071 e 2071 a 2100, e para dois cenários, B2 de baixas emissões e A2 de altas emissões de carbono. Marengo (2007) concluiu que o nordeste brasileiro tenderá a ser mais quente e o ar mais úmido - uma vez que a evaporação será mais intensa - e os solos mais secos, havendo um aumento nas anomalias de chuva durante os períodos chuvosos, que terão menor duração e os de estiagem que serão mais prolongados. No horizonte de 2050, o aquecimento previsto é de aproximadamente $1,6^{\circ} \mathrm{C}$ no cenário de emissões $\mathrm{B} 2$ e $2^{\circ} \mathrm{C}$ no cenário $\mathrm{A} 2$, enquanto as anomalias de chuva chegarão a $+0,4 \mathrm{~mm}$ por dia durante o período de chuvas, em ambos os cenários. No horizonte de 2080, o aquecimento previsto é de $2,5^{\circ} \mathrm{C}$ no cenário de baixas emissões (B2) e $3,5^{\circ} \mathrm{C}$ no cenário de altas emissões (A2), enquanto as anomalias de chuva podem chegar a $+0,5 \mathrm{~mm}$ por dia, nos dois cenários. Marengo (2007) registra uma diferença entre as previsões de dois modelos matemáticos: o modeHadCM3, inglês, que prevê aumentos de temperatura mais altos $\left(2,5^{\circ} \mathrm{C}\right.$ para $\mathrm{B} 2$ e $3,5^{\circ} \mathrm{C}$ para $\left.\mathrm{A} 2\right)$ e o modelo CSIRO, da Austrália, que prevê aumentos de $2,1^{\circ} \mathrm{C}$ e $3,3^{\circ} \mathrm{C}$, respectivamente. Por outro lado, o modelo HadCM3 prevê poucas anomalias de chuva nos dois cenários, diferentemente do modelo CSIRO.

Dessa forma as previsões de Marengo (2007) apontam:

[...] para um clima de Nordeste mais quente e ligeiramente mais úmido. É de esperar que as altas temperaturas do ar podem gerar aumento da evaporação na região e assim o futuro pode ser caracterizado por uma redução do volume de água armazenada no solo e deficiência no balanço hidrológico, e que não seria compensada pelas anomalias positivas de chuva como simuladas pelos modelos. Assim, o problema de "aridização" do Nordeste no futuro poderia ser devido a um aumento nas taxas de evaporação e às altas temperaturas do ar. Isto pode ter consequências graves na atividade agrícola e irrigação. 
Em Dezembro de 2009, durante a 15 a Conferência Anual de Mudanças Climáticas nas Nações Unidas, realizada na Dinamarca, o Centro Hadley de Meteorologia do Reino Unido, em parceria com o Instituto Nacional de Pesquisas Espaciais (INPE), apresentou um quadro mais sombrio sobre os impactos do aquecimento global no Brasil. De acordo com modelo construído com os dados das duas instituições, o aquecimento no Brasil poderá ser $20 \%$ maior que a média mundial durante o século XXI. Isso significa, por exemplo, que se o planeta tiver uma alta de $1,8{ }^{\circ} \mathrm{C}$ na temperatura, a resposta no Brasil será de $2^{\circ} \mathrm{C}$. Pode parecer pouco, mas é preciso lembrar que o planeta terra já se aqueceu $0,7^{\circ} \mathrm{C}$ nos últimos 50 anos e com muitas consequências maléficas identificadas e mensuradas. Os pesquisadores britânicos e brasileiros mostram, nesse estudo, que as chuvas seriam reduzidas em $15 \%$ na Bacia do São Francisco.

Por outro lado, estudos recentes de calibração do modelo matemático desse mesmo Centro Hadley do Reino Unido, conduzidos pela Universidade Federal da Bahia (UFBA) (TANAJURA; GENZ; ARAÚJO, 2010), indicam que os resultados dos modelos estão mais altos do que os dados observados, e que a região sofreria um pouco menos do que o anunciado.

As modelagens matemáticas do IPCC preveem que as mudanças de valores médios de temperatura e chuva vêm acompanhadas de variações de amplitude mais altas, ou seja, que as temperaturas máximas e mínimas irão aumentar, ocorrendo ondas de calor e de frio, mais fortes, de chuvas mais intensas e períodos de estiagem mais longos (IPCC 2007). Portanto, o impacto das mudanças climáticas previsto é maior do que a simples observação das variações médias anuais.

O impacto possível dessas mudanças de clima, sobre o nordeste, foi assim sumarizado por Marengo do INPE, durante a III Conferência Regional sobre Mudanças Globais: América do Sul, 2007, em São Paulo.

Aumento das secas, especialmente no semiárido; Impactos na agricultura de subsistência e na saúde; Perda de biodiversidade da caatinga; Risco de desertificação; Possível migração para outras regiões (refugiados do clima); Chuvas intensas podem aumentar o risco de deslizamentos podendo afetar as populações que moram em morros desmatados; Enchentes urbanas mais intensas. (DIAS et al., 2007) 
Adicione-se a esse sumário os seguintes impactos adicionais descritos no IPCC (2007) e pelo próprio Marengo (2007) em relatórios do INPE:

- Possíveis prejuízos na produção da energia hidroelétrica, com aumento de chuvas intensas e estiagens;

- Aumento do nível do mar, danificando os recifes de corais e manguezais - além de inundar as áreas costeiras ocupadas -, afetando a produção pesqueira que, na região nordeste é muito dependente desses ecossistemas

- Aumento dos vetores epidemiológicos tropicais - portanto a saúde da população animal (ex. vírus desconhecidos) e humana (p. ex. aumento de dengue, de malária);

- Conflitos sociais, decorrentes da migração de populações.

- Possíveis ocorrências de furacões e tufões devido ao aumento da temperatura da superfície do mar (Emanuel, 2005) - como já vem ocorrendo no sul do Brasil nos últimos anos e divulgados amplamente pela mídia.

Para o estado da Bahia são previstos, entre os vários efeitos, dois principais: a elevação do nível do mar, afetando as macrorregiões litorâneas e a elevação da temperatura média com aumento da evapotranspiração, intensificando a aridez, afetando principalmente as regiões interioranas e continentais, ou seja, o Cerrado e o Semiárido.

Principais impactos nas macrorregiões litorâneas: Litoral norte, litoral sul e Recôncavo/RMS.

Devido a mudanças climáticas e evolução geológica, a feição da Baia de Todos os Santos mudou ao longo dos séculos. Há apenas 10.000 anos atrás podíamos andar a pé de Salvador até Itaparica, que não seria uma ilha, e sim uma área um pouco mais elevada. O rio Paraguaçu e outros riachos que deságuam na atual baia, já existiam muito antes dessa época e desaguavam diretamente no oceano. Durante os últimos 9.000 anos, sua forma e dimensões já mudaram muitas vezes. (MARTIN et al. 1979; LEITE, 1995; LEITE, 1997) 
A Baía de Todos os Santos faz parte da bacia sedimentar do Recôncavo e está implantada sobre rochas sedimentares. (BITTENCOURT BRICHTA; DI NAPOLI, 1976) Durante um determinado intervalo de tempo, um movimento descendente denominado subsidência, determinou a sua formação. Alguns estudos antigos e revistos recentemente atribuem a modelagem da baia principalmente a movimentos tectônicos recentes. (MARTIN et al., 1986; CIRANO; LESSA, 2007) Outros trabalhos foram além, levando em consideração as variações eustáticas do nível do mar durante o Cenozoico. (MARTIN; DOMINGUEZ; BITTENCOURT, 1998; MARTIN; DOMINGUEZ; BITTENCOURT, 2003) Considerando esse,

[...] o principal fator a determinar a origem e o modelado da Baía de Todos os Santos, que teria resultado da erosão diferencial associada a um dramático rebaixamento do nível de base. Tanto é assim que existe uma perfeita correlação entre a altitude do terreno e a resistência das diferentes unidades geológicas à erosão. (BITTENCOURT; BRICHATA; DI NAPOLI, 1976)

Esses processos ocorreram em escala geológica, onde a evolução era gradativa e não havia ocupação antrópica. Atualmente, o entorno da Baía de Todos os Santos está ocupado, praticamente na sua totalidade, com aglomerados urbanos e atividades produtivas - industriais e agropastoris - num tecido socioeconômico-ambiental estreitamente entrelaçado, onde mudanças ambientais afetam intensamente a organização social e a economia. Em menor intensidade, situação semelhante ocorre em grande parte do litoral de todo o Estado. Em todos os casos, as mudanças climáticas afetarão toda a zona litorânea baiana. O aumento médio da temperatura do oceano Atlântico entre 1961-1990 foi de $1^{\circ} \mathrm{C}$, o que resultou em um aumento de volume das suas águas devido a expansão térmica - a partir de $4^{\circ} \mathrm{C}$ o volume por unidade de peso de água aumenta. (IPCC, 2007) Esse acontecimento vem sido atribuído aos avanços do mar em toda a costa brasileira nos últimos dez anos e amplamente divulgados pela televisão, particularmente no nordeste. No caso dessas macrorregiões baianas, as ilhas têm sido as maiores vítimas, principalmente as ilhas mais planas, onde as águas adentram facilmente, como Itaparica, na macrorregião Recôncavo/RMS, com o número maior de registros de avanço do mar na sua costa oceânica. No caso de Itaparica, a situação já é séria o suficiente para motivar a 
Prefeitura do Município de Vera Cruz - e que ocupa a maior parte da ilha - a solicitar verba específica ao Governo Estadual para construir uma proteção da parte de sua costa mais vulnerável. A elevação do nível do mar é a maior ameaça decorrente das mudanças climáticas. A partir do ano 2030, quando se espera um aumento de mais 1 ou $2^{\circ} \mathrm{C}$ de temperatura média, o nível do mar deverá subir mais rapidamente, inundando a parte mais baixa da costa continental e das ilhas, inclusive das cidades litorâneas, entre elas parte de Salvador. A depender do aumento que ocorra na temperatura, a inundação será maior ou menor. Em 2100 é de se supor que uma parte significativa da cidade do Salvador, assim como das cidades de Itaparica, Ilhéus, Caravelas, Porto Seguro, entre muitas outras que estão localizadas em áreas baixas, sejam parcialmente invadidas pelo mar. A falta de cartas hipsométricas com resolução mínima de $10 \mathrm{~cm}$ de cota da franja costeira do Estado, ou até mesmo da capital, Salvador, e de outras cidades litorâneas, impede a construção de um cenário mais preciso e detalhado dos efeitos das mudanças do clima no litoral baiano. Outros efeitos que já vem sendo observados em várias partes do mundo, devido à elevação da temperatura do mar, são os danos aos recifes de corais. A presença de recifes de corais é responsável por grande parte da produtividade pesqueira marinha tropical.

A riqueza de fauna marinha na costa brasileira depende, na sua maior parte, dos ecossistemas costeiros, principalmente manguezais e recifes de corais. Isso porque a corrente do Brasil, bordejando a nossa costa, é de águas quentes, portanto pobres em nutrientes e consequentemente em fauna piscosa. Nessa situação, é da maior importância a preservação desses ecossistemas costeiros para a manutenção da riqueza de fauna marinha baiana.

O aumento de temperatura da água, entre outros fatores, pode causar danos aos recifes de corais, inibindo o seu crescimento e danificando sua estrutura - é o fenômeno denominado de branqueamento dos recifes de corais. As colônias recifais branqueadas são susceptíveis à instalação de doenças infecciosas, ou mesmo à mortandade em massa. O branqueamento de corais já vem sendo observado nos recifes baianos desde 1993, - inclusive no Parque Nacional Marinho dos Abrolhos. (KRUG et al., 2012) Nos recifes da Bahia há uma forte relação entre o branqueamento de corais e os eventos de anomalias da temperatura da 
superfície do mar (TSM), e os recifes mais afetados pelo branqueamento são os recifes costeiros. (LEÃO; KIKUCHI; OLIVEIRA, 2008)

Simulações dos efeitos de aumento de temperatura podem ser feitas em função das variações de temperatura dos fenômenos cíclicos de "El Niño" e "La Niña". "La Niña" se caracteriza pelo resfriamento das águas na região do Pacífico Equatorial e pela convecção na região da Indonésia e o "El Niño" apresenta impactos climáticos opostos. Essa oscilação é conhecida como oscilação Sul do "El Niño" (ENSO) e previsões sobre o efeito do aumento de temperatura podem ser feitas estudando-se séries históricas de um fenômeno e correlacionando-se com as variações de oscilações de ENSO. Um estudo desse tipo mostrou que a elevação de temperatura correlaciona-se com a redução do crescimento de corais do estado da Bahia. (EVANGELISTA et al., 2007)

Portanto, um aumento de temperatura das águas do Atlântico deverão reduzir os recifes de coral, consequentemente a produtividade da fauna marinha e de pescados. Os pescados representam uma importante fonte de proteína para os baianos vivendo nas zonas costeiras e, para comunidades de pescadores artesanais, são essenciais.

\section{Principais impactos nas macrorregiões do cerrado e semiárido}

Com o aumento da temperatura, a evapotranspiração aumenta, causando uma diminuição da água do solo e levando a uma gradual substituição da vegetação natural do cerrado, com a atual vegetação da zona semiúmida, por espécies da zona semiárida, e a vegetação da zona semiárida sendo substituída pela vegetação escassa de zonas áridas. A previsão é de perda de $24 \%$ das espécies de árvores para um aumento de temperatura de $2^{\circ} \mathrm{C}$. Nas áreas mais secas a mudança climática deverá provocar salinização e desertificação de áreas hoje agriculturáveis devido ao aumento da evapotranspiração. (MARENGO, 2007)

A produtividade de algumas culturas agrícolas importantes deverá decrescer e a produtividade pecuária deverá declinar nessa região, a menos que espécies modificadas geneticamente para resistência a temperaturas mais altas e menor disponibilidade de água venham a ser desenvolvidas e aí utilizadas. Vale lembrar o número limitado de espécies 
naturais das zonas áridas, que não conseguem substituir a perda da biodiversidade natural das zonas semiáridas e da biomassa de sua vegetação. Além desse fato, existe indisponibilidade de um banco genético de espécies adaptadas a temperaturas médias mais altas do que as existentes, para sua substituição nas zonas áridas. Outro fator a ser considerado é que as mudanças no padrão de precipitação previstas, principalmente em relação à mudança de amplitude da variação aliada a evapotranspiração, deverão afetar a regularidade de disponibilidade hídrica e o potencial hidroelétrico. As previsões indicam que a produção agrícola deverá apresentar tendências negativas após 2025, devido à insuficiência do abastecimento de água para atender às demandas da água de irrigação. (MARENGO, 2007)

Com o aumento da temperatura, os vetores epidemiológicos deverão aumentar (IPCC, 2007). Sendo o nordeste uma região onde a proliferação de insetos é favorecida pelas altas temperaturas perenes, um aumento de temperatura só irá favorecer ainda mais a proliferação da malária, dengue, dentre outras doenças transmitidas por insetos.

Utilizando-se do fenômeno cíclico de "El Niño" e "La Niña", verificou-se que a taxa de incidência da dengue na região nordeste, correlaciona positivamente com a oscilação Sul do "El Niño" (ENOS), durante o período de 1995 e 2007, como indicação de cenários possíveis resultantes das mudanças climáticas futuras. (SANTOS et al., 2011)

Alguns países têm feito esforços de adaptação, particularmente através de conservação de ecossistemas importantes, gerenciamento de riscos na agricultura, estratégias para gerenciamento de seca, entre outros. Entretanto, a efetividade desses esforços é diminuída por falta de informações básicas e sistemas de observação e monitoramento detalhados, além de capacitação e referências políticas, institucionais e tecnológicas apropriadas. (LONDON CLIMATE CHAGE PARTNERSHIP, 2006; DIAS et al., 2009) O Brasil e o estado da Bahia devem aprender com essas experiências.

\section{Contribuição do estado da Bahia para as mudanças climáticas}

As emissões industriais, urbanas e agropastoris influenciam enormemente o clima do planeta, pois emitem diferentes gases para a 
atmosfera. Alguns desses gases têm a capacidade de absorver radiação infravermelha (calor), e quando presentes na baixa troposfera, absorvem o calor emitido, principalmente, pela superfície terrestre. São os Gases de Efeito Estufa, abreviadamente denominados de GEE.

Os principais gases estufa são o dióxido de carbono, ou gás carbônico $\left(\mathrm{CO}_{2}\right)$, emitido principalmente pela queima de combustível fóssil e de biomassa; o metano $\left(\mathrm{CH}_{4}\right), 20$ a 25 vezes mais potente como gás estufa do que o $\mathrm{CO}_{2}$ num período de 100 anos, proveniente da decomposição de matéria orgânica e da produção pastoril, sobretudo gado bovino; o ozônio troposférico, $\mathrm{O}_{3}$, resultado da reação química na atmosfera dos hidrocarbonetos com o dióxido de nitrogênio, $\mathrm{NO}_{2}$, provenientes das emissões da queima de combustível fóssil e biomassa, além de industriais; o óxido nitroso $\left(\mathrm{N}_{2} \mathrm{O}\right)$, com poder de aquecimento da temperatura atmosférica 300 vezes maior do que o $\mathrm{CO}_{2}$, emitido principalmente pelas atividades agropecuárias, sobretudo por solos fertilizados, além do vapor d'água, resultado da evaporação das águas superficiais (rios, lagos e oceanos) e da evapotranspiração do solo, plantas e animais. Atualmente o aumento das emissões de $\mathrm{CO}_{2}$ é responsável por $50 \%$ da elevação da temperatura do planeta. (GRAEDEL; CRUTZEN, 1995; BAILEY et al., 2002, IPCC, 2007)

O principal gás de estufa emitido pelas atividades urbanas e produção de energia é o dióxido de carbono, $\mathrm{CO}_{2}$. $\mathrm{Na}$ cidade, a maior fonte urbana de $\mathrm{CO}_{2}$ é a veicular. Diferentemente de um grande número de países desenvolvidos, que utilizam carvão ou derivados de petróleo para a geração de energia, a energia elétrica do Brasil é essencialmente hidroelétrica, que é de baixa emissão de $\mathrm{CO}_{2}$. No entanto a produção de energia termoelétrica vem crescendo nos últimos anos, e envolvendo maiores emissões de $\mathrm{CO}_{2}$ pelo setor. A maior fonte brasileira de emissão do gás carbônico tem origem na queima da biomassa, essencialmente das queimadas.

O Brasil já apresentou dois inventários de emissões nacionais dos principais gases estufa dentro da Convenção de Mudanças de Clima das Nações Unidas, sempre utilizando os valores de fluxos default do IPCC, que muitas vezes não refletem os fluxos reais no Brasil. (EMBRAPA, 2006)

Em 2010, a Secretaria do Meio Ambiente do Estado da Bahia, publicou o primeiro inventário de gases de efeito estufa do Estado, uti- 
lizando a metodologia do IPCC. O inventário não está disponível na internet e as informações que se seguem foram obtidas de divulgação no site da CETESB, SP.

Os cálculos foram feitos para duas épocas diferentes, 1999 e 2008. No entanto, não há alocação por macrorregião. Foram estimadas todas as emissões e remoções antrópicas relativas aos seguintes gases: dióxido de carbono $\left(\mathrm{CO}_{2}\right)$, o metano $\left(\mathrm{CH}_{4}\right)$ e o óxido nitroso $\left(\mathrm{N}_{2} \mathrm{O}\right)$. O Inventário inclui tanto as emissões decorrentes da queima de combustíveis, quanto às emissões fugitivas. Outros gases, como monóxido de carbono (CO), óxidos de nitrogênio (NOx) e outros compostos orgânicos voláteis não metânicos (NMVOC), mesmo não sendo gases de efeito estufa direto, influenciam as reações químicas que ocorrem na atmosfera. Por essa razão, as suas emissões foram incluídas.

As emissões de GEE do Setor Energético da Bahia em 2008 totalizaram $28.555 \mathrm{GgCO}_{2}$ eq, sendo o segmento energético o maior responsável pelas emissões, com $32 \%$ de participação, seguido dos segmentos de transporte e indústria com $30 \%$ e $20 \%$, respectivamente. Na comparação com 1990, observa-se um significativo crescimento nas emissões totais dos GEE, da ordem de $83 \%$, sendo que as emissões de $\mathrm{CO}_{2}$ tiveram a maior responsabilidade e cresceram $87 \%$ nesse período. Registra-se uma grande inversão nos segmentos mais emissores do setor de energia, uma vez que em 1990, de um total de 15.585 $\mathrm{GgCO}_{2}$ eq emitidos, o setor industrial respondeu por $37 \%$, enquanto que o setor energético amplo contribuiu com apenas $12 \%$. As maiores reduções relativas ocorreram no segmento de cimento, que a partir de 2001, praticamente zerou as suas emissões, no segmento de outros minerais não metálicos, que também apresentaram importante redução das emissões e na indústria química, cujas emissões decresceram 14\%. Considerando-se apenas as emissões do setor industrial, a produção de magnésio, cimento, ferro e aço e ferroligas foram os maiores responsáveis por emissões de $\mathrm{CO}_{2}$ em 2008.

Em janeiro de 2010, foi promulgada a Lei $n^{\circ} 12050 / 11$. Essa lei institui a Política sobre Mudança do Clima do Estado da Bahia com os objetivos que se seguem:

a. Compatibilização do desenvolvimento socioeconômico com a proteção do sistema climático; 
b. Mitigação dos impactos adversos resultantes das interferências antrópicas no sistema climático;

c. Redução da taxa de crescimento das emissões de gases de efeito estufa e a captura e estocagem desses gases;

d. Definição e implementação de medidas para promover a adaptação à mudança do clima em todos os Territórios de Identidade, setores econômicos e sociais, especialmente aqueles mais vulneráveis aos seus efeitos adversos.

Para que essa política seja corretamente implantada e um plano de gestão correto seja adotado, será necessário efetuar-se inventários específicos por macrorregião e por município, onde todas as contribuições da agricultura, produção animal, florestas, atividades industriais e atividades urbanas sejam calculadas. Nesse caso, os fatores de emissões locais deverão ser determinados, substituindo os fatores default do IPCC.

Com a adoção de biocombustíveis no Brasil, a Bahia apresenta um potencial de crescimento no setor de produção de oleaginosas para a produção de biodiesel. No momento somente a soja é economicamente viável para a produção de biodiesel, mas espera-se que avanços tecnológicos viabilizem economicamente o uso de mamona, dendê, girassol, algodão, entre outros. As culturas dessas oleaginosas são bem adaptadas à área do cerrado e do semiárido, portanto é de se esperar uma grande expansão agrícola de oleaginosas nessas macrorregiões. Em termos de mudanças climáticas, essa expansão agrícola deverá envolver maiores emissões de gases estufa, sobretudo de óxido nitroso $\left(\mathrm{N}_{2} \mathrm{O}\right)$, que é um gás de estufa muito potente. Essa perspectiva tem preocupado cientistas proeminentes dos países desenvolvidos como o prêmio Nobel Crutzen. (CRUTZEN et al., 2007)

Os primeiros estudos experimentais relacionados a emissões de gases estufa de plantações de oleaginosas, no estado da Bahia, vêm sendo realizados no Cerrado e em zona de transição do semiárido, já tendo gerado informações interessantes e importantes relatadas abaixo. 


\section{Contribuição do cerrado e semiárido baiano para as mudanças climáticas}

As mudanças de ocupação do solo influenciam enormemente o clima do planeta, pois atividades agropastoris assim como outras atividades antrópicas, emitem gases diferentes para a atmosfera. $\mathrm{O}$ principal gás de estufa emitido por plantas de sequeiro é o óxido nitroso $\left(\mathrm{N}_{2} \mathrm{O}\right)$, que é um gás com a capacidade de aquecimento da atmosfera 300 vezes maior do que o dióxido de carbono $\left(\mathrm{CO}_{2}\right)$. A produção animal, principalmente de gado bovino, é um grande emissor de metano $\left(\mathrm{CH}_{4}\right)$, cuja capacidade de aquecimento atmosférico é 20 a 25 vezes a do $\mathrm{CO}_{2}$ num período de 100 anos, além do óxido nitroso $\left(\mathrm{N}_{2} \mathrm{O}\right)$.

Em termos globais, as emissões de óxido nitroso $\left(\mathrm{N}_{2} \mathrm{O}\right)$ de plantações, contribui com $75 \%$ das emissões antrópicas para a atmosfera. No Brasil, cerca de $10 \%$ da produção de soja é destinada a produção de biodiesel. O governo brasileiro almeja tornar o país líder mundial na produção de biodiesel, prevendo uma grande expansão na produção de oleaginosas, principalmente no semiárido da região nordeste.

A aceitação do biodiesel brasileiro depende das vantagens em termos de emissões de gases estufa que sejam apresentadas. Existem poucos trabalhos de emissões de $\mathrm{N}_{2} \mathrm{O}$ no cerrado brasileiro e sempre focalizam as emissões de diferentes culturas e não em termos de substituição da flora natural pelas plantações. Os primeiros trabalhos desse tipo no cerrado e na zona de transição do semiárido baiano, são também os primeiros do país, com o enfoque de substituição de cobertura, medindo emissões do $\mathrm{N}_{2} \mathrm{O}$ com e sem cobertura de campos de soja, mamona e girassol, além das emissões do cerrado original, da Mata Atlântica e da cultura familiar de subsistência do aipim, estimando-se a contribuição da substituição de florestas originais pela cultura de soja e demais oleaginosas. (GUARÍN, 2010; ARCINIEGAS et al., 2012; TAVARES et al., 2012)

Com base nos dados produzidos experimentalmente de medidas no estado da Bahia, mamona e girassol no município de Cruz das Almas e soja no Cerrado, pode-se calcular as emissões de $\mathrm{N}_{2} \mathrm{O}$ e $\mathrm{CO}_{2}$ pelo estado da Bahia decorrentes da cultura dessas oleaginosas. (GUARÍN, 2010; ARCINIEGAS et al., 2012) 
Foi estimada a contribuição estadual anual e, para fins de comparação, estimou-se a contribuição nacional, expressa em $\mathrm{kg} \mathrm{N}_{2} \mathrm{O}$ ha $^{-1}$ ano $^{-1}$ e $\mathrm{CO}_{2}$-equivalente $\mathrm{ha}^{-1}$ ano $^{-1}$. Utilizaram-se como referência, os dados de áreas agrícolas do estado da Bahia e Brasil de 2008. (Tabela 1).

Tabela 1 - Estimativa das emissões de $\mathrm{N}_{2} \mathrm{O}$ expressas em $\mathrm{CO}_{2}$ - equivalente proveniente das culturas de oleaginosas - mamona e girassol - e de aipim produção familiar de sobrevivência - no estado da Bahia e no Brasil

\begin{tabular}{|c|c|c|c|c|c|c|c|}
\hline \multirow[b]{2}{*}{ Cultura } & \multirow{2}{*}{$\begin{array}{c}\text { Área } \\
\text { cultivada } \\
\text { (ha) }\end{array}$} & \multirow[b]{2}{*}{$\begin{array}{c}\text { Produção } \\
(\mathrm{t})\end{array}$} & \multirow[b]{2}{*}{$\begin{array}{l}\text { Produtividade } \\
\qquad(\mathrm{kg} / \mathrm{ha})\end{array}$} & \multirow{2}{*}{$\begin{array}{l}\text { Biodiesel } \\
\text { (l/t mat. } \\
\text { prima) }\end{array}$} & \multicolumn{2}{|c|}{...Emissão } & \multirow{2}{*}{$\begin{array}{c}\mathrm{CO}_{2-}^{-} \\
\text {equivalente** } \\
\left(\mathrm{TgCO}_{2}-\mathrm{eq}\right)\end{array}$} \\
\hline & & & & & $\begin{array}{l}\mathrm{KgN}_{2} \mathrm{O} \text { ha } \\
{ }^{1} \text { ano }^{-1}\end{array}$ & $\begin{array}{l}\mathrm{Gg} \mathrm{N_{2 }} \mathrm{O} \\
\text { ha }^{-1} \text { ano }^{-1}\end{array}$ & \\
\hline Mamona & & & & & 0,62 & $6,20 \times 10^{-7}$ & \\
\hline Bahia & 122879 & 98706 & 803 & $540-720$ & 76714,73 & 0,077 & 0,024 \\
\hline Brasil & 162700 & 123400 & 758 & & 101575,42 & 0,102 & 0,032 \\
\hline Girassol & & & & & 0,47 & $4,70 \times 10^{-7}$ & \\
\hline Bahia & 1240 & 999 & 806 & $400-672$ & 581,24 & 0,0006 & 0,0002 \\
\hline Brasil & 113900 & 156900 & 130 & & 53389,71 & 0,053 & 0,017 \\
\hline Aipim & & & & & 0,67 & $6,70 \times 10^{-7}$ & \\
\hline Bahia & 392055 & 275017 & 12950 & & 262206,38 & 0,262 & 0,081 \\
\hline Brasil & 1882500 & 26598600 & 14010 & & 1259016,00 & 1,259 & 0,390 \\
\hline $\begin{array}{l}\text { Rem.Mata } \\
\text { Atlântica }\end{array}$ & & & & & 0,92 & $9,20 \times 10^{-7}$ & \\
\hline Brasil & 4662500 & & & & 4288287,78 & 4,288 & 1,330 \\
\hline
\end{tabular}

Fonte: Cadernos NAE, (2005); Petrobras; Parente, Expedito José de Sá-Tecbio, Fortaleza, (2003) apud SEAGRI, (2006); EMBRAPA, (2008); Epagri - CEPA (2008); IBGE (2008); Secretaria de Ciência, Tecnologia e Inovação, (2009); Portela, (2010).

**Fonte: (GUARIN, 2010)

Em função das áreas plantadas na Bahia e território nacional e fatores de emissão determinados em Cruz das Almas, no ano base de 2008, observa-se que, dentre a contribuição das oleaginosas estudadas para a emissão de $\mathrm{N}_{2} \mathrm{O}$, o girassol é a plantação que menos emite $\mathrm{N}_{2} \mathrm{O}$. Quando se levou em consideração as diferentes emissões entre as fileiras plantadas e as entrelinhas, as diferentes taxas de emissão e respectivas durações de cada fase do plantio, as emissões durante a parte do ano sem cobertura entre a pós-colheita e a nova plantação, se comparou com as emissões de $\mathrm{N}_{2} \mathrm{O}$ da floresta natural de Mata Atlântica natural, 
verificou-se que a substituição pelas culturas de oleaginosas resultaram em redução de emissões de $\mathrm{N}_{2} \mathrm{O}$ : redução de $32 \%$, no caso da mamona e $49 \%$ no caso de girassol. A substituição da mata por cultura familiar de mandioca resultou também em redução da emissão desse gás estufa, no caso de $27 \%$. Ou seja, as taxas de emissão da Mata Atlântica superam as emissões de todas as culturas estudadas, conforme pode ser visto na Tabela 1 .

Em estudo equivalente no cerrado baiano, focando a cultura de soja - hoje a principal fonte de biodiesel - realizado por Arciniegas e colaboradores (2012), chegou a conclusões similares. Foi verificado que a substituição da mata de cerrado pela soja resultou na redução de $41 \%$ das emissões de $\mathrm{N}_{2} \mathrm{O}$.

Em termos de contribuição para as mudanças climáticas, esse fato favorece a adoção do biodiesel, além da motivação original do uso do biodiesel envolvendo a reciclagem do $\mathrm{CO}_{2}$. Vale lembrar que essa perspectiva econômica só constituirá uma real vantagem para o país se os bancos genéticos do cerrado ocupado por soja e do semiárido por outras oleaginosas, forem preservados em áreas de conservação adequadas.

Esses dados são importantes não apenas para a aceitação do biodiesel. Constituem uma contribuição importante para cálculos mais exatos dos inventários de emissões nacionais, permitindo a substituição dos fatores de emissão default do IPCC, fatores de emissões médios dos diferentes ecossistemas terrestres por valores de fluxo medidos, e dessa forma permitindo um melhor planejamento econômico-ecológico para o Brasil.

\section{Considerações finais}

As projeções dos modelos climáticos apontam para um aquecimento global até o fim deste século e particularmente uma elevação na temperatura média do nordeste brasileiro. O estado da Bahia sofrerá com as mudanças climáticas previstas. As áreas baixas costeiro-marinhas serão inundadas devido à elevação do nível do oceano, devendo provocar prejuízos materiais e desorganização social, sobretudo nas áreas urbanas. A produção pesqueira será reduzida uma vez que os recifes de corais e manguezais serão afetados. As regiões do semiárido e do cerrado, que constituem cerca de $57 \%$ e $22 \%$ respectivamente, totalizan- 
do $79 \%$ do Estado, terão suas temperaturas médias aumentadas, com aumento mais pronunciado nos meses de verão, fevereiro e março, que é o mês chuvoso. O período de chuvas será reduzido e o período seco irá incrementar, aumentando as secas nordestinas. Com a elevação da temperatura média, a evapotranspiração irá aumentar, incrementando a umidade do ar, mas diminuindo a umidade do solo e reduzindo os recursos hídricos superficiais, inclusive os disponíveis para a irrigação. A salinização irá aumentar e áreas hoje agriculturáveis se tornarão desérticas. A biodiversidade será reduzida, a produtividade agrícola e pecuária decrescerá e haverá aumento de doenças transmitidas por insetos.

Os malefícios sofridos pelo estado da Bahia não devem corresponder à contribuição do Estado para o aumento dos gases estufa. Isso porque, a utilização de agrocombustível não só evita as emissões de dióxido de carbono, mas reduz também a emissão de dióxido de nitrogênio com a substituição das florestas nativas por culturas de oleaginosas.

A maior parte dos cenários climáticos é produzida por modelos matemáticos, os quais ainda podem ter problemas em representar realmente os processos físicos que acontecem na natureza. Além disso, esses modelos têm dificuldade para representar adequadamente características do clima regional, que é onde há interesse de se avaliar impactos ambientais, econômicos e sociais. Adicione-se a essas, as incertezas sobre os cenários futuros de emissões dos gases de efeito estufa para este século e a efetividade do uso de modelos climáticos globais como a melhor ferramenta para estimar-se alterações climáticas resultantes do aquecimento global.

Mesmo diante dessas incertezas, dados de medidas locais têm demonstrado que o clima está mudando e as mudanças observadas seguem as tendências desses cenários.

Por fim vale ressaltar que as projeções dos modelos climáticos permitem a geração de cenários de clima no futuro, mas ainda não distinguem ou separam os efeitos da variabilidade natural de clima e da induzida pelo homem. Portanto, somente um maior conhecimento de ambos poderá apontar com maior exatidão qual o futuro do planeta e, em particular, do estado da Bahia. 


\section{Referências}

ARCINIEGAS, C. L. W. et al. Emissão de óxido nitroso da produção de soja no Cerrado brasileiro. In: ENCONTRO de Química Analítica Ambiental, VI, 2012, Londrina. Anais eletrônicos... Londrina:

Sociedade Brasileira de Química, 1990.

BAILEY, R. A. et al. Chemistry of the Environment, 2. ed. Nova York: Academic Press, 2002. 575p.

BITTENCOURT, A. C. S. P.; BRICHTA, A.; DI NAPOLI, E. Alguns aspectos da sedimentação na Baía de Todos os Santos. Revista Brasileira Geofísica. v. 6, n. 4, p. 246-263, 1976.

CIRANO, M.; LESSA, G. C. Oceanographic characteristics of Baía de Todos os Santos, Brazil. Revista Brasileira de Geofísica, v. 25, p. 363-387, 2007.

CRUTZEN, P. J. et al. $\mathrm{N}_{2} \mathrm{O}$ release from agro-bifuel production negates global warming reduction by replacing fossuel fuels.

Atmos. Chem. Phys. n. 7, p. 11191-11205, 2007

DIAS, P. L. S. et al. Public Policy, Mitigation and Adaptation to

Climate Change in South America. São Paulo: INPE. 2009.

EMANUEL, K. Increasing destructiveness of tropical cyclones over the past 30 years. Nature. v. 436, n. 7051, p. 686-688, ago. 2005.

EMBRAPA. Primeiro inventário brasileiro de emissões antrópicas de gases de efeito estufa. Relatórios de referência. Emissões de óxido nitroso $\left(\mathrm{N}_{2} \mathrm{O}\right)$ provenientes de solos agrícolas. Brasília: Ministério da Ciência e Tecnologia. 2006. 129p.

EVANGELISTA, H. et al. Evidences linking ENSO and coral growth in the Southwestern-South Atlantic. Climate Dynamics, v. 29, p. 869-880, 2007.

GRAEDEL, T. E.; CRUTZEN, P. J. Atmosphere, climate and change. New York: Scientific American Library, 1995.

GUARÍN, R. R. Medidas de óxido nitroso $\left(\mathrm{N}_{2} \mathrm{O}\right)$ emitido por culturas de mamona e girassol para produção do agro diesel e potencial contribuição para as mudanças climáticas. 2010. 210f. Dissertação (Mestrado de Saúde, Ambiente, Trabalho) - Faculdade de Medicina, UFBA. Salvador, 2010.

IPCC - INTERGOVERNMENTAL PANEL ON CLIMATE.

FOURTH ASSESSMENT REPORT. AR4. IPCC 2007.

Disponível em : <http://www.ipcc.ch>

IPCC- INTERGOVERNMENTAL PANEL ON CLIMATE. FOURTH ASSESSMENT IPCC AR4 SYR . In: PACHAURI, R. K; REISINGER, A. Climate Change 2007: Synthesis Report. Contribution of 
Working Groups I, II and III to the Fourth Assessment Report of the Intergovernmental Panel on Climate Change. 2007.

KRUG, L. A. et al. Characterization of coral bleaching environments and their variation along the Bahia state coast, Brazil. International Journal of Remote Sensing, v. 33, p. 4059-4074, 2012.

LONDON CLIMATIC CHANGE PARTNERSHIP - LCCP .

Adapting to Climatic Change: Lessons for London. London: Greater London Authority. 2006.

LEÃO, Z. M. A. N.; KIKUCHI, R. K. P.; OLIVEIRA, M. D. M. Branqueamento de corais nos recifes da Bahia e sua relação com eventos de anomalias térmicas nas águas superficiais do oceano. Biota Neotrop. v. 8, n. 3, p. 69-82, 2008

LEITE, O. R. Evolução da Bahia de Todos os Santos, Revista do IFUFBA, 1995.

. Evolução geológica. In: Baía de Todos os Santos: diagnóstico sócio-ambiental e subsídios para a gestão. Salvador: Germen/UFBA-NIMA, 1997. p. 15-29.

MAGNAVITA, L. P.; DAVISON, I.; KUZNIR, N. J. Rifting, erosion and uplift history of the Reconcavo-Tucano-Jatobá Rift, Northeast Brazil. Tectonics, Washington, v. 13, n. 2, p. 367-388, 1994.

MARENGO, J. Mudanças Climáticas Globais e seus Efeitos sobre a Biodiversidade Caracterização do Clima Atual e Definição das Alterações Climáticas para o Território Brasileiro ao Longo do Século XXI. 2. ed. Brasília: Ministério do Meio Ambiente, 2007a. 213 p.

Caracterização do Clima no século XX e Cenários no Brasil e na América do Sul para o Século XXI derivados dos Modelos de Clima do IPCC. Relatório n. 1. Brasília: Ministério do Meio Ambiente, 2007b. 181 p. . et al. Atlas de Cenários Climáticos Futuros do Brasil. Cachoeira Paulista - SP: CPTEC, INPE, 2007. 124p.

MARTIN, L. et al. Neotectonic movements on a passive continental margin: Salvador region, Brazil. Neotectonics, v. 1, p. 87-103, 1986.

. et al. Courbe de variations Du niveau relatif de La mer au cours dês 7. 000 dernières années sur um secteru homogène Du littoral brésilien (Nord de Salvador). In: International Symposium on Coastal Evolution in the Quaternary, 1978. São Paulo, Proceedings, 1979. p. 264-274.

MARTIN, L.; DOMINGUEZ, J. M. L.; BITTENCOURT, A. C. S. P. Climatic control of coastal erosion during a sea-level fall episode. An Acad. Bras. Ci., n. 70, p. 249-266, 1998. 
MARTIN, L.; DOMINGUEZ, J. M. L.; BITTENCOURT, A. C. S. P. Fluctuating Holocene sea levels is eastern and southeastern Brazil: evidence from a multiple fossil and geometric indicators. Journal of Coastal Research, v. 19, p. 101-124, 2003

RAMANA, M. V. et al. The direct observations of large aerosol radiative forcing in the Himalayan region. Geophys. Res. Lett. n. 31, 2004.

RAMANATHAN, V.; CARMICHAEL, G. Global and regional climate changes due to black carbon, Nature Geoscience, March, 2008.

SANTOS, N. A. C. et al. Association of annual dengue incidence in Northeast Brazil with global climate variability. In: Environmental Health 2011: Resseting Our Priorities, Salvador. Proceedings. Elsevier, 2011.

SCAFETTA, N. Empirical evidence for a celestial origin of the climate oscillations and its implications, Journal of Atmospheric and Solar-Terrestrial Physics, n. 72, p. 951-970, 2010.

A shared frequency set between the historical mid-latitude aurora records and the global surface temperature, Journal of Atmospheric and Solar-Terrestrial Physics, n. 74, p. 145-163, 2012.

SILVA DIAS, P. L. et al. In: Conferência Regional sobre Mudanças Globais: América do Sul, III, São Paulo, 2007, Livro de resumos. São Paulo, USP, 2007.

SRIVASTAVA, A. K. et al. Black carbon aerosols over Manora Peak in the Indian Himalayan foothills: implications for climate forcing, Environ. Res. Lett. n. 7, p. 1-8. 2012

STERN, N. Review on the Economics of Climate Change. London: HM Treasury, 2006. Disponível em: <http://www.sternreview.org.uk.> Acesso em: 15 nov. 2012. STOZHKOV, Y. et al. Data on galactic cosmic fluxes according to the measurements in the atmosphere (1957-2006), preprint of Lebedev Physics Institute, Russian Academy of Sciences, Moscow, n. 14, p. 78, 2007.

TANAJURA, C. A. S; GENZ, F; ARAÚJO, H. A. Mudanças climáticas e recursos hídricos na Bahia: validação da simulação do clima presente do hadrm3p e comparação com os cenários A2 e B2 para 2070-2100. Revista Brasileira de Meteorologia, v. 25, n. 3, p. 345 - 358, 2010.

TAVARES, T. M. et al. Luxos de Óxido Nitroso $\left(\mathrm{N}_{2} \mathrm{O}\right)$ e Dióxido de Carbono $\left(\mathrm{CO}_{2}\right)$ emitido por culturas de mamona e girassol para produção de agrodiesel. In: FAPESB. Relatório do Projeto Inovações no Semiárido, Edital 006/2007. Salvador: FAPESB, 2012. p. 1-6. 


\title{
Medidas de óxido nitroso $\left(\mathrm{N}_{2} \mathrm{O}\right)$ emitido por culturas de mamona e girassol para produção do agro diesel e potencial contribuição para as mudanças climáticas
}

\author{
Tania Mascarenhas Tavares \\ Rodolfo Rojas Guarín \\ Carolina L. Wilches Arciniegas \\ Sergio Telles de Oliva
}

\section{Introdução}

As emissões atmosféricas resultantes das atividades antrópicas constituem um fator decisivo para o aquecimento global e as mudanças climáticas. As relações homem e meio ambiente são complexas e se refletem diretamente na saúde. Os efeitos do desequilíbrio climático estão estreitamente associados com o surgimento de doenças infecciosas e a diminuição da disponibilidade e da qualidade de recursos vitais para o homem - água, alimento e ar. (IPCC, 2007a)

Entre os gases emitidos pelas atividades industriais, urbanas e agropastoris, alguns têm a capacidade de absorver radiação infravermelha (calor) e, quando presentes na troposfera, absorvem o calor emitido, principalmente, pela superfície terrestre, aquecendo a atmosfera. Esses gases são denominados de gases estufa. Entre os principais gases estufa de longa permanência na atmosfera encontra-se o óxido nitroso $\left(\mathrm{N}_{2} \mathrm{O}\right)$ e sua principal fonte antrópica é a agricultura adubada. Esse gás está presente na atmosfera terrestre em nível de traços, na ordem de partes por bilhão ( $\mathrm{ppb}$ ) e sua concentração vem aumentando linearmente durante as últimas décadas. (CRUTZEN; MOSIER; SMITH; WINIWATER, 2007) 
A importância do óxido nitroso no meio ambiente decorre de duas características distintas. Primeira, é a sua capacidade de absorver radiação infravermelha, 300 vezes mais alta do que o gás carbônico $\left(\mathrm{CO}_{2}\right)$, que atualmente, é o principal gás de estufa, pois é responsável por cerca de $50 \%$ do aquecimento global. Embora a concentração de $\mathrm{N}_{2} \mathrm{O}$ seja cerca de mil vezes menor do que a do $\mathrm{CO}_{2}$, sua contribuição é significativa para o efeito estufa, e consequentemente, para a mudança climática. Segundo - $\mathrm{O} \mathrm{N}_{2} \mathrm{O}$ atinge a estratosfera e contribui, junto com alguns gases halogenados, para a destruição da camada de ozônio, a qual atua como uma barreira impedindo a penetração de radiação ultravioleta na superfície da terra, com consequências danosas para a saúde humana. (CRUTZEN; MOSIER; SMITH; WINIWATER, 2007, IPCC 2007a, IPCC 2007b)

O Brasil almeja tornar-se líder na produção de agrodiesel, com expansão de produção de oleaginosas no nordeste do país. No entanto, existe uma preocupação internacional sobre a real vantagem da adoção do agrodiesel como combustível, uma vez que há o risco da produção agrícola de oleaginosas emitirem mais $\mathrm{N}_{2} \mathrm{O}$ do que as equivalentes às emissões evitadas de $\mathrm{CO}_{2}$, e portanto, contribuírem mais para o aquecimento global do que o diesel fóssil. (CRUTZEN; MOSIER; SMITH; WINIWATER, 2007)

O objetivo do estudo aqui descrito foi determinar os fluxos de emissão de óxido nitroso emitido pelo solo em culturas de algumas oleaginosas utilizadas na produção de agrodiesel no nordeste, comparando-os com os fluxos das emissões correspondentes de vegetação nativa, de forma a avaliar se a adoção do agrodiesel nordestino apresenta ou não vantagem para a redução da contribuição do transporte terrestre para o aumento do efeito estufa. Além disso, foram medidas as emissões de $\mathrm{N}_{2} \mathrm{O}$ da produção familiar de mandioca, utilizada na subsistência de populações economicamente desfavorecidas, de forma a verificar se essa prática contribui mais ou menos para o aumento do efeito estufa do que a cobertura vegetal original, ou do que as culturas de oleaginosas usadas para produção de agrodiesel. Os fluxos de $\mathrm{N}_{2} \mathrm{O}$ emitidos foram medidos em culturas de mamona, girassol e soja utilizadas para a produção do agrodiesel, e nas matas Atlântica e de cerrado, para fins de comparação. Esse estudo, de forma comparativa, é pioneiro no Brasil 
e no mundo, tendo sido financiado pela FAPESB, CNPQ e CAPES, essa última na forma de bolsa.

\section{O óxido nitroso e ciclo global do nitrogênio}

O óxido nitroso é muito pouco reativo quimicamente, mas é formado ou transformado em outras formas químicas por microorganismos, fazendo parte do ciclo biogeoquímico do nitrogênio. O ciclo global do nitrogênio representa um dos mais importantes ciclos de nutrientes que sustenta a vida na terra e está intimamente relacionado ao ciclo do carbono. Na sua forma mais comum no estado gasoso $\left(\mathrm{N}_{2}\right)$, o nitrogênio compõe $78 \%$ de nossa atmosfera. No entanto esse gás não reativo, por meio de fixação, converte-se em formas reativas $(\mathrm{Nr})$ tais como: amônia, aminoácidos e proteínas antes de estar disponível para a maior parte de formas de vida. (GALLOWAY; ABER; ERISMAN; SEITZINGER; HOWARTN; COWLING; COSBY, 2003)

Antes do século $\mathrm{XX}$, a fixação de nitrogênio ocorria apenas por meio de um grupo limitado de micro-organismos e por descargas elétricas durante tempestades (raios). Com o rápido crescimento populacional do último século, as fontes naturais de nitrogênio reativo já não eram suficientes para a produção de alimento. Tal demanda levou à descoberta de uma forma de conversão do nitrogênio gasoso não reativo $\left(\mathrm{N}_{2}\right)$ em formas reativas para fins agrícolas, principalmente por meio da produção industrial de fertilizantes, resultando em uma modificação do ciclo global do nitrogênio. (GALLOWAY; ABER; ERISMAN; SEITZINGER; HOWARTN; COWLING; COSBY, 2003)

Devido às ineficiências do uso do nitrogênio na agricultura, a maior parte do nitrogênio que é fixado industrialmente para produção de fertilizante químico para fins de produção de alimento, é lançada no meio ambiente. Essas perdas, acopladas à queima de combustível fóssil, aumentaram o aporte de nitrogênio antrópico muito acima do obtido com as taxas naturais observadas na maior parte do mundo. (GALLOWAY; ABER; ERISMAN; SEITZINGER; HOWARTN; COWLING; COSBY, 2003, IPCC, 2007a)

Estima-se que a emissão de gases efeito estufa provenientes da agricultura corresponde a 5.1-6.1 gigatoneladas equivalentes a $\mathrm{CO}_{2}$ (Gt de $\mathrm{CO}_{2}$-equivalente) por ano. Segundo o IPCC, a estimativa global 
de emissão de $\mathrm{N}_{2} \mathrm{O}$ para o setor agrícola é de $2,8 \mathrm{GtCO}_{2}$-eq/ano devido principalmente ao uso de fertilizantes e à expansão da agricultura. Parte do impacto se deve ao aumento das áreas de lavoura em cerca de $20 \%$, desde 1960, nos países em desenvolvimento. (IPCC, 2007a)

O nitrogênio é geralmente o maior fator limitante na produção de uma série de produtos agrícolas. Atualmente a ação humana adiciona $150 \%$ mais nitrogênio no meio ambiente do que o envolvido em processos naturais por meio da combinação da agricultura e uso de combustível fóssil. Na agricultura o adubo - orgânico ou sintético - é constituído de formas quimicamente reativas que aumentam a produtividade agrícola. No entanto devido ao seu uso ineficiente, parte do nitrogênio é perdida para o meio ambiente, principalmente para a atmosfera. Dentre as formas químicas emitidas está o óxido nitroso, que é emitido essencialmente pela agricultura, seguido da produção animal. Entre as outras formas de nitrogênio reativo lançadas no meio ambiente estão à amônia e seus sais, os óxidos de nitrogênio e os nitratos que causam chuva ácida e acidificação dos ecossistemas, eutroficação de corpos de água, contaminação de recursos hídricos para consumo humano e o smog fotoquímico atmosférico, os dois últimos com efeitos diretos sobre a saúde humana.

Recentemente o Prêmio Nobel, Paul Crutzen, alertou para as suas novas descobertas sobre a liberação de óxido nitroso proveniente do uso de adubo em plantações que pode ser três a cinco vezes mais altas do que estimado originalmente. Esse fato coloca o óxido nitroso no foco das atenções no fenômeno do aquecimento global (CRUTZEN; MOSIER; SMITH; WINIWATER, 2007) e as vantagens para as mudanças de clima dos programas de agrocombustíveis em questionamento.

Raros são os estudos no Brasil sobre o ciclo de nitrogênio que envolvem a atmosfera e particularmente a emissão de óxido nitroso. No nordeste tais estudos são inexistentes, exceto o que será descrito adiante. Esses estudos são da maior importância para a elaboração de planos adequados de desenvolvimento e sustentabilidade do país, para o gerenciamento adequado da expansão agrícola da região e para o programa de agrocombustível assim como para os estudiosos da mudança de clima. 


\section{Fatores que afetam a emissão de $\mathbf{n}_{2} \mathbf{o}$ de solo}

Muitos fatores associados com tipo de cultura, solo, teor de água e adição de fertilizante influenciam as condições e processos do solo, e consequentemente as emissões de $\mathrm{N}_{2} \mathrm{O}$.

Os processos bacterianos de desnitrificação e nitrificação são as fontes dominantes de $\mathrm{N}_{2} \mathrm{O}$ e $\mathrm{NO}$ na maioria dos sistemas de solo, ao tempo em que a desnitrificação é também um sumidouro de $\mathrm{N}_{2} \mathrm{O}$. A nitrificação é um processo aeróbico que ocorre em todos os ecossistemas. O fator mais importante controlando a nitrificação é a disponibilidade de íon amônio $\left(\mathrm{NH}_{4}^{+}\right)$e de oxigênio $\left(\mathrm{O}_{2}\right)$. A desnitrificação é um processo anaeróbico, cujas taxas variam enormemente ao longo do tempo e do espaço. Os principais fatores controlando a desnitrificação biológica incluem a disponibilidade de carbono e de nitrato $\left(\mathrm{NO}_{3}^{-}\right)$além de outros óxidos de nitrogênio e o suprimento de oxigênio. $\mathrm{O}$ óxido nitroso pode ser também produzido pela decomposição de ácido nitroso $\left(\mathrm{HNO}_{2}\right)$ em pH baixo e condições limitadas de $\mathrm{O}_{2}$. O ciclo de nitrogênio está representado na Figura 1.

Figura 1 - Ciclo de Nitrogênio

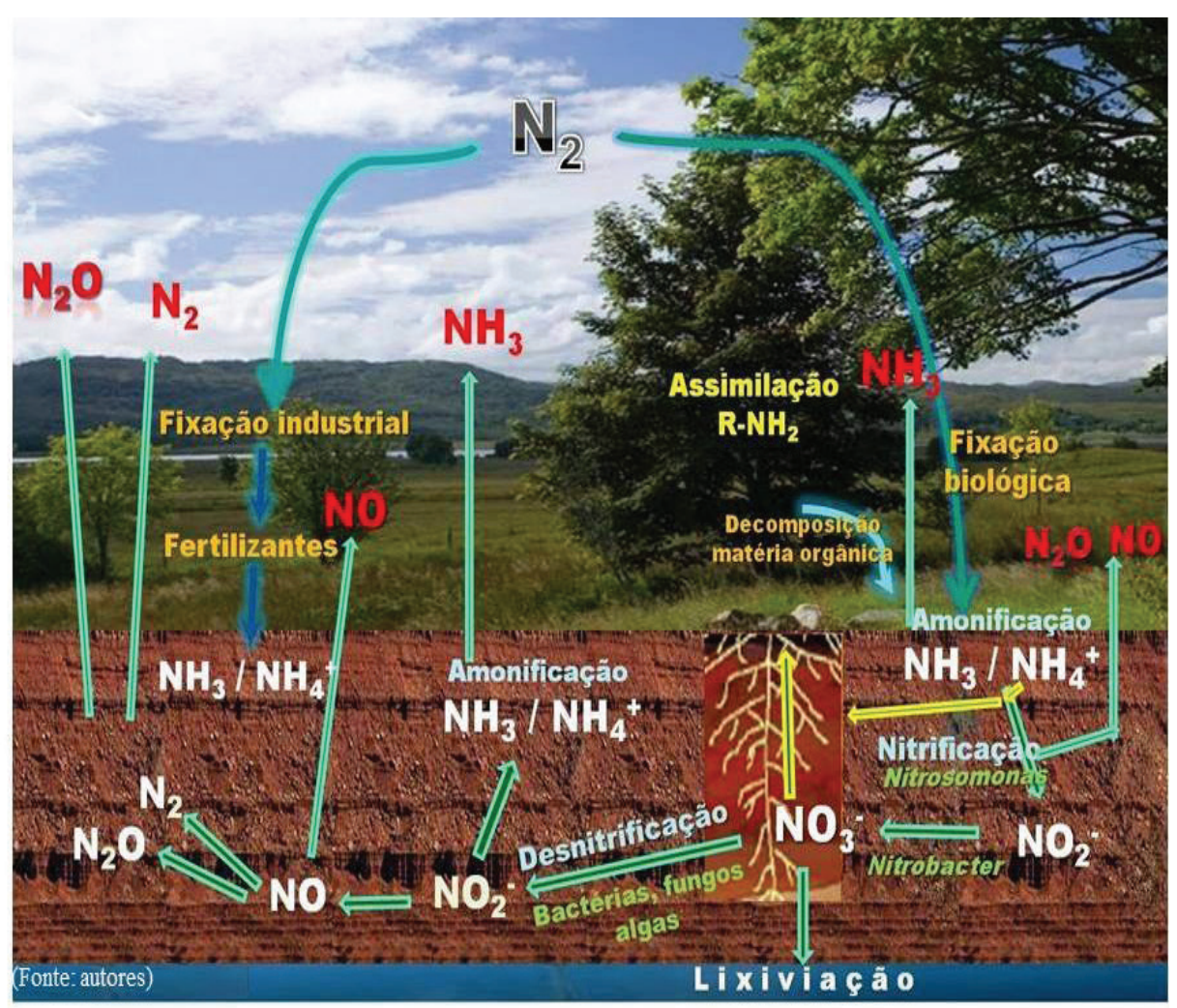

Fonte: (TAVARES; GUARIN; AREINIEGAS; OLIVA, 2010) 
Os outros parâmetros que controlam a emissão de $\mathrm{N}_{2} \mathrm{O}$ do solo são:

- $\mathrm{O}$ pH do solo, com valor médio favorável a emissão de $\mathrm{N}_{2} \mathrm{O}$ por nitrificação entre 6 e 8, mas variando com a espécie e idade do microorganismo assim como a concentração de $\mathrm{NO}_{3}$. Solos com pH ácido - como em grande parte do Brasil e que é encontrado em culturas de baixa renda onde a correção química não é feita - contribuem com emissão de $\mathrm{N}_{2} \mathrm{O}$ em valores consideráveis devido a microrganismos ácido tolerantes. (YAMULKI et al., 1997; HOU et al., 2000)

- A umidade do solo, uma vez que o teor de água no solo influencia o processo de desnitrificação direta ou indiretamente, disponibilizando $\mathrm{C}$ e $\mathrm{N}$, atuando como um meio de difusão através do qual os substratos são disponibilizados aos microorganismos e restringindo a quantidade de $\mathrm{O}_{2}$ nos microssítios ocupando os poros do solo e produzindo condições anaeróbicas. É preciso esclarecer que, no solo, as condições físicas são heterogêneas, particularmente a distribuição de lâminas d'água que atuam como barreira de difusão gasosa e que resultam no desenvolvimento de condições parcialmente anaeróbicas em meio de uma matriz aeróbica. Deste modo, os processos de nitrificação e desnitrificação podem acontecer simultaneamente, resultando em interpretações muito variáveis dos mecanismos responsáveis pela produção de $\mathrm{N}_{2} \mathrm{O}$. Estudos têm evidenciado um aumento das taxas de desnitrificação, após eventos de irrigação e precipitação, no inverno e em regiões com ciclos de congelamento/descongelamento. (LEFFELAAR, 1986)

- A disponibilidade do oxigênio, uma vez que inibe as enzimas envolvidas no processo de desnitrificação, variando o limite crítico com as diferentes espécies bacterianas. O teor de $\mathrm{O}_{2}$ depende do espaço poroso saturado de água (EPSA), do tipo de solo e do grau de compactação. Durante a nitrificação o $\mathrm{N}_{2} \mathrm{O}$ produzido tem uma correlação inversa com a con- 
centração de $\mathrm{O}_{2}$ dissolvido (MOSIER; DUXBURY; FRENEY; HEINEMEYER; MINAMI, 1998).

- O teor de matéria orgânica, onde se observa que a diferença de níveis de matéria orgânica no perfil do solo é provavelmente causada pelo carbono orgânico facilmente degradável, utilizado como fonte energética para a desnitrificação, o qual promove a atividade microbiana, resultando em maior consumo de oxigênio e consequentemente o favorecimento das condições anaeróbias. A incorporação de resíduos de plantas, a fertilização verde e aplicação de adubos incrementam as taxas de desnitrificação. Quando o teor de N é o fator limitante, a desnitrificação pode ser reduzida, devido à imobilização de $\mathrm{N}$ causada por decomposição dos resíduos pelos microrganismos e a sua incorporação na biomassa microbiana. (MOSIER; DUXBURY; FRENEY; HEINEMEYER; MINAMI, 1998; PARRON; BUSTAMANTE; PRADO, 2003)

- A temperatura do solo, que ao aumentar, amplia a emissão de $\mathrm{N}_{2} \mathrm{O}$, sendo a faixa de máxima emissão entre $60-70 \circ$, ou seja, 16-21 ${ }^{\circ} \mathrm{C}$. (MOSIER; DUXBURY; FRENEY; HEINEMEYER; MINAMI, 1998; CHAPIN; MATSON; MOONEY, 2002)

- A textura fina do solo e a compactação resultam em maiores emissões de $\mathrm{N}_{2} \mathrm{O}$. A compactação, principalmente em situação de umidade, conduz à redução na porosidade do solo, retardando a infiltração de água e a difusividade dos gases, provocando a diminuição da concentração de $\mathrm{O}_{2}$ e gerando uma anaerobiose parcial. (MOSIER; DUXBURY; FRENEY; HEINEMEYER; MINAMI, 1998; SITAULA; HANSEN; SITAULA; BAKKEN, 2000)

- A presença, densidade e tipo de plantas afetam a emissão de $\mathrm{N}_{2} \mathrm{O}$ através da assimilação de carbono e nitrato, ficando este último indisponível para a desnitrificação. No caso de matéria orgânica proveniente das raízes observa-se um efeito indireto, já que se pode dar origem a mais nitrato que continua a via da desnitrificação. Estudos mostram que, algumas plantas 
podem constituir uma via de emissão de $\mathrm{N}_{2} \mathrm{O}$. Em campos alagados de arroz a emissão de $\mathrm{N}_{2} \mathrm{O}$ acontece predominantemente através da planta. O trigo é outro exemplo, onde se encontrou emissão de $\mathrm{N}_{2} \mathrm{O}$ através da folhagem. Já no caso particular de culturas de leguminosas, onde associações simbióticas de nitrificação se localizam nas raízes, a emissão de $\mathrm{N}_{2} \mathrm{O}$ é alta. (MOSIER; DUXBURY; FRENEY; HEINEMEYER; MINAMI, 1998)

\section{Parâmetros influenciando as emissões de $\mathrm{n}_{2} \mathrm{O}$ em plantações de mamona, girassol, aipim e área de reserva da mata atlântica}

Este foi o primeiro estudo no nordeste brasileiro determinando emissões de óxido nitroso do solo e focalizou as plantações de oleaginosas, uma vez que há previsão de grande expansão dessas culturas nas extensas áreas semiáridas do cerrado, da catinga e do sertão. Para comparação determinou-se os fluxos de emissões do solo de plantação familiar de aipim de baixa tecnologia e da cobertura vegetal original, ou seja, resquícios de Mata Atlântica. (GUARÍN, 2010)

$\mathrm{Na}$ falta de campos experimentais de oleaginosas na região semiárida, com controle dos principais parâmetros agrícolas, selecionou-se o campo experimental do Centro de Ciências Agrárias, Ambientais e Biológicas da Universidade Federal do Recôncavo da Bahia, no município de Cruz das Almas-BA, (12040'19”S, 3906'23”W), a uma altura de 220 $\mathrm{m}$, onde haviam plantações controladas de duas oleaginosas, mamona e girassol. Próximo a esse campo experimental havia uma plantação familiar de aipim e uma reserva de floresta nativa da Mata Atlântica, que foram tomadas como referência. A temperatura média anual da região é de $24,1^{\circ} \mathrm{C}$ e a precipitação média anual de $1170 \mathrm{~mm}$. O clima é do tipo tropical quente e úmido, mas já classificado como zona de transição devido aos longos períodos de estiagem que por vezes apresenta. $\mathrm{O}$ estudo foi realizado nas seguintes áreas:

- Campo experimental de mamona (Ricinus communis L.) adubado com $60 \mathrm{~kg} \mathrm{ha}^{-1}$ de uréia, $80 \mathrm{~kg} \mathrm{ha}^{-1}$ de $\mathrm{P}_{2} \mathrm{O}_{5}$ e $40 \mathrm{~kg} \mathrm{ha}^{-1}$ de $\mathrm{K}_{2} \mathrm{O}$; 
- Campo experimental de girassol (Helianthus annuus L.) adubado com $60 \mathrm{~kg} \mathrm{ha}^{-1}$ de uréia, $80 \mathrm{~kg} \mathrm{ha}^{-1}$ de $\mathrm{P}_{2} \mathrm{O}_{5}$ e $60 \mathrm{~kg} \mathrm{ha}^{-1}$ de $\mathrm{K}_{2} \mathrm{O}$.

- Como referência e fins de comparação foram feitas medidas nas seguintes áreas presentes na mesma região, e com as mesmas características de solo e meteorologia das áreas de plantação das oleaginosas:

- Cultura familiar de aipim (Manihot esculenta Crantz) sem uso de fertilizante, uma vez que é a cultura de subsistência dominante no nordeste;

- Área natural (remanescente do corredor central da Mata Atlântica), caracterizada por ser floresta tropical de transição subperenifólia/subcaducifólia, com área aproximada de 1,2 hectares, localizado na EMBRAPA-CNPMF, Cruz das Almas.

Nas quatro áreas foram realizadas medidas de fluxo de óxido nitroso. A coleta de gases na interface solo-atmosfera foi feita in situ em períodos semanais durante o verão, entre os meses de novembro e dezembro de 2009, compreendendo a época entre o pós-plantio até a pós-colheita. Utilizou-se o método de câmara estática, que é o método mais utilizado em estudos desse tipo. As câmaras foram construídas localmente de acordo com o modelo descrito por Saggar e colaboradores (2004). Anéis metálicos foram inseridos de forma permanente no solo a uma profundidade de $0,10 \mathrm{~m}$ e retirados somente ao final do período de coleta. Nos campos plantados, foram identificadas duas subáreas principais: a área de fileira onde se dá a semeadura e a área de entrelinha, na qual circulam pessoas e tratores e se observa uma maior compactação. Como a compactação do solo influencia a taxa de formação e emissão de gases, amostrou-se simultaneamente nas fileiras e nas entrelinhas em cada cultura. A Figura 2 apresenta o desenho amostral adotado nas três culturas estudadas. A floresta foi considerada homogênea em termos de compactação resultando em coleta em um só ponto. 
Figura 2 - Esquema da localização espacial das câmaras estáticas no campo de girassol na amostragem simultânea nas fileiras e entrelinhas, Cruz das Almas-BA.

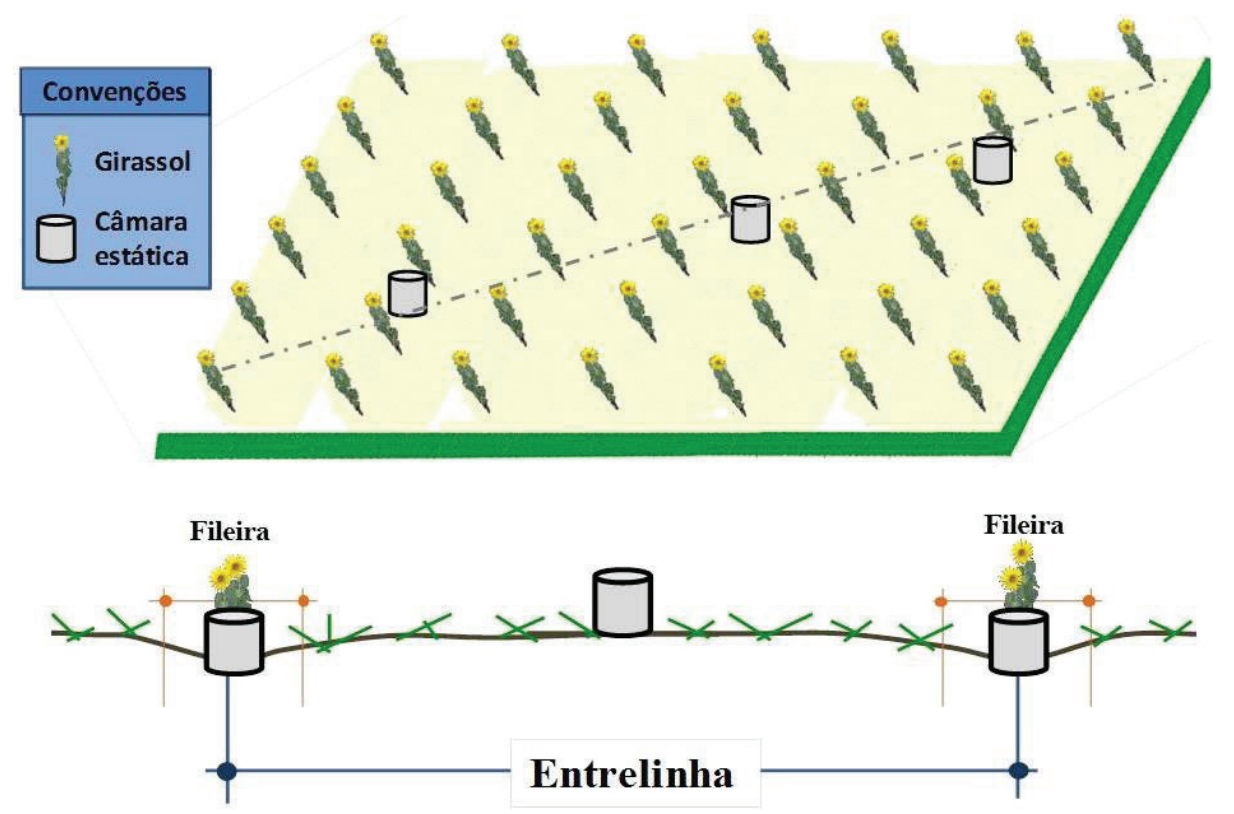

Fonte: (TAVARES; GUARIN; AREINIEGAS; OLIVA, 2010)

No momento de amostragem foi colocada uma câmara cilíndrica de PVC sobre cada anel metálico de $0,30 \mathrm{~cm}$ altura, $25 \mathrm{~cm}$ de diâmetro, adaptadas com termômetro, ventilador e septo de borracha pelo qual foram retiradas as amostras. Para selar a câmara, adicionou-se $200 \mathrm{~mL}$ de água no anel, impedindo a troca gasosa entre o interior da câmara e o ambiente externo.

As coletas foram realizadas entre $06 \mathrm{~h} 00$ e $18 \mathrm{~h} 00$. Duas amostras de gás de $100 \mathrm{~mL}$ foram coletadas, a primeira no tempo zero (ti) e a segunda 90 minutos depois ( $\mathrm{tf}$ ). O tempo selecionado de 90 minutos provou ser suficiente para evitar perturbações no gradiente de emissão e mistura de gases no interior da câmara de acordo com ensaios prévios realizados em laboratório. Para coleta e transporte das amostras foram usadas ampolas de vidro de $100 \mathrm{~mL}$, equipadas com torneira e previamente evacuadas.

As amostras foram analisadas em tempo máximo de 24 horas usando-se um cromatógrafo de gás Varian ${ }^{\circledR}$ equipado com detector por captura de elétrons de ${ }^{63} \mathrm{Ni}$. A coluna utilizada foi Hayesp-D, 80/100 mesh de 3,0 m x $3 \mathrm{~mm}$. Para a calibração analítica foram preparados padrões secundários utilizando-se mistura padrão de $\mathrm{N}_{2} \mathrm{O}$ de 20 ppmv, 
por meio de diluição por pressão em linha de vácuo implementada no LAQUAM. (OLIVA, 1998)

Foi determinada a variabilidade diurna dos fluxos para o estabelecimento do perfil de emissão e identificação dos períodos de emissões máxima e mínima em cada uma das subáreas, conforme pode ser visto na Figura 3.

Figura 3 - Variação diurna dos fluxos de $\mathrm{N}_{2} \mathrm{O}$ de plantações de mamona, girassol e aipim na fileira e entrelinha de plantação e da temperatura média. A floresta é a de referência em todos os casos e considerada como única área homogênea.

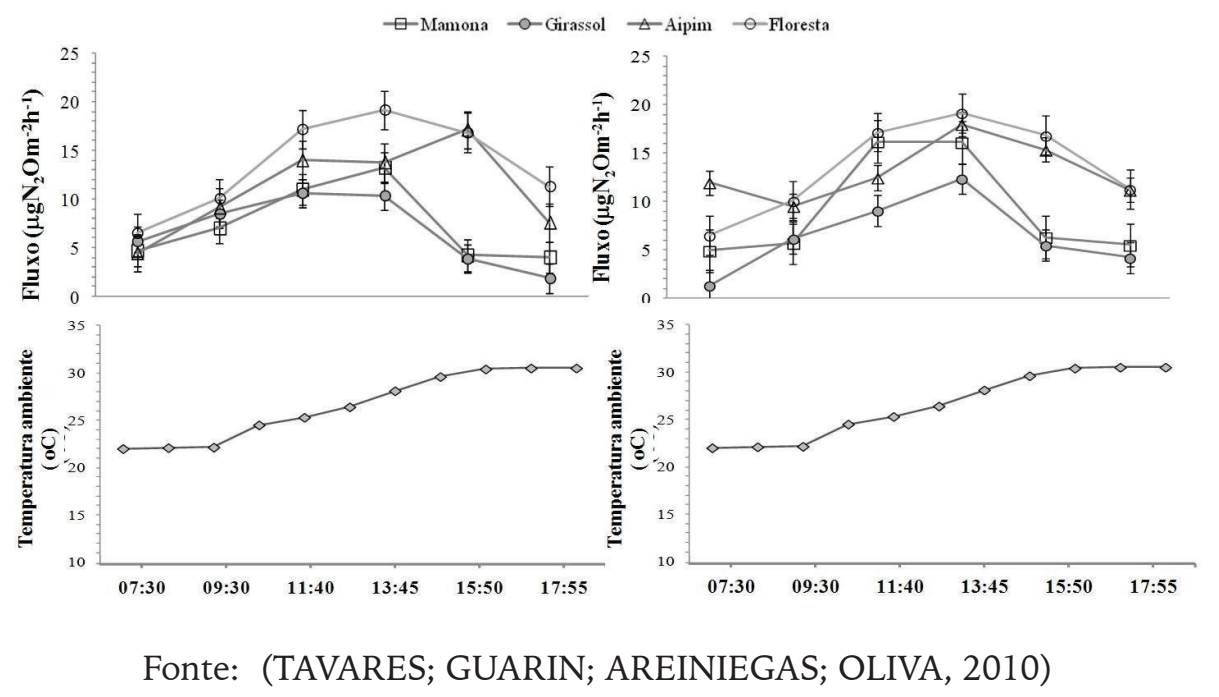

Todas as áreas tiveram seus solos analisados para os parâmetros físico-químicos do solo.

Foram coletadas amostras compostas homogêneas de cada área na camada de 0-10 cm de profundidade, próximo a cada câmara e independente para cada subárea (Tabela 1). As características físicas determinadas foram: umidade gravimétrica (\%), por meio de secagem da amostra durante $24 \mathrm{~h}$ a $105^{\circ} \mathrm{C}$ e densidade aparente $\left(\mathrm{kg} / \mathrm{dm}^{3}\right)$, mediante a técnica de anel volumétrico; macroporosidade e microporosidade (\%), por meio de mesa de tensão e estrutura não deformada. As características químicas analisadas foram: $\mathrm{pH}$ por meio de suspensão solo-água $(1: 5 \mathrm{v} / \mathrm{v})$; matéria orgânica por ignição $\left(550^{\circ} \mathrm{C}, 8 \mathrm{~h}\right)(\%)$; carbono orgânico total por método titulométrico (\%); $\mathrm{NO}_{3}{ }^{-}$e $\mathrm{NH}_{4}{ }^{+}$por analisador de fluxo contínuo $(\mathrm{mg} / \mathrm{kg})$ e nitrogênio total pelo método de Kjeldahl. Os resultados dessas análises podem ser visto nas Tabelas 1 e 2 abaixo. 
Tabela 1 - Características físico-químicas do solo nas fileiras de plantio das culturas de mamona, girassol e aipim e de uma área de reserva da Mata Atlântica, Cruz das Almas, Bahia, nov.-dez. 2010.

\begin{tabular}{l|l|l|l|l}
\hline & \multicolumn{2}{|c|}{ Subárea Fileira } & \multicolumn{2}{c}{} \\
\hline Área & Mamona & Girassol & Aipim & Floresta \\
\hline Umidade (\%) & 4,03 & 2,52 & 1,94 & 6,02 \\
\hline Textura & $\begin{array}{l}\text { F r a n c o } \\
\text { arenoso }\end{array}$ & $\begin{array}{l}\text { Fr a n c o } \\
\text { arenoso }\end{array}$ & $\begin{array}{l}\text { Fr a n co } \\
\text { arenoso }\end{array}$ & $\begin{array}{l}\text { Fr a n c o } \\
\text { arenoso }\end{array}$ \\
\hline Porosidade Total (\%) & 36,41 & 36,76 & 39,99 & 42,91 \\
\hline Macroporosidade (\%) & 20,07 & 20,94 & 22,24 & 21,7 \\
\hline Microporosidade (\%) & 16,34 & 15,79 & 17,75 & 21,22 \\
\hline Densidade do solo (kg/dm $\left.{ }^{3}\right)$ & 1,39 & 1,60 & 1,44 & 1,36 \\
\hline EPSA (\%) & 15,39 & 12,08 & 6,99 & 19,05 \\
\hline Nitrogênio Total (\%) & 0,04 & 0,06 & 0,04 & 0,06 \\
\hline Carbono $(\%)$ & 0,72 & 0,90 & 0,68 & 0,88 \\
\hline Matéria Orgânica (\%) & 1,24 & 1,56 & 1,17 & 1,42 \\
\hline C/N* & 18 & 15 & 17 & 15 \\
\hline Amônia-NH ${ }_{4}^{+}(\mathrm{mg} / \mathrm{kg})$ & 4,60 & 6,40 & 3,30 & 5,14 \\
\hline Nitrato-NO ${ }^{-}(\mathrm{mg} / \mathrm{kg})$ & 5,10 & 8,40 & 5,10 & 8,19 \\
\hline pH & 6,21 & 6,12 & 6,27 & 4,80 \\
\hline
\end{tabular}

Razão C/N, calculado com base nos valores de concentrações de N e C.

Fonte: : (TAVARES; GUARIN; AREINIEGAS; OLIVA, 2010)

Tabela 2 - Características físico-químicas do solo nas entrelinhas de plantio das culturas de mamona, girassol e aipim Cruz das Almas, Bahia, nov.-dez. 2010.

\begin{tabular}{l|l|l|l}
\hline \multirow{2}{*}{ Área } & \multicolumn{2}{c|}{ Subárea Entrelinha } & \\
\hline Umidade (\%) & \multicolumn{1}{c}{ Mamona } & \multicolumn{1}{c}{ Girassol } & \multicolumn{1}{c}{ Aipim } \\
\hline Textura & 4,52 & 3,54 & 3,86 \\
\hline Porosidade Total (\%) & Franco arenoso & Franco arenoso & Franco arenoso \\
\hline Macroporosidade (\%) & 35,05 & 33,39 & 33,05 \\
\hline Microporosidade (\%) & 15,39 & 10,54 & 15,96 \\
\hline Densidade do solo (kg/dm $\left.{ }^{3}\right)$ & 19,66 & 22,85 & 17,09 \\
\hline EPSA (\%) & 1,59 & 1,65 & 1,63 \\
\hline
\end{tabular}




\begin{tabular}{|c|c|c|c|}
\hline Nitrogênio Total (\%) & 0,14 & 0,06 & ND \\
\hline Carbono (\%) & 2,10 & 0,82 & 0,80 \\
\hline Matéria Orgânica (\%) & 3,63 & 1,41 & 1,38 \\
\hline $\mathrm{C} / \mathrm{N}^{*}$ & 15 & 14 & ND \\
\hline Amônia- $\mathrm{NH}_{4}{ }^{+}(\mathrm{mg} / \mathrm{kg})$ & 6,40 & 6,29 & ND \\
\hline Nitrato- $\mathrm{NO}_{3}^{-}(\mathrm{mg} / \mathrm{kg})$ & 5,10 & 7,42 & 5,00 \\
\hline $\mathrm{pH}$ & 5,45 & 4,76 & 6,40 \\
\hline
\end{tabular}

Fonte: (TAVARES; GUARIN; AREINIEGAS; OLIVA, 2010)

Uma maior porosidade total predominou na subárea fileira em todas as culturas, condizente com o da zona preparada para o plantio e crescimento das plantas. A umidade na zona da fileira é mais baixa devido à evaporação e ao consumo da água pelas plantas. O solo das fileiras é mais arejado o que favorece a troca gasosa, à atividade de microorganismos do solo e à decomposição aeróbia da matéria orgânica. $\mathrm{Na}$ mata nativa a maior porosidade encontra-se também como um indicativo de ambiente pouco perturbado e protegido das intempéries tais como insolação, chuva e ventos excessivos.

A maior compactação foi encontrada na subárea entrelinha indicada pelos valores de densidade aumentada e macroporosidade reduzida (Tabela 2). A condição de adensamento está diretamente relacionada com as práticas de manejo do solo, tais como: o tráfego de trator no preparo do solo, a criação de zonas desprotegidas (sem cobertura vegetal, como é o caso das entrelinhas) e o trânsito dos agricultores para realizar as atividades próprias. Uma vez reduzida à porosidade total, a difusão de gases pelos poros diminui e os microhabitats do solo sofrem modificação devido à redução da concentração de $\mathrm{O}_{2}$. Este efeito resulta no incremento de locais anaeróbicos, especialmente em áreas detendo maiores teores de umidade. Como consequência se produzem mudanças na transformação do $\mathrm{N}$ e aumento nas taxas de produção de $\mathrm{N}_{2} \mathrm{O}$. (SITAULA; HANSEN; SITAULA; BAKKEN, 2000)

A condição de compactação do solo reduz as perdas de água, devido à redução da macroporosidade, favorecendo sua conservação e localizando-se predominantemente na microporosidade. Isso explica a diferença na porcentagem do Espaço Poroso Saturado de Água (EPSA) encontrado na entrelinha e na fileira. 
Os conteúdos elevados de amônia $\left(\mathrm{NH}_{4}^{+}\right)$e nitrato $\left(\mathrm{NO}_{3}^{-}\right)$indicam uma alta taxa de oxidação de $\mathrm{N}$ no solo. A oxidação se dá através dos processos de amonificação e nitrificação associados a teores suficientes de matéria orgânica no solo ( $\mathrm{C}$ disponível), promovendo a atividade geral microbiana e resultando em maior consumo de $\mathrm{O}_{2}$.

O teor de matéria orgânica e de carbono (C) no solo foi maior na subárea de entrelinha nas culturas de mamona $(3,63 \%$ e $2,10 \%)$ e aipim $(1,38 \%$ e $0,80 \%)$. Este resultado pode-se associar à ciclagem de nutrientes. Nas culturas de mamona e girassol a queda gradativa das folhas à medida que avançam os estádios fenológicos representa um aporte importante de nutrientes ( $\mathrm{N}$ e $\mathrm{C}$ ) ao solo. Na cultura de aipim também existe à incorporação contínua de resíduos vegetais que o agricultor familiar acumula na plantação.

$\mathrm{Na}$ cultura de mamona os teores de $\mathrm{N}$ total e $\mathrm{C}$ na fileira são baixos $(0,40$ e $0,72 \%)$. Essa variação pode estar diretamente relacionada com uma alta taxa de oxidação destes nutrientes e seu consumo pelas plantas. Em todas as culturas - e inclusive na floresta - a razão $\mathrm{C} / \mathrm{N}$ foi inferior a 20, o que sugere uma lenta decomposição da matéria orgânica. A ciclagem de nutrientes se reflete na baixa quantidade de $\mathrm{N}$ disponível. (PARRON; BUSTAMANTE; PRADO, 2003; VAN SCHÖLL; NIEUWENHUIS, 2003)

Estima-se que a quantidade total de $\mathrm{N}$ acumulada nas folhas de mamona até a colheita possa alcançar cerca de $24 \mathrm{~kg}$ de $\mathrm{N}$ por hectare. (SCHMALZ, 2007) Dessa forma, um maior conteúdo de matéria orgânica nos solos conduz ao aumento da respiração microbiana (decomposição aeróbica), favorecendo a formação de micro-locais anaeróbicos (decomposição anaeróbica) que por sua vez leva à acumulação de elevadas quantidades de $\mathrm{NH}_{4}{ }^{+}$e $\mathrm{NO}_{3}{ }^{-}$no solo.

$\mathrm{Na}$ floresta o carbono disponível pode ter influenciado a rápida transformação de $\mathrm{N}$, efeito que pode explicar o baixo teor de $\mathrm{N}(0,06 \%)$, a baixa concentração de amônia $(5,14 \mathrm{mg} / \mathrm{kg})$ e o maior teor de nitrato $(8,19 \mathrm{mg} / \mathrm{kg}$.). Estas características podem indicar duas situações: primeira, que em solos naturais a reciclagem e entrada de pequenas quantidades de $\mathrm{N}$ (por deposição e/ou fixação biológica) incrementam a competição entre microorganismos e plantas pelo $\mathrm{N}$ disponível $\left(\mathrm{NH}_{4}{ }^{+}\right.$ e $\mathrm{NO}_{3}^{-}$); segunda, que a amônia esteja sendo oxidada rapidamente a nitrato e, portanto, nas condições de $\mathrm{pH}$ encontrada $(4,80)$, a produ- 
ção de $\mathrm{N}_{2} \mathrm{O}$ pelos processos de nitrificação e desnitrificação acontecem pela adaptação das comunidades microbianas a ambientes ácidos. (YAMULKI et al., 1997)

$\mathrm{Na}$ cultura de mamona o conteúdo de $\mathrm{NH}_{4}{ }^{+}$na fileira $(4,60 \mathrm{mg} / \mathrm{kg})$ foi menor que na entrelinha $(6,40 \mathrm{mg} / \mathrm{kg})$. A explicação mais provável é que, na fileira, a oxidação da amônia foi realizada mais rapidamente por bactérias que produzem a enzima amônia monooxigenase (AMO) em presença de $\mathrm{O}_{2}$. Na cultura de girassol a disponibilidade de $\mathrm{N}$ inorgânico $\left(\mathrm{NH}_{4}{ }^{+} \mathrm{e} \mathrm{NO}_{3}{ }^{-}\right)$é alta na fileira, sugerindo que a emissão de $\mathrm{N}_{2} \mathrm{O}$ pode estar acontecendo simultaneamente pelos processos de nitrificação e desnitrificação. Na cultura de aipim a fileira apresentou uma baixa concentração de amônia $(3,30 \mathrm{mg} / \mathrm{kg})$ em relação à concentração de nitrato $(5,10 \mathrm{mg} / \mathrm{gk})$, o que indica que existe uma rápida atividade oxidativa da amônia pelos microorganismos nitrificadores.

$\mathrm{O}$ baixo $\mathrm{pH}$ do solo é frequentemente associado a baixa nitrificação. Em solos ácidos a oxidação microbiológica de $\mathrm{NH}_{4}{ }^{+}$a $\mathrm{NO}_{3}{ }^{-}$ é mínima e a emissão de $\mathrm{N}_{2} \mathrm{O}$ é então favorecida por baixo $\mathrm{pH}$ e altas concentrações de $\mathrm{NO}_{3}$. Embora tenha sido realizada a correção do pH do solo na parcela de mamona, o $\mathrm{pH}$ encontrado na fileira era moderadamente ácido e na entrelinha ácido. Apesar dessas leves diferenças, os teores de $\mathrm{NO}_{3}$ - foram similares e as emissões de $\mathrm{N}_{2} \mathrm{O}$ foram maiores na entrelinha. Não obstante, Parron, Bustamante e Prado (2003) consideraram que o $\mathrm{pH}$ do solo tem efeito pequeno na taxa de nitrificação em solos tropicais. Por outro lado Granli e Bockman (1994), afirmam que a emissão de $\mathrm{N}_{2} \mathrm{O}$ é influenciada por fatores químicos e favorecida por $\mathrm{pH}$ baixo e altas concentrações de $\mathrm{NO}_{3} \cdot \mathrm{Na}$ área estudada os valores de nitrato foram baixos e as emissões de $\mathrm{N}_{2} \mathrm{O}$ poderiam estar associadas a outros fatores físico-químicos.

\section{Emissões de $\mathrm{N}_{2} \mathrm{O}$ das culturas de mamona e girassol e contribuição para mudanças climáticas}

As taxas médias de emissão de $\mathrm{N}_{2} \mathrm{O}$ determinadas em cada uma das áreas avaliadas, no período de verão (novembro-dezembro de 2009) se observam na Tabela 3. No cálculo dessas taxas levou-se em conside- 
ração a variação diurna assim como as diferentes áreas ocupadas por fileiras e entrelinhas no caso das culturas e o ciclo do plantio.

\section{Tabela 3 - Taxa média de emissão de $\mathrm{N}_{2} \mathrm{O}$ do solo das fileiras e entrelinhas de plantio das culturas de mamona, girassol e aipim e de uma área de reserva nativa da Mata Atlântica, Cruz das Almas-BA, nov.-dez 2009.}

\begin{tabular}{l|c|c|c}
\hline \multirow{1}{1}{ Área } & \multicolumn{3}{|c}{$\mathbf{N}_{2} \mathrm{O}\left(\mu \mathrm{g} \mathrm{m}^{-2} \mathbf{h}^{-1}\right)$} \\
\hline Mamona & 5,85 & 7,12 & 7,09 \\
\hline Girassol & 5,26 & 3,99 & 5,53 \\
\hline Aipim & 8,24 & 11,58 & 7,6 \\
\hline Floresta & -- & -- & 10,45 \\
\hline
\end{tabular}

Fonte: ((TAVARES; GUARIN; AREINIEGAS; OLIVA, 2010)

Um fato digno de nota é que a emissão média de $\mathrm{N}_{2} \mathrm{O}$ estimada para o remanescente do bioma Corredor Central de Mata Atlântica foi maior do que os das áreas cultivadas, com valor de fluxo de 10,45 $\mu \mathrm{g}$ $\mathrm{N}_{2} \mathrm{O} \mathrm{m}^{-2} \mathrm{~h}^{-1}$. O segundo fluxo mais alto foi encontrado na cultura de aipim, com valor de $7,60 \mu \mathrm{g} \mathrm{N}_{2} \mathrm{O} \mathrm{m}^{-2} \mathrm{~h}^{-1}$. O aipim é a cultura tradicional de subsistência da região e que historicamente, vem substituindo pequenas áreas da vegetação original.

Na plantação de mamona encontrou-se uma taxa média de 7,09 $\mu \mathrm{g} \mathrm{N}_{2} \mathrm{O} \mathrm{m}^{-2} \mathrm{~h}^{-1}$. O fluxo de emissão médio de $\mathrm{N}_{2} \mathrm{O}$ para a cultura de mamona inclui uma incerteza maior do que a das outras culturas, uma vez que a subárea de entrelinha não é homogênea em relação a compactação, havendo uma maior compactação na rota dos pneus do trator e menor na área entre os pneus. A cultura de girassol apresentou a menor emissão, com valor médio de $5,33 \mu \mathrm{g} \mathrm{N} \mathrm{O} \mathrm{m}^{-2} \mathrm{~h}^{-1}$.

Os fluxos de $\mathrm{N}_{2} \mathrm{O}$ foram influenciados possivelmente pelas propriedades do solo, práticas de manejo e pela estação seca. $\mathrm{O}$ estudo não permitiu uma avaliação específica da influência direta do uso dos fertilizantes químicos nitrogenados, nas emissões deste gás, uma vez que as medidas iniciaram numa época em que a aplicação de fertilizante já tinha acontecido. Na cultura de girassol, a última adubação havia ocorrido um mês antes, e na cultura de mamona, cinco meses antes. 
A cultura de girassol apresentou a emissão mais baixa de $\mathrm{N}_{2} \mathrm{O}$ e pode ser explicada pelo fato dessa planta ser considerada uma grande extratora de nitrogênio, fósforo e potássio do solo, inclusive em camadas mais profundas do solo, incorporando-os no fruto e demais estruturas vegetais - folhas, caule, capítulos, entre outros. (CARVALHO; OLIVEIRA; LIMA, 2007)

Comparando-se os fluxos médios de $\mathrm{N}_{2} \mathrm{O}$ das culturas de mamona e girassol com as da floresta original ou com as de cultura de subsistência adotada localmente, verificamos que não há um aumento da emissão desse gás estufa por substituição da vegetação original pela plantação dessas oleaginosas nas condições estudadas. Embora esse estudo seja apenas o primeiro focalizando emissões de gases estufa de plantações nordestinas, os resultados apontam para uma viabilidade do programa brasileiro de biodiesel.

Em outras partes do mundo existem medidas de emissão de $\mathrm{N}_{2} \mathrm{O}$ obtidas em florestas e plantações diversas, em diferentes tipos de solo, condições climáticas e formas de manejo de solo, e os resultados encontrados estão apresentados na Tabela 4.

Observa-se que as maiores emissões se encontraram em culturas de girassol, trigo, milho e batata na Alemanha, em florestas da Venezuela e feijão no Brasil. Os resultados obtidos no estudo acima descrito, foram incluídos na tabela de forma destacada em negrito. Verifica-se que os valores encontrados para cultura de mamona, girassol e aipim, assim como de floresta tropical são compatíveis com a faixa mais baixa de valores encontrados em outras partes do mundo. Embora comparações entre os dados obtidos nos diferentes estudos devam ser feitas com cautela, uma vez que envolvem diferenças metodológicas nos diferentes estudos, existe uma indicação forte que a cultura de oleaginosas em condições semelhantes às de Cruz das Almas, não contribuirá com emissões de $\mathrm{N}_{2} \mathrm{O}$ mais altas do que outras coberturas vegetais em outras partes do país e do mundo. 
Tabela 4 - Emissões de $\mathrm{N}_{2} \mathrm{O}$ em diversos países de acordo com o uso do solo.

\begin{tabular}{|c|c|c|c|c|}
\hline Cultura & Fertilização & $\begin{array}{c}\text { Fluxo } \\
\left(\operatorname{kgN}_{2} \mathrm{O} \mathrm{ha}^{-1} \mathrm{ano}^{-1}\right)\end{array}$ & Localidade & Referência \\
\hline Floresta & --- & 7,89 & Venezuela & Donoso, 1993 \\
\hline Floresta & --- & 1,99 & Mayombo (Kongo) & Serca, 1994 \\
\hline Floresta & --- & 0,75 & $\begin{array}{c}\text { Costa Rica (La Sel- } \\
\text { va) }\end{array}$ & Keller, 1994 \\
\hline Floresta & --- & 0,34 & $\begin{array}{c}\text { Brasil (Oriente da } \\
\text { Amazônia) }\end{array}$ & Verchot, 1999 \\
\hline Floresta & --- & 0,66 & $\begin{array}{l}\text { Brasil (Fazenda } \\
\text { Vitoria - Pará) }\end{array}$ & $\begin{array}{l}\text { Cattannio, } \\
2002\end{array}$ \\
\hline Floresta & --- & 1,83 & $\begin{array}{c}\text { Austrália (Bellenden } \\
\text { Ker) }\end{array}$ & Kiese (2002) \\
\hline Floresta & --- & $0,64-0,79$ & Áustria (SW) & Kitzler,2006 \\
\hline Floresta & Solo tropical & 0,92 & $\begin{array}{l}\text { Brasil - Cruz das Al- } \\
\text { mas, remanescente } \\
\text { do corredor central } \\
\text { de mata atlântica. }\end{array}$ & Este estudo \\
\hline Girassol & Adubo & 9,4 & Alemanha & Flessa, 1995 \\
\hline Girassol & $\begin{array}{c}\text { Uréia } 30 \mathrm{~kg} / \\
\text { há }\end{array}$ & 0,47 & $\begin{array}{c}\text { Brasil - Cruz das } \\
\text { Almas }\end{array}$ & Este estudo \\
\hline Trigo & $\begin{array}{l}\text { Nitrato de } \\
\text { amônio } \\
30 \mathrm{~kg} \mathrm{ha}^{-1} \\
\begin{array}{c}\text { Uréia } 160 \mathrm{~kg} \\
\mathrm{ha}^{-1}\end{array}\end{array}$ & 9,6 & Alemanha & Flessa, 1995 \\
\hline Pastagens & Nenhuma & 0.15 & USA & Mosier, 1996 \\
\hline $\begin{array}{l}\text { Gram a - } \\
\text { do-prado }\end{array}$ & $\begin{array}{l}\text { Uréia } 360 \mathrm{~kg} \\
\text { ha }^{-1}\end{array}$ & $1.6-5.2$ & Escócia & Clayton, 1997 \\
\hline $\begin{array}{l}\text { Beterraba } \\
\text { doce }\end{array}$ & --- & 3,5 & Alemanha & Kaiser, 1998 \\
\hline Milho & Adubo & 5,3 & Alemanha & Mogge,1999 \\
\hline Aipim & --- & 0,010 & Indonésia & Hadi, 2000 \\
\hline Batata & $\begin{array}{l}\left(\mathrm{Ca}\left(\mathrm{NO}_{3}\right)_{2}\right) \\
75 \mathrm{~kg} \mathrm{ha}^{-1}\end{array}$ & $\begin{array}{l}4,03^{\Delta} \\
6,77^{*}\end{array}$ & Alemanha & Flessa, 2002 \\
\hline Feijão & $\begin{array}{c}\text { Sulfato de } \\
\text { amônio } 32 \mathrm{gN} / \\
\text { parcela }\end{array}$ & $3,5-78,1$ & $\begin{array}{c}\text { Brasil } \\
\text { (UNITAU-SP) }\end{array}$ & $\begin{array}{l}\text { Gonçalves, } \\
2002\end{array}$ \\
\hline
\end{tabular}




\begin{tabular}{|c|c|c|c|c|}
\hline Feijão & $\begin{array}{l}\text { Uréia } 20 \mathrm{~kg} \\
\mathrm{ha}^{-1}\end{array}$ & 1,77 & $\begin{array}{c}\text { Brasil - Embrapa } \\
\text { Arroz e Feijão }\end{array}$ & Madari, 2007 \\
\hline Feijão & $\begin{array}{l}\text { Uréia } 20 \mathrm{~kg} \\
\mathrm{ha}^{-1}\end{array}$ & $\begin{array}{l}1,10^{(\mathrm{d})} \\
0,46^{(\mathrm{e})}\end{array}$ & $\begin{array}{c}\text { Brasil - Embrapa } \\
\text { Arroz e Feijão }\end{array}$ & Melo, 2008 \\
\hline Cevada & --- & $1,5-7,5$ & Finlândia & $\begin{array}{l}\text { Syväsalo E, } \\
2004\end{array}$ \\
\hline $\begin{array}{l}\text { Soja (ino- } \\
\text { culada) }\end{array}$ & $\begin{array}{l}\text { Uréia } 30 \mathrm{~kg} \\
\mathrm{ha}^{-1}\end{array}$ & $1,32^{(\mathrm{a})}$ & Argentina & $\begin{array}{l}\text { Ciampitti, } \\
2005\end{array}$ \\
\hline Arroz & $\begin{array}{c}\text { Sulfato de } \\
\text { amônio } \\
0,3 \mathrm{gNkg}^{-1} \text { solo }\end{array}$ & $\begin{array}{l}1,07-5,2^{(b)} \\
0,46-3,9^{1(c)}\end{array}$ & China & Shuhui,2007 \\
\hline Ervilha & $\begin{array}{l}\text { Uréia } 100 \mathrm{~kg} \\
\mathrm{ha}^{-1}\end{array}$ & 0.71 & Canadá (semi-árido) & $\begin{array}{l}\text { Dusenbury, } \\
2008\end{array}$ \\
\hline Mamona & $\begin{array}{c}\text { Resíduo cultu- } \\
\text { ral de aveia e } \\
\text { uréia }\end{array}$ & $0,31-0,64$ & Brasil - UFSM & Santos, 2009 \\
\hline Mamona & $\begin{array}{l}\text { Uréia } 100 \\
\text { kg/há }\end{array}$ & 0,62 & $\begin{array}{c}\text { Brasil - Cruz das } \\
\text { Almas }\end{array}$ & Neste estudo \\
\hline Aipim & $\begin{array}{l}\text { Sem aduba- } \\
\text { ção }\end{array}$ & 0,67 & $\begin{array}{c}\text { Brasil-Cruz das } \\
\text { Almas }\end{array}$ & Neste estudo \\
\hline
\end{tabular}

*Área compactada ${ }^{\Delta}$ área não compactada. ${ }^{\text {a) }} \mathrm{O}$ estudo faz referência unicamente à máxima emissão obtida num dia. ${ }^{\text {b) }}$ arroz alagado ${ }^{c)}$ arroz com irrigação intermitente. ${ }^{\text {(d) }}$ (com palhada)

(e) (sem palhada) As unidades foram modificadas em alguns casos para obter as mesmas unidades do presente estudo. A tabela mostra valores na maioria de estudos em época seca.

Fonte: (TAVARES; GUARIN; AREINIEGAS; OLIVA, 2010)

\section{Considerações finais}

O presente trabalho estimou o possível impacto ambiental das emissões de óxido nitroso $\left(\mathrm{N}_{2} \mathrm{O}\right)$ a partir de medidas na interface solo-atmosfera, em áreas agrícolas destinadas à produção de matéria prima para agrodiesel. Comparando-se as emissões de $\mathrm{N}_{2} \mathrm{O}$, as culturas de mamona e girassol apresentam fluxos cerca de 30 e $49 \%$ inferiores aos de floresta e um pouco inferiores aos de produção familiar de aipim sem fertilização química. Concluiu-se que as emissões de $\mathrm{N}_{2} \mathrm{O}$ na produção agrícola das oleaginosas estudadas não prejudicam a contribuição pretendida de emissões evitadas de gases estufa pela substituição do óleo 
combustível fóssil pelo agrodiesel. Essas conclusões são importantes para o Brasil, pois dificultam que barreiras ambientais ou sociais sejam utilizadas para dificultar a importação de agrodiesel brasileiro por outras nações.

\section{Referências}

CARVALHO, B. C. L.; OLIVEIRA, E. A. S.; LIMA, F. J. Girassol: recomendações técnicas para o cultivo e utilização do girassol no Estado da Bahia. Salvador: EBDA. 2007. 53p.

CHAPIN, F. S.; MATSON, P. A.; MOONEY, H. A. Principles of terrestrial ecosystem ecology. New York: Springer Science, 2002.

CRUTZEN, P. J. et al. $\mathrm{N}_{2} \mathrm{O}$ release from agro-bifuel production negates global warming reduction by replacing fossil fuels.

Atmos. Chem. Phys, v. 8, p. 389-395, 2007.

GALLOWAY, J. N. et al. The nitrogen cascade.

BioScience, n. 53, p. 341-356, 2003.

GRANLI,T.; BOCKMAN, O. C. Nitrous oxide from agriculture. Norwegian Journal of Agricultural Sciences, n. 12, p. 1-128, 1994.

GUARÍN, R. R. Medidas de óxido nitroso $\left(\mathrm{N}_{2} \mathrm{O}\right)$ emitido por culturas de mamona e girassol para produção do agrodiesel e potencial contribuição para as mudanças climáticas. 2010. 120f. il. Dissertação (Mestrado de Saúde, Ambiente e Trabalho) Faculdade de Medicina da Bahia, UFBA, Salvador, 2010.

HOU, A. X. et al. Methane and nitrous oxide emission from a rice field in relation to soil redox and microbiological process.

Soil Sci. Soc. Am. J, n. 64, p. 2180-2186, 2000.

IBIO - Instituto Bio Atlântica. GeoAtlântica ambiente para o conhecimento; Corredor central da Mata Atlântica, 2010. Disponivel em: < http://www.bioatlantica.org.br/mata>. Acesso em: 13 mar. de 2010.

IPCC. INTERGOVERNMENTAL PANEL ON CLIMATE.

FOURTH ASSESSMENT REPORT. AR4. IPCC 2007a. Disponível em: http://www.ipcc.ch. Acesso em: 12 mar 2010.

IPCC. INTERGOVERNMENTAL PANEL ON CLIMATE. FOURTH ASSESSMENT IPCC AR4 SYR. PACHAURI, R. K; REISINGER, A. Climate Change 2007: Synthesis Report, Contribution of 
Working Groups I, II and III to the Fourth Assessment Report of the Intergovernmental Panel on Climate Change. 2007b.

LEFFELAAR P. A. Dynamics of partial anaerobiosis, denitrification, and water in a soil aggregate: experimental. Soil Science. n. 142, p. 352-366. 1986.

MOSIER, A. R. et al. Assessing and Mitigating $\mathrm{N}_{2} \mathrm{O}$ Emissions From Agriculture Soils. Climatic Changes, n. 40 p. 7-38, 1998.

OLIVA, S. T. Determinação de metanol e etanol na atmosfera urbana de Salvador por CG-DCE. 1998. Dissertação (Mestrado em Ciências Naturais - Química) Instituto de Química, Universidade Federal da Bahia, Salvador, 1998.

PARRON, L. M.; BUSTAMANTE, M. M. C.; PRADO, C. L. C. Mineralização de nitrogênio e biomassa em solos de Mata de Galeria: efeito do gradiente topográfico . Planaltina, DF: Embrapa Cerrados. 2003. 25p.

SAGGAR, S. et al. Modelling nitrous oxide emissions from dairy-grazed pastures. Nutrient Cycling in Agroecosystems, v. 68, p. 243-255, 2004.

SCHMALZ, C. R. et al. Produção e Decomposição de Folhas de Mamona Durante o Ciclo da Cultura. Santa Maria- RS: UFSM, 2007. p. 5

SITAULA, B. K. et al. Effects of soil compaction on $\mathrm{N}_{2} \mathrm{O}$ emission in agricultural soil. Chemosphere - Global Change Science, v. 2, p. 367-371, 2000.

SMITH, K. Nitrous Oxide and Climate Change. London: Earthcan, 2010. YAMULKI, S. et al. $\mathrm{N}_{2} \mathrm{O}, \mathrm{NO}$ and $\mathrm{NO}_{2}$ fluxes from a grassland: effect of soil pH. Soil Biology and Biochemistry, v. 29, n. 8, p. 1199-1208, 1997. VAN SCHÖLL, L.; NIEUWENHUIS, R. Manejo da fertilidade do solo. 1 Wageningen: Fundação Agromisa, 2003. 93 p. 



\section{Uso de neblina ativada para redução das emissões de bioaerossóis em um aterro sanitário}

Tania Mascarenhas Tavares

Eagles M. Alves

Carolina L. Wilches Arciniegas

\section{Introdução}

Aterros sanitários emitem bioaerossóis continuamente para o meio ambiente, principalmente bactérias e fungos, que podem ser transportados a longas distâncias, representando um risco potencial não apenas para os trabalhadores do empreendimento, mas também para os residentes nas áreas do seu entorno. Descreve-se aqui o desenvolvimento de um novo sistema para a purificação do ar emitido da lagoa de chorume de um aterro sanitário, de baixo custo e eficiência, de purificação estável, que não gera resíduos sólidos e cujos efluentes líquidos atendem aos padrões de qualidade internacionais. O sistema é composto de um reator na saída dos gases da lagoa, onde os microorganismos são captados por um sistema de neblina ativada quimicamente e conduzidos para o esgotamento sanitário, liberando o ar purificado para a atmosfera. O sistema desenvolvido comprovou a viabilidade da redução de cerca de $93 \%$ das bactérias e fungos emitidos para a atmosfera pela lagoa de chorume do aterro sanitário metropolitano de Salvador.

Bactérias e fungos apresentam dimensões entre 0,01 $\mu \mathrm{m}$ e $100 \mu \mathrm{m}$ e têm o seu comportamento de transporte no ar governado pelos princípios da física, como qualquer outra partícula (MOHR, 2002), ou seja, pelos princípios da difusão, turbulência e gravitação. Baseado nesses princípios pode-se determinar a taxa de sedimentação de partículas no ar relacionado a suas dimensões e outras propriedades físicas. Estendendo 
esses conceitos aos microorganismos, é possível dizer que as bactérias apresentam uma taxa de sedimentação que varia entre 0,0015 - 0,0021 $\mathrm{m} \mathrm{min}^{-1}$, enquanto os esporos fúngicos, uma taxa de $0,029-2,89 \mathrm{~m}$ $\min ^{-1}$, se nos basearmos nas taxas de sedimentação das partículas no ar, segundo Frank (1937). A exposição aos fatores ambientais, como luz solar, temperatura, oxigênio e umidade do ar mais baixa - além da dessecação durante o transporte através do ar - provocam o decaimento natural dos microorganismos. (KOWALSKI; BAHNFLETH, 1998) Portanto, é de se esperar que os microorganismos não consigam ser transportados a longas distâncias de forma ativa.

Apesar de sua grande maioria ser rapidamente inativada, diversas bactérias e esporos fúngicos podem permanecer vivos e serem transportados pelo ar para regiões distantes do seu local de origem, especialmente os originados de atividades antrópicas, onde as concentrações podem vir a ser muito aumentadas. (RECER et al., 2001; ALBRECHT et al., 2008) Esse fato cria a necessidade de busca de mecanismos que reduzam os microorganismos emitidos para a atmosfera, mantendo assim o bem-estar e a saúde dos trabalhadores expostos, bem como dos moradores vizinhos à fonte. Embora muitos dos microorganismos emitidos em grande quantidade sejam comuns no ambiente, como pela decomposição de matéria orgânica, muitos podem causar infecções oportunistas, principalmente nas pessoas com saúde comprometida.

Somente a partir dos fins da década de oitenta do século passado, surgiram trabalhos mostrando que diversas plantas de produção animal e tratamento de resíduos, tanto urbano como industriais, envolvendo decomposição microbiana, levam ao aumento das emissões de microrganismos para o ar. Como resultado, bactérias e fungos que não existiriam em determinadas quantidades, passam a ser encontrados em altas concentrações, não apenas na atmosfera interna, mas também nas proximidades e até mesmos em pontos mais afastados dos focos de emissão. As principais fontes potencialmente emissoras de bioaerossóis do setor produtivo são: plantas de tratamento biológico de esgotamento sanitário e efluentes orgânicos industriais, estações de compostagem, plantas de classificação e separação de lixo, aterros sanitários, produção confinada de animais, plantas de beneficiamento de produtos animais e agrícolas, entre outros. 
Os estudos sobre emissões e transporte aéreo de bioaerossóis de plantas, de disposição e tratamento de resíduos líquidos e sólidos e os efeitos à saúde humana dessas atividades são limitados, focados principalmente em emissões de atividades de compostagem e foram desenvolvidos essencialmente na Alemanha. Por essa razão relatamos, a seguir, alguns desses estudos que comprovam a necessidade de desenvolvimento de técnicas de redução da emissão de bioaerossóis.

Em processos de compostagem, algumas das espécies de fungos, como Aspergillus e Penicillium são mais abundantes e são dispersos no ar em grande número. (CROOK; BARDOS; LACEY, 1988; FISCHER et al., 2000; FISCHER et al., 2008) Outro exemplo de fungo emitido por compostagem é o Aspergillus fumigatus, um bolor alergênico, tóxico e oportunista, isolado em todo o mundo e comum no meio ambiente por ser termotolerante. A sua concentração no ambiente natural é geralmente baixa quando comparada com outros fungos, como por exemplo o Cladosporium e Alternaria, que são dominantes e bem conhecidos em ambientes naturais. (FISCHER et al., 2000; MILLNER, 1995) A concentração de Aspergillus fumigatus pode aumentar no entorno das unidades de compostagem segundo Crook, Bardos e Lacey (1988), resultando na dominância deste, na direção a favor do vento em regiões próximas, sendo, portanto, uma indicação de emissões desse tipo de planta. (MILLNER, 1995; RECER et al., 2001)

Albrecht e seus colaboradores (2008) concluíram que as concentrações de microrganismos termotolerantes, emitidos por plantas de compostagem, têm que ser avaliadas em distâncias maiores que $300 \mathrm{~m}$ das instalações a jusante da direção dos ventos, para assegurar a ausência de contaminação proveniente da planta. Eles também comprovaram que as concentrações de fungos termotolerantes e actinomicetos termofílicos, a uma distância de 600-1400 m da planta, são uma a duas ordens de grandeza maiores em relação aos níveis naturais, verificando que durante a amostragem de bioaerossóis é essencial a avaliação das condições meteorológicas, como temperatura e umidade do ar, velocidade e direção do vento.

A comprovação que microorganismos na forma ativa são transportados a médias e longas distâncias pelo ar aponta para uma possível relação entre emissões de bioaerossóis, saúde e bem-estar, não apenas dos trabalhadores, mas também dos moradores vizinhos a aterros 
sanitários. Como já mencionado, muitos microrganismos, frequentes no meio ambiente não contaminado, podem causar infecções oportunistas nas pessoas com saúde comprometida, quando presentes em maiores concentrações. Além da suscetibilidade do indivíduo (grau de imunidade), a duração da exposição, a concentração do agente infeccioso, a dose infecciosa, a taxa de respiração e a rota da infecção (por inalação, olhos, nasofaringe, etc.), são fatores importantes para a aquisição de uma infecção transmitida pelo ar. (KOWALSKI; BAHNFLETH, 1998) Por exemplo, em uma pessoa saudável são necessários de 1 a 10 bacilos da tuberculose para provocar uma infecção, enquanto que um total de 200 Rhinovirus virions é necessário para causar um resfriado. Nenhum desses fatores é necessariamente um determinante absoluto, podendo a saúde ou o grau de imunidade serem tão importantes quanto a exposição prolongada ao ar. (KOWALSKI; BAHNFLETH, 1998)

Embora esses e outros trabalhos tenham mostrado que as altas concentrações de bioaerossóis não se restringem ao interior dessas plantas, mas também a pessoas vivendo no entorno de tais estações, o fato recebeu pouca atenção, tanto científica quanto política. Somente em meados deste século surgiram os primeiros estudos epidemiológicos relacionando causa-efeito da exposição ambiental a bioaerossóis provenientes de plantas de tratamento.

Herr e colaboradores (2004a) realizaram um estudo epidemiológico na Alemanha, do tipo transversal, com 356 indivíduos de uma área residencial próxima a uma estação de compostagem, com o objetivo de relacionar possíveis efeitos sobre a saúde com exposição a bioaerossóis. Medidas de bioaerossóis ao ar livre na área residencial (bactérias totais, fungos e actinomicetos termófila), mostraram concentrações maiores do que $10^{5} \mathrm{UFC} \mathrm{m}^{-3}$. Essas concentrações reduziam-se ao longo de 550 metros da estação de compostagem. Os dados foram analisados por regressão logística, indicando uma influência relevante da distância entre a casa e o local de uma planta de compostagem, com sintomas de irritação respiratória e queixas de saúde em geral, mas não resultando em maior prevalência de casos de alergias ou doenças infecciosas nos residentes expostos. Herr e colaboradores (2004a) concluíram que os efeitos observados sobre a saúde em associação com a exposição do bioaerossol ambiental, podem ser classificados como uma irritação das membranas da mucosa, recomendando que em próximas pesquisas 
sobre esse tema fosse necessário focalizar na função pulmonar e em anticorpos específicos contra fungos.

Em outro trabalho realizado por Herr e colaboradores (2004b), demonstraram uma associação entre poluição por bioaerossóis em áreas residenciais e queixas de irritação das vias aéreas, bem como uma excessiva fadiga e tremores, que são sintomas reportados em trabalhadores das estações de compostagem. Estas áreas residenciais, distando 200m das estações de compostagem, apresentaram níveis de actinomicetos termófilos, bactérias totais e fungos similares às exposições ocupacionais nessas estações.

Em 2006, Bunger e colaboradores compararam trabalhadores de estações de compostagem aos controles em 41 estações de compostagem alemãs (mistura de resíduos biodegradáveis domésticos acrescida de resíduos de estaleiros). As medidas revelaram concentrações elevadas de fungos e actinomicetos. Os trabalhadores apresentaram uma prevalência significativamente maior de irritação da mucosa dos olhos e das vias aéreas superiores, bem como maior frequência de conjuntivite e um declínio significativo na capacidade vital. Os resultados diferem dos trabalhadores expostos a poeiras orgânicas em outras instalações, talvez devido a fungos e bactérias termotolerantes em plantas. Bunger e colaboradores (2006) concluíram que a exposição à poeira orgânica em locais de trabalho de estações de compostagem está associada a efeitos respiratórios crônicos e agudos.

Igualmente na Alemanha, Müller e colaboradores (2006) verificaram que 17 jovens saudáveis que foram expostos a uma estação de compostagem por duas horas fazendo atividades moderadas, apresentaram alterações na contagem de células brancas do sangue, um aumento de neutrófilos e uma diminuição de eosinófilos. Os autores concluíram que as exposições de curto prazo de jovens saudáveis produzem leves alterações sistêmicas.

Esses estudos levaram o Conselho Ambiental Alemão a acreditar que os poucos trabalhos sobre a relação entre exposição a bioaerossóis e efeitos na saúde já são suficientes para justificar recomendações de medidas de proteção. Esse fato estimulou técnicos alemães a iniciar o desenvolvimento de sistemas de abatimento de bioaereossóis de plantas emissoras de microorganismos. 


\section{Sistemas de Abastecimento de Bioaerossóis}

Diferentes técnicas, baseadas em diferentes princípios, foram testadas em estação de compostagem, estações de tratamento de resíduos e estações de tratamento biológico, com o objetivo de reduzir exposição ocupacional a bioaerossóis e de suas emissões para a atmosfera através de uma combinação de engenharia de sistemas de controles. A seguir, descreveremos os sistemas desenvolvidos por outros grupos em outros países, assim como um novo sistema desenvolvido na Universidade Federal da Bahia-UFBA, para reduzir as emissões de bactérias e fungos da bacia de chorume de um aterro sanitário em Salvador, Bahia, resultado da parceria do Mestrado de Saúde, Ambiente e Trabalho com o Laboratório de Química Analítica Ambiental do Instituto de Química da UFBA e o extinto Centro de Pesquisas Ambientais da Universidade de Frankfurt (ZUF), tendo apoio financeiro da FAPESB, do CNPQ e da CAPES, este último sob a forma de bolsa de mestrado.

\section{Método}

Trata-se de uma descrição do sistema de abatimento de bioaerossóis, das medidas de controle de bactérias e fungos no ar e da viabilidade do uso deste reator de neblina ativada na redução de bioaerossóis, na bacia de chorume de um aterro sanitário.

\section{Opções tecnológicas para abatimento de bioaerossóis}

Vários são os sistemas desenvolvidos para abatimento de aerossóis. Cada um deles tem seus prós e contras, e nenhum reduz inteiramente os bioaerossóis de forma constante, sem resultar em outro tipo de poluição, com custo viável.

Em 2001, Kühner utilizou membranas semipermeáveis para reduzir a emissão de bactérias através de pilhas. Ao utilizar membranas em pilhas estáticas, as emissões bioaerossol ao longo de todo o processo da estação de compostagem puderam ser reduzidas em $83 \%$ em relação a pilha $\mathrm{C}$ sem membrana, independentemente das espécies de microorganismos. 
Schilling (2003) mostrou resultados de redução na concentração de Aspergillus fumigatus na entrada e saída de ar em biofiltros instalados em estações de tratamento de resíduos. Os dados medidos confirmam que os Aspergillus fumigatus foram retidos por um biofiltro quando operado adequadamente, embora com diferentes eficiências. As concentrações mínima e máxima de microrganismos termotolerantes na saída do ar foram até duas ordens de grandeza inferiores à concentração inicial.

O uso de membranas e de biofiltros apresentam duas desvantagens: a primeira é a queda da eficiência na redução dos microorganismos ao longo do tempo, onde as eficiências máximas são obtidas apenas durante um determinado período, para depois decaírem, resultando na necessidade da sua substituição periódica, a segunda desvantagem é a necessidade de disposição adequada das membranas e biofiltros usados de forma semelhante à disposição de resíduo hospitalar. A combinação de substituições regulares dos biofiltros e custo da disposição encarecem a sua adoção.

Jaeschke e colaboradores (1998), do Centro de Pesquisas Ambientais da Universidade de Frankfurt, entre outros pesquisadores, demonstraram que, na natureza, a neblina é o mecanismo mais eficiente para captação de poluentes atmosféricos. (JAESCHKE et al., 1998; RICCI et al., 1998) Baseado nesse conhecimento, Schumann (2000), sob a orientação do Prof. Jaeschke, utilizou uma neblina produzida artificialmente e ativada quimicamente para reduzir as emissões dos gases amônia, de compostos reduzidos de enxofre gasosos e gases orgânicos emitidos para a atmosfera de atividades industriais. (SCHUMANN, 2000) Essa técnica apresentava como vantagens sobre as outras o fato de ser de baixo custo, não gerar resíduos e apresentar desempenho constante sem flutuações. Essa técnica, embora aplicada a substâncias gasosas, tinha a possibilidade de ser utilizada na redução de partículas desde que a ativação química fosse modificada.

O Laboratório de Química Analítica Ambiental do Instituto de Química tinha uma parceria com o grupo do Prof. Jaeschke para medidas de compostos reduzidos de enxofre (CRE) de áreas naturais e industriais (NUNES et al., 2005), estendida a utilização do sistema para a redução de emissão de CRE e de amônia da bacia de acumulação de chorume do aterro sanitário de Salvador. Um sistema para testes de viabilidade - e modelo para outros a serem construídos no Brasil - 
foi concebido e construído na Alemanha, nas oficinas da Universidade de Frankfurt e trazido para a UFBA. Esse sistema consta basicamente de um nebulizador, de um tubo reator onde o ar a ser limpo reage com a neblina ativada quimicamente, e ao fim de um desnebulizador que recompõe o líquido da neblina, conduzindo-o para o esgotamento sanitário. Todo o estudo, otimização de tamanho de partículas e densidade da neblina, uniformidade ao longo do raio de eficiência de comprimento do reator, assim como a eficiência de desnebulização, foram procedidas previamente pelo grupo alemão na Universidade de Frankfurt.

Em 2009, Alves, na sua dissertação de mestrado, estudou a viabilidade da aplicação da técnica de neblina ativada com o mesmo sistema, para reduzir os microorganismos emanando da mesma bacia de acumulação de chorume. Como a técnica antes só havia sido utilizada na redução de substâncias gasosas de caráter ácido ou básico, e nesse caso, por tratar-se de redução de partículas, modificações no sistema de ativação química tornaram-se necessários. Tratando-se de abatimento de uma mistura de microorganismos de natureza desconhecida, portanto com grande probabilidade de tratar-se de uma mistura de natureza hidrofílica e lipofílica de partículas, optamos por utilizar surfactantes que são moléculas capazes de reagir com ambos os tipos de partículas por possuírem uma extremidade polar (solúvel em água) e outra apolar (solúvel em lipídios). Também nessa etapa, tivemos a colaboração dos parceiros alemães que forneceram alguns dos reagentes de ativação da neblina que não eram disponíveis comercialmente no Brasil. A seguir, descreveremos em mais detalhes esse novo sistema desenvolvido para reduzir as emissões de bactérias e fungos da bacia de chorume.

\section{Descrição do sistema de abatimento de bioaerossóis desenvolvido para o aterro sanitário de Salvador}

A bacia de acumulação de chorume do aterro sanitário de Salvador é coberta com uma lona plastificada, contendo uma saída, denominada respirador, por onde saem os gases e os microorganismos resultantes da decomposição da matéria orgânica. Na saída do respiradouro coloca-se um reator contendo neblina ativada quimicamente. Assim, o ar oriundo da bacia entra diretamente no reator, é purificado pela neblina ativada quimicamente, e é então lançado para a atmosfera. 
Neblina é a suspensão no ar de gotículas microscópicas de água ou de partículas higroscópicas úmidas, com diâmetro de partícula igual ou menor que 50 micrômetros, ou seja, 0,05 mm. Na natureza, a neblina se forma por condensação da umidade do ar (vapor d'água), por contato com massas de ar frias. A neblina artificial pode ser produzida por diversas formas, sendo a mais comum e barata por aspersão, ou seja, por um dispositivo pequeno instalado na extremidade de um fluxo de líquido sob pressão, que fraciona o líquido em gotículas por impactação em uma superfície. Aspersores são geralmente utilizados em irrigação e em resfriamento de unidades de produção confinada de aves, entre outros. Nesse caso as partículas de água produzidas são maiores do que 50 micrômetros. No entanto, para a produção de partículas de neblina, é preciso o uso de aspersores especiais, que produzam partículas menores que 50 micrômetros. Para a purificação do ar, quanto menores as partículas produzidas, mas eficiente será a captação de contaminantes.

No contexto de formação de neblina, denomina-se ativação química a adição de pequenas quantidades de uma ou mais substâncias químicas, que irão interagir com substâncias gasosas ou com as partículas presentes no ar.

O mecanismo de interação da neblina ativada com os bioaerossóis pode ser descrito da seguinte maneira e ilustrado na Figura 1. O fluxo de ar a ser limpo é tratado com gotículas de neblina ativadas quimicamente. A neblina e o ar fluindo para o reator e contendo os bioaerossóis são transportados ao longo do reator pelo fluxo do ar. Depois de um curto tempo de contato os bioaerossóis são adsorvidos pela superfície das gotículas de neblina ativadas quimicamente, com uma mistura de surfactantes e de outros compostos em nível de traço, os quais dependem da composição original do ar. A determinação da eficiência da interação - e, portanto, da purificação - é feita quantificando-se os bioaerossóis no ar antes e depois da passagem do ar pela neblina. 
Figura 1 - Esquema do funcionamento da neblina ativada na captação de bioaerossóis.

Reator de absorção de bioaerossol

- Neblina

- Aerossol / Bactéria

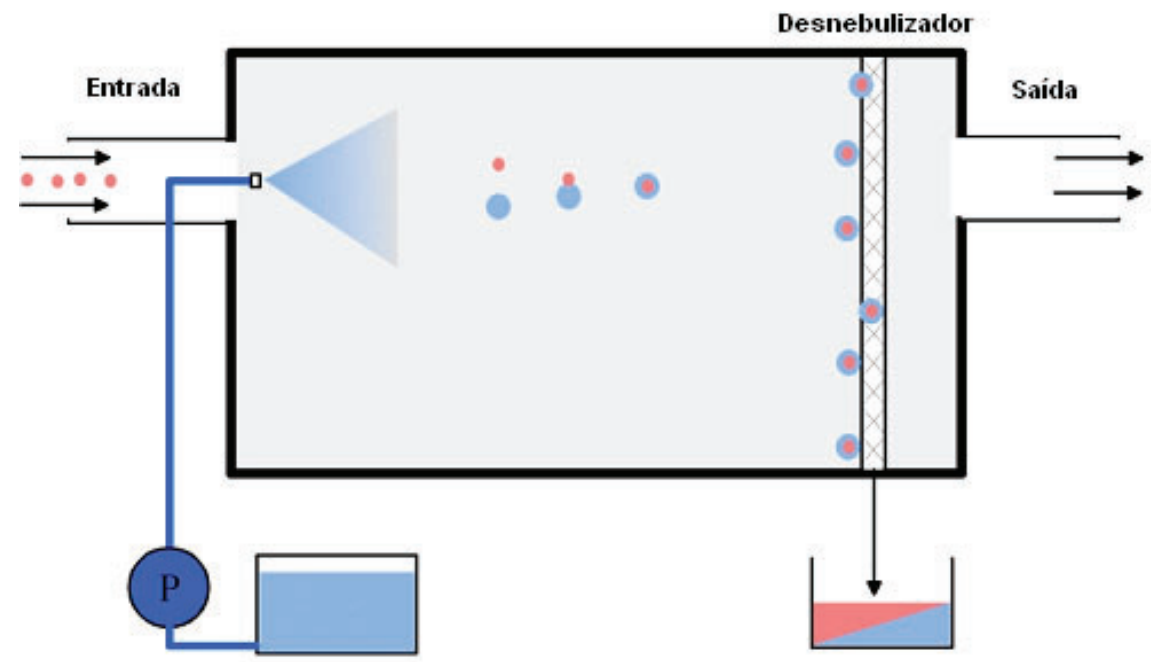

Fonte: JAESCHKE, não publicado, com modificações. In: TAVARES,

T. M. et al., Apresentação feita à Battre. Salvador. BA, dez. 2006.

O sistema de abatimento de bioaerossóis utilizado foi consistido por um reator de PVC de $5 \mathrm{~m}$ de comprimento, um gerador de neblina com dois aspersores e um aspirador do gás a ser limpo. Esse reator foi instalado na saída da bacia de chorume do aterro sanitário de Salvador.

O gerador de neblina foi composto por uma bomba que leva a solução de limpeza até o aspersor, responsável pela formação da neblina com partículas de 0,2 - $20 \mu \mathrm{m}$ e situado na entrada do reator. Um segundo aspersor, idêntico ao primeiro, foi utilizado para aumentar a eficiência do sistema, formando uma neblina mais densa. $\mathrm{Na}$ extremidade da saída do reator foi colocado um desnebulizador em forma de tela de aço inox, que permite somente a passagem do ar limpo, recompondo a solução dispersa como neblina e contendo os bioaerossóis, a qual é descartada ou direcionada para o sistema de esgotamento sanitário. As concentrações de bioaerossóis são pelo menos uma ou duas ordens de grandeza menores do que aquelas presentes em águas descartadas e circulando por esgotamento sanitário. Um esquema do reator sistema pode ser visto na Figura 2. 
Figura 2 - Esquema do sistema de neblina utilizado para abatimento de bioaerossol na bacia de acumulação do chorume do Aterro Sanitário Metropolitano Centro de Salvador.

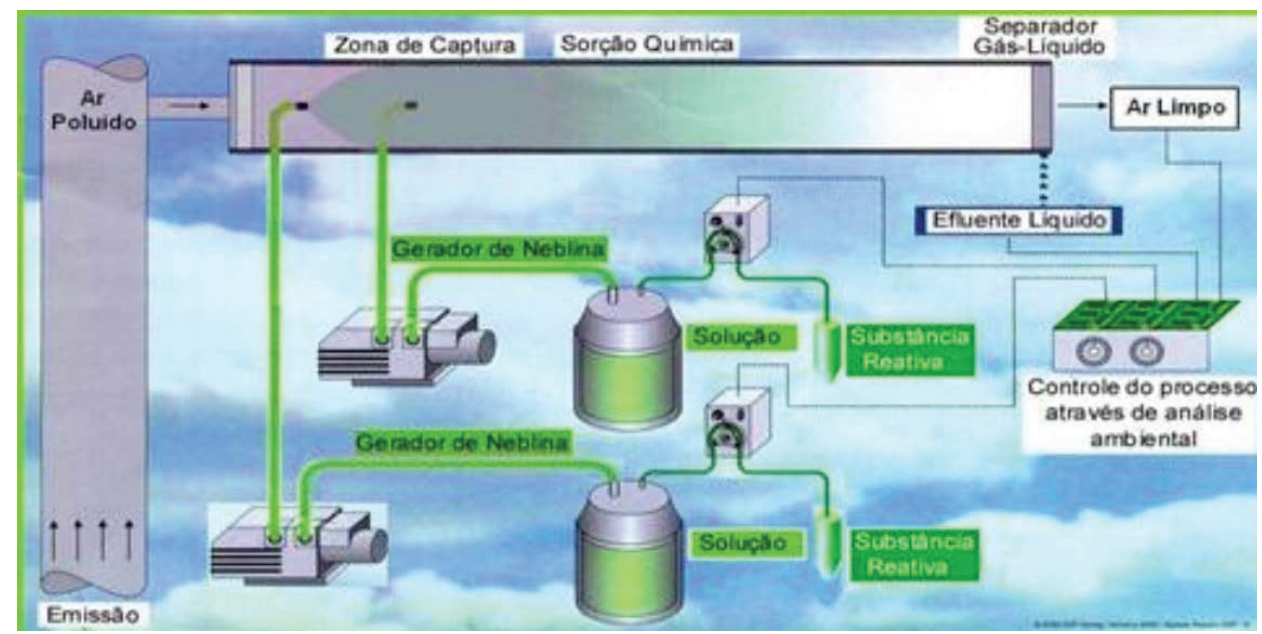

Fonte: JAESCHKE, não publicado, com modificações. In: TAVARES, et al. Apresentação feita à Battre. Salvador. BA, dez. 2006.

\section{Medidas de bioaerossóis: controle de bactérias e fungos no ar}

$\mathrm{O}$ ar foi amostrado com o impactador de cascata Andersen, operado apenas com um estágio, com fluxo constante de ar aspirado de $28,3 \mathrm{~L}$ min $^{-1}$ coletando as partículas acima de diâmetro aerodinâmico de corte $0,4 \mu \mathrm{m}$. Um sistema de pressão para vedação do sistema utilizado dessa forma foi desenhado e construído especialmente em oficina mecânica local. A Figura 3 mostra o impactador Andersen montado com apenas um estágio. O fluxo constante foi obtido com uma bomba de vácuo de regime contínuo, provida com uma válvula de controle ajustável. A vazão, antes e depois de cada amostragem, foi medida com um rotâmetro marca Rota de fabricação alemã, previamente calibrado. 
Figura 3 - Impactador Andersen de um estágio utilizado para amostrar bioaerossóis no ar entrando e saindo do reator de neblina ativada.

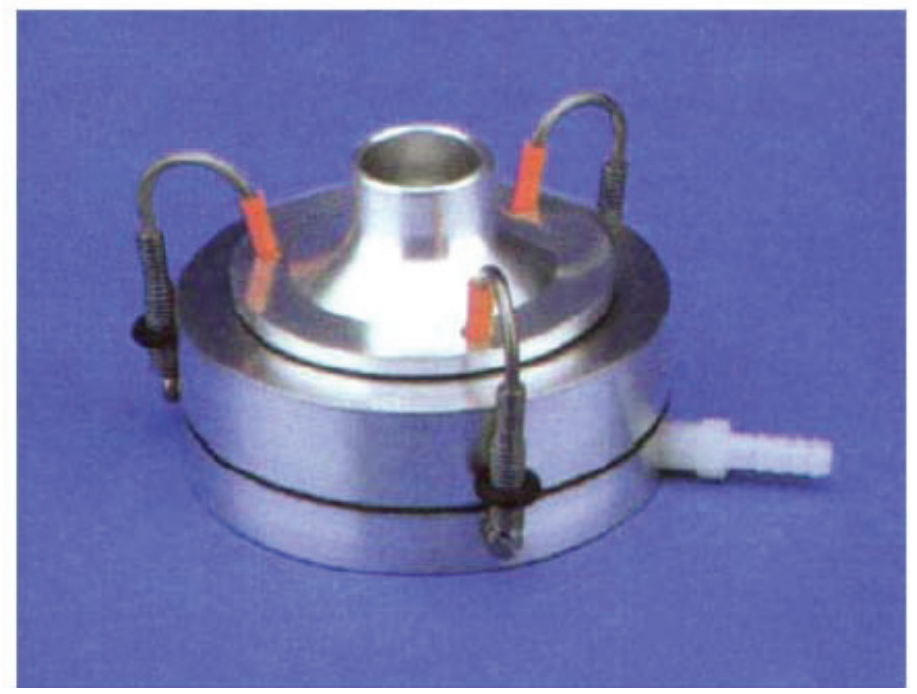

Fonte: (ALVES, 2009)

O meio de coleta foi uma membrana de ésteres mistos de celulose hidrofílicos, poro 0,45 $\mu \mathrm{m}$, diâmetro $80 \mathrm{~mm}$, GN6 - Metricel da Pall, que minimiza artefatos, quais sejam, a inibição ou o estímulo indevido de desenvolvimento de culturas que se seguirão. Estando a umidade relativa do ar alta, tornou-se desnecessário o uso de umedecimento prévio da membrana para evitar repique das partículas ou dessecação e morte das bactérias. O tempo de coleta de cada amostra foi de $10 \mathrm{mi}-$ nutos, num total de volume amostrado de $283 \mathrm{~L}$.

Após a amostragem, as membranas foram colocadas em contato com as placas Petrifilm contendo as duas culturas respectivamente, de bactérias e fungos, previamente umedecidas com $1 \mathrm{~mL}$ de água esterilizada por micro filtração, e mantidas a temperatura ambiente no campo. Após a amostragem, as membranas foram colocadas em contato com os meios de cultura adequados.

O meio de cultura para bactérias foi ágar padrão com incubação posterior à chegada ao laboratório de microbiologia, com incubação a $35^{\circ} \mathrm{C} \pm 1^{\circ} \mathrm{C}$ por $48 \mathrm{~h} \pm 3 \mathrm{~h}$. O meio de cultura para fungos foi ágar Sabouraud, com incubação posterior à chegada ao laboratório durante 5 dias entre $20-25^{\circ} \mathrm{C}$. As contagens das colônias desenvolvidas foram feitas visualmente e quando necessário, com auxílio de um contador composto de uma lupa e uma lâmpada. 
A concentração total de microrganismos cultiváveis foi calculada dividindo-se o número total de colônias observadas em todas as placas pelo volume do ar amostrado. Concentrações de bioaerossóis cultiváveis são relatadas normalmente como unidades de formação de colônias (UFC), que é o número de colônias que se replica de células de bactérias individuais ou em grupos, endoesporos ou esporos fúngicos, por unidade de volume do ar $\left(\mathrm{m}^{3}\right)$. O volume de ar é dado pela vazão de amostragem multiplicada pelo tempo decorrido da amostragem:

$\quad V=\frac{Q \cdot t}{1000} V=\frac{Q \cdot t}{1000}$, onde $\mathrm{V}$ é volume $\left(\mathrm{m}^{3}\right)$, Q é vazão $\left(\mathrm{L} \mathrm{min}{ }^{-1}\right)$ e t é
tempo (min).

Para verificar se existe diferença entre as concentrações de bioaerossóis determinadas antes e após a intervenção, foi utilizado o teste t de Student, que é teste de hipótese para comparação de médias de pequenas amostras dependentes. A eficiência do sistema foi calculada com base na percentagem referente à concentração de microrganismos obtidos após a intervenção, relacionados com as concentrações determinadas antes da intervenção com o sistema proposto.

$$
\eta=\frac{C_{\text {inicial }}-C_{\text {final }}}{C_{\text {inicial }}} \cdot 100
$$

\section{A viabilidade do uso do reator de neblina ativada na redução de bioaerossóis na bacia de chorume do aterro sanitário}

O sistema de neblina ativada foi testado em duas condições: neblina sem e com a mistura de tensoativos $1 \%$, tanto para bactérias quanto para fungos. Os resultados em unidades de formação de colônias por metro cúbico de ar (UFC $\mathrm{m}^{-3}$ ) obtidos do ar sem nenhum tratamento, denominado de inicial, e do ar saindo do sistema de tratamento com a neblina ativada, denominado de final, foram reportados para cada microrganismo.

Comparando-se os valores de UFC $\mathrm{m}^{-3}$ saindo do respiradouro da bacia de chorume (coluna denominada Inicial) e os valores equivalentes saindo do sistema de neblina (coluna denominada final), nota-se que a ação da neblina sem ativação química consegue reduzir em média 
$71,9 \%$ das bactérias presentes e com a ativação resultante da presença da mistura tensoativa a $1 \%$, a redução alcança $93,5 \%$.

Figura 4 - Concentração de bactérias (UFC $\mathrm{m}^{-3}$ ) no ar emanado do respiradouro da bacia de acumulação do chorume do Aterro Sanitário Metropolitano Centro de Salvador, antes e depois da passagem pelo reator de neblina ativada.

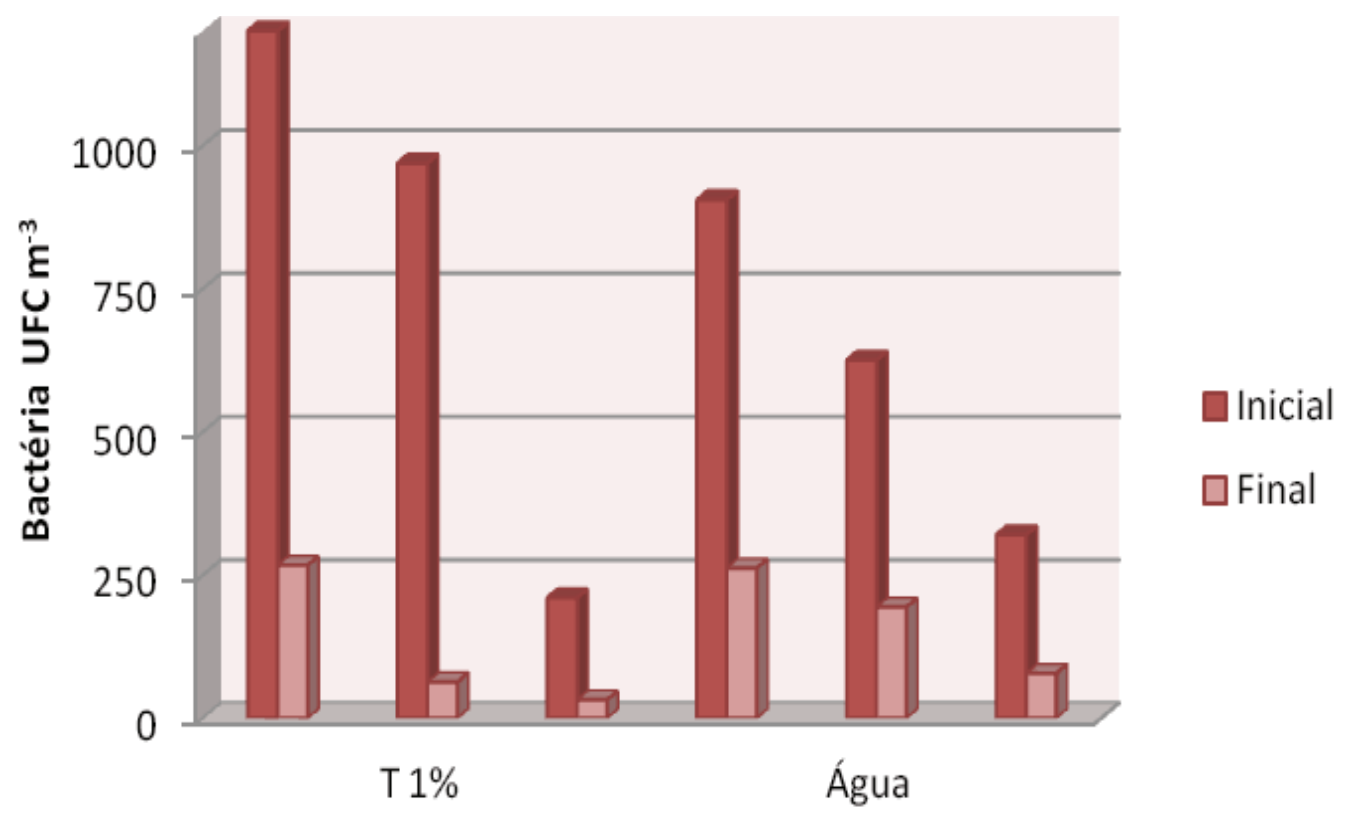

Tipo de neblina

Fonte: (ALVES, 2009)

O teste $\mathrm{t}$ foi aplicado ao conjunto de dados do sistema antes e depois dos tratamentos com neblina (água e mistura química tensoativa). $\mathrm{O}$ valor calculado (Stat $\mathrm{t}=4,351755956$ ) é maior que o valor crítico bi-caudal (t crítico bi-caudal $=2,570581835$ ), e a hipótese de igualdade $\left(\mathrm{H}_{0}\right)$ é rejeitada. Podemos chegar à mesma conclusão comparando o valor do $\mathrm{p}$-value $(\mathrm{P}(\mathrm{T}<=\mathrm{t})$ bi-caudal $)=0,023039$ com o nível de significância adotado $\alpha=0,05$. Como $\alpha>$ valor-p, rejeita-se a hipótese $\mathrm{H}_{0}$. Desta forma, é possível dizer que a concentração de bactérias no ar antes da utilização do sistema é significativamente diferente da concentração após a aplicação da neblina.

Os dados obtidos para fungos podem ser vistos na Figura 5. Cada valor constante nesse gráfico representa a média aritmética de medidas em duplicata. Comparando-se os valores de UFC $\mathrm{m}^{-3}$ de fungos saindo do respiradouro da bacia de chorume (coluna denominada inicial) e os valores equivalentes saindo do sistema de neblina (coluna denomina- 
da final), vemos que a ação da neblina sem ativação química consegue reduzir em média $72,1 \%$ dos fungos presentes, de forma semelhante ao ocorrido com a redução de bactérias. Com a ativação tensoativa a redução alcança 93,4\%, também semelhante à redução de bactérias.

Figura 5 - Concentração de fungos (UC m-3) no ar emanado do respiradouro da bacia de contenção do chorume do aterro sanitário de Salvador, sem

(Inicial) e com (Final) a utilização do reator de neblina ativada.

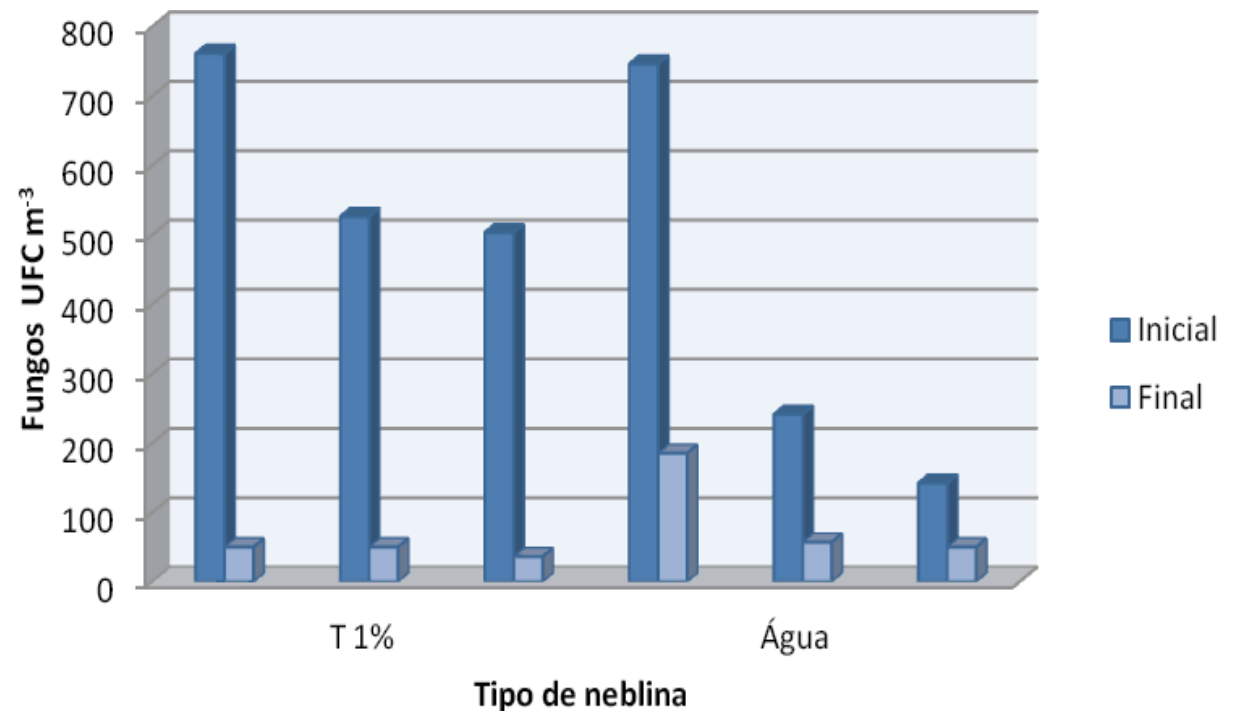

Fonte: (ALVES, 2009)

O teste $\mathrm{t}$ foi aplicado ao conjunto de dados das medidas de fungos antes e depois dos tratamentos com neblina (sem ativação e com ativação tensoativa). Como o valor calculado (Stat $t=4,351755956)$ é maior que o valor crítico bi-caudal (t crítico bi-caudal $=2,570581835$ ), rejeita-se a hipótese $\mathrm{H}_{0}$ de que a concentração de fungos no ar não difere significativamente, antes e depois da utilização do sistema. $(\mathrm{P}(\mathrm{T}<=\mathrm{t})$ bi-caudal $)=0,007347042$ com o nível de significância adotado de $\alpha=0,05$ Como $\alpha>$ p, rejeita-se a hipótese $\mathrm{H}_{0}$. Desta forma é possível dizer que a concentração de fungos no ar, antes da utilização do sistema, é significativamente diferente da concentração após a aplicação da neblina.

Os dados resultantes da aplicação do sistema de neblina ativada sugerem que as especificações do reator construído e a ativação química utilizada, reduzem em até $93 \%$ as bactérias e fungos do ar nas emissões de bioaerossóis de uma lagoa de chorume de um aterro sanitário. 
Nessas mesmas condições esse sistema reduziu em até $98 \%$ a emissão de gases com mau odor, dessa mesma bacia de contenção de chorume. (CRUZ et al., 2005) A eficiência na redução de gases e bioaerossóis dependem, além da composição e da concentração da mistura química tensoativa, de vários outros fatores da engenharia do equipamento, tais como a faixa de tamanho de gotículas da neblina produzida pelo aspersor e especificação de construção do reator. Portanto, a utilização do reator proposto é viável para a redução de bactérias e fungos e otimizações são possíveis para uma redução ainda maior.

\section{Considerações finais}

Embora seja consenso internacional que atividades de disposição e aterro de resíduos orgânicos emitam bioaerossóis para o ar, existem poucos estudos identificando e quantificando os microorganismos emitidos de aterros sanitários em geral, e de bacias de acúmulo de chorume em particular. As emissões atmosféricas de bactérias e fungos do aterro sanitário metropolitano de Salvador, foram comprovadas e quantificadas no estudo relatado neste capítulo.

Estudos internacionais demonstram que os bioaerossóis emitidos em plantas de compostagem - as quais vêm sendo mais estudadas a partir de 2000 - são transportados a distâncias de 1000 m ou mais. Estudos adicionais, principalmente na Alemanha, demonstraram que essas emissões afetam a saúde humana e bem estar de residentes próximos. Essa comprovação aponta para a necessidade de desenvolver-se sistemas que reduzam ou abatam os microorganismos lançados ao ar.

Algumas técnicas vêm sendo aplicadas para essa finalidade em plantas de compostagem. No entanto, as técnicas utilizadas apresentam grandes desvantagens, tais como: desempenho variável ao longo do tempo, necessidade de substituição periódica de membranas ou filtros, e geração de resíduos sólidos demandando disposição especial semelhante às de resíduos hospitalares. Outras envolvem consumo muito alto de energia, tornando-se dispendiosas.

O sistema desenvolvido na UFBA, resultado da parceria do Mestrado de Saúde, Ambiente e Trabalho e o Laboratório de Química Analítica Ambiental do Instituto de Química, baseia-se no princípio da neblina ativada quimicamente, conseguindo reduzir as emissões de 
microorganismos emitidos pela bacia de contenção de chorume do aterro sanitário metropolitano de Salvador em cerca de $93 \%$. O sistema de neblina ativada atua dentro de um reator cilíndrico colocado na saída do ar da bacia. O sistema é de custo baixo, desempenho estável ao longo do tempo, não gerando resíduos ou efluentes contaminados, além de não necessitar de substituição periódica. Como desvantagens de sua aplicabilidade no Brasil, estão a falta de disponibilidade comercial no mercado nacional de aspersores capazes de produzir partículas de diâmetro entre 10 e $20 \mathrm{um}$ - tamanho de partícula da neblina utilizada no sistema construído pelos parceiros alemãs - e das misturas tensoativas de produção estrangeira.

O sistema desenvolvido e aqui descrito comprova a viabilidade do uso da técnica da neblina ativada para purificação do ar contaminado por microorganismos emitidos por uma bacia de acúmulo de chorume. A eficiência 93\% alcançada, embora alta, pode ser aumentada, necessitando-se para isso outros testes, modificando-se vários parâmetros, tais como concentração da solução tensoativa, composição alternativa do tenso ativo, dimensões do reator, fluxo do ar a ser purificado, entre outros.

Além dessa aplicação, o sistema apresenta o potencial de ser aplicado a outras situações, tais como purificação de plantas de compostagem, de tratamento de efluentes contendo matéria orgânica, de unidades de separação de lixo - inclusive utilizado pelos catadores -, de tratamento biológico de efluentes industriais em geral e de plantas de papel celulose em particular, entre outros. Devido ao potencial da técnica de neblina ativada, de abater não apenas partículas, mas também gases, e devido a sua flexibilidade para a construção de outros arranjos, sua gama de possibilidades de aplicação na purificação de ar são enormes.

\section{Referências}

ALBRECHT, A. et al. Recommendations for study design and sampling strategies for airborne microorganisms, MVOC and odours in the surrounding of composting facilities. International Journal of Hygiene and Environmental Health, v. 211, n. 1-2, p. 121-131, 2008.

ALVES, E. M. Uso de Neblina ativada para redução das emissões de bioaróssois em um aterro sanitário, 2009. 66f. 
Dissertação (Mestrado em saúde, ambiente e trabalho) Faculdade de Medicina, Universidade Federal da Bahia, 2009.

BUNGER, J. et al. A 5-year follow-up study on respiratory disorders and lung function in workers exposed to organic dust from composting plants. International Archives of Occupational and Environmental Health. v. 80, n. 4, p. 306-312, 2006.

CROOK, B.; BARDOS, R. P.; LACEY, J. Domestic waste composting plants as sources of airborne micro-organisms. Congress on Aerosols, Their Generation, Behaviour and Applications, 22-24 March 1988, Bournemouth, UK. Proceedings Bournemouth: the Aerosol Society Second Conference, 1988.

CRUZ, L. P. S. et al. Otimização de sistema químico de neblina temperada para abatimento de emissões atmosféricas de $\mathrm{H}_{2} \mathrm{~S}$. Reunião Anual da Sociedade Brasileira de Química, 28ª , 2005, Poços de Caldas - MG. Livro de Resumos, 2005.

FISCHER, G. et al. Exposure to airborne fungi, MVOC and mycotoxins in biowaste-handling facilities. International Journal of Hygiene and Environmental Health, v. 203, n. 2, p. 97-104, 2000.

. Analysis of airborne microorganisms, MVOC and odour in the surrounding of composting facilities and implications for future investigations. International Journal of Hygiene and Environmental Health, v. 21, n. 1-2, p. 132-142, 2008.

FRANK, W. G. Size and Characteristics of Airborne Solids. New York: American Air Filter Company, 1937.

HERR, C. E. W. et al. Bioaerosols in outdoor air - Statement of environmental medical assessment criteria on the basis of an epidemiological cross sectional study. Gefahrstoffe Reinhaltung Der Luft. v. 64, n. 4, p. 143-152, 2004a.

. Health effects associated with exposure to residential organic dust. American Journal of Industrial Medicine. n. 46, p. 381-385, 2004b.

JAESCHKE, W. et al. Mass fluxes and chemical pathways during a fog event. Contr. Atmos. Phys. n. 71, p. 145-157, 1998.

KOWALSKI, W. J.; BAHNFLETH ,W. Airborne Respiratory Diseases and Mechanical Systems for Control of Microbes. HPAC Heating/Piping/Air Conditioning, p. 34-48, 1998.

KÜHNER, M. Kompostierung unter semipermeablen Membranen. Stuttgarter Berichte zur Abfallwirtschaft, Bd. p. 78, 2001. 
KUMMER, V. et al. Untersuchungen zum Abscheide-verhalten von Abluftreinigungsanlagen im Hinblick auf Bioaerosole.

Gefahrstoffe. Reinhaltung der Luft, n. 63, p. 368-372, 2003.

MILLNER, P. Bioaerosols and composting. Bio Cycl, v. 36, n. 1, p. 48-54, 1995.

MOHR, A. J. Microorganisms fate and transport. In: HURST, C. J. et al. Manual of Environmental Microbiology, 2 ed. Washington DC: ASM Press. 2002. p. 827-838,

MULLER, T. et al. Acute Blood Neutrophilia Induced by ShortTerm Compost Dust Exposure in Previously Unexposed Healthy Individuals. International Archives of Occupational and Environmental Health. n. 79, p. 477-482, 2006.

NUNES, L. S. S. et al. Measurements of Atmospheric Concentrations of Reduced Sulphur Compounds in the All Saints Bay Area in Bahia, Brazil. Journal of Atmospheric Chemistry, n. 50, p. 79-100, 2005.

RAHKONEN, P. Airborne Contaminants at Waste Treatment Plants, Waste Manag. Res., v. 92, n. 10, p. 411-421. 1992.

RECER, G. M. et al. Ambient air levels of Aspergillus fumigatus and thermophilic actinomycetes in a residential neighbourhood near a yard waste composting facility. Aerobiologia, n. 17, p. 99-108, 2001.

RICCI, L. et al. Gas-Liquid Equilibria in Polluted Fog.

Contr. Atmos. Phys. n. 71, p. 159-170, 1998.

SCHILLING, B. Emissionsminderung für Bioaerosole durch Biofilter. In: Mikroorganismen in der Umgebung von Abfallbehandlungsanlagen Hessisches Landesamt für Umwelt und Geologie. 2003.

SCHUMANN, M. Nutzungsmöglichkeiten der Chemisorption mit Nebeltropfen zur Minderung der Emission Von Ammoniak, Schwefelwasserstoff und organischen Gasen aus Industriebetrieben. Enthalten im Sonderforschungsbericht 233, Dynamik und Chemie der Hydrometeore, Zentrum für Umweltforschung, 2000. 



\section{As viúvas do amianto: significados da contaminação por asbesto}

Cláudia de Oliveira d'Arede Mônica Angelim Gomes de Lima Maria do Carmo S. Freitas

\section{Introdução}

Este capítulo apresenta um estudo etnográfico sobre os significados da contaminação por amianto da mina de São Felix, em Bom Jesus da Serra, Bahia. O estudo objetiva compreender os significados desta contaminação, a partir do discurso das viúvas de trabalhadores desta mina, que em sua percepção, faleceram em decorrência das doenças provocadas pelo amianto. Este estudo analisa o discurso das viúvas e recupera o significado da contaminação para esta comunidade.

Inicialmente serão apresentadas algumas considerações sobre o uso do amianto e o contexto de sua produção no local de estudo (a comunidade que vive nas proximidades da mina de São Félix). Em seguida serão analisadas as percepções das mulheres sobre o processo de contaminação, doença e morte de seus companheiros. Por fim, serão discutidos aspectos do contexto atual e possibilidades de enfrentamento do problema.

\section{Breves considerações sobre o uso do amianto}

A relação do homem com o uso do asbesto (amianto) é antiga. Era considerado como aliado e facilitador na vida cotidiana, por ser um minério isolante térmico e resistente a altas temperaturas. Em diversas sociedades, os trabalhadores passaram a se expor cada vez mais ao pó do amianto utilizado em indústrias, como matéria prima para vários 
produtos, bem como ficaram expostos às fibras desse minério, em minas. No final do século XIX, alguns médicos observaram doenças em trabalhadores relacionadas ao amianto. (ABREA, 2001)

Figura 1 - Amianto in natura, encontrado na Mina de São Félix.

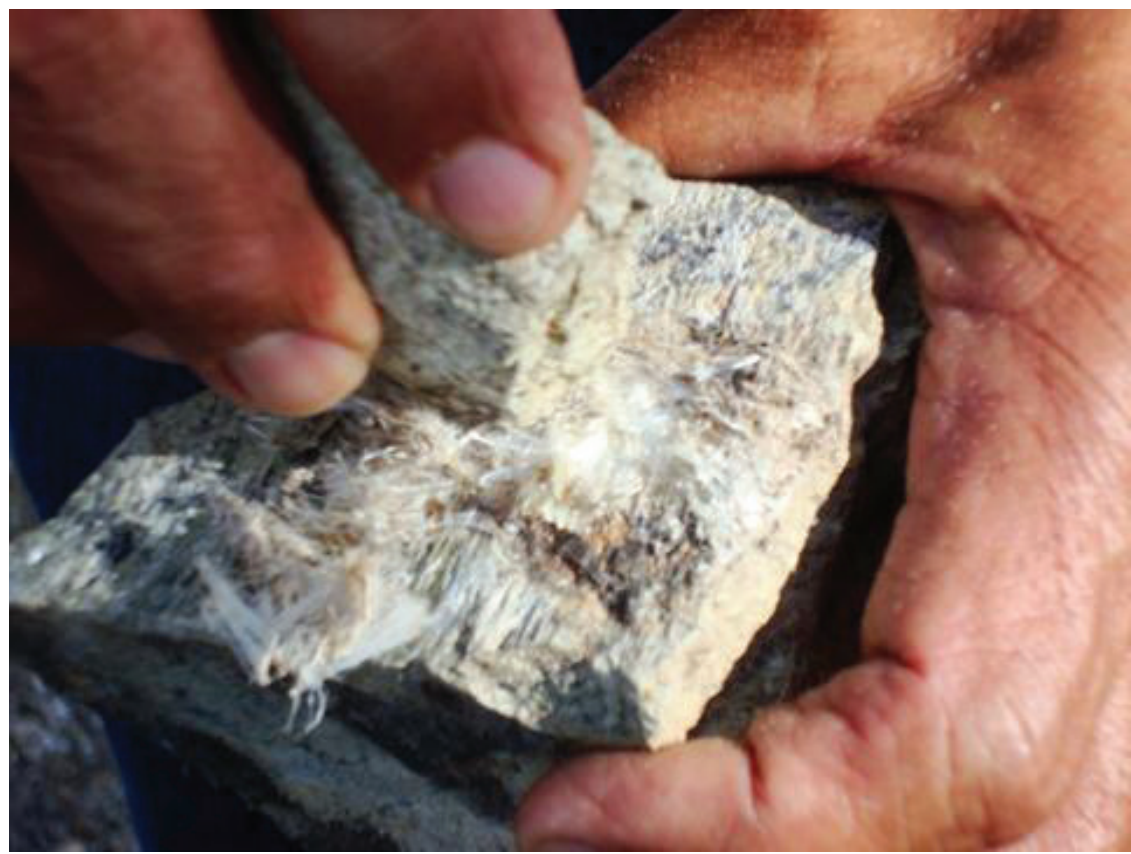

Fonte: (D'AREDE, 2008)

No momento, o amianto ou asbesto é responsável por aproximadamente 100.000 mortes por ano no mundo, segundo estimativa da OIT, principalmente por câncer de pulmão e mesotelioma de pleura. (BRASIL, 2008) O uso de todas as formas de fibras de amianto é proibido em 66 países, incluindo os da América do Norte e da Europa. No Brasil, o amianto do tipo anfibólio está banido desde 1991 pelo Ministério do Trabalho e Emprego em seu Anexo 12 da NR-15, que regulamentou e Convenção 162 da OIT, sendo depois ratificado com a Lei $\mathrm{n}^{\circ} 9055 / 95$, onde se proibiu definitivamente o uso do anfibólio. O Brasil mantém o uso da fibra crisotila, que é o tipo de amianto mais valorizado pela indústria. A Rússia e Cazaquistão lideram o ranking de produtores, seguidos de China, Canadá e Brasil. (REDE BANIMETRO INTERNACIONAL, 2006 apud IBAS, s.d) O Canadá é o segundo maior produtor mundial de amianto, porém consome pouco em seu território. Dados indicam que a população americana se expõe em média per capita a $100 \mathrm{~g} /$ ano; os canadenses a $500 \mathrm{~g} / \mathrm{ano}$; e a população brasileira a, aproximadamente, $1.400 \mathrm{~g} /$ ano. (CASTLEMAN, 1995) 
Até a década de 1930, o Brasil importava todo o amianto que consumia principalmente do Canadá e África do Sul. Em 1939, com a fundação da Sociedade Anônima de Mineração de Amianto - SAMA, este quadro começou a mudar com a descoberta da mina de São Félix em Bom Jesus da Serra, distrito do município de Poções, Bahia, marcando assim, o início de exploração no Brasil. Esta mina permaneceu ativa até 1967 e possuía aproximadamente 540 trabalhadores.

Em 1962, uma expedição geológica chegou a uma região de Goiás onde havia um modesto comerciante que vendia "estranhas pedras cabeludas". Assim foi descoberta a jazida que deu ao Brasil a autossuficiência no setor. Com a descoberta da imensa jazida em Goiás, no maciço de Canabrava, as instalações da mina de São Félix foram transferidas para essa região. Hoje, a Mina de Canabrava - única amiantífera em operação no país - produz amianto do tipo crisotila. Com ela, o Brasil ocupa a posição de terceiro maior produtor mundial, suprindo todo o consumo interno e exportando para dezenas de países. Sua produção atinge aproximadamente 180.000 toneladas/ano. (PAMPLONA, 2003) A cadeia produtiva do amianto crisotila brasileiro, desde a mineração até a revenda dos produtos derivados, gera 170 mil empregos no país. De toda a produção de crisotila brasileira, $6 \%$ é usada em produtos de fricção, massas de vedação, entre outros e $94 \%$ em produtos de cimento amianto: $50 \%$ dos telhados e $80 \%$ das caixas de água brasileiras são fabricados com cimento amianto. (ABREA, 2001)

A grande cava aberta entre as pedras de amianto na mina de São Félix tem um quilômetro de extensão e cerca de setenta metros de profundidade, assim como seus túneis não estão resguardados da presença de pessoas e animais. "O grande cânion", como é chamado pelos moradores, o lago de águas verdes, possui concentração de magnésio na sua composição, a partir de rochas amiantíferas, dando origem à cor da água esverdeada, e levemente salgada, onde ainda se pesca tilápias, traíras e tambaquis, ainda que seu consumo ofereça perigo à saúde. 
Figura 2 - Mina de São Félix, desativada.

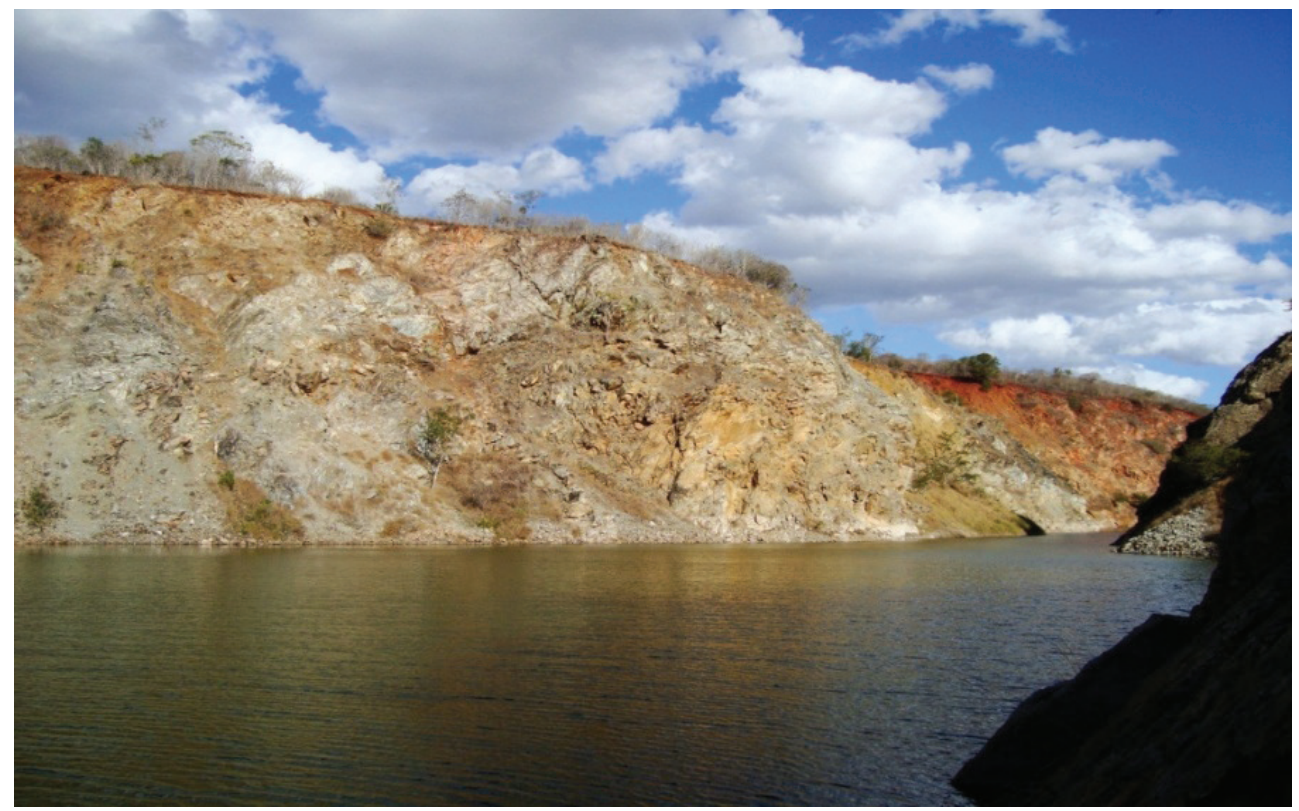

Fonte: (D'AREDE, 2008)

Ainda são desconhecidas as significações deste mineral por pessoas que vivem na região, mesmo tendo a presença do amianto em várias ruas pavimentadas e casas construídas. Hoje, a mina abandonada é local de lazer, de banhos de sol e pesca pela comunidade. Conhecer o processo de adoecer e viver, no cotidiano com o amianto, estruturou alguns dos movimentos deste estudo etnográfico sobre a percepção da contaminação por esse minério. Estas informações denunciam a falta de ações sociais para a melhoria das condições de vida e saúde dos moradores.

\section{As viúvas do amianto: abandono e sobrevivência}

Os discursos das viúvas, aqui analisados, apresentam as lembranças de seus maridos, seu trabalho, o envelhecimento e o abandono que sentem pela falta de apoio da Empresa mineradora e do Estado. Estas questões se configuram como marcas significantes de mudanças, nas identidades dessas mulheres idosas e sozinhas.

Para elas, a "poeira" ou "pó do minério" representa um perigo para a saúde, uma contaminante que provoca vários sintomas e doenças. Entre 
as mais graves estão: o câncer de pulmão, de pleura (mesotelioma) e a asbestose pulmonar - pneumopatia crônica obstrutiva. (BRASIL, 2008)

A análise das redes semânticas das narrativas dessas mulheres apresenta como significantes principais a descrição das enfermidades de seus maridos, marcadas por várias perspectivas. Sobre isto, Byron Good (1994), mostra que a noção de rede semântica indica que o significado de uma doença não é unívoco, mas, um produto plural e interconectado a vários sentidos. Trata-se de relacionar experiências, palavras, sentimentos e ações dos diferentes membros da sociedade. Nesse aspecto, esta investigação antropológica sobre os significados da contaminação por asbesto, interpreta aspectos da realidade e da experiência dos trabalhadores e de suas famílias com o amianto, significados e noções sobre o processo saúde/doença, riscos passados, presentes e futuros decorrentes da exposição do corpo ao amianto.

As histórias sobre o trabalho na mina, adoecimentos e mortes, são partes da memória preservada por viúvas e pelas lápides brancas do cemitério "Brancas de Neve", na Vila Operária. As viúvas denunciam, com indignação, a poeira branca que seus maridos "guardaram no corpo" até à morte. Este estudo como vemos a seguir, reúne informações para tornar visível este problema ambiental e de saúde dos trabalhadores. Nesse sentido, faz-se um intercâmbio de experiências através da narrativa partilhada, produzida no momento etnográfico que envolve o pesquisador e as narradoras, as viúvas do amianto. (BENJAMIM, 1987)

\section{Metodologia}

Trata-se de uma etnografia com análise dos significados atribuídos por viúvas de trabalhadores mineiros que faleceram ao longo da exploração da mina. Ademais das interpretações narrativas, foi realizada a observação participante com um rigoroso registro do modo de vida das famílias do povoado de São Félix. (OLIVEIRA, 2000)

Para Oliveira (2000, p.96-7)

[...] não há descrição, por mais intencionalmente objetiva que seja, sem um mínimo de interpretação [...]. Distingo interpretação de compreensão seguindo Paul Ricoeur quando esse autor examina a relação dialética entre compreensão e explicação em vários de seus escritos. 
Sobre este aspecto, este estudo utiliza teorias compreensivas e interpretativas. (GEERTZ, 1999; RICOEUR, 2009) Os registros obtidos em campo somam-se às descrições analíticas sobre a história do lugar, o abandono das famílias, pela Empresa mineradora e pelo Estado. Busca-se, com isso, a compreensão da contaminação ocupacional ocorrida há mais de quarenta anos e que levou à morte vários trabalhadores desta mina. São as suas viúvas que contam como era o trabalho, os sintomas de adoecimento, o meio ambiente resultante das atividades de exploração do amianto e o fechamento e abandono da mina. O trabalho de campo foi realizado no período de janeiro a dezembro de 2008, com registros diários sobre o cotidiano das famílias. (MINAYO, 1992; GEERTZ, 1999; OLIVEIRA, 2000)

Para sistematizar as informações obtidas das entrevistas em profundidade, foram aplicados três roteiros: o primeiro, baseado em Souza (2006), abordando a história de vida das viúvas, focalizando o trabalho de seus maridos na mina; o segundo, de acordo com Minayo (1992), sobre os modos de vida e saúde das viúvas e seus maridos; o terceiro, sobre a contaminação ambiental e ocupacional. Foram realizadas doze entrevistas com as viúvas e, dada à complexidade do processo interpretativo, foram feitas leituras e análises das informações com minuciosa e cuidadosa interpretação de cada entrevista, categorizando significantes em unidades de análises com os subconjuntos das falas. (BENJAMIM, 1980; RICOEUR, 1994)

Os critérios para escolha dos informantes-chave foram considerados indicações das lideranças da Associação Baiana de Expostos ao Amianto (ABEA), seguindo a recomendação desta pesquisa de apresentarem a descrição das histórias de doenças do asbesto e o tempo de trabalho ou de exposição dos trabalhadores na mina. Da observação e análise das narrativas que expressam a experiência das pessoas, buscou-se o caminho para a compreensão e interpretação dos significados atribuídos às viúvas (idade média 76 anos) ao processo de adoecimento e morte dos seus maridos, pelo amianto. 


\section{Resultados e discussão}

\section{Descrição do modo de vida da Vila Operária}

$\mathrm{Na}$ Vila Operária, durante o período em que a Empresa mineradora se manteve no local, as mulheres representavam dois tipos de papéis sociais: eram filhas de trabalhadores ou esposas. Algumas trabalharam na mina como ensacadoras de minério nas esteiras - o amianto era extraído à mão, com ajuda de um martelo, e depois vendido em sacos para a empresa. Ainda desenvolviam atividades domésticas de arrumadeiras na usina e na casa dos franceses (técnicos e donos da mineradora), lavadeiras e feirantes, além disso, cuidavam da sua própria casa e de sua família.

Os empregados da usina, que saíam do trabalho porque estavam doentes, eram obrigados a deixar as casas que pertenciam à Empresa mineradora, na Vila Operária. Assim, alguns trabalhavam doentes para não perderem o emprego, principal fonte de sustento das famílias, e para não serem despejados de suas casas. Desempregados, doentes e exaustos, migravam para outros lugares ou ficavam próximos à mina, em plantações de culturas de subsistência como feijão e milho, cuja venda era realizada na pequena feira da Vila Operária. Algumas mulheres trabalhavam na roça para complementar a renda, que nunca era suficiente.

Após o sofrimento e a morte do marido, a viúva era retirada da casa da Vila Operária. As viúvas do amianto eram acolhidas por outras famílias de trabalhadores do lugar, morando de favor entre os amigos e parentes.

Depois que o meu marido morreu, eu e meus filhos fomos todos pra fazenda do compadre Jovino, foram todos criados lá. Os meninos trabalharam na mina levando café, água para o povo do corte e vendia minério pra mineradora. (VIÚVA - JOSEFA, 2008)

O abandono das viúvas é expresso através da situação concreta de sofrimento e necessidades vividas a partir da sua condição de viuvez. Esse abandono pode ser percebido em relação à empresa, e aos agentes do Estado, enquanto responsável pelos registros de óbito e nascimento. Com a baixa escolaridade, elas não entendem e não conseguem tomar providências. 
As viúvas sobrevivem das pensões deixadas pelos maridos e como trabalhadoras rurais das atividades rurais de subsistência. As avós, viúvas ou não, permanecem com a guarda dos seus netos, especialmente em função de duas situações: pela morte prematura de seus filhos e pelo fluxo migratório para o centro-sul do país, especialmente para São Paulo, em busca de emprego. Assim, os filhos enviam, esporadicamente, economias para ajudar as mães. Mas, os laços são fortes. Os filhos que migraram ainda visitam suas mães quase todos os anos e algumas viajam para encontrá-los. Os que permanecem por perto, se casam, ficando junto das mães, geralmente morando no mesmo sítio, numa situação clara de matriarcado. A mãe, além de cuidar de netos, é a provedora da família, cuja subsistência é garantida pela agricultura familiar.

Os filhos das viúvas buscam trabalho "fora" da região. Muitos conseguem trabalhar como operários da construção civil e vendedores ambulantes. Nesse sentido, os filhos desempenham papel fundamental no sustento das famílias, repetindo a tradição do êxodo nordestino principalmente em direção à região sudeste do país: "Quando meu marido morreu, eu tinha dois rapazes. Eles foram pra São Paulo trabalhar. Depois eles escreveram dizendo que iam comprar um terreno pra mim e me deram o terreno". (VIÚVA - JOSEFA, 2008)

A condição de viúva remete a uma missão maior: na ausência definitiva do marido, o esforço humano para o sustento, é atribuído ao sagrado e aos filhos. A rede de apoio criada pela família é o suporte mais presente no estado de viuvez para estas mulheres. Estas e suas famílias atribuem significados ao lugar onde estão seus maridos. O cemitério tem uma representatividade de valor cultural: o culto aos túmulos. Estes são frequentemente visitados e ornamentados. As famílias, em especial as viúvas, procuram sentidos para continuarem perto dos seus maridos, realizando rezas junto aos túmulos. De certo modo, o cemitério é uma extensão da casa, pois entendem que seus maridos morreram precocemente. 
Figura 3 - Cemitério "Branca de Neve”, Bom Jesus da Serra, Bahia.

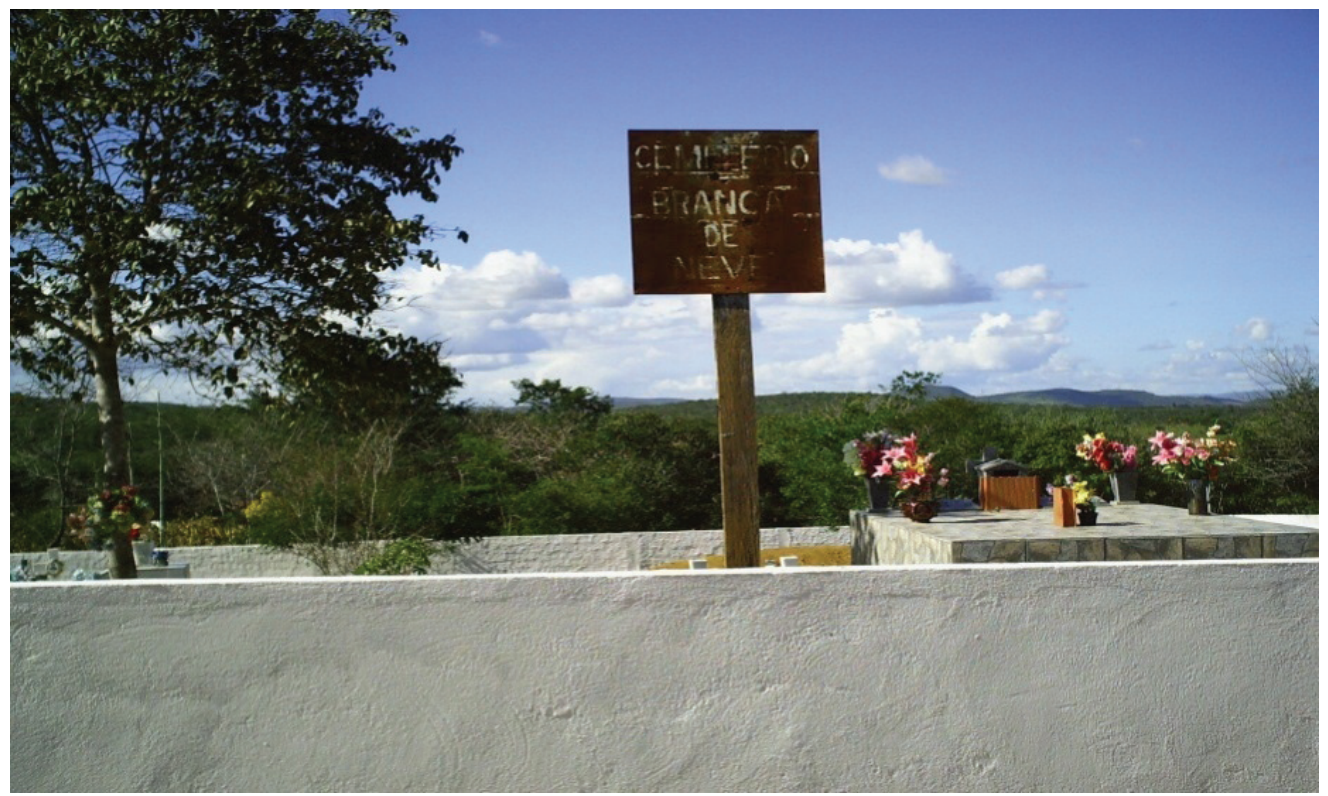

Fonte: (D'AREDE, 2008)

\section{O sentido da contaminação e do perigo}

Dizem que o minério faz mal, o povo fala que essa mina é um perigo. Eu não sei, mas eu acho que todos que vêm dessa região acusa que lá se trabalha até morrer. Tem uns que ficam resfriados, a tosse fica diferente. Meu pai ficou doente assim. (VIÚVA - JOSEFA, 2008)

"A usina, quando trabalhava, rodava os motores, aquela poeira saía tudo lá, fora a que ficava presa, que entrava no corpo. Saía voando, saía pro ar, era esparramado ali e lá embaixo enchendo saco, aquele pó [...]”. (VIÚVA - STELA, 2008)

Para Mary Douglas (1991), as sociedades tradicionais concebem o meio físico como inseparável dos homens. Neste sentido, entendemos que para as viúvas do amianto a poeira deste minerio é parte da vida das pessoas do lugar. É compreendida como algo que entra no corpo e contamina. A contaminação é permanente por causa desse pó do amianto que ainda se encontra presente na mina, no campo de futebol, nas ruas, no ar, nos carros que passam e jogam poeira.

"Meu marido foi contaminado do minério, e morreu assim. Ele era moreno, chegava branquinho, caía poeira assim nos cabelos, olhos, na roupa". (VIÚVA - JOSEFA, 2008) 
"Sempre sentia, porque ele trabalhou na cama de poeira, não tem um que não ficou doente e outros, já morreram quase todo esse pessoal que trabalhava aí, muita gente morreu nova. Morreu todos desse pó". (VIÚVA - ISABEL, 2008)

A contaminação é compreendida de duas maneiras: durante a exposição à poeira na vida cotidiana da mina, e continua na mina abandonada. Trata-se de uma contaminação ocupacional e outra ambiental. A primeira ficou no passado e ainda ecoa no presente, a segunda permanece inalterada.

Com sete anos a doença começa. Nivaldo chegava do trabalho, tinha o macacão da cor dessa toalha (branca), ele não usava máscara. Os filhos dos trabalhadores não sabiam o que fazia mal, a gente almoçava lá, o restaurante lá dentro, trabalhava dentro do pó, mas a gente vivia lá, com todo mundo. (VIÚVA - OLÍVIA, 2008)

A desinformação sobre a contaminação é compreendida como "ofensa". O sentido é de adoecimento, o corpo "prejudicado". As mortes significam para as famílias, a consequência dessa ofensa. A Empresa mineradora e os agentes do Estado não protegeram estas pessoas.

\section{Atitudes sobre riscos e adoecimento}

Segundo Alves (2006), os estudos sobre a experiência da doença, tomam como ponto de partida analítico, o pressuposto de que o social é originalmente toda a situação vivida pelos atores sociais, em contextos culturais e históricos concretos. O mundo da vida ("Lebenswelt") é o horizonte de referência de valores, crenças e ideias, a partir do qual, os indivíduos e grupos sociais interagem entre si, definindo ações previstas de sentido e realizando qualquer empreendimento cognitivo como as "representações". Ao transportar este conceito para o escopo desse trabalho, observamos que as ações humanas em torno da mina, na relação entre contaminador e contaminado, traduzem-se em experiências fundadas no campo específico do mundo da vida, constituindo assim, a base sobre a qual se dão as demais relações sociais.

Ao partir da premissa de que a intersubjetividade se dá pela similitude de interpretações que ocorrem no mundo da vida cotidiana, é importante ressaltar, que para a fenomenologia hermenêutica, a 
doença é um fenômeno que diz respeito a um conjunto de elementos socioculturais que estão interligados entre si. (ALVES, 2006) O mundo da vida dessas viúvas está ilustrado em suas narrativas aqui analisadas. As viúvas desenvolveram processos de sofrimento que se assemelham entre elas, neste mesmo lugar. São diversos elementos comuns encontrados em suas narrativas, como se os fragmentos de suas etnobiografias revelassem a subjetivação da perda precoce dos maridos, como um castigo. (GONÇALVES; MARQUES; CARDOSO, 2012) Sentem a falta da correspondência, do afeto e do antigo lar. Em suas percepções, é como se houvesse "uma ferida aberta" em suas vidas de viúvas pelo amianto. Sobre a doença, descrevem: "Os pés dele eram assim aquele cascão, tudo que saía nas solas dos pés era minério". (VIÚVA - JOSEFA, 2008) "Ele adoeceu. O umbigo dele era aberto, aqui (mostra o abdômen) inchou. É porque eu não tenho a placa pra te mostrar, mas podia botar a placa [pleural] em cima da barriga dele que dava assim". (VIÚVA - STELA, 2008)

A compreensão da contaminação e do adoecimento, se dá pela presença de placas do minério no corpo identificadas nos exames biomédicos. Apesar de não as reconhecer, sabem que o mal do minério (asbestose) está ali presentificado nas variações tonais de preto e branco do Raio X. No contexto deste estudo, saber sobre as placas no Raio X, ratifica o que é sentido no corpo ainda que a informação médica também tenha sido politicamente, valorizada pela Empresa para negar o diagnóstico ao paciente. E quanto à importância do diagnóstico para o paciente, Byron Good (1994), ao analisar a dor crônica e sua invisibilidade, pontua que ao ter um nome para a origem da dor (doença), tem-se também o poder de aliviar o sofrimento, um patamar crítico para a reconstrução do mundo cotidiano e uma autorização da integração do selfque sofre. (GOOD, 1994)

"Ele estava doente, mas não se deitava. Ele estava consciente de tudo. Conversava. E ele falava que tudo era do minério". (VIÚVA BEATRIZ, 2008)

Eles (os médicos locais) não sabem identificar os problemas de asbestose. Disseram pra levar ele lá e ele passando mal. Depois viram as chapas que a gente tinha tirado, pegaram e saíram. Ainda tem duas chapas de raios-X, tudo pretinho. Não se vê nada de pulmão. Vieram uns advogados da firma. Aí eles engabelaram a gente, falou que ia resolver e tal. Eu tive três reuniões 
lá em Minaçu com eles. Chegava lá diziam que os papéis estavam em São Paulo, nos Estados Unidos, no Japão. E foi tapeando, tapeando, até hoje e aí pra Dr. Arthur pra fazer exame, e ele disse: "Seu marido morreu foi de asbestose. (VIÚVA - OLÍVIA, 2008)

"Tanta coisa que ele sentia. Tinha placa do minério. Disse que tinha [...] Eu nem sei o que têm nesses papéis... que atingiu por dentro do pulmão. Era uma plaquinha, não sei quantos milímetros que tinha". (VIÚVA - BEATRIZ, 2008)

O que se passou nos corpos desses mineiros, foi um conjunto de sinais e sintomas descritos e significados por suas viúvas, que assistiram os corpos de seus maridos se modificarem, mudando suas fisionomias, cor da pele e dimensões corporais. Os relatos se assemelham à literatura médica, ainda que seja numa linguagem simples e afetiva (sobre tema semelhante, mostra Luc Boltanski em sua obra As classes Sociais e o Corpo, 2004). Essa vivência descrita, minimamente, entra em sincronia com a percepção do sentido de indignação pela injustiça sofrida por este trabalhador que "deu a vida à Empresa", no dizer de uma viúva.

Quando ele faleceu, tinha minério nos pés. Saía que nem um cravo. Aquilo brotava assim de dentro pra cima, aquela pontinha arranhava, aí tinha mês que ele cortava, aí ficava ruim do pé. Não tinha mais paladar, a cor dele era amarela, parecendo uma pessoa pálida e ficou magrinho [...]. Trabalhou trinta anos, sem perder um dia de serviço, ele não recebia reclamação, não chegava atrasado nunca. (VIÚVA - JANDIRA, 2008)

A falta de informação médica, fez com que estas pessoas só percebessem o adoecimento e o risco de contaminação quando havia manifestação da doença: "Ele sentia cansaço e falta de ar. Quem sente dessa doença, só sente dor nas pernas e cansaço; ele ia na rua, parava umas dez vezes. Ficava amarelão e uma escuridão que dá no corpo que fica preto, a pele dele estralada". (VIÚVA - OLÍVIA, 2008)

Dispneia, emagrecimento, dores no peito, tosse e cansaço são alguns dos sintomas e sinais da doença. O "mal do minério" é compreendido como o mal da mina. Muitos adoeceram com diagnósticos de tuberculose e pneumonia, como forma de desresponsabilizar a Empresa mineradora por doenças provocadas pelo amianto. Não existia um órgão fiscalizador que pudesse ajudar os trabalhadores, no sentido de 
apontar um tratamento adequado para as doenças do amianto e fazer o contraponto do diagnóstico, muitas vezes negado.

A Empresa mineradora não se comprometeu em cuidar dos ex-trabalhadores doentes e colocava a responsabilidade no governo como um provedor ausente das medicações necessárias. A doença dos maridos para estas mulheres é "um mal que não tem cura". A dedicação do marido ao trabalho é percebida como um esforço que não valeu à pena viver, que não gerou estabilidade financeira, e só produziu adoecimento e morte.

Chama a atenção algumas expressões, como o significado da placa pleural, que para elas é a marca da doença. O primeiro sinal descrito no corpo contaminado.

A placa pleural é tirada do intestino, a placa do minério cozido, placa amarela. Parece que o tumor era da placa entre o couro e a carne. Migue [...] Ficou dessa cor (amarela). Fez o exame de ultrassom. Lá no hospital fez a limpeza na placa, era uma água grossa que nem uma coisa dissolvida, que nem fubá de milho dissolvido no leite. Na barriga estava aquela água grossa, pocou, murchou a barriga. Teve que enterrar logo ele (VIÚVA - ISABEL, 2008). (Esse trabalhador morreu de câncer de estômago conforme a entrevista de sua viúva).

A narrativa seguinte revela que algumas mulheres recorrem ao tratamento alternativo como solução para este mal do minério:

O mal atingindo, aquele pó entrando... o minério. Ele estava sentindo um entupimento no nariz, achava que era do pó do minério e sentia uma gastura na garganta, a garganta cheia de farinha ficava sem poder mastigar. Ele não queria ver cheiro de comida, o nariz dele estava cheio de pau. Eu peguei a paulista que é uma bucha amarga que nem fel [...] tem uma sementinha preta. Bati o pó bem batido e fervi e ele colocou dentro do nariz e respirou esse pó e foi soando o nariz e foi saindo carnegão, amarelo, depois saía azul, saía amarelo da pedra do minério, saía azul [...] que nem a lama. (VIÚVA STELA, 2008)

A desinformação quanto às doenças dos maridos, a falta de assistência da Empresa mineradora e dos agentes de saúde do Estado em relação às viúvas e suas famílias, são ainda visíveis em Bom Jesus da Serra. A Empresa manipulou informações e se apresentou em visitas às casas das viúvas, reivindicando documentos e exames realizados por 
seus maridos, com o discurso de rever direitos trabalhistas a serem repassados às viúvas, mas ainda não houve qualquer solução.

As famílias que reivindicam direitos sociais (benefícios previdenciários) sofrem com a indiferença do serviço social da Empresa mineradora: "A firma não ajuda mais no funeral dos que morrem, porque teve reunião na (ABEA) e eu fui e diz que eu não deveria ter ido, que ficou ruim e que os chefes lá da empresa cortaram o benefício por isso". (VIÚVA - BEATRIZ, 2008)

As providências que podem ser tomadas pelas viúvas e familiares para reaver seus direitos, são ainda incipientes. A busca por indenizações passou a ser o motivo central da Associação dos trabalhadores. Mas, como não há atestados de óbitos registrados com o nexo causal relacionado à morte à exposição ao amianto, observa-se um sentimento de desesperança. Também, a devassa realizada pela Empresa nas casas das viúvas e de seus familiares, na busca de documentos que pudessem comprometer a Empresa (exames de saúde), logo após as primeiras mortes, resultou numa condição social de solidão, humilhação e desespero por parte das viúvas. Sentem-se invadidas, sem apoio de autoridades públicas, e sua Associação é a única alternativa que encontram para reunir os interesses da comunidade e procurar soluções.

Eu nem pensei em mais nada da empresa, porque está sendo muito difícil pra gente. Sairpra procurar, pra mexer com isso, eu não quero me envolver mais. Agora, se for uma coisa pra continuar, ir paras reuniões eu posso acompanhar. Mas pra correr atrás, eu não corro, porque pra mim o mais importante já foi: a vida dele. (LIA, FILHA DA VIÚVA BEATRIZ, 2008)

O movimento social da ABEA funciona como único movimento contrário à Empresa na busca das indenizações das vítimas. Tem encontrado, ao longo do tempo, embates com o poder judiciário. ${ }^{1}$ A ABREA, em Bom Jesus da Serra, vem buscando soluções judiciais para ex-trabalhadores (indenizações trabalhistas), e informa aos moradores de toda a região sobre os perigos inerentes no lidar com o amianto no seu estado natural, e com subprodutos industrializados, fazendo

1 Existe uma ação judicial movida pela ABEA contra a empresa desde 2001. Em 2008, através da Ação Civil Pública e como resultado de um termo de ajuste de conduta firmado pelo Ministério Público do Trabalho com a Secretaria de Saúde do Estado da Bahia e secretarias municipais da região, alguns mineiros e seus parentes passaram a serem avaliados clinicamente, com o objetivo de medir os impactos da saúde e definir tratamentos. 
dessa uma ação política que busca banir o amianto definitivamente do Brasil (como acontece em vários países).

Apesar dos maridos terem dedicado parte de suas vidas à Empresa mineradora, não houve qualquer tipo de direito trabalhista assegurado aos ex-trabalhadores e suas famílias. O salário que recebiam pelo trabalho era direcionado apenas à subsistência das famílias. Depois que a mina foi desativada e os maridos morreram, essas mulheres nunca foram procuradas pela Empresa mineradora para discutir os seus direitos. Elas se sentem abandonadas:

A ajuda mesmo pra meu marido foi só dos nossos filhos. Uma casinha que ele tinha lá no sul não tem nada a ver com o dinheiro da empresa. Quando ele vendeu esta casa ele comprou uma criaçãozinha, mas tudo foi acabando. O resto quem deu foram os filhos, os netos . (VIÚVA - BEATRIZ, 2008).

Durante o adoecimento e morte, a família tem sido o principal apoio, inclusive financeiro. A Empresa mineradora fornece plano de saúde aos trabalhadores mais doentes e quando estes morrem não recebem qualquer tipo de ajuda. $\mathrm{O}$ fato de não receberem indenizações, é compreendido pelas viúvas como "usura e egoísmo" dos que detém o poder. A omissão dos agentes do Estado e o descaso dos empresários da mineradora são evidenciados nos relatos dessas mulheres.

"A Empresa veio aqui depois. A gente tinha os exames todos que ele (o marido) fez. Eles (responsáveis pela empresa) sumiram com todos os exames e documentos". (VIÚVA OLÍVIA, 2008)

"Quando eu fui pedir ajuda à Empresa, eles queriam só pagar a minha passagem de ônibus. Isso é egoísmo, usura”. (VIÚVA D. BEATRIZ, 2008).

A partir de 2010, o Centro de Estudos da Saúde do Trabalhador (CESAT), instituição da Secretaria Estadual de Saúde da Bahia, em parceria com o Centro de Referência em Saúde do Trabalhador (CEREST) da Secretaria de Saúde de Vitória da Conquista, vem realizando o cadastramento dos ex-trabalhadores para a realização de exames no SUS, no município vizinho, Vitória da Conquista. 


\section{O cotidiano da morte: 0 ritual do sepultamento}

A morte é um momento a ser partilhado com a família, entre parentes e vizinhos. A percepção mítica que envolve interpretações sobre a morte, marca a presença contínua do morto no imaginário dos parentes. Depois do sepultamento, cumpre-se um ritual de purificação em relação à separação do morto e do cemitério, principalmente do contato com a "terra contaminada", se dá com a realização de alguns critérios: não entrar em casa com os sapatos utilizados no funeral; tomar banho completo, incluindo lavar os cabelos; lavar todas as roupas e os calçados que tiveram algum contato com o "morto", podendo contaminar a casa com as impurezas do morto. Nesse sentido, a purificação é necessária para retornar ao estado anterior, desvinculado os vivos da morte. É possível perceber que, para além de servir de proteção contra possíveis doenças, a purificação tem um sentido de novamente colocar vida e morte em oposição. (DOUGLAS, 1976)

Inserem-se, neste contexto, narrativas que ilustram percepções sobre a viuvez como se fosse parte da vida perder seus companheiros precocemente. A morte desses trabalhadores da mina de São Félix, marca a vida de todas as famílias que ali vivem. Morreram pela contaminação e por condições violentas de trabalho:

\footnotetext{
Morreu tanta gente nessa mina! Morreu muita gente, de tomar pancada, de bater pedra. Tinha um vagão que quando descia, o pessoal tinha que se esconder num cantinho, porque o vagão batia e esmagava quem ficasse perto. E morreu muita gente lá embaixo, esmagada. A pedra do corte que dava fogo estourava NAS EXPLOSÕES. Morreu foi gente. Era pedra pra estourar, pra poder botar pra fazer minério, porque tinha dinamite que explodia. (VIÚVA - JOSEFA, 2008)
}

Manoel Cândido era o feitor geral da mina, conhecido por todos que lá viveram. Era ele quem comandava os operários. Ele e outros seguiram trabalhando na Empresa, em Minaçu, Goiás e morreram por lá. Entre as causas das mortes destaca-se: tuberculose, pneumonia, derrame pleural, câncer e Acidente Vascular Cerebral. Qualquer morte é compreendida como condenação por ter trabalhado e ter tido contato com o amianto: "Morreu Manoel Cândido, morreu o irmão, morreu genro, morreu tudo em Goiás. Disse que morreu porque todo mundo 
que trabalhou nessa mina, morreu. Não tem nenhum vivo". (VIÚVA D. JOSEFA)

Os ex-trabalhadores da mina que foram expostos à poeira do amianto, estão doentes ou morreram. Isso reflete a tendência mundial de morte de mineiros, que não tiveram acesso à proteção individual e coletiva nos postos de trabalho, na atividade de mineração. (SCAVONE, 1997) Os únicos exames feitos pelos trabalhadores são os realizados pela Empresa mineradora, que entrega laudos sem registros de doenças, dando a impressão que nenhum deles está doente ou morreu por causa da exposição ao amianto. Como podemos observar nesta narrativa:

Tem o compadre Zé, cunhado de Margarida, que está doente. Tem meu cunhado também, ele foi prejudicado do minério, disse que tem a manchinha no pulmão. Todos que têm o plano de saúde têm algum problema do minério. A empresa só dá plano pra quem atingiu do minério. Os resultados dos exames que fala que foi a plaquinha, essa coisa toda aí. Tem meu irmão lá em Poções. Trabalhou, trabalhou foi muito. Compadre Zé aqui trabalhou também em Minaçu, o cunhado de Lia. Morreu outro que chamava Nivaldo. Morreu todos declarados do minério, todos morreram. Morreu o que teve problema de pulmão também, Aílton. Tem Antenor lá de Poções. Néu até disse também: - "Antenor morreu foi também desse minério". Aí o médico da empresa disse: - "Não, é porque esse aí teve foi enfarte". Mas foi do minério também. Ninguém conta os que morreram". (VIÚVA - BEATRIZ, 2008)

A morte tem o ritual de despedida afetivo. Participar de todo o ritual, como: vestir o morto e velar por toda a noite, não parece ser um evento comum como em outros velórios. Neste, predominava o sentido de morte por amianto, morte pelo trabalho da mina. A descrição reflete o medo que se tinha de contaminar-se e de ser o próximo a morrer. Depois do enterro, vem o cuidado e a dedicação aos túmulos. A ida aos cemitérios faz parte do cotidiano das viúvas que revelam resignação, conformidade aos desígnios divinos, não cabendo mais denunciar o descaso histórico da Empresa mineradora e do Estado por estas terem se ausentado do tratamento da doença dos trabalhadores. Para as viúvas e seus familiares, resta a indenização, que ainda requerem. Relembrar as consequências da contaminação, doença e morte de seus maridos, ex-trabalhadores da mina, é um conflito que elas não querem mais reviver. Entre a denúncia de morte por contaminação e o conformismo pela perda de seus maridos, há um silêncio de dor e falta. 
Não há uma contradição aparente nestes processos, mas um conflito entre a explicação a interpretação, desde a contaminação à morte.

\section{Considerações finais}

Existe um passado de lembranças e tragédias, mas a convivência com a pedra de amianto é naturalizada em Bom Jesus da Serra. Isso faz parecer que lidar com este objeto não faz qualquer mal aparente. É como se coubesse a pergunta: "afinal de contas, que mal tem em bater umas pedrinhas, uma nas outras e retirar as lãzinhas?" O que foi uma consequência maléfica no passado, permeia ludicamente o universo cotidiano e o simbólico até os dias de hoje e adquire forma naturalizada pela comunidade, como se não houvesse perigo implícito ao lidar com este minério, "a pedra". O conhecimento e a experiência do cotidiano, a relevância da necessidade de trabalhar para o sustento da vida, trata com naturalidade, interagem entre si e exercem influência sobre $o$ homem.

O estrago causado ao corpo e à comunidade, por este minério, resulta do abandono da Empresa e dos agentes do Estado aos familiares enlutados. O movimento social dos trabalhadores resgata esta discussão, para tomar providências em relação às vítimas, culpados e omissos desta situação.

Como resultado desse abandono, as viúvas convivem com a Empresa que ainda exerce poder sobre elas, devido à falta de apoio do Estado e de informações sobre seus direitos e soluções. As famílias que buscaram seus direitos não conseguiram seguir com suas ações contra a Empresa. Não apareceram ainda advogados que queiram conduzir os casos e que lutem por elas. Os moradores de Bom Jesus da Serra se sentem "esquecidos", como se estivessem num lugar sem proteção legal e sem amparo institucional do Estado.

A resistência das viúvas, apesar da sua aparente submissão, é revelada na história e no cotidiano de cada uma, de como compreendem e conseguem se expressar sobre a contaminação e a morte de seus companheiros. O "calar" e a aparente aceitação implícita das relações de poder, por parte de alguns ex-trabalhadores e viúvas, tem sustentação nas precárias condições de sobrevivência. 
O processo de discussão sobre a situação do amianto, em Bom Jesus da Serra é bem mais complexo do que no resto do país. Tendo sido a primeira mina explorada no Brasil, mantém a relação do homem com o amianto in natura. E, por isso, requer uma política de educação em saúde ambiental direcionada ao local.

Nascer, viver e morar no entorno da mina, tem um significado profundo para estas pessoas. A proposta de interdição da mina significa não ir mais nadar, pescar, passear, lavar roupa, coisas que ainda fazem parte do cotidiano desses moradores.

Nesse sentido, ações de comunicação e educação em saúde precisam ser mais elaboradas para que haja um sentido de competência comunicativa, com informações repassadas e compartilhadas entres os membros da comunidade. (RANGEL, 2008) Para o caso aqui estudado, a vocalização de demandas quanto à contaminação ambiental por amianto no município, não só das viúvas e de seus familiares, mas da comunidade de Bom Jesus da Serra, pode ser vista como um começo para a construção compartilhada de soluções para essa complexa questão ambiental. A população local ainda não foi esclarecida, nem consultada, e a comunicação é aqui assumida enquanto recurso para redução da iniquidade social que acentua a vulnerabilidade desta comunidade à contaminação ambiental. Ao tomar a vulnerabilidade, como proposto por Meyer e colaboradores (2006), a comunicação é aqui defendida, enquanto dimensão do cuidado à saúde e requer tomar a contaminação ambiental por amianto em Bom Jesus da Serra, a partir da visibilidade do fenômeno construída pela comunidade e seus modos de apropriação e atribuição de sentidos. Nesse aspecto, é importante examinar as condições contextuais de trocas simbólicas entre os pares (comunidade e movimento social) e sua competência comunicativa na inserção política com atores sociais, com diferentes interesses nesta questão.

É de se esperar que a proposição de uma efetiva política de saúde ambiental, direcionada a esta realidade, possa mudar definitivamente a realidade de resignação e conformidade das famílias dos trabalhadores mortos pelo amianto, fruto do poder da Empresa e ausência de justiça social. 


\section{Referências}

ABREA - Associação Brasileira de Expostos ao Amianto. História do Amianto. 2001. Disponível em:

< http://www.abrea.org.br>. Acesso em: 22 abr. 2007.

ADFA - Asbestos Disease Foundation of Australian.

History. Disponível em < http://www.asbestosdisease.au/

historyasbestos.aspx > Acesso em: 11 jan. 2009.

AFL-CIO da Oil, Chemical and Atomic Workers International Union, 1995.

ALVES. P. C. A Experiência da Enfermidade. Cadernos de Saúde Pública, Rio de Janeiro, v. 9, n. 1, p. 263-271. jul. - set. , 1993.

. A fenomenologia e as Abordagens Sistêmicas nos Estudos Sócio-Antropológicos da Doença: breve revisão crítica. Cadernos de Saúde Pública, Rio de Janeiro, v. 22, n. 8, p. 1547-1554, ago. 2006.

; RABELO, M. (Orgs. ). Antropologia da Saúde: traçando identidade e explorando fronteiras. In: Alves, P. C; Rabelo, M. Repensando os Estudos sobre Representações e Práticas em Saúde/Doença. Rio de Janeiro: Relume Dumará/Fiocruz, 1998. p. 107-121. ; MINAYO, C. (Orgs. ) Saúde e Doença: um olhar antropológico. Rio de Janeiro: Fiocruz, 1994. p. 153-66.

ASBESTOS - News PaperArhive - History - Disponível em <http:// www.asbestosarchive.com/history.aspx> Acesso em: 15 jan. 2009.

BAHIA. ASSEMBLÉIA LEGISLATIVA DA BAHIA. Comissão de Proteção ao Meio Ambiente. Amianto, Desinformação Mata. Bahia: Grifo/Audiovisual, 2004.

BARBIERI, J. C. Desenvolvimento e Meio Ambiente: as estratégias de mudanças da Agenda 21. Petrópolis: Vozes, 1997.

BARTHES, R. A. Aventura Semiológica. São Paulo: Martins Fontes, 2001.

BEAUVOIR, S. A. Velhice. Rio de Janeiro: Nova Fronteira, 1990.

BECK, H. Sociedade de Risco: rumo a uma outra modernidade. São Paulo: Ed 34, 2010.

BECKER H. S. Métodos de Pesquisa em Ciências

Sociais. São Paulo: Hucitec; 1994.

BENJAMIM, W. O Narrador. In. : TEXTOS ESCOLHIDOS.

São Paulo, Abril Cultural, 1980. Col. Os pensadores. 
BENJAMIM, W. Obras escolhidas: magia e técnica, arte e política, 3 ed. São Paulo: Brasiliense, 1987.

BERGER, P; LUCKMAN, T. A Construção Social da Realidade: tratado de Sociologia do Conhecimento. Petrópolis: Vozes, 2004.

BOLTANSKI, L. As classes sociais e o corpo. Trad. Regina Machado. Rio de Janeiro, 4. ed. São Paulo: Graal, 2004.

BOSI, E. Memória \& sociedade: lembrança de velhos. São Paulo: T. A. Editor, 1979.

BRAITH, B. Bakhtin e Outros Conceitos - Chaves. São Paulo: Contexto, 2006.

BRASIL, Ministério da Saúde do Brasil. Representação no Brasil da OPAS/OMS. Doenças Relacionadas ao Trabalho - Manual de Procedimentos para os Serviços de Saúde. Série A Normas e Manuais Técnicos, Brasília, n. 114, 2008. p. 291.

BROSIUS, J. P. Analyses and interventions. Anthropological engagements with environmentalism. Current Anthropology, v. 40, n. 3, p. 277-309, 1999.

CASTLEMAN, B. Building a future without asbestos. New Solutions - Journal of Environmental and Occupational Health Policy, Lakewood, v. 5, n. 2, p. 58-63. 1995. . Asbestos: Medical and legal aspects. 4 ed. New york: Aspen Law \& Business, 1996. . Responsible Care and the Third World. Environmental Health Perspectives, v. 1, n. 105, p. 16-17, jan. 1997.

CASTRO, H.; GIANNASI, F; NOVELO, C. A Luta pelo Banimento do Amianto na Américas: uma questão de Saúde Pública.

Cadernos de Saúde Pública, v. 4, n. 8, p. 903-911, 2001.

D'AREDE, C. O Tempo das Águas e dos Ventos: significações do asbestos atribuídas às viúvas e ex-trabalhadores da Mina de São Félix, em Bom Jesus da Serra, Bahia. 2009. Dissertação (Mestrado em Saúde, Ambiente e Trabalho) Faculdade de Medicina da Bahia, Universidade Federal da Bahia, Salvador, 2009.

DICKINSON, E. Poemas Escolhidos. Porto Alegre: L\&PM, 2008

DIEGUES, A. O Mito Moderno da Natureza Intocada.

São Paulo: Hucitec, 2004. 
DOUGLAS, M. Pureza e Perigo. Ensaio sobre as Noções de Poluição e Tabu. Lisboa: Edições 70, 1991. (col. Perspectivas do Homem, n. 39).

DURAND, G. A Imaginação Simbólica. São Paulo: Cultrix, 1993.

FERREIRA, A. M. C. A linguagem Originária. Salvador: Quarteto, 2007

FOLADORI, G.; TAKS, J. Um Olhar Antropológico sobre a questão Ambiental. Mana, v. 10, n. 2, p. 323-348, 2004.

FRIEDSON, E. Profession of Medicine. Chicago:

The University of Chicago Press, 1988.

GEERTZ, C. A Interpretação das Culturas. In: GEERTZ, C. Uma Descrição Densa: por uma teoria interpretativa da Cultura. Rio de Janeiro: Editora Guanabara, 1999.

. O Saber Local: novos ensaios em antropologia interpretativa. In: Do ponto de vista dos nativos. Petrópolis, RJ: Vozes, 1997.

. Nova luz sobre a Antropologia. Rio de Janeiro: Jorge Zahar, 2001.

GIANNASI F.; MONY, A. T. Occupational Exposures to Asbestos in Brasil. International Journal of Occupational Environmental Health (IJOEH), 3, Hanley \& Belfus, INC. , Philadelphia, EstadosUnidos, 1997, p. 150-157.

GIANNASI, F. Asbesto / Amianto no Brasil. Um Grande Desafio. Caderno CRH-Centro de Recursos Humanos da Bahia da Universidade Federal da Bahia (UFBA), n. 23, p. 128-140. Jul. /dez. 1995.

GONÇALVES, M. A.; MARQUES, R; CARDOSO, V. Etnobiografia: esboço de um conceito. In. : . (orgs), Etnobiografia: subjetivação e etnografia. Rio de Janeiro: Edt. 7 Letras, 2012. p. 9-42.

GOOD. B. Medicine, rationality, and experience: an anthropological perspective. Cambridge: Cambridge University Press, 1994. . The Heart of What's the Matter: The Semantics of Illness in Iran. Culture, Medicine, and Psychiatry, n. 1, p. 25-58, 1976.

; GOOD, M. J. The Meaning of Symptoms: a Cultural Hermeneutic Model for Clinical Practice. In: L. Einserberg\& A. Kleinman. The relevance of social science for medicine. Boston: D. Reidel Publishing Company, 1980.

HALL, S. A Centralidade da Cultura: notas sobre as revoluções culturais do nosso tempo. Educação e Realidade, v. 22, n. 2, p. 15-46, 1997.

HELMAN. Cultura Saúde e Doença. In: Tratamento e Cura: as alternativas de assistência à saúde. Porto Alegre: Artes Médicas, 1994. 
HUSSERL, E. A. Crise da Humanidade Europeia e a Fenomenologia. Trad. Urbano Zilles. Porto Alegre: Edipucrs, 1996.

IBAS - International Ban Asbestos Secretariat, s. d. Disponível em: < http://ibasecretariat. org/> Acesso em: 12 jan. 2009.

KLEINMAN, A. et al. Pain as human experience.

Berkeley: University of California Press; 1994.

. Patients ND Healers in the Context of Culture: an exploration of the Borderland between Anthropology, Medicine, and Psychiatry. California: University of California press: Berkeley Los Angeles, 1994.

. The Illness Narratives: Suffering, Healing and the Human Condition. New York: Basic Books, 1988.

KUPER, A. Anthropologists and Anthropology: The British school (1922-1972). New York: Pica Press, 1973.

LEFF, E. Saber Ambiental. Petrópolis: Vozes, 2001. 343 p.

LÉVI-STRAUS C. O Pensamento Selvagem. Campinas, SP: Papirus, 1989.

LOPATA, H. Current Widowhood: myths and realities.

Thousand Oaks, CA: Sage Publications, 1996.

LOYOLA, M. A. Médicos e Curandeiros Conflito Social e Saúde. In: As

Doenças, os Doentes e os Especialistas. São Paulo: Ed. Difel, 1984.

LECLERC, G. Antropología y Colonialismo. Madrid:

Ed. Comunicación, 1973.

MENDES, R. Asbesto (amianto) e Doença: Revisão do

Conhecimento Científico e fundamentação para uma urgente

mudança da atual política brasileira sobre a questão. Cadernos

de Saúde Pública, Rio de Janeiro, v. 17, n. 1, p. 07-29, 2001.

MEILLASSOUX, C. Mulheres, Celeiros e Capitais.

Lisboa: Afrontamento, 1977.

MEYER, D. E. E. et al. “Você aprende. A gente ensina?”Interrogando relações entre educação e saúde desde a perspectiva da vulnerabilidade. Cadernos de Saúde Pública, Rio de Janeiro, v. 22, n. 6, p. 1335-1342, jun. 2006.

MINAYO, M. C. O Desafio do Conhecimento: pesquisa qualitativa em saúde. São Paulo: Hucitec Abrasco, 1992.

MONTAIGNE, M. Ensaios. . Rio Grande do Sul: Globo, 1961. v. 51, Coleção Biblioteca dos Séculos. 
MORIN, E. La méthode 4. Les ideés, leur habitat, leur vie, leurs moeurs, leur organization. Paris: Seuil, 1991.

MOTTA, A. B. Viúvas, O Mistério da Ausência. Estudos Interdisciplinares de Envelhecimento. Porto Alegre, 2005.

OLIVEIRA, R. C. de. O trabalho do Antropólogo.

2 ed. São Paulo: Editora UNESP, 2000.

PAMPLONA, R. O Amianto Crisotila e a SAMA: 40 anos de História Minaçu-Goiás. 1962-2003. Minaçu-GO, 2003.

PARSONS, T. The Social System. London: Routledge \& Kegan Paul, 1951.

RABELO, M.; ALVES, P. C.; SOUZA, I. A Experiência de Doença e Narrativa. Rio de Janeiro: Fiocruz, 1999.

PIZZI, J. O mundo da vida: Husserl e Habermas. Ijuí: Editora Unijuí, 2006.

PORTO, M. F. de S. Uma Ecologia Política de Riscos: princípios para integrarmos o local e local na promoção da saúde e da justiça ambiental. In: Riscos, Saúde e Vulnerabilidade: em Busca de uma Ciência Sensível. Rio de Janeiro: Fiocruz, 2007.

RAMOS, G. Vidas Secas. Rio de Janeiro: Record, 2008.

RICOEUR, P. Teoria da Interpretação. Lisboa: Ed. 70, 2009.

Tempo e Narrativa. Campinas, SP: Papirus, 1994. 1v.

RANGEL, M. L. Cultura, Tecnologias em Saúde e Medicina. In: CAROSO, C.

Notas para uma Etnografia da Comunicação em Serviços de Saúde.

(Org. ). Perspectiva antropológica. Salvador: EDUFBA, 2008.

SCAVONE, L. Invisibilidad social de dolenciasprofesionales ligadas

a laexposicion al amianto. In Cuadernos Mujer Salud/2. Trabajo

Y Salud. Mujeresen Riesgo. Publica oda Red de Salud Delas

Mujeres Latino americanas Y Caribe. n. 2, 1997, p. 143-147.

; GIANNASI, F; TÉBAUD-MONY, A. Cidadania e Doenças

Profissionais: o Caso do Amianto. São Paulo: ABRA, 1996.

Amianto e suas consequências sóciofamiliares:

uma abordagem comparativa franco-brasileira. Relatório

Final de Pesquisa, INSERM/CNPq, 1997.

SARTRE, J. P. Esboço de uma Teoria das Emoções.

Lisboa: Editorial Presença, 1972. 
SCHUTZ, A. Schutz A. O mundo da vida. In: WAGNER, H. R. Fenomenologia e as relações sociais (Org.).

Rio de Janeiro: Zahar Editores, 1979.

SCOONES, I. New Ecology and the Social Sciences: What Prospects for a fruitful Engagement? Annual Reviewof Anthropology, v. 28, p. 479- 507, 1999.

SILVA, D. TRENTINI, M. Narrativas como Técnica de Pesquisa em enfermagem. Revista Latino Americana de Enfermagem. 2002. v. 10, n. 3, p. 423-432, maio-jun. 2002.

SOUZA, E. C. A arte de contar e trocar experiências: reflexões teóricometodológicas sobre história de vida em formação. Revista Educação em Questão. Natal, Ed. UFRN, v. 25, n. 11, p. 22-39, jan. /abr. 2006.

THOMPSON, P. B.; DEAN, W. E. Competing Conceptions of Risk. New Hampshire: Franklin. Pierce Law Center, 1996.

TIEZZI, E. Tempos Históricos, Tempos Biológicos - A Terra ou a Morte: Os Problemas da Nova Ecologia. São Paulo: Nobel, 1988.

UNIVERSIDADE ESTADUAL PAULISTA - UNESP - Silicatos Crisotila Disponível em: <http. www.rc.unesp/museudpm/banco/ silicatos/filossilicatos/crosotila.html> Acesso em: 12 de jun. 2008. 



\section{O gerenciamento ambiental das perdas de catalisador usado nas unidades de craqueamento catalítico em refinarias de petróleo: riscos à saúde pública e ao meio ambiente}

Wanderley Ferreira da Silva Júnior

Severino Soares Agra Filho

Fernando Martins Carvalho

\section{Introdução}

A indústria de petróleo e seus derivados têm papel destacado na economia mundial, pois são responsáveis pela produção de fonte energética e insumos para a indústria petroquímica. As unidades de craqueamento das refinarias de petróleo são responsáveis pelo processo de conversão de resíduos das unidades de destilação em produtos com alto valor agregado. (CB\&I, 2009; WIKIMEDIA, 2011) A utilização do catalisador aumenta a produção de gasolina em $27 \%$ e reduz a produção total de óleo combustível de $59 \%$ para $37 \%$, o que representa razoável vantagem econômica e ambiental. (BIRA, 2004; CORRADI, 2008; FCC, 2010) Por outro lado, essas unidades são importantes fontes geradoras de poluentes atmosféricos. (BAPTISTA, 2005)

De acordo com a Environmental Protection Agency (1996), o material particulado descartado pelas chaminés das unidades de craqueamento, em leito fluidizado (catalisador gasto ou de equilíbrio), apesar de passar por um processo de regeneração do coque, este processo não elimina os metais pesados. O descarte de catalisador usado (E-CAT) das unidades de craqueamento é uma preocupação mundial para a saúde ambiental, por conter sílica e estar sujeito à contaminação por 
coque e metais pesados, a exemplo de Níquel, Vanádio e Antimônio. (BAHIA, 1987; MARIANO, 2001; AFONSO; AGUIAR; SILVA, 2003; BAPTISTA, 2005)

De acordo com informações da Fábrica Carioca de Catalisadores - FCC S.A -, os finos de catalisador correspondem às partículas com diâmetro aerodinâmico entre 0 e $40 \mu \mathrm{m}$ e são economicamente desejáveis às unidades de craqueamento catalítico. (RIBEIRO; FLORES, 2008) A fração inalável $\left(\mathrm{PM}_{10}\right)$ pode atingir a mucosa nasal, faringe, laringe e parte superior da traqueia, correspondendo às vias aéreas superiores. Partículas com diâmetro aerodinâmico $\leq 2,5 \mu \mathrm{m}\left(\mathrm{PM}_{2,5}\right)$ atingem a parte inferior da traqueia, brônquios, bronquíolos e alvéolos. A fração respirável, partículas com diâmetro aerodinâmico $\leq 1 \mu \mathrm{m}\left(\mathrm{PM}_{1,0}\right)$, são absorvidas pelo sangue, distribuídas pelo organismo e ao final metabolizadas por meio de biotransformações mediadas por enzimas. (SALGADO, 2003)

Segundo norma do Ministério do Trabalho e Emprego do Brasil, anexo 11 da NR-15, alguns agentes químicos cujos limites de tolerância possam ser ultrapassados em algum momento da jornada de trabalho se enquadram em valores teto, que, de acordo com a NR-03, coloca o trabalhador sob grave e iminente risco, pois a condição ambiental do trabalho pode causar doença profissional com lesão grave à integridade física do trabalhador. Neste caso, a unidade operacional é passível de interdição ou embargo. O cálculo do limite de tolerância para poeira total (respirável e não-respirável) deve utilizar o percentual de sílica livre identificado no material particulado. (BRASIL, 1978)

A segunda maior Refinaria do Brasil em capacidade instalada, caso de estudo desta pesquisa, possui capacidade de 323 mil barris por dia e emprega 1.409 trabalhadores diretos. (PETROBRAS, s.d; FIEB, 2010) A refinaria localiza-se no município de São Francisco do Conde, com população estimada de 30.069 habitantes e Produto Interno Bruto per capita de USD 125.483,88, um dos mais elevados do Brasil. (IBGE, 2007)

O catalisador, quando ainda não utilizado, é composto de $58 \%$ a $60 \%$ de óxido de silício amorfo, de $36 \%$ a $37 \%$ de óxido de alumínio e concentrações de vanádio, níquel e antimônio que variam de 0,0\% a 0,03\%. (CERQUEIRA; RAWET; PINTO, 2000; PETROBRAS, 2002 apud SILVA-JUNIOR et al, 2010, p.45; FCC, 2010) Diante da possibilidade de 
emissões de material particulado conterem essas substâncias, entidades nacionais e internacionais estabelecem limites para as concentrações atmosféricas destas substâncias, em $\mathrm{mg} / \mathrm{m}^{3}$, em ambientes ocupacionais. Informações sobre concentrações atmosféricas de óxido de silício amorfo e de óxido de alumínio não foram disponibilizadas pela refinaria. Entretanto, os valores esperados por Cerqueira (2001) e compostos do catalisador descritos pelo fabricante FCC S.A. e da ACGIH (2010), revelam que as concentrações de metais pesados identificadas na poeira de catalisador exausto desta refinaria, estão muito acima dos padrões nacionais e internacionais.

Com o desenvolvimento da indústria de petróleo, as 15 unidades de craqueamento catalítico em leito fluidizado da Petrobras no Brasil passaram a descartar 40.000 toneladas/ano de catalisador gasto ou de equilíbrio. Três dessas unidades integram o PACRC (Petrobras Advanced Conversor Residue Cracking), reutilizando 15.000 toneladas/ ano de catalisador usado. Estas três unidades foram desenvolvidas e patenteadas pelo Centro de Pesquisa da Petrobras (CENPES) e representam cerca de U\$ 330 milhões em rentabilidade para a empresa. (CORRADI, 2008) No entanto, à medida que aumenta o ciclo de reutilização do catalisador, também se eleva a contaminação do seu resíduo por hidrocarbonetos policíclicos aromáticos, compostos reconhecidamente cancerígenos. (CERQUEIRA; RAWET; PINTO, 2000; CERQUEIRA et al., 2001; CERQUEIRA; BAPTISTA; FUSCO, 2006) O catalisador virgem ou silício aluminato de terras raras é o catalisador que ainda não foi utilizado pelas unidades de craqueamento. Segundo a ficha de informação de segurança disponibilizada pela Fábrica Carioca de Catalisadores, esse composto químico não possui limite de exposição ocupacional estabelecido, além de ser considerado como relativamente seguro para o meio ambiente e seres humanos, apesar de poder causar irritações na pele, olhos e aparelho respiratório. (FCC, 2010) Cabe ressaltar que consultores técnicos da Petrobras em craqueamento catalítico advertem que as refinarias de petróleo têm processado cargas cada vez mais pesadas e com maior severidade (sic). Isto tem implicado em maiores contaminações do catalisador virgem, devido aos maiores teores de contaminantes na carga e maior formação de coque no processo de craqueamento catalítico. (COSTA et al., 2004) 
Uma pesquisa realizada em uma refinaria localizada na cidade de Paulínia, Brasil, identificou uma taxa de emissão de catalisador pelas chaminés em torno de 5 toneladas/dia. Cerca de $50 \%$ desse resíduo era depositado em sua própria área interna e foram encontradas partículas de catalisador em até 7,46 milhas de distância da fonte de emissão do poluente. (ALMEIDA, 2000) Esta perda está relacionada com a eficiência dos ciclones que só retém partículas com diâmetro aerodinâmico $\geq 5 \mu \mathrm{m}$, isto é, antes dos ciclones sofrerem desgastes em seus componentes internos pela elevada abrasividade do catalisador. (SBRT, 2007; CORRADI, 2008)

Este trabalho tem como objetivo avaliar o gerenciamento ambiental das perdas de catalisador da segunda maior refinaria do Brasil, buscando identificar e caracterizar os destinos desse resíduo. Mais especificamente, o trabalho buscou: a) identificar e caracterizar as fontes de geração de emissão e destinação dos resíduos e as perdas de catalisador de craqueamento; b) caracterizar os procedimentos de gestão ambiental adotados pela Refinaria para as perdas de catalisador de craqueamento; e c) avaliar a pertinência e adequação das medidas adotadas quanto aos aspectos normativos e institucionais.

\section{Metodologia}

A metodologia adotada foi a de estudo de caso, usando abordagem quali-qualitativa. A empresa estudada é a segunda maior refinaria do Brasil em capacidade instalada, com duas unidades de craqueamento, a saber: uma Unidade de Craqueamento Catalítico em Leito Fluidizado (UFCC), com capacidade de processamento de até $5.000 \mathrm{~m} 3 /$ dia, e uma Unidade de Craqueamento Catalítico de Resíduo em Leito Fluidizado (URFCC), com capacidade de processamento de até $10.000 \mathrm{~m} 3 /$ dia. (BIRA, 2004)

A refinaria foi certificada em Responsabilidade Social pela Norma SA-8000, fato que implicaria em compromisso de transparência junto às partes interessadas em relação aos seus processos produtivos e possíveis impactos à saúde e meio ambiente das populações sob sua influência. (SAI, [2008])

Os procedimentos metodológicos da pesquisa envolveram revisão da legislação pertinente e dos documentos existentes nos diversos 
órgãos relacionados à questão, incluindo as informações constantes do Inquérito civil público 003.1.13889/2007, formado pelo Ministério Público Estadual - Primeira Promotoria de Justiça do Meio Ambiente de Salvador, para averiguar denúncia de degradação ambiental consistente no lançamento de metais pesados causando contaminação de moluscos e adoecimento de trabalhadores pela RLAM/PETROBRAS. A coleta de dados fundamentou-se em documentos institucionais do período de 1998 a 2010, entre eles, os indicadores sociais e ambientais, internos e externos, publicados no balanço social da empresa. (IBASE, 2010)

A partir dos dados obtidos, buscou-se caracterizar, identificar destinos e estimar as perdas de catalisador de craqueamento da Refinaria e as possíveis populações atingidas: trabalhadores e comunidades.

A Gerência de Saúde, Meio Ambiente e Segurança e a Gerência de Meio Ambiente da Refinaria, foram consultadas sobre o Plano de Gerenciamento de Resíduos Sólidos (PGRS) adotado pela Refinaria, bem como sobre a quantidade de catalisador de craqueamento que é descartado pela mesma e se existiam estudos epidemiológicos em populações sob influência da Refinaria, em especial, sobre a comunidade vizinha de Caípe. (PETROBRAS/ABAST/PG-1T-00020-A, 2006; SAI, [2008])

Considerando que a legislação ambiental no Brasil (2003), determina que as informações existentes no Sistema Nacional do Meio Ambiente (SISNAMA) sejam de domínio público e que os órgãos de controle ambiental sejam responsáveis pela fiscalização e aprovação de atividades e sistemas de produção que possam provocar degradação ambiental, foram solicitadas informações às partes envolvidas sobre as possíveis licenças e autorizações relativas ao manuseio, transporte, armazenamento, incineração e coprocessamento do resíduo de catalisador de craqueamento da Refinaria. (BRASIL, 1989; SALGADO, 2003)

Diante das dificuldades em obter informações da fonte geradora do resíduo dos órgãos de controle ambiental e da empresa receptora de parte do resíduo, foram utilizadas as informações disponíveis no inquérito civil público (003.1.13889/2007), formado pela Primeira Promotoria de Justiça do Meio Ambiente, da Comarca de Salvador, para investigar o possível lançamento de metais pesados e adoecimento de trabalhadores causados pela Refinaria em estudo. Foram realizadas visitas às Promotorias do Meio Ambiente, da Comarca de Salvador e de São Francisco do Conde, com o objetivo de ter acesso aos originais e 
estudar detalhadamente os seus documentos ali contidos, baseado na Lei Federal no 9.099. (BRASIL, 1995)

A pesquisa não envolveu contato direto, nem lidou com dados individuais das populações em estudo, sendo assim, não foi necessário submetê-la ao Comitê de Ética de Pesquisa, mas atendeu as conformidades descritas no Código Internacional de Ética Médica. (BRASIL, 1996; WMA, s.d.) Neste sentido, manteve-se o compromisso ético de que os resultados fossem apresentados à comunidade e enviados às autoridades locais responsáveis pela saúde e meio ambiente da região, para que pudessem incluir as ações adequadas.

\section{Resultados e discussão}

A partir dos procedimentos metodológicos desenvolvidos, foram identificados quatro pontos de perda/descarte de catalisador das unidades de craqueamento da refinaria, conforme indicado na Figura 1, a saber: o descarte de rotina operacional em torno de 5 toneladas de catalisador exausto, após esgotado os ciclos de regeneração e a perda direta para a atmosfera nos seguintes pontos: emissões de finos após ciclones dos regeneradores; perdas fugitivas por vazamentos por equipamentos e conexões, que são coletadas nas varrições das áreas internas da unidade; e as perdas pelas chaminés dos fornos e caldeiras de finos de catalisador contidos no óleo decantado usado como combustível na unidade. Em condições normais de operação, a perda direta de catalisador para o meio ambiente supera 6 toneladas/dia. Esta perda direta de catalisador ocorre em apenas uma das unidades de craqueamento, pela mistura gasosa de poluentes gerados no processo de catalítico com os finos de catalisador, que passaram pelos ciclones e foram arrastados através das chaminés dos regeneradores. Porém, em situações atípicas, estas perdas chegam a 41,72 toneladas/dia. (PETROBRAS/RLAM/OT/ COT, 2007 apud SILVA JÚNIOR, 2010 p. 86 e 87; BRASIL, 2006) 
Figura 1 - Fluxograma de uma unidade de craqueamento com riser. Adaptada da fonte. (KARAN, 2004)

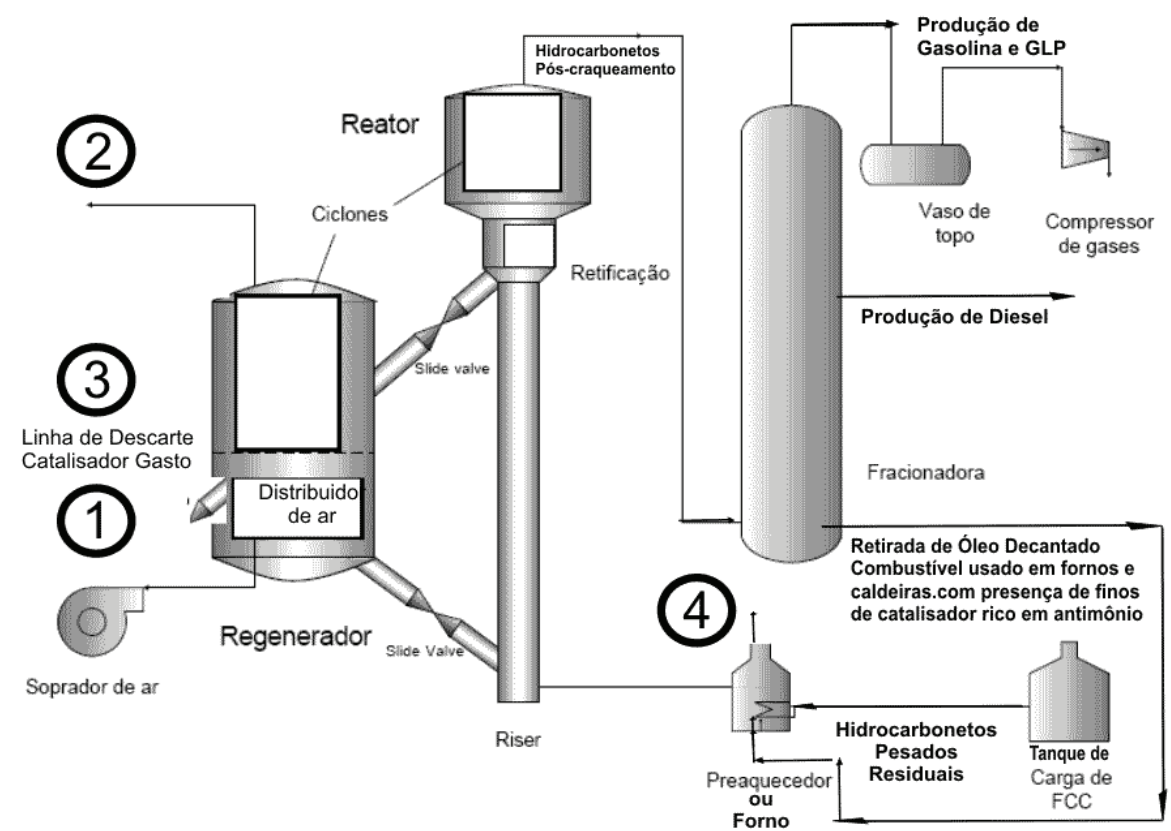

Fonte: (SILVA JUNIOR; AGRA FILHO; CARVALHO, 2010)

As perdas por emissões fugitivas para o meio ambiente, ocorrem por vazamentos do produto nos equipamentos, tubulações e conexões sob pressão, sendo incorporadas ao Resíduo Sólido de Varrição (RSV) da refinaria. Segundo o representante dos trabalhadores na Comissão Interna de Prevenção de Acidentes de Trabalho (CIPA), este resíduo seria removido da área industrial e agregado a outros resíduos por trabalhadores terceirizados. Esta atividade estaria sendo realizada sem o uso correto de equipamento de proteção individual. Uma síntese da origem, quantidade e respectivas destinações finais, bem como as medidas praticadas, estão indicadas no Quadro 1. 
Quadro 1 - Identificação das fontes, destino, quantidades e medidas adotadas para os resíduos/emissões de catalisador de craqueamento.

\begin{tabular}{|c|c|c|c|}
\hline $\begin{array}{c}\text { FONTE DE GERAÇÃO } \\
\text { DO RESÍDUO DE } \\
\text { CATALISADOR }\end{array}$ & DESTINO & QUANTIDADE & MEDIDAS \\
\hline $\begin{array}{l}\text { Ponto } 1 \\
\text { Descarte rotineiro de } \\
\text { catalisador exausto }\end{array}$ & $\begin{array}{l}\text { Cimenteiras locali- } \\
\text { zadas no Estado de } \\
\text { Sergipe }\end{array}$ & $\begin{array}{l}\text { Cerca de } 5 \text { tone- } \\
\text { ladas/ dia }\end{array}$ & $\begin{array}{l}\text { Reutilização na } \\
\text { produção de } \\
\text { cimento (Meio } \\
\text { Ambiente) }\end{array}$ \\
\hline & $\begin{array}{l}\text { Cerca de 50\% na área } \\
\text { interna da RLAM }\end{array}$ & \multirow{5}{*}{$\begin{array}{l}\text { Superior a } 6 \text { to- } \\
\text { neladas por dia }\end{array}$} & \multirow{5}{*}{$\begin{array}{l}\text { Disposição no } \\
\text { meio ambiente } \\
\text { sem tratamento } \\
\text { adequado }\end{array}$} \\
\hline $\begin{array}{l}\text { Perda de finos de catalisa- } \\
\text { dor pelos ciclones }\end{array}$ & $\begin{array}{l}\text { Comunidades em } \\
\text { torno da RLAM }\end{array}$ & & \\
\hline $\begin{array}{l}\text { Ponto } 3 \\
\text { Perda pelas emissões } \\
\text { fugitivas }\end{array}$ & $\begin{array}{l}\text { Área interna da RLAM } \\
\text { (RSV) }\end{array}$ & & \\
\hline \multirow{2}{*}{$\begin{array}{l}\text { Ponto } 4 \\
\text { Perda pelas chaminés }\end{array}$} & $\begin{array}{l}\text { Cerca de } 50 \% \text { na área } \\
\text { interna da RLAM }\end{array}$ & & \\
\hline & $\begin{array}{l}\text { Comunidades em } \\
\text { torno da RLAM }\end{array}$ & & \\
\hline
\end{tabular}

Fonte: (SILVA JÚNIOR; AGRA FILHO; CARVALHO, 2009.)

\section{Medidas de gerenciamento praticadas}

O resíduo de catalisador exausto é transportado por carretas silos, com capacidade média de 21 toneladas de catalisador, por meio de empresas contratadas. Parte desse resíduo vinha sendo transportado para uma fábrica de cimento localizada no Estado de Sergipe, com o objetivo de ser co-processado na produção de cimento. (PETROBRAS, 2007 apud BAHIA, 2007, p. 186) O descarte de catalisador exausto dos silos, equipamentos que integram às unidades de craqueamento da refinaria é uma atividade realizada por 72 trabalhadores, técnicos de operação da empresa.

As operações de transferência, armazenamento, adição, retirada, abertura e fechamento de recipientes com resíduos tóxicos ou, sob qualquer outro modo nocivo ao homem, devem ser executadas por pessoal dotado do Equipamento de Proteção Individual (EPI) adequado, continuamente capacitado por treinamento adequado dado pelo 
empregador. (ASSOCIAÇÃO BRASILEIRA DE NORMAS TÉCNICAS, 1992; BRASIL, 1978) Esses trabalhadores estavam expostos à poeira de catalisador em até 2,95 vezes acima da jornada de trabalho permitida pela legislação. (GAIA, 2005 apud SILVA JÚNIOR, 2010 p. 94-97)

O descarte de catalisador exausto para fábricas de cimento é uma medida de gestão questionável, pois, serve apenas para diluir o resíduo de catalisador de craqueamento no cimento. Esse procedimento representa um perigo ao meio ambiente e à saúde pública, uma vez que, mantêm as características iniciais dos metais e substâncias tóxicas persistentes que contaminam o catalisador. No Estado de São Paulo, por exemplo, as fábricas de cimento não são autorizadas pelo órgão de controle ambiental para receptar este tipo de resíduo. (SANTOS, 2005)

No Brasil, o transporte de resíduos perigosos também depende de autorização emitida por órgãos de controle ambiental. No caso da refinaria, esta documentação também está prevista em sua Licença de Operação (LO), em legislação específica em norma da Associação Brasileira de Normas Técnicas. (ASSOCIAÇÃO BRASILEIRA DE NORMAS TÉCNICAS, 1992; BAHIA, 1994; BAHIA, 2001b; BAHIA, 2002; BRASIL, 2003)

A refinaria integra o Programa Petrobras Advanced Conversor Residue Cracking (PAC ${ }^{\mathrm{RC}}$ ) por reutilizar parte do catalisador da UFCC como insumo na URFCC. No entanto, segundo Cerqueira e colaboradores. (2001; 2006), cada reciclo de utilização do catalisador pelas unidades de craqueamento, aumenta a sua contaminação por substâncias tóxicas.

Cabe ressaltar, que a licença de operação da refinaria prevê medições de material particulado em fontes fixas, a exemplo do catalisador exausto dispersado para o meio ambiente, através das chaminés. (BAHIA, 2006) Medições do catalisador exausto não vinham sendo feitas de modo rotineiro.

Diante das medidas identificadas, evidencia-se que o gerenciamento ambiental se restringe a uma destinação para o catalisador usado (exausto). Dessa forma, constatam-se lacunas importantes no gerenciamento dos finos de catalisador, sobretudo, em relação às emissões para atmosfera sem qualquer procedimento de minimização e o devido monitoramento, indicando a existência de sérios riscos para a saúde dos trabalhadores e para as comunidades circunvizinhas, sob possível exposição. Cabe ressaltar ainda que a medida adotada para a utilização 
em cimenteiras torna-se uma transferência de um potencial risco para as comunidades do entorno da fabrica de cimento.

\section{Riscos para saúde dos trabalhadores}

Com base no padrão de responsabilidade social que era adotado pela Refinaria, foram analisados os riscos ambientais aos quais os trabalhadores estavam expostos. Para isto, utilizou-se o Programa de Prevenção a Riscos Ambientais (PPRA), do ano de 2006. O PPRA adota limites de exposição estabelecidos pela NR-15 do Ministério do Trabalho e Emprego ou, quando na inexistência de limites na legislação nacional, utiliza padrões estabelecidos pela NIOSH ou ACGIH. Não foi identificado no PPRA o método de amostragem para a poeira de catalisador, nem seus limites de tolerância. A empresa contratada para a elaboração do PPRA utilizou como referência orientações da Gerência de Saúde, Meio Ambiente e Segurança (SMS) da empresa, em que orienta avaliações apenas para os agentes químicos definidos por ela mesma. (GAIA, 2005 apud SILVA JÚNIOR, 2010 p.94-97) Foram realizadas discussões com estes trabalhadores e os representantes dos trabalhadores, na Comissão Interna de Prevenção de Acidentes de Trabalho (CIPA) e no comitê de Responsabilidade Social pela Norma SA-8000. (BRASIL, 1978; PETROBRAS/ABAST/PG-1T-00020-A, 2006; SAI, 2008)

De acordo com a Portaria $N^{\circ} 3.214$ do Ministério do Trabalho e Emprego, o PPRA consiste em um relatório no qual a empresa deve identificar os grupos homogêneos de exposição (GHE) definidos a partir das atividades dos trabalhadores e seus respectivos postos de trabalho. (BRASIL, 1978) Em cada grupo, os riscos ambientais devem ser identificados, mapeados e registrados em laudo técnico de condições ambientais do trabalho (LTCAT). No caso em estudo, o tempo de jornada de trabalho utilizado para cálculos dos limites de exposição foi de 8 horas. (NIOSH, 2010; ACGIH, 2010)

\section{Riscos para as comunidades circunvizinhas sob possível exposição}

As condições meteorológicas possibilitam estabelecer uma forma de ligação entre a fonte poluidora e o receptor, tendo como referência 
o transporte e a dispersão dos poluentes. (TORRES; MARTINS, 2005) No Nordeste do Brasil e especificamente na Bahia, a direção predominante do vento é de Leste, com flutuações para Sudeste e Nordeste. (SILVA et al., 2002)

O material particulado é um dos poluentes mais importantes da região sob influência da refinaria e provavelmente atinge uma população que vem adoecendo devido à poluição por produtos tóxicos, o que tem chamado à atenção do poder público. (NEVES; MENEZES; ASSUNÇÃO, 2001 NATIVOS, 2010) Com base no estudo de Almeida (2000), estabeleceu-se um raio de ação de 10,8 milhas de distância da fonte e estimou-se uma população de 56.305 habitantes que residem nas cidades de São Francisco do Conde, Madre de Deus e no Distrito de Saubara. (IBGE, 2007)

Dentro deste raio de ação está o distrito de Caípe, localizado a poucos metros de distância da refinaria e na direção dos ventos que provém da empresa, com 11.203 moradores. (IBGE, 2007) A atmosfera de Caípe apresenta níveis significativos de Hidrocarbonetos Policíclicos Aromáticos e de Material Particulado (PM) de provável origem petrogênica. (SILVA JÚNIOR et al., 2009; PPGSAT, 2010)

\section{A precarização do trabalho}

Os dados coletados permitiram identificar a terceirização dos serviços de varrição e limpeza e certa incumbência de responsabilidades às empresas contratadas, responsáveis pelo processo de coleta, armazenamento, transporte e destinação final do catalisador. É importante ressaltar que essas terceirizadas lidam com um resíduo perigoso, Classe I, segundo norma técnica da Associação Brasileira de Normas Técnicas (2004). O elevado grau de precarização influencia no aceite de qualquer labor, submetendo os trabalhadores a riscos operacionais mesmo sob a supervisão da gestão, mais preocupada com a produtividade da organização. (DEJOURS, 1996) Esse quadro proporciona o aparecimento de fragilidades na relação entre os trabalhadores da empresa, decorrentes do processo competitivo que agride a saúde física e mental dos trabalhadores. (GODINHO, 2007; VAZQUEZ, 2009) Quando a organização reduz o seu núcleo estável abaixo de $25 \%$, ela atinge o grau máximo de precarização pelo aumento da 'flexibilização' dos contratos de trabalho. 
(DRUCK et al., 2007) O balanço social da empresa identificou um processo de precarização que atinge cerca de $80 \%$ de sua força de trabalho. (PETROBRAS, 2008 apud IBASE, 2010)

\section{Política ambiental da organização}

A análise do Balanço Social da empresa também indica uma atuação reativa, possivelmente um dos fatores que tem elevado seus custos operacionais. De acordo com os relatórios de exercício da empresa do período entre 2003 e 2009, que são enviados anualmente para a Comissão de Valores Mobiliários (CVM), o custo médio com paradas não programadas subiu de U\$ $\$ 93,2$ milhões nos últimos seis anos para U\$\$ 418 milhões no ano de 2009, o que representa um aumento de $448 \%$. (PETROBRAS, 2010) A empresa integra o índice Down Jones de Sustentabilidade Empresarial (DJSI), fortalecendo suas ações no mercado internacional. (DJSI, 2010) Segundo o balanço social da organização, as metas anuais para minimização de resíduos visando o consumo, em geral, na produção/operação e o aumento na eficácia da reutilização de recursos naturais, estão sendo realizadas em uma faixa de 75 a $100 \%$. No entanto, os resultados divulgados pela empresa revelam que, ao final de 2008 , foram investidos apenas $0,89 \%$ do rendimento líquido da empresa na área ambiental e 0,05\% em saúde e segurança. (PETROBRAS, 2008 apud IBASE, 2010) Esses dados apoiam a hipótese de que a empresa tem atuado dentro de uma óptica reativa, causando desgastes desnecessários à sua imagem, a exemplo da recente saída do índice Bovespa de Responsabilidade Social por não atingir metas ambientais no Brasil. (BOVESPA, 2010) Segundo a RepRisk (s.d.), empresa responsável pela análise dos riscos de operação das empresas do setor de Petróleo, a empresa utilizada como caso de estudo desta pesquisa está posicionada entre as 10 empresas do setor com grau mais elevado de risco de operação.

O local de armazenamento temporário do resíduo de catalisador removido por varrição possui isolamento, com sinalização de segurança que identificava áreas definidas da instalação e os riscos de acesso ao local, dificultando o acesso de pessoas estranhas, conforme determina norma técnica da Associação Brasileira de Normas Técnicas (1992). No entanto, esse local é uma Área de Proteção Ambiental (APA), para 
a qual a legislação prevê fiscalizações, disciplina sobre o uso e ocupação do solo, entre outros condicionantes. (BAHIA, 1999) Esta APA é uma área sensível, por estar próxima a um mangue e 'habitat' de espécies protegidas. Entretanto, no passado, já recebeu recarga de aquíferos de forma direta, pelas chuvas, e, indireta, alimentada por uma bomba instalada sobre uma lagoa adjacente ao local. A Figura 2 mostra o local de armazenamento temporário do catalisador removido da área industrial por varrição, feita por trabalhadores terceirizados, no ano de 2007. O processo de terceirização neste caso, além de expor desnecessariamente o trabalhador, transfere a responsabilidade da empresa às contratadas para com a destinação final do resíduo de catalisador de craqueamento. Entretanto, o Decreto $\mathrm{n}^{\circ} 7.967$ delega esta responsabilidade ao gerador do resíduo. (BAHIA, 2001a)

Figura 2 - Catalisador usado removido por varrição da área industrial e armazenado em local temporário da refinaria.

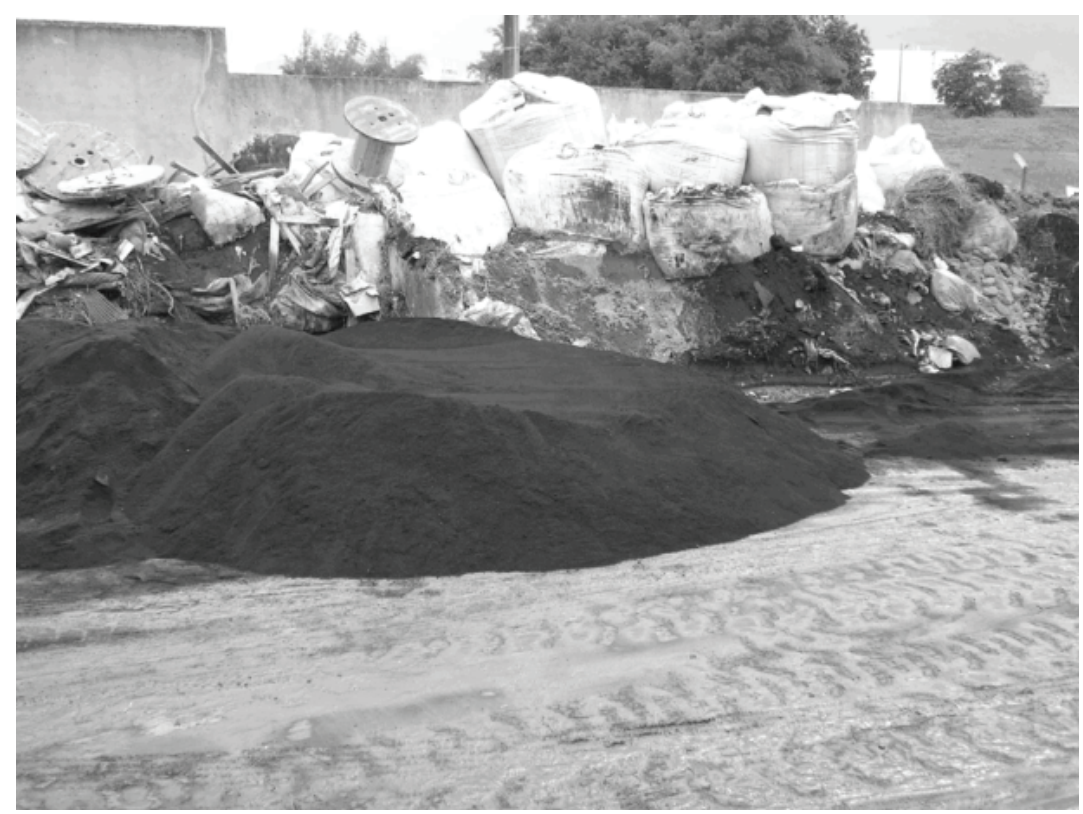

Fonte: PETROBRAS, 2007, apud BAHIA, 2007, p. 57 e 58.

Grande parte do arcabouço jurídico voltado para as questões ambientais e sociais é fruto da mobilização da sociedade civil, iniciada ao final da década de 80, visando sair da óptica corretiva para a preventiva, quando o conceito de Responsabilidade Social começou a se formar no Brasil. A competição pela liderança, visando à geração mínima de resíduo como prioridade de gestão, aumenta os ganhos de sustentabilidade dos negócios. Resultados positivos na marca da organização refletem 
diretamente na imagem da empresa, consequentemente elevando o lucro nos seus investimentos.

Deve ser ressaltada a falta de cooperação dos técnicos da empresa e dos órgãos estaduais de meio ambiente da Bahia e de Sergipe, responsáveis pela fiscalização, que dificultaram a determinação da quantidade e o destino do resíduo de catalisador removido por varrição da área industrial da refinaria.

Como resultado da divulgação da presente pesquisa, a empresa introduziu no processo produtivo uma nova metodologia para injeção de antimônio, reduzindo o contato dos trabalhadores com este metal pesado e minimizando a toxicidade desse resíduo. Em vista dessa prática, torna-se recomendável a revisão da gestão ambiental para este resíduo tóxico de forma multidisciplinar, com a participação dos demais atores sociais envolvidos: órgãos de controle ambiental; poder público; populações sob influência e instituições de pesquisas. Recomenda-se também o cumprimento imediato dos requerimentos legais e normativos cabíveis.

\section{Considerações finais}

As unidades de craqueamento catalítico das refinarias se constituem em fontes relevantes de material particulado e, sobretudo, pelo risco que representa a composição dos finos de particulados contendo metais tóxicos para a saúde e o ambiente em geral. Os resultados da pesquisa indicam que existe um potencial de descarte e perda para o meio ambiente de cerca de 11 toneladas diárias de finos de catalisador exausto, sendo que somente em torno de 5 toneladas possui alguma medida sistemática adotada. As perdas para a atmosfera, que compreendem mais da metade da carga total, não está devidamente gerenciadas e suas consequências nas comunidades vizinhas e no ambiente de trabalho, são desconhecidas ou sem a devida divulgação pela empresa e pelas autoridades ambientais.

Essas constatações sugerem que as medidas de gerenciamento ambiental adotadas na refinaria analisada estão insuficientes para equacionar e minimizar os riscos ambientais que ocasionam e, portanto, aquém das expectativas de uma empresa que se diz publicamente comprometida com a responsabilidade socioambiental. 


\section{Referências}

ASSOCIAÇÃO BRASILEIRA DE NORMAS TÉCNICAS.

NBR 12235: armazenamento de resíduos sólidos perigosos.

Rio de Janeiro, 1992. Disponível em: <http://www.abnt.

org.br/default.asp> Acesso em: 26 mar. 2011.

. NBR 10004: resíduos sólidos - classificação. Rio

de Janeiro, 2004. Disponível em: < http://www.abnt.org. br/default.asp> Acesso em: 26 de mar. 2011.

ACGIH - American Conference of Industrial Hygienists. Cincinnati, Ohio 45240. USA: 2010. Disponível em: <http://www.acgih. org/about/history.htm> Acesso em: 21 mar. 2010.

AFONSO, J. C.; AGUIAR, R. M.; SILVA, G. C. O problema do descarte de catalisadores industriais de hidrotratamento. Boletim técnico.

Petrobras, Rio de Janeiro, v. 46, n. 3/4, p. 325 - 333, jul. /dez. , 2003.

Disponível em: <http://pessoal. utfpr. edu. br/ marlenesoares/ arquivos/recuper_niquel2. pdf > Acesso em: 26 mar. 2011.

ALMEIDA, E. S. Caracterização parcial do material particulado atmosférico na região de Paulínia usando o modelo de receptores. 2000. 76f. Dissertação (Mestrado em Química) Instituto de Química, Universidade de Campinas, 2000. Disponível em: <http://biq. iqm. unicamp. br/arquivos/teses/vtls000219849. pdf> Acesso em: 20 mar. 2010.

BAHIA. Secretaria do Meio Ambiente. Resolução CEPRAM n. 13. Aprova a modificação da Resolução $\mathrm{n}^{\circ} 313$, de 30.05 .84 e seus anexos, que dispõe sobre o controle de resíduos sólidos perigosos no estado da Bahia. Diário Oficial do Estado da Bahia, 1, 2 ago. 1987, Bahia. Brasil: 1987. Disponível em: <http://www.meioambiente.ba.gov.br/legislacao/resolucao_ cepram/Resolucao_13_29_julho_1987.pdf> Acesso em: 26 mar. 2011.

. Secretaria do Meio Ambiente. Resolução CEPRAM n. 1. 039. Aprova a Norma Administrativa NA001/94, que dispõe sobre o Controle do Transporte Rodoviário de Produtos e Resíduos Perigosos no Estado da Bahia. Diário Oficial do Estado da Bahia, 31 mar. 1995, Bahia. Disponível em: <http://www.sema.ba.gov.br/legislacao/resolucao_cepram/ Resolucao_1039_06_dezembro_1994.pdf> Acesso em: 26 mar. 2011.

. DECRETO no 7. 595 de 05 de junho de 1999. Cria a área de proteção ambiental - APA da Baía de Todos os Santos e dá outras providências. Diário Oficial do Estado da Bahia, 09 jun. 1999, Bahia. Brasil: 1999. Disponível em: < http://www.semarh.ba.gov.br/ DecretosUnidadesdeConservacao/Dec7595.pdf> Acesso em: 26 mar. 2011. 
BAHIA. DECRETO $\mathrm{n}^{\circ} 7.967$ de 05 de junho de 2001. Aprova o Regulamento da lei $\mathrm{n}^{\circ}$ 7. 799, de 07 de fevereiro e 2001, que institui a política estadual de administração de recursos ambientais e dá outras providências. Publicado no Diário Oficial do Estado, Bahia, 06 jun. 2001a. Disponível em: <http:// www.semarh.ba.gov.br/Legislacao/Decretos\%20Estaduais/Meio\%20 Ambiente-Biodiversidade/Dec7967.pdf> Acesso em: 26 mar. 2011.

. CRA. Centro de Recursos Ambientais. PORTARIA CRA ${ }^{\circ}$ 1. 225. Aprova a renovação da licença de operação da RLAM. Salvador. Bahia. Brasil: 2001b. Impresso.

. CRA. Centro de Recursos Ambientais. Termo de referência com instruções para elaboração do plano de gerenciamento de resíduos sólidos - PGRS. Bahia. Brasil, 2002. Disponível em: < http://www.derba. ba.gov.br/download/meioambiente/4.pdf> Acesso em: 26 mar. 2011.

. CRA. PORTARIA CRA $\mathrm{n}^{\circ}$ 6. 672. Aprova a renovação da licença operação da RLAM. Salvador. Bahia. Brasil, 2006. Impresso.

. Ministério Público Estadual. Inquérito civil público 003. 1. 13889/2007 pelo Ministério Público Estadual - Primeira Promotoria de Justiça do Meio Ambiente de Salvador, para averiguar denúncia de degradação ambiental consistente no lançamento de metais pesados causando contaminação de moluscos e adoecimento de trabalhadores pela RLAM/PETROBRAS. Salvador - Bahia. 2007.

BAPTISTA, A. Avaliação do potencial de recuperação de metais de catalisadores equilibrados através da técnica de remediação eletrocinética. 2005. 152f. Dissertação (Mestrado em Engenharia de Materiais e Processos) Universidade Federal do Paraná. Curitiba, 2005. Disponível em: <http://dspace. c3sl. ufpr. br/dspace / bitstream/1884/2583 /1/DISSERTACAO\%20VERSAO\%20FINAL\%20 ADALBERTO \%20BAPTISTA. pdf . >Acesso em: 26 mar. 2011.

BIRA, M. Os desafios tecnológicos do refino de petróleo no Brasil - perspectivas futuras. UNIFEI, ago. 2004. Disponível em: <http://www.prh16.unifei.edu.br/downloads/palestra petrobras2004.ppt> Acesso em: 09 mar. 2010.

BOVESPA. Bolsa de Valores do Estado de São Paulo. Disponível em: <http://www.bmfbovespa.com.br/indices/ResumoIndice. aspx ? Indice $=I S E \& I d i o m a=p t-B R>$ Acesso em: 09 mar. 2010.

BRASIL. Ministério do Trabalho e Emprego. Norma Regulamentadora n $^{\circ} 15$ - Atividades e Operações Insalubres, Portaria no 3. 214, de 8 jun. 1978. . Resolução CONAMA nº 001, de 23 de janeiro de 1986. Estabelece as definições, as responsabilidades, os critérios básicos e as diretrizes gerais 
para uso e implementação da avaliação de impacto ambiental como um dos instrumentos da política nacional do meio ambiente. Publicação - Diário Oficial da União, Brasília, 17 fev. 1986. Disponível em: < http://www.mma. gov.br/port/conama/res/res86/res0186.html> Acesso em: 26 mar. 2011.

BRASIL. Lei Federal n ${ }^{\circ}$ 7. 735. Dispõe sobre a extinção de órgão e de entidade autárquica, cria o Instituto Brasileiro do Meio Ambiente e dos Recursos Naturais Renováveis (IBAMA) e dá outras providências. Publicado no Diário Oficial da União, Brasília, 23 fev. 1989. Disponível em: < http://www. planalto.gov.br/ccivil_03/Leis/L7735.htm> Acesso em: 26 mar. de 2011.

. Lei no 9. 099. Dispõe sobre os juizados especiais cíveis e criminais e dá outras providências. Publicada no Diário Oficial da União, 26 set. 1995. Brasil: 1995. Disponível em: <http://www. planalto.gov.br/ccivil_03/Leis/L9099.htm> Acesso em: 26 mar. 2011.

. Resolução no 196 Conselho Nacional de Saúde - CNS. Aprova as diretrizes e normas regulamentadoras de pesquisas envolvendo seres humanos. Diário Oficial da União, Brasília, n. 201, 16 out. 1996. Disponível em: <http://www.ufrgs.br/ bioetica/res19696.htm> Acesso em: 26 mar. 2011.

. Lei Federal no 9. 605. Dispõe sobre as sanções penais e administrativas derivadas de condutas e atividades lesivas ao meio ambiente, e dá outras providências. Diário Oficial da União. 13 fev. 1998. Disponível em: < http://www. planalto. gov. br/ ccivil_03/Leis/L9605. htm> Acesso em: 26 mar. 2011.

. Presidência da República. Casa Civil. Subchefia para Assuntos Jurídicos Lei $\mathrm{N}^{\circ} 10.650$, de 16 de abril de 2003. Dispõe sobre o acesso público aos dados e informações existentes nos órgãos e entidades integrantes do SISNAMA. Diário Oficial da União, 17 abr. 2003. Disponível em: < http://www. planalto. gov. br/ ccivil_03 /Leis/2003/L10. 650. htm> Acesso em: 26 mar. 2011.

BRASIL. Resolução CONAMA no 382, de 26 de dezembro de 2006. Estabelece os limites máximos de emissão de poluentes atmosféricos para fontes fixas. Diário Oficial da União. n. 1, 02 jan. 2007. Disponível em: <http://www. mma. gov. br/port/ conama/ res/res06/res38206. pdf> Acesso em: 26 mar. 2011.

CASTRO, H. A.; GOUVEIA, N.; ESCAMILIA-CEJUDO, J. A. Questões metodológicas para a investigação dos efeitos da poluição do ar na saúde. Revista Brasileira de Epidemiologia. v. 6, n. 2, 2003. Disponível em: <http://www. scielosp. org/ pdf/rbepid/v6n2/07. pdf> Acesso em: 26 mar. 2011. 
CB\&I - CHICAGO BRIDGE \& IRON COMPANY. Fluid Catalytic Cracking. Hague. Netherlands 2009. Disponível em: < http://www. cbi. com/ images/uploads/tech_sheets/FCC. pdf > Acesso em: 26 mar. 2011.

CCOHS. Canadian Centre for Occupational Health \& Safety. Canadá, 2009. Disponível em: <http://www. ccohs. ca/oshanswers/ chemicals/convert. html> Acesso em: 09 mar. 2010.

CERQUEIRA, H. S. et al. Avaliação da efetividade do antimônio para passivação de níquel nas refinarias da PETROBRAS. Boletim Técnico PETROBRAS, Rio de Janeiro, v. 44, n. 1/4, p. 29-36, jan. /dez. 2001.

; BAPTISTA, C. M. L. A.; FUSCO, J. M. O que acontece no vaso "stripper" de uma UFCC? FCC em Revista. n. 47, Ano VIII, abr. /maio/ jun. 2006. Disponível em: < http://www. fccsa. com. br/templates/ fccsa2010/Publicacao/ Revistas. asp?cod_Canal $=25 \&$ cod_pai $=360 \&$ cod grupo $=0 \&$ cod_publicacao $=349 \&$ cod_idioma $=0>$ Acesso em: 08 mar. 2010 .

; RAWET, R.; PINTO, J. C. La Influencia de los Errores Experimentales Durante La Evaluación Laboratorial de Catalizadores de FCC . FCC en Revista, v. 23, n. 3 p. 15. , 2000

CORRADI, S. R. Ecoeficiência na indústria de petróleo: o estudo do craqueamento catalítico na PETROBRAS. 2008. Dissertação (Mestrado em Gestão Empresarial) Escola Brasileira de Administração Pública e Empresas - Fundação Getúlio Vargas, 2008. Disponível em: <http://virtualbib. fgv. br/dspace/bitstream/ handle/10438/3758/ scorradi. pdf? sequence =1> Acesso em: 26 mar. 2011.

COSTA, A. F. et. al. Preparo de catalisadores de FCC modificados com siloxanos para redução do índice de atrito e aumento da acessibilidade. Boletim Técnico Petrobras, Rio de Janeiro, v. 47, n. 2/4, p. 255 - 265, abr. /dez. 2004.

DEJOURS, C. Introduction: psychodynamique du travail. Revue Internationale de Psychosociologie, n. 5, p. 5-12, 1996.

DRUCK, G.; FRANCO, T. (orgs. ). A perda da razão social do trabalho: terceirização e precarização. São Paulo: Boitempo, 2007.

DJSI. Dow Jones. Sustainability Indexes. Zurich. Switzerland, 2010. Disponível em: < http://www. sustainabilityindex. com/> Acesso em: 09 mar. 2010.

ENVIRONMENTAL PROTECTION AGENCY. Hazardous Waste Minimization and Management Division Office of Solid Wastw. Waste Minimization for Selected Residuals in the Petroleum 
Refining Industry. Washington. D. C. 1996. Disponível em: <http:// www.epa.gov/nscep/index.html> Acesso em: 26 mar. 2011.

FCC S. A. Fábrica Carioca de Catalisadores. Aumento na produção de catalisadores no País. Rio de Janeiro, 2005. Disponível em: $<$ http://www. fccsa.com.br/templates/fccsa/noticia/noticia.asp?cod_ canal $=1 \&$ cod_noticia $=6 \&$ cod_idioma $=0>$ Acesso em: 09 mar 2010.

FCC S. A. Fábrica Carioca de Catalisadores. Ficha de Informação de Segurança de Catalisador. Rio de Janeiro, 2010. Impresso

FIEB. Federação das Indústrias do Estado da Bahia - Cadastro do guia industrial do estado da Bahia. Brasil: 2010. Disponível em: < http://www. fieb. org. br/guia/dados_industria. asp? industria $=1778>$ Acesso em: 26 mar. 2011.

GODINHO, L. F. R. Laços frágeis, labor trincado: Interação, discriminações e conflitos entre trabalhadores da Refinaria Landulpho Alves - 1990-2005. Revista Estudos do Trabalho, Marilia, UNESP, Ano I, n. 1, 2007. Disponível em: < http://www. estudosdotrabalho. org> Acesso em: 27 mar. 2011.

IBASE. Instituto Brasileiro de Análises Sociais e Econômicas.

Relativo aos balanços sociais do modelo IBASE publicados no portal Balanço Social. 2010. Disponível em: <http:// www. balancosocial. org.br/> Acesso em: 09 mar. 2010.

IBGE. Instituto Brasileiro de Análises Sociais e Econômicas. Produto interno bruto dos municípios 2002 - 2005, Rio de Janeiro, 2007. Disponível em <http://www. ibge. gov. br>/ Acesso em: 21 mar. 2007

MARIANO, J. B. Impactos ambientais do refino de petróleo. COPPE/UFRJ, M. Sc. , Planejamento Energético. Rio de Janeiro, 2001. Disponível em: <http://www. ppe. ufrj. br/ppe/ production/tesis/jbmariano. pdf> Acesso em: 26 mar. 2011.

NATIVOS da Ilha de Maré adoecem devido à poluição por produtos tóxicos.

A Tarde on line. Salvador - BA, 2010. Disponível em: < http://www. atarde. com. br/cidades/noticia. jsf?id=1413796> Acesso em: 9 mar. 2010.

NEVES, N. M. S.; MENEZES, P. S. F.; ASSUNÇÃO, R. S. Rede de monitoramento do ar na área de influência da Refinaria Landulpho Alves - RLAM. Congresso Brasileiro de Engenharia Sanitária e Ambiental, 21ㅇ, 2001. Disponível em < http://www. bvsde. paho. org/bvsaidis/brasil21/vi-110. pdf> Acesso em: 27 mar. 2011

NIOSH - The National Institute for Occupational Safety and Health. GA 30333, Atlanta, USA. 2010. 
PETROBRAS/ABAST/PG-1T-00020-A. Cópia não controlada do padrão de responsabilidade social no abastecimento da PETROBRAS - Brasil, 2006.

PETROBRAS. Informações obtidas do portal eletrônico da PETROBRAS, s. d. . Disponível em: <www. petrobras. com. br> Acesso em: 21 mar. 2010.

PPGSAT. Programa de Pós-graduação em Saúde, Ambiente e Trabalho pela Faculdade de Medicina da UFBA. Mestrandos produzem vídeo sobre poluição atmosférica em São Francisco do Conde. 15 ago. 2010. Disponível em: < http://www. sat. ufba. br/site/ main. asp?view $=$ noticia\&id $=388>$ Acesso em: 2 mar. 2011

REPRISK. Reputational Risk Radar. Zurich, Switzerland. Disponível em: $<$ http://www. reprisk. com/downloads/innews/100917\%20Petrobras\%20 esta\%20entre\%20empresas\%20mais\%20controversas\%20do\%20setor\%20 diz\%20consultoria\%20europeia. pdf> Acesso em: 19 out. 2010.

RIBEIRO, F. C.; FLORES, M. G. Fluidização - conceitos e troubleshooting. FCC en Revista, ANO XV , n. 53,. Brasil: 2008.

SAI, Social Accountability International. Norma de responsabilidade social SA-8000. - [2008] Disponível em: <http://www. sa-intl. org/_ data/n_0001/resources/live/ 2008StdEnglish Final. pdf >EUA: 2008.

SALGADO, P. E. T. Informações gerais e ecotoxicológicas de material particulado. Salvador: Centro de Recursos Ambientais CRA, 2003. 156 p. (Cadernos de Referência Ambiental, v. 14).

SANTOS, E. L. Estudo sobre a utilização de resíduos industriais não-inertes e perigosos na produção de cimento. São Paulo, 2005. Disponível em: <http://www. ecelambiental. com. br/artigos/UTILIZACAO_RESIDUOS_PERIGOSOS FORMULACAO_CIMENTO. pdf> Acesso em: 09 mar. 2010.

SBRT. Serviço Brasileiro de Respostas Técnicas. Ciclones e lavadores de gases. - Disponível em < http:// www. sbrt. ibict. br> Acesso em: 12 mar. 2007.

SILVA, B. B. et al. Potencial eólico na direção predominante do vento no nordeste brasileiro. Revista Brasileira Engenheira Agrícola Ambiental [online]. v. 6, n. 3, p. 431-439. 2002. Disponível em: < http://www. scielo. br/pdf/rbeaa/v6n3/v6n3a09. pdf> Acesso em: 13 mar. 2012. SILVA JÚNIOR, W. F; AGRA FILHO; CARVALHO. Avaliação da poluição atmosférica por HPAS em material particulado - MP10, no Distrito de CAÍPE, Município de São Francisco do Conde - Bahia. Apresentado em formato pôster e publicado em edição suplementar 
da Revista Ciência e Saúde Coletiva (ISSN1413-8123) - Anais do IX Congresso Brasileiro de Saúde Coletiva. Recife - Brasil: 2009.

SILVA JÚNIOR, W. F. Avaliação da gestão ambiental de uma Refinaria de Petróleo para as perdas de catalisador de craqueamento.

2010. 106f. Dissertação (Mestrado em Saúde, Ambiente e Trabalho)

Faculdade de Medicina da Bahia, Universidade Federal da Bahia, 2010. Disponível em: < http://www. sat. ufba. br/site/db / dissertacoes/1272010185144. pdf> Acesso em: 03 out. 2010.

TORRES, F. T. P.; MARTINS, L. A. Fatores que influenciam na concentração do material particulado inalável na cidade de Juiz de Fora (MG). Caminhos de Geografia, v. 4, n. 16, p. 23-39, out. 2005. Disponível em < http:// www. ig. ufu. br/revista/caminhos. html> Acesso em: 05 out. 2011.

VAZQUEZ, P. S. Análise da presença de violência/assédio moral na organização e gestão do trabalho na PETROBRAS. 2009.

Disponível em <www. aepetro. org. br> Acesso em: 15 mar. 2011.

WMA - World Medical Association. International Code of

Medical Ethics. Disponível em: <http://www. wma. net/ en/30publications/10policies/c8/index. html> Acesso 03 out. 2010.

WIKIMEDIA FOUNDATION, Inc. Fluid Catalytic Cracking. 2011. Disponível em: < http://en. wikipedia. org/wiki/

Fluid_catalytic_cracking > Acesso em: 26 mar. 2011. 



\section{PARTE III}

Novos desafios do campo da saúde, ambiente e trabalho: temas emergentes e abordagens metodológicas 
A amplitude e complexidade das problemáticas emergentes da triangulação saúde, ambiente e trabalho, constantemente atualizadas, refletem múltiplas interações e interrelações entre fenômenos sociais, biológicos, psicológicos, em diferentes contextos econômicos e culturais. Esta dinâmica abre novas frentes de estudo, delineia novos objetos e requer dos pesquisadores a progressiva aproximação de diferentes abordagens teórico-metodológicas.

A necessidade de compreender o comportamento humano na relação com a promoção da saúde, a prevenção de doenças e a experiência do adoecimento crônico tem suscitado investigações sobre possíveis mediadores do processo de tomada de decisão do sujeito na interação com o serviço de saúde e suas influências na relação com os diferentes sistemas sociais, principalmente a família, a comunidade e o trabalho.

Nesta seção são apresentados três trabalhos empíricos que focalizam temas correlatos sobre prevenção, promoção da saúde e contexto familiar e um capítulo que explora o percurso metodológico em um estudo de abordagem etnográfica. Em "Comportamento de industriários quanto à prevenção do câncer da próstata”, os autores exploram as razões para a pouca realização de exames de próstata entre industriários e identificam que, apesar do bom conhecimento sobre a doença, a adesão a essa prática é pequena, embora reconheçam que o aumento da percepção de susceptibilidade, severidade, autoficácia e benefício contribuem com a prevenção. De maneira semelhante, em "Conhecimentos e atitudes sobre câncer de mama e de colo de útero entre trabalhadoras de saúde", os autores discutem os principais motivos que levaram essas profissionais a realizarem a mamografia e o exame de Papanicolaou, bem como as principais barreiras, dentre elas a falta de tempo e o medo de descobrirem a doença. Estes estudos em categorias distintas contribuem para a valorização das ações de promoção à saúde em ambientes de trabalho. Em "O trabalhador-doente e sua família: interações e repercussões sobre o absenteísmo e o processo de retorno ao trabalho", os autores discutem as mudanças na estrutura e função da família em consequência da presença do trabalhador-doente na residência; as mudanças no seu papel social e as interações com o serviço de saúde durante o processo de adoecimento e reabilitação. A literatura revisada atualiza as principais tendências dessa discussão e 
o reconhecimento da importância das diferentes dinâmicas familiares como facilitador ou obstáculo para o retorno ao trabalho.

A presença crescente de abordagens compreensivas neste campo de estudo tem resultado na aproximação com as ciências sociais, marcadamente com a sociologia da saúde e com a antropologia interpretativa, com ênfase, em alguns estudos, na tradição etnometodológica. Em "O percurso etnometodológico de uma pesquisa em Santo Amaro-BA”, os autores discutem a produção do conhecimento e sua interface (ou falta de) com a comunidade afetada. Esta problematização parte do questionamento sobre a distância ou mesmo a dicotomia entre produção do conhecimento e a sua apropriação pelos sujeitos de pesquisa, tomando o caso da contaminação por chumbo em Santo Amaro-Ba. Os sujeitos de estudo - marisqueiras, pescadores e professoras ativos ou aposentados das comunidades de Caeira e São Braz - são convidados a falar. A primeira autora associa sua experiência como jornalista à imersão em campo, produzindo, neste capítulo, um relato ensaístico do percurso metodológico em uma perspectiva autoetnográfica. Toma, portanto, a sua subjetividade, alimentada pela experiência em campo e reflexão teórica, como fundamentos para a interpretação sobre a avaliação e comunicação do risco às comunidades atingidas e a necessidade de novas metodologias para a tomada de decisão sobre riscos ambientais. 



\section{Conhecimento e atitudes sobre câncer da mama e do colo do útero entre trabalhadoras da área de saúde}

Gilberto Andrade Tavares

Marco Antônio Vasconcelos Rêgo

\section{Introdução}

O câncer da mama é um importante problema de saúde pública em todo o mundo. As repercussões dessa doença não se limitam ao corpo da mulher, e são também, de ordem econômica, psíquica e social. Trata-se da principal doença neoplásica do sexo feminino, tanto em países desenvolvidos quanto naqueles em desenvolvimento, com uma maior tendência de aumento das taxas de incidência nos países menos desenvolvidos. (AGARWAL et al., 2007) Por exemplo, mais de 200.000 novos casos de câncer invasivo da mama e 55.000 casos de câncer in situ são diagnosticados anualmente nos Estados Unidos da América (EUA). (BRODY; TICKNER; RUDEL, 2005) No Brasil, cerca de 53 mil casos eram esperados em 2012, o que significa quase $30 \%$ de todos os tumores do sexo feminino. Dentre esses casos, estima-se que 2.100 ocorram no estado da Bahia. (BRASIL, 2012)

A difusão da mamografia como principal forma de prevenção deste câncer nos EUA aumentou nos últimos 25 anos. Estima-se que $63 \%$ das mulheres entre 50 a 69 anos realizam mamografia entre nove a 20 meses, com média de 14 meses. (KERLIKOWSKE, 2009) Neste mesmo país, apesar do aumento na frequência da realização dos exames de detecção precoce do câncer da mama nas últimas décadas, as mulheres de baixa renda e as que compõem grupos étnicos minoritários têm sido menos rastreadas para câncer da mama que o restante da população. As principais barreiras para a realização da mamografia são: a falta de 
um médico de referência, custo, falta de percepção de risco e medo de exposição à radiação. (THOMPSON; MONTAÑO; MAHLOCH, 1997)

Outras questões apresentadas como barreiras aos métodos de prevenção são o pouco conhecimento sobre a doença, a cultura do indivíduo, o nível educacional e o medo do adoecimento e do morrer. Em um estudo entre mulheres hispânicas residentes nos EUA, em relação à percepção e conhecimento, descreveram-se a relação entre o câncer no geral e a morte, medo e/ou doença mortal. Quando perguntadas sobre as fontes de informação sobre o câncer, metade das entrevistadas respondeu que receberam nenhuma ou mínima informação sobre o câncer da mama. (LUQUIS; CRUZ, 2006)

A análise de recursos de multimídia interativos em um estudo recente, mostrou que aqueles recursos podem prover informações sobre saúde para mulheres de baixa educação e de minoria étnica. Os instrumentos utilizados expandiram o leque de ferramentas disponíveis para os educadores em saúde, tal como: materiais impressos, áudio, vídeo e outros recursos áudios-visuais. Esses recursos podem ser utilizados por educadores em saúde e ser uma ferramenta de manipulação de dados devido a sua capacidade eletrônica de armazenamento. Futuramente poderão ser usados em outros assuntos além do câncer da mama. (VALDEZ et al., 2002)

Portanto, para a adesão aos métodos de detecção, também são importantes a informação correta e o interesse do profissional de saúde. Em um estudo com enfermeiras em Cingapura, revelou-se que, apesar de uma agressiva política pública de educação nacional sobre o câncer da mama e os benefícios na detecção primária, 1,5\% das mulheres com câncer foram diagnosticadas com os estágios III e IV da doença. As enfermeiras, por serem importante grupo entre os profissionais da área de saúde, têm grande responsabilidade na educação pública nesta área. No entanto, foi detectado pouco conhecimento ou conhecimento equivocado. Este fato pode perpetuar preconceitos comuns e resultar em diagnóstico e tratamento tardios. (SEAN; TAN, 2007) Em um estudo entre médicos atuantes na rede pública e particular de saúde, demonstrou-se que o reconhecimento dos fatores de risco para o câncer da mama foi inadequado em relação às diretrizes do Ministério da Saúde. Essas recomendações de rastreamento do câncer da mama pareceram pouco claras aos médicos, com grande parte deles fornecendo respostas 
conflitantes. Os médicos identificaram escassez de equipamentos e o custo do exame como as principais barreiras à realização de mamografia, o que não coincidiu com a visão das mulheres atendidas. Os médicos pareciam receptivos às atividades de atualização. (GODINHO; $\mathrm{KOCH}, 2004$ )

O câncer do colo do útero é o segundo tipo mais comum de câncer entre as mulheres em todo o mundo. Na América Latina as taxas de incidência são quatro vezes maiores do que nos EUA e em outros países desenvolvidos. (DELUCA et al., 2004) As mais altas incidências são encontradas na África e no sudoeste da Ásia, em torno de 40 por 100.000 mulheres. (MURTA et al., 1999) No Brasil, cerca de 17 mil casos eram esperados em 2012, o que significa 9,3\% de todos os tumores do sexo feminino. Dentre esses, estima-se que 800 casos ocorram no estado da Bahia. (BRASIL, 2012)

Esta doença tem uma evolução lenta, apresentando fases pré-invasivas, caracterizadas por sua benignidade, conhecidas como neoplasias intraepiteliais cervicais (NIC). O rastreamento dessas lesões através do exame de Papanicolaou permite o diagnóstico precoce do tumor. (PINHO; MATTOS, 2002) Alguns estudos mostram uma cobertura satisfatória do exame preventivo em mulheres em idade fértil no Brasil. Em um estudo no Rio Grande do Sul, a cobertura de exame Papanicolaou foi de $65 \%$, superando a meta de $60 \%$ preconizada pelo Ministério da Saúde do Brasil no começo da década de 90, tendo como referência o Plano quinquenal de saúde 1990-1995. No entanto, preconiza-se que, a efetividade dos programas de controle para o câncer de colo uterino, deva atingir coberturas acima de 80\%. (COSTA et al., 1998) Em um estudo mais recente no Maranhão, a cobertura do Papanicolaou em mulheres de 25 a 49 anos, que já haviam iniciado a atividade sexual, foi de $82,4 \%$. Muitas mulheres realizaram o exame em intervalos curtos, o que pouco contribui para a prevenção da doença. (OLIVEIRA et al., 2006)

A cobertura pode ser ampliada se algumas barreiras à realização do exame forem superadas. Em um estudo com mulheres brasileiras com diagnóstico firmado para o câncer uterino, as principais barreiras para o diagnóstico e acompanhamento da doença, por elas apontadas, foram as seguintes: médicos que não as examinavam (60\% de todas as mulheres); tempo de espera longo para a consulta ( $48 \%$ daquelas com 
NIC e $60 \%$ daquelas com câncer invasivo) e agendamento tardio (47\% das mulheres com NIC e 50\% das com câncer invasivo). (BRENNA et al., 2001)

A comunicação em saúde é um instrumento necessário para a sensibilização das mulheres na prevenção do câncer do colo do útero. Em uma revisão sobre o assunto, Britto da Cruz e Loureiro (2008), consideraram que a abordagem de comunicação com as mulheres na faixa etária proposta pelos programas de prevenção ainda se mostra deficiente. Isto pode ser explicado pelo fato que esta abordagem está sendo realizada sem identificação com estas mulheres, muitas vezes levando ao constrangimento por não terem suas histórias, vivências e valores contextualizados. Os autores ressaltam também que os fatores que desestimulam as mulheres, principalmente as que se encontram em grupos de maior vulnerabilidade social, a se envolverem nas campanhas preventivas para o câncer do colo do útero, podem estar muito além de suas dificuldades econômicas e de seu desconhecimento sobre a importância de realização dos exames. Portanto, os projetos que pretendem incluir essas mulheres nas campanhas devem considerar as questões culturais que as envolvem. Para isso, é importante que a linguagem utilizada seja menos tecnicista e mais adequada aos seus interesses e necessidades.

O conhecimento adequado entre os profissionais de saúde é essencial para uma boa prática de prevenção do câncer de colo do útero. No entanto, esta condição por muitas vezes não é alcançada. Num estudo com médicos mexicanos, incluindo ginecologistas atuantes em serviços de saúde público e privado, a maioria não tinha informação sobre as normas oficiais para o câncer do colo do útero. Foi também detectada discrepância na recomendação para periodicidade na realização do exame de Papanicolaou. No entanto, a grande maioria dos médicos (80\%) indicava que as suas pacientes realizassem o preventivo, o significado e benefícios em realizá-lo. Em relação ao manejo de lesões NIC I e NIC II, houve uma menor indicação de laserterapia ou crioterapia entre os clínicos gerais em comparação com os ginecologistas. (ALDRICH et al., 2005)

Além do conhecimento, é importante explorar o quanto este saber é transportado para a vida das profissionais da área da saúde, haja vista que a percepção do cuidado de sua saúde deverá transparecer no cuidado com a saúde do outro. Estudantes de enfermagem reconhe- 
ciam a necessidade de realizar a prevenção do câncer do colo do útero, assim como a sua periodicidade e a forma correta de fazerem tal prevenção. No entanto, algumas não o faziam com a periodicidade adequada. Os principais motivos para isso foram: não ter tido relação sexual vaginal e medo de ser portadora da doença. A prática discente deve ser reformulada, de forma a criar hábito de realização de exames preventivos, melhorando o estilo de vida e estudando sempre as inovações a respeito do tema. Todos esses aspectos têm o intuito de aprimorar o cuidar de si, para poder cuidar da saúde das mulheres com mais segurança, dignidade, sabedoria, humanização e o mais importante, com amor. (BEGHINI et al., 2006)

O objetivo desse estudo foi avaliar o nível de conhecimento sobre os cânceres de mama e do colo do útero entre trabalhadoras da área de saúde, e estabelecer uma associação entre o conhecimento e a prevenção primária da doença.

\section{Métodos}

Trata-se de um estudo de corte transversal, realizado de maio a setembro de 2011, em uma empresa de Serviço de Atenção Domiciliar (SAD), situada em Salvador e Lauro de Freitas, Bahia. Realizou-se um censo no qual foram entrevistadas 246 trabalhadoras da área de saúde, com idade entre 20 e 69 anos (médicas, enfermeiras, fisioterapeutas, fonoaudiólogas, nutricionistas, terapeutas ocupacionais, odontólogas, farmacêutica, técnicas em enfermagem, auxiliares de enfermagem, pessoal do serviço administrativo e do serviço geral).

As trabalhadoras responderam um questionário dividido em blocos. Inicialmente foram coletados dados sociodemográficos (idade, raça, estado civil, escolaridade, número de filhos, pessoas que residem no domicílio, renda mensal da família e meio de comunicação mais utilizado) e ocupacionais (vínculo empregatício, profissão/ocupação atual, tempo de serviço e experiência profissional com o câncer da mama).

No segundo bloco foi pesquisado o conhecimento sobre câncer da mama, onde foram abordados os principais fatores de risco (menarca precoce, nuliparidade, idade à primeira gestação a termo após os 30 anos, uso de anticoncepcionais orais, menopausa tardia, uso de terapia de reposição hormonal, idade, obesidade, dieta rica em gordura, 
herança genética, falta ou pouca atividade física programada, ingestão de moderada a elevada de álcool e exposição a radiações ionizantes entre os menores de 35 anos), sinais e sintomas dessa doença (nódulo, edema, retração da pele, pele em "casca de laranja", eritema do seio; ulceração, sangramento e desvio da aréola e mamilo; nódulo em axilas), métodos de detecção precoce (mamografia e exame clínico da mama) e frequência para realização dos métodos de detecção (exame clínico da mama para todas as mulheres que procuram serviço de saúde, para as mulheres sem história de câncer da mama em parentes de primeiro grau anual a partir dos 40 anos até 49 anos; anualmente para aquelas com história positiva a partir dos 35 anos; mamografia para as mulheres sem história de câncer da mama em parentes de primeiro grau a cada dois anos a partir dos 50 anos até 69 anos; anualmente para aquelas com história positiva a partir dos 35 anos).

Ainda no segundo bloco foi pesquisado o conhecimento sobre câncer do colo do útero, onde foram questionados principais fatores de risco (infecção pelo HPV, tabagismo, baixa ingesta de vitaminas, multiplicidade de parceiros sexual, iniciação sexual precoce e uso de anticoncepcionais orais), sinais e sintomas dessa doença (hemorragia, corrimento vaginal e dor), método de prevenção primária (exame de Papanicolaou) e frequência para realização do método (para mulheres entre 25 a 59 anos de idade, inicialmente anual e, caso dois exames seguidos (em um intervalo de um ano) apresentassem resultado normal, o exame poderia passar a ser feito a cada três anos). Neste bloco, o questionário seguiu a lógica de pesquisa espontânea e induzida, ou seja, inicialmente a trabalhadora foi estimulada a responder sobre as questões conforme seus conhecimentos, sem apoio de alternativas. A resposta era correta quando a trabalhadora concordava com os parâmetros determinados no questionário. Os parâmetros foram definidos a partir de orientações do INCA e de outros estudos. (POWE et al., 2005; RODRÍGUEZ; WARD; PÉREZ-STABLE, 2005; FERREIRA; OLIVEIRA, 2006; LUIQUIS; CRUZ, 2006; SEAH; TAN, 2007; BRASIL, 2011a; BRASIL, 2011b)

Em seguida, a entrevistada foi questionada ativamente sobre os conhecimentos esperados. Novamente a resposta era correta quando a trabalhadora concordava com os parâmetros determinados no questionário. $\mathrm{Na}$ sequência, a entrevista focou o comportamento das 
entrevistadas no geral (religião, frequência de ida a igreja, culto ou terreiro; aceitação de conselhos sobre sua saúde por familiares, vizinho ou orientador espiritual), tipo de acesso aos serviços de saúde (convênio particular/empresa ou Sistema Único de Saúde) e comportamento sobre a detecção precoce (realização de consultas periódicas, compartilhamento de informações e resultados dos exames pelo médico ginecologista, segurança na orientação médica, acesso às informações sobre o câncer da mama e sobre o câncer do colo de útero, bem como sobre a finalidade da mamografia e do exame de Papanicolaou, respectivamente).

Foram perguntados os motivos para realização da mamografia: possuir histórico familiar positivo para câncer; influência de amigos; apoio e companhia do cônjuge; influência de familiares; solicitação médica; atendimento às campanhas sobre a doença; vontade própria; percepção dos sintomas da doença; consciência da importância da detecção precoce; estar na idade de realizar; por ser parte dos exames de rotina; facilidade para marcar o exame; afinidade com os técnicos que realizam o exame; facilidade de transporte ao local do exame e outros motivos. Foram também questionadas as barreiras que influenciaram a não realização do exame entre aquelas mulheres com indicação para fazê-lo: nunca ter pensado sobre o assunto; a mamografia é desnecessária por não ter problema nas mamas; não ter tempo; não recomendação médica do exame; alto custo do exame; descuido; não ter quem a acompanhe para realizar o exame; não ter histórico familiar para câncer; medo de sentir dor durante o exame; medo de descobrir doença; desconfiança no resultado do exame; não saber qual médico procurar para realizar o exame; não saber onde realizar o exame; achar que o exame expõe à radiação por raios $\mathrm{X}$; achar que a máquina ao pressionar a mama pode causar câncer; medo de ser mal tratada pelos técnicos que realizam o exame; informação negativa de parente, amigo ou colega sobre o exame e outras razões.

Da mesma forma, perguntou-se sobre os motivos para realização do exame de Papanicolaou: possuir histórico familiar positivo para câncer; influência de amigos; apoio e companhia do cônjuge; influência de familiares; solicitação médica; atendimento às campanhas sobre a doença; vontade própria; percepção dos sintomas da doença; consciência da importância na prevenção primária; estar na idade de realizar; por ser parte dos exames de rotina; se sentir vulnerável à doença e outros 
motivos. Foram também questionadas as barreiras que influenciaram a não realização do Papanicolaou entre aquelas mulheres com indicação para fazê-lo: nunca ter pensado sobre o assunto; considerar o exame de Papanicolaou desnecessário por não ter problemas ginecológicos; não ter tempo; não recomendação médica do exame; custo elevado do exame; descuido; não ter companhia para realizar o exame; não ter histórico familiar para câncer; medo de sentir dor durante o exame; medo de descobrir doença; desconfiança no resultado do exame; não saber qual médico procurar para realizar o exame; não saber onde realizar o exame; informação negativa de parente, amigo ou colega e outras razões.

Finalmente o questionário foi encerrado com um bloco sobre antecedentes médicos (idade da menarca em anos, início da atividade sexual, número de parceiros em toda vida e nos últimos 12 meses); história obstétrica (idade primeira gestação, número de gestações incluindo abortos e idade quando da menopausa); história pessoal para câncer (mama, colo do útero, endométrio, ovário, colón e/ou reto, traqueia, brônquios e pulmão; estômago, leucemia e outros); métodos anticoncepcionais (contraceptivo oral, injetável, uso de dispositivo intrauterino, preservativo, método da tabela, tempo de uso de método predominante); uso de terapia de reposição hormonal, número de infecções ginecológicas tratadas ou não tratadas no último ano; história familiar para os cânceres citados; anotações sobre estatura e peso atual para o cálculo do Índice de Massa Corpórea (IMC) informados pela entrevistada.

As variáveis independentes principais "nível de conhecimento sobre o câncer da mama" e "nível de conhecimento sobre o câncer do colo do útero" foram dicotomizadas em nível adequado (mais de 70\% de respostas corretas) e não adequado (menos de $70 \%$ das respostas corretas). Calcularam-se razões de prevalência (RP) considerando a realização de consultas de prevenção, da mamografia e do exame de Papanicolau como variáveis dependentes. Num segundo momento, as variáveis "conhecimento sobre câncer da mama" e "conhecimento sobre câncer do colo de útero" foram caracterizadas como dependentes, e calcularam-se as RP para verificação de fatores associados. Realizou-se análise de regressão logística com o procedimento backward através do programa estatístico SPPS 13. (SPSS, 2004) 
O estudo seguiu a orientação da declaração de Helsinque de 1989 e da Rsolução no 196/96, sobre pesquisa envolvendo seres humanos do Conselho Nacional de Saúde, sendo aprovada no Comitê de Ética em Pesquisa da Escola Estadual de Saúde Pública (EESP), parecer 04/2011. As entrevistadas e o coordenador do estudo assinaram o Termo de Consentimento Livre e Esclarecido.

\section{Resultados}

Das 385 trabalhadoras da empresa de SAD, 246 (63,9\%) participaram do estudo. A maioria das trabalhadoras tinha de 20 a 29 anos $(41,5 \%)$, variando entre 20 e 58 anos, com média de 36,1 anos e mediana de 35 anos. Aproximadamente metade das trabalhadoras $(49,6 \%)$ se declarou parda. Quanto à escolaridade, 146 (59,3\%) possuíam ensino médio completo e $48(19,5 \%)$ possuíam pós-graduação. Cento e treze $(45,9 \%)$ não tinham filhos e $127(51,6 \%)$ possuíam até três filhos. A maioria $(64,6 \%)$ recebia entre um a cinco salários mínimos. Em relação ao vínculo de trabalho junto à empresa, 146 (59,3\%) eram cooperadas e $82(33,3 \%)$ eram empregadas com carteira assinada. Cerca de $60 \%$ eram auxiliares de enfermagem. Cento e setenta e oito trabalhadoras $(72,4 \%)$ possuíam entre um e nove anos de serviço.

Para o grupo de trabalhadoras da área de saúde, com indicação para realizar mamografia regularmente, os principais motivos que as levavam a realizar o exame foram: consciência da prevenção (96,9\%), estar na idade de realizar $(89,2 \%)$, por ser exame de rotina $(87,7 \%)$, solicitação médica $(84,6 \%)$ e por vontade própria $(75,3 \%)$ (Tabela 1 ). As principais barreiras que as impediam de realizar o exame foram: descuido e falta de tempo $(66,6 \%)$, alto custo do exame $(44,4 \%)$ e medo de ser mal tratada durante o exame $(33,3 \%)$. 
Tabela 1 - Características das trabalhadoras da área de saúde ${ }^{(1)}$ em relação aos motivos para realização da mamografia ${ }^{(2)}$ em Empresa de Atenção Domiciliar Salvador e Região, 2011.

\begin{tabular}{|c|c|c|}
\hline Variável & $n=65$ & $\%$ \\
\hline Consciência da prevenção & 63 & 96,9 \\
\hline Estar na idade de realizar o exame & 58 & 89,2 \\
\hline Exame de rotina & 57 & 87,7 \\
\hline Solicitação médica & 55 & 84,6 \\
\hline Vontade própria & 49 & 75,3 \\
\hline Facilidade de transporte & 45 & 69,2 \\
\hline Facilidade de marcação & 37 & 56,9 \\
\hline Afinidade com os técnicos que realizam o exame & 31 & 47,7 \\
\hline Influência de campanhas & 25 & 38,5 \\
\hline Se sentir Vulnerável a doença & 23 & 35,4 \\
\hline Outras razões & 23 & 35,3 \\
\hline Histórico familiar positivo para câncer & 22 & 33,8 \\
\hline Influência do cônjuge & 15 & 23,1 \\
\hline Percepção de sinais da doença & 14 & 21,5 \\
\hline Influência de familiares & 09 & 13,8 \\
\hline
\end{tabular}

(1) Excluídas as não envolvidas diretamente na assistência ao paciente.

(2) Excluídas as que não realizaram mamografia nos últimos 02 anos, nunca ter realizado ou não estar na idade de realizar.

Fonte: (TAVARES; RÊGO, 2011)

O nível de conhecimento sobre o câncer da mama esteve mais associado ao compartilhamento de resultados de exames de detecção precoce da doença $(\mathrm{RP}=1,53)$ e informações em geral $(\mathrm{RP}=1,39)$ por parte do médico. Histórico familiar positivo para câncer da mama $(\mathrm{RP}=$ 1,18) também pode estar envolvido (Tabela 2). A realização de consultas para detecção precoce do câncer da mama foi associada: ao médico ginecologista ter o hábito de examinar as mamas $(\mathrm{RP}=1,26)$, de compartilhar informações $(\mathrm{RP}=1,31)$ e compartilhar os resultados dos exames de detecção precoce da doença $(\mathrm{RP}=1,24)$. As demais variáveis não foram relevantes (Tabela 3). Na análise multivariada, mantiveram-se as associações entre a realização de consultas de detecção precoce do câncer da mama com o exame das mamas pelo médico ginecologista, com Odds Ratio (OR) igual a 4,45 e o compartilhamento de informações pelo mesmo profissional $(\mathrm{OR}=3,40)$. 
Tabela 2 - Razões de Prevalência (RP) entre conhecimento sobre câncer da mama e variáveis sociodemográficas, ocupacionais, atitudes para detecção precoce do câncer da mama e histórico familiar para câncer entre trabalhadoras da área de saúde de empresa de Atenção Domiciliar Salvador e Região, 2011, (n=246).

\begin{tabular}{|c|c|c|c|c|c|}
\hline Variável & \multicolumn{5}{|c|}{ Conhecimento } \\
\hline & \multicolumn{2}{|c|}{ Adequado } & \multicolumn{2}{|c|}{ Não adequado } & \multirow[b]{2}{*}{ RP } \\
\hline Idade & $\mathbf{N}$ & $\%$ & $\mathrm{n}$ & $\%$ & \\
\hline$>40$ anos & 53 & 63,1 & 31 & 36,9 & 0,96 \\
\hline$<40$ anos & 106 & 65,4 & 56 & 34,6 & \\
\hline \multicolumn{6}{|l|}{ Escolaridade } \\
\hline$>$ Superior incompleto & 66 & 69,5 & 29 & 30,5 & 1,13 \\
\hline$<$ Ensino médio & 93 & 61,6 & 58 & 38,4 & \\
\hline \multicolumn{6}{|l|}{ Renda } \\
\hline > 05 Salários Mínimos & 58 & 66,7 & 29 & 33,3 & 1,05 \\
\hline < 05 Salários Mínimos & 101 & 63,5 & 58 & 36,5 & \\
\hline \multicolumn{6}{|l|}{ Acesso aos serviços de saúde } \\
\hline Convênio particular/empresa & 92 & 67,2 & 45 & 32,8 & 0,73 \\
\hline Atendimento Sistema Único de Saúde & 67 & 61,5 & 42 & 38,5 & \\
\hline \multicolumn{6}{|l|}{ Profissional da área de saúde } \\
\hline Sim & 123 & 60,6 & 80 & 39,4 & 0,73 \\
\hline Não & 36 & 83,7 & 07 & 16,3 & \\
\hline \multicolumn{6}{|c|}{ Experiência profissional com câncer da mama ${ }^{(1)}$} \\
\hline Sim & 50 & 64,1 & 28 & 35,9 & 1,10 \\
\hline Não & 73 & 58,4 & 52 & 41,6 & \\
\hline \multicolumn{6}{|l|}{ Tempo de serviço } \\
\hline$>10$ anos & 42 & 61,8 & 26 & 38,2 & 0,94 \\
\hline$<10$ anos & 117 & 65,7 & 61 & 34,3 & \\
\hline \multicolumn{6}{|c|}{ Acesso informação sobre câncer da mama } \\
\hline Sim & 130 & 66,0 & 67 & 34,0 & 1,11 \\
\hline Não & 29 & 59,2 & 20 & 40,8 & \\
\hline \multicolumn{6}{|c|}{ Médico compartilha informações sobre câncer da mama } \\
\hline Sim & 149 & 66,2 & 76 & 33,8 & 1,39 \\
\hline Não & 10 & 47,6 & 11 & 52,4 & \\
\hline \multicolumn{6}{|c|}{ Médico compartilha resultados dos exames de detecção precoce do câncer da mama } \\
\hline Sim & 152 & 66,1 & 78 & 33,9 & 1,53 \\
\hline Não & 07 & 43,8 & 09 & 56,3 & \\
\hline
\end{tabular}




\begin{tabular}{|c|c|c|c|c|c|}
\hline \multicolumn{6}{|c|}{ Médico tem hábito de examinar as mamas } \\
\hline Sim & 131 & 66,5 & 66 & 33,5 & 1,16 \\
\hline Não & 28 & 57,1 & 21 & 42,9 & \\
\hline \multicolumn{6}{|c|}{ Histórico familiar positiva para câncer } \\
\hline Sim & 07 & 41,2 & 10 & 58,8 & 0,62 \\
\hline Não & 152 & 66,4 & 77 & 33,6 & \\
\hline \multicolumn{6}{|c|}{ Histórico familiar positiva para câncer da mama ${ }^{(2)}$} \\
\hline Sim & 04 & 44,4 & 05 & 55,6 & 1,18 \\
\hline Não & 03 & 37,5 & 05 & 62,5 & \\
\hline
\end{tabular}

Excluídas as não envolvidas diretamente na assistência ao paciente

Excluídas as sem antecedentes para câncer.

Fonte: (TAVARES; RÊGO, 2011)

Tabela 3 - Associação entre realização de consultas para detecção precoce do câncer da mama e variáveis sociodemográficas, ocupacionais, atitudes para detecção do câncer da mama e histórico familiar para câncer entre trabalhadoras da área de saúde

(1) de empresa de Atenção Domiciliar Salvador e Região, 2011, ( $n=203)$.

\begin{tabular}{|c|c|c|c|c|c|}
\hline Variável & \multicolumn{4}{|c|}{ Realização consultas } & \\
\hline & \multicolumn{2}{|l|}{ Sim } & \multicolumn{2}{|c|}{ Não } & \\
\hline Idade & $\mathrm{n}$ & $\%$ & $\mathbf{N}$ & $\%$ & RP \\
\hline$>40$ anos & 63 & 90,0 & 07 & 10,0 & 0,99 \\
\hline$<40$ anos & 120 & 90,2 & 13 & 9,8 & \\
\hline \multicolumn{6}{|l|}{ Escolaridade } \\
\hline$>$ Superior incompleto & 63 & 91,3 & 06 & 8,7 & 1,02 \\
\hline$<$ Ensino médio & 120 & 89,6 & 14 & 10,4 & \\
\hline \multicolumn{6}{|l|}{ Renda } \\
\hline > 05 Salários Mínimos & 64 & 90,1 & 07 & 9,9 & 1,00 \\
\hline < 05 Salários Mínimos & 119 & 90,2 & 13 & 9,8 & \\
\hline
\end{tabular}

Acesso aos serviços de saúde

\begin{tabular}{l|l|l|l|l|l}
\hline Convênio particular & 91 & 91,0 & 09 & 9,0 & 1,02 \\
\hline Sistema Único de Saúde & 92 & 89,3 & 11 & 10,7 & \\
\hline
\end{tabular}

Tempo de serviço

\begin{tabular}{l|l|l|l|l|l}
\hline$>10$ anos & 57 & 93,4 & 04 & 6,6 & 1,05 \\
\hline$<10$ anos & 126 & 88,7 & 16 & 11,3 & \\
\hline
\end{tabular}

Experiência profissional com câncer da mama

\begin{tabular}{l|l|l|l|l|l}
\hline $\operatorname{Sim}$ & 74 & 94,9 & 04 & 5,1 & 1,08 \\
\hline
\end{tabular}




\begin{tabular}{|c|c|c|c|c|c|}
\hline Não & 109 & 87,2 & 16 & 12,8 & \\
\hline \multicolumn{6}{|c|}{ Acesso informação sobre câncer da mama } \\
\hline Sim & 150 & 90,9 & 15 & 9,1 & 1,06 \\
\hline Não & 33 & 86,8 & 05 & 13,2 & \\
\hline \multicolumn{6}{|c|}{ Conhecimento sobre câncer da mama } \\
\hline Adequado & 113 & 91,9 & 10 & 8,1 & 1,04 \\
\hline Não adequado & 70 & 87,5 & 10 & 12,5 & \\
\hline \multicolumn{6}{|c|}{ Médico compartilha informações sobre câncer da mama } \\
\hline Sim & 169 & 92,3 & 14 & 7,7 & 1,31 \\
\hline Não & 14 & 70,0 & 06 & 30,0 & \\
\hline \multicolumn{6}{|c|}{ Médico compartilha resultados dos exames de detecção precoce do câncer da mama } \\
\hline Sim & 172 & 91,5 & 16 & 8,5 & 1,24 \\
\hline Não & 11 & 73,3 & 04 & 26,7 & \\
\hline \multicolumn{6}{|c|}{ Médico tem hábito de examinar as mamas } \\
\hline $\operatorname{Sim}$ & 150 & 94,3 & 09 & 5,7 & 1,26 \\
\hline Não & 33 & 75,0 & 11 & 25,0 & \\
\hline \multicolumn{6}{|c|}{ Histórico familiar positiva para câncer } \\
\hline $\operatorname{Sim}$ & 14 & 100,0 & 0 & 0,0 & 1,12 \\
\hline Não & 169 & 89,4 & 20 & 10,6 & \\
\hline
\end{tabular}

Excluídas as não envolvidas diretamente na assistência ao paciente.

Fonte: (TAVARES; RÊGO, 2011)

Avaliando a realização de mamografia para detecção precoce do câncer da mama, as principais associações foram: conhecimento adequado sobre câncer da mama $(\mathrm{RP}=1,26)$ e acessos aos serviços de saúde por convênio particular ou da empresa $(\mathrm{RP}=1,20)$ (Tabela 4). $\mathrm{Na}$ análise multivariada observaram-se associações entre a realização de mamografia e conhecimento adequado sobre o câncer da mama $(\mathrm{OR}=6,13)$, acesso aos serviços de saúde através de convênio particular ou empresa $(\mathrm{OR}=5,40)$ e tempo de serviço maior que 10 anos $(\mathrm{OR}=3,62)$. 
Tabela 4 - Associação entre realização de mamografia para detecção precoce do câncer da mama e variáveis sociodemográficas, ocupacionais, atitudes para detecção do câncer da mama e histórico familiar para câncer no geral e câncer da mama em trabalhadoras da área de saúde ${ }^{(1)}$ de empresa de Atenção Domiciliar Salvador e Região, 2011, $(n=74)$.

\begin{tabular}{|c|c|c|c|c|c|}
\hline Variável & \multicolumn{4}{|c|}{ Realização mamografia } & \multirow[b]{3}{*}{$\mathrm{RP}$} \\
\hline & \multicolumn{2}{|c|}{ Sim } & \multicolumn{2}{|c|}{ Não } & \\
\hline Idade $^{(2)}$ & $\mathbf{N}$ & $\%$ & $\mathrm{n}$ & $\%$ & \\
\hline$>45$ anos & 30 & 83,3 & 06 & 16,7 & 0,90 \\
\hline$<45$ anos & 35 & 92,1 & 03 & 0,9 & \\
\hline \multicolumn{6}{|l|}{ Escolaridade } \\
\hline$>$ Superior incompleto & 20 & 95,2 & 01 & 4,8 & 1,13 \\
\hline$<$ Ensino médio & 45 & 84,9 & 08 & 15,1 & \\
\hline \multicolumn{6}{|l|}{ Renda } \\
\hline > 05 Salários Mínimos & 22 & 88,0 & 03 & 12,0 & 1,01 \\
\hline$<05$ Salários Mínimos & 43 & 87,7 & 06 & 12,3 & \\
\hline \multicolumn{6}{|c|}{ Acesso aos serviços de saúde } \\
\hline Convênio particular & 38 & 95,0 & 02 & 5,0 & 1,20 \\
\hline Sistema Único de Saúde & 27 & 79,4 & 07 & 20,6 & \\
\hline \multicolumn{6}{|l|}{ Tempo de serviço } \\
\hline$>10$ anos & 35 & 94,6 & 02 & 5,4 & 1,16 \\
\hline$<10$ anos & 30 & 81,1 & 07 & 18,9 & \\
\hline \multicolumn{6}{|c|}{ Experiência profissional com câncer da mama } \\
\hline Sim & 36 & 92,3 & 03 & 7,7 & 1,12 \\
\hline Não & 29 & 82,9 & 06 & 17,1 & \\
\hline \multicolumn{6}{|c|}{ Acesso informação sobre câncer da mama } \\
\hline Sim & 58 & 89,2 & 07 & 10,8 & 1,14 \\
\hline Não & 07 & 77,7 & 02 & 22,3 & \\
\hline \multicolumn{6}{|c|}{ Conhecimento sobre câncer da mama } \\
\hline Adequado & 42 & 95,4 & 02 & 4,6 & 1,26 \\
\hline Não adequado & 23 & 76,7 & 07 & 23,3 & \\
\hline
\end{tabular}

Médico compartilha informações sobre câncer da mama

\begin{tabular}{l|l|l|l|l|l}
\hline Sim & 63 & 87,5 & 09 & 12,5 & 0,87 \\
\hline Não & 02 & 100,0 & 0 & 0,0 & \\
\hline
\end{tabular}

Médico compartilha resultados dos exames de detecção precoce

\begin{tabular}{l|l|l|l|l|l}
\hline Sim & 63 & 88,7 & 08 & 11,3 & 1,76 \\
\hline Não & 02 & 66,6 & 01 & 33,4 & \\
\hline
\end{tabular}

Médico tem hábito de examinar as mamas 


\begin{tabular}{l|l|l|l|l|l}
\hline Sim & 58 & 89,2 & 07 & 10,8 & 1,14 \\
\hline Não & 07 & 77,7 & 02 & 22,3 & \\
\hline
\end{tabular}

Histórico familiar positiva para câncer

\begin{tabular}{l|l|l|l|l|l}
\hline Sim & 05 & 100,0 & 0 & 0,0 & 1,16 \\
\hline Não & 60 & 86,9 & 09 & 13,1 & \\
\hline
\end{tabular}

Excluídas as não envolvidas diretamente na assistência ao paciente, que nunca realizaram mamografia ou não estar na idade de realizar.

Ajustada para o grupo de trabalhadoras com indicação para realização da mamografia.

Fonte: (TAVARES; RÊGO, 2011)

Para o grupo de trabalhadoras da área de saúde com indicação para realizar o exame de Papanicolaou, os principais motivos que as levavam a realizar o exame foram: ser um exame de rotina $(98,4 \%)$, consciência da prevenção primária do câncer $(97,9 \%)$, vontade própria $(96,8 \%)$, estar na idade de realizar $(93,7 \%)$ e por solicitação médica $(71,0 \%)$ (Tabela 5). As principais barreiras que as impediam de realizar o exame foram: descuido e falta de tempo $(72,7 \%)$, considerar o exame desnecessário por não ter problemas ginecológicos, alto custo do exame e medo de descobrir doença $(27,3 \%)$. 
Tabela 5 - Características das trabalhadoras da área de saúde ${ }^{(1)}$ em relação aos motivos para realização do exame de Papanicolaou ${ }^{(2)}$ em Empresa de Atenção Domiciliar Salvador e Região, 2011.

\begin{tabular}{l|c|c}
\multicolumn{1}{c|}{ Variável } & $\mathrm{n}=190$ & $\%$ \\
\hline Exame de rotina & 187 & 98,4 \\
\hline Consciência da prevenção & 186 & 97,9 \\
\hline Vontade própria & 184 & 96,8 \\
\hline Estar na idade realizar o exame & 178 & 93,7 \\
\hline Solicitação médica & 135 & 71,0 \\
\hline Influência de campanhas & 88 & 46,3 \\
\hline Sentir-se vulnerável à doença & 80 & 42,1 \\
\hline Influência do cônjuge & 42 & 22,1 \\
\hline Histórico familiar positivo para câncer & 30 & 15,8 \\
\hline Percepção de sinais/sintomas da doença & 28 & 14,7 \\
\hline Influência de familiares & 20 & 10,5 \\
\hline Outras razões & 14 & 7,3 \\
\hline
\end{tabular}

Excluídas as não envolvidas diretamente na assistência ao paciente.

Excluídas as que não realizaram o exame de Papanicola ou nos últimos três anos, nunca ter realizado ou não estar na idade de realizar.

Fonte: (TAVARES; RÊGO, 2011)

O nível de conhecimento sobre o câncer do colo do útero esteve mais associado à história familiar positiva para câncer $(\mathrm{RP}=1,20) \mathrm{e}$ ser profissional da área da saúde $(\mathrm{RP}=1,17)$. Renda mensal da família maior que cinco salários mínimos $(\mathrm{RP}=1,10)$ também pode estar envolvida (Tabela 6). A realização de consultas de prevenção primária para o câncer do colo do útero foi associada: ao médico ginecologista compartilhar as informações $(\mathrm{RP}=1,32)$ e os resultados dos exames $(\mathrm{RP}=1,25)$. As demais variáveis não foram relevantes (Tabela 7). Na análise multivariada, manteve-se a associação entre a realização de consultas de prevenção e compartilhamento de informações sobre o câncer do colo do útero pelo médico ginecologista $(\mathrm{OR}=6,87)$. 
Tabela 6 - Razões de Prevalência (RP) entre conhecimento sobre câncer do colo do útero e variáveis sociodemográficas, ocupacionais, atitudes para prevenção primária do câncer do colo do útero e histórico familiar para câncer entre trabalhadoras da área de saúde de empresa de Atenção Domiciliar Salvador e Região, 2011, (n=246).

\begin{tabular}{|c|c|c|c|c|c|}
\hline \multirow{3}{*}{$\begin{array}{ll} & \text { Variável } \\
\text { Idade } & \\
\end{array}$} & \multicolumn{4}{|c|}{ Conhecimento } & \multirow[b]{3}{*}{ RP } \\
\hline & \multicolumn{2}{|c|}{ Adequado } & \multicolumn{2}{|c|}{ Não adequado } & \\
\hline & $\mathrm{n}$ & $\%$ & $\mathrm{n}$ & $\%$ & \\
\hline$>36$ anos & 77 & 67,5 & 37 & 32,5 & 0,96 \\
\hline$<36$ anos & 93 & 70,5 & 39 & 29,5 & \\
\hline \multicolumn{6}{|l|}{ Escolaridade } \\
\hline$>$ Superior incompleto & 68 & 71,6 & 27 & 28,4 & 1,06 \\
\hline$<$ Ensino médio & 102 & 67,5 & 49 & 32,5 & \\
\hline \multicolumn{6}{|c|}{ Renda mensal média familiar } \\
\hline > 05 Salários Mínimos & 64 & 73,6 & 23 & 26,4 & 1,10 \\
\hline < 05 Salários Mínimos & 106 & 66,7 & 53 & 33,3 & \\
\hline \multicolumn{6}{|c|}{ Acesso aos serviços de saúde } \\
\hline Convênio particular & 95 & 69,3 & 42 & 30,7 & 1,01 \\
\hline Sistema Único de Saúde & 75 & 68,8 & 34 & 31,2 & \\
\hline \multicolumn{6}{|c|}{ Profissional da área da saúde } \\
\hline $\operatorname{Sim}$ & 144 & 70,9 & 59 & 29,1 & 1,17 \\
\hline Não & 26 & 60,5 & 17 & 39,5 & \\
\hline \multicolumn{6}{|l|}{ Tempo de serviço } \\
\hline$>10$ anos & 44 & 64,7 & 24 & 35,3 & 0,91 \\
\hline$<10$ anos & 126 & 70,8 & 52 & 29,2 & \\
\hline \multicolumn{6}{|c|}{ Experiência profissional com câncer do colo do útero ${ }^{(1)}$} \\
\hline Sim & 35 & 74,5 & 12 & 25,5 & 1,06 \\
\hline Não & 109 & 69,9 & 47 & 30,1 & \\
\hline \multicolumn{6}{|c|}{ Acesso a informação sobre câncer do colo do útero } \\
\hline Sim & 134 & 69,1 & 60 & 30,9 & 0,99 \\
\hline Não & 36 & 69,2 & 16 & 30,8 & \\
\hline \multicolumn{6}{|c|}{ Médico compartilha informações sobre câncer do colo do útero } \\
\hline Sim & 153 & 68,0 & 72 & 32,0 & 0,84 \\
\hline Não & 17 & 81,0 & 04 & 19,0 & \\
\hline \multicolumn{6}{|c|}{ Médico compartilha resultados dos exames de prevenção primária } \\
\hline $\operatorname{Sim}$ & 159 & 69,1 & 71 & 30,9 & 1,00 \\
\hline Não & 11 & 68,8 & 05 & 31,3 & \\
\hline
\end{tabular}




\begin{tabular}{|c|c|c|c|c|c|}
\hline \multicolumn{6}{|c|}{ Histórico familiar positivo para câncer } \\
\hline Sim & 14 & 82,4 & 03 & 17,6 & 1,20 \\
\hline Não & 156 & 68,1 & 73 & 31,9 & \\
\hline \multicolumn{6}{|c|}{ Histórico familiar positivo para câncer do colo do útero ${ }^{(2)}$} \\
\hline Sim & 06 & 75,0 & 02 & 25,0 & 0,85 \\
\hline Não & 08 & 88,9 & 01 & 11,1 & \\
\hline
\end{tabular}

Excluídas as não envolvidas diretamente na assistência ao paciente.

Excluídas as sem histórico familiar para câncer.

FONTE: (TAVARES; RÊGO, 2011)

Tabela 7 - Associação entre realização de consultas para prevenção primária do câncer do colo do útero e variáveis sociodemográficas, ocupacionais, atitudes para prevenção primária do colo do útero e histórico familiar para câncer entre trabalhadoras da área de saúde ${ }^{(1)}$ de empresa de Atenção Domiciliar Salvador e Região, 2011, (n=203).

\begin{tabular}{|c|c|c|c|c|c|}
\hline Variável & \multicolumn{4}{|c|}{ Realização de consultas } & \multirow[b]{2}{*}{$\mathbf{R P}$} \\
\hline & \multicolumn{2}{|c|}{ Sim } & \multicolumn{2}{|c|}{ Não } & \\
\hline I dade & $\mathrm{n}$ & $\%$ & $\mathbf{N}$ & $\%$ & \\
\hline$>36$ anos & 83 & 87,4 & 12 & 12,6 & 0,94 \\
\hline$<36$ anos & 100 & 92,6 & 08 & 7,4 & \\
\hline \multicolumn{6}{|l|}{ Escolaridade } \\
\hline$>$ Superior incompleto & 63 & 91,3 & 06 & 8,7 & 1,02 \\
\hline$<$ Ensino médio & 120 & 89,6 & 14 & 10,4 & \\
\hline \multicolumn{6}{|l|}{ Renda mensal média familiar } \\
\hline > 05 Salários Mínimos & 64 & 90,1 & 07 & 9,9 & 1,00 \\
\hline < 05 Salários Mínimos & 119 & 90,2 & 13 & 9,8 & \\
\hline \multicolumn{6}{|l|}{ Acesso serviços de saúde } \\
\hline Convênio particular & 91 & 91,0 & 09 & 9,0 & 1,02 \\
\hline Sistema Único de Saúde & 92 & 89,3 & 11 & 10,7 & \\
\hline \multicolumn{6}{|l|}{ Tempo de serviço } \\
\hline$>10$ anos & 57 & 93,4 & 04 & 6,6 & 1,05 \\
\hline$<10$ anos & 126 & 88,7 & 16 & 11,3 & \\
\hline \multicolumn{6}{|c|}{ Experiência profissional câncer do colo do útero } \\
\hline Sim & 43 & 91,5 & 04 & 8,5 & 1,02 \\
\hline Não & 140 & 89,7 & 16 & 10,3 & \\
\hline \multicolumn{6}{|c|}{ Acesso informação câncer do colo do útero } \\
\hline Sim & 145 & 90,6 & 15 & 9,4 & 1,03 \\
\hline Não & 38 & 88,4 & 05 & 11,6 & \\
\hline
\end{tabular}


Conhecimento adequado sobre câncer do colo do útero

\begin{tabular}{l|l|l|l|l|l} 
Sim & 131 & 91,0 & 13 & 9,0 & 1,03 \\
\hline Não & 52 & 88,1 & 07 & 11,9 & \\
\hline
\end{tabular}

Médico compartilha informações sobre câncer do colo do útero

\begin{tabular}{l|l|l|l|l|l}
\hline Sim & 169 & 92,3 & 14 & 7,7 & 1,32 \\
\hline Não & 14 & 70,0 & 06 & 30,6 &
\end{tabular}

Médico compartilha resultados dos exames de prevenção primária

\begin{tabular}{l|l|l|l|l|l}
\hline Sim & 172 & 91,5 & 16 & 8,5 & 1,25 \\
\hline Não & 11 & 73,3 & 04 & 26,7 &
\end{tabular}

Histórico familiar positivo para câncer

\begin{tabular}{l|l|l|l|l|l}
\hline Sim & 12 & 92,3 & 01 & 7,7 & 1,02 \\
\hline Não & 171 & 90,0 & 19 & 10,0 &
\end{tabular}

Histórico familiar positivo para câncer do colo do útero ${ }^{(2)}$

\begin{tabular}{l|l|l|l|l|l} 
Sim & 05 & 83,3 & 01 & 16,7 & 0,83 \\
\hline Não & 07 & 100,0 & 0 & 0,0 & \\
\hline
\end{tabular}

Excluídas as não envolvidas diretamente na assistência ao paciente.

Excluídas as sem histórico familiar para câncer.

Fonte: (TAVARES; RÊGO, 2011)

Avaliando a realização do exame de Papanicolaou para prevenção primária do câncer do colo do útero, a associação mais importante foi com o fato de o médico compartilhar informações sobre o câncer do colo do útero $(\mathrm{RP}=1,20)$ (Tabela 8$)$. $\mathrm{Na}$ análise multivariada observaram-se associações da realização do exame de Papanicolaou entre as trabalhadoras da área da saúde com compartilhamento de informações pelo médico $(\mathrm{OR}=7,85)$ e escolaridade maior ou igual ao nível superior incompleto $(\mathrm{OR}=5,33)$.

Tabela 8 - Associação entre realização do exame de Papanicolaou para prevenção primária do câncer do colo do útero e variáveis sociodemográficas, ocupacionais, atitudes para prevenção primária do câncer do colo do útero e histórico familiar para câncer em trabalhadoras da área de saúde ${ }^{(1)}$ de empresa de Atenção Domiciliar Salvador e Região, 2011, (n=201).

\begin{tabular}{l|l|l|l|l|l|l}
\hline \multicolumn{1}{c|}{ Variável } & \multicolumn{5}{c|}{ Realização do Papanicolaou } & \\
\hline Idade & $\mathbf{n}$ & $\%$ & \multicolumn{2}{c|}{ Não } & RP \\
\hline$>36$ anos & 89 & 94,7 & 05 & 5,3 & 0,99 \\
\hline$<36$ anos & 102 & 95,3 & 05 & 4,7 & \\
\hline
\end{tabular}




\begin{tabular}{|c|c|c|c|c|c|}
\hline \multicolumn{6}{|l|}{ Escolaridade } \\
\hline$>$ Superior incompleto & 67 & 98,5 & 01 & 1,5 & 1,06 \\
\hline$<$ Ensino médio & 124 & 93,2 & 09 & 6,8 & \\
\hline \multicolumn{6}{|c|}{ Renda mensal média familiar } \\
\hline > 05 Salários Mínimos & 67 & 97,1 & 02 & 2,9 & 1,03 \\
\hline < 05 Salários Mínimos & 124 & 93,6 & 08 & 6,1 & \\
\hline \multicolumn{6}{|c|}{ Acesso aos serviços de saúde } \\
\hline Convênio particular & 95 & 96,9 & 03 & 3,1 & 1,04 \\
\hline Sistema Único de Saúde & 96 & 93,2 & 07 & 6,8 & \\
\hline \multicolumn{6}{|l|}{ Tempo de serviço } \\
\hline$>10$ anos & 58 & 98,3 & 01 & 1,7 & 1,05 \\
\hline$<10$ anos & 133 & 93,7 & 09 & 6,3 & \\
\hline \multicolumn{6}{|c|}{ Experiência profissional com câncer do colo do útero } \\
\hline $\operatorname{Sim}$ & 43 & 93,5 & 03 & 6,5 & 0,98 \\
\hline Não & 148 & 95,5 & 07 & 4,5 & \\
\hline \multicolumn{6}{|c|}{ Acesso informação sobre câncer do colo do útero } \\
\hline $\operatorname{Sim}$ & 151 & 95,0 & 08 & 5,0 & 0,99 \\
\hline Não & 40 & 95,2 & 02 & 4,8 & \\
\hline \multicolumn{6}{|c|}{ Conhecimento adequado sobre câncer do colo do útero } \\
\hline Sim & 134 & 94,4 & 08 & 5,6 & 0,97 \\
\hline Não & 57 & 96,6 & 02 & 3,4 & \\
\hline \multicolumn{6}{|c|}{ Médico compartilha informações sobre câncer do colo do útero } \\
\hline Sim & 175 & 96,7 & 06 & 3,3 & 1,20 \\
\hline Não & 16 & 80,0 & 04 & 20,0 & \\
\hline \multicolumn{6}{|c|}{ Médico compartilha resultados dos exames de prevenção primária } \\
\hline Sim & 177 & 95,2 & 09 & 4,8 & 1,02 \\
\hline Não & 14 & 93,3 & 01 & 6,7 & \\
\hline \multicolumn{6}{|c|}{ Vergonha de realizar Papanicolaou } \\
\hline Não & 143 & 94,7 & 08 & 5,3 & 0,98 \\
\hline $\operatorname{Sim}$ & 48 & 96,0 & 02 & 4,0 & \\
\hline \multicolumn{6}{|c|}{ Histórico familiar para câncer } \\
\hline Sim & 13 & 100,0 & 0 & 0,0 & 1,06 \\
\hline Não & 178 & 94,7 & 10 & 5,3 & \\
\hline
\end{tabular}

Excluídas as não envolvidas diretamente na assistência ao paciente, que nunca realizaram o exame de Papanicolaou ou não estar na idade de realizar.

Fonte: (TAVARES; RÊGO, 2011) 


\section{Discussão}

O fato de o médico ginecologista compartilhar os resultados dos exames e informações sobre câncer da mama apresentou relação com aumento do conhecimento sobre câncer da mama entre as trabalhadoras. Este achado está de acordo com vários estudos sobre o assunto. Em um estudo nos EUA, comparando-se duas amostras de mulheres da população geral, entre aquelas que discutiam os parâmetros para o rastreamento do câncer da mama com seus médicos, houve maior taxa de adesão à realização da mamografia. (ROETZHEIM; FOX; LEAKE, 1994) Entre mulheres com mais de 65 anos, o aumento da habilidade na comunicação médico/paciente foi muito efetiva na estratégia de aprendizado sobre o câncer da mama, o que aumentou as taxas de rastreamento da doença no geral. (FOX; SIU; STEIN, 1994) Numa população semelhante, também houve associação entre a recomendação médica e a realização da mamografia entre essas mulheres. (SCHONBERG et al., 2007)

Em um estudo de intervenção educacional sobre câncer da mama entre mulheres imigrantes nos EUA, após o período de cinco meses de sessões sobre a importância do rastreamento e saúde da mama, houve um nítido aumento no conhecimento sobre o câncer da mama $(\mathrm{p}<0,01)$ e com maior impacto $(\mathrm{p}<0,001)$ quando relacionado à indicação precoce da mamografia pelo médico que as acompanhava. (YI; LUONG, 2005) Extensa metaanálise realizada por Legler e colaboradores (2002) traz, entre outros resultados, que em intervenções direcionadas individualmente em serviços de saúde, demonstraram-se efeitos impressionantes na realização da mamografia, entre outros fatores, com fortes motivadores as recomendações do médico e outros profissionais de saúde para a realização do exame.

Maior conhecimento foi também relacionado à história familiar positiva para câncer da mama. Este dado foi pouco abordado pelos estudos revisados, sendo os resultados conflitantes. Em um estudo realizado entre mulheres com diagnóstico de câncer, a realização de mamografia foi $28,1 \%$ maior $(\mathrm{p}<0,001)$ entre as mulheres que tinham parentes com câncer da mama do que aquelas mulheres que não tinham histórico na família. (SOUZA et al., 1998) No estudo de Roetzheim, 
Fox e Leake (1994), o histórico familiar positivo para câncer da mama não influenciou na aderência aos métodos de rastreamento.

No presente estudo, houve fraca associação entre a experiência profissional com o câncer da mama e conhecimento sobre este câncer. Esses dados são semelhantes aos de alguns estudos internacionais. Nos EUA, foi realizado um estudo com estudantes universitárias, incluindo estudantes de enfermagem, utilizando-se um instrumento denominado de Pesquisa do Conhecimento e Percepções sobre Câncer de Mama (Breast Cancer Perceptions and Knowledge Survey - BCPKS) adaptado de um instrumento maior, o Modelo de Crença na Saúde (Health Belief Model), que contempla conhecimento, susceptibilidade, severidade, barreiras e benefícios dos métodos de detecção precoce do câncer da mama. Nesse estudo, apenas o bloco sobre o conhecimento foi utilizado. O nível de conhecimento em câncer da mama no geral foi de 7,48 (máximo de 12 pontos) com acerto de $62 \%$. As estudantes de enfermagem tiveram um menor acerto $(7,46)$ em comparação às outras estudantes (7,50). (POWE et al., 2005) Em um estudo no Irã, com a população feminina geral e utilizando o BCPKS, a média de acertos para a percepção do câncer da mama e conhecimento foi de cinco (máximo de 10 pontos) com acerto de apenas 45,6\%. (PARSA; KANDIAH, 2005)

Ainda em relação ao conhecimento, no estudo de Sean e Tan (2007), a maioria das enfermeiras declarou ter alguma experiência com câncer da mama (77\%). No entanto, sobre a progressão da idade e uso de TRH, $32 \%$ e $37 \%$ das enfermeiras não sabiam que estes eram fatores de risco para o câncer da mama, respectivamente. Nos EUA em um estudo entre médicos, médicos residentes e enfermeiras, 90\% dos profissionais se declaram aptos a indicar corretamente as pacientes que deveriam realizar a mamografia e a frequência do exame. Tomando como base as diretrizes da American Cancer Socety (ACS) e da Força Tarefa de Serviços de Prevenção (USPSTF), aproximadamente $98 \%$ dos profissionais sabiam que a mamografia é efetiva na redução da mortalidade entre mulheres entre 50 a 69 anos, mas apenas $38 \%$ sabiam que o exame não é efetivo nas maiores de 70 anos. Entre mulheres com história familiar para câncer da mama entre parentes do primeiro grau, para a maioria (56\%), a indicação do rastreamento deveria ser iniciada aos 30 anos. (JOHNSON et al., 1998) 
Em outro estudo no Brasil envolvendo médicos clínicos, não houve acerto em relação aos métodos de prevenção para o câncer da mama pelo INCA, pela ACS ou pela Canadian Task Force(CTF). Os resultados mostraram que os médicos solicitavam $83,8 \%$ mais mamografias do que o adequado. Ao mesmo tempo, houve um déficit de $16,2 \%$ nas solicitações das mamografias para mulheres com indicação de realizála. (TUCUNDUVA et al., 2004) No presente estudo, não foi encontrada influência da progressão do tempo de serviço sobre o nível de conhecimento do câncer da mama. Outros estudos mostraram conflitos com os resultados apresentados. Médicos de um serviço universitário, comparados aos médicos residentes, sabiam mais que estes em relação ao aumento do risco do câncer nas classes sociais com menor poder econômico $(24 \%$ e $4 \%$ respectivamente p $<0,10)$, que o autoexame não reduz a mortalidade $(54 \%$ e $20 \%$ respectivamente, $\mathrm{p}<0,05)$ e que a mamografia em maiores de 70 anos também não reduzia (60\% e $24 \%$ respectivamente, $\mathrm{p}<0,05)$. (JOHNSON et al., 1998) Médicas norte-americanas que tinham mais de 15 anos de serviço mostraram maior conhecimento do que aquelas com menos tempo de serviço. (JAIN et al., 2006) Outro estudo cita o tempo de serviço dos trabalhadores, mas não o correlaciona ao nível de conhecimento sobre câncer da mama. (LURIE et al., 1997)

Consciência da prevenção, estar na idade para realizar o exame, por ser um exame de rotina, solicitação médica e vontade própria, foram os principais motivos que levaram a realização da mamografia regularmente. O conhecimento adequado sobre o câncer da mama, acesso aos serviços de saúde através de convênios particulares e tempo de serviço maior do que 10 anos influenciaram positivamente para a realização da mamografia. Estes dados foram condizentes com outros estudos na literatura. Entre mulheres provenientes de países asiáticos e de ilhas do pacífico, observaram-se associações entre a realização da mamografia e ter sido avaliada por um médico no último ano $(\mathrm{OR}=5,6$; IC 95\%: $3,7-8,4)$ e possuir um convênio de saúde (OR=2,1; IC 95\%: 1,2-3,7). Neste mesmo estudo, os fatores que levaram à realização do exame clínico da mama foram: não estar apta para o trabalho (OR $=4,8$; IC 95\%: $1,4-15,9)$, ter sido avaliada por um médico no último ano $(\mathrm{OR}=4,3$; IC 95\%: 2,8-6,5) e possuir um convênio de saúde (OR=2,8; IC 95\%: 1,5-5,0). (COUGHLIN; UHLER, 2000) 
Em um estudo entre mulheres com tumor da mama na zona rural dos EUA, foi estudada a atitude em realizar mamografia de seguimento e observaram-se associação com: ser afrodescendente americana $(\mathrm{OR}=1,46$; IC 90\%: 1,07-2,00), discussão pelo médico sobre seu risco para desenvolver câncer da mama (OR=1,51; IC 90\%: 1,14-2,00) e realização de mamografia prévia (OR=0,63; IC 90\%: 0,44-0,89). (ALTPETER; MITCHELL; PENNELL, 2005) No Brasil entre as mulheres que realizavam a mamografia regularmente os principais motivos foram a importância de tranquilizar-se e o autocuidado. (FERREIRA; OLIVEIRA, 2006)

Entre as trabalhadoras que não realizavam a mamografia regularmente, mesmo quando indicado, os principais fatores foram: descuido falta de tempo, custo do exame e medo de ser mal tratada durante a realização do exame. No estudo de Johnson e colaboradores (2008), as principais barreiras para a realização da mamografia pelos pacientes na visão dos profissionais de saúde foram: medo da dor ou desconforto (91\%); pouco entendimento sobre os benefícios da detecção precoce (89\%); percepção que a mesma não está em risco para o desenvolvimento do câncer da mama (85\%); dificuldades para transporte (79\%); custo do exame $(72 \%)$ e medo que a mamografia possa causar câncer (47\%). No estudo de Sean e Tan (2007), 21\% das enfermeiras entrevistadas acreditavam que estariam imunes ao câncer da mama se não possuíssem nenhum fator de risco. Cinco por cento das trabalhadoras acreditavam que a radiação emitida pelo mamógrafo poderia ser um fator de risco e $12 \%$ não tinham certeza.

Médicos brasileiros, quando interrogados quanto a possíveis barreiras para o adequado exercício do rastreamento do câncer, consideraram a falta de agentes educadores em saúde para a população $(82,9 \%)$ e sua própria falta de conhecimento ou treinamento $(77,1 \%)$ para fazer este tipo de rastreamento. (TUCUNDUVA et al., 2004) Em um estudo populacional no Irã, a atitude na rotina de rastreio do câncer da mama foi pobre em $10,4 \%$ das mulheres, moderada para $10,1 \%$ e boa atitude para $79,5 \%$ das entrevistadas. As principais barreiras para realização dos exames foram: pouco conhecimento de como realizá-lo (48\%), esquecimento $(20 \%)$, medo de encontrar uma massa (17\%), não achar necessário (9\%) e pouco tempo disponível (4\%). (PARSA; KANDIAH, 2005) 
O fato de a trabalhadora ser profissional da área de saúde apresentou relação com aumento do conhecimento sobre o câncer do colo do útero. Este dado está de acordo com alguns estudos sobre o tema. Em um estudo no México, com trabalhadoras da área de saúde, a classificação geral média do conhecimento foi de oito acertos, sendo considerada baixa. Como esperado, as médicas tiveram um maior número de acertos (média de 12). (GONZÁLEZ-SALINAS et al., 1996) Em outro estudo com médicos mexicanos generalistas e ginecologistas-obstetras, $79 \%$ daqueles e $86 \%$ destes sabiam que o HPV é identificado como a principal causa de câncer do colo do útero. Os generalistas, no entanto, atribuíam mais importância à hereditariedade como fator de risco e citavam menos outros fatores, como pobre higiene genital, uso de anticoncepcional oral e tabagismo. Houve uma grande discrepância quanto à idade para se iniciar a realização do exame de Papanicolaou e sua frequência; $87 \%$ dos generalistas e $32 \%$ dos especialistas responderam que a prevenção deveria se iniciar após o primeiro intercurso sexual e $73 \%$ de ambos os grupos indicariam exame anual mesmo se normal anteriormente. (ALDRICH et al., 2005)

Em mais um estudo com médicos de família norte-americanos, a maioria (89\%) concordou que a infecção por HPV era o principal fator de risco para desenvolvimento do câncer do colo do útero. A maior proporção de acertos ocorreu entre as médicas que atuavam fora do setor privado e que participavam de grupos de trabalho multidisciplinar. (JAIN et al., 2006) Em um estudo entre estudantes de enfermagem, foi reconhecido que é necessário realizar a prevenção do câncer do colo do útero, assim como a sua periodicidade e a forma correta de fazer tal prevenção. Isto levava as estudantes anualmente a procurar um profissional especializado para realizar o exame de Papanicolaou. (BEGHINI et al., 2006)

Outros estudos demonstraram resultados diferentes sobre o tema. No estudo de Mutyaba, Mmiro e Weiderpass (2006), entre trabalhadores alocados num hospital de referência em câncer, o conhecimento sobre o câncer do colo do útero foi baixo. A maioria dos participantes (81\%) sabia que o câncer do colo do útero é curável se detectado nos estágios iniciais e que o exame de Papanicolaou (83\%) poderia detectar tais lesões; no entanto, o conhecimento sobre os fatores de risco (29\%) e rotina de periodicidade do Papanicolaou (39\%) foi baixo. No 
estudo realizado por Tucunduva e colaboradores (2004), com médicos generalistas, apenas $37,14 \%$ seguiam corretamente as diretrizes fornecidas pelo INCA para a prevenção deste câncer. Dentro deste contexto, $29,3 \%$ recomendavam de maneira excessiva o Papanicolaou e $24,1 \%$ de maneira insuficiente. Em um estudo com enfermeiras sul africanas que prestavam assistência na atenção básica, apenas 58\% eram suficientemente treinadas para realização do preventivo; na zona rural esses números caiam para $14 \%$. Apenas $35 \%$ dessas enfermeiras realizavam o Papanicolaou na população assistida. (KAWONGA; FONN, 2008)

Maior conhecimento sobre o câncer do colo do útero foi também relacionado com história familiar de câncer, mas poucos estudos trazem essa discussão. Isto se deve, provavelmente, ao fato de não haver associação descrita entre o risco de desenvolver o câncer do colo do útero e hereditariedade. Em um estudo colombiano, a história familiar de câncer não foi associada à realização do exame de Papanicolaou $(\mathrm{RP}=0,9 ;$ IC 95\%: 0,7-1,2). (CASTRO-JIMÉNEZ; VERA-CALA; POSSO-VALENCIA, 2006) Em um estudo com mulheres espanholas, o comportamento sexual e hereditariedade foram apontados pelas entrevistadas como duas das principais causas do câncer do colo do útero. No geral o conhecimento sobre o câncer e a relação com a infecção por HPV era muito limitada ou inexistente. (VANSLYKE et al., 2008) No estudo de caso com mulheres da população geral, a herança genética levou algumas entrevistadas a pensar sobre a realização do Papanicolaou. (DUAVY et al., 2007)

Não houve mudança do nível do conhecimento sobre o câncer do colo do útero mesmo com a progressão do tempo de serviço. Esse resultado é contraditório com alguns estudos sobre tema. No Brasil, foi observado que médicos com mais de dez anos de formado indicavam menos a realização do exame de Papanicolaou, de acordo com o INCA $(p=0,016)$. (TUCUNDUVA et al., 2004) Em outro estudo, as médicas que tinham mais de 15 anos de serviço mostraram maior conhecimento do que aquelas com menos tempo de serviço. (JAIN et al., 2006) Verificou-se que mulheres com menos de 20 anos de serviço demonstraram um maior nível de conhecimento. (GONZÁLEZ-SALINAS et al., 1996) Outros estudos citam o tempo de serviço dos trabalhadores, mas não o correlacionam ao nível de conhecimento. (LURIE et al., 1997; ALDRICH et al., 2005 e ALDRICH et al., 2006) 
A experiência profissional com câncer do colo do útero também não influenciou no nível de conhecimento das trabalhadoras. Este dado está de acordo com vários estudos. Em um estudo africano em um hospital em Uganda, $87 \%$ dos estudantes de medicina do último ano nunca tinham feito o exame especular em suas pacientes, $56 \%$ nunca haviam feito um exame especular em nenhum momento de sua formação e apenas $14 \%$ sentiam-se seguros em realizar este exame. Apesar da maioria dos participantes lidar com pacientes do sexo feminino, o exame especular era realizado por apenas $12 \%$ desses profissionais. A maioria deles também $(78 \%)$ nunca perguntou aos seus pacientes se já haviam sido rastreadas para o câncer do colo do útero. (MUTYABA; MMIRO; WEIDERPASS, 2006)

Ainda sobre esse tópico, em um estudo comparando a realização de exames de prevenção para o câncer do colo do útero na Inglaterra, foi constatando que médicas tinham uma maior experiência com a doença. Envio de lembretes e de questionamento de ter realizado o exame de Papanicolaou às pacientes foram, respectivamente, 9\% e 11\% maior entre as médicas em comparação aos médicos. Em relação às suas habilidades em realizar o preventivo, $62 \%$ das médicas disseram ser excelentes, $99 \%$ se sentiam confortáveis em realizá-lo e $89 \%$ consideravam-se responsáveis pela realização do exame nas pacientes. (LURIE et al., 1997) Em um estudo entre médicos de família nos EUA, que avaliou o conhecimento sobre o HPV e outras afecções correlacionadas, a maioria (90\%) falou que haviam prestado assistência a pacientes com alguma queixa anogenital. Entretanto, a maioria desses médicos viu poucos pacientes (dois em média) com essas afecções no último ano. Eles também viram poucos casos de infecção por clamídia ou herpes vírus (cinco em média) no último ano. (JAIN et al., 2006)

Em um estudo entre médicos mexicanos, comparando a experiência entre ginecologistas-obstetras e médico generalistas, foi observado que $30 \%$ dos obstetras e $8 \%$ dos generalistas regularmente tratavam displasia ou câncer do dolo do útero $(\mathrm{p}=0,000)$. Houve uma proporção similar (65\% e 59\%, respectivamente) entre ginecologistas/bstetras e generalistas na realização do Papanicolaou nos últimos dois meses. (ALDRICH et al., 2006) No estudo de Gonzáles-Salinas et al. (1996), as trabalhadoras que manifestaram ter experiência com câncer do colo do útero mostraram maior nível de conhecimento. Em outro estudo, 
médicos com mais de dez anos de formados, tenderam a tomar conduta insuficiente na realização do exame de Papanicolaou de acordo com o INCA $(p=0,016)$. (TUCUNDUVA et al., 2004)

Os principais motivos que levaram à realização do exame de Papanicolaou regularmente foram: o fato de ser um exame de rotina; de se ter consciência na prevenção; a vontade própria; por estar na idade de realizar e solicitação médica. O fato de o médico compartilhar informações sobre a doença, influenciou positivamente na realização de consulta de prevenção regularmente e realização do exame de Papanicolaou. Esses achados são concordantes com alguns estudos sobre o tema. No estudo de Coughlin e Uhler (2000), avaliando mulheres migrantes de ilhas do Pacífico nos EUA, entre outros fatores, ter tido consulta médica esteve associado à realização do exame de Papanicolaou nos últimos três anos. Em um estudo entre mulheres de origem vietnamita que viviam nos EUA, as variáveis que influenciaram positivamente $(\mathrm{p}<0,05)$ na realização do preventivo foram: ser casada; possuir recursos e provedor regular de cuidados de saúde; acreditar que a realização regular do Papanicolaou reduz o risco para desenvolver o câncer do colo do útero e acreditar que este é curável se detectado precocemente. (TAYLOR et al., 2004) Para mulheres colombianas os fatores que mais motivam na realização do exame são: autocuidado; preocupação pela família; e percepção de uma boa qualidade do serviço de saúde. (WISNER-CEBALLOS et al., 2006)

No Brasil, Yassoyama, Salomão e Vicentini (2005), observaram que mulheres que tiveram acesso às orientações sobre planejamento familiar e realização do exame de Papanicolaou, foram beneficiadas por ações e atividade da saúde da mulher desenvolvida na Unidade de Saúde da família. Em outro estudo com população semelhante, foi observado que o uso de tecnologias leves de comunicação aumentava o conhecimento das usuárias, por consequência, maior adesão à realização do exame de Papanicolaou. (OLIVEIRA; PINTO; COIMBRA, 2007) Outro estudo sugere que mulheres resistentes à realização de exame de Papanicolaou deveriam ser encaminhadas para médicas, pois isto poderia reduzir este efeito. No mesmo estudo, foi observado que o grande foco na prevenção levou às maiores taxas no rastreio do câncer do colo do útero para aquelas pacientes atendidas por médicas. (LURIE et al., 1997) 
Maior escolaridade também foi associada à realização adequada do exame de Papanicolaou. Estudando uma tribo indígena nos EUA, após intervenção educacional que incluiu conhecimentos sobre o câncer do colo do útero, foi encontrada associação entre a intenção $(\mathrm{OR}=4,56)$ e realização $(\mathrm{OR}=1,63)$ do exame de Papanicolaou no estrato populacional com maior nível educacional. (DIGNAN et al., 1998) Em outro estudo nos EUA, avaliando o nível de conhecimento sobre esta doença da população no geral, mulheres com mais de 12 anos de estudo iniciaram a prevenção na idade correta $12,8 \%$ mais do que aquelas com menos de 12 anos de estudo. Em relação à idade correta para suspensão do exame preventivo, a diferença foi de $27,5 \%$. A chance de sobrevivência se houvesse detecção precoce do câncer do colo do útero calculada para o grupo de maior escolaridade, seria $24,8 \%$ maior. (GAZIANO; HOROWITZ, 2001) Em um estudo populacional com mais de 100 mil mulheres indianas, entre outros fatores, níveis educacionais mais elevados estiveram associados ( $\mathrm{OR}=1,62$; IC 95\%: 1,50-1,80) com maior realização do exame de Papanicolaou. (NENE et al., 2007)

Descuidar-se, falta de tempo, considerar o exame desnecessário por não ter problemas ginecológicos, considerar o exame caro e medo de descobrir doença, foram os principais fatores para não realizar a prevenção adequadamente. Estes dados são corroborados por vários estudos. No estudo de Kawonga e Foon (2008), apesar da difusão da técnica do exame de Papanicolaou para todas as enfermeiras do setor público, em duas províncias sul-africanas, a meta de rastreamento foi cumprida apenas em $25 \%$ e $45 \%$, respectivamente. Outros fatores importantes observados para esse pobre resultado foram: falta do acesso ao tratamento após o diagnóstico de lesões precursoras do câncer; sobrecarga de trabalho das enfermeiras com o crescimento da população e consequente demanda, influindo na não realização do preventivo ou periodicidade incorreta; má distribuição dos profissionais pelo país e pouca habilidade na realização do exame por parte dessas profissionais.

Em outro estudo sul-africano entre profissionais da área da saúde, $93 \%$ dos entrevistados sabiam que o câncer do colo do útero era um problema de saúde pública, $68 \%$ achavam fácil de diagnosticar, e $65 \%$ das entrevistadas não se achavam susceptíveis, enquanto $66 \%$ dos entrevistados achavam que suas parceiras poderiam ser afetadas. Muitas enfermeiras e auxiliares achavam que o exame de Papanicolaou 
era um procedimento exclusivamente médico. Entre as entrevistadas as principais razões para não realização do exame foram: não se sentir com risco para a doença; não ter sintomas; descuido; medo da realização do exame; pouco interesse; achar que o exame é desnecessário ou estar fora da faixa de idade de risco. Além disso, $25 \%$ delas só aceitam ser examinadas por mulheres. Entre os estudantes de medicina, 35\% não achavam que podem realizar o exame, $26 \%$ não sabiam como realizar o exame, $22 \%$ achavam que deveria ser feito por médicos mais experientes e $15 \%$ nunca pensou a respeito. (MUTYABA; MMIRO; WEIDERPASS, 2006) No estudo de Tucunduva e colaboradores (2004) médicos brasileiros, quando questionados quanto a possíveis barreiras para o adequado exercício do rastreamento do câncer do colo do útero, consideraram que a falta de agentes educadores em saúde para a população $(82,9 \%)$ e sua própria falta de conhecimento ou treinamento para fazer esse tipo de rastreamento $(77,1 \%)$, são de grande importância.

Em estudos populacionais com mulheres de alto risco para desenvolverem o câncer do colo do útero nos EUA, o custo do exame (47\%) foi a principal barreira para realização do exame. (BURGER et al., 1995) Em outro estudo, as justificativas para a não a realização do preventivo foram: falta de motivação e vergonha ( $87 \%$ das mulheres diagnosticadas com NIC e $81 \%$ com câncer invasivo); falta de exame físico por parte do médico (60\% para todas as mulheres); tempo de espera longo para a consulta ( $48 \%$ das mulheres com NIC e $60 \%$ daquelas com câncer invasor); e agendamento tardio ( $47 \%$ das mulheres com NIC e $50 \%$ daquelas com câncer invasor). (BRENNA et al., 2001)

Em outro estudo, observou-se que inatividade sexual e medo de dor ou desconforto na realização do exame estavam associados à não realização do preventivo. (TAYLOR et al., 2004) No estudo conduzido por Wiesner-Ceballos et al. (2006), as principais barreiras para realização do Papanicolaou expressadas pelas mulheres foram: vergonha; medo de dor durante a realização do exame; desaconselhamento ou impedimento por parte do companheiro; desaconselhamento ou impedimento por parte das famílias principalmente entre aquelas mais jovens; e dificuldade de acesso aos serviços de saúde (tempo de espera para marcar o exame, custo para realização do exame, atraso na entrega do resultado, má relação com a equipe de saúde e relação médico-paciente prejudicada). Em recente artigo, Rogers e Cantu, (2009) afirmam que 
a falta de conhecimento sobre a infecção pelo HPV e o quanto o exame de Papanicolaou pode detectar anormalidades no colo do útero estão associados ao aumento do risco para desenvolvimento da doença.

No Brasil, num estudo em São Luis, Maranhão, as principais barreiras que estiveram associadas com a não realização do exame de Papanicolaou foram: não ter companheiro; menor escolaridade; viver em domicílio cujo chefe de família é trabalhador braçal e não ter realizado consulta médica nos últimos meses. (OLIVEIRA et al., 2006) Em outro estudo com mulheres atendidas em unidades básicas de Fortaleza, Ceará, as principais barreiras na realização do preventivo foram: vergonha em realizar o exame; desconforto da posição para realização do preventivo; medo de dor na realização do exame; medo do diagnóstico do câncer do colo do útero; realização do exame por profissional do sexo masculino; impedimento por parte do companheiro e dificuldades no acesso aos serviços de saúde (desinformação sobre a maneira da realização do exame, despesas para realização do exame, tempo de espera para agendar ou realizar o exame e falta de material para realizar o exame). (DUAVY et al., 2007) Na Bahia, analisando o discurso de mulheres atendidas no SUS, a falta de esclarecimento e conhecimento das mulheres sobre o seu corpo; implicava no não entendimento sobre o exame de Papanicolaou como relacionado à prevenção do câncer do colo do útero. Além disso, a dificuldade de acesso à assistência médica foi outro ponto importante na não realização do exame. (BARROS, 2005)

\section{Considerações finais}

Este estudo agrega algumas informações ao conhecimento corrente sobre atitudes de prevenção dos cânceres da mama e do colo do útero. Traz dados sobre o conhecimento prático das trabalhadoras de saúde sobre o assunto em relação às atuais diretrizes do INCA. Chama a atenção também como o meio pode interagir com fatores sociais e pessoais, podendo ser cruciais no entendimento de uma atitude preventiva.

Os principais motivos que levaram essas profissionais a realizar a mamografia regularmente foram à consciência da prevenção, estar na idade de realizar, por ser parte dos exames de rotina, solicitação médica e vontade própria. Nesta perspectiva, o conhecimento adequado sobre o câncer da mama, o acesso aos serviços de saúde através de 
convênio particular ou da empresa e tempo de serviço maior que 10 anos, contribuíram positivamente para a realização do exame. Para a minoria, que não realizava a prevenção como recomendada, as principais barreiras foram: descuido de sua saúde; falta de tempo; custo do exame e medo de ser mal tratada durante a realização do exame. Quanto ao câncer de colo do útero, os principais motivos que levaram essas profissionais a realizar o exame preventivo foram: ser parte dos exames de rotina; consciência da prevenção; vontade própria; estar na idade de realizar e solicitação médica. Nesta perspectiva, o compartilhamento de informações sobre o câncer do colo do útero pelo médico e maior escolaridade, contribuíram positivamente para a realização do exame. Para a minoria que não realizava a prevenção como recomendada, as principais barreiras foram: descuido falta de tempo; considerar o exame desnecessário por não ter problemas ginecológicos; custo do exame e medo de descobrir doença.

Em conclusão, encontrou-se uma atitude positiva das trabalhadoras da área de saúde quanto à prevenção dos cânceres da mama e do colo do útero. Recomenda-se, entretanto, cautela quanto à generalização desses resultados mesmo para outras trabalhadoras da saúde, em função de algumas importantes limitações do estudo. Citam-se, principalmente, o tamanho da população estudada e as perdas. Outros estudos com maior número de profissionais são necessários para corroborar os resultados aqui evidenciados. É importante, o incentivo das instituições formadoras e os locais de trabalho dessas profissionais, tanto no setor privado como no público, para a educação continuada. Isso também é importante para elas e para que haja o repasse de informações corretas sobre a detecção precoce dessas doenças para a população no geral.

\section{Referências}

AGARWAL, G. et al. Spectrum of breast cancer in Asian women. World Journal of Surgery, v. 31, n. 5, p. 1031-1040, 2007.

ALDRICH, T. et al. Mexican physicians' knowledge and attitudes about the human papillomavirus and cervical cancer: a national survey. Sexually Transmitted Infections, v. 81, p. 135-141, 2005. 
ALDRICH, T. Cervical cancer and HPV link: Identifying areas for education in Mexico City's public hospital. Salud Pública de México, v. 48, n. 3, p. 236-43, 2006.

ALTPETER, M.; MITCHELL, J.; PENNELL, J. Advancing Social Workers' Responsiveness to Health Disparities: The Case of Breast Cancer Screening. Health \& Social Work, v. 30, n. 3, p. 221-232, 2005.

BARROS, D. O. S. Mulheres com câncer invasivo do colo do útero: estratégias de enfrentamento. 2005, 148f. Dissertação (Mestrado em enfermagem). Programa de Pós-Graduação da Escola de Enfermagem, Universidade Federal da Bahia, 2005.

BEGHINI, A. B. et. al. Adesão das acadêmicas de enfermagem à prevenção do câncer ginecológico: da teoria à prática. Texto \& Contexto Enfermagem, v. 15, n. 4, p. 637-644, 2006.

BRASIL. Instituto Nacional de Câncer / Ministério da Saúde. Tipos de câncer: Mama. Disponível em: <http://www2. inca. gov. br/wps/wcm/ connect/tiposdecancer/site/ home/ mama> Acesso em: 12 dez. 2011.

. Instituto Nacional do Câncer / Ministério da Saúde.

Tipos de câncer: Colo do Útero. 2011a. Disponível em: < http:// www2. inca. gov. br/wps/wcm/connect/ tiposdecancer/ site/home/colo_utero>. Acesso em: $12 \mathrm{dez} .2011$.

. Instituto Nacional de Câncer/ Ministério da Saúde. Estimativa 2012: Incidência de Câncer no Brasil. 2011b. Disponível em: < http:// www. inca. gov. br/estimativa/2012/>. Acesso em: 06 mar. 2012.

BRENNA, S. M. F. et al. Conhecimento, atitude e prática do exame de Papanicolaou em mulheres com câncer do colo uterino. Cadernos de Saúde Pública, Rio de Janeiro, v. 17, n. 4, p. 909-914, 2001.

BRODY, J. G.; TICKNER, J.; RUDEL, R. A. Community-Initiated Breast Cancer and Environment Studies and Precautionary Principle. Environmental Health Perspectives, v. 113, n. 8, p. 920-925, 2005.

BURGER, R. A. et al. Single-Visit Program for Cervical Cancer Prevention in a High-Risk Population. Obstetrics \& Gynecology, v. 86, n. 4, p. 491-8, 1995.

CASTRO-JIMÉNEZ, M. A.; VERA-CALA, L. M.; POSSO-VALENCIA, H. J. Epidemiología del cáncer de cuello uterino: Estado del arte. Colombiana de Obstetricia y Ginecología, v. 57, n. 1, p. 182-189, 2006.

COSTA, J. S. D. da et al. Cobertura do exame citopatológico na cidade de Pelotas, Brasil. Panamericana Salud Publica, v. 3, n. 5, p. 308-313, 1998. 
COUGHLIN, S. S.; UHLER, R. J. Breast and Cervical Cancer Screening Practices among Asian and Pacific Islander Women in the United States, 1994-1997. Cancer Epidemiology

Biomarkers Prevention, n. 9, p. 597-603, 2000.

CRUZ, L. M. B. da; LOUREIRO, R. P. A Comunicação na Abordagem Preventiva do Câncer do Colo do Útero: importância das influências histórico-culturais e da sexualidade feminina na adesão às campanhas. Saúde e Sociedade, v. 17, n. 2, p. 120-31, 2008.

DELUCA, G. D. et al. Human papilomavirus in women with cervical cytological abnormalities from an area with high incidence of cervical cancer. Instituto de Medicina Tropical, São Paulo, v. 46, n. 1, p. 9-12, 2004.

DIGNAN, M. B. et al. Health education to increase screening for cervical cancer among Lumbee Indian Women in North Caroline. Health Education Research, v. 13, n. 4, p. 545-556, 1998.

DUAVY, L. M. et al. A percepção da mulher sobre o exame preventivo do câncer cérvico-uterino: estudo de caso. Ciência \& Saúde Coletiva, v. 12, n. 3, p. 733-742, 2007.

FERREIRA, M. L. M.; OLIVEIRA, C. Conhecimento e significado para funcionárias de indústrias têxteis sobre prevenção do câncer do colo-uterino e detecção precoce do câncer da mama. Revista Brasileira de Cancerologia, v. 52, n. 1, p. 5-15, 2006.

FOX, S. A.; SIU, A. L.; STEIN, J. A. The importance of physician communication on breast cancer screening of older women. Archives of Internal Medicine, v. 154, n. 18, p. 2058-2068. 1994.

GAZIANO, C.; HOROWITZ, A. Knowledge Gap on Cervical, Colorectal Cancer Exist Among U. S. Women. Newspaper Research Journal, v. 22, n. 1, p. 12-27, 2001.

GODINHO, E. R.; KOCH, H. A. Rastreamento do câncer de mama: aspectos relacionados ao médico. Radiologia Brasileira, v. 37, n. 2, p. 91-99, 2004.

GONZÁLEZ-SALINAS, C. et al. Conocimientos y actitudes de trabajadoras de salud em torno al programa de detección oportuna de cáncer cérvico-uterino. Atención Primaria, v. 18, n. 5, p. 237-42, 1996.

JAIN, N. et al. Family Physicians' Knowledge of Genital Human Papillomavirus (HPV) Infection and HPV-related Conditions, United States, 2004. Family Medicine, v. 38, n. 7, p. 483-489, 2006.

JOHNSON, K. M. et al. Inner city primary care provider's breast cancer screening knowledge: implications for intervention. Journal of Community Health, v. 23, n. 1, p. 1-13, 1998. 
KAWONGA, M.; FONN, S. Achieving effective cervical screening coverage in South Africa through human resources and health systems development. Reproductive Health Matters Journal, v. 16, n. 32, p. 32-40, 2008.

KERLIKOWSKE, K. Evidence-Based Breast Cancer Prevention: The Importance of Individual Risk. Annals of Internal Medicine, v. 151, n. 10, p. 750-752, 2009.

LEGLER, J. et al. The Effectiveness of Interventions to Promote Mammography among Women with Historically Lower Rates of Screening. Cancer Epidemiology, Biomarkers \& Prevention, n. 11, p. 59-71, 2002.

LUQUIS, R. R.; CRUZ, I. J. Knowledge, attitudes, and perceptions about breast cancer and breast cancer screening among Hispanic women residing in south central Pennsylvania. Journal of Community Health, v. 31, n. 1, p. 25-42, 2006.

LURIE, N. et al. Why Do Patients of Female Physicians Have Higher Rates of Breast and Cervical Cancer Screening? Journal of General Internal Medicine, n. 12, p. 34-43, 1997.

MURTA, E. F. C. et al. Câncer do Colo uterino: correlação com o início da atividade Sexual e Paridade. Revista Brasileira de Ginecologia e Obstetrícia, v. 21, n. 9, p. 555-559, 1999.

MUTYABA, T.; MMIRO, F. A.; WEIDERPASS, E. Knowledge, attitudes and practices on cervical screening among the medical workers of Mulango Hospital, Uganda. BMC Medical Education, v. 6 , n. 13, 2006. Disponível em: <http://www. biomedcentral. com/1472-6920/6/13 >. Acesso em: 25 ago. 2009.

NENE, B. et al. Determinants of women's participation in cervical screening trial, Maharashtra, India. Bulletin of the World Health Organization, n. 85, p. 264-272, 2007.

OLIVEIRA, M. M. H. N. et al. Cobertura e fatores associados a não realização do exame preventivo de Papanicolaou em São Luís, Maranhão.

Revista Brasileira de Epidemiologia, v. 9, n. 3, p. 325-34, 2006.

; PINTO, I. C.; COIMBRA, V. C. C. Potentialities in integral care: uterine cervical cancer prevention according to the users of the family health strategy. Revista LatinoAmericana de Enfermagem, v. 15, n. 3, p. 426-30, 2007.

PARSA, P.; KANDIAH, M. Breast cancer knowledge, perception and breast self-examination practices among Iranian women. The International Medical Journal, v. 4, n. 2, p. 17-24, 2005. 
PINHO, A. A.; MATTOS, M. C. F. I. Validade da citologia cervicovaginal na detecção de lesões pré-neoplásicas e neoplásicas de colo de útero. Jornal Brasileiro de Patologia e Medicina Laboratorial, v. 38, n. 3, p. 225-231, 2002.

POWE, B. D. et al. Perceptions About Breast Cancer Among College Students: Implications for Nursing Education. Journal of Nursing Education, v. 44, n. 6, p. 257-265, 2005.

RODRÍGUEZ, M. A.; WARD, L. M.; PÉREZ-STABLE, E. J. Breast and Cervical Cancer Screening: Impact of Health Insurance Status, Ethnicity, and Nativity of Latinas. Annals of Family Medicine, v. 3, n. 3, p. 235-241, 2005.

ROETZHEIM, R. G.; FOX, S. A.; LEAKE, B. The effect of risk on changes in breast cancer screening rates in Los Angeles, 1988-1990. Cancer, v. 74, n. 2, p. 625-631, 1994.

ROGERS, N. M.; CANTU, A. G. The Nurse's in the Prevention of Cervical Cancer Among Underserved and Minority Populations. Journal of Community Health, v. 34, p. 135-143, 2009.

SCHONBERG, M. A. et al. Factors influencing elderly women's mammography screening decisions: implications for counseling. BMC Geriatrics, n. 7, p. 26, 2007. Disponível em <http://www. biomedcentral. com/1471-2318/7/26> . Acesso em: 22 fev. 2012.

SEAH, M.; TAN, S. M. Am I breast cancer smart? Assessing breast cancer knowledge among healthcare professionals. Singapore Medical Journal, v. 48, n. 2, p. 158-62, 2007.

SOUZA, R. M. et al. História Familiar em Segundo Grau como Fator de Risco para Câncer de Mama. Revista Brasileira de Ginecologia e Obstetrícia, v. 20, n. 8, p. 469-473, 1998.

SPSS Inc, Chicago, IL, 2004. Disponível em:<http://www. manta. com/c/mm7z120/spss-inc > Acesso em: 25 fev. 2012.

TAYLOR, V. M. et al. PapTestingAdherenceAmongVietnamese American Women. Cancer Epidemiology, Biomarkers \& Prevention, v. 13, n. 4, p. 613-619, 2004.

THOMPSON, B.; MONTAÑO, D. E.; MAHLOCH, J. Attitudes and Beliefs Toward Mammography Among Women Using an Urban Public Hospital. Journal of Health Care for the Poor and Underserved, v. 8, n. 2, p. 186-201, 1997.

TUCUNDUVA, L. T. C. et al. Estudo da atitude e do conhecimento dos médicos não oncologistas em relação às medidas de 
prevenção e rastreamento do câncer. Revista da Associação

Médica Brasileira, v. 50, n. 3, p. 257-262, 2004.

VALDEZ, A. et al. A multimedia breast cancer education intervention for lowincome Latinas. Journal of Community Health, v. 27, n. 1, p. 33-51, 2002.

VANSLYKE, J. G. et al. HPV and Cervical Cancer Testing and

Prevention: Knowledge, Beliefs, and Attitudes Among Hispanic Women.

Qualitative Health Research, v. 18, n. 5 p. 584-596, 2008.

WISNER-CEBALLOS, C. et al. La Citología de Cuello Uterino em Soacha, Colombia: Representaciones Sociales, Barreras y Motivaciones. Revista Salud Pública, v. 8, n. 3, p. 185-96, 2006.

YASSOYAMA, M. C. B. M.; SALOMÃO, M. L. M.; VICENTINI, M. E. Características das mulheres que realizam exame preventivo do colo de útero durante a gestação: bases para estratégias do Programa de Saúde da Família (PSF). Revista Arquivo Ciências da Saúde, v. 12, n. 4, p. 172-176, 2005.

YI, J. K.; LUONG, K. N. T. Apartment-based Breast Cancer Education Program for Low Income Vietnamese American Women. Journal of Community Health, v. 30, n. 5, p. 345-353, 2005. 



\section{Comportamento de industriários quanto à prevenção do câncer da próstata}

André Luis Santos Virgulino Marco Antônio Vasconcelos Rêgo

\section{Introdução}

A saúde do homem vem sendo vista com mais atenção na atualidade. Diversos são os agravos à saúde que possuem grande importância no sexo masculino. Dentre esses, destacam-se os problemas cardiovasculares e os tumores. Entre as neoplasias, o câncer da próstata é um problema de saúde pública de abrangência mundial, e sua incidência anual, padronizada por idade, é de aproximadamente 25,3 casos por 100.000 . (CRAMER, 2007) No Brasil, a incidência é de 52,4 casos por 100.000, ou seja, o dobro da taxa mundial. (INCA, 2005) Em 2008, esta doença foi responsável pela morte de 258.381 homens em todo o mundo. No Brasil, é a segunda causa de morte por câncer entre homens, e desde o ano de 2002 é a primeira na Bahia. (GLOBOCAN, 2008; INCA, 2009)

Parte do aumento na incidência do câncer da próstata é decorrente do aumento da expectativa de vida, e consequentemente do envelhecimento da população, visto que esta neoplasia tem a idade avançada como um dos seus fatores de risco. No Brasil, entre os anos de 1980 e 2005, a expectativa de vida para os homens cresceu de 59,7 para 68,2 anos, ou seja, quase nove anos a mais de vida, decorridos apenas 26 anos. (IBGE, 2009) As neoplasias da próstata são raras antes dos 50 anos e sua incidência aumenta com a idade. Quase $50 \%$ dos indivíduos com 80 anos e, estima-se que, 100\% dos indivíduos que chegaram aos 100 anos têm câncer da próstata, porém, em um número elevado de indivíduos, a doença se apresenta sem sintomas importantes. (SROUGI, 1997) 
A prevenção primária do câncer da próstata é uma tarefa difícil, pois os fatores mais fortemente associados com a doença não são modificáveis, a saber: idade, raça e história familiar. Entre esses, a idade parece ser o mais importante. Outros fatores de risco considerados modificáveis como: vida sedentária; hábitos alimentares; obesidade; tabagismo e alcoolismo também têm sido estudados. (LIU et al., 2000; NORMAN et al., 2002; ROBINSON et al., 2005)

A fase inicial do câncer da próstata é assintomática e já que a prevenção primária ainda não é possível, deve-se trabalhar na prevenção secundária, através da detecção precoce, ou seja, do rastreamento de homens assintomáticos por meio da realização do exame digital retal (EDR) (toque retal como é mais conhecido) e pela dosagem do antígeno prostático específico (PSA). O PSA é uma proteína produzida exclusivamente pela próstata, que se eleva de maneira significativa nos casos de câncer. O EDR é relativamente indolor, ainda insubstituível e presta ao médico importantes informações como: estado do esfíncter anal; estado das fezes dentro do reto; presença de tumores do reto; presença de dor na próstata, vesículas seminais e reto, que podem indicar inflamação; tamanho da próstata; presença de nódulos suspeitos de câncer da próstata; consistência da próstata (dura, mole ou elástica); e estado das bordas, limites e simetria da próstata. (LEFORT; ALMEIDA, 2004) $\mathrm{Na}$ fase mais avançada da doença, os primeiros sintomas são: dificuldade para urinar, jato urinário fraco e aumento do número de micções. (SBU, 2009)

Algumas controvérsias existem sobre a detecção precoce do câncer da próstata.

Embora esses exames possam detectar o câncer da próstata em seus estádios
iniciais, as evidências científicas não permitem concluir se tal detecção reduz
a mortalidade por esse câncer ou melhora a qualidade de vida dos pacientes.
Apesar da detecção e do tratamento precoce prevenirem a progressão do
câncer e o aparecimento de metástases, também é possível que sejam detec-
tados tumores que teriam um crescimento muito lento e que não causariam
problemas à saúde do homem. (INCA, 2005)

Entretanto, admite-se que o diagnóstico precoce aumenta as chances de cura. De $70 \%$ a $98 \%$ dos pacientes são curados quando a doença ainda está alojada dentro da glândula. (SROUGI, 1997) 
Sob a ótica da eficácia, o EDR falha em $30 \%$ a $40 \%$ dos pacientes e o PSA em $20 \%$. O PSA feito em paralelo ao EDR falha em apenas $5 \%$ dos casos, o que justifica a necessidade de realização de ambos os testes. (SROUGI, 1997) Os protocolos internacionais são divergentes sobre os exames e suas combinações para a detecção precoce, porém a maioria inclui o EDR como um dos escolhidos e muitas vezes combinado com a dosagem do PSA. No Brasil, a Sociedade Brasileira de Urologia (SBU) recomenda a realização de exame médico anual, incluindo o EDR, a dosagem sérica do PSA e a dosagem sérica da fração prostática da fosfatase ácida para homens entre 45 e 70 anos de idade, ou a partir dos 40 anos se houver história familiar de câncer da próstata.

Durante séculos, a diferença entre os gêneros foi baseada na relação anatomofisiológica, onde a mulher era vista como o homem invertido. Neste processo, o modelo de perfeição estava representado na anatomia masculina, onde a regra fálica distinguia perfeitamente o domínio de superioridade masculina sobre a feminina. Foi na passagem do século XVIII para o XIX que esta visão mudou e a relação passou a ser a político-ideológica, e as diferenças passaram a ser morais e comportamentais. Neste ponto, a diferença anatômica dos sexos é usada para fundar a diferença de gêneros masculino e feminino, e a partir daí uma série de regras, papéis e traços foram construídos para representar a condição do masculino e do feminino. (ALVES, 2001)

Assim, o masculino é tudo o que se contrapõe ao feminino e para garantir essa soberania, a masculinidade é sempre definida e associada à virilidade, ao poder, à imponência, ao não curvar-se, ao não submeter-se e, assim, seria desonroso para o homem: submeter-se; ser passivo; ficar por baixo; ser impotente; ficar recluso ou restrito no convívio social ou ser invadido. (BOURDIEU, 1999; ALVES, 2004) Porém, levando em consideração o câncer de próstata, estes mesmos aspectos comportamentais e culturais que o enaltecem, são os mesmos que podem contribuir para a ocorrência de desfechos desfavoráveis.

Um dos aspectos que seguramente contribui para a detecção do câncer da próstata é a atitude de muitos homens quanto ao cuidado da saúde como um todo, e no particular quanto aos medos e crenças em torno do EDR. O ambiente de trabalho industrial, por conter normalmente um número maior de homens e atividades que por vezes requerem força física, salienta o comportamento machista que permeia 
a sociedade, e esse comportamento termina por interferir diretamente na relação do trabalhador com a sua saúde.

Dois estudos realizados em ambientes de trabalho encontraram evidências do impacto desse tipo de comportamento no cuidado que os homens dedicam à sua saúde. O primeiro foi realizado com trabalhadores do porto de Santos, em São Paulo, para avaliar a relação do trinômio homem/trabalho/saúde, e reafirmou o modelo ocidental hegemônico de masculinidade, a partir da visão destes trabalhadores sobre o cuidado com a saúde. Para eles, homem é sinônimo de força, virilidade e invulnerabilidade. Nesse contexto, não se permitem estar doentes, e mais, admitem que o cuidado seja algo da natureza feminina. Em seus diálogos, expressam que a saúde é a própria condição de trabalho e a doença é o impedimento para este. A doença os colocaria em um lugar marginal, com risco de perda do trabalho, e consequentemente, da sua condição de provedor. (MACHIN; COUTO; ROSSI, 2009)

O segundo estudo, realizado na Finlândia, avaliou a relação homem, masculinidade e alimentação, comparando engenheiros e carpinteiros. Os resultados apontaram para um comportamento machista mais evidente entre os carpinteiros, justificado pela necessidade de vigor e boa condição física para a realização do seu trabalho, normalmente manual, e diferente do trabalho "leve" dos engenheiros. Os carpinteiros relacionaram o corpo a uma máquina e sua alimentação ao combustível necessário para esta máquina operar. Assim, informaram que enquanto homens necessitam de alimentação pesada, como carne bovina, afirmaram que conhecem os benefícios de uma alimentação mais saudável, rica em vegetais, mas que esta alimentação é coisa de mulher. Os engenheiros também expressaram um consumo de carne, citando o peixe e o frango como alternativas de substituição da carne bovina, além da inclusão de vegetais em suas dietas. (ROOS; PRÄTTÄLÄ; KOSKI, 2001)

Um estudo canadense recente encontrou um menor percentual de homens com idade entre 40 e 60 anos (65\%) quando comparado a mulheres na mesma faixa etária $(79 \%)$ que tenham discutido ou realizado o exame diagnóstico para câncer da próstata ou mamografia, respectivamente. (MCCREARY; GRAY; GRACE, 2006) Não existem no Brasil estudos que façam uma relação entre realização e não realização do EDR como teste de detecção precoce desta neoplasia. Porém, 60\% a 
$70 \%$ dos casos são diagnosticados quando a doença já está disseminada e o tratamento já não é muito eficaz. (SROUGI, 1997)

Muitos são os fatores que poderiam estimular ou inibir um homem a fazer este exame diagnóstico. Alguns estudos realizados no Brasil, Chile, Alemanha e Estados Unidos, já identificaram alguns fatores impeditivos: preocupação quanto ao desconforto físico; embaraço; preocupação com o resultado anormal e crença em algum tipo de distúrbio sexual; falta de tempo, ausência de sintomas urológicos e ausência de dor ou desconforto; falta de informação avaliada em estudos de intervenção; e a masculinidade, sob seus mais variados elementos. (MYERS et al., 1996; NASCIMENTO, 2000; KISS; MERYN, 2001; LUCUMI; CABRERA, 2003; WEIRINCH et al., 2003; KEIJER, 2003; MIRANDA et al., 2004; GOMES, 2008) Como promotores, os já estudados foram: benefício pessoal e presença de sintomas urológicos; educação e informação; e ter histórico familiar. (MYERS et al., 1996; TAYLOR et al., 1999; LEFORT; ALMEIDA, 2004; GOMES; NASCIMENTO; ARAÚJO, 2007)

Muitos outros prováveis fatores impeditivos ou seus desdobramentos ainda não foram bem avaliados, tais como: medo do exame; preconceito; ser muito saudável; descuido pessoal; confiança no resultado do PSA; não ter histórico familiar; falta de acesso à assistência médica; constrangimento com o exame; medo de ficar excitado; desconhecimento da doença; medo da violação anal; custo com o exame; resistência a ir ao médico; achar que cuidados com a saúde é coisa de mulher; vergonha de ficar exposto a outro homem; medo de mudança de orientação sexual; falta de conhecimento do exame; falta de cobertura do plano de saúde; horário do médico inconveniente (mesmo horário do trabalho); não saber que tipo de médico procurar; não saber aonde ir; recusar-se a ir; medo da impotência; ou achar que não precisa do exame. Da mesma forma que os seguintes prováveis promotores: influência de familiares amigos, colegas de trabalho, esposa ou companheiro; solicitação médica; decisão própria; atendimento às campanhas veiculadas em jornais, revistas, televisão, rádio; por consciência da importância do exame para o diagnóstico e saúde; estar na idade de fazer; ou fazer parte de um exame geral de rotina.

No Brasil, há escassez de estudos sobre essa temática, cujos resultados possam indicar a realização de ações voltadas à redução do número de casos diagnosticados em estágios avançados e redução da 
letalidade. O presente estudo visa avaliar o comportamento dos homens quanto à prevenção do câncer de próstata, tomando-se como referência um grupo de trabalhadores da indústria. Essa investigação está em consonância com um dos atuais objetos de atenção do Ministério da Saúde: a saúde do homem. Esse estudo se alinha também a dois dos eixos do Plano de Ação Nacional - PAN (2009), vinculado à Política Nacional de Atenção Integral à Saúde do Homem, qual sejam: a promoção da saúde, informação e comunicação. (BRASIL, 2009a; 2009b)

\section{Notas metodológicas}

Trata-se de um estudo de corte transversal que incluiu 69 trabalhadores com idades entre 42 e 65 anos, pertencentes a três indústrias do Complexo Petroquímico de Camaçari (COPEC). Todos os indivíduos responderam um questionário padronizado e autoaplicável baseado no Modelo de Crenças em Saúde (MCS) de Rosentock, desenvolvido na década de 50. (ROSENTOCK, 1996) Esse modelo prima pela avaliação do comportamento de prevenção em saúde a partir da percepção de cinco dimensões: susceptibilidade; severidade; autoeficácia; benefícios e barreiras para a ação. Além disso, avalia as variáveis demográficas, sociopsicológicas e estruturais.

Como não foram encontrados modelos completos e validados para uso em português, construiu-se um modelo com base em outros três: um sobre prevenção do câncer da próstata; um sobre o câncer da mama; e outro sobre a prevenção de acidentes com agulha. (BREVIDELLI; CIANCIARULLO, 2001; MOORE; BOYLE, 2002; YAN, 2009) O conteúdo das afirmações foi baseado no conhecimento dos pesquisadores e nos fatores identificados nos estudos sobre as barreiras e soluções no comportamento de prevenção encontrado na literatura.

Por se tratar de um instrumento novo, foi realizada uma validação de conteúdo por dois urologistas e uma avaliação de clareza, especificidade e compreensão por dois indivíduos, que atendiam aos critérios de inclusão da pesquisa, mas que não pertenciam ao grupo a ser investigado. Todas as necessidades de revisão identificadas foram reavaliadas. O instrumento final continha 26 questões divididas em quatro partes: características socioeconômicas e culturais; conhecimento sobre 
a doença; características e comportamentos de saúde; e fatores modificadores do comportamento.

As respostas à grande maioria das perguntas foram de escolha simples ou múltipla, dentro de uma lista pré-definida. As respostas aos itens de crença foram obtidas com quatro pontos em escalas tipo Likert (discordo totalmente, discordo, concordo e concordo totalmente). Os valores das escalas do MCS no questionário foram estruturados na direção positiva, ou seja, quanto maior o valor da escala maior a sua percepção.

Os questionários foram entregues aos trabalhadores selecionados pelos médicos do trabalho de suas respectivas empresas. Depois de preenchidos (duração média de 30 minutos), os questionários foram lacrados e guardados em uma pasta. Os dados foram transferidos para uma base de dados sem a identificação dos participantes, havia apenas uma chave de correlação que ficou sobre a guarda dos pesquisadores/ coordenadores. Esta base foi avaliada para certificação da correta transcrição das informações.

Durante a análise, formaram-se dois grupos de indivíduos: trabalhadores que realizaram o EDR e o PSA anualmente (Grupo A) e trabalhadores que só fizeram um ou nenhum deles (Grupo B). Foram realizadas análises descritivas (frequência, média e desvio padrão) para os dados do perfil da população, do conhecimento e do comportamento de saúde. A análise da relação entre as crenças e o comportamento de realização dos exames, foi feita através do cálculo das razões de prevalência.

Para a verificação da validade e confiabilidade das escalas do MCS, utilizou-se o alfa de Cronbach. Para a confirmação de que a escala realmente mede o que se dispõe, foi adotado o critério do $\alpha \geq 0,75$. Desta maneira, a escala severidade para o grupo A e as escalas susceptibilidade, severidade e autoeficácia para o grupo $B$, não demonstraram medir o que se propunha. Assim, a análise foi feita por afirmativa, e não somente pela dimensão. Para a análise das diferenças das médias entre as afirmativas das escalas do modelo, foi utilizado o teste de Mann-Whitney. Utilizou-se o software SPSS (Statistical Package for the Social Sciences) versão 17.0.

O projeto foi aprovado pelo Comitê de Ética em Pesquisa do Instituto de Saúde Coletiva da Universidade Federal da Bahia, através do 
Parecer $n^{\circ}$ 031/2010. Além disso, todos os participantes da pesquisa assinaram um Termo de Consentimento Livre e Esclarecido, que continha os objetivos do estudo, procedimentos, riscos e proposta de minimização, benefícios, sigilo e privacidade, além da informação de participação voluntária. Os termos de consentimento foram arquivados em uma pasta que foi posteriormente lacrada, de modo a garantir o sigilo das informações.

\section{Resultados}

Os trabalhadores eram na sua maioria brancos, casados, que moram com esposa ou esposa e filhos, católicos, com até o ensino médio de escolaridade e que possuem em média dois filhos. Eles trabalham principalmente em horário administrativo, têm uma média de 22 anos na indústria, com uma renda familiar entre $\mathrm{R} \$ 2.400,00$ e $\mathrm{R} \$ 5.100,00$. Uma comparação entre os homens dos grupos A e B demonstrou uma diferença apenas para a idade, os homens do grupo A tinham idade média de 51,3 anos e os do grupo B, 46,1 anos (Tabela 1).

Tabela 1 - Distribuição dos indivíduos segundo variáveis sociodemográficas e realização de exames para detecção do câncer da próstata. Salvador, 2011.

\begin{tabular}{l|l|l|l} 
& \multirow{2}{*}{ Características } & \multirow{2}{*}{ Total (\%) } & \multicolumn{2}{c}{ PSA + EDR (anual) } \\
\cline { 3 - 4 } & & \multicolumn{1}{c}{ Sim (\%) } & \multicolumn{1}{c}{ Não (\%) } \\
\hline Idade (média em anos) & 48,0 & 51,3 & 46,1 \\
\hline Estado Civil & & & \\
\hline Casado & $53(81,5)$ & $20(83,3)$ & $33(80,5)$ \\
\hline Não casado & $12(18,5)$ & $04(16,7)$ & $08(19,5)$ \\
\hline Escolaridade & & & \\
\hline Até o ensino médio & $42(63,6)$ & $16(66,7)$ & $26(61,9)$ \\
\hline Superior \& Pós-graduação & $24(36,4)$ & $08(33,3)$ & $16(38,1)$ \\
\hline Cor ou Raça & & & \\
\hline Branca & $27(42,2)$ & $07(30,4)$ & $20(48,8)$ \\
\hline Parda & $24(37,5)$ & $08(34,8)$ & $16(39,0)$ \\
\hline Negra & $13(20,3)$ & $08(34,8)$ & $05(12,2)$ \\
\hline Outras & --- & -- & -- \\
\hline Número médio de filhos & 1,9 & 2,2 & 1,78 \\
\hline
\end{tabular}




\begin{tabular}{l|l|l|l}
\hline Com quem mora & & & \\
\hline Esposa \& esposa e filhos & $56(84,8)$ & $22(91,7)$ & $34(81,0)$ \\
\hline Outros & $10(15,2)$ & $02(8,3)$ & $08(19,0)$ \\
\hline Religião ou Culto & & & \\
\hline Católico & $48(70,6)$ & $20(80,0)$ & $28(65,1)$ \\
\hline Não católico & $17(25,0)$ & $05(20,0)$ & $12(27,9)$ \\
\hline Nenhuma/Ateu & $03(4,4)$ & --- & $03(7,0)$ \\
\hline Jornada de Trabalho & & & \\
\hline Administrativo & $56(82,4)$ & $23(92,0)$ & $33(76,7)$ \\
\hline Turno & $12(17,6)$ & $02(8,0)$ & $10(23,3)$ \\
\hline Noturno & --- & --- & --- \\
\hline Renda Familiar & & & \\
\hline$<\mathrm{R} \$ 2.040,00$ & $14(21,2)$ & $05(21,7)$ & $09(21,0)$ \\
\hline R\$2.041,00 - 5.100,00 & $23(34,8)$ & $08(34,8)$ & $15(34,8)$ \\
\hline R\$ 5.101,00 - 10.200,00 & $19(28,8)$ & $07(30,4)$ & $12(27,9)$ \\
\hline$>$ R\$ 10.200,00 & $10(15,2)$ & $03(13,1)$ & $07(16,3)$ \\
\hline Tempo médio de trabalho na indústria (anos) & 22,0 & 24,6 & 20,7 \\
\hline
\end{tabular}

Fonte: (VIRGULINO; RÊGO, 2011)

\section{Informação em saúde e conhecimento da doença}

Cerca de dois terços dos indivíduos obtém informação ou conselho de como tratar de sua saúde com o médico. Em seguida aparece a esposa ou companheira $(27,9 \%)$. As principais fontes de informação sobre o câncer da próstata foram: jornal ou revista; televisão ou rádio; e médico ou profissional de saúde $(88,4 \%)$. Amigos apareceram em segundo lugar $(75,4 \%)$, seguidos da internet $(65,2 \%)$ e dos familiares $(59,4 \%)$. Dois participantes responderam que não tinham informações sobre esta neoplasia. Como resultado da autoavaliação, 46,2\% dos homens consideraram seu conhecimento como bom e $30,8 \%$ como muito bom ou excelente. Apenas $23,0 \%$ acreditaram ter pouco ou muito pouco conhecimento sobre o câncer da próstata (Tabela 2).

A média geral de acertos obtidos com o questionário de conhecimento foi de $78,6 \%$, e mesmo na comparação entre o Grupo A e B, a diferença entre as médias gerais de acertos é muito pequena, conforme Tabela 2. Os itens deste questionário que apresentaram as menores 
pontuações foram aqueles relativos aos fatores de risco, prevenção e sintomatologia do câncer da próstata. Quanto a esse último aspecto, chamou a atenção, a baixa proporção média de acertos $(21,7 \%)$. No cômputo geral, o grupo A, apresentou frequências médias de acertos mais que $10 \%$ maiores que o grupo B. Mesmo com a expressiva proporção de conhecimento demonstrado, 92,2\% dos respondentes gostariam de obter mais informações sobre esta doença.

Tabela 2 - Distribuição dos indivíduos segundo variáveis relacionadas ao conhecimento sobre o câncer da próstata. Salvador, 2011.

\begin{tabular}{l|l|l|l} 
& \multicolumn{3}{|c}{ Acertos (\%) } \\
\cline { 2 - 4 } \multicolumn{1}{c|}{ Afirmativa } & \multicolumn{1}{c}{ Total } & \multicolumn{1}{c}{$\begin{array}{c}\text { PSA + EDR } \\
\text { (anual) }\end{array}$} \\
\cline { 3 - 4 } & & \multicolumn{1}{c}{ Sim } & \multicolumn{1}{c}{ Não } \\
\hline $\begin{array}{l}\text { O câncer de próstata é o tipo de câncer mais comum entre os } \\
\text { homens no Brasil. (V) }\end{array}$ & 87,0 & 88,0 & 86,4 \\
\hline $\begin{array}{l}\text { O toque retal é um exame importante no diagnóstico do câncer } \\
\text { de próstata. (V) }\end{array}$ & 98,6 & 100,0 & 97,7 \\
\hline $\begin{array}{l}\text { O “PSA" é um exame de sangue utilizado no diagnóstico do } \\
\text { câncer de próstata. (V) }\end{array}$ & 92,8 & 100,0 & 88,6 \\
\hline $\begin{array}{l}\text { Alguns homens podem ter o câncer de próstata e não ter co- } \\
\text { nhecimento disso. (V) }\end{array}$ & 95,7 & 88,0 & 100,0 \\
\hline $\begin{array}{l}\text { O câncer de próstata pode ser curado se for descoberto (diag- } \\
\text { nosticado) logo no início. (V) }\end{array}$ & 97,1 & 100,0 & 95,5 \\
\hline $\begin{array}{l}\text { O câncer de próstata pode ser prevenido pela realização regular } \\
\text { de exercícios físicos. (F) }\end{array}$ & 68,1 & 76,0 & 63,6 \\
\hline O fumo contribui para o surgimento do câncer de próstata. (F) & 50,7 & 44,0 & 54,5 \\
\hline $\begin{array}{l}\text { A bebida alcoólica contribui para o surgimento do câncer de } \\
\text { próstata. (F) }\end{array}$ & 59,4 & 56,0 & 61,4 \\
\hline $\begin{array}{l}\text { Os homens devem fazer o exame de toque retal anualmente, a } \\
\text { partir dos 60 anos. (F) }\end{array}$ & 73,9 & 84,0 & 68,2 \\
\hline $\begin{array}{l}\text { Os homens devem fazer o exame de PSA anualmente, a partir } \\
\text { dos 45 anos. (V) }\end{array}$ & 82,6 & 88,0 & 79,5 \\
\hline $\begin{array}{l}\text { Os exames da próstata só precisam ser feitos quando aparecem } \\
\text { os sintomas. (F) }\end{array}$ & 97,1 & 100,0 & 95,5 \\
\hline $\begin{array}{l}\text { A forma de descobrir o câncer de próstata antecipadamente é } \\
\text { através de exames. (V) }\end{array}$ & 97,1 & 100,0 & 95,5 \\
\hline $\begin{array}{l}\text { Os principais sintomas do câncer de próstata são jato urinário } \\
\text { fraco e dor nos testículos. (F) }\end{array}$ & 21,7 & 28,0 & 18,2 \\
\hline $\begin{array}{l}\text { A idade é o principal fator de risco para o desenvolvimento do } \\
\text { câncer de próstata. (V) }\end{array}$ & 65,2 & 68,0 & 63,6 \\
\hline & & & \\
\hline
\end{tabular}




\begin{tabular}{l|l|l|l}
\hline Não existe cura para o câncer de próstata. (F) & 91,3 & 88,0 & 93,2 \\
\hline Média & $\mathbf{7 8 , 6}$ & $\mathbf{8 0 , 5}$ & $\mathbf{7 7 , 4}$ \\
\hline
\end{tabular}

$$
\mathrm{V}=\text { verdadeiro e } \mathrm{F}=\text { falso. }
$$

Fonte: (VIRGULINO; RÊGO, 2011)

\section{Percepção, características e comportamento de saúde}

A percepção quanto à própria saúde foi muito positiva, pois $87,3 \%$ dos indivíduos reportaram que consideram sua saúde, de modo geral, muito boa e excelente. Apenas 9,5\% consideraram como boa e 3,2\% como ruim ou muito ruim. Quanto à frequência de visita ao médico, apenas $55,1 \%$ vão anualmente ao clínico, $23,2 \%$ só quando não se sentem bem, $14,5 \%$ a cada dois anos ou mais e $2,9 \%$ só foram uma vez ou não informaram. Apenas 1,4\% dos participantes informaram nunca ter ido ao médico. Se a visita for ao urologista, a frequência é ainda menor. Apenas $42 \%$ reportaram ir anualmente, $15,9 \%$ quando sentem algo, $10,1 \%$ nunca foram ou foram a cada dois anos ou mais e $18,8 \%$ reportaram nunca terem ido ao urologista. A preferência sobre ser o médico urologista do sexo masculino ou feminino está apresentada na Figura 1.

Figura 1 - Distribuição dos indivíduos segundo o sexo do urologista a ser procurado. Salvador, 2011.

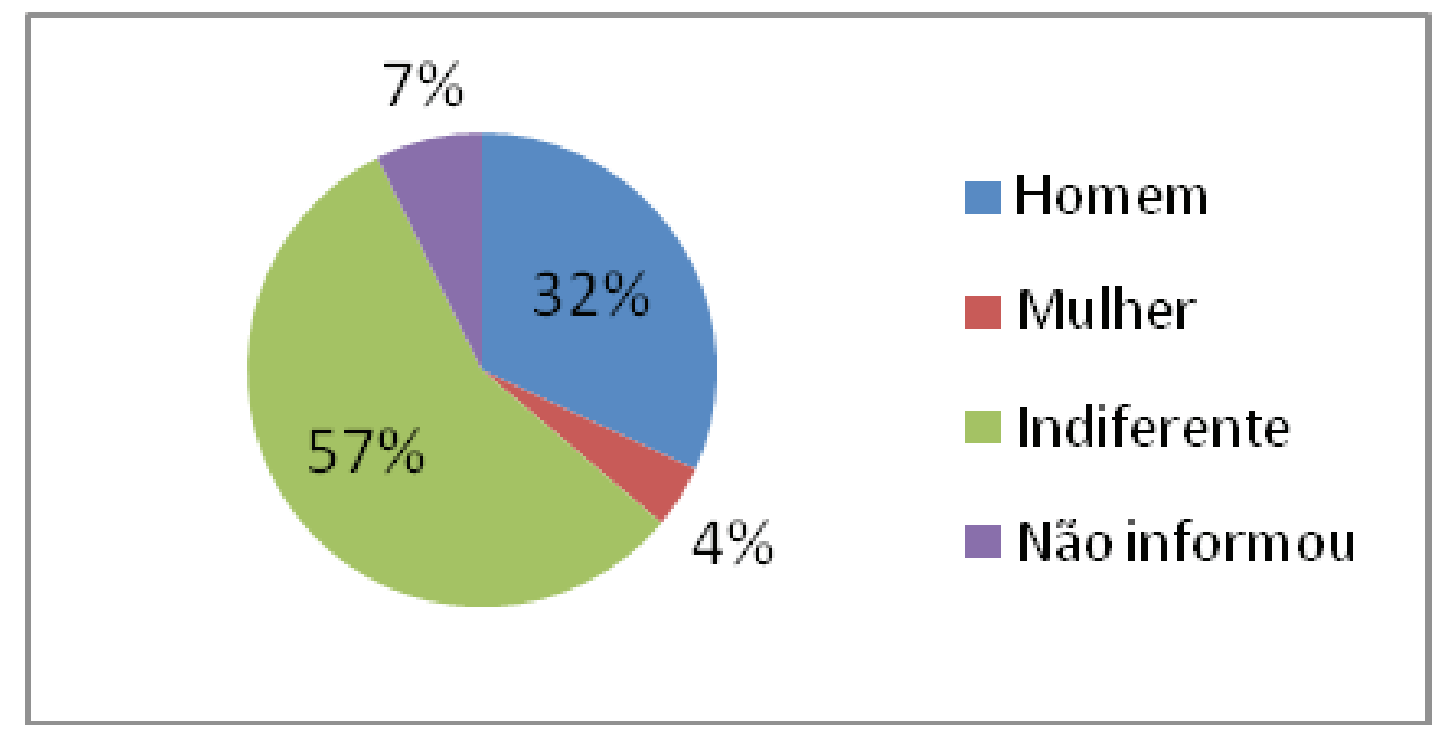

Fonte: (VIRGULINO; RÊGO, 2011) 
Apenas $36 \%$ reportaram ter feito o EDR e dosado o PSA anualmente (Grupo A), contra 64\% que não os fizeram (Grupo B). A Tabela 3 apresenta um resumo dos achados. Uma análise separada dos exames demonstrou que um total de $59,4 \%$ dos participantes realizou o PSA anualmente contra apenas $36,2 \%$ do EDR. De modo geral, a realização do PSA é sempre maior do que a realização do EDR. Muitos participantes $(44,9 \%)$ reportaram nunca terem feito o EDR. Quase um quarto dos participantes relatou histórico familiar de câncer da próstata, com maiores ocorrências entre pai $(14,5 \%)$ e tios $(11,6 \%)$. Uma grande parcela $(46,4 \%)$ reportou desconhecer este histórico familiar (Tabela 4).

Tabela 3 - Distribuição dos indivíduos segundo a frequência de realização dos exames para avaliação da próstata. Salvador, 2011.

\begin{tabular}{l|l|l}
\multicolumn{1}{c|}{ Frequência } & PSA (\%) & EDR (\%) \\
\hline Nunca fez & $11(15,9)$ & $31(44,9)$ \\
\hline Anualmente, por solicitação da empresa & $20(29,0)$ & $08(11,6)$ \\
\hline Anualmente, por iniciativa própria & $21(30,4)$ & $17(24,6)$ \\
\hline A cada dois anos ou mais & $08(11,6)$ & $05(7,2)$ \\
\hline Fez só uma vez & $06(8,7)$ & $07(10,1)$ \\
\hline Desconhece o exame & $01(1,4)$ & -- \\
\hline
\end{tabular}

* O percentual total não reflete \% devido à ausência de resposta de alguns participantes Fonte: (VIRGULINO; RÊGO, 2011)

Tabela 4 - Distribuição dos indivíduos segundo o histórico familiar de câncer próstata. Salvador, 2011.

\begin{tabular}{l|c|c}
\multicolumn{1}{c|}{ Grau de parentesco } & N & $\% *$ \\
\hline Desconhece & 32 & 46,4 \\
\hline Não existe histórico & 24 & 34,8 \\
\hline Pai & 10 & 14,5 \\
\hline Tio & 08 & 11,6 \\
\hline Avô & 03 & 4,3 \\
\hline Primo & -- & -- \\
\hline Irmão & -- & -- \\
\hline
\end{tabular}

* O percentual total não reflete \% devido a múltiplas respostas dos participantes.

Fonte: (VIRGULINO; RÊGO, 2011) 


\section{Análise da influência das crenças sobre o comportamento de prevenção}

Segundo o MCS, o comportamento de prevenção de uma doença pode ser explicado através da relação existente entre a percepção de cinco dimensões e a possibilidade da ação preventiva. Estas dimensões são: susceptibilidade; severidade; autoeficácia; benefícios e barreiras. Fazendo uma análise geral da relação entre o grau de percepção das dimensões do MSC e sua influência na realização do rastreamento anual, foi observado que uma percepção mais alta das dimensões susceptibilidade, severidade, autoeficácia e benefício contribuíram para uma maior realização dos exames anuais. Contraditoriamente, a percepção mais alta de barreiras também proporcionou uma maior frequência de realização dos exames (Tabela 5). Uma análise mais detalhada do MCS foi realizada comparando os resultados das médias encontradas de cada dimensão do modelo entre os Grupos A e B. Todos os resultados sumarizados nas Tabelas 6 e 7 .

\section{Percepção de susceptibilidade}

A susceptibilidade percebida refere-se à avaliação individual de chances de adquirir uma doença ou de vivenciá-la. Os resultados encontrados demonstram não haver diferença significativa entre as médias encontradas para os dois grupos comparados $(p=0,258)$. Mesmo na avaliação de cada uma das cinco afirmativas que compõem esta dimensão, não foi encontrada diferença significativa ( $p>0,05)$. Assim, conclui-se que os dois grupos analisados apresentam uma mesma percepção de susceptibilidade e que esta dimensão não influiu no comportamento de prevenção do câncer da próstata para a população estudada.

\section{Percepção de severidade}

A severidade percebida é o julgamento individual do quão severo é a doença ou seus desdobramentos. A percepção geral de severidade entre os dois grupos não apresentou diferença significativa, porém na avaliação individual de cada uma das nove afirmativas que compõe esta dimensão, uma apresentou esta diferença. A afirmativa "o tratamento deste câncer causa impotência” foi maior em $21,4 \%$ para o grupo B. 
Desta forma, essa circunstância parece ter influenciado de modo inverso, ou seja, ao invés de atuar na percepção de severidade se tornou uma barreira para a realização dos exames.

De modo geral, assim como a susceptibilidade, a percepção de severidade foi igual entre os dois grupos, e não atuou na motivação de realização dos exames da próstata.

\section{Percepção de autoeficácia}

A percepção de autoeficácia refere-se à crença pessoal na própria capacidade de fazer algo, neste caso, do cuidado com a própria saúde. Observando os resultados gerais, foi verificada uma diferença de 16,7\% maior da percepção de autoeficácia do grupo A $(p=0,021)$. A análise individual apontou para a diferença na afirmativa "eu me sinto saudável tomando conta da minha própria saúde”. Assim, verificou-se que esta percepção influenciou no comportamento de prevenção, motivando os trabalhadores a realizar os exames para diagnóstico precoce.

\section{Percepção de benefícios}

A percepção de benefícios é uma conclusão individual de que uma nova ação lhe trará resultados positivos. Uma ação pode ser vista como benéfica se esta atua na redução da susceptibilidade ou na severidade, ou em ambas, da doença. Fazendo a comparação geral da percepção de benefícios entre os dois grupos, não foi encontrada diferença significativa entre suas médias $(\mathrm{p}=0,351)$. A mesma conclusão foi feita na análise individual de cada afirmativa que compõe esta dimensão. Desta forma, a percepção de benefícios também não implicou em um maior comportamento de realização do rastreamento anual.

\section{Percepção de barreiras}

A percepção de barreiras é uma visão individual de todos os aspectos negativos da ação em saúde que interferem na prevenção. Das dimensões do MCS avaliadas, e que apresentaram diferenças significativas entre suas médias, a percepção de barreiras foi a que resultou em um maior valor $(28,8 \%)$. Sua influência foi no comportamento não 
preventivo, ou seja, as barreiras percebidas inibiram os trabalhadores a realizarem os exames de prevenção.

$\mathrm{Na}$ avaliação detalhada, 13 afirmativas apresentaram diferenças significativas entre suas médias na comparação entre os grupos A e B, variando de $21,9 \%$ a $45,3 \%$. Da mesma forma que a média geral da dimensão, estas 13 afirmativas atuaram negativamente no comportamento de prevenção do câncer. Agrupando-se essas 13 afirmativas, observam-se três aspectos que atuaram como barreira para a realização dos exames de detecção precoce do câncer da próstata.

O primeiro deles foi a masculinidade, composto pelas afirmativas: "eu tenho medo de descobrir que estou com câncer da próstata"; "eu tenho medo de fazer o EDR"; "eu não faço os exames da próstata porque me sinto uma pessoa muito saudável"; "eu não faço os exames da próstata porque sou descuidado com minha saúde"; "eu não faço os exames da próstata porque não gosto de ir ao médico"; "eu tenho medo de ter ereção durante o EDR"; e "eu tenho medo de mudar de orientação sexual ao fazer o EDR".

Em segundo lugar, a falta de conhecimento sobre a doença, com quatro barreiras identificadas, composta pelas seguintes afirmativas: "eu tenho medo de sentir dor durante o EDR"; "eu não faço os exames porque não tenho sintomas"; "eu não conheço quais são os métodos de prevenção do câncer da próstata"; e "eu não sei que médico devo procurar para fazer os exames da próstata". Por último, com duas barreiras identificadas, a barreira médica, composta pelas afirmativas: "o médico me informou que não é necessário fazer os exames da próstata" e "nenhum médico me solicitou os exames da próstata". Os valores e as diferenças entre as médias obtidas na dimensão e em cada afirmativa podem ser encontrados na Tabela 5 . 
Tabela 5 - Distribuição dos indivíduos, segundo as dimensões do Modelo de Crenças em Saúde e situação de rastreamento. Salvador, 2011.

\begin{tabular}{|c|c|c|c|c|}
\hline \multirow{3}{*}{ Dimensão/Afirmativas } & \multirow{2}{*}{\multicolumn{2}{|c|}{$\begin{array}{c}\text { Pontuação média } \\
\begin{array}{c}\text { EDR + PSA } \\
\text { anual }\end{array}\end{array}$}} & \multirow{3}{*}{$\Delta \%$} & \multirow{3}{*}{$\begin{array}{c}\text { p- } \\
\text { valor* }\end{array}$} \\
\hline & & & & \\
\hline & Sim & Não & & \\
\hline Susceptibilidade percebida & 2,65 & 2,48 & 6,9 & 0,258 \\
\hline O câncer de próstata é uma doença inevitável. & 2,09 & 2,11 & $-0,9$ & 0,541 \\
\hline Eu fico preocupado em um dia ter câncer de próstata. & 3,00 & 2,65 & 13,2 & 0,127 \\
\hline $\begin{array}{l}\text { Eu tenho chances de desenvolver o câncer de } \\
\text { próstata. }\end{array}$ & 2,73 & 2,78 & $-1,8$ & 0,571 \\
\hline É provável que eu venha a ter câncer de próstata. & 2,50 & 2,27 & 10,1 & 0,269 \\
\hline $\begin{array}{l}\text { Com o passar dos anos eu tenho mais chances de } \\
\text { ter CaP. }\end{array}$ & 2,91 & 2,59 & 12,4 & 0,199 \\
\hline Severidade percebida & 2,87 & 2,87 & 0,0 & 0,817 \\
\hline O câncer de próstata é uma doença grave. & 3,55 & 3,29 & 7,9 & 0,078 \\
\hline $\begin{array}{l}\text { O câncer de próstata resulta em morte se não for } \\
\text { tratado. }\end{array}$ & 3,73 & 3,68 & 1,4 & 0,880 \\
\hline O tratamento deste câncer causa impotência. & 2,50 & 3,18 & $-21,4$ & 0,004 \\
\hline Eu seria um peso para a minha família se tivesse $\mathrm{CaP}$. & 2,50 & 2,41 & 3,7 & 0,747 \\
\hline $\begin{array}{l}\text { Ter CaP poderia afetar a minha vida social e } \\
\text { profissional. }\end{array}$ & 2,91 & 2,65 & 9,8 & 0,160 \\
\hline Assusta-me pensar que um dia eu possa ter $\mathrm{CaP}$. & 2,95 & 3,06 & $-3,6$ & 0,734 \\
\hline Eu ficaria com baixa autoestima se tivesse CaP. & 2,95 & 3,00 & $-1,7$ & 0,818 \\
\hline $\begin{array}{l}\text { Minha segurança financeira estaria ameaçada se eu } \\
\text { tivesse CaP. }\end{array}$ & 2,59 & 2,59 & 0,0 & 0,870 \\
\hline Não existe cura para o câncer de próstata. & 2,18 & 1,94 & 12,4 & 0,299 \\
\hline Autoeficácia & 2,86 & 2,45 & 16,7 & 0,021 \\
\hline
\end{tabular}




\begin{tabular}{|c|c|c|c|c|}
\hline $\begin{array}{l}\text { Eu me sinto saudável tomando conta da minha } \\
\text { própria saúde. }\end{array}$ & 2,78 & 1,95 & 42,6 & 0,001 \\
\hline Eu sinto que tenho o controle do meu corpo. & 2,65 & 2,62 & 1,1 & 0,781 \\
\hline Eu sou responsável pela minha saúde. & 3,13 & 2,79 & 12,2 & 0,075 \\
\hline Benefício percebido & 3,38 & 3,27 & 3,4 & 0,351 \\
\hline $\begin{array}{l}\text { O EDR ajuda na detecção precoce do câncer de } \\
\text { próstata. }\end{array}$ & 3,61 & 3,21 & 12,5 & 0,201 \\
\hline $\begin{array}{l}\text { Se o câncer for detectado precocemente, o tempo de } \\
\text { tratamento será menor. }\end{array}$ & 3,39 & 3,50 & $-3,1$ & 0,307 \\
\hline O exame de PSA ajuda na detecção precoce do CaP. & 3,48 & 3,39 & 2,7 & 0,846 \\
\hline Eu acredito que o exame de PSA é confiável. & 3,26 & 3,05 & 6,9 & 0,394 \\
\hline $\begin{array}{l}\text { Seguindo as recomendações médicas, eu cuido } \\
\text { melhor da minha saúde. }\end{array}$ & 3,39 & 3,29 & 3,0 & 0,625 \\
\hline $\begin{array}{l}\text { Eu acredito que o EDR é um procedimento de fácil } \\
\text { realização. }\end{array}$ & 3,17 & 3,11 & 1,9 & 0,803 \\
\hline $\begin{array}{l}\text { O CaP pode ser curado se for descoberto logo no } \\
\text { início. }\end{array}$ & 3,39 & 3,26 & 4,0 & 0,515 \\
\hline Eu acredito que o exame de toque retal é confiável. & 3,35 & 3,32 & 0,9 & 0,852 \\
\hline $\begin{array}{l}\text { Eu acredito que o exame de PSA é um procedimento } \\
\text { de fácil realização. }\end{array}$ & 3,39 & 3,29 & 3,0 & 0,645 \\
\hline
\end{tabular}

* Teste de Mann-Whitney.

Fonte: (VIRGULINO; RÊGO, 2011)

Tabela 6 - Distribuição dos indivíduos, segundo a situação de rastreamento e os constructos do modelo de crenças em saúde. Salvador, 2011.

\begin{tabular}{l|c|c|c}
\multirow{2}{*}{\multicolumn{1}{c|}{ Dimensão }} & \multicolumn{2}{c|}{ (\%) Informado } & \multirow{2}{*}{$\begin{array}{c}\text { Razão de } \\
\text { Prevalência }\end{array}$} \\
\cline { 2 - 3 } & \multicolumn{2}{|c}{ EDR + PSA anual } & 1,58 \\
\cline { 2 - 3 } Susceptibilidade & Sim (\%) & Não (\%) & \\
\hline Alta - média & $12(52,2)$ & $15(34,9)$ & \\
\hline Baixa - nenhuma & $11(47,8)$ & $28(65,1)$ & \\
\hline Severidade & & & 1,54 \\
\hline Alta - média & $20(87,0)$ & $32(78,0)$ & \\
\hline Baixa - nenhuma & $03(13,0)$ & $09(22,0)$ & \\
\hline
\end{tabular}




\begin{tabular}{l|c|c|c}
\hline Autoeficácia & & & 1,71 \\
\hline Alta - média & $16(69,6)$ & $20(50,0)$ & \\
\hline Baixa - nenhuma & $07(30,4)$ & $20(50,0)$ & \\
\hline Benefícios & & & 1,08 \\
\hline Alta - média & $22(95,7)$ & $39(95,1)$ & \\
\hline Baixa - nenhuma & $01(4,3)$ & $02(4,9)$ & \\
\hline Barreiras & & & 1,18 \\
\hline Alta - média & $03(16,7)$ & $05(13,5)$ & \\
\hline Baixa - nenhuma & $15(83,3)$ & $32(86,5)$ & \\
\hline
\end{tabular}

Alta - média $=$ respostas concordo e concordo totalmente.

Baixa - nenhuma $=$ respostas discordo e discordo totalmente.

Fonte: (VIRGULINO; RÊGO, 2011)

Tabela 7 - Distribuição dos indivíduos, segundo a consistência dos valores das dimensões do Modelo de Crenças em Saúde por situação de rastreamento. Salvador, 2011.

\begin{tabular}{l|c|c|c|c}
\multirow{2}{*}{\multicolumn{1}{c}{ Dimensão }} & \multicolumn{4}{|c}{ EDR + PSA annual } \\
\cline { 2 - 5 } & Média & $\begin{array}{c}\text { Alfa de } \\
\text { Cronbach }\end{array}$ & Média & $\begin{array}{c}\text { Alfa de } \\
\text { Cronbach }\end{array}$ \\
\cline { 2 - 5 } & 2,65 & 0,752 & 2,48 & 0,167 \\
\hline Susceptibilidade & 2,87 & 0,660 & 2,87 & 0,676 \\
\hline Severidade & 2,86 & 0,777 & 2,45 & 0,408 \\
\hline Autoeficácia & 3,38 & 0,962 & 3,27 & 0,857 \\
\hline Benefícios & 1,52 & 0,958 & 2,12 & 0,915 \\
\hline Barreiras & & & & \\
\hline
\end{tabular}

Fonte: (VIRGULINO; RÊGO, 2011)

\section{Análise da influência das características sociodemográficas sobre o comportamento de prevenção}

Observou-se que idade, estado civil, escolaridade, religião e tempo de trabalho demonstraram ter alguma influência positiva no comportamento de prevenção. Os demais fatores analisados, como raça, número de filhos, renda mensal, histórico familiar e grau de conhecimento 
testado não apresentaram nenhuma influência neste comportamento (Tabela 8).

Tabela 8 - Razões de prevalência segundo variáveis soiodemográficas e situação de rastreamento. Salvador, 2011.

\begin{tabular}{|c|c|c|c|}
\hline \multirow{3}{*}{ Variável } & \multirow{2}{*}{\multicolumn{2}{|c|}{$\begin{array}{c}\text { (\%) Informado } \\
\text { EDR + PSA anual }\end{array}$}} & \multirow{3}{*}{$\begin{array}{c}\text { Razão de } \\
\text { Prevalência }\end{array}$} \\
\hline & & & \\
\hline & $\operatorname{Sim}(\%)$ & Não (\%) & \\
\hline Total de participantes & 24 & 41 & \\
\hline Idade (anos) & & & 3,12 \\
\hline $50-59$ & $17(70,8)$ & $11(27,5)$ & \\
\hline $40-49$ & $07(29,2)$ & $29(72,5)$ & \\
\hline Estado civil & & & 1,21 \\
\hline Casado & $20(80,0)$ & $33(75,0)$ & \\
\hline Não casado & $05(20,0)$ & $11(25,0)$ & \\
\hline Grau de escolaridade & & & 1,14 \\
\hline Menor ou igual ao ensino médio & $16(66,7)$ & $26(61,9)$ & \\
\hline Maior que o ensino médio & $08(33,3)$ & $16(38,1)$ & \\
\hline Cor ou raça & & & 0,60 \\
\hline Branca & $07(30,4)$ & $20(48,8)$ & \\
\hline Não branco & $16(69,6)$ & $21(51,2)$ & \\
\hline Número de filhos & & & 0,56 \\
\hline$\leq 02$ & $15(62,5)$ & $33(82,5)$ & \\
\hline$>02$ & $09(37,5)$ & $07(17,5)$ & \\
\hline Religião & & & 1,67 \\
\hline Católico & $20(80,0)$ & $28(65,1)$ & \\
\hline Não católico & $05(20,0)$ & $15(34,9)$ & \\
\hline Renda mensal & & & 1,02 \\
\hline$\leq \mathrm{R} \$ 5.100,00$ & $13(56,5)$ & $24(55,8)$ & \\
\hline$>\mathrm{R} \$ 5.100,00$ & $10(43,5)$ & $19(44,2)$ & \\
\hline Tempo de trabalho (anos) & & & 2,16 \\
\hline$>20$ & $16(76,2)$ & $21(51,2)$ & \\
\hline$\leq 20$ & $05(23,8)$ & $20(48,8)$ & \\
\hline Histórico familiar de câncer da próstata & & & 0,41 \\
\hline Sim & $02(10,0)$ & $07(31,8)$ & \\
\hline Não & $18(90,0)$ & $15(68,2)$ & \\
\hline Grau de conhecimento testado & & & 0,62 \\
\hline
\end{tabular}




\begin{tabular}{l|l|l|l}
\hline Muito pouco - muito bom & $13(52,0)$ & $31(70,5)$ & \\
\hline Excelente & $12(48,0)$ & $13(29,5)$ & \\
\hline
\end{tabular}

Fonte: (VIRGULINO; RÊGO, 2011)

\section{Discussão}

O objetivo deste estudo foi avaliar o comportamento de prevenção do câncer da próstata entre industriários. Os resultados demonstram que a população estudada não frequenta muito os consultórios médicos e a taxa de realização dos exames da próstata é muito pequena. Não foram encontrados estudos que investigassem a frequência de realização entre trabalhadores, mas normalmente elas não são muito altas, com uma média de 40\%. (TALAVERA et al., 2002; CORMIER et al., 2003)

O conhecimento sobre o câncer da próstata apresentou bons resultados. Outros estudos apresentaram níveis de conhecimento semelhantes, corroborando com o resultado encontrado. (CORMIER et al., 2003) Porém, quando se analisaram as barreiras percebidas no MCS constatou-se que este conhecimento não foi forte o suficiente para promover as ações de detecção precoce, uma vez que algumas barreiras foram relacionas à falta ou pouco conhecimento em algum item específico.

A análise do MCS demonstrou que o aumento nas percepções de susceptibilidade, severidade, autoeficácia e benefício contribuem com a prevenção do câncer da próstata, através do aumento da frequência de realização dos exames. Este é o comportamento esperado destas dimensões neste modelo e encontrado em outros estudos que usaram esta metodologia. (BREVIDELLI; CIANCIARULLO, 2001) A contradição surgiu apenas na dimensão das barreiras, pois a regra é que a maior prevenção ocorra no grupo com menor percepção. Este fato pode ser explicado pelo tamanho da amostra, que talvez não tenha sido grande o suficiente para representar melhor esta dimensão.

A avaliação das escalas e de suas afirmativas entre os grupos A e B não apresentaram diferenças significativas nas dimensões susceptibilidade, severidade e benefícios percebidos. Isso se traduz na concepção de que os dois grupos possuem a mesma percepção destas dimensões e que elas não influenciaram no comportamento de prevenção. Uma afir- 
mativa surgiu na dimensão severidade de modo negativo. A afirmativa "o tratamento deste câncer causa impotência" foi a única a apresentar diferença significativa entre os dois grupos, porém com uma percepção maior do Grupo B, o que pode ser traduzido como mais uma barreira. $\mathrm{O}$ medo da possibilidade de perda da virilidade, característica marcante do comportamento machista, aparenta atuar como uma barreira neste caso.

A dimensão autoeficácia, como esperado, apresentou diferença significativa entre os grupos, sendo maior no grupo A. A afirmativa deste grupo de maior expressão foi "eu me sinto saudável tomando conta da minha própria saúde". Uma contradição do modelo machista hegemônico, no qual o comportamento de cuidado com a saúde é de responsabilidade da mulher. Este pensamento da responsabilidade feminina do cuidado com a saúde foi identificado como uma barreira na prevenção do câncer da próstata no estudo de Madjar, Denham e Rashid (2007). Assim, esta percepção de autoeficácia aparece como uma solução para a prevenção.

A percepção das barreiras foi a mais marcante. Apesar da primeira análise do MCS ter indicado um maior comportamento de prevenção entre os homens com a percepção de barreiras mais altas, nesta análise mais detalhada isto é retificado. A diferença entre as médias de cada grupo foi significativa para o grupo B. Isso indica que quanto maior a percepção das barreiras, menor será o comportamento preventivo, premissa essa esperada do modelo e encontrada em alguns estudos. (LUCUMÍ; CABRERA, 2005)

As barreiras com diferença significativa entre os grupos foram organizadas em três categorias: masculinidade; falta de conhecimento; e barreiras médicas. A masculinidade, ou o comportamento machista e sua relação com o cuidado da própria saúde parece ser o elemento mais estudado quando se trata do assunto prevenção do câncer da próstata. Diversos autores, como Lucumí e Cabrera (2005), Bloom e colaboradores (2006) e Gomes e colaboradores (2008) pesquisaram e elucidaram esta barreira como a mais evidente. Neste estudo, foi esta categoria que apresentou maior número de barreiras e com maior intensidade. Uma parcela dos trabalhadores que não fizeram o exame acredita que: o EDR dói durante a sua realização, o que não ocorre se for feito por um profissional experiente e treinado; diz não fazer o exame por falta de sintomas, quando é sabido que esta neoplasia é assintomática no início; 
informa não conhecer os métodos de prevenção ou qual especialidade médica procurar.

Estas mesmas barreiras relacionadas à falta de conhecimento foram encontradas por Reynolds (2008) e Patel e colaboradoes (2010) em seus estudos realizados em Afro-Americanos. Isto sugere a necessidade de promoção na educação sobre a próstata com ênfase na sintomatologia, fatores de risco e exames de prevenção. Por sua vez, Paiva, Motta e Griep (2010) encontraram no seu estudo uma prevalência de 7,6 (IC95\%=2,4-23,6) para referência de prática adequada dos exames, entre homens que apresentaram conhecimento adequado do que a encontrada entre aqueles que demonstraram conhecimento inadequado.

Por fim, as barreiras médicas. Estas são encontradas na literatura como sendo relativas à pouca interação médico/paciente; não solicitação dos exames por parte do médico, que pode ser uma representação da falta de um protocolo de rastreamento instituído; e não confiar ou gostar de ir ao médico. (ROBINSON; ASHLEY; HAYNES, 1996; REYNOLDS, 2008;) A primeira observação que se pode fazer sobre esta categoria é a baixa frequência relatada de visita ao médico clínico, anualmente, e ainda menor ao urologista. Segundo, uma das afirmativas que foi categorizada como masculinidade também se adapta aqui. No MCS a afirmativa "eu não faço os exames da próstata porque não gosto de ir ao médico" é maior no grupo que não faz os exames anualmente. Em seguida, as afirmativas "o médico me informou que não é necessário fazer os exames" e "nenhum médico me solicitou ainda", também são mais evidentes no grupo B, pois reforçam uma falta de atuação ou atenção médica a este problema de saúde pública.

Alguns achados apontam barreiras relacionadas ao acesso à assistência médica. (PATEL et al., 2010; ROBINSON; ASHLEY; HAYNES, 1996) Entretanto, este item não foi avaliado porque a população estudada dispõe de médico do trabalho na empresa e de assistência médica particular.

\section{Limitações do estudo}

O estudo apresentou quatro limitações. A primeira refere-se ao caráter não-probabilístico da amostragem. Porém, os achados podem 
ser aplicados às situações onde a população apresente as mesmas características deste estudo.

A segunda limitação está relacionada ao fato de que as informações sobre realização dos exames (PSA e EDR) foram autoreportadas, o que pode superestimar o resultado encontrado, diante da tendência dos indivíduos a dar as respostas que satisfaçam ao pesquisador. Com isso, a frequência de realização do PSA e do EDR pode ser menor do que as descritas.

A terceira surgiu na comparação do comportamento de prevenção entre os grupos A e B. Para esta comparação, seriam necessários 52 participantes para cada grupo. A amostra foi composta por $24(46,2 \%)$ participantes do grupo A e $45(86,5 \%)$ do grupo B, e isso reduziu o poder do estudo. Esta limitação foi criada pela dificuldade que ocorreu durante a coleta dos dados em função da não devolução de alguns questionários. Por fim, assumindo que os componentes do grupo A não apresentariam barreiras para o comportamento de prevenção, eles não precisariam responder a esta pergunta. Assim, apenas 14 participantes dos 24 que compunham o grupo responderam. Mesmo assim, realizouse uma comparação entre grupos.

\section{Considerações finais}

Este é o primeiro estudo no Brasil a utilizar o MCS e a estudar os trabalhadores da indústria para a análise do comportamento de prevenção do câncer da próstata. Seus resultados podem, até certo ponto, contribuir na orientação de estratégias locais para a prevenção desta neoplasia.

Neste modelo, variáveis como idade, situação socioeconômica, educação e conhecimento atuam diretamente nas percepções de susceptibilidade, severidade, autoeficácia e benefícios. Estas atuam sobre as barreiras percebidas, minimizando-as, influenciando no comportamento de prevenção a ser adotado. Dentre estas variáveis, as mais evidentes no comportamento de prevenção foram masculinidade e conhecimento. Porém, a partir da percepção das respostas encontradas, admite-se que um melhor conhecimento pode atuar sobre o comportamento machista desta população de modo a reduzi-lo, permitindo direcionar estes trabalhadores para a prática preventiva. 
Este conhecimento poderia advir de um Programa de Educação e Comunicação em Saúde da Próstata, com o objetivo de maximizar o conhecimento atual e esclarecer as dúvidas encontradas. Este programa deve ter um foco na sintomatologia, exames de detecção, fatores de risco e tratamento desta neoplasia. Além disso, deve ser levada em consideração a inclusão da participação das mulheres/companheiras. Apesar de não ter surgido como uma barreira significativa, elas foram, com $27,9 \%$, a segunda pessoa a quem os pesquisados mais procuraram para conselhos de como tratar de sua saúde, atrás apenas para os médicos.

\section{Referências}

ADDIS, M. E.; MAHALIK, J. R. Men, masculinity and the contexts of help seeking. American Psychologist Association, v. 58, n. 1, p. 5-14, 2003.

ALMEIDA, J. A implantação da indústria automobilística no Brasil. Rio de Janeiro: FGV, 1972.

ALVES, J. E. D. O discurso da dominação masculina. In: GENERAL Population Conference IUSSP International Union For The Scientific Study of Population, 24. Salvador, 2001. . A linguagem e as representações da masculinidade. Rio de Janeiro: Escola Nacional de Ciências Estatísticas, 2004. 33p. BLOOM, J. R. et al. Family history, perceived risk, and prostate cancer screening among African American men. Cancer Epidemiol Biomarkers Prev, n. 15, p. 2167-2173. 2006. BOURDIEU, P. A dominação masculina. Rio de Janeiro: Bertrand Brasil, 1999.

BRASIL. Ministério da Saúde. Sistema de Informação sobre Mortalidade/DATASUS, 2010. Disponível em: <http:// www. datasus. gov. br. > Acesso em: 18 out. 2010. . Ministério da Saúde. Secretaria de Atenção à Saúde, Departamento de Ações Programáticas e Estratégicas Política nacional de atenção integral à saúde do homem: princípios e diretrizes. Brasília: Ministério da Saúde 2009a. . Ministério da saúde, Secretaria de atenção à Saúde, Departamento de Ações Programáticas Estratégicas. Plano de ação 
nacional 2009-2011 da Política nacional de atenção integral á saúde do homem. Brasília: Ministério da Saúde, 2009b.

BREVIDELLI, M. M.; CIANCIARULLO, T. I. Aplicação do modelo de crenças em saúde na prevenção dos acidentes com agulha.

Revista de Saúde Pública, São Paulo, v. 35, n. 2, abr. 2001.

CORMIER, L. et al. Screening behavior in brothers and sons of men with prostate cancer. J. Urol. , v. 169, n. 5 p. 1715-1719. May. 2003.

CRAMER, S. D. Prostate cancer: deadly diseases and epidemics. [S. 1]: Chealsea House, 2007. 112p.

GLOBOCAN 2008 (IARC), Section of Cancer Information. Disponível em: <http://globocan. iarc. fr/>. Acesso em: 27 abr. 2010.

GOMES, R. Sexualidade masculina, gênero e saúde. 1. ed. Rio de Janeiro: Fiocruz, 2008.

GOMES, R. et al. As Arranhaduras da masculinidade: uma discussão do toque retal como medida de prevenção do câncer prostático. Ciência e Saúde Coletiva, Rio de Janeiro, v. 13, n. 6, nov. /dez. , 2008.

; NASCIMENTO, E. F.; ARAÚJO, F. C. Por que os homens

buscam menos os serviços de saúde do que as mulheres? As explicações de homens com baixa escolaridade e homens com ensino superior. Cadernos de Saúde Pública, v. 23, p. 565-574, 2007.

IBGE - Instituto Brasileiro de Geografia e Estatística. Tábuas de vidas. Disponível em: <www. ibge. gov. br>. Acesso em: 26 out. 2009.

INCA - Instituto Nacional de Câncer. Síntese de resultados e comentários, 2005. Disponível em: <http://www. inca. gov. br/estimativa/2008 >. Acesso em: 15 abr. 2008.

. Instituto Nacional de Câncer. Hábitos alimentares, 2009.

Disponível em: < http://www. inca. gov. br/>. Acesso em: 20 out. 2009.

KEIJZER, B. Hasta donde el cuerpo aguante: género, cuerpo y salud masculina. In: CÁCERES, C. F et al. La salud como derecho ciudadano: perspectivas y propuestas desde América Latina. Lima: Universidad Peruana Cayetano Heredia; 2003. p. 137-152.

KISS, A.; MERYN, S. Effect of sex and gender on psychosocial aspects of prostate and breast cancer. BMJ, v. 323, Nov, 2001.

LEFORT, A; ALMEIDA, J. C. Câncer de próstata: a importância das campanhas de prevenção. Belo Horizonte: CIAPE, 2004. 
LIU, S. et al. A prospective study of physical activity and risk of prostate cancer in US physicians. International Journal of Epidemiology. n. 29, p. 29-35, 2000.

LUCUMÍ, D.; CABRERA, G. Creencias sobre examen digital rectal como tamiz para cáncer en la próstata: hallazgos cualitativos de un estudio en Cali. Colomb Med, n. 34, p. 112-119. 2003.

. Beliefs of men from Cali, Colombia, about digital rectal examination: findings of an exploratory study. Caderno de Saúde Pública, Rio de Janeiro, v. 21, n. 5, Out. 2005.

MACHIN, R; COUTO, M. T.; ROSSI, C. C. S. Representações de trabalhadores portuários de Santos-SP sobre a relação trabalhosaúde. Saúde soc. , São Paulo, v. 18, n. 4, dez. 2009.

MADJAR, I.; DENHAM, J.; RASHID, P. Do women have a role in early detection of prostate cancer? Lessons from a qualitative study. Australian Family Physician, v. 36, n. 5, May 2007.

MCCREADY, D. R.; GRAY, R. E.; GRACE, S. L. Gender differences in cancer mortality risk perceptions and screening behaviors among adults 40-60 tears of age. International Journal of Men's Health, v. 5, n. 1, p. 53-63.

MIRANDA, P. S. C. et al. Práticas de diagnóstico precoce de câncer de próstata entre professores da faculdade de medicina - UFMG.

Rev. Assoc. Med. Bras., São Paulo, v. 50, n. 3, 2004.

MOORE, A. D. M.; BOYLE, G. Assessing the knowledge, self-efficacy and health behaviors of male beneficiaries assigned to the national capital area regarding participation in prostate screening. 2002. Dissertação (Mestrado). Uniformed Services, University of the Health Sciences, 2002.

MYERS, R. E. et al. Factors associated with intention to undergo annual prostate cancer screening among African American men in Philadelphia. American Cancer Society. v. 78, n. 3, p. 471-479, Aug. 1996.

NASCIMENTO, M. R. Câncer de próstata e masculinidade: motivações e barreiras para a realização do diagnóstico precoce da doença. 2000. Disponível em < http://www. abesp. nepo. unicamp. br. > Acesso em: 20 maio 2010.

NIJS, H. G. T. et al. Why do men refuse or attend population-based screening for prostate cancer? Faculty of Public Health Medicine, v. 22, n. 3, p. 312-316, 2000.

NORMAN, A. et. al. Occupational physical activity and risk for prostate cancer in a nationwide cohort study in Sweden. Br J Cancer. v. 86, n. 1, p. 70-75, Jan. 2002. 
PAIVA, E. P.; MOTTA, M. C. S.; GRIEP, R. H. Conhecimentos, atitudes e práticas acerca da detecção do câncer de próstata. Acta Paul Enferm, v. 23, n. 1, p. 88-93. 2010.

PATEL, K. et al. Factors influencing prostate cancer screening in lowincome African Americans in Tennessee. Journal of Health Care for the Poor and Underserved, v. 21, n. 1, p. 114-126, Feb, 2010.

REYNOLDS, D. Prostate cancer screening in African American men: barriers and methods for improvement. American Journal Men's Health, v. 2, n. 2, p. 172-177, Jun, 2008.

ROBINSON, S. B.; ASHLEY, M.; HAYNES, M. A. Attitudes of African Americans regarding screening for prostate cancer. Journal Natl. Med. Assoc, v. 88, n. 4, p. 241-246, Apr, 1996.

ROBINSON, W. R. Obesity before Age 30 years and risk of advanced prostate cancer. American Journal of Epidemiology, v. 161, n. 12, p. 1107-1114, 2005.

ROOS, G; PRÄTTÄLÄ, R; KOSKI, K. Men, masculinity and food: interviews with Finnish carpenters and engineers. Appetite, v. 37, n. 1, p. 47-56, Aug. 2001.

ROSENSTOCK, I. M. Why people use health services. Milbank Memorial Fund, n. 44, p. 94-121, 1996.

SBU - Sociedade Brasileira de Urologia. Manual de boas práticas urológicas. 2009. Disponível em: <http://www. sbu. org. br. > Acesso em: 26 out. 2010.

SCHRÖDER, F. H. et al. Screening and prostate cancer mortality in a randomized european study. N Engl J Med, n. 360, p. 1320-1328, Mar, 2009.

SROUGI, M. Câncer de próstata: uma opinião médica. Sociedade Brasileira de Urologia (SBU), 1997. Disponível em: $<$ http://www. sbu. org. br. > Acesso em: 15 abr. 2010.

STEELE, C. B. et al. Knowledge, attitudes, and screening practices among older men regarding prostate cancer. American Journal Public Health, v. 90, n. 10, p. 1595-1600, Oct. 2000.

TALAVERA, G. A. et al. Predictors of digital rectal examination in U. S. Latinos. American Journal Prev. Med, v. 22, n. 1, p. 36-41, Jan. 2002.

TAYLOR, K. L. et al. Demographics, family histories, and psychological characteristics of prostate carcinoma screening participants. American Cancer Society, v. 85, n. 6, 1999. 
VOLK, R. J. et al. Patient education for informed decision making about prostate cancer screening: a randomized controlled trial with 1-year follow-up. Annals for Family Medicine, v. 1, n. 1, May/Jun. 2003.

YAN, Y. Y. Breast cancer: knowledge and perceptions of Chinese women in Hong Kong. Global Journal of Health Science, v. 1, n. 2, Oct. 2009.

WEINRICH, S. P. et al. Self-reported reasons men decide not to participate in free prostate cancer screening. ONF, v. 30, 2003. 


\section{O trabalhador-doente e sua família no contexto do adoecimento, absenteísmo e o processo de retorno ao trabalho}

Paulo Roberto Ferreira da Rocha Mônica Angelim Gomes de Lima

\section{Introdução}

As doenças crônicas, relacionadas ou não ao trabalho, são responsáveis em grande medida pelo absenteísmo e aposentadoria precoce dos trabalhadores. Nos Estados Unidos da América, o total anual de custos diretos e indiretos com o afastamento do trabalhador-doente excede os gastos associados com SIDA e Doença de Alzheimer e alcançam valores equivalentes aos custos totais do câncer e da doença coronariana. No Brasil, os gastos com auxílio doença e tratamento de trabalhadores acidentados chegam a $\mathrm{R} \$ 42$ bilhões por ano. (DEMBE, 2002; AGÊNCIA, [2008])

As síndromes que causam incapacidade, muito frequentes nas sociedades contemporâneas, geram grande sofrimento, contribuem para reduzir autonomia do indivíduo e limitar o seu papel social. O significado particular do sujeito, que modela a forma de lidar com a doença pode definir o modo como será atendido pelos serviços de saúde, a relação médico-paciente, a aderência ao tratamento e até mesmo o curso da enfermidade e o tempo de afastamento do trabalho. (KLEINMAN, 1988; FERRARI; KWAN; FRIEL, 2001)

De uma maneira geral entende-se que estar doente, para a maioria das pessoas, é uma condição indesejável, embora seja muito atual no campo da psicologia comportamental a discussão sobre perdas e ganhos para o indivíduo e para o seu entorno. Possivelmente o balanço entre estes influenciará no processo de adoecimento e na permanência no 
estado provocado pela doença. Este debate tem-se orientado no sentido de identificar, nos indivíduos, comportamentos a favor de se manterem doentes sem problematizar as perdas advindas desse processo e sem questionar sobre o contexto no qual esse fenômeno se desenvolve. (FERRARI; KWAN; FRIEL, 2001)

Para entender a contribuição do ambiente social na cronicidade da doença, entre as oscilações dos sintomas e incapacidade, devemos ser capazes de ver o doente envolto em uma rede de relacionamento que constitui o mundo da vida cotidiana ${ }^{1}$. Cabe reconhecer no estudo deste tema as interações que acontecem com os serviços de saúde e os sistemas sociais, que interferem na transição do estado de incapacidade para o estado social normal. (KLEINMAN, 1988)

O trabalhador portador de doença crônica está frequentemente submetido a sérias limitações nas atividades da vida diária em geral e à incapacidade ${ }^{2}$ para o trabalho em particular, além de estar susceptível a aposentadoria precoce. O que se propõe para lidar com a condição de incapacidade é promover a reabilitação do trabalhador-doente o mais breve possível, começando logo que se inicie o tratamento, utilizando processo de gerenciamento que integre os setores clínicos e de saúde ocupacional, os sistemas de seguro e o Estado. (WADDELL; BURTON, 2004)

Para compreensão do que facilita ou dificulta, para o indivíduo, recuperar sua capacidade laboral, deve-se buscar avaliar os fatores biopsicossociais envolvidos. Gatchel e colaboradores (2004) citam como exemplo destes, entre outros, o balanço das perdas e ganhos secundários, os transtornos psíquicos menores, a motivação, a compreensão sobre a doença e os efeitos iatrogênicos do tratamento. Incluem, também, os processos que ocorrem no local de trabalho (política e cultura organizacional), as interações no ambiente da família, as políticas públicas de segurança da saúde do trabalhador, o sistema de crença da comunidade em que vive e dos profissionais da saúde, que se movem ao longo do processo diagnóstico-terapêutico, da experiência humana e

1 O mundo da vida, às vezes chamado de mundo da vida cotidiana refere-se ao mundo experiencial de cada pessoa em atitude natural. (HUSSERL, 1946)

2 A Classificação Internacional de Funcionalidade, Incapacidade e Saúde (CIF), baseada numa abordagem biopsicossocial, define incapacidade como produto da interação entre a disfunção apresentada pelo indivíduo (funções e estruturas do corpo), a limitação das atividades e restrição na participação social, e os fatores ambientais. (WHO, 2001) 
níveis sociais de significados. (ENGEL, 1977; DEMBE, 2003; YOUNG et al., 2005)

A dinâmica desencadeada na interação do trabalhador-doente com sua família, durante a convivência cotidiana pode interferir no tempo de afastamento do trabalho. A doença provoca na família mudanças na sua função e estrutura, exigindo de seus membros um esforço para lidar com as novas demandas provocadas pelo adoecimento. (ROLLAND, 1994) Estudos recentes de Dembe (2002), Franche e Krause (2002), Baril, Berthelette e Massicotte (2003), Allebeck e Mastekaasa (2004) e Rocha (2010) apontam a importância de reconhecer as situações geradas na família, em consequência do afastamento do trabalhador para se obter elementos que possam ajudar a compreender e gerenciar a reabilitação profissional.

Para ampliar o entendimento sobre as dinâmicas que ocorrem no ambiente da família, no processo de afastamento do trabalhador/doente, apresenta-se neste capítulo, uma revisão narrativa desta temática reunindo informações sobre as repercussões biopsicossociais do adoecimento do trabalhador, as dinâmicas familiares na relação com o trabalhador doente afastado do trabalho e o processo de retorno ao trabalho de afastamentos prolongados.

\section{Método}

Trata-se de uma revisão narrativa da literatura no período de 1991 a 2010, em bases de dados indexadas (Lilacs, Medline, Google Acadêmico) e livros especializados, em língua inglesa e portuguesa. Este método de pesquisa permite apresentar informações atualizadas de maneira exploratória, contribuindo para o delineamento da problemática e de futuras questões de pesquisa. (SLAVIN, 1995) A abrangência temporal possibilitou identificar a evolução desta discussão, no que diz respeito às mudanças da conformação das famílias e do entendimento sobre incapacidade para o trabalho. Nesta revisão foram incluídos estudos controlados, revisões sistemáticas, estudos de coortes e caso-controle, além de capítulos de livros. Foram excluídos os textos não disponibilizados e os que não tratavam dos tópicos de interesse da pesquisa. A limitação deste método se define pela forma subjetiva de escolha, da análise e conclusões dos estudos selecionados. (GELIJNS, 1990) 
Nesta perspectiva, buscou-se apresentar a atual discussão sobre a interação entre trabalhador-doente e sua família e as repercussões sobre a situação de incapacidade e do retorno ao trabalho. As palavras-chave utilizadas na busca foram em português: doença crônica-incapacidade, incapacidade-absenteísmo, a família no contexto do adoecimento do trabalhador, apoio à reabilitação-família, reabilitação e o processo de retorno ao trabalho ( em Inglês: "family and process of returning to work", "chronic disease and absenteeism", "family and illness of worker" e "family and rehabilitation"). Procurou-se examinar a literatura quanto às mudanças na estrutura e função da família, em consequência da presença do trabalhador-doente na residência; mudanças no seu papel social e as interações que acontecem com o serviço de saúde durante o processo de adoecimento e reabilitação. Estes aspectos permitem uma melhor compreensão sobre o tema e o reconhecimento da importância das diferentes dinâmicas familiares como facilitador ou obstáculo para o retorno ao trabalho do trabalhador-doente.

Com o objetivo de apresentar os achados da literatura e tornar compreensível a multidimensionalidade envolvida no processo de adoecimento e recuperação do trabalhador e sua família, dividimos este capítulo em três secções que abordam: 1- As facetas do adoecimento do trabalhador: as repercussões biopsicossociais; 2- As dinâmicas da família na relação com o trabalhador-doente afastado do trabalho; e 3- O processo de retorno ao trabalho: sua complexidade, os papéis dos atores sociais e a importância da família na recuperação do trabalhador.

\section{Resultados e discussão}

\section{As facetas do adoecimento do trabalhador: as repercussões biopsicossociais}

Segundo Kelly (2001), a trajetória do adoecimento se apresenta sob quatro facetas assim descritas: a fisiológica, que versa sobre as interpretações do paciente em relação aos aspectos biológicos e os processos inerentes à própria doença; a temporal, refletindo os significados vindos do uso do tempo (horários de consultas, fisioterapia, etc.); o sentimental, reconhecido pelas interações envolvendo em profundidade 
os anseios e emoções diante da possibilidade de confrontar dor ou morte; e a social, que se apresenta como resultado das interpretações que os indivíduos dão às atividades cotidianas que compõem os cuidados à saúde em sua totalidade.

O trabalhador-doente quase sempre tem restrições fisiológicas para executar as atividades diárias em casa e no trabalho como consequência primária da dor, fadiga e limitações físicas. Durante o adoecimento de um dos seus membros, a depender da forma como a família está estruturada, este fato pode levar à tensão e, até mesmo, à desestruturação. A magnitude do problema e a habilidade para lidar com a incapacidade estão na dependência do perfil do sujeito (capacidade de percepção, sexo, escolaridade e idade) e do suporte social presente, com grande variação do grau de repercussão biopsicossocial. (BOOT et al., 2008)

Durante a trajetória de adoecimento o trabalhador pode experimentar uma serie de eventos de natureza sentimental. A perda da atividade produtiva, a crise financeira, o estresse na família, o estigma e a dependência física e emocional conduzem o trabalhador-doente a perder a autoestima e a identidade pessoal, levando a uma diminuição do controle sobre a própria vida e o futuro. O sofrimento se expressa não só pela dor física, estresse psicológico ou pelos efeitos deletérios do tratamento, mas também pelo amplo significado dado à convivência com os membros da família e as repercussões do adoecimento nestas relações. As experiências do passado sobre as quais foi construída uma imagem positiva, agora não estão mais disponíveis. O modo de apresentação do problema está na dependência do modo de ver, dos valores adquiridos e na forma de viver no mundo. (CHARMAZ, 1983)

A doença remete a outra dimensão referente ao papel social que o sujeito doente assume na sociedade e tem variado a sua legitimação ao longo do tempo e cultura. Envolve os direitos e as obrigações que o sujeito tem de cumprir como parte da interação social. (PARSONS, 1964) A flexibilização das exigências na representação do papel social, é muitas vezes legitimada por um médico através de um diagnóstico e emissão de atestado, notificando a incapacidade do trabalhador e determinando o tempo de afastamento do trabalho.

No ambiente da empresa, as condições que contribuem para o adoecimento e o afastamento prolongado do trabalho estão relacionadas, em grande medida, à organização do trabalho como: o tempo 
de execução das tarefas prescritas (ritmo e tempo de jornada, hora de descanso), concepção do trabalho (complexidade da tarefa, habilidade e esforço pessoal, controle do trabalho), relacionamento interpessoal (relação com supervisores e colegas), perspectiva de crescimento, possibilidade de demissão, estilo de gerenciamento e característica organizacional (ambientação, cultura). Além desses, citam-se a falta de apoio social no trabalho, como disponibilização de seguro de saúde patrocinado pelo empregador e a inexistência de programas de prevenção de doenças e ergonomia no trabalho. (NIOSH, 1996; DEMBE, 2002; WADDELL; BURTON, 2006)

Outras condições relacionadas ao trabalhador e ao ambiente de trabalho têm sido descritas como responsáveis pelo absenteísmo nas empresas. Vingard e colaboradores (2005) acompanharam 5.224 mulheres empregadas do setor público durante três anos, incluindo as trabalhadoras que responderam que estavam bem de saúde. Ao final do seguimento observou-se que 918 delas estiveram afastadas do trabalho por mais de 28 dias. As análises uni-variadas e multivariadas, destinadas a avaliar os fatores associados ao absenteísmo, evidenciaram associação estatisticamente significante com idade (risco Relativo $(R R=1,4)$, obesidade $(R R=1,3)$, assédio moral $(R R=1,5)$, demanda física maior do que a capacidade de trabalho $(R R=1,5)$ e demanda psíquica maior do que a capacidade $(R R=1,2))$. Os autores concluíram que esses fatores, considerados como evitáveis, poderiam ser prevenidos e gerenciados no ambiente das empresas.

O processo de adoecimento também conduz a uma identidade de trabalhador-doente no espaço da empresa implicando, muitas vezes, em submissão ao discurso médico. Sair dessa condição independe da vontade individual. Esta nova identidade é reforçada por um conjunto de práticas linguísticas ou de mediadores sócio funcionais que, nem sempre, são aceitas sem resistência pelos atores sociais que fazem o movimento duplo de subordinação e insubordinação para driblar as formas de exclusão do trabalho. Embora a aceitação da situação vivenciada implique garantia do trabalho, não é o suficiente para evitar o estigma de portador de uma doença. (BRANT; MINAYO, 2004)

Por outro lado, podemos dizer que o fato de um trabalhador estar doente não significa estar de licença médica. Muitas vezes, o trabalhador continua na atividade laboral, mesmo com dificuldade para 
o desempenho das tarefas com o objetivo de manter-se empregado; sabe que se estiver desempregado experimentará dificuldades ainda maiores para se reinserir no mercado de trabalho. (ALEXANDERSON; NORLUND, 2004)

Estudos de Boden e colaboradores (2001) e Burton e colaboradores (2002), mostram que o trabalhador-doente tem maior chance de se ausentar do trabalho e, em longo prazo, pode apresentar mudanças na qualidade e expectativa de vida. Evidências neste sentido estão descritas no estudo de coorte prospectivo de Vahtere, Pentti e Kivima (2004), realizado na Finlândia com trabalhadores do setor público municipal, para determinar se o absenteísmo por motivo de doença é um fator preditivo de mortalidade. Foram incluídos na pesquisa 41.736 trabalhadores sendo $69,3 \%$ do sexo feminino com média de idade de 45,9 anos. Após tempo médio de acompanhamento de 4,5 anos os autores encontraram os seguintes resultados (ajustando-se os dados por idade, estado ocupacional e tipo de contrato de trabalho): mortalidade de 4,3 vezes maior para homens (IC de 95\%: 2,6-7,0) e 3,3 vezes maior para mulheres (IC de 95\%: 2,1-5,3) no grupo de trabalhadores que apresentou um ou mais períodos de absenteísmo prolongado (considerado $>3$ dias), em comparação com os trabalhadores que não se ausentaram do trabalho. Os autores concluíram que as evidências mostram maior mortalidade nesta população por todas as causas, inclusive as relacionadas à doença cardiovascular, câncer, complicação do alcoolismo e suicídio.

Burton e colaboradores (2002) no estudo sobre as consequências psicossociais do adoecimento relatam que: o trabalhador arca com $30 \%$ do total das despesas resultante do absenteísmo; a personalidade do indivíduo influencia o modo como ele ou ela reage ao adoecimento; às vezes, por ser um processo de diagnóstico e evolução lentos, este dificulta o reconhecimento do sujeito de que estava doente; a doença pode causar estresse emocional e isolamento social, interferindo no convívio com os familiares; os pesquisados relataram falta de suporte por parte das instituições responsáveis pelo seu atendimento e oito dos quinze casos entrevistados referiram que sua profissão foi afetada diretamente pela doença. Todos estes fatores foram citados como responsáveis pela reduzida capacidade de lidar com a condição de incapacitado, assim como de dificultar a recuperação profissional. 
Bernardo (2006) chama atenção sobre a experiência do afastamento do trabalho por doença, que apesar do reconhecimento e consciência de se tratar de uma situação, na maioria das vezes, provisória, provoca nos trabalhadores uma "ilusão de trabalho", principalmente quando o afastamento é de longa duração, porque continuam a receber parte do salário. Entretanto, a possibilidade de perder a renda e de ter que sobreviver exclusivamente do benefício pago pela previdência social, que geralmente é inferior ao que usualmente se ganhava, é uma constante em suas vidas. $\mathrm{O}$ trabalhador do setor privado sofre com a possibilidade de desemprego, pois a sua recuperação ou reabilitação não garante o retorno ao trabalho. Em alguns casos o futuro não parece promissor, pois há o risco concreto do preconceito, do estigma e da incompreensão das empresas para sua reinserção no trabalho. No setor público, apesar da estabilidade do servidor no emprego, durante o adoecimento também se observa perdas de vantagens salariais que interfere no processo de recuperação e a perspectiva de alcançar crescimento profissional fica ameaçada pelo afastamento do trabalho.

As demandas atuais impostas pelas organizações têm desafiado o trabalhador em combinar as tarefas do trabalho e as necessidades da vida familiar. Em consequência da sobrecarga do turno estendido, assim como do número crescente de famílias monoparentais e de casais que trabalham fora de casa, associado à dupla jornada de trabalho, a falta de energia do trabalhador para lidar com assuntos do cotidiano doméstico é uma temática recorrente. O conflito de interesse entre empresa e família é reconhecido como um fator de absenteísmo principalmente no sexo feminino. (JANSEN et al., 2006)

Outro aspecto também a ser considerado durante o processo de adoecimento refere-se à economia das perdas e ganhos. O papel dos ganhos secundários, seja motivado de causa psicológica, ou de outras formas, como os tipicamente associados a ganhos monetários, evitar obrigações sociais, dentre outros, tem sido considerado como uma importante barreira para a recuperação do trabalhador incapacitado por motivo de doença. Embora seja um tema extremamente controverso e fonte de discussão na área médico-legal e social, entende-se como necessário seu reconhecimento nos processos de retorno ao trabalho, como parte das demandas para o gerenciamento de programas de reabilitação. 
Entretanto, segundo Gatchel e colaboradores (2004), esse conceito está vinculado erroneamente ao fingimento consciente do paciente para receber benefícios financeiros. Este autor chama atenção aos prejuízos que este ponto de vista traz ao paciente: gera a ampliação de seu esforço para obter a legitimação do adoecimento, acentua seu sentimento de injustiça, leva-o a resistir ao reconhecimento de resultados terapêuticos e influencia no prolongamento do afastamento do trabalho. Aponta ainda a necessidade de identificar e incluir também, neste registro, as perdas secundárias que se infiltram praticamente em todos os domínios da vida do indivíduo doente e incapacitado. A perda da autonomia, as mudanças das relações sociais, a instabilidade financeira, a dificuldade de manutenção do emprego, as mudanças dos papéis familiares, o impacto sobre a autoestima, e mesmo sobre a visão geral do mundo, influenciam o comportamento do indivíduo em relação à doença e à incapacidade prolongada.

Neste contexto devem-se analisar também as perdas e ganhos terciários, que são aqueles obtidos ou perdidos com a doença por alguém, que não o próprio paciente, um membro da família, um médico, etc. O resultado desta economia de perdas e ganhos pode influenciar o tempo de afastamento do trabalho e, por razões óbvias, por exemplo, quando as perdas superam os ganhos, servem de reforço para um retorno ao trabalho precoce, sem a adequada reabilitação. (KWAN; FRIEL, 2002; DERSH et al., 2004)

Segundo Kaiser (1998), as explicações que determinam o comportamento de absenteísmo, sob uma perspectiva interdisciplinar (psicologia organizacional, psicologia social e economia) devem ir além dos significados isolados dos modelos de motivação individual, social e econômico, entendidos aqui como não mutuamente exclusivos e sim interdependentes e complementares. No modelo explicativo, que incorpora a motivação individual, se distinguem três categorias: a característica pessoal (valores pessoais, personalidade, atitude frente ao trabalho, aspecto demográfico e status social); a resposta individual ao estímulo no ambiente organizacional (por exemplo, tipo e condição de trabalho); e as respostas aos estímulos, aos ambientes fora do trabalho (circunstâncias da vida e da família, valores do uso do tempo fora do trabalho). O modelo psicossocial reconhece que a decisão de estar ausente será tomada em diferentes circunstâncias baseada no pressuposto que 
o trabalhador assume, observando tanto o status e o comportamento dos outros trabalhadores (dentro e fora da organização), como os sentimentos de igualdade e de justiça. $\mathrm{O}$ modelo econômico sugere que em grande medida, os benefícios e custos associados com o absenteísmo são ditados pelas forças do mercado de trabalho. Enfim, esses três modelos presentes em uma abordagem biopsicossocial, conduz a um melhor entendimento da(s) causa(s) do afastamento do trabalhador e vai de encontro ao peso relativo de cada modelo nas circunstâncias em que a ausência ao trabalho for observada.

O trabalhador-doente, incapacitado e afastado do trabalho, independentemente do motivo que o levou à situação de restrição das atividades e necessidade de suporte, procura abrigo no ambiente da família onde se sente acolhido. É neste local, considerado como um sistema de saúde, que procura cicatrizar as suas "feridas" provocadas por uma doença que não esperava e que lhe roubou a vitalidade e a perspectiva de viver com um futuro promissor.

O sujeito procura aportar em um lugar seguro onde os pares lhe são familiares e que já ganhou a confiança após anos de convivência. É exatamente no seu mundo familiar que tem de representar o seu novo papel, o de doente e que nem sempre será bem interpretado ou compreendido. A família, no seu processo de transformação, absorverá ou não este impacto na dependência da forma como os seus membros agem e gerenciam esta nova contingência.

\section{As dinâmicas da família na relação com o trabalhador-doente afastado do trabalho}

Singly (2007), em publicação sobre a Sociologia da Família Contemporânea chama atenção sobre as transformações ocorridas nas últimas décadas na família, em termos de estrutura e função, em consequência do modo como os seus membros se posicionam no cotidiano contemporâneo, resultado das mudanças derivadas das relações de gênero, da inserção intensiva da mulher no mercado de trabalho e da maior mobilidade conjugal. A família participa do dinamismo intrínseco às relações sociais e sofre influências do contexto político, econômico e cultural. Torna-se cada vez mais relacional, ainda que inscrita num processo de individualização e autonomização de seus membros. Processo que não 
se restringe aos papéis ordenados pela instituição família, mas uma forma contemporânea de criar laços sociais.

As transformações na sociedade fizeram com que a família mudasse de forma e sentido. Em lugar de se impor aos seus membros, a família se tornou, de alguma maneira, um "serviço" que pode ser colocado à disposição dos indivíduos preocupados em viver juntos. Na atualidade, a definição de família fica mais complicada até para os seus próprios atores sociais, diante da dificuldade para delimitar os seus contornos mutantes. (SINGLY, 2007)

Podemos dizer que a família é relacional porque existe ligação através dos pais e filhos, e ela está inserida em um cotidiano complexo onde seus membros, mesmo mantendo sua individualidade, compartilham sentimentos e valores formando vínculos de interesse, solidariedade e reciprocidade. A família é também, ao mesmo tempo, pública e privada, pois se caracteriza pela sua relativa dependência em relação ao Estado e aos grupos de parentesco. Os homens e as mulheres, os adultos e as crianças organizam suas vidas privadas no quadro da dualidade: buscam sua independência em termos individuais e mantém uma dependência da esfera pública. Ainda em relação a este ponto de vista, observam-se mudanças na função da família onde os seus papéis foram transferidos para outras instituições (escolas, creches) fruto da inserção da mulher no mercado de trabalho e da globalização da sociedade. (SIMIONATO; OLIVEIRA, 2003; SINGLY, 2007)

$\mathrm{Na}$ perspectiva do modelo sistêmico, a família desempenha suas funções incorporando os conceitos de organização referente à sua força, papéis, hierarquia e integridade de fronteiras; adaptabilidade (flexibilidade versus rigidez), coesão (estar juntos ou afastados) e estilo de comunicação. Dessa forma, executa três tipos de tarefas no cuidado dos seus membros na convivência cotidiana: o básico, como obter alimento e abrigo; o apoio ao desenvolvimento em busca de novos horizontes sociais e o de proteção frente às situações adversas como uma doença e incapacidade. Contudo, existem inúmeras situações contemporâneas que fogem aos padrões descritos acima e que determinam outras formas da família agir e gerenciar o cuidado dos seus membros. (BERTALANFFY, 1969; ROLLAND, 1994)

O papel social da família inclui, entre outros, o cuidado da saúde que transita entre o autoevidente e o velado, a administração das 
economias e o suporte para facilitar a condição de trabalho de seus membros. A família tem uma materialidade onde, na convivência entre seus membros, ora como pano de fundo, ora como determinante explícito é tecida a especificidade de cada sujeito. Quando acometido por uma doença, os membros apoiam-se mutuamente, buscam e mediam esforços para atenuar ou resolver o impacto do adoecimento e desempenham seus papéis, que são as expectativas de comportamento, obrigações e direitos respeitando a sua posição no grupo familiar influenciado pelas circunstâncias sociais e culturais. (ROLLAND, 1994)

Quando uma doença atinge um indivíduo, se expressa em certo contexto, que é resultado de uma construção social, como um processo que não é simples e que envolve múltiplos sistemas de significado, interagindo nesse momento especial de vida. Dessa forma, o processo de adoecimento está envolto a uma complexa rede de significados produzidos pelos atores sociais envolvidos, numa constante edificação e redefinição. Na maioria das vezes o trabalhador-doente se encontra no "olho deste furacão" de significados correntes e pode muito bem ser imobilizado, dificultando a sua recuperação. (BLOCH, 1994)

As consequências não se restringem apenas aos efeitos no doente, mas dependendo da fase de desenvolvimento da família pode abranger todos os seus membros, requerendo deles um esforço desafiador para organizar a estrutura familiar ao longo dos diversos ciclos da vida. Por sua parte, a família tem uma estrutura organizacional própria para enfrentar as situações rotineiras e de contingências e, desta forma, tenta administrar habilmente suas demandas através da construção de certos padrões representados pela divisão de responsabilidades, hierarquia e delimitação de fronteiras entre os seus membros. (SACHS; ELLENBERG, 1994)

Dembe (2002), em um artigo de revisão sobre o adoecimento do trabalhador e suas consequências sociais, mostra evidências de que o adoecimento do trabalhador está associado à alteração do seu bem-estar, mudanças no convívio no interior da família e desestruturação da sua condição financeira. Diz ainda que as consequências sociais, difíceis de serem mensuradas na prática, envolvem as diversas relações recíprocas entre os diversos atores participantes deste processo. Estão também na dependência da magnitude da incapacidade provocada pela doença, do 
perfil sociodemográfico, da experiência com os serviços de saúde e com a seguridade social e dos efeitos, em particular, no ambiente da família.

O trabalhador-doente se vê diante de mudanças nos seus hábitos e em seu estilo de vida. Percebe-se diante de inúmeras perdas de seus papéis e de suas responsabilidades e o retorno à convivência dentro do ambiente familiar obriga-o a renegociar a sua identidade. Ele se sente como se fosse outra pessoa e descreve que as mudanças que acontecem na sua vida se estendem além das limitações físicas provocadas pela enfermidade. Como resultado dessa reestruturação, experimenta sentimento de culpa, ansiedade e depressão que podem interferir na forma de conviver na família. (STRUNIN; BODEN, 2004)

A redescoberta do domicílio familiar acontece quando se vê obrigado a ficar em casa diuturnamente por causa da doença. Como é o único lugar onde passa a viver, requer que desenvolva pluralidade e criatividade para sobreviver. A arte de estar entre os membros de sua família, na atual circunstância determina a construção de uma nova ação do que se espera das regras de convivência e manutenção dos vínculos parentais. (CERTEAU, 1988)

Sabe-se que algumas famílias estão mais bem preparadas do que outras para gerenciar as mudanças provocadas pela doença. São capazes de tolerar situações de alto estresse através da troca dos papéis (alguém assume o papel para fazer certas atividades domésticas em substituição ao doente) e, desta forma, tentam enfrentar os problemas de maneira mais eficiente. Entretanto, o grau de incapacidade do trabalhador-doente vai determinar um estresse adicional à família.

A forma de administrar esta nova demanda implica negociação das fronteiras individuais, que esbarra na importância dos papéis desempenhados por cada membro. Na divisão das tarefas domésticas há um espaço para o surgimento de novos conflitos ou acentuação de antigos mal resolvidos. (ROLLAND, 1994) Muitas vezes, o ambiente familiar está desestruturado pelas circunstâncias sociais contemporâneas, resultado das mudanças profundas e permanentes que dizem respeito à atividade produtiva e a organização do trabalho, devido às condições geradas pelas relações atuais de emprego, produzidas pelas situações de baixa remuneração, fragilidade dos vínculos empregatícios e turnos extensos de trabalho. (GOMES, 2008) Diante de tal perspectiva, o mundo da vida cotidiana ganha uma dimensão mais complexa, exigindo 
de cada membro um esforço particular para manter o equilíbrio nas relações interpessoais.

Por outro lado, alguns assumem que o trabalhador doente, se recuperando em casa, vai ter mais tempo para os afazeres domésticos. Em certas circunstâncias isto é possível, particularmente se as atividades realizadas não demandam muito esforço. Entretanto, a incapacidade provocada pela doença na execução do trabalho na empresa se estende também às tarefas executadas no cotidiano da residência, interferindo com a autoestima e autoconfiança do indivíduo, chegando ao ponto de criar obstáculo na interação habitual da família. (BODEN et al., 2001)

O afastamento do trabalho e o impacto do adoecimento nas famílias que tem uma única fonte de renda, geralmente originada do trabalho assalariado, serão de grande monta, principalmente se houver redução salarial por conta de perdas dos complementos recebidos durante o turno de trabalho. Algumas vezes, a cobertura do seguro social é insuficiente para absorver as crescentes demandas de gastos com medicamentos, consultas a especialistas, deslocamento para os serviços de tratamento e recuperação. (BODEN, 2005)

A revisão de literatura de Foreman, Murphy e Swerissen, (2006) mostra os principais fatores que facilitam ou dificultam o retorno ao trabalho, entre estes a oferta de serviços especializados para o tratamento, o papel da seguridade social ou outras dimensões de apoio no ambiente da empresa. Contudo, pouco ou raramente se encontram estudos avaliando o impacto econômico no cotidiano familiar dos trabalhadores afastados por doença, merecendo maior atenção dos pesquisadores interessados nesta problemática. (DEMBE, 2002)

O tempo que o trabalhador-doente passa em casa é determinado não só pelo grau de incapacidade em consequência da doença, mas também pelas circunstâncias do seu convívio no ambiente familiar. Esse processo pode ser longo e de alto custo para o indivíduo isoladamente ou para a sociedade como um todo. Rocha (2010), em estudo realizado com servidores públicos da Universidade Federal da Bahia afastados do trabalho, por motivo de doença, observou que o apoio dos familiares atuava como um fator importante na recuperação da incapacidade e era considerado como um facilitador positivo para o retorno ao trabalho. A contribuição mais significativa desta pesquisa foi desvelar a importância do papel da família na reabilitação do trabalhador-doente atra- 
vés do relato das experiências sobre as dificuldades dos servidores na convivência cotidiana em casa.

A recuperação do trabalhador com incapacidade é um dos maiores desafios para os serviços de saúde porque têm de lidar com os aspectos físicos, psíquicos e sociais da doença e com fatores contextuais. Para melhor gerenciar o processo de retorno ao trabalho, autores como Schultz e Stewart (2008) e Loisel et al. (1994) propõem um modelo de abordagem biopsicossocial que integre as suas ações, intervindo nas barreiras e nos facilitadores contextuais (sistema de saúde, previdência social, local de trabalho e contexto pessoal, onde está presente a família). Trata-se de um modelo de atuação voltado à prevenção da incapacidade prolongada, que incorpora o sistema de crença, os profissionais da saúde, pacientes e família de maneira flexível, para além do tratamento biomédico. (LOISEL 2007)

Neste horizonte de significados distintos e muitas vezes tensionados, em um momento de profundas mudanças provocadas pelo adoecimento, as demandas dos processos de trabalho e familiares surge a necessidade de gerenciamento deste processo por parte dos diversos atores sociais envolvidos com a reabilitação de pessoas. Um suporte importante tem sido os posicionamentos assumidos pela Organização Internacional do Trabalho (OIT, Convenção nº159 e Recomendação $\mathrm{n}^{\circ} 168$ ). Desta forma, empresa, sistemas de saúde e o Estado devem se mobilizar para recuperar e reinserir o trabalhador o mais brevemente possível ao mercado de trabalho.

\section{O processo de retorno ao trabalho}

O processo de retorno ao trabalho do trabalhador-doente é complexo, envolve, como mencionado anteriormente, os aspectos relacionados à doença e ao doente, ao tratamento, aos fatores do local de trabalho (organização, função, cultura) e aos fatores fora do ambiente do trabalho como atitude da família e as políticas públicas de saúde do trabalhador. Inclui muitos atores sociais com distintos papéis, objetivos e prioridades. Essas diferentes perspectivas refletem significados que os indivíduos, dos diferentes sistemas, atribuem às mudanças provocadas pela doença, a natureza da interação com o trabalhador-doente e a da relação com o trabalho. (BARIL; BERTHELETTE; MASSICOTTE, 2003) 
Engloba também uma série de eventos desde a fase inicial do diagnóstico da condição clínica, que motivou o afastamento do trabalhador e provocou a incapacidade, até o resultado satisfatório (recuperação laboral) a curto, médio ou a longo prazo. Diferentes ocorrências têm características particulares e consequências distintas a depender das etapas do seu acompanhamento.

Para melhor gerenciamento deste processo Franche e Krause (2002) sugerem três fases evolutivas, definidas pelo número de dias de afastamento do trabalho: aguda ( $\leq 1$ mês); subaguda (2-3 meses) e crônica (>3 meses). Young e colaboradores (2005) propõem um modelo conceitual baseado na dinâmica na qual a condição de incapacidade é desenvolvida em etapas: fase 1 ou de afastamento do trabalho, período durante o qual há recuperação de parte da capacidade funcional; fase 2 ou de reentrada ao trabalho, período que o trabalhador recomeça o seu trabalho; fase 3 ou de manutenção, durante a qual o trabalhador se esforça para manter a sua recuperação e fase 4 ou de avanço, quando o trabalhador experimenta novas qualificações.

De uma forma geral, as ações desenvolvidas para gerenciar a recuperação do trabalhador são realizadas pelos serviços de saúde ocupacional; nos quais, na maioria das vezes, são empregados apenas os princípios médicos de tratamento - um tipo de acompanhamento considerado como linear e que tem por objetivo fazer o diagnóstico e estimar o período necessário de afastamento laboral. A trajetória que o trabalhador doente segue para se recuperar é construída durante as consultas médica e/ou cirúrgica e no acompanhamento no setor de reabilitação profissional (fisioterapia, de terapia ocupacional, serviço social). O quê se vê, na maioria dos casos, é um total desconhecimento do trabalhador dos caminhos necessários para a sua recuperação e reintegração ao trabalho (BERNARDO, 2006).

Nesta perspectiva, a condição para o retorno ao trabalho limita-se à resolução da situação clínica baseada no seu estadiamento e extensão da incapacidade. Dessa forma, perde-se a oportunidade de compreender a complexidade e as várias dimensões deste processo, principalmente as que fazem parte de outras áreas de interdependência deste sistema. (BARIL; BERTHELETTE, D.; MASSICOTTE; 2003)

Partindo deste pressuposto, Takahashi (2000) comparou dois modelos assistenciais para portadores de Lesões por Esforço Repetitivo 
(LER) em serviços de Reabilitação Profissional do Instituto Nacional de Seguro Social do Brasil (INSS) ${ }^{3}$. O primeiro modelo (biopsicossocial), implantado no Centro de Reabilitação Profissional de Campinas/ São Paulo apresentava uma proposta inovadora de atendimento onde se realizava ações terapêuticas integrais por uma equipe multidisciplinar. O segundo modelo (biomédico), no Núcleo de Reabilitação Profissional de Americana/São Paulo considerado como tradicional, de atenção mínima, restrito praticamente a abordagem pericial e com objetivos exclusivos de reinserção imediata do trabalhador-doente ao trabalho. Utilizando uma metodologia avaliativa que comparou os resultados de intervenção no resgate da autonomia de adoecidos com LER, a autora concluiu que o primeiro modelo se mostrou mais adequado para a reabilitação desses trabalhadores. Este achado está em consonância com as pesquisas mais recentes que reforçam a ideia de que o modelo biopsicossocial parece ser o mais adequado para acompanhar o trabalhador incapacitado por doença. (SCHULTZ ; STEWART, 2008)

Posto que o retorno ao trabalho do trabalhador-doente é multifatorial, entende-se de uma maneira geral que é difícil fazer uma previsão, com precisão, de quando o retorno acontecerá, usando apenas como referência o conhecimento médico e as características da doença. Depende, sobretudo das ações gerenciais empregadas para lidar com as interações dos fatores biológico, psíquico e ambiental. A depender da condição que levou ao afastamento observa-se uma predominância de um fator sobre o outro. A Figura 1 é possível descrever a complexidade da rede de interdependência que envolve os principais fatores biopsicossociais.

3 Serviços executores de reabilitação do INSS representados pelos Núcleos e Centros de Reabilitação profissional que se encontram atualmente com função apenas reguladora, sendo destituída de qualquer atividade terapêutica. 
Figura 1 - Rede de interdependência dos fatores biopsicossociais

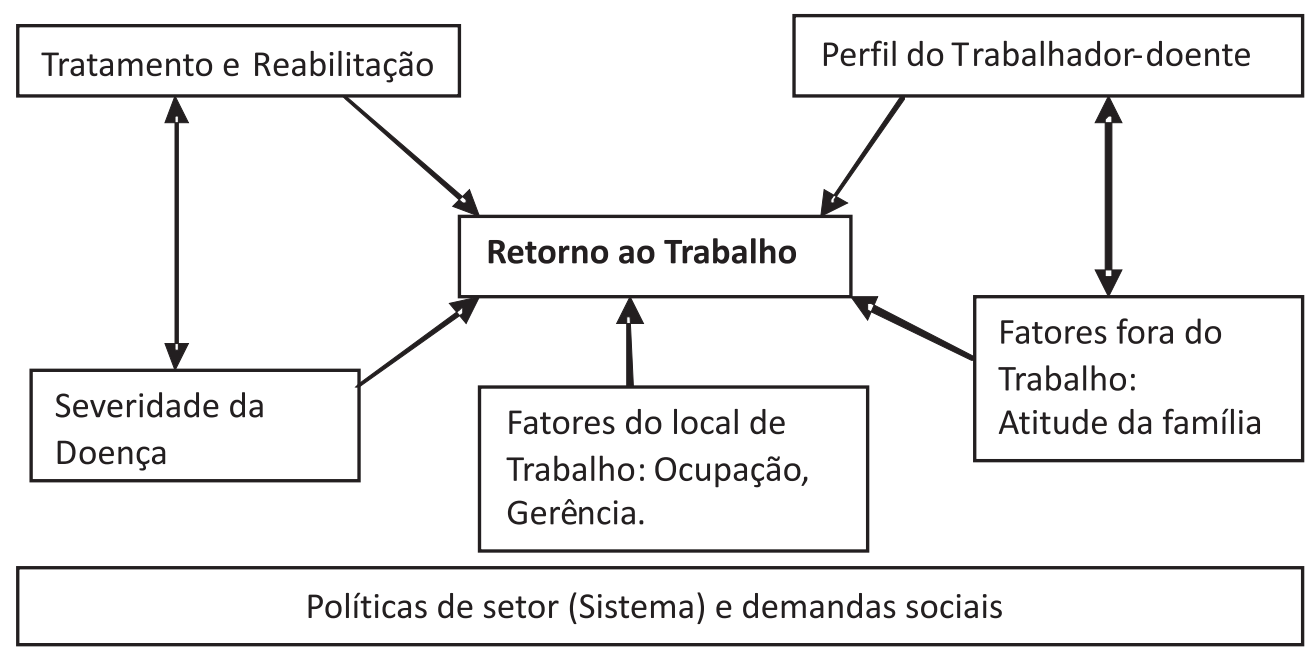

Fonte: (FOREMAN; MURPHY; SWERI, 2006).

Como o processo de retorno ao trabalho pode ser longo e custoso deve-se buscar as informações e analisar se as condições biopsicossociais que levaram ao afastamento do trabalho foram estabilizadas, a fim de determinar se o indivíduo recuperou sua capacidade laboral e se as condições do contexto de trabalho permitem este retorno. É importante ressaltar que o gerenciamento do retorno ao trabalho implica reconhecer que a condição de afastamento prolongado implica aumento do custo com os cuidados com a saúde; baixa (35\%) reinserção do trabalhador incapacitado no mercado de trabalho em comparação com a população adulta normal $(78 \%)$ e o desconhecimento sobre os efeitos em longo prazo da incapacidade do trabalhador-doente. (YOUNG et al., 2005)

No início do afastamento, o indivíduo não tem a noção exata da extensão da sua incapacidade e à proporção que o tempo passa e a recuperação funcional demora é que se percebe que a situação é mais complexa. O trabalhador apresenta mudança no estilo de vida que é dependente da natureza da doença, do grau e persistência da incapacidade, das suas necessidades econômicas e das preferências de lazer e consumo que adota. Por exemplo, uma pessoa doente que tem boas condições financeiras pode se afastar do trabalho e esperar a recuperação, enquanto outras são impedidas de realizar o afastamento por causa da limitação econômica, da obrigação de suprir as necessidades básicas familiares - o que força o trabalhador a fazer adaptações ou a procurar outras formas de trabalho. Além da perda salarial, tem-se que lidar com 
a depreciação dos hábitos e habilidade do trabalho, o que leva ao declínio de produtividade e de rendimentos futuros. Por outro lado, maior tempo de incapacidade é um importante determinante da probabilidade de estar empregado após um ano de afastamento; quanto mais retardada for a reinserção, maior repercussão terá na vida do trabalhador. (BOUND et al., 2003; GALIZZI; BODEN, 2003)

As observações aqui apresentadas reforçam o conceito de que quanto mais precocemente forem adotadas as medidas apropriadas para a reabilitação do trabalhador-doente, mais rápido será o seu retorno ao trabalho. Além disso, um grande número de estudos aponta para a relação entre doença e aposentadoria precoce, o que pode ser indesejável para alguns e representar para o sujeito uma perda do poder aquisitivo e isolamento social. Bound e colaboradores (2003), com base em dados dos US Health and Retirement Study, estimaram que trabalhadores com problema de saúde tem dez vezes mais chance para se aposentar em comparação com indivíduos saudáveis. Dados obtidos do serviço público no Brasil mostram uma elevada percentagem de servidores sendo aposentados precocemente por falta de melhor gerenciamento da doença do trabalhador. (DOMINGUES JÚNIOR, 2005)

Algumas condições, de uma forma geral estão associadas com o tempo de afastamento prolongado do trabalho. Além das inerentes à própria doença, vale a pena ressaltar as que dizem respeito ao trabalhador, como a idade (indivíduos de maior faixa etária), o sexo (o feminino) e a baixa escolaridade. Em relação aos fatores psicossociais, a literatura aponta como causa de absenteísmo prolongado a organização do trabalho, com ênfase no efeito do baixo controle e alta demanda nas situações de trabalho. Além disso, citam-se a falta de informação do trabalhador sobre o modo como deve ser acompanhado pelo serviço de saúde ocupacional, o desconhecimento sobre os seus direitos e o baixo comprometimento dos colegas e supervisores. (DEMBE, 2002; LABRIOLA, 2006)

Franche e colaboradores (2002) sugerem que para se alcançar melhores resultados no processo de reabilitação é imprescindível ter uma relação partilhada entre as partes interessadas. Devem-se incorporar atores sociais como a família, os representantes da empresa (supervisores e diretores), os profissionais da área da saúde (médico, fisioterapeuta, terapeuta ocupacional e assistente social) e os representantes 
da seguridade social. O sucesso dos programas de retorno ao trabalho é proporcional à interação entre empregador, trabalhador e demais atores sociais interessados. No contexto brasileiro, a assimetria de poder dessas relações tem sido objeto de questionamento entre pesquisadores da área de saúde do trabalhador. (MAENO; TAKAHASHI; LIMA, 2009)

Segundo Loisel (2007), os atores sociais envolvidos no processo de retorno ao trabalho devem observar os múltiplos significados atribuídos pelo trabalhador-doente ao adoecimento e à sua relação com o trabalho, na dimensão cultural e cognitiva, assim como reconhecer as situações geradas pelo afastamento do trabalho, para melhor compreender a incapacidade e obter elementos que ajudem a gerenciar a reabilitação profissional. Posto desta forma evita-se colocar o trabalhador como um "simples objeto perdido" neste sistema, resgatando seu lugar de sujeito do cuidado.

Franche e colaboradores (2005), em revisão sistemática da literatura, sugerem as melhores intervenções para se reduzir a duração da incapacidade para o trabalho. Em relação aos achados de estudos quantitativos propõem: o contato precoce com o trabalhador no ambiente do trabalho; intervenção nas acomodações do trabalho gerenciada por um especialista em ergonomia; facilitar a interação entre os membros da equipe multidisciplinar da saúde (médicos, fisioterapeutas e terapeutas ocupacionais); e os responsáveis pela empresa (diretores e supervisores). Além de adotar um programa de educação continuada sobre os aspectos ergonômicos e de segurança no local de trabalho. Citando estudos qualitativos, sugerem a necessidade de melhorar a comunicação entre as partes interessadas neste processo, sensibilizando e incentivando a participação dos colegas de trabalho; assim como delegar ao supervisor direto um importante papel para o retorno ao trabalho e eleger os profissionais da saúde como ponte de ligação entre o local de trabalho e o sistema de saúde.

Baseado no trabalho de Franche e colaboradores (2005), o Institute for Work \& Health do Canada (2007) recomenda às empresas adotarem os sete princípios para o sucesso no processo de retorno ao trabalho:1a existência de forte compromisso das pessoas no ambiente do trabalho com o retorno do trabalhador-doente; 2 - a necessidade de transformação no ambiente físico do local de trabalho para facilitar a readaptação do trabalhador com incapacidade temporária; 3- assegurar que o retor- 
no do trabalhador não sobrecarregue os colegas e cause dificuldade para o supervisor direto; 4- treinar os supervisores diretos do trabalhador sobre os processos envolvidos no retorno ao trabalho; 5- o empregador deve se comunicar o mais cedo possível com o trabalhador-doente e acompanhar o processo de retorno ao trabalho; 6- designar uma pessoa para coordenar o processo de retorno ao trabalho; e 7- empregadores e equipe multidisciplinar da saúde (médicos, enfermeiros, fisioterapeutas e terapeutas ocupacional) devem ficar em contato permanente e trocar informações sobre a recuperação do trabalhador-doente.

No Brasil, o processo de reabilitação profissional está regulamentado pela Lei 8.213/91, baseada na Convenção 159 da Organização Internacional do Trabalho e clamada pela $3^{\text {a }}$ Conferência Nacional de Saúde do Trabalhador realizada em 2005. A partir da Constituição de 1988, a reabilitação é uma atribuição do SUS; no entanto, as ações de saúde voltadas para a reabilitação profissional não foram integradas a este sistema nos últimos 20 anos, mantendo-se o INSS como o principal responsável pela reabilitação profissional para os trabalhadores celetistas. Contudo, as dificuldades crônicas de pessoal qualificado, o cunho assistencialista e previdenciário, o modelo convencional de reabilitação do trabalhador têm sido questionados quanto a sua eficácia, efetividade desse serviço e legitimação de seus objetivos. Não existe uma ação integrada com a participação da empresa, trabalhador e os diversos órgãos governamentais para mudar ou minimizar as condições de adoecimento. Com estas limitações expõem-se o trabalhador às mesmas situações que levaram ao seu afastamento. (TAHAKASHI, 2000; CUT, 2007)

$\mathrm{Na}$ atualidade há crescimento do debate sobre esta temática. A defesa da Previdência Social solidária, de gestão pública, democrática e universal deve ser rediscutida no âmbito da política nacional da saúde do trabalhador. O que se propõe é incorporar os diversos atores sociais na construção de um modelo gerencial que atenda às necessidades das partes interessadas na reabilitação profissional com igualdade de papéis e responsabilidades. O Estado como gestor deve tomar o seu papel de guardião das Leis e de regulador dos benefícios sociais e cidadania. (MAENO; TAKAHASHI; LIMA, 2009)

A legislação brasileira atual na área de saúde do trabalhador não faz distinção de direitos entre os empregados do setor privado, que trabalham regidos pela Consolidação das Leis Trabalhistas (CLT), e do 
servidor estatutário, regido pelo Regime Jurídico Único. Entretanto, o que se vê é um distanciamento das ações nos dois setores. Contudo, o setor público, que faz cumprir as normas de atenção à saúde e segurança do trabalhador nas empresas privadas, não consegue reproduzir os mesmos cuidados com os servidores estatutários. Este descompasso reflete a distância da administração pública em se apropriar da problemática para responder as demandas na área de saúde dos servidores, levando a um contingente crescente de afastados do trabalho por doença, em decorrência das condições de trabalho. (CARNEIRO, 2006)

Até recentemente os trabalhadores doentes do serviço público no Brasil eram acompanhados sem ter disponível uma estrutura organizada para cuidar da sua saúde. Ao longo dos anos foi desestimulada uma atenção especial com vista a promover melhoria das condições de saúde e de trabalho nas instituições. Este descaso levou a um número crescente de absenteísmo e aposentadoria precoce nessa população, com significativa repercussão socioeconômica. (DOMINGUES JÚNIOR, 2005)

\section{Considerações finais}

A revisão narrativa da literatura mostra, com base em diversos estudos, que o adoecimento do trabalhador, que interfere na sua capacidade laboral, pode ter repercussão no ambiente da família e interferir no processo de retorno ao trabalho. Entende-se que a família participa ativamente no gerenciamento do processo de adoecimento, através da mobilização de seus membros na contingência da convivência cotidiana. Este suporte é um fator importante na recuperação da incapacidade e pode ser considerado como um facilitador positivo para o retorno à condição laborativa o mais breve possível. (ROCHA, 2010)

Neste sentido, sugere-se que sejam revistas às práticas adotadas nos serviços de reabilitação, restrita ao indivíduo e ao ambiente de trabalho, entendendo-se que as fronteiras entre o trabalho e a família são flexíveis e permeáveis e indicando que o que acontece em um domínio influencia o outro domínio. Propõe-se, dentre as ações desenvolvidas para gerenciar a reabilitação profissional, incluir o gerenciamento dos processos que ocorrem na família neste contexto.

Por consequência, os profissionais envolvidos nesses processos devem procurar entender os horizontes de significados originados na 
interação familiar e incentivar, por exemplo, a mediação de conflitos entre os membros e ampliação do suporte social ao trabalhador-doente. A avaliação dessas famílias pode ser feita também se observando o contexto histórico e socioeconômico no qual esta está inserida durante o processo de desajuste, procurando-se respostas sobre a melhor forma de lidar com o problema. Os membros da família devem ser encorajados a desenvolver novos mecanismos e competências para compartilhar ações de suporte no sentido de fortalecer a família para superar obstáculos no gerenciamento da condição do trabalhador-doente e na possibilidade do retorno ao trabalho.

\section{Referências}

AGÊNCIA Brasil, [2008]. Disponível em: < http://www. agenciabrasil.gov.br/noticias /2008/05/13/materia.20080513. 929010578/view >. Acesso em: 10 jul. 2008.

ALEXANDERSON, K.; NORLUND, A. Chapter 1. Aim, background, key concepts, regulations, and current statistics. Scandinavian Journal of Public Health, v. 32, n. 63 Suppl. , p. 12-30, Oct. 2004.

ALLEBECK, P.; MASTEKAASA, A. Chapter 5. Risk factors for sick leave - general studies. Scandinavian Journal of Public Health, v. 32, n. 63 Suppl., p. 49-108, Oct. 2004.

BARIL, R.; BERTHELETTE, D.; MASSICOTTE, P. Early return to work of injured workers: multidimensional patterns of individual and organizational factors. Safety Science, v. 41, n. 4, p. 277-300, June 2003.

BARIL, R.; BERTHELETTE, D.; MASSICOTTE, P. Management of return-to-work programs for workers with musculoskeletal disorders: a qualitative study in three Canadian provinces. Social Science \& Medicine, v. 57, n. 11, p. 2101-2114, Dec. 2003.

BERNARDO, L. D. Os significados do trabalho e da reabilitação profissional para o trabalhador incapacitado para o exercício da profissão habitual. 2006. 72f. Dissertação (Mestrado em Saúde Pública) Faculdade de Medicina, Universidade Federal de Minas Gerais. Disponível em: < http://www. bibliotecadigital. ufmg. br /dspace/bitstream/1843/ ECJS-73BKA6/1/lilian_dias_bernardo. pdf>. Acesso em: 25 out. 2007.

BERTALANFFY, L. VON. General System Theory. 1 ed. New York, USA: George Braziller, 1969. 295 p. 
BLOCH, D. A. Foreword in Roland J S, Families, Illness, and Disability: an integrative treatment model. 1ed. New York, USA: Basic Books, 1994. 320p.

BODEN, L. I. et al. Social and economic impacts of workplace illness and Injury: current and future directions for research. American Journal of Industrial Medicine, v. 40, n. 4, p. 398-402, Oct. 2001. . Running on Empty: Families, Time, and Workplace Injuries. American Journal of Public Health, v. 95, n. 11, p. 1894-1897, Nov. 2005. BOOT, C. R. L. et al. The role of illness perceptions in labor participation of the chronically ill. International Archives of Occupational and Environmental Health, v. 82, n. 1, p. 13-20, Jan. 2008.

BOUND, J. et al. Health, Economic Resources and the Work Decision of Older Men, 2003. Disponível em: <http://socserv. socsci. mcmaster. ca /cesg2003/stinepaper. pdf>. Acesso em: 10 jul. 2007.

BRANT, L. C.; MINAYO, C. G. A transformação do sofrimento em adoecimento: do nascimento da clínica à psicodinâmica do trabalho. Ciência \& Saúde Coletiva, v. 9, n. 1, p. 213-223, jan./mar. 2004. BURY, M. Chronic illness as biographical disruption. Sociology of health \& illness, v. 4, n. 2, p. 167-182, July 1982.

BURTON, J. et al. Evaluating the Social and Economic Consequences of Workplace Injury and Illness, 2002. Disponível em: <http://www.evaluationcanada.ca/distribution /20021030_rajan_rashmi.pdf>. Acesso em: 23 dez. 2009.

CARNEIRO, S. A. M. Saúde do trabalhador público: questão para a gestão de pessoas - a experiência na Prefeitura de São Paulo. Revista do Serviço Público, Brasília, v. 57, n. 1, p. 23-49, jan. /mar. 2006.

CERTEAU, M. The Pratice of Everyday life. 1 ed. United States of America: University of California Press, 1988, 229 p.

CHARMAZ, K. Loss of self: a fundamental form of suffering in the chronically ill. Sociology of Health and Illness, v. 5, n. 2, p. 168-195, July 1983.

CUT. Central Única do Trabalhador, BRASIL, 2007. Disponível em: $<$ http://www. cut. org. br/site/start. cut?infoid $=14883 \&$ sid $=22>$. Acesso em: 13 jul. 2008.

DEMBE, E. A. The Social Consequences of Occupational Injuries and Illnesses. American Journal of Industrial Medicine, v. 40, n. 5, p. 403-417, 2002. 
DEMBE, E. A. The Impact of Occupational Injuries and Illnesses on Families and Children. Center for Health Policy and Health Services Research. University of Massachusetts Medical School. 2003. Disponível em: <www. popcenter. umd. edu /events/ nichd/papers/dembe. pdf. > Acesso em: 21 jul. 2008.

DERSH, J. et al. The Management of Secondary Gain and Loss in Medicolegal Settings: Strengths and Weaknesses. Journal of Occupational Rehabilitation, v. 14, n. 4, p. 267- 729, Dec. 2004. DOMINGUES JÚNIOR, L. R. P. Trabalhar, Sim! Adoecer, Não! In: Conferência Nacional de Saúde do Trabalhador , III $^{\mathrm{a}}$ - Coletânea de Textos. 2005. Disponível em:<http://www. saude. ba. gov. br/ cesat/3aCNST/DOCAPOIO3CNST. pdf>. Acesso em: 04 nov. 2007.

ENGEL, G. L. The need for a New Medical Model: a challenge for Biomedicine. Science, v. 196, n. 4286, p. 129-136, Apr. 1977. Disponível em:< www. sciencemag. org >. Acesso em: 6 nov. 2008.

FERRARI, R.; KWAN, O.; FRIEL, J. Cognitive theory and illness behavior in disability syndromes. Medical Hypotheses, v. 57, n. 1, p. 68-75, July 2001.

FOREMAN, P.; MURPHY, G.; SWERISSEN, H. Barriers and facilitators to return to work: A literature review. Melbourne: Australian Institute for Primary Care, La Trobe University, 2006. Disponível em: <www. workcover. com/documents. aspx? fno=1353> Acesso em: 13 jul. 2008.

FRANCHE, R. L.; KRAUSE, N. Readiness for Return to Work Following Injury or Illness: Conceptualizing the Interpersonal Impact of Health Care, Workplace, and Insurance Factors. Journal of Occupational Rehabilitation, v. 12, n. 4, p. 233-256, Dec. 2002.

- Workplace-based return-to-work interventions: A systematic review of the quantitative literature. Journal of Occupational Rehabilitation, v. 15, n. 4, p. 525-542, Dec; 2005.

GALIZZI, M.; BODEN, L. I. The return to work of injured workers: evidence from matched unemployment insurance and workers compensation data. Labour Economics, v. 10, n. 3, p. 311-337, June 2003.

GELIJNS, A. C. Modern Methods of Clinical Investigation. 1. ed. Washington, DC, USA: National Academy Press, 1990, 244 p.

GATCHEL, R. J. et al. Psychosocial Factors That Can Influence the Self-Assessment of Function. Journal of Occupational Rehabilitation, v. 14, n. 3, p. 197-206, Sept. 2004.

GOMES, C. A. C. A Globalização da Defesa do Trabalho. 1. ed. Salvador, Bahia: UNIFACS, 2008, 206 p. 
HUSSERL, E. Phenomenology: its elementary forms. 14.

ed. Chicago, USA; University of Chicago Press, 1946.

INSTITUTE FOR WORK \& HEALTH, Toronto Canada, 2007. Disponível em: <www. rubberassociation. ca/pdf_docs/SafetyGroups/2008/

RTW_7_principles. pdf>. Acesso em: 13 jul. 2008.

JANSEN, N. W. H. et al. Work-family conflict as a risk factor for sickness absence. Occupational \& Environmental Medicine, v. 63, n. 7, p. 488-494, July 2006.

KAISER, C. P. What Do We know About Employee Absence Behavior? An Interdisciplinary Interpretation. Journal of Socio-Economics, v. 27, n. 1, p. 79-96, Jan. 1998.

KELLY, R. The Illness Trajectory: understanding being ill as a sociological phenomenon, 2001. Disponível em: < http://ethnomethodologist. tripod. com /ethnomethodologyatwork /id3. html.> Acesso em: 24 maio 2009.

KLEINMAN, A. The Illness Narratives. 1. ed. United States of America: Basic Books, 1988. 284 p.

KWAN, O.; FRIEL, J. Clinical relevance of the sick role and secondary gain in the treatment of disability syndromes. Medical Hypotheses, v. 59, n. 2, p. 129-134, Aug. 2002.

LABRIOLA, M. Work environment factors associated with long-term sickness absence and return to work. Ph. D Thesis. Denmark: National Institute of Occupational Health, Institute of Public Health University of Copenhagen. 2006. 60p. Disponível em: $<$ www. arbejdsmiljoforskning. dk/upload/mla phd. pdf > . Acesso em: 13 jul. 2008.

LOISEL, P. Pshychosocial Semiotics: The Specific Paradigm of Work Rehabilitation. Cognitio-Estudos: Revista eletrônica de Filosofia, v. 4, n. 1, p. 20-24, Jun. 2007. Disponível em:< http:// www. pucsp. br/pos/filosofia/Pragmatismo/cognitio_estudos/ cognitio_estudos. htm>. Acesso em: 7 jan. 2010.

. Intervention for return to work: What is really effective? (editorial). Scadinavian Journal of Work Environmental and Health, v. 31, n. 4, p. 245-247. 2005.

. et al. Management of occupational back pain: the Sherbrooke model. Results of a pilot and feasibility study. Occupational and Environmental Medicine. v. 51, p. 597-602, 1994. 
MAENO, M.; TAKAHASHI, M. A.; LIMA, M. A. G.

Reabilitação profissional como política de inclusão social.

Acta Fisiátrica, v. 16, n. 2, p. 53-58, Jun. 2009.

NIOSH (NATIONAL INSTITUTE FOR OCUPATIONAL SAFETY

AND HEALTH), 1996. Disponível em: < http://www. cdc. gov/

niosh/programs/workorg/>. Acesso em: 05 fev. 2010.

ORGANIZAÇÃO INTERNACIONAL DO TRABALHO. Convenção $\mathrm{n}^{\circ} 159$, da Organização Internacional do Trabalho - OIT, sobre Reabilitação Profissional e Emprego de Pessoas Deficientes.

Disponível em: <http://www. ilo. org/skills /what/pubs/lang--en/ docName--WCMS_103529/index. htm. Acesso em: 17 jan. 2010.

PARSONS, T. Social structure and personality. 1. ed. New York, USA; The Free Press, 1964. 376 p.

ROCHA, P. R. F. O trabalhador-doente e sua família nos seus papéis como atores sociais no processo de retorno ao trabalho. 2010, 120f. Dissertação (Mestrado em Saúde, Ambiente e Trabalho) - Faculdade de Medicina, Universidade Federal da Bahia, 2010. Disponível em: <http://www. sat. ufba. br/site/db/dissertacoes/1462010141107. pdf>. Acesso em: 18 jan. 2012.

ROLLAND, J S. Families, Illness, and Disability: an integrative treatment model. 1. ed. New York, USA: Basic Books, 1994, 320 p.

SACHS, P. R.; ELLENBERG, D. B. The family system and adaptation to an injured worker. American Journal of Family Therapy, v. 22, n. 3, p. 263-272, July 1994.

SCHULTZ, I. Z.; STEWART, A. M. Disentangling the Disability Quagmire in Psychological Injury and Law. Psychological Injury and Law, v. 1, n. 2, p. 103-21, June 2008.

SIMIONATO, M. A. W.; OLIVEIRA. R. G. Funções e transformações da família ao longo da história, 2003. Disponível em:<www.abpp.com.br/ abppprnorte/pdf/a07Simionato03. pdf. Acesso em: 20 de maio de 2008.

SINGLY, F. Sociologia da Família Contemporânea. 1. ed. Rio de Janeiro, Brasil: Editora FGV, 2007. 208 p.

SLAVIN, R. E. Best evidence synthesis: an intelligent alternative to metaanalysis. Journal of Clinical Epidemiology, v. 48, n. 1, p. 9-18 1995.

STRUNIN. L.; BODEN, L. I. Family consequences of chronic back pain. Social Science \& Medicine, v. 58, n. 7, p. 1385-1393, 2004.

TAKAHASHI, M. A. C. Avaliação em Reabilitação Profissional. A experiência de adoecer por LER e o resgate da autonomia: uma 
trajetória singular. 2000, 111f. Dissertação (Mestrado em Ciências Medicas) - Faculdade de Ciências Médicas, Universidade Estadual de Campinas, 2000. Disponível em:<http://libdigi.unicamp.br / document $/$ code $=$ vtls000197873 > . Acesso em: 23 jan. 2010.

VAHTERA, J.; PENTTI, J.; KIVIMA, M. Health Sickness absence as a predictor of mortality among maleand female employees. Journal of Epidemiology and Community Health, v. 58, n. 4, p. 321-326, Apr. 2004.

VINGÅRD, N. E. et al. Long-term sick-listing among women in the public sector and its associations with age, social situation, lifestyle, and work factors: A three-year follow-up study. Scandinavian Journal of Public Health, v. 33, n. 5, p. 370-375, Oct. 2005.

WADDELL, G.; BURTON, K. Concepts of rehabilitation for the management of common health problems, 2004. Disponível em: <http:// www. workingforhealth.gov.uk/documents/concepts-of-rehabilitation.pdf. Acesso em: 01 nov. 2009.

WADDELL, G.; BURTON, K. Is Work Good for your Health and Wellbeing?, 2006. Disponível em: < http://books. google. com/ books?hl=ptBR\&lr $=\& i d=b E Z l E m z n J c c C \& o i=$ fnd \&pg $=$ PR $5 \& d q=I s+$ Work + Good + for + your ++ Health + and ++ Wellbeing\%3F $+2006 \&$ ots $=8 \mathrm{JCI} 8432 \mathrm{M}$ $z \&$ sig =1P86etqUMQMuu7rABpio0-bW0u42006 >. Acesso em: 13 jul. 2008.

WHO (WORLD HEALTH ORGANIZATION). The WHO Family of International Classifications. Disponível em:

< http://www. who. int/classifications/en>. Acesso em: 24 mar 2009.

WALSH, F. The Concept of Family Resilience: Crisis and Challenge. Family Process, v. 35, n. 3, p. 261-81, Sept. 1996.

YOUNG, A. E. et al. A Developmental Conceptualization of Return to Work. Journal of Occupational Rehabilitation, v. 15, n. 4, p. 557-568, Dec. 2005. 


\section{O percurso etnometodológico de uma pesquisa em Santo Amaro-BA}

Maiza Ferreira de Andrade Luiz Roberto Santos Moraes

\section{Introdução}

Este capítulo apresenta o percurso metodológico da pesquisa de mestrado intitulada $A$ contaminação por chumbo em Santo Amaro - BA: a ciência e o mundo da vida no estuário do Rio Subaé. Necessário se faz antecipar as razões pelas quais a autora adota a narrativa em primeira pessoa ao apresentar os seus resultados de campo, numa aparente transgressão das normas do texto científico. Apoiada na etnometodologia, a autora constrói um percurso fortemente marcado pelo contato com comunidades ribeirinhas do estuário do Rio Subaé, a partir da compreensão de que os objetos sociais são construídos pela interação dos sujeitos envolvidos no processo. Sua experiência de pesquisa a fez transitar entre a condição de sujeito e objeto, de pesquisadora e repórter, de observadora e observada, em um constante exercício autorreflexivo. Segundo Oliveira e Piccinini (2009), ao confrontar-se com o outro, reconhece a pesquisa como uma ação social, rica em reflexividade por possibilitar a interação da própria experiência com a do outro. O gênero de escrita adotado é predominantemente autoetnográfico, de acordo com o que recomenda Cho e Trent (2006) no que se refere à subjetividade do pesquisador como fundamento da interpretação e validação dos dados em pesquisa qualitativa. Desse modo, em um ensaio pessoal, a autora assume a sua fala, e a apresenta tal qual um dos resultados da pesquisa. 


\section{A escolha do tema}

Motivada pela possibilidade da pesquisa que articula saúde, ambiente e trabalho numa proposta multi e interdisciplinar, elegi o caso da contaminação por chumbo em Santo Amaro, para resgatar uma dívida do passado, quando fui premiada por uma reportagem sobre o descaso com o qual vinham sendo tratados os ex-trabalhadores da Companhia Brasileira de Chumbo-Cobrac. Estava diante de uma conquista da qual jamais poderia me vangloriar e que provocou mais inquietação do que alegria. Era preciso, por um dever ético, de alguma forma retribuir a Santo Amaro aquela conquista.

Fui, então, para Santo Amaro tentar compreender o significado da contaminação para pescadores e marisqueiras. A escolha desses sujeitos deu-se a partir da leitura do relatório da Avaliação de Risco à Saúde Humana por Metais Pesados em Santo Amaro da Purificação, realizada pelo Ministério da Saúde que classifica como foco secundário de contaminação por metais pesados as comunidades ribeirinhas do estuário do Rio Subaé. (BRASIL, 2003) Personagens atadas a uma dura rotina de trabalho na lama do mangue ou nos areais das coroas, as marisqueiras são consideradas como população exposta, tanto pelo contato com os sedimentos aonde se depositaram os metais pesados lançados no rio durante mais de trinta anos, quanto pelo consumo de moluscos que estariam contaminados, segundo a avaliação de risco. (BRASIL, 2003)

Conhecer esses sujeitos, e observá-los em sua jornada de trabalho, dormir sob o mesmo teto, compartilhar do alimento provido pelo estuário do Rio Subaé e ouvi-los falar de suas angústias, e da insatisfação para com a ciência e com o Estado, ofereceu material consistente para a análise aqui apresentada como um primeiro passo para a construção de um processo de comunicação de risco. A pergunta norteadora da pesquisa emergiu da lacuna deixada pela avaliação de risco do Ministério da Saúde por não realizar a comunicação de risco junto à comunidade estudada. (ANDRADE; MORAES, 2010)

Por outro lado, a constante referência dos sujeitos às pesquisas feitas sobre o caso e ao desconhecimento dos seus resultados, bem como à falta de políticas para a proteção da saúde humana e ambiental, abriram um caminho autônomo no conjunto da pesquisa. A incômoda condição de ser mais um, naquele campo visivelmente saturado de pesquisas, 
provocou a necessidade de ir além, e o que poderia ter ficado restrito a citações dos estudos mais emblemáticos feitos ao longo dos últimos 36 anos, ganhou tamanha força que requereu um levantamento exaustivo de toda a produção científica sobre a contaminação promovida pela antiga fábrica de chumbo. Desse esforço resultou uma segunda frente da revisão de literatura que inicialmente se restringia à temática do risco. Em uma busca do conjunto das pesquisas realizadas no Município, foram encontrados 64 títulos, entre teses, dissertações, monografias e artigos científicos, que, posteriormente foram doados a uma biblioteca de Santo Amaro. (ANDRADE, 2012)

As escolhas metodológicas possibilitaram lidar com tais eventos como problemas próprios do percurso da pesquisa. Deste modo, a escolha do método qualitativo se mostrou a mais adequada para a investigação proposta no projeto de dissertação que foi aprovado pelo Conselho de Ética em Pesquisa do Complexo Hospitalar Universitário Professor Edgard Santos. O primeiro contato de campo se deu por meio de incursões no estuário do Rio Subaé e nas comunidades de Caeira e São Braz com registro fotográfico, observação e notas de campo, além de entrevistas gravadas. O referencial teórico metodológico baseou-se essencialmente na análise social de riscos e na etnometodologia.

O processo de pesquisa se desenvolveu numa perspectiva subjetivista, sendo a dissertação apresentada em forma de ensaio autoetnográfico. A escolha desta orientação de pesquisa qualitativa resultou do intenso processo de autoavaliação da experiência vivenciada possibilitando a construção de um texto que conecta o pessoal com o cultural, sendo escrito na primeira pessoa. (OLIVEIRA; PICCININI, 2009; CHO; TRENT, 2006) Dessa forma, assume-se também com esta escolha, que, em um estudo qualitativo de abordagem interpretativa, o conhecimento depende da perspectiva da pessoa que o produz. (SANDBERG, 2005)

A opção pelo exercício do texto autoetnográfico ancorou-se, também, na possibilidade de transgressão da objetividade pretendida pelo gênero jornalístico, no qual moldei a minha expressão escrita, e do qual me afastei no período da pesquisa na pretensão de alcançar a condição "super-repórter", que o jornalista Robert Park atribuiu ao sociólogo. (COULON, 1995) 


\section{Etnometodologia}

A etapa de campo da pesquisa de mestrado que originou a dissertação A contaminação por chumbo em Santo Amaro-BA: a ciência e o mundo da vida no estuário do Rio Subaé, foi orientada pela etnometodologia, tendo como principal referência à obra de Alain Coulon (1995). (ANDRADE, 2012) Trata-se de uma corrente da sociologia americana que surge nos anos 1960 tendo como obra fundadora Studies in Etnomethodology, de Harold Garfinkel e efetua uma ruptura radical com os modos de pensamento da sociologia tradicional. "Mais que uma teoria constituída, ela é uma perspectiva de pesquisa, uma nova postura intelectual" que amplia o pensamento sociológico, dando mais importância à compreensão do que a explicação. (COULON, 1995, p.7)

Compreender o mundo social da população ribeirinha do estuário do Rio Subaé era um dos propósitos da pesquisa, na tentativa de encontrar respostas para questões como: por que marisqueiras e pescadores mantinham sua rotina no Rio, indiferentes ao risco da contaminação por metais pesados?; Havia meios de identificar as áreas que foram classificadas como foco de contaminação no Rio Subaé?; Isso faria alguma diferença?; Como eles lidavam com o risco avaliado pela ciência?; Eles aceitavam o risco estabelecido pela ciência?; e Seria esta uma questão de aceitar os riscos, ou de se estar involuntariamente submetido a uma situação que lhe fora imposta?

Encontrei em Coulon (1995) a base teórica que precisava para ir ao campo, mesmo convivendo com a dualidade da minha condição de pesquisadora/repórter, que marcou a fase inicial da pesquisa. No embate entre jornalismo $\mathrm{x}$ pesquisa social, dois aspectos importantes foram trazidos para situar cada um desses campos. (COULON, 1995) O primeiro aspecto, segundo Coulon (1995), é que a sociologia teria negligenciado a importância dos aportes teóricos e metodológicos do interacionismo simbólico e tratado esta corrente de pensamento com desprezo "como uma empreitada de tipo jornalístico, sem um verdadeiro estatuto científico”. (COULON, 1995, p.15) Estava evidente aí a condição de subciência atribuída então ao jornalismo, atividade pela qual fui inserida na problemática de Santo Amaro.

O segundo aspecto veio com o destaque do papel do jornalista estadunidense Robert Park para os pilares da etnometodologia. (COULON, 
1995) Robert Park, um dos fundadores da Escola de Chicago, estudou sociologia na Universidade de Heidelberg, na Alemanha e começou a ensinar sociologia aos 49 anos, mas sem negar o seu passado de jornalista. Para Park, o sociólogo era uma espécie de super-repórter, "que informa de maneira um pouco mais precisa e com um pouco mais de distância que a média". (PARK, 1921 apud COULON, 1995, p.15) As pesquisas sociológicas para Robert Park, em suas técnicas e conteúdo não seriam mais do que formas superiores de jornalismo: "a ciência é simplesmente mais persistente em sua curiosidade, um pouco mais exigente e exata em suas observações do que o senso comum". (PARK, 1921 apud COULON, 1995, p.15)

A compreensão de que objetos sociais são construídos embasou o percurso da pesquisa a partir do fenômeno empírico de observação do mundo da vida das marisqueiras nas comunidades pesqueiras do Rio Subaé. Concordando com a definição de que a etnometodologia seja uma via para a tentativa de compreensão do que os indivíduos veem, descrevem e propõem em conjunto para uma dada situação, a questão de como os pescadores e marisqueiras se colocam ante o risco de contaminação, iluminou-se diante deste e de outros conceitos. (COULON, 1995)

Foi, dessa forma, mobilizada pela etnometodologia, que parti para o campo da pesquisa, para fazer contato com o dia a dia das pessoas que vivem da cata de mariscos no estuário do Rio Subaé. Começava a vislumbrar o objeto da pesquisa, ciente de que a compreensão dos fenômenos sociais só é possível no contexto em que eles se inserem. (LAPERRIÈRE, 2008) O contato com o campo transcorreu no período de nove meses, de fevereiro a novembro de 2011, quando se deram os encontros com os sujeitos nas ruas, em eventos públicos, em suas casas e em seu trabalho e, especialmente, no manguezal do estuário.

\section{Ensaio pessoal}

Definida a perspectiva subjetivista como primeira das decisões metodológicas tomadas, a próxima veio a ser quanto à linguagem a ser utilizada. Os dados foram se delineando a partir da fala das pessoas, em conversas informais e em entrevistas gravadas, das anotações no diário de campo, e da observação, partindo sempre do princípio fundamental 
de que os fatos sociais são construções práticas das interações dos sujeitos, sejam observadores ou observados. A experiência pessoal de campo embasou a interpretação dos dados encontrados, a partir do equilíbrio de uma escuta crítica e empática. (LAPERRIÈRE, 2008)

A opção por ensaio pessoal de cunho autoetnográfico surgiu em decorrência de todo o processo, fortemente marcado pelo impacto da interação da pesquisadora com os sujeitos que foram tomando seu lugar na narrativa e contribuindo para o alcance do objetivo geral da pesquisa, o de refletir sobre a contaminação por chumbo em Santo Amaro a partir das pesquisas realizadas sobre o tema e do ponto de vista de marisqueiras e pescadores.

O percurso entre a mesa de trabalho do pesquisador e o campo é permeado pelas condições da pesquisa, pela postura do pesquisador e até mesmo os problemas encontrados são parte integrante da pesquisa, como destaca Coulon (1995). A dificuldade que tive em ir para o campo, a resistência em deixar a mesa e ir para o mangue para compartilhar o dia a dia nas comunidades pesqueiras foi um dos problemas enfrentados.

A pesquisa é por si só uma ação social, rica em reflexividade. (OLIVEIRA; PICCININI, 2009) Tal conceito, também caro à etnometodologia, mostra que as práticas reflexivas são aquelas nas quais refletimos sobre o que fazemos ao confrontar a nossa experiência com a do outro. A experiência da pesquisa foi um exercício constante de reflexividade desde o momento no qual reconheci o sentimento de saturação por pesquisas e uma latente demanda por participação na construção do conhecimento em torno da contaminação, demonstrados pelos sujeitos. Seria essa pesquisa mais uma a somar-se a tantas outras já realizadas em Santo Amaro e sobre as quais o senso comum é de que não tiveram retorno para a comunidade? Como enfrentar esse desafio, explicitamente verbalizado na fala do pescador ao queixar-se das pesquisas anteriores: "Me sinto enganado por pesquisadores. Trouxeram o que de reparação para a comunidade ao dizer que o mangue está contaminado?”.(PESCADOR - JOSÉ ROQUE DE JESUS FILHO, 2011) Estava diante do fato social que seria determinante para a compreensão que buscava. Uma decisão decorrente dessa constatação foi a de ampliar a revisão bibliográfica, até então restrita à temática do risco, para abarcar a produção científica sobre o caso da contaminação por chumbo em 
Santo Amaro. Era preciso conhecer mais a fundo o que fora pesquisado, na tentativa de encontrar alguma resposta possível para o porquê da saturação da comunidade por pesquisas.

Se, por um lado, a revisão da literatura sobre a contaminação por chumbo em Santo Amaro possibilitou o acesso ao conhecimento construído pela ciência, por outro, me convocou a olhar o campo a partir da perspectiva de pescadores e marisqueiras, o que se fez possível quando participei de uma jornada de trabalho com as marisqueiras da Caeira, dentro do manguezal. Essa experiência vivida é o ponto de partida do conhecimento que foi possível construir a cerca da realidade de homens e mulheres que têm suas vidas atadas ao ciclo da maré que banha o estuário do Rio Subaé. É, também, reveladora da raiz fenomenológica dessa empreitada de pesquisa, de abordagem interpretativa, porque calcada na relação inseparável entre o sujeito e o mundo no qual atua, seja na condição de pesquisadora ou de pesquisada. (SANDBERG, 2005)

São sujeitos deste estudo três professoras de São Braz, cinco marisqueiras aposentadas de São Braz, quatro marisqueiras ativas de Caeira, um pescador aposentado de São Braz, um pescador ativo de Caeira, e um agente de saúde de São Braz. Os encontros aconteceram no período de fevereiro de 2011 a fevereiro de 2012 com registros de campo, reunidos em entrevistas gravadas, observação participante, captação de imagens e, principalmente, anotações em diário de campo.

\section{Resultados de campo}

\section{Um dia no mangue}

Numa manhã de tempo aberto e maré tardeira ${ }^{1}$ juntei-me ao grupo de marisqueiras liderado por Rosália. Quando cheguei ao local, o grupo já estava embarcado em duas canoas, e Rosália deu pressa. Como tinha sido prevenida das peças que deveria trajar, e as estava usando por baixo da roupa, só fiz tirar as peças de cima e acrescentar a touca que Rosália me emprestou. Ela também forneceu o sapatão, um tipo de calçado improvisado para proteger os pés na andada pela lama. Era feito com pedaços da perna da calça jeans, costurado em uma das extremidades,

1 Maré cheia começando mais tarde 
permitindo que fosse calçado como uma meia e com tiras de plástico presas ao tecido para serem amarradas na canela. Ouvi a recomendação para amarrar fortemente as tiras para que o sapatão não saísse do pé. Uma das marisqueiras, irmã de Rosália, relatou que, após longas jornadas de trabalho, fica com os pés inchados, o que a faz pensar que seja devido à amarração das tiras.

Embarquei em uma das canoas e fui apresentada ao grupo de cinco mulheres e um homem. Pouco tempo depois, as remadas cessaram e Rosália falou que as outras mulheres queriam que lhes fosse explicado o motivo da minha presença ali. Disse de onde vinha, minha afiliação institucional e do propósito de conhecer o trabalho das marisqueiras para uma pesquisa sobre as condições de saúde, do ambiente e do trabalho no Rio Subaé. Eram explicações um tanto vagas, mas optei por não detalhar muito, até porque, assim como Cicourel (apud COULON, 1995), antes da ida ao campo, também não sabia muito bem o que estava procurando. Propositadamente não explicitei o interesse pela questão da contaminação para que a mesma emergisse da fala delas. De novo, como Cicourel (apud COULON, 1995), receei que a apresentação do tema pudesse influenciar no comportamento delas.

Apesar do grupo contar com a presença de um homem, que também iria mariscar naquele dia, optei por usar o termo marisqueiras para me referir ao grupo, concordando com a ideia de que o uso da denominação no feminino resulta do reconhecimento da centralidade do papel da mulher nesse tipo de trabalho.

A questão do gênero é marcante na divisão do trabalho de extração de mariscos, realizada principalmente por mulheres e crianças. O trabalho de homens na extração do marisco ocorre quando estes não dispõem de recursos para adquirir canoas para participar da pesca, ou em situações de invalidez parcial ou ainda quando idosos. (PENA; FREITAS; CARDIM, 2011, p.3385)

Descemos o Rio Subaé até o trecho do manguezal, conhecido como Tarioba, próximo à cidade de São Francisco do Conde. Rosália explicaria depois, que elas preferem locais mais distantes de Santo Amaro porque têm mais mariscos do que mais perto da cidade. Na viagem, o clima de total camaradagem é marcado pelo riso constante, compartilhado entre todas e provocado pela sucessão de casos do dia a dia da comunidade ou de fatos da vida delas, sempre narrados com muito humor. "Aqui, a gente trabalha e brinca muito, não é pra você estranhar, nem 
tomar nota de tudo que a gente fala". (MARISQUEIRA - MARIA ROSÁLIA DA CRUZ DE JESUS, 2011) Essa ressalva era, principalmente, por causa do conteúdo sexual das brincadeiras. Entre elas, ri-se de tudo e de todos, ri-se da própria condição que as submete àquele tipo de rotina de trabalho árduo que as cobre de lama, que maltrata o corpo, que as adoece, mas que as diverte e as proporciona o ganho, mesmo não sendo no justo valor do esforço que empreendem na tarefa de extrair o marisco do manguezal. Essa situação também é descrita por Pena, Freitas e Cardim (2011, p. 3385), ao destacarem que devido à "insuficiência de produção e sem condições de conservação e armazenagem, a mariscadeira necessita vender o produto imediatamente por preços abaixo do valor de mercado".

Desembarcamos na Tarioba cerca de 40 minutos depois de deixarmos o porto da Caeira. As canoas foram atadas nos troncos da vegetação do mangue, bem como sacolas com objetos que não seriam usados na faina. Calçada, com o sapatão, dei os primeiros passos dentro da lama como uma criança que está aprendendo a andar, e segui Rosália. Estava diante da realidade da vida cotidiana das mulheres que sobrevivem da extração de mariscos no mangue. "A realidade por excelência", que segundo Luckmann e Berger (1999, p.38), "está aí, e não requer verificação". Nos primeiros instantes, tive sensação de nojo, e certo desespero pela falta de chão firme sob os pés. Os passos eram vacilantes pelo temor de afundar nos buracos dos caranguejos. Fui prontamente orientada a pisar nos afloramentos das raízes das árvores em lugar das partes mais limpas, onde podiam estar os buracos. Rosália riu ao ver os meus primeiros passos e quis saber o que eu pretendia fazer. Disse que a acompanharia, observando o seu trabalho, que ela ficasse à vontade em sua rotina e que contasse com a minha ajuda se fosse preciso. Não demorou para que Rosália começasse a me passar as 'camas' de sururu para eu ir debulhando. É que para se fixarem no solo lamacento, os mariscos enredam-se em fibras que os prendem a porções de lama, chamadas de camas e onde se reproduzem. Assim, aos poucos fui entendo a lógica daquele trabalho ambulante:

O trabalho das mariscadeiras no arenoso da praia e no manguezal é de natureza ambulante onde mantém a flexão dorsal por longo tempo. Deambulam e cavam com movimentos dos membros superiores em ritmo acelerado, quase sempre em flexão dorsal, se deslocam por pedras e pelo arenoso da 
praia, sob sol intenso e com os olhos fixos no arenoso para identificar mariscos. São ambientes sempre úmidos e completamente diferentes, quando se consideram as características do manguezal. (PENA; FREITAS; CARDIM, 2011, p. 3387)

Aos poucos, o grupo começa a se dispersar, com cada uma tomando o seu rumo dentro do manguezal, em busca da 'mina', lugar com muita concentração de sururus. Escondidos sob a lama, só podem ser encontrados por olhos treinados a distingui-los em meio a galhos caídos, tocos, raízes do mangue, tudo numa coloração cinza que pouco a pouco vai se tornando a mesma das roupas usadas pelas mulheres. É quando "mimetizam-se" como se refere Josué de Castro às populações extrativistas dos manguezais do Nordeste (PENA; FREITAS CARDIM, 2011). A primeira das seis horas passadas dentro do mangue foi a mais longa de todas, pela sensação de desconforto, por me achar em um ambiente à primeira vista tão inóspito e do qual não seria possível sair a qualquer momento. Estava totalmente entregue a decisões alheias a minha vontade e o melhor a fazer seria submeter-me às condições dadas. Passada esta fase, aos poucos fui entendendo a razão pela qual elas, apesar de dependerem de um trabalho tão difícil para ganhar a vida, pareciam contentes, simplesmente. Isso era notado pela calma com que se deslocavam, pela movimentação incessante, pela ausência de lamentação, irritação, estresse, ou qualquer outra manifestação de contrariedade. Estavam ali por inteiro, apesar de admitirem que fariam outra coisa, caso tivessem escolha. Que preferiam tudo aquilo ao trabalho de empregada doméstica pelo qual já haviam passado.

Em todo o estuário, não há qualquer referência aos resultados da análise da água, sedimentos e dos moluscos coletados em 16 pontos de amostragem quando da realização da avaliação de risco do Ministério da Saúde, há 8 anos. Elas não se referem à contaminação, mas usam estratégias como a de ir para locais mais distantes da Cidade, onde teria maior ocorrência dos mariscos e a de lavarem as mãos e os pés com cloro quando saem do manguezal. Para elas, a lama do mangue não é suja. "Esse cheiro, é dele mesmo". (MARISQUEIRA - MARIA ROSÁLIA DA CRUZ DE JESUS, 2011) Aceitei a explicação e segui a jornada, lembrando-me das reflexões de Beck sobre a indiferença aos riscos: 
A indiferença diante dos riscos, de todo modo imperceptíveis, que sempre encontra na superação da carência palpável sua justificação (Terceiro Mundo) é o terreno cultural e político no qual os riscos e ameaças florescem, crescem e frutificam. (BECK, 2010, p. 54)

As conversas iam se tornando esparsas, devido à distância que tomavam uma das outras e, nesse instante, o silêncio do mangue chegava a causar certo torpor, dando projeção ao canto de pássaros e até mesmo ao sutil estalar das cascas dos sururus. ${ }^{2}$ Assim, passaram-se seis horas, sem que as tivesse visto parar para lanchar ou beber água. De acordo com Pena, Freitas e Cardim (2011), a falta de pausa no trabalho revela a pressão social para intensificar as atividades a fim de coletar a maior quantidade possível de mariscos. Àquela altura já tinha dado uma boa ajuda a Rosália arrancando os sururus das camas, o que causou divertidos comentários das outras, afinal ela era a única que contava com uma "assistente".

Quando percebem que se aproxima a hora do retorno, antes que a maré comece a encher, o ritmo é acelerado. Pouco a pouco, as que se distanciaram procuram retornar para perto das companheiras, tendo Rosália como referência. Ela exerce uma liderança natural, mas o que prevalece é o senso de colaboração mútua, apesar de a produção ser individual. Pude observar o cuidado de uma delas em prestar ajuda à colega que, por causa do peso da carga de sururu que levava na cabeça, afundava uma das pernas até a altura da coxa ao pisar nos buracos de caranguejo. Foram quedas sucessivas, que a obrigava a arriar a carga na lama, e com muita dificuldade, levantar-se do buraco, e com a ajuda da colega, recolocá-la sobre a cabeça. Ao retornarem ao local onde haviam deixado à canoa, cuidavam de lavar os mariscos para tirar o excesso de lama e catavam galhos secos para serem usados nos fogareiros que fariam em suas casas para fermentá-los. Com muito cuidado adentravam na maré para tirar a lama das roupas e começavam a fazer comentários sobre a jornada. Com o grupo todo reunido, embarcavam e seguiam rio acima, animadas para alcançarem a coroa ainda em tempo de poder tomar banho em local mais seguro e, finalmente, merendar.

2 Essa observação de campo contradiz a fala da marisqueira Mara, da Ilha de Maré, segundo a qual, o sururu do mangue, porque fica embaixo da lama, não estala. (PENA; FREITAS; CARDIM, 2011, p.3388) 
Dali, retornariam para casa, dando sequência à jornada que só terminaria após o cozimento, descasca, pesagem, ensacamento e armazenamento do produto sob refrigeração. $\mathrm{Na}$ volta, as canoas foram unidas com corda e em uma delas foi levantada um pequena vela conhecida por traquete, que, empurrada pelo vento, dispensava o grupo do esforço de remar contra a corrente. No retorno, as conversas já não são tão animadas quanto na ida para o trabalho. Com o deslocamento mais lento das canoas, percebe-se que o cansaço vai dando lugar ao silêncio e à inevitável contemplação da paisagem estuarina, confirmando a tese de Pena, Freitas e Cardim, (2011, p. 3386) que:

[...] objeto de trabalho da mariscadeira não é apenas uma coleta de mariscos existentes na natureza, mas um universo de representações subjetivas compreensíveis nas esferas sócio antropológicas, essencial para a construção de sua identidade $[\ldots]$

\section{A vida de Lívia}

Conheci Lívia na minha primeira visita ao estuário do Rio Subaé, na comunidade de São Braz. Era uma tarde do mês de novembro de 2010 e Lívia tinha acabado de chegar da maré, e a fiz interromper a lida. Após a coleta, ela ainda tinha que ferventar e catar o marisco, separando o material comestível da casca. Em outros tempos, naquele horário ela estaria à numa sala de aula, exercendo o magistério. Cheguei até ela por indicação de um agente comunitário de saúde que, por sua vez, fora indicado por um informante de Santo Amaro. A prática do método bola de neve para a construção da rede de relacionamentos na comunidade permeou todo o trabalho de campo, o que facilitou os encontros e enriqueceu o universo de sujeitos envolvidos.

Desempregada, para sobreviver, naquele ano vivia de alguma renda aferida com aulas de reforço escolar, cata de siri, e lavagem de roupa, além da ajuda do marido. Era novembro, aproximava-se o final de um ano em que esteve fora da escola, depois de dez dedicados ao ensino, por razões segundo ela, de ordem política.

Se você for de casa em casa e perguntar quem é a melhor professora de São Braz, vão dizer: é Lívia, e, no entanto, fiquei um ano desempregada. É tanta barbaridade, que dá vontade de renunciar ao magistério. Não se pode misturar política com educação. (PROFESSORA - LIVIA OLIVEIRA, 2010) 
A compreensão clara da incompatibilidade dessas duas dimensões e a falta de modéstia ao se autoavaliar dispensava explicações. Compreendi isso ao ver a reverência com que todos, jovens e velhos a tratam na comunidade. A sua pequena estatura não lhe impede de se impor como gigante em defesa da educação, e da decência da condição humana mesmo enfrentando tantas adversidades. Naquela tarde, ainda em trajes da maré, com a blusa enlameada, recebeu-me com certa desconfiança, mas me deixou ver o quanto tinha e precisava falar, com sua voz firme e seu português limpo e bem pronunciado. No seu casebre, a poucos metros do porto, vivia com dois dos três filhos e o companheiro, pescador.

A lida principal da família era no Rio Subaé. Lívia tanto pescava de rede, quanto mariscava. Entusiasta da associação local de pescadores e mariscadeiras, lamentava o pouco interesse dos associados, que não contribuíam, apesar de a entidade estar "toda legalizada". Quando retornei meses depois, a encontrei acometida de catapora, febril e visivelmente debilitada. Foi um reencontro rápido, somente para marcar a próxima vinda, em momento mais apropriado.

\section{Contaminação}

Lívia não reconhece que haja contaminação por metais pesados nas áreas de pesca de São Braz - que é um braço do Rio Subaé conhecido como "canal" de São Braz. Ela acusa a contaminação por esgotos domésticos.

Todo o esgoto de São Braz vai para a maré. Tanto que, o estudo de impacto ambiental (do Ecoresort Cajaíba) não achou poluente pesado, só fezes. Mas, lá perto de Santo Amaro não. A professora que estudava os mariscos daqui, levando a lama e os mariscos para examinar, nunca encontrou nada nos mariscos de São Braz. (PROFESSORA - LIVIA OLIVEIRA, 2010)

Lívia expressa o que é do senso comum em São Braz quando o assunto é a contaminação por metais pesados. A contaminação química não é ali. Os dejetos domésticos são drenados para a maré e não parecem incomodar. "Fortalece os caranguejos e siris", é o que diz o pai de Lívia.

Desde a década de 1970, as águas e sedimentos do rio têm sido examinados, mesmo que de forma esporádica. A carga de metais pesados lançados diretamente no rio, que foi responsável por teores de 
chumbo até 60 vezes superiores aos limites estabelecidos pela Organização Mundial de Saúde, segundo Reis (1975), cessou em 1993 com o fechamento da fábrica, mas ainda preocupa. A literatura mais recente sobre o caso da contaminação do Rio Subaé por metais pesados difere da opinião de Lívia ao afirmar que a contaminação afetou e ainda afeta toda a extensão do estuário do rio, de Santo Amaro até a sua foz na Baía de Todos os Santos. A avaliação de risco à saúde humana por metais pesados em Santo Amaro realizada pelo Ministério da Saúde em 2003, traz em suas conclusões:

Os dados levantados neste estudo, bem como os dados de estudos anteriores, quando avaliados pelos valores de referência ("níveis limites de efeito" TELs $=$ Threshold effects) utilizados pela USEPA (1996) indicam a contaminação dos sedimentos do Rio Subaé, a partir de Santo Amaro da Purificação e até sua foz na Baía de Todos os Santos, com os contaminantes chumbo, cádmio, cobre, mercúrio, níquel e zinco. Estes sedimentos contaminados representam uma rota potencial de exposição para as populações que consomem a biota proveniente destes ambientes aquáticos. (BRASIL, 2003, p. 250)

O relatório do MS é desconhecido na comunidade de São Braz, assim como em toda Santo Amaro. Os seus resultados não foram discutidos com a população identificada como exposta nos dois focos da contaminação definidos no estudo, a área em torno da PLUMBUM (antiga Cobrac) e no Rio Subaé. Embora ateste a contaminação, o relatório também afirma que não é possível prever a mobilização e o deslocamento dos metais contidos nos sedimentos do rio coletados nas proximidades da PLUMBUM para áreas de maior desenvolvimento biótico, como nos manguezais, utilizado para atividades de captura de moluscos, importante segmento concentrador de metais pesados na biota marinha comestível. Decorridos 10 anos do término das atividades da fábrica, os contaminantes ainda se concentram nas proximidades do ponto de emissão. (BRASIL, 2003)

$\mathrm{Na}$ exposição das recomendações de saúde para os dois grupos da população exposta - a população moradora em torno da PLUMBUM (500m) e a população consumidora de moluscos, em especial as famílias de pescadores da colônia de Caieiras $(s i c)^{3}$ - o relatório da avaliação de risco afirma que o molusco (sururu) está contaminado com chumbo e cádmio:

3 Diferentemente do relatório do MS, em Santo Amaro a grafia desta palavra é Caeira. 
Conforme pode ser observado no capítulo V - Seleção dos Contaminantes de Interesse -, os moluscos contaminados são todos originários de uma única coroa (borda da praia do rio onde nascem os sururus), aquela situada mais próxima à colônia e identificada como coroa de caieiras. Os moluscos originários das outras 16 coroas pesquisadas não estão contaminados. (BRASIL, 2003, p.247)

Mais adiante, o relatório reafirma: "os moluscos das outras coroas não estão contaminados, porém como os sedimentos do rio Subaé estão contaminados, é necessário realizar um monitoramento periódico". Neste sentido, a compreensão de Lívia de alguma forma está articulada com as conclusões do relatório, que especifica como contaminados os sururus da coroa da Caeira, embora reconheça a necessidade de monitorização do estuário como um todo.

Depois de percorrer o Rio Subaé, do porto da Caeira até a foz, e da convivência com pescadores e marisqueiras foi possível distinguir o ambiente da coroa, do ambiente do manguezal e saber que o molusco sururu ocorre com mais predominância no mangue e não nas coroas. Nessas áreas, marisca-se o mapé, e um dos locais onde são mais procurados é na coroa de Brotas, situada à jusante da foz do Rio Pitinga, um dos afluentes do Rio Subaé, e onde são lançados os resíduos da fábrica de papel Penha (antiga Impasa), ainda em atividade em Santo Amaro. A morte total do manguezal do Rio Pitinga nos anos 1980 é fato conhecido de todos os ribeirinhos e tema de um documentário feito por pesquisadores estrangeiros que ainda são lembrados em São Braz. Assim, a discussão da avaliação de risco com a comunidade precisa acontecer e esclarecer a que mariscos estão se referindo, se mapé, se sururu.

A avaliação de risco do MS calculou as doses de exposição ao chumbo e ao cádmio na alimentação em Santo Amaro, para duas faixas etárias, até 11 anos e peso corporal médio de 30kg, e 12 anos e mais, com peso médio de 70kg. Os cálculos foram baseados em estudos com animais, sendo a extrapolação para humanos considerada envolta em muitas incertezas, como admite o relatório. Os cálculos foram feitos tomando por referência a frequência de uma refeição à base de moluscos por semana, e com uma estimativa de consumo de $50 \mathrm{~g}$ de mariscos para crianças e $100 \mathrm{~g}$ para adultos. O estudo concluiu que, nessas condições, para a população em geral, em especial a da colônia de pescadores de Caeira, as doses de exposição para chumbo e cádmio estão abaixo do 
PTWI (ingesta semanal provisória tolerável) definido pela Organização Mundial de Saúde (OMS). Para as crianças que ingerem moluscos, no entanto, a dose de exposição encontrada se iguala ao nível de risco mínimo para o cádmio. O relatório adverte, no entanto, que, diante das incertezas da relação do chumbo e cádmio com o câncer, e admitindo que ambos sejam carcinogênicos, há risco de desenvolver câncer para toda dose diferente de zero. (BRASIL, 2003)

Nas cozinhas das comunidades de Caeira e São Braz, assim como deve ser também em Santo Amaro e nas inúmeras cozinhas aonde chegam os sururus do Rio Subaé, o risco do consumo que consta no relatório do MS não faz parte das preocupações dos consumidores. Em Caeira e em São Braz os mariscos estão presentes na alimentação cotidiana e, preparados como muqueca, servidos com molho de pimenta, são irresistíveis ao paladar, inclusive das crianças, como foi possível observar na casa de Lívia. Em Caeira, a muqueca de mapé também é iguaria ricamente preparada com os ingredientes e modo de fazer tradicionais há muitas gerações. O que o relatório também sinaliza nas recomendações para a saúde, e que até então não se configurou em Santo Amaro, é a necessidade de se:

[...] estabelecer um programa de educação ambiental e comunicação de risco para a população a fim de que ela possa apropriar-se de conhecimentos para melhor conduzir-se, com autonomia, para a proteção e promoção de sua saúde. (BRASIL, 2003, p. 249)

A contaminação não preocupa tanto Lívia quanto a falta de uma escola de segundo grau na comunidade. "A prefeitura dá o transporte para os jovens irem estudar o segundo grau lá (em Santo Amaro). Só aqui que não tem escola de segundo grau”. Ela acha que é porque nunca teve alguém para representar politicamente a localidade. "O que tentava ser, morreu do coração". Segundo Lívia, ele tocava pandeiro no samba chula, grupo que ficou famoso após a conquista de um importante prêmio cultural. O cantor do grupo, e compositor de 500 sambas, é gari e analfabeto e quando não está viajando com o grupo, em turnês nacionais e internacionais, pode ser visto em serviço na limpeza das ruas de São Braz, ou tocando o seu pequeno rebanho bovino, no final da tarde, como pude observar. 


\section{Crianças}

São Braz fica a $6 \mathrm{~km}$ de Santo Amaro. O meio de transporte mais utilizado são as vans que partem da Ponte do Moringa, no centro de Santo Amaro. Fomos de van à aula presencial do curso de Pedagogia à distância que Lívia frequenta, em Santo Amaro, com a ajuda de uma bolsa de estudos do governo federal. É visível a sua satisfação em estar na faculdade. Na turma, ela se destaca pela leitura fluente dos textos e pela atenção durante a aula, o que não é comum a toda a turma, de 29 mulheres e apenas um homem.

Quando a professora tutora falou da necessidade de o professor perceber em que nível está cada um dos alunos, mediante o diagnóstico do seu grau de alfabetização (se domina a escrita, leitura e interpretação), Lívia comentou sobre um aluno que, estando na $4^{\mathrm{a}}$ série ainda não estava alfabetizado, e que ela não conseguiu evitar que ele repetisse o ano. Sua colega, de São Braz, também relatou caso semelhante. "Tem muitos casos assim lá (em São Braz)”, disse Lívia. Tais observações me fizeram lembrar dos estudos que foram feitos com crianças de Santo Amaro quanto aos níveis de chumbo no sangue.

É sabido que o chumbo está associado à deficiência de cognição em crianças. Pensei se o fato relatado por elas não estaria relacionado a isso. Evitei falar disso com elas, pois, na condição de observadora não seria recomendável entrar no tema/objeto da observação sem que o mesmo surgisse espontaneamente. Pensei também de como tem sido negligenciada a necessidade de estudos mais aprofundados na população exposta à contaminação em Santo Amaro. Os estudos epidemiológicos até então realizados foram do tipo transversal e revelaram a situação em momentos pontuais, como em 1980, 1985 e em 1992, não tendo sido feitos de forma continuada como os de coorte, que permitiriam um acompanhamento mais aprofundado.

A impressão que dá, ouvindo os depoimentos e observando como a pesquisa se desenvolveu em Santo Amaro é que o caso da contaminação se tornou atraente e ainda atrai porque fornece evidências, garante resultados rápidos, estatisticamente significantes e publicáveis, e condizentes com os estudos de corte transversal. Até então ninguém se interessou em realizar um estudo longitudinal (coorte), que talvez garantisse maior acesso da população estudada aos resultados e ao 
conhecimento das suas reais condições de saúde, enquanto expostos a fatores de riscos da contaminação por metais pesados, como a ingestão de peixes e mariscos do Rio Subaé, e pelo contato com a escória de chumbo, sobretudo entre as crianças.

De acordo com Guerra (2010), a coleta esporádica de sangue de alguns indivíduos de uma população dificilmente refletirá o grau de exposição da população, especialmente se essas coletas não forem feitas de forma sistemática, baseadas em desenhos epidemiológicos adequados e com intervalos bem definidos. Ela cita o exemplo dos EUA:

[...] pela grande pressão da sociedade civil e pela notória contaminação dos ambientes urbanos de algumas cidades americanas, há atualmente nos EUA um programa nacional para detecção de crianças contaminadas por chumbo. Nesse programa, o sangue é utilizado como marcador de contaminação e as coletas são realizadas anualmente em todas as crianças do país, sendo todas as amostras analisadas em um único Centro. (GUERRA, 2010, p. 7)

Em sua avaliação, Guerra (2010, p.13) afirma que a ausência de achados clínicos na população de Santo Amaro estudada "pode refletir a ausência de investigação específica do desenvolvimento psicomotor das crianças envolvidas" e que, "em nenhum dos estudos analisados foi relatada a realização de avaliação do desenvolvimento psicomotor das crianças afetadas, sejam os realizados pela Universidade Federal da Bahia, sejam nos relatórios de acompanhamento realizado pela PLUMBUM por determinação judicial”. (GUERRA, 2010, p.13)

A preocupação com as crianças frente ao risco da contaminação por chumbo e a falta de retorno das pesquisas realizadas com esse segmento da população são recorrentes nos relatos como pôde ser observado na entrevista de grupo realizada em São Braz, da qual participaram três professoras, um agente comunitário de saúde e um pescador.

Professora 1: Esse povo que fez a coleta nas escolas não era nem de Santo Amaro. Era de São Paulo, era de não sei aonde.

ACS: Justamente isso...

Professora 1: É um problema sério. Precisa vir gente de outro estado pra descobrir alguma coisa, pra fazer um estudo, levantamento de pessoas afetadas, enquanto a própria prefeitura, o Poder Público podia tomar uma posiçãa.

Vocês conhecem os levantamentos que foram feitos?

Professora 1: Não 
ACS: Hum... só por alto assim. É justamente o que estou dizendo, a gente ficou excluso. A gente só sabe das coisas através da Avicca.

Professora 2: A única coisa que eu sei também sobre isso é que detectou algum problema nas crianças, no colégio, na escola.

Aqui?

Professora 2: Sim. Ficou as crianças indo tomar medicação na escola. Então, tomou aquela medicação, e depois ninguém veio dar o retorno. Tomou a medicação e acabou. Não levou pra avaliar as crianças novamente.

Não ouviu dizer se teve algum efeito ou não?

Professora 2: Foi só pra dizer que tava dando a medicação...

Pescador: Até minha neta teve problema também.

Quando foi isso?

Professora 2: Muitas crianças iam pro colégio tomar essa medicação. Até dia de sábado, quando tava marcado pra tomar a medicação, mesmo que não tivesse aula, todas as crianças tinham que ir pro colégio. Acho que foi em 2004.

Durante quanto tempo?

Professora 2: Acho que mais de um mês. E veio já assim, as doses certinhas de cada um, mas aí o diretor chamou os pais na escola

Os pais receberam os exames?

Professora 2: Não. Eu acho que não. Até onde eu sei é que chegou a relação das crianças que teriam que tomar aquela medicação e os professores tinham que tá sempre chamando, mandando recado pros pais pra mandar no horário pra tomar a medicação.

Alguém aqui teve algum filho ou parente nesta situação?

ACS: Tive um vizinho. Acho que Rodrigo teve, não foi Rodrigo?

Os pais da sua neta receberam o exame?

Pescador: Que nada...

ACS: Foi uma coisa superficial...

Professora 2: Foi só mesmo pra distribuir aquela medicação, como se as crianças fossem uma cobaia.

ACS: E nem todos os lugares foram contemplados com isso, né?

Professora 2: nem nós professores sabiam porque, realmente, aquela criança tava tomando aquilo e quando ia encerrar esse tratamento, quer dizer, tratamento tem um prazo. Todo mundo tinha o mesmo diagnóstico. Tomou. Acabou a dose de uma, acabou da outra e da outra. Não levou novamente pra fazer outra avaliação pra ver se realmente a medicação tinha feito efeito.

E quem era o responsável pela... 


\section{Professora 2: Medicação?}

Pela medicação?

Professora 2: Quando chegou na escola, o diretor do colégio ficou responsável pela medicação.

Sim, mas, quem trazia a medicação?

Professora 2: Não sei quem trazia não.

Professora 1: Eu lembro que foi um grupo de pessoas de outro estado que estavam fazendo um trabalho. Não era nem daqui da Bahia.

\section{Samba}

Lívia cria versos de cordel e é entusiasta do samba chula. O grupo se reúne esporadicamente em um bar do povoado. Naquele domingo tive a sorte de assistir a uma apresentação para uma equipe de filmagem. Com todo o instrumental, o grupo encanta pela riqueza do ritmo e autenticidade dos seus integrantes. As letras são do compositor João do Boi, homem de mais de 60 anos, farrista e galante. Em total sintonia com o parceiro Alumínio, a todo instante puxa os sambas, mesmo quando os músicos fazem pausa, e pontua os versos com brados como: "no samba, sou eu e Alumínio. Quando a gente se for, acabou o samba de São Braz". E mais: "Se eu fosse um homem que soubesse assinar o meu nome, ninguém ia poder comigo". Logo o pequeno espaço do bar encheu-se da alegria do samba. Homens, mulheres e crianças estavam todos integrados ao canto e à dança. Há muita força e poder em gestos tão simples. O requebro não é privilégio das moças. Na roda de samba, manda a elegância, que não escolhe idade, mas que se encorpa mais soberana nas mulheres maduras. Vi Lívia bater palmas, balançar o corpo, mas não entrou na roda. Um pescador que havia encontrado na maré, naquela manhã, perguntou pelas fotos que eu estava fazendo (o observador sendo observado). Ele falou da minha semelhança com "Charlotte", a pesquisadora norte-americana que estudou a contaminação do manguezal na década de 1980, segundo os relatos que ouvi repetidas vezes.

Seis meses depois, encontrei Lívia novamente exercendo o magistério, no colégio de São Braz, graças à intervenção de um vereador de Santo Amaro, o que a fez contar com a renda de um salário mínimo. 
Neste caso, a política se aliou à educação, e, felizmente, por uma boa causa.

\section{Considerações finais}

A ausência das ciências humanas nas pesquisas sobre a contaminação em Santo Amaro acompanhou uma tendência global observada desde a década de 1980 pelos críticos do modelo de avaliação de risco, sendo recente o interesse desse campo do conhecimento, notadamente da comunicação. (SHORT JR., 1984) A manifesta saturação da população local por mais pesquisas é um sinal de que os interesses dos afetados não têm sido considerados, tanto pela falta de acesso aos resultados dos inúmeros estudos já realizados, quanto pela inação dos setores públicos responsáveis pela adoção de medidas recomendadas pelos pesquisadores. (DI GIULIO, 2010) Tudo quanto podia ter sido quantificado pelos peritos já o foi. Como aproximar esses dois mundos, o da ciência e o mundo da vida dos sujeitos das pesquisas senão pela comunicação, em um processo construído com a participação de todas as vozes legítimas?

O interesse por Santo Amaro como campo de pesquisa é crescente, se observada a evolução das pesquisas ao longo dos últimos 36 anos, desde que a contaminação por chumbo e cádmio apresentou suas primeiras evidências, tanto nas águas do Rio Subaé, quanto na urina dos trabalhadores da antiga fábrica.

O caso de Santo Amaro volta e meia chega às mais altas tribunas, do Senado e da Câmara dos Deputados, impulsionado pelo desejo latente de justiça para com os ex-trabalhadores, e com todas as outras vítimas da contaminação, incluindo aí o estuário do Rio Subaé. O desafio é pensar no que fazer com o passivo ambiental. Soluções como o reprocessamento das cerca de 500 mil toneladas de escória de chumbo a base de ácido clorídrico separaram os campos da engenharia e da saúde em um embate de racionalidades dado o potencial de risco da operação. (ANDRADE, 2012) Sem a participação qualificada da comunidade de Santo Amaro nessa discussão, corre-se o risco de o valor de mercado do chumbo remanescente na escória ser o balizador das decisões a serem tomadas. 
A crítica consolidada pelas ciências sociais aos modelos quantitativistas, por meio da análise social de riscos, tem significativa contribuição a dar. Do mesmo modo, metodologias apoiadas na participação das comunidades afetadas apontam um novo e promissor caminho para a pesquisa. A epidemiologia popular vem estabelecer o protagonismo dos leigos na pesquisa, desde a coleta e interpretação de dados juntamente como os peritos em um processo que leva à compreensão das ameaças existentes e a busca por soluções no campo das políticas públicas de saúde. (BROWN, 1992)

Uma das abordagens da epidemiologia popular, a pesquisa baseada na participação da comunidade - Community based participatory research - CBPR - revela-se adequada para o caso das comunidades afetadas pela contaminação química, não somente no estuário do Rio Subaé, mas na Baía de Todos os Santos, devido ao passivo ambiental da indústria petroquímica. (LEUNG; YEN; MINKLER, 2004) De acordo com esses autores, apesar dos avanços da epidemiologia moderna, este campo permanece limitado em sua capacidade para explicar por que certos resultados ocorrem e para gerar o tipo de resultados que podem ser traduzidos em programas ou políticas para melhorar a saúde.

A criação de parcerias com a comunidade, de tal forma que representantes da comunidade possam participar na definição do problema de pesquisa, na interpretação dos dados, e aplicação das descobertas, pode ajudar a responder a estas preocupações. (LEUNG; YEN; MINKLER, 2004, p. 499)

A demanda por participação na tomada de decisão envolvendo riscos é uma tendência global e desafia a busca por novas metodologias para além do que estabelece as agências norte-americanas, que tem sido referência no País. A fala de um pescador do Rio Subaé ao revelar sua decepção para com os pesquisadores decorre da esperança frustrada por conhecimento sobre o ambiente no qual trabalha e do qual sobrevive e também por alternativas à sentença condenatória dos sururus por um crime que eles não cometeram.

A rotina de marisqueiras e pescadores no estuário do Rio Subaé em nada se alterou ao longo de todos esses anos em que o Rio recebeu toneladas de metais pesados, e outras contribuições de efluentes industriais e domésticos desde a sua nascente, em Feira de Santana, a $55 \mathrm{~km}$ da foz, na Baía de Todos os Santos. Se não parou a coleta, também não 
cessou o consumo desses produtos, especialmente do sururu, que teve o seu consumo desaconselhado pelo Ministério da Saúde (2003) após a realização da Avaliação de Risco à Saúde Humana por Metais Pesados em Santo Amaro.

Para pescadores e marisqueiras, o tema causa desconforto uma vez que a referência à contaminação é uma ameaça a sua atividade de subsistência. O desconforto também é proveniente da falta de informações precisas sobre a situação da contaminação no estuário. "Sim, está contaminado, mas onde, em que parte do Rio tem metais pesados, onde é que tem marisco contaminado, quanto tem de contaminação?" são questões que um pescador levanta, desafiando o conhecimento técnico. Assim, como o da maioria das pesquisas realizadas em Santo Amaro, o relatório da avaliação de risco à saúde humana empreendida pelo Ministério da Saúde, em 2003, repousa numa estante. Não somente porque o relatório não esteja acessível à população interessada, mas também por não ter envolvido a comunidade e pelo fato de as suas recomendações ainda não terem sido implementadas, a avaliação de risco ainda não parece ter cumprido o seu papel.

\section{Referências}

ANDRADE, M. F. de. A contaminação por chumbo em Santo Amaro-BA: a ciência e o mundo da vida no estuário do Rio Subaé. 2012. 106f. Dissertação (Mestrado em Saúde, Ambiente e Trabalho), Universidade Federal da Bahia, Salvador, 2012.

ANDRADE, M. F.; MORAES, L. R. S. A abordagem da comunicação em estudos de avaliação de risco: uma análise crítica do caso de Santo Amaro. In: SIMPÓSIO BRASILEIRO DE SAÚDE AMBIENTAL, I. , 2010, Belém. Anais. . Rio de Janeiro: Abrasco, 2010. p 69.

BECK, U. Sociedade de Risco: rumo a uma outra modernidade. 1. ed. São Paulo: Editora 34, 210. 368p.

BRASIL. Ministério da Saúde. Avaliação de Risco à Saúde Humana por Metais Pesados em Santo Amaro da Purificação. Brasília, 2003.

BROWN, P. Popular Epidemiology and Toxic Waste contamination: lay and professional ways of knowing. Journal of Health and Social Behavior, n. 33, p. 267-281, 1992. 
CHO, J.; TRENT, A. Validity in qualitative research revisited.

Qualitative Research. London. England, v. 6, n. 3, p. 319-40, 2006.

COULON, A. Etnometodologia. Petrópolis: Ed. Vozes, 1995. 134p.

DI GIULIO, G. M. Comunicação e governança do risco: exemplos de comunidades expostas à contaminação por chumbo no Brasil e Uruguai. 2010. 327f. Tese (Doutorado em Ambiente e Sociedade), Universidade Estadual de Campinas, São Paulo, 2010.

GUERRA, C. S. Utilização de dentes decíduos de regiões com diferentes históricos de contaminação ambiental para detecção de grupos de crianças expostas ao chumbo no Brasil. 2010. 175f. Tese (Doutorado em Biologia Buco-Dental), Universidade Estadual de Campinas, Campinas, São Paulo, 2010.

LAPERRIÈRE, A. Os critérios de cientificidade dos métodos qualitativos. In: POUPART, Jean et al. A pesquisa qualitativa: enfoques epistemológicos e metodológicos. Petropólis: Ed. Vozes, 2008. 464p. (Coleção Sociologia)

LEUNG, M. W.; YEN, I; MINKLER, M. Community-based participatory research: a promising approach for increasing epidemiology's relevance in the 21 st century. International Journal of Epidemiology, n. 33 p. 499-506, 2004

LUCKMANN, T.; BERGER, P. L. A construção social da realidade: tratado de sociologia do conhecimento. Petropólis/RJ: Ed. Vozes, 1999.

OLIVEIRA, S. R.; PICCININI, V. C. Validade e reflexividade na pesquisa qualitativa. Cadernos EbapeBR, Rio de Janeiro, v. 7, n. 1, p. 89-98, 2009.

PENA, P. G. L.; FREITAS, M. C. S.; CARDIM, A. Trabalho artesanal, cadências infernais e lesões por esforços repetitivos; estudo de caso em uma comunidade de mariscadeiras na Ilha de Maré, Bahia.

Ciência \& Saúde Coletiva, v. 16, n. 8, p. 3383-3392, 2011.

REIS, J. O. N. Determinação polarográfica de $\mathrm{Pb} 2+$ e Cd2+ em águas do rio Subaé - Sto. Amaro - Bahia. 81f. Tese (apresentada para concurso de Professor Assistente do Departamento de Química Geral e Inorgânica) Instituto de Química. Universidade Federal da Bahia, Salvador, 1975.

SANDBERG, J. How do we justify knowledge produced within interpretative approaches? Organizational Research Methods, v. 8. n. 1, p. 41-68, 2005.

SHORT JR. , J. F. The social fabric at risk: toward the social transformation of risk analysis. American Sociological Review, v. 49, p. 711-725, 1984. 


\section{Sobre os autores}

Adilton Luiz Pio Pereira é Bacharel em Relações Internacionais, Especialização em Ergonomia - UFMG. Mestre pelo Programa de Pós-Graduação em Saúde, Ambiente e Trabalho da Universidade Federal da Bahia. Técnico em Segurança do Trabalho. Técnico em Meio Ambiente. Trabalha na Refinaria Landulpho Alves/PETROBRAS, em Segurança e Meio Ambiente. E-mail: adiltonluiz@yahoo.com.br

André Luis Santos Virgulino Graduação em Tecnologia de Processamento de Dados, Mestre pelo Programa de Pós-Graduação em Saúde, Ambiente e Trabalho da Universidade Federal da Bahia. Especialista e auditor para América Latina em Higiene Ocupacional na Dow Brasil S.A. E-mail: ASVirgulino@dow.com

Carolina L. Wilches Arciniegas Graduação em Microbiologia. Mestre em Microbiologia. Doutoranda em Química na Universidade Federal da Bahia. E-mail: clwilchesa@gmail.com

Cláudia de Oliveira d'Arede Graduação em Ciências Sociais (Antropologia). Especialização em Saúde Coletiva. Mestre pelo Programa de Pós-Graduação em Saúde, Ambiente e Trabalho da Universidade Federal da Bahia. Professora substituta do Departamento de Medicina Preventiva e Social, UFBA. Pesquisadora e Coordenadora de Campo do Projeto de Pesquisa: Risco de Contaminação Ambiental e Humana Relacionadas à Exploração da Unidade de Concentrado de Urânio no Sudoeste da Bahia - UFBA / Ministério Público do Trabalho E-mail: claudiadared@gmail.com

Denise Alves Miranda de Oliveira é Enfermeira. Mestre pelo Programa de Pós-Graduação em Saúde, Ambiente e Trabalho da Universidade Federal da Bahia. Especialista em Saúde do Trabalhador e Saúde da Família pela Universidade Federal da Bahia e em Saúde Coletiva pela UNAERP. Enfermeira da $7^{\text {a }}$ DIRES. E-mail: deniamo@hotmail.com

Eagles M. Alves Graduação em Ciências Biológicas pela Universidade Federal da Bahia, UFBA. Mestre pelo Programa de Pós-Graduação em Saúde, Ambiente e Trabalho da Universidade Federal da Bahia. E-mail: eaglesmuniz@gmail.com 
Fernando Martins Carvalho é Médico. Mestre em Saúde Comunitária. Doutorado em Occupational Health na University of London. Pós-doutorado na Universidade de Massachusetts em Lowell. Professor titular do Departamento de Medicina Preventiva e Social, UFBA. Professor do Programa de Pós-Graduação em Saúde, Ambiente e Trabalho da Universidade Federal da Bahia. Pesquisador do CNPQ. E-mail: fmc. ufba@gmail.com

Flávia Silva Santa Mônica é Fonoaudióloga. Pós-Graduanda em Disfagia e Fonoaudiologia Hospitalar (FonoHosp INCISA/IMAM Belo Horizonte - MG). E-mail: flaviaafono@gmail.com

Gilberto Andrade Tavares é Médico. Especialista (Residência Médica) em Medicina da Família e Comunidade. Mestre pelo Programa de Pós-Graduação em Saúde, Ambiente e Trabalho da Universidade Federal da Bahia. Médico visitador e emergencista da Atenção Domiciliar. E-mail: beto_tavares77@yahoo.com.br

Denismar Borges de Miranda é Enfermeiro. Mestre pelo Programa de Pós-Graduação em Saúde, Ambiente e Trabalho da Universidade Federal da Bahia. Especialista em Gestão de Sistemas e Serviços de Saúde pela Universidade de Brasília. Especialista em Enfermagem em Neonatologia e Pediatria pela Pontifícia Universidade Católica de Goiás. Enfermeiro da rede SARAH. E-mail: denismarmiranda@hotmail.com.

Edriene Barros Teixeira é Médica. Mestre pelo Programa de Pós-Graduação em Saúde, Ambiente e Trabalho da Universidade Federal da Bahia. Especialista em Auditoria de Sistemas e Serviços de Saúde pela Universidade Federal da Bahia. Perita do Instituto Nacional do Seguro Social (INSS). E-mail: edrieneteixeira@yahoo.com.br.

Gerfson Moreira Oliveira é Psicólogo. Mestre pelo Programa de Pós-Graduação em Saúde, Ambiente e Trabalho da Universidade Federal da Bahia. Especialização sob forma de Residência em Saúde da Família. Especialização em Avaliação Psicológica. Coordenador de Capacitação do CAPS ad Gregorio de Matos, Salvador, BA. E-mail: gerfson@gmail.com

Luiz Roberto Santos Moraes é Engenheiro Civil e Sanitarista. Mestre em Engenharia Sanitária (IHE/Delft University of Technology); Doutor em Saúde Ambiental (LSHTM/University of London). Pós-doutorado na Universidade do Minho, Portugal. Professor Titular em Saneamento/Participante Especial do Departamento de Engenharia Ambiental da 
Escola Politécnica. Professor do Programa de Pós-Graduação em Saúde, Ambiente e Trabalho da UFBA. E-mail: moraes@ufba.br

Maiza Ferreira de Andrade Graduação em Comunicação com Habilitação em Jornalismo. Mestre pelo Programa de Pós-Graduação em Saúde, Ambiente e Trabalho da Universidade Federal da Bahia. Jornalista com atuação em temas socioambientais com destaque para a preservação da mata atlântica, a contribuição dos catadores de materiais recicláveis para a coleta seletiva, a transposição do Rio São Francisco e a situação das vítimas dos passivos ambientais da mineração de amianto e de chumbo. E-mail: maiza.andrade@uol.com.br

Marco Antônio Vasconcelos Rêgo é Médico. Doutor em Saúde Pública/Epidemiologia (ISC/UFBA), com estágio pela CAPES na University of North Carolina, EUA. Professor Associado do Departamento de Medicina Preventiva e Social, UFBA. Professor do Programa de Pós-Graduação em Saúde, Ambiente e Trabalho da UFBA. E-mail: mrego@ ufba.br

Maria de Fátima Prates Knoke Budde é Psicóloga. Mestre pelo Programa de Pós-Graduação em Saúde, Ambiente e Trabalho da Universidade Federal da Bahia. Atua no CAPS NZINGA e na Secretaria Municipal de Saúde de Salvador - Área Técnica em Saúde Mental. E-mail: fatimaknoke@hotmail.com

Maria do Carmo S. Freitas Graduação em Nutrição. Mestrado em Saúde Pública (Escuela de Salud Pública de Mexico). Doutora em Saúde Pública (ISC/UFBA). Pós-doutorado na Escola Nacional de Saúde Pública, RJ. Professora Associada da Universidade Federal da Bahia. Professora do Programa de Pós-Graduação em Saúde, Ambiente e Trabalho da UFBA e orienta alunos no Mestrado de Alimentação, Nutrição e Saúde da Escola de Nutrição, UFBA. Atua no Centro Colaborador de Alimentação Escolar (CECANE - UFBA). E-mail: mcarmos@ufba.br

Maria Lúcia Vaz Masson é Fonoaudióloga. Doutora em Educação. Professora Adjunto do Departamento de Fonoaudiologia da UFBA e Professora do Programa de Pós-Graduação em Saúde, Ambiente e Trabalho da Universidade Federal da Bahia. E-mail: masson@ufba.br

Mônica Angelim Gomes de Lima Médica. Mestre em Saúde Comunitária. Doutora em Saúde Pública (ISC/UFBA). Professora Adjunto do Departamento de Medicina Preventiva e Social, UFBA. Professora do Programa de Pós-Graduação em Saúde, Ambiente e Trabalho da UFBA. 
Atualmente em Pós-doutorado na University of Toronto, Canadá. E-mail: angelim@ufba.br

Patrícia Farias Uchôa Graduação em Arquitetura e Urbanismo. Mestre pelo Programa de Pós-Graduação em Saúde, Ambiente e Trabalho da Universidade Federal da Bahia. Professora Assistente do Departamento de Geometria das Representações, Faculdade de Arquitetura da UFBA. E-mail: pmffarias@ufba.br

Paulo Gilvane Lopes Pena Médico. Doutor em Ciências Sociais pela École des Hautes Études en Sciences Sociales (França). Professor Associado da Faculdade de Medicina da Bahia da UFBA e Professor do Programa de Pós-Graduação em Saúde, Ambiente e Trabalho da Universidade Federal da Bahia (UFBA). E-mail: pena@ufba.br.

Paulo Roberto Ferreira da Rocha Médico. Especialista em Cardiologia. Mestre pelo Programa de Pós-Graduação em Saúde, Ambiente e Trabalho da Universidade Federal da Bahia. Médico do Serviço Médico Universitário Rubens Brasil (SMURB) da Universidade Federal da Bahia (UFBA). E-mail: paurocha@ufba.br

Rita de Cássia Franco Rêgo Médica. Doutora em Saúde Pública/ Epidemiologia pelo Instituto de Saúde Coletiva da UFBA. Professora Associada da Faculdade de Medicina da Bahia da UFBA. Professora do Programa de Pós-Graduação em Saúde, Ambiente e Trabalho da Universidade Federal da Bahia (UFBA). E-mail: ritarego@ufba.br.

Rita de Cássia Pereira Fernandes Médica. Mestre em Saúde Comunitária/Epidemiologia. Doutora em Saúde Pública/Epidemiologia (ISC/UFBA), com estágio pela CAPES na McGill University, Canada. Professora Adjunto do Departamento de Medicina Preventiva e Social, UFBA. Professora do Programa de Pós-Graduação em Saúde, Ambiente e Trabalho da UFBA. E-mail: ritafernandes@ufba.br

Rodolfo Rojas Guarín Graduação em Engenharia Ambiental pela Universidade Nacional da Colômbia. Mestre pelo Programa de Pós-Graduação em Saúde, Ambiente e Trabalho da Universidade Federal da Bahia. Pesquisador na Central de Laboratórios da Empresa Baiana de Desenvolvimento Agrícola (EBDA). E-mail: rodolforojas@gmail.com

Rosangela Cunha da Rocha Fisioterapeuta. Especialista em Saúde Pública. Mestre pelo Programa de Pós-Graduação em Saúde, Ambiente e Trabalho da Universidade Federal da Bahia. É fisioterapeuta da Universidade Federal da Bahia. E-mail: rcrocha@ufba.br 
Sérgio Telles de Oliva Graduação em Química Industrial pela Universidade Federal da Bahia. Licenciatura em Química pela Universidade Federal de Santa Catarina. Mestrado e doutorado em Química pela Universidade Federal da Bahia. Professor Adjunto do Departamento de Química Analítica da Universidade Federal da Bahia. E-mail: oliva@ ufba.br

Severino Soares Agra Filho Graduação em Engenharia Química. Mestrado em Planejamento Energético. Doutorado em Economia Aplicada ao Meio Ambiente. Professor no curso de engenharia ambiental e dos programas de pós-graduação Mestrado Saúde, Ambiente e Trabalho - PPgSAT e Mestrado em Meio Ambiente, Águas e Saneamento - MAASA, da UFBA. E-mail: severino@ufba.br

Tânia Maria de Araújo Graduação em Psicologia (UFMG), Doutora em Saúde Pública (ISC/UFBA). Pós-Doutorado na Universidade de Massachusetts (EUA). Professora Titular Pleno do Departamento de Saúde da Universidade Estadual de Feira de Santana (UEFS). Professora do Programa de Pós-Graduação em Saúde, Ambiente e Trabalho (UFBA). Pesquisadora do CNPQ. E-mail: araujo.tania@terra.com.br, araujo.tania@uefs.br

Tânia Mascarenhas Tavares Graduação em Química. Mestre em Química (UFBA). Doutora em Química (USP). Pós-doutorado na Universidade de Dortmund e Instituto de Ciências Analíticas (ISAS), Alemanha. Professora Titular do Departamento de Química Analítica. Professora do Programa de Pós-Graduação em Química e do Mestrado em Saúde, Ambiente e Trabalho, UFBA. Coordenadora do Laboratório de Química Analítica Ambiental (LAQUAM), Núcleo Interdisciplinar do Meio Ambiente (NIMA) da UFBA. É membro do Comitê Gestor do Instituto Nacional de Avaliação Integral de Riscos Ambientais INAIRA (CNPQ). E-mail: ttavares@ufba.br

Thais Mara Dias Gomes Fisioterapeuta. Mestre pelo Programa de Pós-Graduação em Saúde, Ambiente e Trabalho da Universidade Federal da Bahia. Fisioterapeuta do Grupo de Pesquisa em Saúde do Trabalhador da Pesca Artesanal/Serviço de Saúde Ocupacional - SESAO do Hospital Universitário Professor Edgar Santos - HUPES. Fisioterapeuta do Hospital Geral Roberto Santos. E-mail: thais_diasgomes@hotmail. com 
Wanderley Ferreira da Silva-Júnior Bacharel em Ciência da Computação. Mestre pelo Programa de Pós-Graduação em Saúde, Ambiente e Trabalho da Universidade Federal da Bahia. Especialista em Responsabilidade Social e Terceiro Setor pela UFRJ. Atuou como Técnico de Operações da Petrobras, Supervisor em Unidade de Craqueamento Catalítico Fluido, Técnico de Comercialização e Logística na área de Gestão de Estoques e Apropriação de Produção pela Otimização. E-mail: wanderleyjr@folha.com.br 



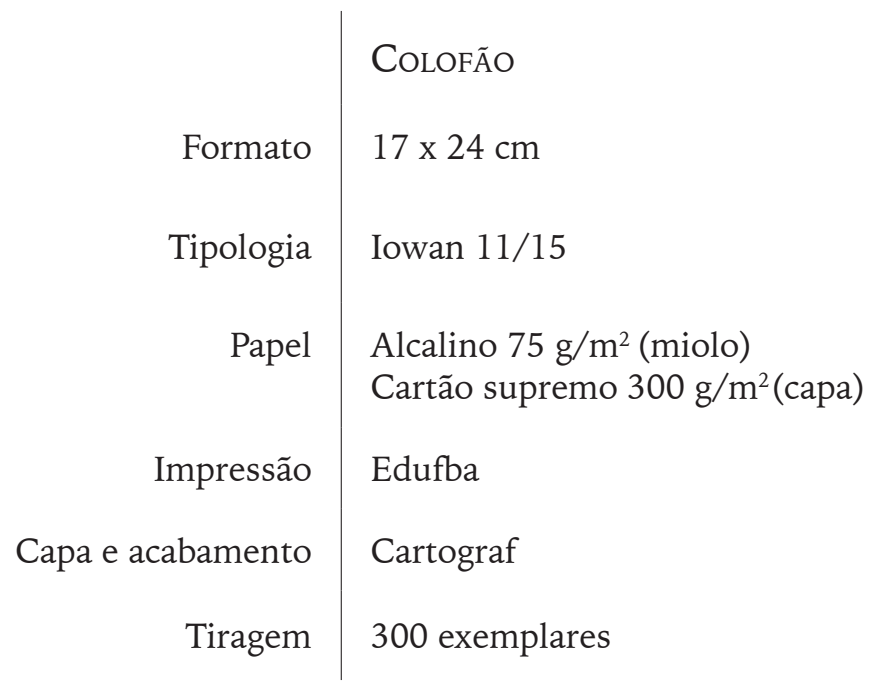

